$$
\begin{aligned}
& \text { UNIVERSIDADE DE SÃO PAULO } \\
& \text { INSTITUTO DE GEOCIÊNCIAS }
\end{aligned}
$$

\title{
O SISTEMA DE NAPPES ANDRELÂNDIA ORIENTAL - PROVENIÊNCIA SEDIMENTAR E EVOLUÇÃO TECTÔNICA
}

Gabriella Labate Frugis

Orientador: Prof. Dr. Mario da Costa Campos Neto

\section{DISSERTAÇÃO DE MESTRADO}

Programa de Pós-graduação em Mineralogia e Petrologia

São Paulo

2016 


\section{O SISTEMA DE NAPPES ANDRELÂNDIA ORIENTAL - PROVENIÊNCIA SEDIMENTAR E EVOLUÇÃO TECTÔNICA}

Dissertação apresentada ao
Instituto de Geociências da
Universidade de São Paulo para
obtenção de título de Mestre em
Geologia.

Área de concentração:

Petrologia ígnea e metamórfica

Orientador: Prof. Dr. Mario da Costa Campos Neto 
Autorizo a reprodução e divulgação total ou parcial deste trabalho, por qualquer meio convencional ou eletrônico, para fins de estudo e pesquisa, desde que citada a fonte.

Ficha catalográfica preparada pelo Serviço de Biblioteca e Documentação do Instituto de Geociências da Universidade de São Paulo

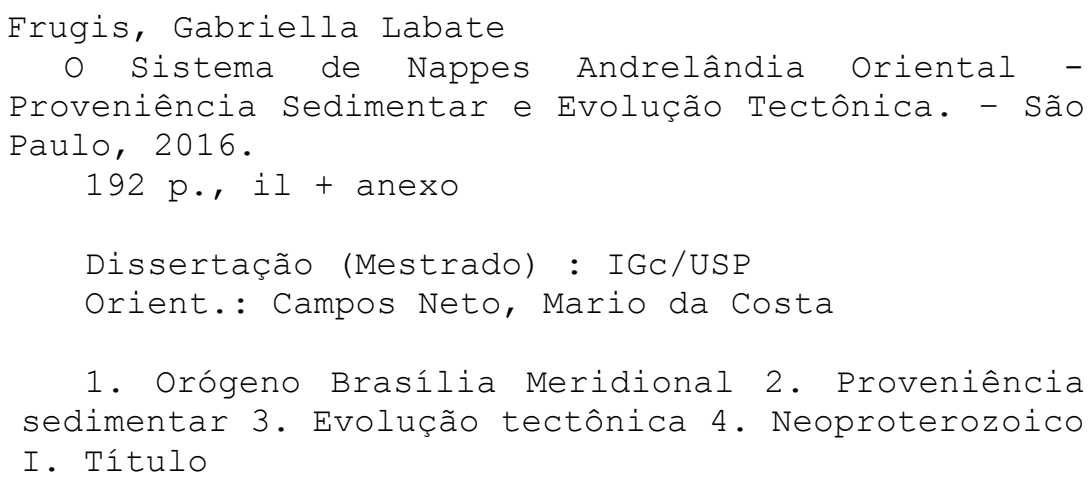


Nome: Gabriella Labate Frugis

Título: O SISTEMA DE NAPPES ANDRELÂNDIA ORIENTAL PROVENIÊNCIA SEDIMENTAR E EVOLUÇÃO TECTÔNICA

Dissertação apresentada ao
Instituto de Geociências da
Universidade de São Paulo para
obtenção de título de Mestre em
Geologia.

Área de concentração: Petrologia ígnea e metamórfica

Orientador: Prof. Dr. Mario da Costa Campos Neto

Aprovado em:

Prof. Dr.: Instituição:

Julgamento: Assinatura:

Prof. Dr.: Instituição:

Julgamento: Assinatura:

Prof. Dr.: Instituição:

Julgamento: Assinatura: 
Às mulheres. 


\section{AGRADECIMENTOS}

Agradeço à FAPESP pelo apoio financeiro através do projeto de pesquisa 2013/13530-8. À CAPES, pelo apoio e suporte à pesquisa.

Agradeço à todos que contribuíram diretamente para que este trabalho pudesse ser realizado. Ao Mario, por me orientar e me guiar nos momentos de dúvidas e questionamentos. Ao Samuel Egídio e ao Vasco Loios por sempre ajudarem na preparação das amostras. À Sandra Andrade, que além das análises no laser, me auxiliou bastante para o entendimento da metodologia. Ao Walter Sproeser e Solange de Souza pelo auxílio nas etapas de aquisição dos dados de U-Pb e Lu-Hf. Ao Marcos Mansueto e Leandro de Moraes durante as análises na microssonda.

À Alice (Kenga) que me ajudou infinitamente em todos os momentos de desespero. Ao Pedro (Porra) por me auxiliar na confecção das tabelas para cálculo dos membros finais de granada. À Brenda pela ajuda em relação aos coeficientes de partição e ao Cauê (Carrapato) por algumas discussões relevantes. Ao Felipe (Alargado) pela ajuda com os mapas geológicos de pontos.

Às pessoas que contribuíram para o meu desenvolvimento pessoal, que indiretamente ajudaram no desenvolvimento deste trabalho. À minha família. Ao Fladmir por sempre estar ao meu lado e por me apoiar nos momentos de epifania. Aos amigos da geologia, em especial Natalia (Manuel) e Beatriz (Intubada), por animarem os dias que passamos na faculdade. Aos porteiros, seguranças e todo o pessoal que trabalha no Instituto de Geociências. 
Distintos segmentos paleogeográficos foram reconhecidos nas margens das paleoplacas São Francisco e Paranapanema e resultaram, quando da colisão, nas pilhas tectônicas de nappes sin-metamórficas do Orógeno Brasília Meridional. A partir da química de elementos maiores, menores, traços e dos sistemas isotópicos $\mathrm{Sm}-\mathrm{Nd}$ e $\mathrm{Rb}$-Sr em rochatotal; de ETR e dos sistemas U-Pb e Lu-Hf em zircão, foi possível evidenciar distintos ambientes de sedimentação e distintas características químicas e isotópicas das fontes das unidades Santo Antônio e Serra da Boa Vista da Nappe Andrelândia, e das rochas metassedimentares da Nappe Liberdade.

As rochas da Nappe Liberdade registram uma proveniência a partir de arco magmático continental do Toniano, com máxima idade de sedimentação em 790 Ma. Ocorrem fontes mais antigas no Mesoproterozoico, de 1,10-1,25 Ga e 1,35-1,50 Ga, e do Estateriano-Orosiriano de 1,75-1,85 Ga. Metawackes da Unidade Santo Antônio, com idade máxima de deposição em $680 \mathrm{Ma}$, registram baixa taxa de intemperismo químico e origem a partir de fontes empobrecidas neoproterozoicas, do Toniano-Criogeniano, oriundas de um sistema de arco insular intraoceânico e, subordinadamente, de seus produtos mais evoluídos. Fontes com 1,00-1,25 Ga contribuíram em menor expressão. A unidade superior da Nappe Andrelândia, Serra da Boa Vista, possui maior taxa de intemperismo químico e não registra cristais detríticos de zircão oriundos do magmatismo neoproterozoico. As áreasfonte destes metassedimentos foram constituídas por rochas mesoproterozoicas, de 1,001,28 Ga e 1,35-1,48 Ga, e do Estateriano-Orosiriano, 1,75-1,95 Ga. Em menor expressão ocorrem fontes riacianas de 2,07-2,15 Ga.

O predomínio de área-fonte mesoproterozoica sugere fontes com afinidades grenvillianas, provavelmente relacionadas a um continente ocidental e sugerindo a correlação entre Paranapanema e Rodínia. Os cristais detríticos de zircão riacianos presentes na unidade superior, Serra da Boa Vista, aliados a ausência de registro do magmatismo de arco neoproterozoico, sugerem depósitos de flysch colisional, com duplicidade de áera-fonte, Rodinia a oeste e São Francisco-África a leste.

As rochas retroeclogíticas e metavulcânica estudadas, da Nappe Liberdade, apresentam idades ígneas de 1,46-1,48 Ga, mais antigas que a máxima idade de deposição das rochas metassedimentares $(790 \mathrm{Ma})$ nas quais elas se encontram inseridas. São admitidas como blocos ou lentes tectônicas tombados da área-fonte como olistolitos na bacia de sedimentação.

As lentes retroeclogíticas indicam uma longa vida para o processo de subducção de fatias continentais. A recristalização metamórfica de cristais de zircão (entre $760 \mathrm{Ma}$ e 670 Ma) é concomitantes com o crescimento de núcleos de granadas e indica o início da 
descompressão. Estes blocos foram possivelmente inseridos tectonicamente nos sedimentos do canal de subducção durante o processo de extrusão.

Um intervalo de 35 m.y. é admitido para a migração colisional do sistema de nappes da margem ativa. Encontra-se registrado nas idades U-Pb entre 635-600 Ma dos sobrecrescimentos de baixa razão Th/U dos cristais de zircão.

A colisão entre estes segmentos de Rodinia e África ocorreu entre $670 \mathrm{Ma}$ e $635 \mathrm{Ma}$, como indicado pelas idades dos distintos eventos metamórficos e pela idade máxima de deposição do metawacke Santo Antônio. 


\section{ABSTRACT}

Distinct paleogeographic segments were recognized in the São Francisco and Paranapanema paleoplate margins and resulted, during the collision, in the tectonic piles of sin-metamorphic nappes from the Southern Brasília Orogen. Through major, minor and trace elements and $\mathrm{Sm}-\mathrm{Nd}$ and $\mathrm{Rb}-\mathrm{Sr}$ isotopic systems in whole-rock, REE and $\mathrm{U}-\mathrm{Pb}$ and $\mathrm{Lu}-\mathrm{Hf}$ isotopic systems in zircon, it was possible to evidence distinct sedimentation environments and distinct chemistry characters of the sources from the Santo Antônio and Serra da Boa Vista units, Andrelândia Nappe, and from the Liberdade Nappe metasedimentary rocks.

The Liberdade Nappe rocks register provenance from a tonian magmatic continental arc, with maximum depositional age of $790 \mathrm{Ma}$. Older sources also occur from the Mesoproterozoic, of 1.10-1.25 Ga and 1.35-1.50 Ga, and from the Statherian-Orosirian of 1.75-1.85 Ga. Metawackes from the Santo Antônio Unit, with maximum depositional age of $680 \mathrm{Ma}$, register low index of chemical alteration and origin from depleted Neoproterozoic sources, of the Tonian-Cryogenian, derived from an intra-oceanic island arc system and, subordinately, from its more evolved products. Sources of 1.00-1.26 Ga contributed in minor expression. The upper Andrelândia Nappe Unit, Serra da Boa Vista, shows the highest rates of chemical alteration and does not register zircon detritic crystals from the Neoproterozoic magmatism. This metasediment sources were composed by Mesoproterozoic rocks, of 1.001.28 $\mathrm{Ga}$ and 1.35-1.48 Ga, and from the Shatherian-Orosirian, of 1.75-1.95 Ga. In minor expression Rhyacian sources, of 2.07-2.15 Ga occur.

The predominance of Mesoproterozoic ages suggest sources with Grenville affinities, probably related to a western continent suggesting the correlation between Paranapanema and Rodinia. The Rhyacian zircon detritic crystals in the upper unit, Serra da Boa Vista, allied to the absence of Neoproterozoic arc magmatism register, suggest flysch-type collisional sedimentary deposits, with source duplicity, Rodinia to the west and São Francisco-Africa to the east.

Ages of 0.99-1.27 Ga, mainly from depleted rocks, suggest sources with Grenville affinity, defining a western continent and marking a possible correlation between Paranapanema and Rodinia.

The retroeclogitic and metavulcanic rocks studied, from the Liberdade Nappe, present igneous ages of 1.46-1.48 Ga, older than the maximum depositional age of the metassedimentary rocks (790 Ma) in which they are inserted. They are admitted as blocks or tectonic lenses fallen from the source-area as olistoliths into the sedimentary basin.

The retroeclogitic lenses indicate a long-lived subduction process of continental slices. The zircon crystal metamorphic recrystallizations (between $760 \mathrm{Ma}$ and $670 \mathrm{Ma}$ ) are concomitant to the garnet cores growth and suggest the beginning of the decompression. Probably these 
blocks were tectonically inserted into the subduction channel sediments during the extrusion process.

An interval of $35 \mathrm{~m} . \mathrm{y}$. is admitted for the collisional migration of the active margin nappe system. It is registered in the $\mathrm{U}-\mathrm{Pb}$ ages of $635-600 \mathrm{Ma}$ from the zircon crystal overgrowths with low Th/U ratio.

The collisional between these segments of Rodinia and Africa occurred between 670 $\mathrm{Ma}$ and $635 \mathrm{Ma}$, as indicated through the distinct metamorphic events and by the Santo Antônio metawackes maximum depositional age. 


\section{LISTA DE FIGURAS}

Figura 1 1. Mapa da localização geográfica da área de estudo com a localização dos afloramentos estudados neste trabalho. A figura-base é o mapa altimétrico da região, retirado do Brasil em Relevo - EMBRAPA.

Figura 2 1. Mapa da articulação das folhas topográficas 1:50.000 utilizadas nas etapas de campo. Em vermelho estão as folhas que não foram utilizadas, mas que se encontram na região de estudo.

Figura 2 2. Diagrama da razão Th/Sc versus o índice de alteração química (CIA) para diferenciar ambiente orogênico de ambiente tectonicamente estável. (NESBITT; YOUNG, 1982; TAYLOR; MCLENNAN, 1985).

Figura 2 3. Diagrama condrito-normalizado com a média dos dados de folhelhos australianos pós-arqueanos (PAAS), folhelhos norte-americanos (NASC) e folhelhos europeus $(\mathrm{ER})$

Figura 2 4. Diagrama de Th/Sc versus $\varepsilon N d$, ressaltanto os componentes félsicos, máficos (MCLENNAN et al., 1990) e os campos referentes à composições de MORB, crosta superior e crosta antiga além das composições típicas de vários reservatórios geoquímicos (TAYLOR; MCLENNAN, 1985).

Figura 2 5. (A) Diagrama $143 \mathrm{Nd} / 144 \mathrm{Nd}$ versus $87 \mathrm{Sr} / 86 \mathrm{Sr}$ ( $\varepsilon \mathrm{Nd}$ versus $\varepsilon \mathrm{Sr}$ ) extraído e modificado de DePaolo e Wasserburg (1979) mostrando os campos das fontes enriquecidas e depletadas, assim como os quadrantes referentes às razões isotópicas de $\mathrm{Nd}$ e Sr para a crosta continental e manto depletado; (B) Diagrama de $\varepsilon N d(t)$ versus $87 \mathrm{Sr} / 86 \mathrm{Sr}$ (t) extraído e modificado de McLennan et al. (1990), onde os campos delimitados são referentes às amostras analisadas pelos autores para os diferentes ambientes tectônicos.

Figura 2 6. (A) Diagrama de distribuição da probabilidade das idades de zircão detrítico do litoral leste da Austrália. Extraído e modificado de Sircombe (2000); (B) Diagrama da distribuição cumulativa da densidade de probabilidade (K-S test) de zircão detrítico de várias amostras do Orógeno Saldania Ocidental. Extraído e modificado de Frimmel et al. (2013)

Figura 27 . Diagrama da proporção cumulativa (\%) versus a idade de cristalização IC subtraída a idade de deposição ID (Ma) para os campo de baciais convergentes ( $A$, em rosa), colisionais (B, em azul) e extensionais ( $C$, em verde). Extraído e modificado de Cawood, Hawkesworth e Dhume (2012).

Figura 2 8. Diagrama esquemático da evolução isotópica de Hf, ilustrando como um episódio de fusão parcial no manto terrestre no tempo $t 1$ resultaria em caminhos de evolução isotópica de $\mathrm{Hf}$ divergentes para a nova crosta formada (baixo $\mathrm{Lu} / \mathrm{Hf}$ ) e o manto residual (alto Lu/Hf). Retirado e modificado de Kinny e Maas (2003). 
Figura 2 9. Diagrama de $\varepsilon \mathrm{Hf}(\mathrm{t})$ representando a evolução isotópica de Hf de Depleted Mantle (DM) e New Crust (NC), no qual está representado o $\mathrm{EHfDM}$ atual de $\sim 16,9$ e o $\mathrm{HHFNC}$ de 13,2. As idades modelo calculadas através de New Crust são geralmente mais jovens, no máximo $300 \mathrm{Ma}$, do que as idade modelo TDM. Figura retirada de Dhuime, Hawkesworth, Cawood (2011).

Figura 2 10. Diagrama spider com as concentrações de elementos terras raras, normalizados pelo condrito, de cristais de zircão de diversos tipos de rochas (BELOUSOVA et al., 2002).

Figura 2 11. Árvore de classificação e regressão binária (BELOUSOVA et al., 2002) para a determinação de diferentes tipos de rocha como fonte de um determinado cristal de zircão.

Figura 2 12. (A) Diagrama spider, normalizado pelo condrito, com as concentrações dos ETR dos cristais de granada analisados por Li et al. (2013): SM-29 e WM-10 referem-e à eclogitos associados à gnaisses, SM-35 e WDW-45 estão associados à mármores, e BXL2 e MW-24 são eclogitos associados à rochas ultramáficas; (B) Diagrama dos coeficientes de partição/distribuição entre zircão e granada do eclogito (MSTa), do granulito (GP7) e do leucossoma coexistente (GL7), analisados por Rubatto (2002).

Figura 2 13. Imagem por elétron retroespalhado (BSE - backscattered eletron image) do cristal de granada do eclogito do trabalho de Rubatto (2002) juntamente com a localização e porcentagem em peso relativa das análises de $\mathrm{CaO}$ e $\mathrm{MgO} / \mathrm{MgO}+\mathrm{FeOtot}$ (Mg\#) por microssonda realizadas através do grão. Abaixo está o perfil do conteúdo de Ca. O núcleo rico em Ca é provavelmente uma relíquia pré-metamorfismo alpino.

Figura 3 1. Mapa baseado nas principais províncias estruturais segundo Bizzi et al. (2003), com a localização do Bloco Paranapanema segundo Campos Neto et al. (2000). Imagem do relevo retirado de Brasil em relevo - EMBRAPA.

Figura 3 2. Mapa geológico da Megassequência Andrelândia (TROUW et al., 2002). Unidades do Embasamento (em branco): I-Faixas Greenstone; II-Complexo Gnáissico; GRGranitoides; MG-Metagabro; MS-Supergrupo Minas; DC-Diorito Capivari; GP-Gnaisse Piedade; GM-Gnaisse Sienítico Matola. Unidades Proterozoicas: 1+2-Paragnaisse com intercalações de anfibolitos, quartzitos e xistos; 3-Mica verde quartzito; 4-Filito/xisto cinzento com quartzitos subordinados; 5-Biotita filito/xistos finos; 6-Biotita xisto/gnaisses grossos com intercalações de anfibolitos, quartzitos, gonditos e rochas calciossilicáticas; PT-Plataforma Tiradentes; DL-Delta do Lenheiro; MC-Megassequência Carandaí; GnNappe Guaxupé.

Figura 3 3. Estratigrafia da Megassequência Andrelândia segundo Trouw et al. (2002). Dc = desconformidade; $\mathrm{DAL}=$ discordância angular e litológica; $\mathrm{A} 1$ à $\mathrm{A} 5$ = associações de litofácies. 
Figura 34 . Mapa geológico do Orógeno Brasíla Meridional. Modificado de Campos Neto et al. (2010), Gengo (2014), Nunes et al. (2008), Paciullo et al. (2002), Quéméneur et al. (2002), Ribeiro et al. (2002), Trouw et al. (2008, 2002), Vinagre et al. (2014) e Westin et al. (2016)

Figura 3 5. Estratigrafia do Sistema de Nappes Andrelândia (CAMPOS NETO et al., 2007). XRC-Xisto Rio Capivari; XSA-Xisto Santo Antônio; XSBV-Xisto Serra da Boa Vista .56

Figura 4 1. Mapa geológico do setor oriental do Sistema de Nappes Andrelândia (CAMPOS NETO et al., 2007).

Figura 4 2. (A) Dobra parasita assimétrica de flanco superior sustentada por vênulas de quartzo; (B) Camadas granoblásticas centimétricas à decimétricas dobradas em dobras suaves; (C) Falha inversa com rejeito centimétrico em vênulas de quartzo; (D) Fenda de tração preenchida por vênula de quartzo com foliação adjacente levemente defletida. Fotos do afloramento NESG-1010 (LIMA, 2013), coordenadas: 591771/7609604.

Figura 4 3. (A) Afloramento na área-tipo do Unidade Santo Antônio, na Serra de Santo Antônio com a seção geológica da serra, ilustrando as unidades da Nappe Andrelândia em sinformes transpressivos de alta inclinação. NpL-Nappe Liberdade; USBV-Unidade Serra da Boa Vista; USA-Unidade Santo Antônio; URC-Unidade Rio Capivari; GpC-Grupo Carrancas (CAMPOS NETO et al., 2007); (C) Disposição geral da superfície do afloramento com vênulas de quartzo dobradas; (D) Destaque para a foliação S2, dobrada, marcada por vênula de quartzo, com fábrica de forma dos cristais em disposição de S3 convergente; (E) e (F) Vênulas de quartzo S2 dobradas e cavalgadas. Coordenadas: $570551 / 7591158$

Figura 4 4. (A) Fotomicrografia da seção delgada completa (lado maior com $4 \mathrm{~cm}$ de comprimento), com a localização das fotomicrografias da Figura 45 (polarizador cruzado). Detalhe para o porfiroblastos de granada que exibe uma foliação interna em continuação com a foliação externa, indicando portanto que seu crescimento se deu de forma cedo- à sin-cinemática; (B) Interpretação das principais estruturas e minerais da seção delgada. Imagens referentes à amostra SNA-214

Figura 4 5. (A) Porfiroblasto de granada em forma de indicador cinemático, indicando topo para a esquerda (polarizador cruzado); $(B)$ e (C) Cristais de cianita junto à aglomerados de pequenos cristais de estaurolita (polarizador descruzado); (D) Cristal de cianita com bordas corroídas, aparentemente sendo invadida por cristais de estaurolita (polarizador descruzado). Fotomicrografias referentes à amostra SNA-214.

Figura 4 6. (A) Cristais de quartzo com avanço de borda/bulging e extinção em domínios de subgrãos (polarizador cruzado); (B) Agulhas decussadas de sillimanita em aglomerados (polarizador descruzado). Fotomicrografias referentes à amostra SNA-201. .65 
Figura 4 7. (A) Orientação da textura nematoblástica gerada pelos cristais de hornblenda (polarizador cruzado); (B) Textura de intercrescimento entre quartzo e plagioclásio (polarizador cruzado). Fotomicrografias referentes à amostra NESG-1552 .66

Figura 4 8. Seção geológica transversal à Serra da Boa Vista, norte-noroeste de Sousa, com a localização de dois afloramentos cujas amostras foram analisadas, provenientes da Unidade Serra da Boa Vista

Figura 4 9. (A) Afloramento em curso d'água da amostra SNA-225; (B) Detalhe para a textura superficial do afloramento e presença de porfiroblastos de granada bem distribuídos. Coordenadas: 568733 / 7584612 . .68

Figura 4 10. (A) Fotomicrografia da seção delgada completa (lado maior com $4 \mathrm{~cm}$ de comprimento), com a localização das fotomicrografias da Figura 411 (polarizador cruzado); (B) Imagem escaneada da lâmina; (C) Interpretação das principais estruturas e minerais encontrados. Todas imagens são referentes à lâmina da amostra SNA227.

Figura 4 11. (A) Cristais de muscovita dispostos obliquamente à foliação micácea principal (polarizador cruzado); (B) Cristais de muscovita plano-axiais das dobras preservadas como arcos poligonais da foliação principal (polarizador cruzado); (C) Possível reação de substituição entre sillimanita e biotita (polarizador descruzado); (D) Arcos poligonais formados por cristais de muscovita (polarizador cruzado); (E) e (F) Finos cristais de sillimanita aprisionados no interior dos porfiroblastos de granada (polarizador descruzado). Fotomicrografias $A, B$ e $D$ são referentes à lâmina da amostra SNA-227, já as fotomicrografias $C, E$ e $F$ são referentes à amostra SNA-223. 70

Figura 4 12. Porfiroblastos de granada cujas foliações internas compostas por inclusões não apresentam continuação com a foliação externa. Notar que as bordas dos cristais tendem a apresentar menor quantidades de inclusões, indicando que podem ter crescido em momentos distintos. .71

Figura 4 13. (A) Fotomicrografia da seção delgada completa (lado maior com $4 \mathrm{~cm}$ de comprimento), com a localização das fotomicrografias C e D (polarizador cruzado); (B) Interpretação das principais estruturas e minerais encontrados; (C) Arcos poligonais formados por cristais de muscovita (polarizador cruzado); (D) Porfiroblasto de granada cuja foliação interna apresenta continuação com a externa. . .72

Figura 4 14. (A) Cristais de quartzo com bordas irregulares sugerindo provável avanço de borda (polarizador cruzado); (B) Grão de plagioclásio saussuritizado e bastante fraturado, com geminação incipiente (polarizador cruzado); (C) Cristais de clorita (polarizador cruzado); (D) Cristais de estaurolita subidioblásticos e fraturados (polarizador descruzado). Fotomicrografias referentes à amostra SNA-125.

Figura 4 15. (A) Textura geral do muscovita quartzito do afloramento SNA-224, exibindo foliação marcada pela orientação dos cristais de muscovita e pela orientação dos eixos 
maiores dos cristais de quartzo (polarizador cruzado); (B) Mesma fotomicrografia, agora com polarizador descruzado; (C) Extinção em domínios de subgrãos dos cristais de quartzo do muscovita quartzito do afloramento SNA-213 (polarizador cruzado).

Figura 4 16. Seções geológicas do Sistema de Nappes Andrelândia Oriental (CAMPOS NETO et al., 2007) com a posição de algumas afloramentos e amostras estudadas, ambas localizadas na retaguarda do sistema de nappes.

Figura 4 17. (A) Estrutura geral do afloramento SNA-169, com porções granoblásticas dobradas e (B) porfiroblastos de plagioclásio como indicadores cinemáticos exibindo movimentação sinistral com topo para o norte; (C) Vênulas de quartzo em dobras intrafoliais do afloramento SNA-197; (D) Detalhe para os cristais de cianita orientados no plano da foliação no afloramento SNA-169. .78

Figura 4 18. (A) Fotomicrografia da seção delgada completa (lados maiores com $4 \mathrm{~cm}$ de comprimento), da amostra SNA-169, com a localização de algumas das fotomicrografias da Figura 419 (polarizador cruzado); (B) Interpretação das principais estruturas e minerias da lâmina SNA-169; (C) Fotomicrografia da seção delgada completa da amostra SNA-175, com a localização de algumas das fotomicrografias da Figura 419 (polarizador descruzado); (D) Interpretação das principais estruturas e minerais da lâmina SNA-175...80

Figura 4 19. (A) Grãos de quartzo com bordas irregulares e extinção em domínios de subgrãos da lâmina SNA-197 (polarizador cruzado); (B) Cristal de plagioclásio geminado e saussuritizado da lâmina SNA-169 (polarizador cruzado); (C) Cristais de cianita e estaurolita como fases acessórias (polarizador descruzado); (SNA-172A) (D) Minerais constituintes das bandas nematolepidoblásticas da lâmina SNA-169 (polarizado descruzado); (E) Porfiroblasto de granada da lâmina SNA-175 cuja foliação interna não apresenta continuidade com a foliação externa (polarizador descruzado); (F) Cristais de granada quase sem inclusões, crescidos sobre a foliação essencialmente lepidoblástica da lâmina SNA-169 (polarizador descruzado).....

Figura 4 20. (A) Pequenos cristais xenoblásticos de estaurolita dispostos aleatoriamente entre os grãos de granada e turmalina (polarizador descruzado); (B), (C) e (D) Megacristais de turmalina com inclusões de quartzo, granada e grãos de minerais opacos, e ocorrem ao longo de toda a seção delgada (polarizador descruzado)......

Figura 4 21. (A) e (B) Textura macroscópica geral do granada-biotita-muscovita-plagioclásiofeldspato potássico-quartzo xisto porfiroblástico do afloramento SNA-180. Coordenadas: $532280 / 7564361$

Figura 4 22. (A) Fotomicrografia da seção delgada completa (lados maiores com $4 \mathrm{~cm}$ de comprimento), da amostra SNA-182, com a localização de algumas das fotomicrografias da Figura 423 (polarizador descruzado); (B) Interpretação das principais estruturas e texturas da lâmina SNA-182; (C) Fotomicrografia da seção delgada completa da amostra 
SNA-172 E, com a localização de algumas das fotomicrografias da Figura 423 (polarizador cruzado); (D) Interpretação das principais estruturas e texturas da lâmina SNA-172 E......85

Figura 4 23. (A) Grão de quartzo com extinção heterogênea em domínios de subgrãos da lâmina SNA-182 (polarizador cruzado); (B) Cristais de plagioclásio e feldspato potássico no leucossoma da lâmina SNA-182 (polarizador cruzado); (C) Porfiroblasto de feldspato potássico da lâmina SNA-172 E (polarizador cruzado); (D) Presença de mirmequita próxima dos contatos entre cristais de quartzo e feldspato potássico na lâmina SNA-172 E (polarizador cruzado)

Figura 4 24. (A) Orientação dos cristais de muscovita marcando a foliação principal do muscovita quartzito (polarizador cruzado); (B) Grão de quartzo com extinção em subgrãos paralela à foliação marcada pela orientação dos cristais de muscovita (polarizador cruzado).

Figura 4 25. (A) Porções ricas em biotita de granulação mais grossa na lâmina SNA-170 A (polarizador descruzado); (B) Níveis ricos em cristais de granada na lâmina SNA-170 A (polarizador descruzado); (C) Grão de plagioclásio com geminação lei da albita bastante proeminente na lâmina SNA-170 A (polarizador cruzado); (D) Cristal de carbonato com as duas direções de clivagem bem marcadas na lâmina SNA-170 B (polarizador cruzado).

Figura 4 26. (A) e (B) Pleocroísmo do verde amarelado ao verde musgo dos cristais de hornblenda na lâmina SNA-172 D (polarizador descruzado); (C) Cristal de hornblenda com inclusões arredondadas de quartzo na lâmina SNA-171 B (polarizador cruzado); (D) Grão de plagioclásio geminado com terminação em lança na lâmina SNA-172 B (polarizador cruzado); (E) Cristais de carbonato espalhados pela lâmina SNA-172 D (polarizador cruzado); (F) Porções granoblásticas espessas constituídas de quartzo e plagioclásio na lâmina SNA-172 B (polarizador cruzado).

Figura 4 27. (A) Amostra de mão da amostra SNA-205B, exibindo a capa de alteração da qual são visíveis as coronas esbranquiçadas ricas em plagioclásio no em torno dos cristais de granada; (B) Amostra de mão já serrada exibindo uma grande densidade de cristais de granada, aqui com granulação um pouco mais fina e em (C) com granulação um pouco mais grossa e cristais mais espaçados.

Figura 4 28. Porfiroblasto de granada com corona principalmente de plagioclásio e eventualmente por crescimento simplectítico de hornblenda com plagioclásio (polarizador descruzado). .93

Figura 4 29. (A) Porfiroblasto de granada com inclusão de bolsão mostrando crescimento simplectítico entre hornblenda e plagioclásio (polarizador descruzado); (B) Textura semelhante ao intercrescimento de ilmenita e plagioclásio (polarizador descruzado); (C) Aparente substituição de ilmenita por rutilo, e ambos por titanita (polarizador descruzado); (D) Mesma fotomicrografia, com polarizado descruzado e com conversor de luz; (E) 
Textura simplectítica de clinopiroxênio e plagioclásio e entre hornblenda e plagioclásio (polarizador descruzado); (F) Mesma fotomicrografia, agora com polarizador cruzado. .95

Figura 4 30. (A) Fotomicrografia da seção delgada completa (lados maiores com $4 \mathrm{~cm}$ de comprimento), da amostra SNA-168, com a localização de algumas das fotomicrografias da Figura 431 (polarizador cruzado); (B) Interpretação das principais estruturas e texturas da lâmina SNA-168; (C) Fotomicrografia da seção delgada completa da amostra SNA-218, com a localização de algumas das fotomicrografias da Figura 431 (polarizador descruzado); (D) Interpretação das principais estruturas e texturas da lâmina SNA218. 96

Figura 4 31. (A) Grande cristal de anfibólio geminado com birrefringência azul, medindo em torno de 7,0 mm (polarizador cruzado); (B) Diferença na cor de birrefringência das duas gerações de anfibólio (polarizador cruzado); (C) Cristais de anfibólio de birrefringência amarela fibrorradiais (polarizador cruzado); (D) Substituição de anfibólio por clorita (polarizador cruzado); (E) Contatos irregulares e extinção em domínios de subgrãos dos cristais de quartzo (polarizador cruzado)

Figura 4 32. (A) Foliação marcada por grãos de anfibólio defletindo ao redor de cristal de granada (polarizador descruzado); (B) Cristal de granada tipo atol, com inclusões de quartzo (polarizador descruzado); (C) Ribbons de quartzo recristalizados separados por finas bandas nematoblásticas (polarizador cruzado); (D) Substituição de anfibólio por minerais opacos (polarizador descruzado)

Figura 5 1. Diagrama de Th/Sc versus CIA (Chemical Index of Alteration - McLennan et al. (1995), modificado de Nesbitt e Young (1982) e Taylor e McLennan (1985)). Os dados em cinza foram retirados de Campos Neto et al. (2011) 102

Figura 5 2. (A) Diagrama Th/U versus Th (ppm) de McLennan et al. (1993) com os dados das rochas aqui estudadas. Para comparação foram plotados dados de sedimentos de margens ativa e passiva e de folhelhos australianos de McLennan et al (1983); (B) Diagrama de $\mathrm{Th} / \mathrm{Sc}$ versus $\mathrm{Zr} / \mathrm{Sc}$ com os dados deste trabalho e como comparativo os dados dos turbiditos de margem ativa e passiva retirados de McLennan et al. (1993)

Figura 5 3. (A) Diagrama dos ETR normalizados pelo condrito das rochas metassedimentares da Unidade Serra da Boa Vista; (B) Diagrama dos ETR normalizados pelo condrito das rochas da Unidade Santo Antônio; (C) Diagrama dos ETR normalizados pelo condrito das rochas metassedimentares da Nappe Liberdade. Condrito utilizado para normalização foi o C1 de Sun e McDonough (1989). 106

Figura 5 4. Exemplos de cristais de zircão provenientes da Unidade Serra da Boa Vista, analisados através das amostras SNA-116, SNA-125, SNA-213, SNA-228 e NESG-1434. 
Parte dos cristais da amostra NESG-1434 foram analisados por Lima (2013). Idades $207 \mathrm{~Pb} / 206 \mathrm{~Pb}$ erros em $2 \sigma$ 108

Figura 5 5. Diagramas A, C, E, G e I são histogramas de densidade de idades 207Pb/206Pb das rochas metassedimentares da Unidade Serra da Boa Vista da Nappe Andrelândia, em cada um notar o diagrama weighted average geral com todos os dados; Diagramas $B, D$, $\mathrm{F}, \mathrm{H}$ e $\mathrm{J}$ são diagramas weighted average com as idades resultantes dos principais conjuntos de dados destacados tanto pelos picos dos histogramas quanto pela heterogeneidade dos diagramas weighted average com todos os dados. 109

Figura 5 6. Exemplos de cristais de zircão provenientes da Unidade Santo Antônio, analisados através das amostras SNA-201, NESG-1010 e NESG-1552. Idades 207Pb/206Pb e erros em $2 \sigma$.

Figura 5 7. Diagramas A, C e E são histogramas de densidade de idades 207Pb/206Pb das rochas da Unidade Santo Antônio da Nappe Andrelândia, em cada um notar o diagrama weighted average geral com todos os dados; Diagramas B, D e F são diagramas weighted average com as idades resultantes dos principais conjuntos de dados destacados tanto pelos picos dos histogramas quanto pela heterogeneidade dos diagramas weighted average com todos os dados. 112

Figura 5 8. Histograma de densidade de idades $\mathrm{U}-\mathrm{Pb}$ com os dados de amostras da Unidade Santo Antônio dos trabalhos de Santos (2011), Belém et al. (2011) e Trouw (2008) juntamente com os resultados obtidos neste trabalho.

Figura 5 9. Exemplos de cristais de zircão provenientes das rochas metassedimentares da Nappe Liberdade, analisados através das amostras SNA-172E e SNA-180A. Idades $207 \mathrm{~Pb} / 206 \mathrm{~Pb}$ e erros em $2 \sigma$. 115

Figura 5 10. Diagramas A e C são histogramas de densidade de idades 207Pb/206Pb das rochas metassedimentares da Nappe Liberdade, em cada um notar o diagrama weighted average geral com todos os dados; Diagramas B e D são diagramas weighted average com as idades resultantes dos principais conjuntos de dados destacados tanto pelos picos dos histogramas quanto pela heterogeneidade dos diagramas weighted average com todos os dados.

6

Figura 5 11. (A) Diagrama de $\varepsilon N d$ versus idade das rochas metassedimentares, e de algumas rochas metabásicas, das unidades estudadas. As setas e os campos em cinza destacam as idades-modelo TDM, ou seus intervalos, para cada unidade; (B) Diagrama $\varepsilon N d(t)$ versus $87 \mathrm{Sr} / 86 \mathrm{Sr}(\mathrm{t})$ com as delimitações de alguns ambientes tectônicos e os dados das amostras estudadas plotados. (t) Unidade Serra da Boa Vista = 0,68 Ga; (t) Unidade Santo Antônio $=0,68 \mathrm{Ga} ;(\mathrm{t})$ Nappe Liberdade = 0,79 Ga.

Figura 5 12. Diagrama de $\varepsilon N d(t)$ versus $\mathrm{Th} / \mathrm{Sc}$ ressaltanto os componentes félsicos, máficos (MCLENNAN et al., 1990) e os campos referentes à composições de MORB, crosta 
superior e crosta antiga além das composições típicas de vários reservatórios geoquímicos (TAYLOR; MCLENNAN, 1985). (t) Unidade Serra da Boa Vista = 0,68 Ga; (t) Unidade Santo Antônio = 0,68 Ga; (t) Nappe Liberdade = 0,79 Ga.

Figura 5 13. Diagrama de $\varepsilon \mathrm{Hf}$ versus idade com as composições isotópicas das amostras de rochas metassedimentares da Unidade Serra da Boa Vista, pertencente à Nappe Andrelândia, plotadas

Figura 5 14. Diagrama de $\varepsilon \mathrm{Hf}$ versus idade com as composições isotópicas das amostras de rochas metassedimentares da Unidade Santo Antônio, pertencente à Nappe Andrelândia, plotadas. 120

Figura 5 15. Diagrama de $\varepsilon \mathrm{Hf}$ versus idade com as composições isotópicas das amostras de rochas metassedimentares da Nappe Liberdade plotadas.

Figura 5 16. (A) Diagrama dos padrões da concentração dos ETR de todos os cristais de zircão analisados das rochas metassedimentares da Unidade Serra da Boa Vista; (B) Diagrama com os dados dos cristais de zircão com idades entre 924-1089 Ma; (C) Diagrama com os dados dos cristais de zircão com idades entre 1149-1277 Ma; (D) Diagrama com os dados dos cristais de zircão com idades entre 1374-1485 Ma; (E) Diagrama com os dados dos cristais de zircão com idades entre 1730-1971 Ma. Elementos normalizados pelo condrito C1 de Sun e McDonough (1989). 123

Figura 5 17. Árvore de classificação e regressão para o reconhecimento de cristais de zircão provenientes de diversos tipos de rocha retirado de Belousova et al. (2002), com os dados dos cristais detríticos de zircão das rochas da Unidade Serra da Boa Vista. Cada cor indica uma idade e os números inseridos nas formas indicam a quantidade de dados com o mesmo resultado. 125

Figura 5 18. Diagrama $U / Y b$ versus $Y$ (ambos em ppm) com os campos de arco magmático e crosta continental e crosta oceânica de Grimes et al. (2007), os demais campos foram retirados de Teixeira (2015) que compilou os dados disponibilizados por GEOROC; (B) Diagrama $Y$ versus $U$ (ambos em ppm) discriminante para diversos tipos de rocha retirado de Belousova et al. (2002), onde os campos em 'granitoides' correspondem à (1) aplitos e leucogranitos, (2) granitos e (3) granodioritos e tonalitos. Os dados em ambos os diagramas correspondem aos cristais detríticos de zircão das rochas referentes à Unidade Serra da Boa Vista, onde cada cor corresponde a um intervalo de idade. 126

Figura 5 19. (A) Diagrama dos padrões da concentração dos ETR de todos os cristais de zircão analisados das rochas metassedimentares da Unidade Santo Antônio; (B) Diagrama com os dados dos cristais de zircão com idades entre 682-699 Ma; (C) Diagrama com os dados dos cristais de zircão com idades entre 764-785 Ma; (D) Diagrama com os dados dos cristais de zircão com idades entre 805-1005 Ma; (E) Diagrama com os dados dos cristais de zircão com idades entre 1242-1262 Ma. Elementos normalizados pelo condrito C1 de Sun e McDonough (1989). 
Figura 5 20. Árvore de classificação e regressão para o reconhecimento de cristais de zircão provenientes de diversos tipos de rocha retirado de Belousova et al. (2002), com os dados dos cristais de zircão das rochas da Unidade Santo Antônio. Cada cor indica uma idade e os números inseridos nas formas indicam a quantidade de dados com o mesmo resultado

Figura 5 21. Diagrama $\mathrm{U} / \mathrm{Yb}$ versus $\mathrm{Y}$ (ambos em ppm) com os campos de arco magmático e crosta continental e crosta oceânica de Grimes et al. (2007), os demais campos foram retirados de Teixeira (2015) que compilou os dados disponibilizados por GEOROC; (B) Diagrama $Y$ versus $U$ (ambos em ppm) discriminante para diversos tipos de rocha retirado de Belousova et al. (2002), onde os campos em 'granitoides' correspondem à (1) aplitos e leucogranitos, (2) granitos e (3) granodioritos e tonalitos. Os dados em ambos os diagramas correspondem aos cristais de zircão das rochas referentes à Unidade Santo Antônio, onde cada cor corresponde a um intervalo de idade. 130

Figura 5 22. (A) Diagrama dos padrões da concentração dos ETR de todos os cristais de zircão analisados das rochas metassedimentares da Nappe Liberdade; (B) Diagrama com os dados dos cristais de zircão com idades entre $791 \mathrm{Ma}$; (C) Diagrama com os dados dos cristais de zircão com idades entre 1093-1240 Ma; (D) Diagrama com os dados dos cristais de zircão com idades entre $1515 \mathrm{Ma}$. Elementos normalizados pelo condrito C1 de Sun e McDonough (1989).

Figura 5 23. Árvore de classificação e regressão para o reconhecimento de cristais de zircão provenientes de diversos tipos de rocha retirado de Belousova et al. (2002), com os dados dos cristais de zircão detríticos das rochas da Nappe Liberdade. Cada cor indica uma idade e os números inseridos nas formas indicam a quantidade de dados com o mesmo resultado.

Figura 5 24. (A) Diagrama U/Yb versus $Y$ (ambos em ppm) com os campos de arco magmático e crosta continental e crosta oceânica de Grimes et al. (2007), os demais campos foram retirados de Teixeira (2015) que compilou os dados disponibilizados por GEOROC; (B) Diagrama $Y$ versus $U$ (ambos em ppm) discriminante para diversos tipos de rocha retirado de Belousova et al. (2002), onde os campos em 'granitoides' correspondem à (1) aplitos e leucogranitos, (2) granitos e (3) granodioritos e tonalitos. Os dados em ambos os diagramas correspondem aos cristais de zircão detríticos das rochas metassedimentares da Nappe Liberdade, onde cada cor corresponde a uma idade e cada formato à uma amostra. 133

Figura 6 1. (A) Diagrama AFM destacando os campos de composição tholeiitica e calcioalcalina (IRVINE; BARAGAR, 1971). Em verde os dados dos granada-clinopiroxênio anfibolitos retroeclogíticos; (B) Diagrama (Na2O + K2) versus $\mathrm{SiO} 2$ com os campos das composições de rochas vulcânicas (LE BAS et al., 1986). Dados em cinza foram retirados 
de Faleiros et al. (2011) e Campanha et al. (2015), e correspondem à rochas metabásicas encontradas sequências metavulcanossedimentares do Terreno Apiaí..... 139

Figura 6 2. Diagrama dos ETR normalizados pelo condrito das rochas exóticas à bacia de sedimentação estudada: em vermelho as rochas metavulcanossedimentares e em verde as rochas anfibolíticas retroeclogíticas. Como comparação estão plotadas tanto as composições de rochas tipo E- e N- MORB, OIB e as composições das rochas metabásicas que ocorrem no Grupo Votuverava, Terreno Apiaí (CAMPANHA et al., 2015; FALEIROS et al., 2011) 140

Figura 6 3. Exemplo de cristais de zircão datados das amostras do anfibolito retroeclogítico e da rocha metavulcanossedimentar.

Figura 6 4. (A) Diagrama concordia com todos os dados plotados com intercepto inferior em $1427 \pm 58$ Ma e intercepto superior de $2062 \pm 130$ Ma da amostra SNA-168, detalhe para o diagrama weighted average; (B) Diagrama concordia com os dados do Mesoproterozoico resultando em uma idade de $1463 \pm 17 \mathrm{Ma}$, detalhe para o diagrama weighted average que resultou em $1464 \pm 20 \mathrm{Ma}$; (C) Diagrama concordia com os dados do Paleoproterozoico resultando em uma idade de $2039 \pm 37 \mathrm{Ma}$, detalhe para o diagrama weighted average que resultou em $2048 \pm 39 \mathrm{Ma}$; (D) Diagrama concordia com todos os dados plotados com intercepto inferior em $1441 \pm 130$ Ma e intercepto superior de $2162 \pm 110$ Ma da amostra SNA-205B, detalhe para o diagrama weighted average; (E) Diagrama concordia com os dados do mesoproterozoico resultando em uma idade de $1480 \pm 43 \mathrm{Ma}$, detalhe para o diagrama weighted average que resultou em $1477 \pm 46$ Ma; (F) Diagrama concordia com os dados do paleoproterozoico resultando em uma idade de $2055 \pm 30 \mathrm{Ma}$, detalhe para o diagrama weighted average que resultou em $2059 \pm 34 \mathrm{Ma}$ 142

Figura 6 5. Diagrama $\varepsilon N d t$ versus idade para as rochas exóticas à bacia de sedimentação: um anfibolito retroeclogítico e uma rocha metavulcanossedimentar. Como comparação está plotado o campo das composições de rochas metabásicas encontradas nas sequências Água Clara, Votuverava, Perau e Betara retirada de Siga et al. (2011). (t) anfibolito retroeclogítico = 1480; (t) rocha metavulcânica $=1460$

Figura 6 6. (A) Diagrama $\varepsilon N d t$ versus $87 \mathrm{Sr} / 86 \mathrm{Srt}$ e (B) Diagrama $\varepsilon N d t$ versus $\mathrm{Th} / \mathrm{Sc}$ com as delimitações de alguns ambientes tectônicos e os dados das amostras estudadas plotados. 144

Figura 6 7. Diagrama $\varepsilon \mathrm{Hft}$ versus idade com os dados de $\varepsilon \mathrm{Hf}$ plotados em relação às idades de cristalização dos cristais da rocha e herdados. Para a amostra SNA-205B os valores de $\varepsilon \mathrm{Hf}$ foram calculados para $1480 \pm 43 \mathrm{Ma}$ e $2055 \pm 30 \mathrm{Ma}$, enquanto que para a rocha metavulcânica (SNA-168) as idades foram $1463 \pm 17$ Ma e $2039 \pm 37$ Ma.

Figura 6 8. (A) Histograma das idades U-Pb e TDM da amostra do anfibolito retroeclogito; (B) Histograma das idades U-Pb e TDM da amostra da rocha metavulcanossedimentar.......146 
Figura 6 9. (A) Diagrama dos padrões da concentração dos Elementos Terras Raras da rocha metavulcânica e (B) do anfibolito retroeclogítico. Todos os elementos foram normalizados pelo condrito C1 de Sun e McDonough (1989).

Figura 7 1. (A) Fotomicrografia com polarizador descruzado de corona de plagioclásio em torno da granada evidenciando a reação (1); (B) Fotomicrografia com polarizador descruzado exibindo crescimento simplecítico entre diopsídio e plagioclásio (reação 2), entre hornblenda e plagioclásio e a substituição de diopsídio + plagioclásio por hornblenda (reação 3); (C) Mesma fotomicrografia, agora com polarizador cruzado. 149

Figura 7 2. Exemplos de cristais de zircão, analisados ou não, cujos sobrecrescimentos metamórficos são tidos como representantes do metamorfismo de alta pressão registrado pela amostra SNA-205B (granada-clinopiroxênio anfibolito retroeclogítico). Idades $207 \mathrm{~Pb} / 206 \mathrm{~Pb}$ com erro em $2 \sigma$.

Figura 7 3. Diagrama weighted average cuja idade resultante é de $761 \pm 18 \mathrm{Ma}$ a partir de 20 pontos analisados em diferentes cristais metamórficos de zircão. 151

Figura 7 4. Razão Th/U versus idade U-Pb dos cristais de zircão da amostra SNA-205B referente ao anfbolito retroeclogítico exótico à bacia de sedimentação. À esquerda o detalhe somente das razões Th/U dos cristais metamórficos, em verde os grãos que resultaram em idade de $612 \pm 24 \mathrm{Ma}$, e em vermelho os que resultaram em $761 \pm 18$ Ma. 152

Figura 7 5. Diagrama spider dos elementos terras raras em zircão metamórfico do granadaclinopiroxênio anfibolito retroeclogítico 153

Figura 76 . Diagrama $176 \mathrm{Hf} / 177 \mathrm{Hf}$ versus $176 \mathrm{Lu} / 177 \mathrm{Hf}$ com todos as razões isotópicas dos cristais de zircão da amostra do anfibolito retroeclogítico. Notar que os cristais metamórficos apresentam as menores razões de $176 \mathrm{Lu} / 177 \mathrm{Hf}$ 154

Figura 7 7. (A) Fotomicrografia com polarizar descruzado da granada SNA-205 B1 com a posição dos pontos analisados tanto por microssonda quanto por LA-ICP-MS; (B) Diagrama da composição de cada ponto analisado segundo os quatro membros finais: piropo, almandina, espessartita e grossulária da granada SNA-205 B1; (C) Fotomicrografia com polarizar descruzado da granada SNA-205 B2 com a posição dos pontos analisados tanto por microssonda quanto por LA-ICP-MS; (D) Diagrama da composição de cada ponto analisado segundo os quatro membros finais: piropo, almandina, espessartita e grossulária da granada SNA-205 B2. 155

Figura 7 8. (A) Diagrama da porcentagem em peso de $\mathrm{CaO}$ nos diversos pontos analisados de ambas as granadas; (B) Diagrama da porcentagem em peso de FeOTOT nos diversos pontos analisados de ambas as granadas; (C) Diagrama da porcentagem em peso de $\mathrm{MgO}$ nos diversos pontos analisados de ambas as granadas; (D) Diagrama de $\mathrm{MgO} /(\mathrm{MgO}+$ FeOTOT) nos diversos pontos analisados de ambas as granadas. (E) Diagrama da 
porcentagem em peso de $\mathrm{MnO}$ nos diversos pontos analisados de ambas as granadas 156

Figura 7 9. (A) Diagrama dos padrões da concentração dos ETR das bordas e núcleos dos cristais de granada B1 e (B) da granada B2 analisados da amostra SNA-205B. Os ETR foram normalizados pelo condrito C1 de Sun e McDonough (1989). 157

Figura 7 10. Diagrama da média da concentração, normalizada pelo condrito, dos ETR leves, médios e pesados do núcleo e borda dos dois cristais B1 e B2 de granada analisados da amostra SNA-205B. Notar que os núcleos de ambos os grãos são mais enriquecidos em ETR médios e pesados do que as bordas. 158

Figura 7 11. (A) e (C) Diagramas de coeficiente de partição zircão/granada entre os cristais metamórficos individuais de zircão e as porções internas e externas de dois grãos de granada do granada-clinopiroxênio anfibolito retroeclogítico (SNA0205B), como comparação estão plotados os dados obtidos através de estudo experimental de Rubatto e Hermann (2007), realizado a 20 kbar de pressão e Taylor et al. (2015) realizado a 7 kbar de pressão; (B) e (D) Diagramas do coeficiente de partição entre a média da composição dos cristais de zircão de $761 \pm 18$ Ma e a média das porções (núcleo e borda) dos grãos de granada. 159

Figura 7 12. Razões Th/U versus idade $\mathrm{U}-\mathrm{Pb}$ dos cristais de zircão provenientes das rochas metassedimentares que apresentaram sobrecrescimentos metamórficos analisados nos quais proveram as concentrações de Th e U para tal cálculo. USBV = Unidade Serra da Boa Vista; USA = Unidade Santo Antônio; NpLib = Nappe Liberdade

Figura 7 13. Diagramas weighted average com as idades $207 \mathrm{~Pb} / 206 \mathrm{~Pb}$ resultantes dos conjuntos de sobrecrescimentos metamórficos em zircão. Em laranja as amostras da Unidade Serra da Boa Vista; em azul as amostras da Unidade Santo Antônio; em verde as amostras das rochas metassedimentares da Nappe Liberdade e em vermelho a amostra do granada-clinopiroxênio anfibolito retroeclogítico exótico à bacia de sedimentação.....162

Figura 8 1. (A) Diagrama $\varepsilon \mathrm{Hf}$ versus idade das três unidades estudadas; (B) Diagrama dos padrões dos elementos terras raras de cada uma das três unidades 165

Figura 8 2. (A) Diagrama $\varepsilon N d t$ versus idade (Ga) com os dados da Unidade Santo Antônio das amostras aqui estudadas, das amostras analisadas por Santos (2011), assim como os resultados referentes ao metawackes do Sistema de Nappes Carrancas (SNC) (TEIXEIRA, 2011; WESTIN; CAMPOS NETO, 2013); (B) Diagrama ENdt versus idade (Ga) das três unidades analisadas, dos metawackes do Sistema de Nappes Carrancas (SNC) (TEIXEIRA, 2011; WESTIN; CAMPOS NETO, 2013) e das rochas do arco de ilha de Mara Rosa e Anicuns (FUCK et al., 2014; JUNGES; PIMENTEL; MORAES, 2002; LAUX et al., 2004, 2005; MATTEINI et al., 2010; PIMENTEL; FUCK; GIOIA, 2000; PIMENTEL et al., 1997). 
Figura 8 3. Diagrama da Idade de cristalização - idade de sedimentação (IS) versus proporção cumulativa (CAWOOD; HAWKESWORTH; DHUIME, 2012). ID Unidade Serra da Boa Vista e Unidade Santo Antônio = 680 Ma e ID Nappe Liberdade $=790$ Ma.

Figura 8 4. (A) Diagrama da idade versus distribuição cumulativa e (B) histograma das idades de todas as amostras da três unidades estudadas juntamente com os intervalos de idades das possíveis áreas-fonte dos sedimentos. Arco Mgamático de Goiás (Arenópolis, Mara Rosa e Anicuns) (LAUX et al., 2004, 2005; PIMENTEL; FUCK; GIOIA, 2000; PIMENTEL; HEAMAN; FUCK, 1991; PIMENTEL et al., 1997); Nappe Socorro-Guaxupé (DUFFLES et al., 2016; GENGO, 2014; VINAGRE et al., 2014); Orógeno Sunsás (TEIXEIRA et al., 2010); Província Rondoniano-San Ignácio (BETTENCOURT et al., 2010; TEIXEIRA et al., 2010); Terreno Juruena-Jamari (SCANDOLARA et al., 2016); Cráton Rio Apa (CORDANI et al., 2010a; FALEIROS et al., 2016); províncias Ventuari-Tapajós e Maroni Itacaúnas (CORDANI; TEIXEIRA, 2007); rochas metabásicas do Grupo Votuverava (CAMPANHA et al., 2015; FALEIROS et al., 2011; SIGA JR et al., 2011a); Embasamento do Terreno Apiaí (SIGA JR et al., 2011b, 2011c); Complexo Pouso Alegre (CIOFFI et al., 2016; WESTIN et al., 2016); Cinturão Mineiro (TEIXEIRA et al., 2015)... 168

Figura 8 5. Diagrama esquemático da evolução da assinatura de elementos terras raras nos cristais de zircão e de granada da amostra do retroeclogito. Em (A) a assinatura de ETR nos cristais de zircão do protólito ígneo na ausência de granada; em (B) ocorre a recristalização dos cristais de zircão do protólito concomitante ao crescimento de granada, ambos em fácies eclogito em $761 \mathrm{Ma}$, notar o empobrecimento em ETR pesados dos cristais de zircão e de granada, assim como o diagrama do coeficiente de partição que ilustra valores próximos a 1; Em (C) há recristalização das bordas dos cristais de granada possivelmente concomitante a cristalização de bordas de cristais de zircão em metamorfismo de menor grau, em $612 \mathrm{Ma}$, notar o diagrama de ETR da granada ainda depletado em ETR pesados, já no diagrama do coeficiente de partição é possível notar maior preferência dos ETRP em relação ao zircão (valores maiores que 1).....

Figura 8 6. Esquema paleogeográfico da evolução subducção-colisão entre os blocos Paranapanema (Prp) e São Francisco (SF) ao longo do Neoproterozoico. .175

\section{LISTA DE TABELAS}

Tabela 2 1. Resumo das relações amostra versus análises utilizadas nesta dissertação. A abreviação das fases minerais segue Kretz (1983). FRX = fluorescência de Raio-X; ETR = elementos terras raras; ICP = Laser Ablation Inductively Coupled Plasma Spectrometry; RT = rocha-total; Min = mineral; USBV = Unidade Serra da Boa Vista; USA = Unidade Santo Antônio; NpLib = Nappe Liberdade. 
Tabela 2 2. Valores obtidos para os materiais de referência durantes as análises. Valores em ppm

Tabela 2 3. Valores de índices de alteração química (CIA) da crosta continental superior e rochas sedimentares variadas. Adaptado de Nesbitt e Young (1982).

Tabela 2 4. Resultados das análises dos materiais de referência durante a investigação dos elementos traço e terras raras das amostras dos lotes 1 e 2 . Valores em ppm

Tabela 2 5. Resultados das análises dos materiais de referência durante a investigação dos elementos traço e terras raras das amostras dos lotes 3 e 4 . Valores em ppm. * ${ }^{* *}$ valor não reportado por problema durante as análises.

Tabela 2 6. Resumo das principais características geoquímicas e de isotopia de possíveis terrenos fonte. Retirado de McLennan et al. (1990 e 1993).

Tabela 2 7. Os pares dos isótopos pai e filho, seus tempos de meia-vida e constante de decaimento (JAFFEY et al., 1971).

Tabela 2 8. Resumo das quantidades de idades $\mathrm{U}-\mathrm{Pb}$ analisadas e utilizadas neste trabalho, destacando o número de análises em porções metamórficas ou ígneas do zircão.

Tabela 5 1. Resumo dos dados dos elementos maiores e menores das rochas, principalmente metassedimentares e um anfibolito, das unidades Santo Antônio e Serra da Boa Vista, ambos da Nappe Andrelândia e rochas metassedimentares da Nappe Liberdade

Tabela 5 2. Resumo dos parâmetros calculados dos elementos terras raras em rocha total, em sua maioria metassedimentares, das amostras estudadas 105

Tabela 5 3. Resumo de todas as idades encontradas por Santos (2011), Belém et al. (2011), Trouw (2008), Lima (2013) e por este trabalho para a Unidade Santo Antônio. (c.a.) = concordia age; * = idades resultantes geradas a partir de um conjunto de dados através de diagramas weighted average com erro em $2 \sigma$; o restante são os resultados de cada cristal de zircão com erro em $1 \sigma$

Tabela 5 4. Resumo dos parâmetros calculados em relação aos Elementos Terras Raras das amostras analisadas referentes à Unidade Serra da Boa Vista, da Nappe Andrelândia.

Tabela 5 5. Resumo dos parâmetros calculados em relação aos Elementos Terras Raras das amostras estudadas da Unidade Santo Antônio, da Nappe Andrelândia. 128

Tabela 5 6. Resumo dos parâmetros calculados em relação aos Elementos Terras Raras das amostras SNA-172E e SNA-180A da Nappe Liberdade.

Tabela 5 7. Resumo das idades máximas de sedimentação (IMS) das rochas metassedimentares estudadas. Observar que tanto para as idades $207 \mathrm{~Pb} / 206 \mathrm{~Pb}$ como para as $206 \mathrm{~Pb} / 238 \mathrm{U}$, foram inseridos os dados provenientes do grupo de idades mais jovem assim como a idade do cristal individual mais jovem. As idades resultantes de um conjunto de dados foram geradas a partir de diagramas weighted average com MSWD 
menor que 1,0. As idades individuais correspondem à concordância de $100 \%$, exceto três que estão destacadas com suas respectivas concordâncias (99\% ou 101\%).

Tabela 6 1. Resumo dos dados dos elementos maiores e menores dos granada-clinopiroxênio anfibolitos retroeclogíticos e dos quartzo-granada-cummingtonita fels/xistos. 138

Tabela 6 2. Resumo dos parâmetros calculados dos elementos terras raras em rocha total para as rochas, em sua maioria metassedimentares, estudadas. 139

Tabela 6 3. Resumo dos parâmetros calculados em relação aos Elementos Terras Raras em zircão do anfibolito retroeclogítico e da rocha metavulcânica. 146

Tabela 7 1. Parâmetros calculados a partir das análises dos ETR em zircão metamórfico do granada-clinopiroxênio anfibolito retroeclogítico (SNA-205 B).

Tabela 7 2. Resumo dos parâmetros calculados em relação aos Elementos Terras Raras em granada das amostras SNA-205B 1 e SNA-205B 2, exóticas à bacia de sedimentação estudada. 156

Tabela 8 1. Resumo dos principais registros isotópicos e químicos das rochas metassedimentares estudadas. As idades aqui plotadas referem-se às idades resultantes em de diagrama weighted average 164

\section{LISTA DE SIGLAS E ABREVIAÇÕES}

ETR: Elementos Terras Raras

LA-ICP-MS: Laser Ablation Inductively Coupled Plasma Mass Spectrometer

MC: Multi-Coletor

TIMS: Thermal Ionization Mass Spectrometry

SNA: Sistema de Nappes Andrelândia (nomenclatura das amostras)

NESG: Nappe Socorro-Guaxupé

MSWD: Mean Square Weighted Deviation (desvio ponderado médio quadrático)

CIA: Chemical Index of Alteration (índice de alteração química)

ES: European Shale composite (combinação de folhelhos europeus)

PAAS: Post-Archean Average Australian shale (combinação da média de folhelhos pósarqueanos australianos)

NASC: North American Shale composite (combinação dos folhelhos norte-americanos)

LILE: Large-Ion Lithophile Elements (elementos litófilos de íons grandes)

HFSE: High Field Strength Elements

CHUR: Chondritic Uniform Resevoir (reservatório condrítico uniforme)

TCHUR: Idade modelo calculada por CHUR

DM: Depleted Mantle (manto depletado)

TDM: Idade-modelo calculada por DM

NC: New Crust (crosta nova) 
TNC: Idade-modelo calculada por NC

ppm: parte por milhão

CPGeo: Centro de Pesquisas Geocronológicas da Universidade de São Paulo et al: et alia (e outros)

MORB: Middle Ocean Ridge Basalt (basalto de cordilheira meso-oceânica)

$\lambda$ : Constante de decaimento

t1/2: Tempo de meia-vida

$\sigma:$ erro/desvio padrão

IC: Ion Counter (contador de íon)

L: Low mass collector (coletor de massa baixa)

$\mathrm{H}$ : High mass collector (coletor de massa alta)

W: Watts

$\mathrm{Hz}:$ Hertz

m: metro

cm: centímetro

mm: milímetro

$\mu \mathrm{m}$ : micrometro

J: Joule

$\mathrm{mJ}$ : Milijoule

L: litros

min: minuto

Ma: milhões de anos

Ga: bilhões de anos

Kd ou D: Coeficiente de partição

m.y.: million years (milhões de anos) 


\section{CAPÍTULO 1 - Introdução}

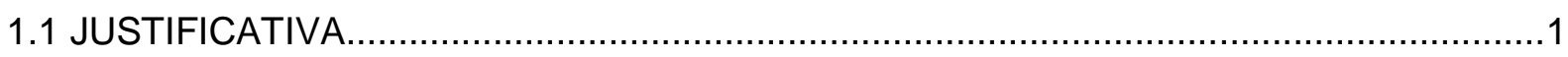

1.2 OBJETIVOS

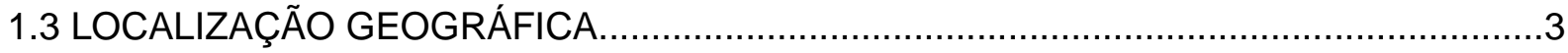

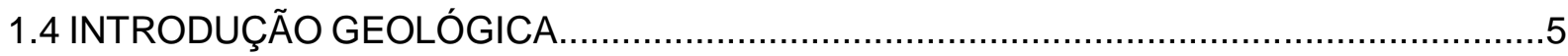

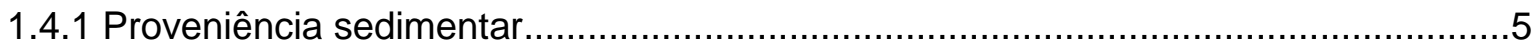

1.4.2 Evolução Geotectônica pré-Gondwana Ocidental..............................................6

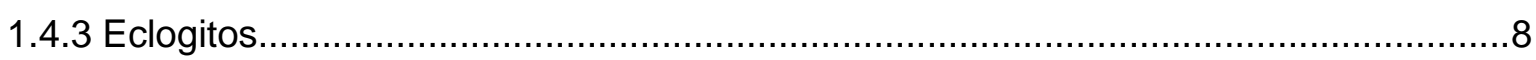

\section{CAPÍTULO 2 - Materiais e métodos}

2.1 TRABALHOS DE CAMPO E AMOSTRAGEM.......................................................11

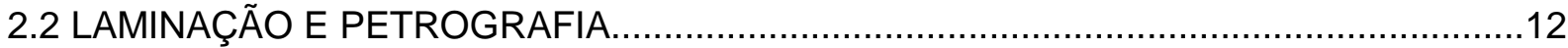

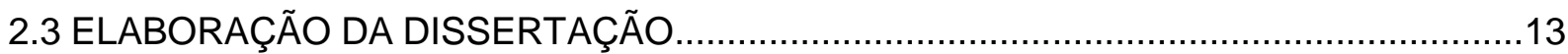

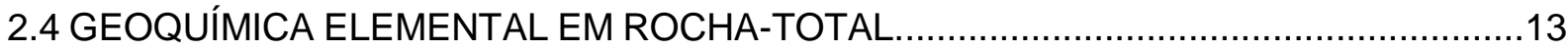

2.4.1 Elementos maiores, menores e traço por Fluorescência de Raio-X.........................13

2.4.2 Elementos traço e terras raras por LA-ICP-MS .................................................16

2.5 GEOQUÍMICA ISOTÓPICA EM ROCHA-TOTAL ......................................................21

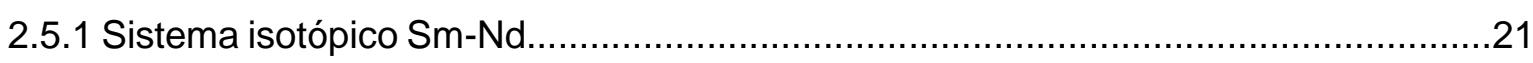

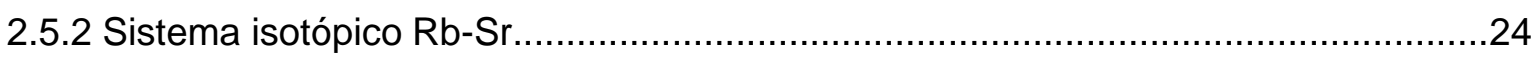

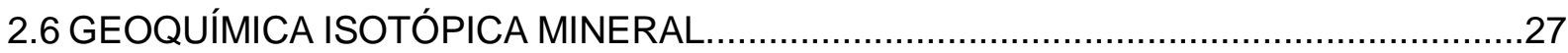

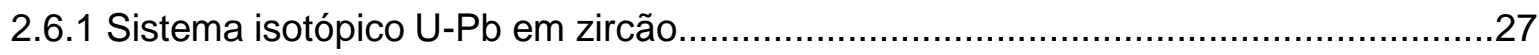

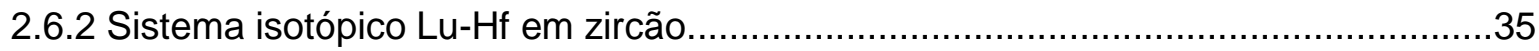

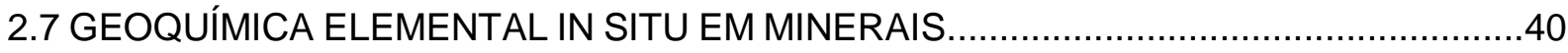

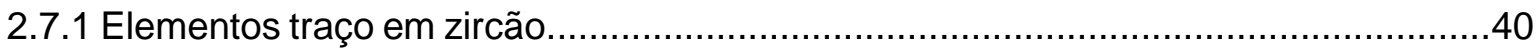

2.7.2 Elementos traço em granada.........................................................................44

2.7.3 Elementos maiores e menores em granada.....................................................46

\section{CAPÍTULO 3 - O Orógeno Brasília Meridional}

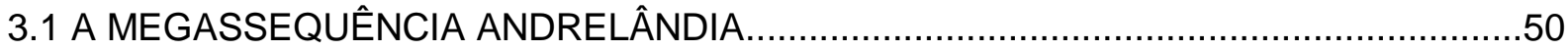

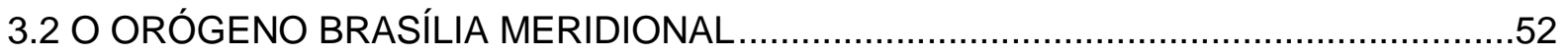

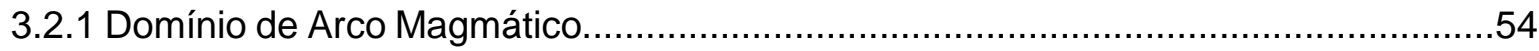

3.2.2 Domínio de Crosta Continental Subductada.......................................................55

3.2.3 Domínio de Margem Continental Passiva.............................................................56

CAPÍTULO 4 - O Sistema de Nappes Andrelândia Oriental 


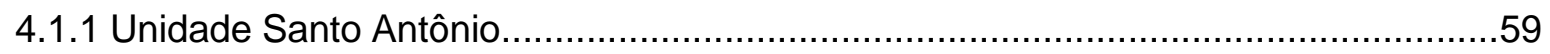

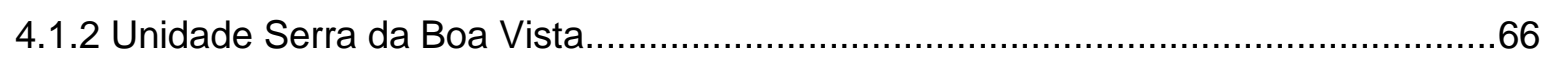

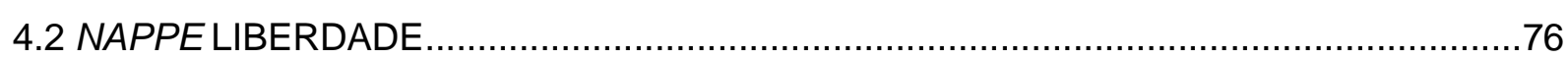

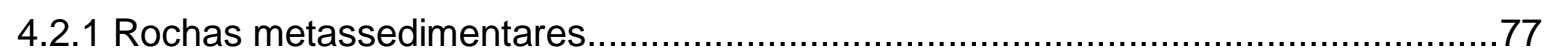

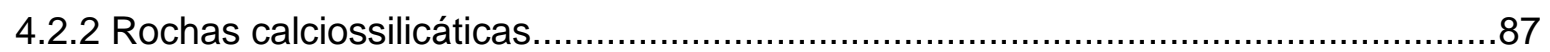

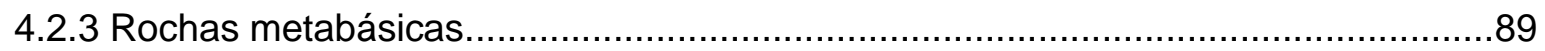

4.2.4 Granada-clinopiroxênio anfibolito retroeclogítico e quartzo-granada-cummingtonita xisto/fels.

\section{CAPÍTULO 5 - Proveniência Sedimentar}

5.1 GEOQUÍMICA ELEMENTAL EM ROCHA-TOTAL...................................................101

5.1.1 Elementos maiores, menores e traço............................................................... 101

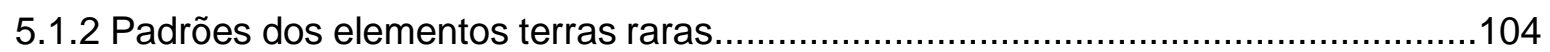

5.2 SISTEMA ISOTÓPICO U-PB EM CRISTAIS DETRÍTICOS DE ZIRCÃO.....................107

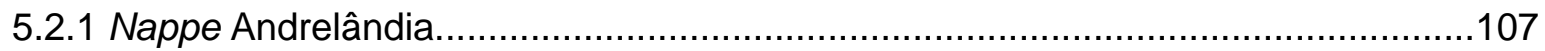

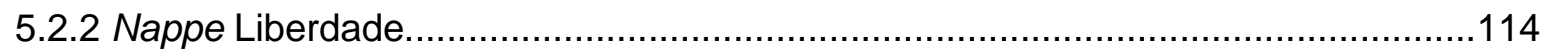

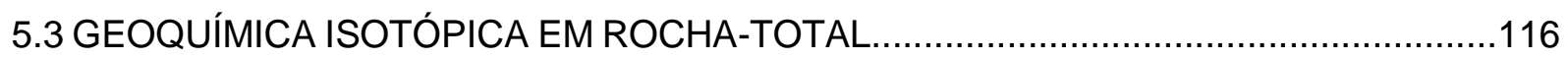

5.4 SISTEMA ISOTÓPICO LU-HF EM CRISTAIS DETRÍTICOS DE ZIRCÃO....................118

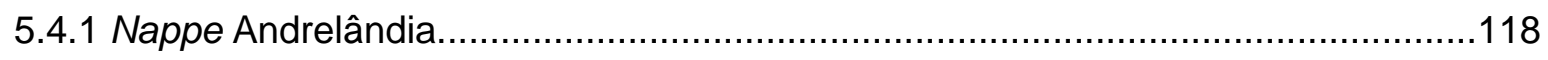

5.4 .2 Nappe Liberdade................................................................................ 121

5.5 ELEMENTOS TERRAS RARAS EM CRISTAIS DETRÍTICOS DE ZIRCÃO..................122

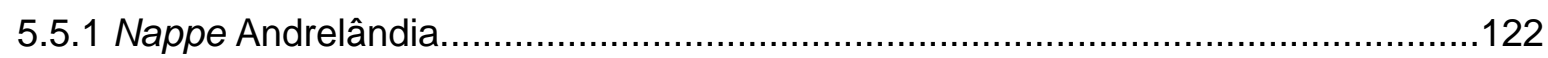

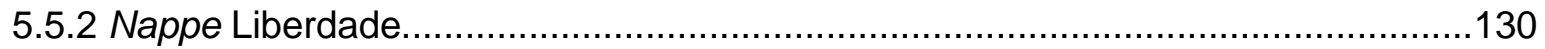

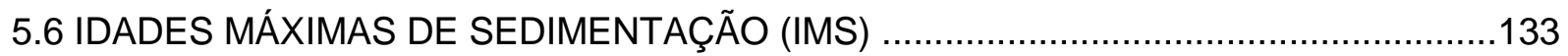

5.7 O CARÁTER ÍGNEO OU VULCANOCLÁSTICO DO ANFIBOLITO NA UNIDADE SANTO

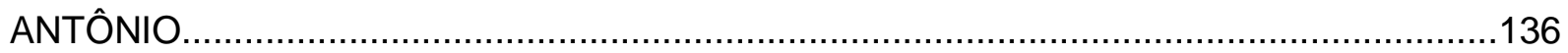

\section{CAPÍTULO 6 - Rochas exóticas à bacia de sedimentação}

6.1 GEOQUÍMICA ELEMENTAL EM ROCHA-TOTAL .................................................138

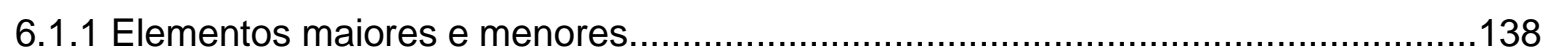

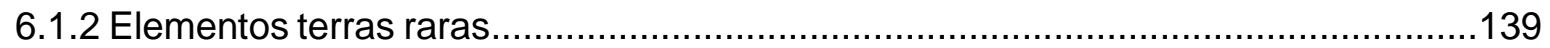

6.2 SISTEMA ISOTÓPICO U-PB EM CRISTAIS DE ZIRCÃO ..........................................140

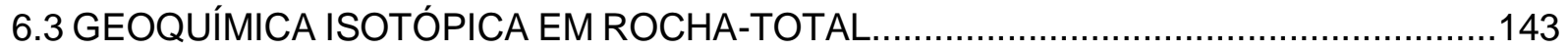

6.4 SISTEMA ISOTÓPICO LU-HF EM CRISTAIS DE ZIRCÃO .......................................144

6.5 ELEMENTOS TERRAS RARAS EM CRISTAIS DE ZIRCÃO....................................146

\section{CAPÍTULO 7 - Metamorfismo}


7.1.1 Aspectos petrográficos e condições de metamorfismo..........................................148

7.1.2 Morfologia dos cristais de zircão metamórficos...................................................149

7.1.3 Idade do evento metamórfico de alta pressão...................................................150

7.1.4 Razão Th/U e elementos terras raras em zircão...................................................151

7.1.5 Sistema isotópico Lu-Hf em cristais metamórficos de zircão...................................153

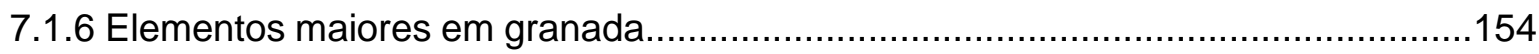

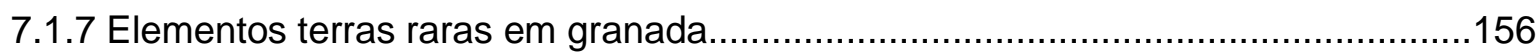

7.1.8 coeficiente de partição de ETR entre zircão metamórfico e granada......................158

7.2 METAMORFISMO DE COLISÃO E MIGRAÇÃO DE NAPPES ..................................160

7.2.1 Condições do metamorfismo de colisão...........................................................160

7.2.2 Razão Th/U em sobrecrescimento metamórfico de zircão.......................................161

7.2.3 Idades do evento metamórfico relacionado a migração de nappes sin-colisão.......162

\section{CAPÍTULO 8 - Discussões e conclusões}

8.1 AMBIENTE DE SEDIMENTAÇÃO E POSSÍVEIS ÁREAS-FONTE ................................163

8.2 METAMORFISMO DE ALTA PRESSÃO E EVOLUÇÃO DA SUBDUCÇÃO...................170

8.3 METAMORFISMO DE COLISÃO E A MIGRAÇÃO DO SISTEMA DE NAPPES.............171

8.4 ANFIBOLITO RETROECLOGÍTICO E A ROCHA METAVULCÂNICA - CONEXÃO COM

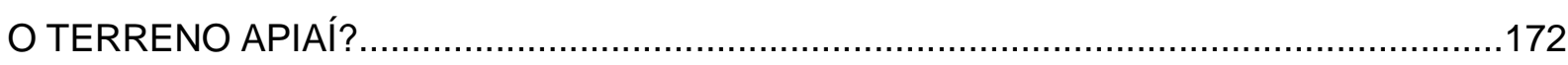

8.5 EVOLUÇÃO TECTÔNICA DA MARGEM ATIVA DO BLOCO PARANAPANEMA..........173

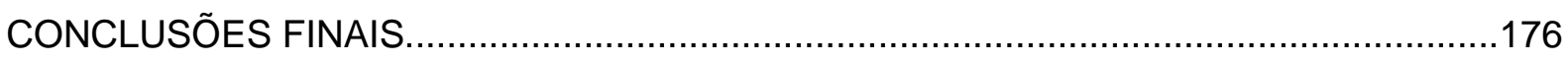

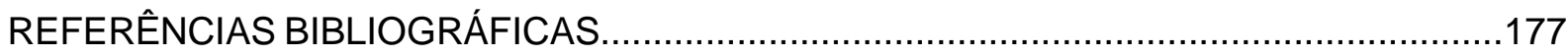

ANEXO I: Mapa Geológico de pontos

ANEXO II: Geoquímica elemental em rocha-total (elementos traço e terras raras)

ANEXO III: Geoquímica isotópica em rocha-total (sistemas Sm-Nd e Rb-Sr)

ANEXO IV: Sistema isotópico U-Pb em zircão

ANEXO V: Sistema isotópico Lu-Hf em zircão

ANEXO VI: Geoquímica elemental em zircão (elementos traço e terras raras)

ANEXO VII: Geoquímica elemental em granada (elementos traço e terras raras)

ANEXO VIII: Geoquímica elemental em granada (elementos maiores) 


\section{CAPÍTULO 1}

\section{INTRODUÇÃO}

O estudo de depósitos sedimentares, com o objetivo de melhor entender os ambientes tectônicos onde se instalaram as bacias e os processos que regeram a evolução desses ambientes, são de grande interesse na construção do esboço paleogeográfico. Os diversos tipos de depósitos gravam as características químicas e geológicas de sua época de sedimentação, o que permite relacionar ambientes de deposição com rochas-fontes.

Conforme os olhares se voltam para a evolução pré-cambriana dos blocos continentais, o registro de suas relações de rifteamento e amalgamação ficam ainda mais complexas e encobertas por processos superimpostos. As relações litoestratigráficas das unidades geológicas em estudo e a determinação das áreas-fonte e, em certos casos, das rochas que originaram tais sedimentos, são procedimentos indispensáveis para o entendimento da evolução tectônica, sobretudo de domínios metamórficos, não fossilíferos e sem o registro sedimentar original.

A partir dos métodos geoquímicos de rocha-total, geocronológicos de U-Pb, isotópicos de Lu-Hf, Sm-Nd e Rb-Sr, e elementos traço em zircão aplicados às investigações de proveniência sedimentar, o presente trabalho teve como principal objetivo investigar as áreas-fonte de sedimentos brasilianos e seus ambientes tectônicos de sedimentação e, indiretamente, a composição do Bloco Paranapanema e como sua porção leste se comportou durante o Neoproterozoico através de sua interação com a Placa São FranciscoCongo. Os objetos de estudo foram unidades metassedimentares do Orógeno Brasília Meridional, adjacente à porção nordeste do Bloco Paranapanema.

\subsection{Justificativa}

Espessos pacotes metassedimentares, empilhados em uma sequência neoproterozoica de nappes, decorrente da interação entre os blocos Paranapanema e São Francisco-Congo, constituem geologicamente a porção sul do Orógeno Brasília e registram uma longa e complexa história.

A importância de estudos como este se ancoram no fato de que a geologia do embasamento do Bloco Paranapanema é praticamente desconhecida, já que grande parte deste se encontra recoberta pelas espessas camadas de sedimentos da Bacia do Paraná. O estudo e compreensão da evolução das unidades (meta)sedimentares nas periferias do bloco e que se envolveram na construção das faixas móveis neoproterozoicas adjacentes, podem fornecer evidências tanto da composição do próprio embasamento do Paranapanema, quanto o modo como ele se comportou durante sua interação, da subducção à colisão, com São Francisco-Congo. 
A proveniência sedimentar, através dos métodos $\mathrm{U}-\mathrm{Pb}$, Lu-Hf e ETR em zircão detrítico, aliado às assinaturas isotópicas de $\mathrm{Nd}$ e $\mathrm{Sr}$ em rocha total, contribuiu para a caracterização das fontes dos sedimentos dispostos na margem nordeste do Bloco Paranapanema. Tais parâmetros foram comparados com a geologia conhecida dos terrenos adjacentes para a determinação ou exclusão das possíveis fontes dos sedimentos.

Os pacotes metassedimentares abordados foram os das unidades intermediária e superior da Nappe Andrelândia - Unidade Santo Antônio e Unidade Serra da Boa Vista, respectivamente - e rochas metassedimentares da Nappe Liberdade, todos na porção oriental do Sistema de Nappes Andrelândia.

Fez-se também necessária a investigação da idade e a caracterização do metamorfismo de subducção pré-colisão Paranapanema-São Francisco/Congo utilizando-se rochas retroeclogíticas da base da Nappe Liberdade. Desta forma, foi obtido um melhor esboço e controle do início da interação entre os blocos.

\subsection{Objetivos}

O objetivo principal foi traçar um panorama paleogeográfico da margem nordeste do Bloco Paranapanema, alicerçado no estudo da proveniência sedimentar e da paleogeografia de unidades metassedimentares do Orógeno Brasília Meridional. Para tanto, fez-se necessário:

- Caracterização das idades, das composições das rochas que originaram os (meta)sedimentos e dos reservatórios mantélicos originais, através de investigações geocronológicas e isotópicas, por U-Pb e Lu-Hf, e geoquímicas dos elementos terras raras, por LA-ICP-MS, utilizando-se cristais detríticos de zircão;

- Caracterização dos ambientes tectônicos em que se formaram e/ou que foram erodidas as rochas-fonte dos sedimentos, através de análises geoquímicas de rocha-total;

- Análises isotópicas de Rb-Sr e Sm-Nd, através de geoquímica de rocha-total, para o estabelecimento de um modelo petrogenético da área-fonte;

- Abordagem metamórfica a partir de estudos petrográficos da textura e paragêneses minerais das rochas e através das composições de Th e $U$ em sobrecrescimentos metamórficos de zircão;

Paralelamente ao estudo de proveniência sedimentar, foi abordado o tema do metamorfismo de alta pressão através de cristais metamórficos de zircão e grãos de granada de rochas retroeclogíticas, através de dados $\mathrm{U}-\mathrm{Pb}$, $\mathrm{Lu}-\mathrm{Hf}$ e elementos terras raras em zircão, e elementos maiores e terras raras em porções internas e externas de grãos de granada.

A partir destes aspectos pretendeu-se responder as questões: (i) em quais ambientes tectônicos foram depositados os sedimentos originários das unidades estudadas 
e o que pode indicar as diferenças composicionais entre elas; (ii) quais foram os principais conjuntos de áreas-fonte, baseados em idades U-Pb e composição de Lu-Hf e ETR em zircão, dos sedimentos das nappes Andrelândia e Liberdade, no setor Oriental do Sistema de Nappes Andrelândia; (iii) as unidades do Sistema de Nappes Andrelândia possuem afinidades Paranapanema, afinidades São Francisco-Congo, ou Amazonas; (iv) idade e duração do metamorfismo de subducção e o início do metamorfismo de colisão.

\subsection{Localização geográfica}

A área de estudo abordada neste trabalho encontra-se no sudeste brasileiro, ao sul do Estado de Minas Gerais. O acesso aos municípios de Caxambu, Cruzília, Aiuruoca, Bom Jardim de Minas e Santana do Garambéu pode ser realizado, a partir da cidade de São Paulo, pela Rodovia Fernão Dias (BR-381) até a região de Careaçu, onde pega-se a rodovia BR-456 e a BR-460 para acesso à rodovia BR-267 que interliga os municípios de Caxambu e Juiz de Fora. Já para o acesso aos municípios mais ao norte, Itumirim, Luminárias, Carrancas, São João Del Rei, Tiradentes, Barroso e Barbacena, segue-se, pela Rodovia Fernão Dias, até Lavras, de onde pega-se a rodovia BR-265 que interliga Lavras à Barbacena (Figura 1-1).

Figura 1-1. Mapa da localização geográfica da área de estudo com a localização dos afloramentos estudados neste trabalho. A figura-base é o mapa altimétrico da região, retirado do Brasil em Relevo - EMBRAPA. 


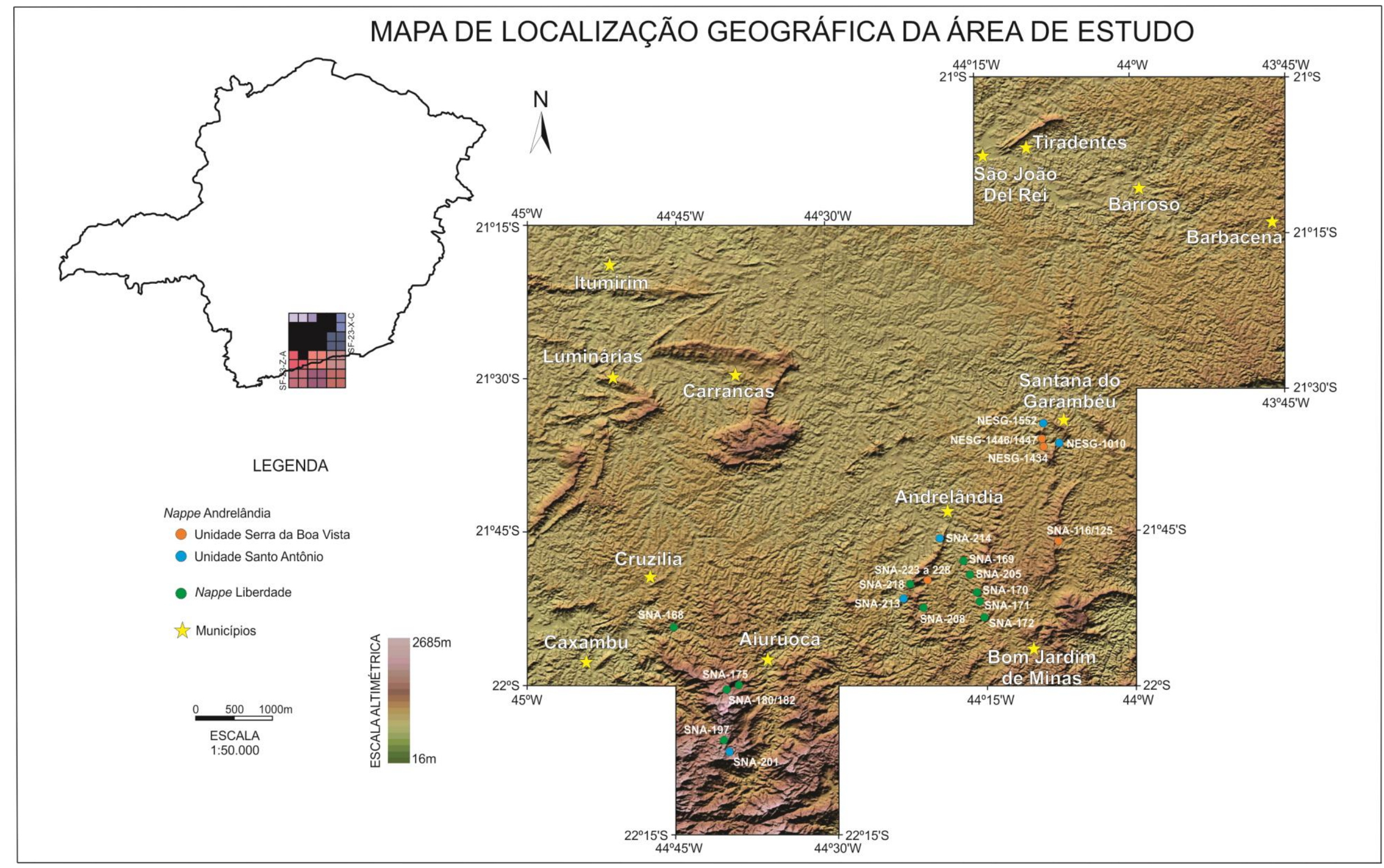




\subsection{Introdução Geológica}

\subsubsection{Proveniência sedimentar}

O estudo de proveniência sedimentar se utiliza de diversas áreas da geologia mineralogia, geoquímica, geocronologia, sedimentologia e petrologias ígnea e metamórfica e tem como principais objetivos descobrir a localização e a natureza das áreas-fonte dos sedimentos, quais caminhos foram percorridos pelos sedimentos a partir de sua fonte até a bacia de deposição e os fatores que influenciam na composição das rochas sedimentares, como relevo, clima e diferentes ambientes tectônicos. Informações a respeito da proveniência de sedimentos exibem papeis importantes em reconstruções paleogeográficas, nos deslocamentos laterais de orógenos, na caracterização de crosta que não estão mais expostas, entre outros aspectos, importantes para o reconhecimento e entendimento da evolução do planeta (HAUGHTON; TODD; MORTON, 1991).

No caso de rochas sedimentares, a validade e alcance de qualquer estudo de proveniência sedimentar são determinados por diversos aspectos em relação à rocha sedimentar/sedimentos: granulação, grau de alteração, disponibilidade de diversos dados, alcance dos processos diagenéticos, entre outros. Em adição deve ser considerado o grau de mudança que o material sedimentar original sofreu em relação à composição de sua fonte, como intemperismo, erosão, abrasão, segregação hidráulica, diagênese e reciclagem sedimentar (HAUGHTON; TODD; MORTON, 1991).

O estudo da proveniência de arenitos geralmente baseia-se em diversas técnicas, já que a grande parte destas rochas compreende uma mistura de diferentes fontes. Além da determinação da composição QFL (quartzo, feldspatos e fragmentos líticos) (DICKINSON; SUCZEK, 1979), deve ser levado em consideração fatores temporais e espaciais, como sedimentos correlatos ou não, de primeiro ciclo ou reciclados, intrabacinais ou extrabacinais. O método convencional de análise de minerais pesados tem sido revitalizado a partir de estudos que consideram as diferentes composições dentro de uma mesma espécie de mineral, evitando alguns controles que regem a distribuição de minerais pesados na subsuperfície. Além disso, a composição de minerais específicos pode ter implicações importantes para a determinação da área-fonte. Já a determinação da proveniência de argilitos é dificultada por causa da rápida alteração diagenética dos argilominerais primários durante o soterramento, e por mais que a mineralogia primária destas rochas seja facilmente modificada é comumente assumido que a química original da rocha se mantém inalterada, possibilitando análises isotópicas e de elementos maiores e traços para determinar sua proveniência (HAUGHTON; TODD; MORTON, 1991). O desenvolvimento de estudos geoquímicos de elementos traço e terras raras em rochas de granulação fina têm se mostrado de grande valia: a uniformidade dos padrões de elementos terras raras em 
folhelhos pós-arqueanos têm sido utilizados para estimar a composição média da crosta continental superior (TAYLOR; MCLENNAN, 1985).

No entanto, quando se trata de rochas sedimentares metamorfisadas, as texturas e estruturas primárias, assim como sua mineralogia, são alteradas e a abordagem e aplicação do estudo de proveniência sedimentar como descrita anteriormente, são inadequadas. 0 estudo geoquímico de rochas metamórficas parte do pressuposto que o sistema se mantém fechado, não havendo perdas ou ganhos químicos, no entanto esta assertiva não é verdadeira. Desta forma, assumir que a composição química de uma rocha sedimentar não se modifica durante os processos metamórficos pode, dependendo do conjunto de rochas estudadas, levar a desvios significativos de interpretação. Um mineral pesado - o zircão que é usualmente utilizado nos estudos de proveniência sedimentar, sofre poucas alterações durante o metamorfismo e desta forma é amplamente utilizado nestes casos. Análises de elementos traço, terras raras e $\mathrm{Lu}-\mathrm{Hf}$, além da idade $\mathrm{U}-\mathrm{Pb}$, são abordagens que auxiliam na determinação da presença de diferentes fontes com características químicas e petrogenéticas distintas, e a partir delas é possível se estimar, no tempo, o ambiente tectônico da sedimentação. Mesmo assim, quaisquer aplicação de técnicas de proveniência sedimentar em rochas metamórficas deve ser realizada com cautela e sempre ponderar a confiabilidade dos resultados.

\subsubsection{Evolução Geotectônica pré-Gondwana Ocidental}

Os processos de quebra e construção de supercontinentes pretéritos há muito são alvos de pesquisas de diferentes áreas do conhecimento, e os esboços paleogeográficos acerca do posicionamento global e intercontinental continuam sendo construídos. Como parte deste quebra-cabeça está a ruptura do Supercontinente Rodinia e a construção de Gondwana (CONDIE, 2001 e 2003; ROGER; SANTOSH, 2002; CORDANI et al., 2003; ZHAO et al., 2004; THOVER et al., 2006; LI et al., 2008; FUCK et al., 2008; CORDANI et al., 2009, 2010; PISAREVSKY et al., 2014). Destes processos, aqueles do Neoproterozoico e conhecidos como a colagem orogênica Brasiliano-Pan Africana do Gondwana Ocidental, encontram-se no registro diacrônico da maioria dos orógenos brasileiros. É sabido que a quebra de Rodínia ocorreu em diferentes momentos, assim como a dispersão dos diversos blocos que o constituía, desta forma não havendo uma idade concisa de construção e quebra deste paleocontinente (FUCK; BRITO NEVES; SCHOBBENHAUS, 2008). Diferentes hipóteses sugerem que os principais blocos continentais constituíam uma única placa Rodínia - ou que alguns blocos ocupavam placas distintas.

A aplicação de estudos paleomagnéticos tem sido imprescindível para a reconstrução da paleo-latitude dos blocos cratônicos que estiveram presentes na amalgamação de Gondwana. A escassez de dados paleomagnéticos em certos blocos 
inviabiliza seus posicionamentos ao longo do Neoproterozoico, fazendo com que sejam necessárias outras abordagens, indiretas, como proveniência sedimentar. Por muitas vezes estes estudos deixam de lado blocos que estão encobertos pelas bacias sedimentares paleozoicas, como Bacia do Paraná e Parnaíba, mas que tiveram papeis importantes durante as orogenias neoproterozoicas brasileiras, como é o caso do Bloco Paranapanema.

As reconstruções paleogeográficas que posicionam os blocos que futuramente construiriam Gondwana, a partir de dados de polos magnéticos, usualmente assumem que os crátons Amazonas e Oeste-África constituíam um único continente desde o Mesoproterozoico (TROMPETTE, 1994) e que também a semelhança das histórias acrescionárias no Paleoproterozoico-Mesoproterozoico entre a Amazônia, (províncias Ventuari-Tapajós e Rio Negro-Juruena) e Báltica (orógenos Svecofennian e Gothian, JOHANSSON, 2014, 2009; PISAREVSKY et al., 2014), poderia posicioná-los juntos. No entanto, existem evidências de que um orógeno de idade grenvilliana truncaria as províncias do Cráton Amazônas em sua porção setentrional, inviabilizando a continuidade entre Amazônia e Báltica (FUCK; BRITO NEVES; SCHOBBENHAUS, 2008). Já no fim do Mesoproterozoico ( 1,2 Ga), acredita-se que a Amazônia compartilhava a mesma placa tectônica de Laurentia, evidenciado pela similaridade entre as faixas Sunsás e Grenville. Dados paleomagnéticos suportam a teoria de que uma sutura grenvilliana teria agrupado o Cráton Amazonas (juntamente com o Oeste África) e Laurentia (TOHVER; D'AGRELLAFILHO; TRINDADE, 2006). Entre $\sim 1,2 \mathrm{Ga}$ e $\sim 0,6 \mathrm{Ga}$ as posições paleomagnéticas colocavam Oeste África-Amazonas próximo à Laurentia, no entanto, no final do Neoproterozoico, Laurentia inicia um drift em direção à latitudes equatorianas, enquanto que Oeste África-Amazonas permaneceria quase estático entre $\sim 0,6 \mathrm{Ga}$ e o fim do Cambriano ( 0,52 Ga), em maiores latitudes. Essa separação reflete a abertura do paleoceano lapetus entre Amazônia e Laurentia (TOHVER; D’AGRELLA-FILHO; TRINDADE, 2006).

Os dados paleomagnéticos do Cráton São Francisco-Congo são usualmente interpretados a partir da inferência que ambos os blocos estavam interligados durante o Mesoproterozoico, e levam a considerar que este continente não fazia parte de Rodínia, assim como Kalahari e Arabia-Nubia (CORDANI et al., 2009; TOHVER; D'AGRELLA-FILHO; TRINDADE, 2006).

A transição entre Rodínia e Gondwana Ocidental através dos polos paleomagnéticos, destaca dois principais momentos de amalgamação: junção entre São Francisco-Congo, Kalahari, Rio de la Plata e Arabia-Nubia entre 0,58-0,55 Ga para a formação do Gondwana Central; e a colisão entre estes blocos com Oeste África-Amazonas, já no Cambriano (TOHVER; D'AGRELLA-FILHO; TRINDADE, 2006). No entanto, há evidências da chegada da Amazônia em aproximadamente $\sim 0,62 \mathrm{Ga}$, a partir de idades de colisão na borda oeste do Cráton São Francisco-Congo, o que implica que Laurentia, ainda conectada à Amazônia, fez parte de Gondwana antes da abertura do Oceano lapetus. Já o aulacógeno de 
Tucavaca, uma das maiores unidades tectônicas extensionais associada a separação de Amazônia e Laurentia, indica que este evento pode ter ocorrido pouco depois de 0,6 Ga (CORDANI et al., 2009).

Sínteses geológicas recentes como as de Kröner e Cordani (2003), Cordani (2010) e de Brito Neves e Fuck (2013) segmentaram o embasamento da Plataforma Sul-Americana em dois amplos domínios geotectônicos: o domínio Amazonas ou pré-Brasiliano (de afinidades Laurencianas) e o domínio Brasiliano (de afinidades Gondwânicas). Essa abordagem permitiu uma correlação intercontinental entre fragmentos de arcos insulares e lascas tectônicas eclogíticas que, no Neoproterozoico, deixaram registros desde o contraforte alpino na África Ocidental, à Borborema e Centro-Oeste brasileiros, por mais de $5.000 \mathrm{~km}$ lineares. Os registros geológicos de regimes convergentes de placas oceânicas e de uma sucessão de colisões entre blocos continentais ao longo de uma faixa contínua (ANCELMI et al., 2015; ARTHAUD et al, 2015; BERGER ET AL., 2011, 2014; BOSCH et al., 2015; CABY, 2014; CABY; MONIÉ, 2003; ENNIH; LIÉGEOIS, 2008; JUNGES et al., 2002; LAUX et al., 2005; MATTEINI et al., 2010; PIMENTEL et al., 1997, 2000) definiriam um sistema orogênico denominado de Gondwana Ocidental por Ganade Araujo (2012, 2016). Este sistema orogênico seria a cicatriz do fechamento diacrônico de um grande oceano, o Oceano Farusiano-Goiás (CORDANI et al., 2013), cujos registros geológicos apontam para uma longa vida, compatível, no tempo e extensão, com o Oceano Pacífico, ou seja, ca. 250 m.y.

O Bloco Paranapanema constituiu parte importante na construção do Orógeno Brasília Meridional em sua interação com o Cráton São Francisco-Congo, no entanto não existem dados paleomagnéticos que o posicionem no quadro geral da formação de Gondwana. É sabido, através de estudos geofísicos de sismicidade intraplaca, anisotropia magnética e assinatura gravimétrica (ASSUMPÇÃO et al., 2004, 2006, 2013; FENG; ASSUMPÇÃO; VAN DER LEE, 2004; LESQUER et al., 1981; MANTOVANI; BRITO NEVES, 2009; MANTOVANI; BRITO-NEVES, 2005; MANTOVANI; DE FREITAS; SHUKOWSKY, 2001; MANTOVANI et al., 2005; ROCHA; SCHIMMEL; ASSUMPÇÃO, 2011), que há uma quilha cratônica sob a Bacia do Paraná e que esta constitui um bloco pré-brasiliano Paranapanema - que interagiu com os crátons São Francisco-Congo e Amazonas durante a colagem gondwânica, tendo sido responsável pela construção das faixas móveis Brasília Meridional e Paraguai.

\subsubsection{Eclogitos}

As rochas metamorfisadas em fácies eclogito são observadas comumente em zonas de subducção nas quais a placa oceânica subductada leva porções da crosta continental sob a placa cavalgante. A grande parte de terrenos de alta pressão são compostos por 
rochas de composições crustais, com raras ocorrências de rochas eclogíticas associadas à crostas oceânicas. A presença de rochas metamorfisadas nestas condições pode conter informações a respeito da idade, duração e condições dos processos orogênicos iniciais.

Geralmente eclogitos ocorrem como lentes tectônicas em rochas metamórficas que não registram o mesmo regime bárico. Podem ter sido colocadas tectonicamente nestas rochas ou representarem relíquias de alta pressão entre rochas que também experimentaram o metamorfismo de alta pressão (DAVIS; WHITNEY, 2008).

O metamorfismo de pressão ultra-alta refere-se às rochas que experimentaram pressões mantélicas de no mínimo 25 kbar. Nessas condições o quartzo, instável, dá lugar ao polimorfo de alta pressão, coesita, próximo a $100 \mathrm{~km}$ de profundidade. Em profundidades de aproximadamente $120 \mathrm{~km}$ ocorre a transformação de grafita para diamante metamórfico. Tais minerais incomuns são os principais diagnósticos do metamorfismo de pressão ultraalta. Pensava-se que sob crostas espessadas de aproximadamente $80 \mathrm{~km}$ (ex. Tibet) as condições de metamorfismo seriam tão severas que as rochas entrariam em fácies eclogito de pressão ultra-alta, o que não ocorre, pois nessas condições o quartzo ainda se encontra em seu campo de estabilidade (GILOTTI, 2013).

A coesita, o polimorfo de alta pressão de $\mathrm{SiO}_{2}$, foi primeiramente observada por Christian Chopin em 1984, que descreveu o mineral como pequenas inclusões em granadas de um quartzito de Dora-Maira, na Itália. No mesmo ano, David Smith descobriu inclusões de coesita em clinopiroxênios de um eclogito de Grytting, em Western Gneiss Region, na Noruega. Mais tarde, em 1990, foram descritos inclusões de microdiamantes em granadas de eclogitos, gnaisses e xistos na unidade Kumdy Kol do maciço Kokchetav no Kazaquitão, por Sobolov e Shatsky. Diferentemente dos diamantes com qualidade de gema encontrados em terrenos kimberlíticos, esses microdiamantes são geralmente cristais relativamente mal formados e esqueletais.

As condições de metamorfismo de rochas eclogíticas de pressão ultra-alta podem ser estimadas na presença de coesita e/ou diamante. No entanto, são poucos os terrenos onde estes minerais índices são observados, sendo necessárias outras ferramentas para o estudo do metamorfismo e da trajetória P-T-t. O estudo do metamorfismo de rochas sem coesita e/ou diamante pode ser realizada através de minerais que comumente ocorrem zonados, como fengita e granada. $O$ volume molar desses minerais foi explorado como sendo uma função da composição e da pressão destas rochas e, então, como resultado, as propriedades termodinâmicas destes minerais, como entalpia, entropia e volume molar são conhecidos. Sendo assim, cálculos que utilizam dados termodinâmicos podem posicionar uma fase mineral específica em equilíbrio em um campo específico de pressão e temperatura.

Atualmente são reconhecidos pouco mais de vinte terrenos de pressão ultra-alta no mundo com a presença de coesita ou microdiamante e se encontram, todos, em orógenos 
fanerozóicos (CABY et al., 2014; MASSONNE, 2013, entre outros). A grande parte dos exemplos descritos é proveniente de metamorfismo de crostas continentais, no entanto alguns exemplos de crosta oceânica são observados, como é o caso de Lago di Cignana, Zambezi e Tianshan. Esses terrenos são resultados de orógenos fanerozóicos de colisão continente-continente, o que contrasta com chaminés kimberlíticas pré-cambrianas com diamantes de qualidade gemológica (HARLOW; DAVIES, 2005).

A maior parte das rochas expostas em terrenos de pressão ultra-alta exibe uma assembleia mineral comum, como quartzo, anfibólio, granada, feldspato, biotita e mica branca, podendo ser derivadas de protólitos ígneos ou sedimentares e geralmente estão associadas a quartzitos e margas. Um indicativo para a presença de metamorfismo de pressão ultra-alta é a presença de lentes de eclogitos junto à gnaisses quartzo-feldspáticos (GILOTTI, 2013). 


\section{CAPÍTULO 2}

\section{MATERIAIS E MÉTODOS}

\subsection{Trabalhos de campo e amostragem}

Os trabalhos de campo, realizados em etapas distintas nas regiões de AiuruocaArantina-Andrelândia-Carrancas-Barroso, MG serviram-se das folhas topográficas, de escala 1:50.000: Caxambu (SF-23-X-C-IV-3), Aiuruoca (SF-23-X-C-IV-4), Alagoa (SF-23-ZA-I-2), Andrelândia (SF-23-X-C-V-1), Santana do Garambéu (SF-23-X-C-V-2), Arantina (SF23-X-C-V-3), Bom Jardim de Minas (SF-23-X-C-V-4), Itumirim (SF-23-X-C-I-3), Itutinga (SF23-X-C-I-4), Tiradentes (SF-23-X-C-II-2), Barbacena (SF-23-X-C-III-1) e Piedade do Rio Grande (SF-23-X-C-II-4). A articulação destas folhas encontra-se na Figura 2-1.

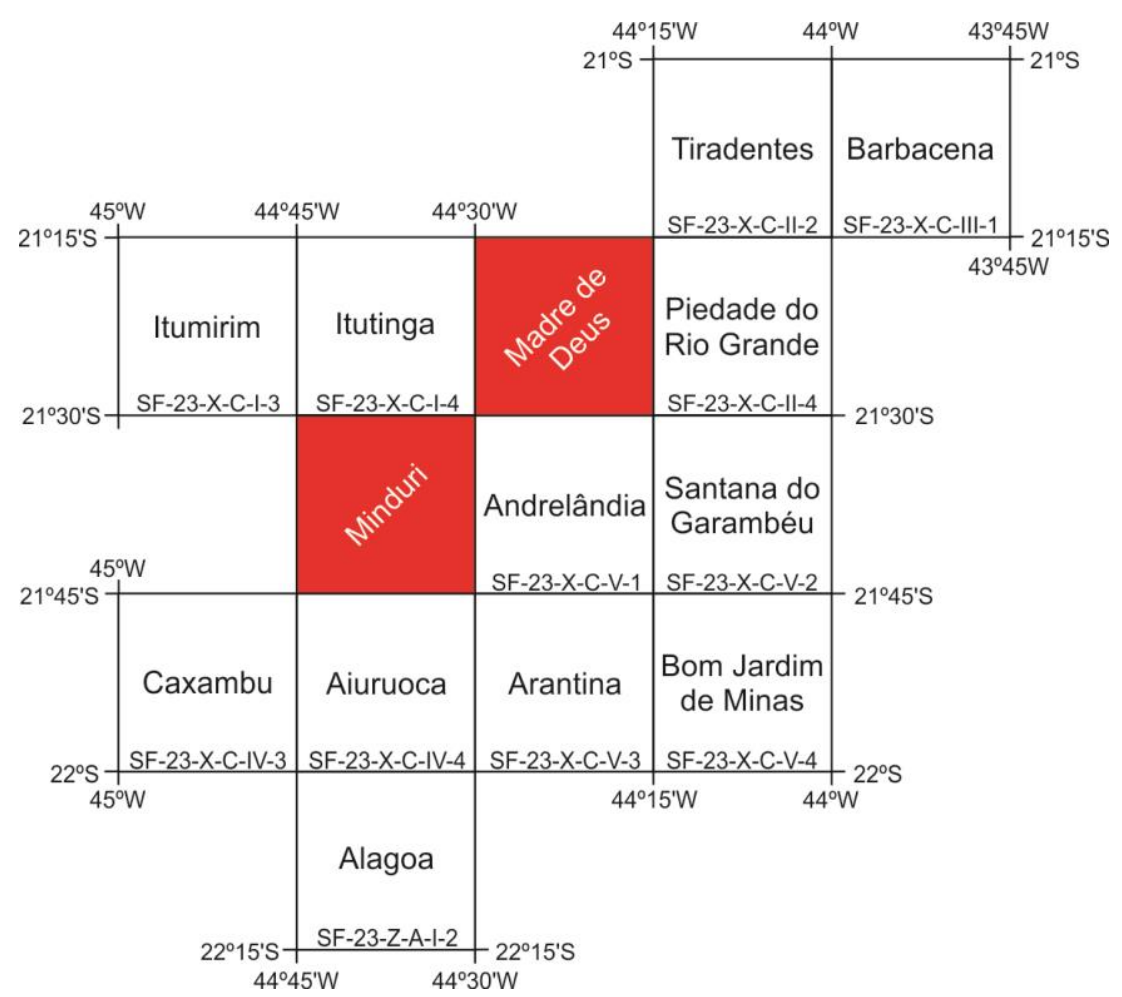

Figura 2-1. Mapa da articulação das folhas topográficas 1:50.000 utilizadas nas etapas de campo. Em vermelho estão as folhas que não foram utilizadas, mas que se encontram na região de estudo.

Em todas as etapas de campo foram realizadas amostragens dos litotipos de interesse, que se juntaram ao acervo de amostras analisadas pelo orientador, por Lima (2013) e por Frugis (2013). As amostras foram selecionadas para análises voltadas para o estudo de proveniência sedimentar e encontram-se sumarizadas na Tabela 2-1. 


\begin{tabular}{|c|c|c|c|c|c|c|c|c|c|c|c|c|}
\hline \multirow{3}{*}{ Afloramento } & \multirow{2}{*}{\multicolumn{2}{|c|}{$\begin{array}{c}\text { Coordenadas } \\
\text { UTM }\end{array}$}} & \multirow{3}{*}{ Und. } & \multirow{3}{*}{ Rocha } & \multirow{3}{*}{ 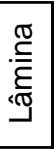 } & \multicolumn{3}{|c|}{ Geoq. Elemental } & \multicolumn{4}{|c|}{ Geoq. Isotópica } \\
\hline & & & & & & \multirow{2}{*}{\multicolumn{2}{|c|}{\begin{tabular}{|c|c|} 
FRX & ICP \\
RT \\
\end{tabular}}} & \multirow{3}{*}{\begin{tabular}{|c|} 
ETR - ICP \\
Min \\
\end{tabular}} & $\mathrm{Sm}-\mathrm{Nd}$ & $\mathrm{Rb}-\mathrm{Sr}$ & \multirow{2}{*}{\multicolumn{2}{|c|}{\begin{tabular}{|c|c|} 
Lu-Hf & U-Pk \\
$\mathrm{Zr}$ \\
\end{tabular}}} \\
\hline & $\mathrm{X}$ & $\mathrm{Y}$ & & & & & & & \multicolumn{2}{|c|}{\begin{tabular}{|l|} 
RT \\
\end{tabular}} & & \\
\hline SNA-116 & 590615 & 7595841 & USBV & metapsamito & & & & & & & & $x$ \\
\hline SNA-125 & 591041 & 7596018 & USBV & metapelito & $x$ & & & $x(Z r)$ & & & $x$ & $x$ \\
\hline SNA-168 & 524541 & 7575493 & NpLib & metavulcanoclástica & $x$ & $x$ & $x$ & $\mathrm{X}(\mathrm{Zr})$ & $x$ & $x$ & $x$ & $x$ \\
\hline SNA-169 & 574785 & 7588013 & NpLib & metapelito & $x$ & $x$ & $x$ & & & & & $x$ \\
\hline SNA-170 & 576172 & 7583968 & NpLib & calciossilicática & $x$ & $x$ & $x$ & & & & & \\
\hline SNA-171 & 576340 & 7583038 & NpLib & metapelito & $x$ & & & & & & & \\
\hline SNA-172 & 577066 & 7580288 & NpLib & metapelito & $x$ & & & & & & & \\
\hline SNA-172E & 577066 & 7580288 & NpLib & metapelito & $x$ & $x$ & $x$ & $x(Z r)$ & & & $x$ & $x$ \\
\hline SNA-175 & 535138 & 7566390 & NpLib & metapelito & $x$ & $x$ & $x$ & & & & & \\
\hline SNA-180A & 532280 & 7564361 & NpLib & metapsamito & $x$ & & & $x(Z r)$ & & & $x$ & $x$ \\
\hline SNA-180B & 532280 & 7564361 & NpLib & metapelito & $x$ & & & & & & & \\
\hline SNA-182 & 531322 & 7562316 & NpLib & metapelito & $x$ & & & & & & & \\
\hline SNA-197 & 532232 & 7561261 & NpLib & metapelito & $x$ & & & & & & & \\
\hline SNA-201 & 533600 & 7560848 & USA & metawacke & $x$ & $x$ & $x$ & $\mathrm{x}(\mathrm{Zr})$ & $x$ & $x$ & $x$ & $x$ \\
\hline SNA-205A & 574407 & 7586316 & NpLib & metabásica & $x$ & $x$ & $x$ & & & & & \\
\hline SNA-205B & 574407 & 7586316 & NpLib & metabásica & $x$ & $x$ & $x$ & $\begin{array}{c}x(Z r e \\
\text { Grt })\end{array}$ & $x$ & $x$ & $x$ & $x$ \\
\hline SNA-208 & 566175 & 7579666 & NpLib & metabásica & $x$ & $x$ & $x$ & & & & & \\
\hline SNA-213 & 563231 & 7580771 & USA & metawacke & $x$ & $x$ & $x$ & $\mathrm{x}(\mathrm{Zr})$ & & & $x$ & $x$ \\
\hline SNA-214 & 570551 & 7591158 & USA & metawacke & $x$ & $x$ & $x$ & & & & & \\
\hline SNA-218 & 565166 & 7583747 & NpLib & metavulcanoclástica & $x$ & $x$ & $x$ & & & & & \\
\hline SNA-223 & 569290 & 7584633 & USBV & metapelito & $x$ & & & & & & & \\
\hline SNA-224 & 568647 & 7584473 & USBV & metapsamito & $x$ & & & & & & & \\
\hline SNA-225 & 568733 & 7584612 & USBV & metapelito & $x$ & $x$ & $x$ & & & & & \\
\hline SNA-227 & 568315 & 7584732 & USBV & metapelito & $x$ & & & & & & & \\
\hline SNA-228 & 568503 & 7584193 & USBV & metapelito & $x$ & $x$ & $x$ & $x(Z r)$ & & & $x$ & $x$ \\
\hline NESG-1010 & 591771 & 7609604 & USA & metawacke & $x$ & $x$ & $x$ & $x$ & $x$ & $x$ & $x$ & $x$ \\
\hline NESG-1552 & 590262 & 7613501 & USA & metabásica & $x$ & $x$ & $x$ & $x$ & $x$ & $x$ & $x$ & $x$ \\
\hline NESG-1434 & 589489 & 7609338 & USBV & metapelito & $x$ & $x$ & $x$ & & $x$ & & $x$ & $x$ \\
\hline NESG-1446 & 589665 & 7610447 & USBV & metapelito & $x$ & $x$ & $x$ & & & & $x$ & $x$ \\
\hline NESG-1447 & 589599 & 7610365 & USBV & metapelito & $x$ & $x$ & $x$ & & $x$ & & & $x$ \\
\hline
\end{tabular}

Tabela 2-1. Resumo das relações amostra versus análises utilizadas nesta dissertação. $A$ abreviação das fases minerais segue Kretz (1983). FRX = fluorescência de Raio-X; ETR = elementos terras raras; ICP = Laser Ablation Inductively Coupled Plasma Spectrometry; RT = rocha-total; Min = mineral; USBV = Unidade Serra da Boa Vista; USA = Unidade Santo Antônio; NpLib = Nappe Liberdade.

A localização dos pontos estudados, amostrados e analisados encontram-se no mapa geológico do Anexo I.

\subsection{Laminação e petrografia}

$\mathrm{Na}$ Seção de Laminação do IGc-USP foram confeccionadas lâminas de $30 \mu \mathrm{m}$ de espessura que foram descritas no Laboratório de Microscopia Petrográfica, utilizando-se microscópio Olympus BX50. 


\subsection{Elaboração da dissertação}

O texto desta dissertação foi escrito através do programa Word do pacote Microsoft Office Professional Plus 2013, e as tabelas inseridas foram confeccionadas no programa Excel deste mesmo pacote. Todas as figuras utilizadas foram feitas no software CorelDRAW® Graphics Suite $\mathrm{X} 7$, sendo elas figuras elaboradas pela autora ou gráficos e diagramas refeitos da literatura. Os gráficos dos dados das idades foram feitos através do software ISOPLOT® versão 4.11 (LUDWIG, 2008) e editados no CorelDRAW®.

\subsection{Geoquímica elemental em rocha-total}

\section{Preparação das amostras}

As amostras selecionadas para o estudo de geoquímica elemental em rocha-total foram preparadas no Laboratório de Tratamento de Amostras (LTA) do IGc-USP. O processo de preparação se deu com a limpeza e retirada das partes alteradas, cominuição do núcleo fresco em prensa hidráulica até fragmentos menores que $1 \mathrm{~cm}$ de diâmetro. Este material foi quarteado para a separação de cerca de $100 \mathrm{~g}$. Tais porções seguiram para o moinho de ágata para a obtenção de pó de granulação inferior a 200 mesh. Deste material foram confeccionadas as pastilhas prensadas, no próprio LTA, e as pastilhas fundidas no Laboratório de Química e ICP-AES/MS, também no IGc-USP. Após o processo de moagem, uma porção do pó de cada amostra foi micronizada, seca em estufa, homogeneizada com $20 \%$ de ligante em pó e então levada à prensa hidráulica para que fossem feitas as pastilhas prensadas. No caso das pastilhas fundidas, $1 \mathrm{~g}$ do pó foi misturado junto à $9 \mathrm{~g}$ de fundente para posterior fusão e confecção das pastilhas.

\subsubsection{Elementos maiores, menores e traço por Fluorescência de Raio-X}

\section{Análise e tratamento dos dados}

As análises dos elementos maiores, menores e traço por fluorescência de raio-x foram realizadas no Laboratório de Química e ICP-NAP Geoanalítica do IGc-USP, onde foi empregado o equipamento Philips - PW2400 e a metodologia utilizada está descrita em Mori et al. (1999). Os materiais de referência para o controle dos resultados foram o JB-1a (basalto) e o JG-1a (granodiorito) (Tabela 2-2). 


\begin{tabular}{|c|c|c|c|c|c|c|c|c|c|c|}
\hline \multirow{3}{*}{$\begin{array}{l}\text { Lotes } \\
\text { Padrão }\end{array}$} & \multicolumn{2}{|c|}{$\begin{array}{c}\text { SNA-205 A3, } \\
\text { A4, A5, SNA- } \\
\text { 205 B2, SNA- } \\
\text { 208, SNA-213, } \\
\text { SNA-214, SNA- } \\
\text { 218, SNA-225, } \\
\text { SNA-228, C- } \\
\text { 561, C-562 B, } \\
\text { C-571 a C-574 }\end{array}$} & \multicolumn{2}{|c|}{$\begin{array}{l}\text { SNA-168, } \\
\text { SNA-169, } \\
\text { SNA-170, } \\
\text { SNA-170 D }\end{array}$} & \multirow[t]{2}{*}{$\begin{array}{c}\text { SNA- } \\
169, \\
\text { SNA-172 } \\
\text { E, SNA- } \\
175, \\
\text { SNA-201 } \\
\\
\text { JB-1a }\end{array}$} & \multicolumn{2}{|c|}{$\begin{array}{l}\text { NESG-1010, } \\
\text { NESG-1434, } \\
\text { NESG-1447, } \\
\text { NESG-1552 }\end{array}$} & $\mathrm{JB}-1 \mathrm{a}$ & JG-1a & \multirow[t]{3}{*}{$\begin{array}{l}\text { Limite } \\
\text { de } \\
\text { Detec. }\end{array}$} \\
\hline & JB-1a & JG-1a & $\mathrm{JB}-1 \mathrm{a}$ & JG-1a & & JB 1a & $J G 1 a$ & \multirow{2}{*}{\multicolumn{2}{|c|}{ recomendado }} & \\
\hline & obtido & obtido & obtido & obtido & obtido & obtido & obtido & & & \\
\hline $\mathrm{SiO}_{2}$ & 52,97 & 72,38 & 52,17 & 72,32 & 52,15 & 52,64 & 72,5 & 52,16 & 72,19 & 0,03 \\
\hline $\mathrm{TiO}_{2}$ & 0,131 & 0,243 & 1,291 & 0,242 & 1,301 & 1,293 & 0,24 & 1,3 & 0,25 & 0,003 \\
\hline $\mathrm{Al}_{2} \mathrm{O}_{3}$ & 14,81 & 14,25 & 14,79 & 14,04 & 14,82 & 14,63 & 14,30 & 14,51 & 14,22 & 0,02 \\
\hline $\mathrm{Fe}_{2} \mathrm{O}_{3}$ & 9,10 & 1,98 & 8,96 & 1,97 & 9,03 & 9,01 & 1,95 & 9,1 & 2,05 & 0,01 \\
\hline $\mathrm{MnO}$ & 0,10 & 0,06 & 0,146 & 0,06 & 0,147 & 0,145 & 0,06 & 0,15 & 0,06 & 0,002 \\
\hline $\mathrm{MgO}$ & 7,80 & 0,58 & 7,79 & 0,52 & 7,85 & 7,80 & 0,66 & 7,75 & 0,69 & 0,01 \\
\hline $\mathrm{CaO}$ & 9,36 & 2,21 & 9,34 & 2,14 & 9,28 & 9,27 & 2,09 & 9,23 & 2,13 & 0,01 \\
\hline $\mathrm{Na}_{2} \mathrm{O}$ & 2,85 & 3,53 & 2,78 & 3,34 & 2,72 & 2,82 & 3,47 & 2,74 & 3,41 & 0,02 \\
\hline $\mathrm{K}_{2} \mathrm{O}$ & 1,42 & 4,00 & 1,42 & 3,98 & 1,41 & 1,39 & 3,92 & 1,42 & 4,01 & 0,01 \\
\hline $\mathrm{P}_{2} \mathrm{O}_{5}$ & 0,264 & 0,080 & 0,255 & 0,081 & 0,262 & 0,252 & 0,08 & 0,26 & 0,08 & 0,003 \\
\hline Lol & 1,1 & 0,59 & 1,1 & 0,59 & 1,1 & 1,1 & 0,59 & 1,1 & 0,59 & 0,01 \\
\hline Total & 99,91 & 99,90 & 100,04 & 99,28 & 100,07 & 100,35 & 99,88 & \begin{tabular}{|c|}
99,72 \\
\end{tabular} & 99,68 & \\
\hline
\end{tabular}

Tabela 2-2. Valores obtidos para os materiais de referência durantes as análises. Valores em ppm.

\section{Aplicação}

A determinação da composição química de rochas (meta)sedimentares clásticas auxilia a restringir a composição das rochas fonte dos sedimentos, desta forma é esperado que estas composições representem a crosta continental superior exposta ao intemperismo (TAYLOR; MCLENNAN, 1985). As fontes das rochas sedimentares clásticas foram divididas, por estes autores, em: (i) rochas ígneas primárias (e seus equivalentes metamórficos) derivadas do manto através de um ou mais estágios de fusão parcial; (ii) rochas ígneas secundárias derivadas da refusão de rochas crustais pré-existentes; e (iii) rochas sedimentares e metassedimentares recicladas.

Os principais processos presentes no ciclo sedimentar incluem intemperismo, erosão química e física, transporte, deposição, litificação (diagênese e possivelmente metamorfismo) e também soerguimento e reciclagem. Os processos químicos e físicos envolvidos no ciclo sedimentar resultam no fracionamento químico dos elementos presentes nos diversos tipos de sedimentos. Reconhecer (e, quando possível, quantificar) os efeitos destes processos sobre as rochas é de grande importância, quando o objetivo é restaurar a evolução de rochas sedimentares (TAYLOR; MCLENNAN, 1985).

O intemperismo pode ser dividido em três estágios principais, descritos por Taylor e McLennan (1985) como: 
1. Estágio inicial - dominado pelos minerais primários e pela formação de fases amorfas, clorita e argilominerais, como esmecita, vermiculita, illita, com capacidade de troca de cátions.

2. Estágio intermediário - no qual a argila é dominada por argilominerais complexos, particularmente esmectita e menores quantidades de illita.

3. Estágio tardio - no qual a fração argila é dominada pela mineralogia caolinita-gibbsitaquartzo-óxido de ferro.

O avanço dos processos de intemperismo químico ocorrem em períodos de estabilidade tectônica, enquanto que altas taxas de erosão física geralmente seguem períodos de soerguimento.

Os feldspatos são os minerais reativos mais abundantes na crosta superior e desta forma os principais processos de alteração química incluem a degradação dos feldspatos e a formação de argilominerais (NESBITT; YOUNG, 1982). Sendo assim, Ca, Na e K são removidos do feldspato, aumentando a proporção de alumina em relação aos álcalis nos produtos do intemperismo. Com base nestas relações estes autores desenvolveram o índice de alteração química - CIA (sigla em inglês para Chemical Index of Alteration), calculado em proporções moleculares, através da equação:

$$
\mathrm{ClA}=\left[\mathrm{Al}_{2} \mathrm{O}_{3} /\left(\mathrm{Al}_{2} \mathrm{O}_{3}+\mathrm{CaO}^{*}+\mathrm{Na}_{2} \mathrm{O}+\mathrm{K}_{2} \mathrm{O}\right)\right] \times 100
$$

onde $\mathrm{CaO}^{*}$ representa a quantidade de $\mathrm{CaO}$ nas frações silicáticas da rocha. Valores de CIA iguais a 50 representam albita, anortita e feldspatos potássicos inalterados, enquanto que para o diopsídio este valor é zero. Para as rochas basálticas os valores de CIA variam entre 30 e 45, e para os granitos e granodioritos entre 45 e 55. Os índices de alteração química de muscovita, illita e montmorillonitas variam entre 75 e 85, já caolinitas e clorita apresentam os valores mais altos, próximos a 100. Desta forma os valores médios para folhelhos estão entre 70 e 75, pela grande quantidade de argilominerais (NESBITT; YOUNG, 1982). A Tabela 2-3 exemplifica os valores de índices de alteração química para diversos materiais.

\begin{tabular}{lc}
\hline & CIA \\
\hline Média da crosta continental superior & 50 \\
Till pleistocênico (matriz) & $50-55$ \\
Argilas glaciais pleitocênicas & $60-65$ \\
Loess & $55-70$ \\
Média de folhelhos & $70-75$ \\
Lamas do cone amazônico & $80-90$ \\
Argilas residuais & $85-100$
\end{tabular}


Tabela 2-3. Valores de índices de alteração química (CIA) da crosta continental superior e rochas sedimentares variadas. Adaptado de Nesbitt e Young (1982).

A razão Th/Sc é um índice sensível de composição, no qual valores baixos podem indicar heterogeneidade e geralmente fonte pouco diferenciada. Valores próximos a 1,0 são encontrados na crosta superior (TAYLOR; MCLENNAN, 1985), e utilizados como diferenciador de fontes félsicas e máficas (MCLENNAN et al., 1990). Cruzando estas informações com o índice de alteração química, como mostrado na Figura 2-2, tem-se que domínios regidos por alteração física e baixa razão Th/Sc são encontrados em regiões instáveis e orogênicas, enquanto que valores altos desta razão juntamente com intemperismo químico mais intenso (valores altos de CIA), são encontrados em áreas tectonicamente estáveis.

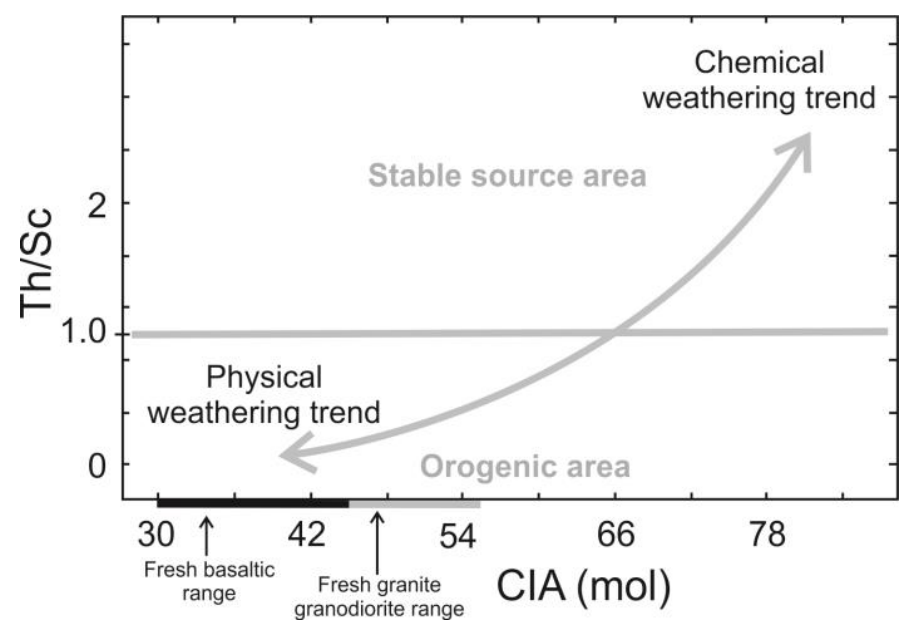

Figura 2-2. Diagrama da razão Th/Sc versus o índice de alteração química (CIA) para diferenciar ambiente orogênico de ambiente tectonicamente estável. (NESBITT; YOUNG, 1982; TAYLOR; MCLENNAN, 1985)

\subsubsection{Elementos traço e terras raras por LA-ICP-MS}

\section{Análise e tratamento dos dados}

As concentrações dos elementos traço e dos terras raras em rocha-total foram obtidas no Laboratório de Química e ICP-AES/MS, onde foi utilizado o espectrômetro de massa do tipo quadrupolo ELAN 6100DRC da PerkinEImer/Sciex. Os procedimentos seguidos durante as análises é descrito por Navarro (2008).

As amostras foram analisadas em 4 lotes distintos:

- Lote 1: amostras NESG-1010, NESG-1434, NESG-1447, NESG-1552 (LIMA, 2013), materiais de referência do Serviço Geológico do Japão: JG-3 - (granito) e JR-1 (riolito) (Tabela 2-4).

- Lote 2: amostras SNA-168, SNA-170 e SNA-172D, SNA-180B, materiais de referência do Serviço Geológico do Japão: JG-3 (granito) e JR-1 (riolito) (Tabela 2-4). 


\begin{tabular}{|c|c|c|c|c|c|c|c|c|c|c|}
\hline Lotes & \multicolumn{4}{|c|}{$\begin{array}{l}\text { NESG-1010, NESG-1434, } \\
\text { NESG-1447, NESG-1552 }\end{array}$} & \multicolumn{4}{|c|}{$\begin{array}{c}\text { SNA-168, SNA-170, } \\
\text { SNA-172D }\end{array}$} & \multicolumn{2}{|c|}{ Desvio Padrão } \\
\hline \multirow{2}{*}{ Padrão } & \multicolumn{2}{|c|}{ JG-3 } & \multicolumn{2}{|c|}{ JR-1 } & \multicolumn{2}{|c|}{ JG-3 } & \multicolumn{2}{|c|}{ JR-1 } & \multirow{2}{*}{ JG-3 } & \multirow{2}{*}{ JR-1 } \\
\hline & obtido & recom. & obtido & recom. & obtido & recom. & obtido & recom. & & \\
\hline $\mathrm{Rb}$ & 58,2 & 67,3 & 248 & 257 & 60,5 & 67,3 & 262 & 257 & 7,3 & 16 \\
\hline $\mathrm{Sr}$ & 344 & 379 & 23,9 & 29,1 & 360 & 379 & 30,5 & 29,1 & 29 & 5,2 \\
\hline $\mathrm{Y}$ & 15,4 & 17,3 & 41,1 & 45,1 & 15,4 & 17,3 & 43,0 & 45,1 & 1,5 & 5,2 \\
\hline $\mathrm{Zr}$ & 121 & 144 & 79,0 & 99,9 & 144 & 144 & 98,1 & 99,9 & 12 & 6,3 \\
\hline $\mathrm{Nb}$ & 6,86 & 5,88 & 14,7 & 15,2 & 5,56 & 5,88 & 14,8 & 15,2 & 0,85 & 1,7 \\
\hline Cs & 1,93 & 1,78 & 20,4 & 20,8 & 2,04 & 1,78 & 21,5 & 20,8 & 0,22 & 2,6 \\
\hline $\mathrm{Ba}$ & 448 & 466 & 46,7 & 50,3 & 418 & 466 & 54,2 & 50,3 & 44 & 10,2 \\
\hline $\mathrm{La}$ & 17,5 & 20,6 & 20,2 & 19,7 & 20,1 & 20,6 & 20,1 & 19,7 & 2,2 & 1,77 \\
\hline $\mathrm{Ce}$ & 32,3 & 40,3 & 40,0 & 47,2 & 40,9 & 40,3 & 48,4 & 47,2 & 4,8 & 4,3 \\
\hline $\mathrm{Pr}$ & 4,08 & & 5,82 & 5,58 & & 4,70 & 5,69 & 58 & 1,24 & 0,69 \\
\hline $\mathrm{Nd}$ & 14,9 & 17,2 & 22,4 & 23,3 & 17,0 & 17,2 & 23,0 & 23,3 & 1,8 & 2,8 \\
\hline $\mathrm{Sm}$ & 3,06 & 3,39 & 5,56 & 6,03 & 3,18 & 3,39 & 6,09 & 6,03 & 0,44 & 0,81 \\
\hline $\mathrm{Eu}$ & 0,86 & 0,9 & 0,28 & 0,3 & 0,85 & 0,90 & 0,29 & 0,3 & 0,08 & 0,041 \\
\hline $\mathrm{Gd}$ & 2,69 & 2,92 & 5,42 & 5,06 & 2,95 & 2,92 & 5,60 & 5,06 & 0,28 & 1,05 \\
\hline $\mathrm{Tb}$ & 0,43 & 0,46 & 0,96 & 1,01 & 0,42 & 0,46 & 1,00 & 1,01 & 0,05 & 0,2 \\
\hline Dy & 2,42 & 2,59 & 5,75 & 5,69 & 2,43 & 2,59 & 6,14 & 5,69 & 0,53 & 1,06 \\
\hline $\mathrm{Ho}$ & 0,51 & 0,38 & 1,26 & 1,11 & 0,51 & 0,38 & 1,37 & 1,11 & 0,16 & 0,24 \\
\hline $\mathrm{Er}$ & 1,47 & 1,52 & 3,84 & 3,61 & 1,45 & 1,52 & 4,04 & 3,61 & 0,36 & 0,91 \\
\hline $\mathrm{Tm}$ & 0,23 & 0,24 & 0,63 & 0,67 & 0,23 & 0,24 & 0,67 & 0,67 & 0,05 & 0,071 \\
\hline $\mathrm{Yb}$ & 1,62 & 1,77 & 4,52 & 4,55 & 1,62 & 1,77 & 4,71 & 4,55 & 0,35 & 0,46 \\
\hline $\mathrm{Lu}$ & 0,25 & 0,26 & 0,68 & 0,71 & 0,25 & 0,26 & 0,72 & 0,71 & 0,05 & 0,08 \\
\hline $\mathrm{Hf}$ & 4,14 & 4,29 & 5,06 & 4,51 & 4,96 & 4,29 & 5,05 & 4,51 & 0,41 & 0,67 \\
\hline $\mathrm{Pb}$ & 11,0 & 11,7 & 18,1 & 19,3 & 11,4 & 11,7 & 20,4 & 19,3 & 1,4 & 3,8 \\
\hline Th & 6,82 & 8,28 & 27,3 & 26,7 & 8,40 & 8,28 & 28,9 & 26,7 & 0,65 & 2,6 \\
\hline$U$ & 2,13 & 2,21 & 9,36 & 8,88 & 2,35 & 2,21 & 9,35 & 8,88 & 0,41 & 1,32 \\
\hline
\end{tabular}

Tabela 2-4. Resultados das análises dos materiais de referência durante a investigação dos elementos traço e terras raras das amostras dos lotes 1 e 2 . Valores em ppm.

- Lote 3: amostras SNA-169, SNA-172E, SNA-175 e SNA-201, material de referência do Serviço Geológico do Japão JGb-1 (gabbro), material de referência do Centre de Recherches Pétrographiques et Géochimiques da França BR (basalto) (Tabela 2-5).

- Lote 4: amostras SNA-205B2, SNA-208, SNA-213, SNA-218, SNA-225, SNA-228, material de referência do Serviço Geológico do Japão JGb-1 (gabbro), material de referência do Centre de Recherches Pétrographiques et Géochimiques da França BR (basalto) (Tabela 2-5). 


\begin{tabular}{|c|c|c|c|c|c|c|c|c|c|c|}
\hline \multirow{3}{*}{ Padrão } & \multicolumn{4}{|c|}{$\begin{array}{r}\text { SNA-169, SNA-172E, } \\
175, \text { SNA-201 }\end{array}$} & \multicolumn{4}{|c|}{$\begin{array}{c}\text { SNA-205B2, SNA-208, SNA- } \\
\text { 213, SNA-218, SNA-225, } \\
\text { SNA-228 }\end{array}$} & \multicolumn{2}{|c|}{ Desvio Padrão } \\
\hline & \multicolumn{2}{|c|}{$\mathrm{BR}$} & \multicolumn{2}{|c|}{ JGb-1 } & \multicolumn{2}{|c|}{ BR } & \multicolumn{2}{|c|}{ JGb-1 } & \multirow{2}{*}{ BR } & \multirow{2}{*}{ JGb-1 } \\
\hline & $\begin{array}{l}\text { obtido } \\
\text { abta }\end{array}$ & recom & obtido & recom. & obtido & recom. & obtido & recom. & & \\
\hline $\mathrm{Rb}$ & 46,7 & 47 & 5,87 & 6,87 & 45,7 & 47,00 & 6,51 & 6,87 & 3 & 3 \\
\hline $\mathrm{Sr}$ & 1355 & 1320 & 335 & 327 & 1350 & 1320,00 & 328 & 327,00 & 51 & 39 \\
\hline $\mathrm{Y}$ & 27,7 & 30,0 & 9,40 & 10,4 & 28,7 & 30,00 & 10,6 & 10,40 & 1,5 & 2,4 \\
\hline$\overline{Z r}$ & 267 & 260 & 27,6 & 32,8 & 265 & 260,00 & 30,0 & 32,80 & 16 & 6,8 \\
\hline $\mathrm{Nb}$ & 1 & & 82 & 3,34 & 102 & 98,00 & 2,35 & 3,34 & 6 & 1,33 \\
\hline Cs & 0,77 & 0,80 & 0,21 & 0,26 & 0,79 & 0,80 & 0,21 & 0,26 & 0,15 & 0,076 \\
\hline $\mathrm{Ba}$ & 1082 & 1050 & 63,9 & 64,3 & 1026 & 1050,00 & 63,7 & 64,3 & 44 & 17,1 \\
\hline $\mathrm{La}$ & 82,5 & 82,0 & 3,61 & 3,6 & 83,9 & 82,00 & 4,00 & 3,60 & 1,5 & 0,56 \\
\hline $\mathrm{Ce}$ & 156 & 151 & 8,21 & 8,17 & 152 & 151,00 & 9,08 & 8,17 & 4 & 1 \\
\hline $\mathrm{Pr}$ & 16,7 & 17 & 14 & 13 & 16,6 & 17,00 & 1,23 & 1,13 & 0,6 & 0,14 \\
\hline $\mathrm{Nd}$ & 64,3 & 65,0 & 5,25 & 5,47 & 65,5 & 65,00 & 5,28 & 5,47 & 2 & 0,83 \\
\hline $\mathrm{Sm}$ & 12,2 & 12,2 & 48 & 1,49 & 12,1 & 12,20 & 1,44 & 1,49 & 0,3 & 0,19 \\
\hline $\mathrm{Eu}$ & 3,65 & 3,70 & 0,62 & 0,62 & 3,60 & 3,70 & 0,62 & 0,62 & 0,2 & 0,052 \\
\hline $\mathrm{Gd}$ & 9,89 & 9,50 & 1,63 & 1,61 & 9,67 & 9,50 & 1,68 & 1,61 & 0,6 & 0,14 \\
\hline $\mathrm{Tb}$ & 1,24 & 1,25 & 0,28 & 0,29 & 1,27 & 1,25 & 0,27 & 0,29 & 0,1 & 0,071 \\
\hline Dy & 6,27 & 6,40 & 1,70 & 1,56 & 6,18 & 6,40 & 1,63 & 1,56 & 0,2 & 0,37 \\
\hline $\mathrm{Ho}$ & 1,09 & & & & 1,12 & 1,10 & 0,37 & 0,33 & 0,13 & 0,052 \\
\hline $\mathrm{Er}$ & 2,44 & 2,50 & 1,03 & 1,04 & 2,52 & 2,50 & 0,94 & 1,04 & 0,1 & 0,24 \\
\hline $\mathrm{Tm}$ & 0,31 & 0,30 & 0,15 & 0,16 & 0,33 & 0,30 & 0,14 & 0,16 & 0,04 & 0,033 \\
\hline $\mathrm{Yb}$ & 1,72 & 1,80 & 0,94 & 1,06 & 1,78 & 1,80 & 0,92 & 1,06 & 0,2 & 0,3 \\
\hline $\mathrm{Lu}$ & 0,25 & 0,25 & 0,14 & 0,15 & 0,25 & 0,25 & 0,14 & 0,15 & 0,03 & 0,025 \\
\hline $\mathrm{Hf}$ & 5,61 & 5,60 & 0,83 & 0,88 & 5,78 & 5,60 & 0,83 & 0,88 & 0,2 & 0,19 \\
\hline $\mathrm{Pb}$ & ** & 5,00 & 1,66 & 1,92 & 5,41 & 5,00 & 1,29 & 1,92 & 2,5 & 0,74 \\
\hline Th & 10,4 & 11,0 & 0,43 & 0,48 & 10,3 & 11,00 & 0,39 & 0,48 & 1 & 0,1 \\
\hline$U$ & 2,40 & 2,50 & 0,13 & 0,13 & 2,43 & 2,50 & 0,10 & 0,13 & 0,3 & 0,048 \\
\hline
\end{tabular}

Tabela 2-5. Resultados das análises dos materiais de referência durante a investigação dos elementos traço e terras raras das amostras dos lotes 3 e 4 . Valores em ppm. ${ }^{* *}$ valor não reportado por problema durante as análises.

\section{Aplicação}

Os elementos terras raras nas rochas (meta)sedimentares são utilizados para a descrição da composição média da crosta continental superior, onde as variações dos padrões de abundância destes elementos podem refletir diferentes fontes. Certos elementos, como os terras raras, Th e Sc, por serem pouco móveis e praticamente insolúveis, podem fornecer informações geoquímicas de sua proveniência e a composição média da rocha-fonte. Mudanças importantes na composição dos sedimentos ocorreram na transição entre o Arqueano e o Proterozoico como respostas às mudanças químicas da crosta e na maneira como ela se diferencia (MCLENNAN et al., 1990). A presença de monazita, que apresenta grandes concentrações de ETR, mesmo que em pequena quantidade, resulta em um aumento significante da razão $\mathrm{Gd}_{N} / \mathrm{Yb}_{N}$ (fracionamento dos ETR 18 
pesados - $\mathrm{N}$ subscrito indica que as concentrações dos elementos estão normalizadas pelo condrito). O enriquecimento em ETR resultante da presença de monazita é geralmente observado nas rochas sedimentares pós-Arqueanas (MCLENNAN et al., 1993).

A média das composições de folhelhos pós-arqueanos são utilizadas como comparativos pois são tidos como representantes da composição da crosta continental superior. Haskin et al. (1966) sugeriram que a média da composição da crosta continental superior seria representada pelo conjunto de dados de folhelhos paleozoicos norteamericanos - NASC (sigla em inglês para North American Shale Composite). Outros conjuntos distintos resultaram em valores semelhantes como é o caso de folhelhos paleozoicos europeus - ES (sigla em inglês para European Shale composite) (HASKIN; HASKIN, 1966) e folhelhos pós-arqueanos da Austrália - PAAS (sigla em inglês para PostArchean Average Australian Shale) (NANCE; TAYLOR, 1976). Os dados citados acima estão plotados em diagrama condrito-normalizado na Figura 2-3.

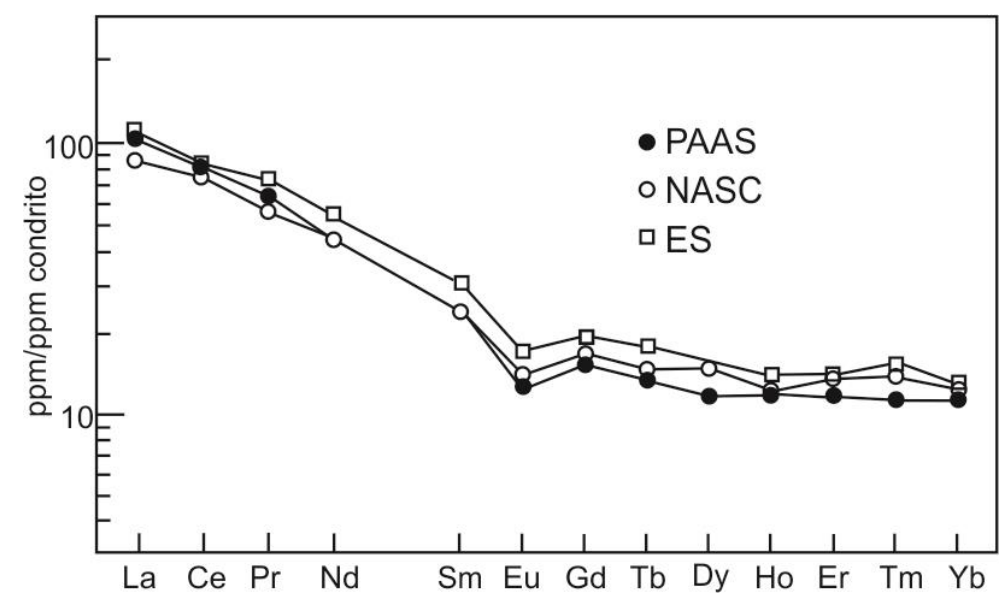

Figura 2-3. Diagrama condrito-normalizado com a média dos dados de folhelhos australianos pós-arqueanos (PAAS), folhelhos norte-americanos (NASC) e folhelhos europeus (ER).

A razão Th/Sc é um bom indicador de processos químicos de diferenciação ígnea, pois Th se comporta geralmente como um elemento incompatível enquanto que o Sc é compatível nos sistemas ígneos (MCLENNAN et al., 1993). A razão Th/U em rochas sedimentares pode indicar a presença de oxidação, que se espera estar presente durante os processos de intemperismo e reciclagem, resultando na remoção de $U$ e acarretando um aumento na razão $\mathrm{Th} / \mathrm{U}$. Rochas sedimentares provenientes de margens ativas apresentam valores baixos da razão $\mathrm{Th} / \mathrm{U}$, normalmente entre 1,0 e 4,0, enquanto que turbiditos arqueanos apresentam valores mais altos, em torno de 3,0 a 5,0 (MCLENNAN et al., 1990).

McLennan et al. (1990 e 1993) descreveram as características geoquímicas (de elementos maiores, traço e isotopia) de cinco domínios distintos, reunidos na Tabela 2-6. 


\begin{tabular}{|c|c|c|c|c|c|}
\hline $\begin{array}{l}\text { Tipo de } \\
\text { Terreno }\end{array}$ & $\varepsilon N d$ & $\mathrm{Eu} / \mathrm{Eu}^{*}$ & $\mathrm{Th} / \mathrm{Sc}$ & $\mathrm{Th} / \mathrm{U}$ & Outros \\
\hline $\begin{array}{l}\text { Crosta } \\
\text { continental } \\
\text { superior } \\
\text { antiga }\end{array}$ & $\leq-10$ & $\begin{array}{c}\sim 0,60- \\
0,70\end{array}$ & $\sim 1,0$ & $\begin{array}{c}>3,8 \\
\text { (folhelhos) }\end{array}$ & $\begin{array}{l}\text { Composição dos elementos maiores } \\
\text { evoluída (alta razão Si/AI, CIA); altas } \\
\text { abundâncias de LILE; composições } \\
\text { uniformes. }\end{array}$ \\
\hline $\begin{array}{l}\text { Rochas } \\
\text { sedimentare } \\
\text { s recicladas }\end{array}$ & $\leq-10$ & $\begin{array}{c}\sim 0,60- \\
0,71\end{array}$ & $\geq 1,0$ & & $\begin{array}{l}\text { Evidência de concentrações de de } \\
\text { minerais pesados através dos } \\
\text { elementos traço (Zr, Hf em zircão, ETR } \\
\text { em monazita). }\end{array}$ \\
\hline $\begin{array}{l}\text { Arco jovem } \\
\text { não } \\
\text { diferenciado }\end{array}$ & $\geq+5$ & $\sim 1,0$ & $<1,0$ & $<3,0$ & $\begin{array}{l}\text { Composições não evoluídas dos } \\
\text { elementos maiores (baixa razão Si/AI, } \\
\text { CIA); baixas abundâncias de LILE; } \\
\text { composições variadas. }\end{array}$ \\
\hline $\begin{array}{l}\text { Arco jovem } \\
\text { diferenciado }\end{array}$ & $\geq+5$ & $\begin{array}{c}\sim 0,50- \\
0,90\end{array}$ & variável & variável & $\begin{array}{l}\text { Composição evoluída dos elementos } \\
\text { maiores (alta razão Si/AI, CIA); altas } \\
\text { abundâncias de LILE; composições } \\
\text { variadas. }\end{array}$ \\
\hline MORB & $>+5$ & & baixa & baixa & $\begin{array}{l}\text { Baixas abundâncias de LILE. Diferencia } \\
\text { se de Arco jovem não diferenciado } \\
\text { pelas grandes abundâncias de } \\
\text { elementos traço ferromagnesianos (Cr e } \\
\text { Ni), e pelas razões Ba/La menores que } \\
1,0 \text {. }\end{array}$ \\
\hline
\end{tabular}

Tabela 2-6. Resumo das principais características geoquímicas e de isotopia de possíveis terrenos fonte. Retirado de McLennan et al. (1990 e 1993).

Todos os ETR ocorrem com valência 3+ com exceção do Eu e de Ce que ocorrem também na forma reduzida $\left(\mathrm{Eu}^{2+}\right)$ e na forma oxidada $\left(\mathrm{Ce}^{4+}\right)$, o que permite que eles desenvolvam anomalias de enriquecimento ou empobrecimento em relação aos demais elementos. São os coeficientes de partição (Kd) dos elementos reduzido e oxidado que produzem as anomalias (NEAL; TAYLOR, 1989).

As anomalias de Eu são características diagnósticas da presença de certas fases minerais, pois ele é o único ETR que ocorre na forma 2+ podendo substituir o $\mathrm{Sr}^{2+}$ ou o $\mathrm{Ca}^{2+}$ em cristais de plagioclásio $\left(\mathrm{Kd}_{\text {plag }} \mathrm{Eu}^{2+}>\mathrm{Kd}_{\text {plag }} \mathrm{Eu}^{3+}\right.$ ) (NEAL; TAYLOR, 1989). Anomalias negativas de Eu em rochas sedimentares indicam a cristalização de seu protólito ígneo em presença de plagioclásio, que ocorre em profundidades menores que $40 \mathrm{~km}$, campo no qual o plagioclásio é estável. Desta forma as anomalias de Eu são utilizadas em trabalhos de proveniência como um dos diferenciadores de fonte mantélica e fonte intracrosta (MCLENNAN; TAYLOR, 1991). A anomalia de Eu é calculada através de $E u / E u^{*}=E u_{N} /$ $\left[\left(\mathrm{Sm}_{\mathrm{N}}+\mathrm{Gd} \mathrm{d}_{\mathrm{N}}\right) / 2\right]$, onde resultados maiores que 1 indicam anomalias positivas, enquanto que valores menores que 1 representam anomalias negativas.

As anomalias de $\mathrm{Ce}$ ainda são enigmáticas, já que é improvável que $\circ \mathrm{Ce}^{4+}$ ocorra em sistemas magmáticos devido à equação $\mathrm{Ce}^{4+}+\mathrm{Fe}^{2+}=\mathrm{Ce}^{3+}+\mathrm{Fe}^{3+}$. Considerando que o $\mathrm{Fe}^{2+}$ ocorre sempre em excesso em magmas basálticos, são reduzidas as chances do $\mathrm{Ce}^{4+}$ 
ocorrer nestes sistemas, e nos que derivam deles, estando presente apenas na forma 3+. Dessa forma, aparentemente nenhum sistema ígneo seria capaz de produzir tais anomalias (NEAL; TAYLOR, 1989). As hipóteses para a geração de anomalias negativas de Ce é que elas estariam presentes anteriormente à fusão parcial ou que as anomalias ascenderiam do manto através do fracionamento fluido-rocha associado ao slab. Já a água do mar apresenta anomalias negativas de Ce devido à remoção do $\mathrm{Ce}^{4+}$ da coluna d'água através de nódulos ricos em $\mathrm{Fe}-\mathrm{Mn}$, que contém grandes anomalias positivas de $\mathrm{Ce}$, resultando em anomalias negativas em sedimentos pelágicos neste ambiente. Uma hipótese em relação às anomalias negativas de Ce encontradas em alguns xenólitos do manto e basaltos de ilhas oceânicas, está na subducção de sedimentos pelágicos e contaminação do manto (NEAL; TAYLOR, 1989).

\subsection{Geoquímica isotópica em rocha-total}

\subsubsection{Sistema isotópico Sm-Nd}

\section{Método}

O Sm é um elemento terras raras que apresenta sete isótopos que ocorrem naturalmente, destes, somente $0{ }^{147} \mathrm{Sm},{ }^{148} \mathrm{Sm}$ e ${ }^{149} \mathrm{Sm}$ são radioativos, sendo que os dois últimos apresentam uma longa meia-vida (na ordem de $10^{16}$ ) o que torna a medição de seus isótopos filho, ${ }^{144} \mathrm{Nd}$ e ${ }^{145} \mathrm{Nd}$, respectivamente, improvável. O método de datação $\mathrm{Sm}-\mathrm{Nd}$ baseia-se então no decaimento do ${ }^{147} \mathrm{Sm}$ que apresenta tempo de meia-vida de $1,16 \times 10^{11}$ anos, tempo que permite a medição de seu isótopo filho ${ }^{143} \mathrm{Nd}$ (DICKIN, 2005).

Se for considerado um dado sistema, a equação baseada no decaimento de ${ }^{147} \mathrm{Sm}$ será:

$$
{ }^{143} \mathrm{Nd}={ }^{143} \mathrm{Nd}_{1}+{ }^{147} \mathrm{Sm}\left(\mathrm{e}^{\lambda t}-1\right)
$$

onde I indica a abundância inicial e $t$ a idade do sistema. Como qualquer sistema isotópico, é comum medir razão isotópica ao invés de concentração de nuclídeo e para isso é conveniente dividir a equação pelo ${ }^{144} \mathrm{Nd}$, que é o segundo isótopo mais abundante de $\mathrm{Nd}$. Então têm-se:

$$
\left(\frac{143 \mathrm{Nd}}{144 \mathrm{Nd}}\right)=\left(\frac{143 \mathrm{Nd}}{144 \mathrm{Nd}}\right) \mathrm{I}+\frac{147 \mathrm{Sm}}{144 \mathrm{Nd}}\left(\mathrm{e}^{\lambda t}-1\right)
$$

A partir destas premissas, a composição isotópica inicial do sistema solar e sua evolução se tornaram de grande interesse para que se possa explicar a evolução isotópica terrestre de Sm-Nd. Desta forma, os materiais de interesse foram os meteoritos condríticos, 
que são considerados como representantes mais próximos da composição primordial do sistema solar. Dando origem ao chondritic uniform reservoir (CHUR) (DE PAOLO; WASSERBURG, 1976), que é a linha de evolução isotópica de $\mathrm{Nd}$ em um reservatório condrítico uniforme.

De Paolo e Wasserburg (1976) foram os primeiros a determinar a composição isotópica de $\mathrm{Nd}$ em rochas ígneas terrestres e quando plotadas as razões iniciais de ${ }^{143} \mathrm{Nd} /{ }^{144} \mathrm{Nd}$ destas rochas, em diagramas de evolução isotópica de $\mathrm{Nd}$ versus o tempo, eles perceberam que os plutons arqueanos apresentavam razões iniciais bastante consistentes com a evolução de CHUR encontradas nos condritos. Sendo Sm e Nd dois elementos terras raras com propriedades químicas bastante semelhantes, eles sofrem os mesmos processos de fracionamento durante a cristalização, indicando que para rochas terrestres, a separação da razão ${ }^{143} \mathrm{Nd} /{ }^{144} \mathrm{Nd}$ da linha de evolução CHUR é pequena em relação à inclinação dela. Para tanto, os autores desenvolveram uma notação onde a razão isotópica inicial de ${ }^{143} \mathrm{Nd} /{ }^{144} \mathrm{Nd}$ pudesse ser representada, em partes por $10^{4}$, como um desvio da linha CHUR, denominada $\varepsilon \mathrm{Nd}$, que é calculada através da equação:

$$
\varepsilon N d(t)=\left(\frac{(143 \mathrm{Nd} / 144 \mathrm{Nd}) \operatorname{amostra}(t)}{(143 \mathrm{Nd} / 144 \mathrm{Nd}) \operatorname{CHUR}(t)}-1\right) \times 10^{4}
$$

onde $t$ indica o tempo no qual $\varepsilon N d$ é calculado.

Se a linha de evolução CHUR representa as razões iniciais das rochas ígneas continentais através do tempo, a medição das razões ${ }^{143} \mathrm{Nd} /{ }^{144} \mathrm{Nd}$ e ${ }^{147} \mathrm{Sm} /{ }^{144} \mathrm{Nd}$ de qualquer rocha crustal iria resultar em uma idade-modelo, relacionada ao fracionamento isotópico de $\mathrm{Sm}$ e $\mathrm{Nd}$, para a formação desta rocha a partir de um reservatório condrítico (DEPAOLO; WASSERBURG, 1976). Então a idade-modelo TCHUR é dada por:

$$
T C H U R=\frac{1}{\lambda} \ln \left[\frac{\left(\frac{143 \mathrm{Nd}}{144 \mathrm{Nd}}\right) \text { amostra }-\left(\frac{143 \mathrm{Nd}}{144 \mathrm{Nd}}\right) \text { CHUR }}{\left(\frac{147 \mathrm{Sm}}{144 \mathrm{Nd}}\right) \text { amostra }-\left(\frac{147 \mathrm{Sm}}{144 \mathrm{Nd}}\right) \text { CHUR }}\right]
$$

A idade-modelo TCHUR, segundo DePaolo e Wasserburg (1976), indicaria a idade de formação crustal da rocha se a razão $\mathrm{Sm} / \mathrm{Nd}$ de uma certa amostra não sofresse nenhuma mudança desde sua separação do reservatório condrítico (aqui tido como uma fonte mantélica). Como ambos os elementos em questão são elementos terras raras, eles permanecem praticamente imóveis durante os diversos processos geológicos como intemperismo, metamorfismo de baixo e alto grau, desta forma, o método isotópico $\mathrm{Sm}-\mathrm{Nd}$ é capaz de datar rochas que experimentaram diversos tipos de processos geológicos. 
A partir da observação dos dados de basaltos tipo MORB, que apresentavam $\varepsilon N d$ de +7 a +12, DePaolo e Wasserburg (1976) reconheceram que esses dados poderiam estar alinhados sobre uma linha de evolução isotópica de um manto depletado (DM - depleted mantle), que apresenta uma razão $\mathrm{Sm} / \mathrm{Nd}$ mais elevada que CHUR. Idades-modelo calculadas a partir desta nova linha são denominadas $\mathrm{T}_{\mathrm{DM}}$. Idades-modelo resultam em um limite superior no qual houve o último equilíbrio do sistema, mas são mais acuradas quando o fracionamento entre os isótopos pai e filho é maior.

\section{Preparação, análise e tratamento dos dados}

O material utilizado para as análises de Sm-Nd foi uma porção do pó resultante do processo de cominuição, quarteamento, moagem e peneiramento das amostras, utilizado para as análises dos elementos maiores e menores em rocha-total. As análises foram realizadas no Centro de Pesquisas Geocronológicas da USP (CPGeo) onde foi utilizado um Thermo-Scientific Neptune Plus ICP-MS para avaliar as concentrações de Sm e $\mathrm{Nd}$. As razões ${ }^{143} \mathrm{Nd} /{ }^{144} \mathrm{Nd}$ foram normalizadas pelo valor 0,7219 a partir da razão ${ }^{146} \mathrm{Nd} /{ }^{144} \mathrm{Nd}$ de DePaolo (1981). O $\varepsilon_{\mathrm{Nd}(0)}$ corresponde ao valor atual e é calculado pela equação $\left\{\left[\left({ }^{143} \mathrm{Nd} /{ }^{144} \mathrm{Nd} \text { )am/0,512638] - } 1\right\}^{*} 104\right.\right.$, onde a razão ${ }^{143} \mathrm{Nd} /{ }^{144} \mathrm{Nd}$ chur é 0,512638 (HAMILTON et al., 1983). Como material para certificação do padrão de qualidade foi utilizado o JNDi-1, o qual durante as análises apresentou uma razão ${ }^{143} \mathrm{Nd} /{ }^{144} \mathrm{Nd}$ de $0,512096 \pm 0,000005$.

Os valores de $\varepsilon_{\mathrm{Nd}(\mathrm{t})}$ foram calculados a partir das idades máximas de sedimentação por U-Pb em cristais de zircão.

\section{Aplicação}

A principal aplicação do método $\mathrm{Sm}-\mathrm{Nd}$ é a aproximação da idade na qual a rocha iniciou sua evolução isotópica a partir de um reservatório mantélico. Sua eficiência em relação às demais metodologias é a pouca mobilidade dos elementos terras raras durantes os processos geológicos, que poderia resetar outros métodos de datação (DICKIN, 2005).

Em ambientes sedimentares, o sistema Sm-Nd pode prover uma estimativa do tempo de residência crustal dos sedimentos através da comparação das idades das fontes com as idades-modelo calculadas. Idades $\mathrm{T}_{\mathrm{DM}}$ próximas das idades máximas de sedimentação indicam pequena reciclagem sedimentar relacionada a ambientes orogênicos, enquanto que idades-modelo mais antigas que as idades máximas de deposição sugerem longos períodos de residência crustal, possivelmente com maior mistura de fontes.

A imobilidade dos ETR podem ser observadas na escala de mineral, o que no entanto não implica que o sistema $\mathrm{Sm}-\mathrm{Nd}$ se comporte como sistema aberto na escala de rocha-total (DICKIN, 2005). Perturbações podem eventualmente ocorrer em rochas que apresentem empobrecimento em ETR leves, o que acaba resultando em razões $\mathrm{Sm} / \mathrm{Nd}$ 
anomalamente altas, desta forma as idades-modelo calculadas podem não ser representativas.

As razões isotópicas de $\mathrm{Nd}$ e o desvio de $\varepsilon N d$ em relação às curvas $\mathrm{CHUR}$, e principalmente à $\mathrm{DM}$, irão prover o caráter da fonte principal dos sedimentos, o que pode ser um indicativo do ambiente tectônico onde se encontrava a área-fonte. As idades-modelo de um conjunto e amostras irão dar uma estimativa do tempo de formação da rocha-fonte a partir de um reservatório mantélico, e que poderão servir de parâmetro para associar amostras co-genéticas.

Como as composições isotópicas de $\mathrm{Nd}$ indicam as características isotópicas das fontes, podendo diferenciá-las em juvenil ou crustal, e a razão Th/Sc diferencia fontes félsicas de fontes máficas, a partir da Figura 2-4 (MCLENNAN et al., 1990), pode-se distinguir a composição média da crosta continental superior, crosta continental antiga, MORB e arco andesítico, assim como composições de diversos reservatórios geoquímicos registrados para os diferentes ambientes tectônicos (TAYLOR; MCLENNAN, 1985).

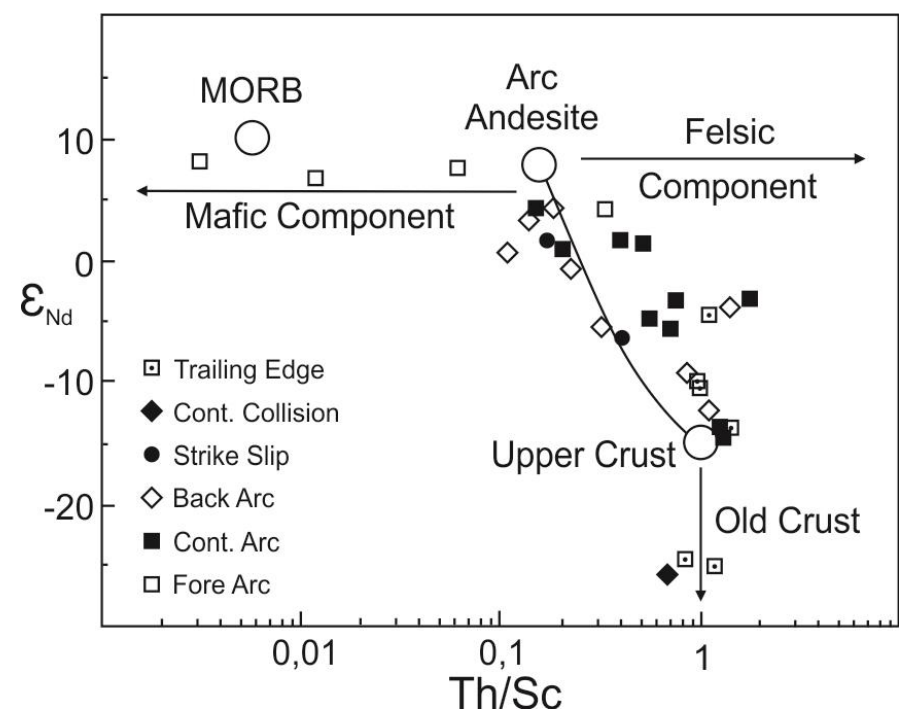

Figura 2-4. Diagrama de Th/Sc versus $\varepsilon N d$, ressaltanto os componentes félsicos, máficos (MCLENNAN et al., 1990) e os campos referentes à composições de MORB, crosta superior e crosta antiga além das composições típicas de vários reservatórios geoquímicos (TAYLOR; MCLENNAN, 1985).

\subsubsection{Sistema isotópico $\mathrm{Rb}-\mathrm{Sr}$}

\section{Método}

$\mathrm{O} \mathrm{Rb}$ apresenta dois isótopos que ocorrem naturalmente, o ${ }^{85} \mathrm{Rb}$ e o ${ }^{87} \mathrm{Rb}$. Este último é radioativo e decai para o isótopo estável ${ }^{87} \mathrm{Sr}$ através da emissão de uma partícula $\beta$ e de um anti-neutrino com uma energia de decaimento bastante baixa, o que gera dificuldades na determinação da constante de decaimento de Rb. Desta forma diversos métodos para se quantificar a constante de decaimento e o tempo de meia-vida de Rb foram aplicados. Um 
dos métodos, utilizando-se um foto-multiplicador com uma solução líquida dopada em Rb, resultou nos valores de meia-vida do ${ }^{87} \mathrm{Rb}$ de 47,0 \pm 1,0 Ga (FLYNN; GLENDENIN, 1959) e $52,1 \pm 1,5 \mathrm{Ga}$ (BRINKMAN et al., 1965). Outra forma de medir é através de fontes sólidas de $\mathrm{Rb}$ utilizando-se um contador proporcional, e Neumann e Huster (1976) alcançaram os valores de meia-vida do ${ }^{87} \mathrm{Rb}$ de 48,8 \pm 0,8 Ga com uma constante de decaimento de 1,42 $\mathrm{x}$ $10^{-11} a^{a n o}{ }^{-1}$. Já através da quantificação de ${ }^{87} \mathrm{Sr}$ produzido pelo decaimento de uma quantidade conhecida de ${ }^{87} \mathrm{Rb}$ em um intervalo de tempo conhecido, em laboratório, Davis et al. (1977) propuseram os valores de 48,9 \pm 0,4 Ga para a meia-vida a uma constante de decaimento de $1,42 \times 10^{-11}$ ano $^{-1}$ (DICKIN, 2005).

A quantidade de átomos de ${ }^{87} \mathrm{Sr}$ produzido pelo decaimento do ${ }^{87} \mathrm{Rb}$ em um sólido, desde sua formação há $t$ anos atrás, é dada pela equação:

$$
{ }^{87} \mathrm{Sr}={ }^{87} \mathrm{Sr}_{1}+{ }^{87} \mathrm{Rb}\left(\mathrm{e}^{\lambda t}-1\right)
$$

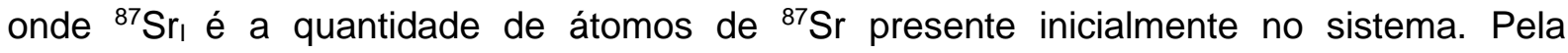
dificuldade de se medir a abundância absoluta de um nuclídeo, se faz necessário a conversão para razão isotópica dividindo a equação por ${ }^{86} \mathrm{Sr}$, que não é produzido por decaimento radioativo e permanece constante através do tempo.

$$
\left(\frac{87 \mathrm{Sr}}{86 \mathrm{Sr}}\right) \mathrm{P}=\left(\frac{87 \mathrm{Sr}}{86 \mathrm{Sr}}\right) \mathrm{I}+\frac{87 \mathrm{Rb}}{86 \mathrm{Sr}}\left(\mathrm{e}^{\lambda t}-1\right)
$$

A quantidade atual da razão isotópica de $\mathrm{Sr}(\mathrm{P})$ é medida por espectrometria de massa e a razão atômica ${ }^{87} \mathrm{Rb} /{ }^{86} \mathrm{Sr}$ é calculada pela razão de peso de $\mathrm{Rb} / \mathrm{Sr}$. Se a razão inicial I é conhecida, então $t$ pode ser determinado.

A partir do entendimento de que a equação acima é equivalente à equação de uma reta $(y=c+x m)$, Nicolaysen (1961) plotou os valores de ${ }^{87} \mathrm{Sr} /{ }^{86} \mathrm{Sr}(\mathrm{y})$ versus ${ }^{87} \mathrm{Rb} /{ }^{86} \mathrm{Sr}(\mathrm{x})$, onde $c$ corresponde à razão inicial ${ }^{87} \mathrm{Sr} /{ }^{86} \mathrm{Sr}$. Nestes gráficos, diagramas isocrônicos, uma suíte de minerais que permaneceu como sistema fechado definem uma linha conhecida como 'isócrona'. A inclinação desta reta $(m)$, resulta na idade do sistema. A aplicação do método já havia sido estendida ao estudo de amostras de rocha-total (SCHREINER, 1958), no qual foi utilizada uma suíte de rochas co-genéticas, que para ser eficaz deve apresentar variação no conteúdo modal de minerais de tal forma que as amostras apresentem uma grande variedade de razões $\mathrm{Rb} / \mathrm{Sr}$. Papanastassiu e Wasserburg (1970) desenvolveram a notação $\varepsilon$ para designar o desvio de um ponto com a isócrona que melhor engloba todos os dados (best-fit isochron), que é dada por: 


$$
\varepsilon S r=\left(\frac{(87 \mathrm{Sr} / 86 \mathrm{Sr}) \text { medido }}{(87 \mathrm{Sr} / 86 \mathrm{Sr}) \text { best }- \text { fit }}-1\right) \times 10^{4}
$$

\section{Preparação, análise e tratamento dos dados}

O mesmo material empregado nas análises de Sm-Nd foi utilizado para o estudo isotópico de Rb-Sr, realizado no mesmo Centro de Pesquisas Geocronológicas da USP (CPGeo). Neste caso, um Triton-Thermo Fischer Scientific mass spectrometer (TIMS) analisou as concentrações de $\mathrm{Rb}$ e $\mathrm{Sr}$ onde as razões ${ }^{87} \mathrm{Sr} /{ }^{86} \mathrm{Sr}$ foram normalizadas para ${ }^{86} \mathrm{Sr} r{ }^{88} \mathrm{Sr}=0,1194$. O valor médio de branco para o $\mathrm{Sr}$ foi de $188 \mathrm{pg}$ e o valor médio para a razão ${ }^{87} \mathrm{Sr} /{ }^{86} \mathrm{Sr}$ do padrão externo NBS-987 (National Bureau Standards) foi de 0,710259 \pm 0,000040 durante as análises.

\section{Aplicação}

A datação de rochas sedimentares depende da suposição de que o sistema isotópico de $\mathrm{Sr}$ foi homogeneizado durante a deposição dos sedimentos e que tenha permanecido como um sistema fechado até o presente. Rochas sedimentares detríticas são tidas como moderadamente resistentes ao comportamento de sistema aberto para o $\mathrm{Sr}$, mas as diferentes assinaturas isotópicas herdadas das distintas rochas-fonte podem causar problemas e distúrbios no sistema. É esperado que minerais que contenham Rb, como micas, feldspato potássico e argilominerais, apresentem conteúdos importantes de $\mathrm{Sr}$ radiogênico herdado e portanto a datação destes materiais resultará na média das idades isotópicas das diversas fontes (DICKIN, 2005).

Em estudos de rochas metamórficas é necessário a coleta um grande número de amostras para que seja confeccionado diagramas com diversas isócronas, e um estudo de detalhe para que conclusões regionais sejam feitas. Mesmo em graus baixos de metamorfismo o sistema pode ser aberto, aumentando a mobilidade de Rb e Sr. Geralmente o sistema abre quando há incremento na temperatura e tende a fechar quando ocorre 0 resfriamento, desta forma a datação por Rb/Sr pode indicar o resfriamento pós um evento termal.

O método Rb-Sr foi bastante utilizado como ferramenta de datação, no entanto, com a evolução do conhecimento, perdeu credibilidade quando começaram a surgir evidências de que rocha-total, e mesmo mineral, comportam-se como sistemas abertos (DICKIN, 2005). Desta forma, atualmente este método é empregado quando aliado à métodos mais eficazes e confiáveis, como é o caso do Sm-Nd.

Mesmo assim, razões isotópicas de ${ }^{143} \mathrm{Nd} /{ }^{144} \mathrm{Nd} \mathrm{e}{ }^{87} \mathrm{Sr} /{ }^{86} \mathrm{Sr}$ e o $\varepsilon \mathrm{Nd}$ e $\varepsilon \mathrm{Sr}$ delimitam os campos de fontes enriquecidas e depletadas, características isotópicas da crosta continental e do manto (Figura 2-5 A). Ambientes tectônicos distintos também apresentam distintas assinaturas isotópicas de $\mathrm{Nd}$ e de $\mathrm{Sr}$ (Figura 2-5 B). 

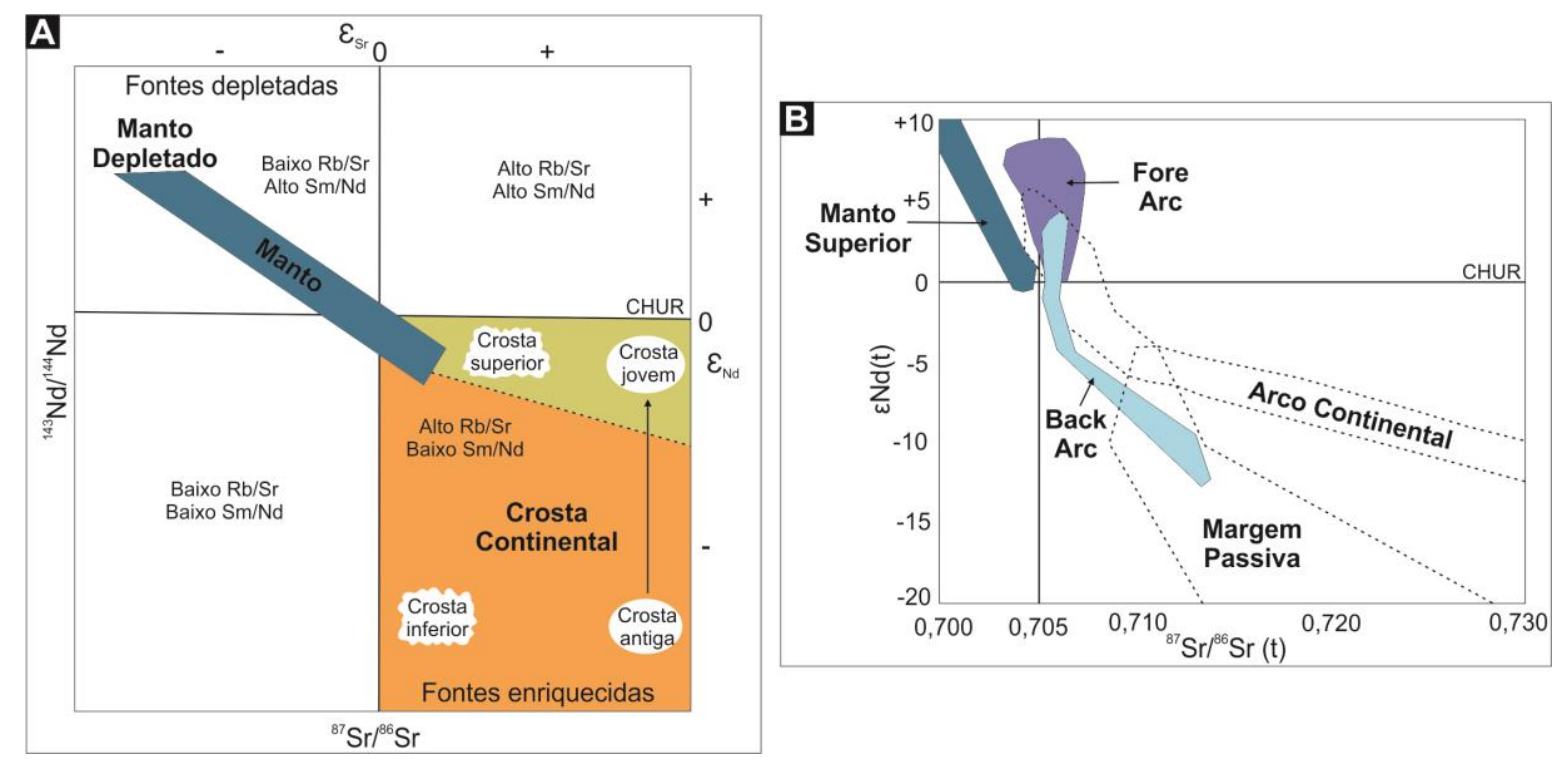

Figura 2-5. (A) Diagrama ${ }^{143} \mathrm{Nd} /{ }^{144} \mathrm{Nd}$ versus ${ }^{87} \mathrm{Sr} /{ }^{86} \mathrm{Sr}$ ( $\varepsilon \mathrm{Nd}$ versus $\varepsilon \mathrm{Sr}$ ) extraído e modificado de DePaolo e Wasserburg (1979) mostrando os campos das fontes enriquecidas e depletadas, assim como os quadrantes referentes às razões isotópicas de $\mathrm{Nd}$ e $\mathrm{Sr}$ para a crosta continental e manto depletado; (B) Diagrama de $\varepsilon \mathrm{Nd}_{(\mathrm{t})}$ versus ${ }^{87} \mathrm{Sr}^{86} \mathrm{Sr}_{(\mathrm{t})}$ extraído e modificado de McLennan et al. (1990), onde os campos delimitados são referentes às amostras analisadas pelos autores para os diferentes ambientes tectônicos.

As composições de sedimentos de margem passiva geralmente são plotadas próximo do campo da crosta continental antiga, enquanto que rochas de arco continental estão relacionadas com composições de crosta continental jovem. Fontes empobrecidas estão associadas a baixas razões de ${ }^{87} \mathrm{Sr} /{ }^{86} \mathrm{Sr}$, valores negativos de $\varepsilon \mathrm{Sr}$, assim como altas razões de ${ }^{143} \mathrm{Nd} /{ }^{144} \mathrm{Nd}$ e valores positivos de $\varepsilon \mathrm{Nd}$. Já fontes enriquecidas estão associadas à razões mais altas de ${ }^{87} \mathrm{Sr} /{ }^{86} \mathrm{Sr}$, com $\varepsilon S r$ positivos, valores baixos de ${ }^{143} \mathrm{Nd} /{ }^{144} \mathrm{Nd}$ e negativos de $\varepsilon \mathrm{Nd}$.

\subsection{Geoquímica isotópica mineral}

\subsubsection{Sistema isotópico U-Pb em zircão}

\section{Método}

O chumbo possui quatro isótopos estáveis, dos quais apenas o ${ }^{204} \mathrm{~Pb}$ não é radiogênico, os outros três são produtos finais do decaimento em cadeia de urânio e tório, onde os membros intermediários de cada série apresentam tempo de vida bastante curto e geralmente são ignorados quando se trata de períodos muito longos na escala de tempo geológica. A Tabela 2-7 apresenta os pares de isótopos pai e filho e seus tempos de meiavida e constante de decaimento. 


\begin{tabular}{ccc}
\hline Decaimento & $t_{1 / 2}(\mathrm{Ga})$ & $\begin{array}{c}\text { Constante de Decaimento } \lambda \\
\left(\mathrm{ano}^{-1}\right)\end{array}$ \\
\hline \hline${ }^{238} \mathrm{U} \rightarrow{ }^{206} \mathrm{~Pb}$ & 4,47 & $1,55125 \times 10^{-10}$ \\
${ }^{235} \mathrm{U} \rightarrow{ }^{207} \mathrm{~Pb}$ & 0,704 & $9,8485 \times 10^{-10}$ \\
${ }^{232} \mathrm{Th} \rightarrow{ }^{208} \mathrm{~Pb}$ & 14,01 & $0,49475 \times 10^{-10}$ \\
\hline
\end{tabular}

Tabela 2-7. Os pares dos isótopos pai e filho, seus tempos de meia-vida e constante de decaimento (JAFFEY et al., 1971).

Se for considerado um sistema de idade $t$, as equações de decaimento para cada par de isótopos envolvido será:

$$
\begin{aligned}
& { }^{206} \mathrm{~Pb}_{\mathrm{P}}={ }^{206} \mathrm{~Pb}_{\mathrm{I}}+{ }^{238} \mathrm{U}\left(\mathrm{e}^{\lambda 238 t}-1\right) \\
& { }^{207} \mathrm{~Pb}_{\mathrm{P}}={ }^{207} \mathrm{~Pb}_{\mathrm{I}}+{ }^{235} \mathrm{U}\left(\mathrm{e}^{\lambda 235 t}-1\right) \\
& { }^{208} \mathrm{~Pb} \mathrm{P}={ }^{208} \mathrm{~Pb}_{1}+{ }^{232} \mathrm{Th}\left(\mathrm{e}^{\lambda 232 t}-1\right)
\end{aligned}
$$

onde $\mathrm{P}$ indica a abundância atual de um certo nuclídeo e I indica a abundância inicial deste mesmo. Usualmente não é determinada a abundância absoluta de nuclídeo, e para tanto é conveniente dividir as equações por ${ }^{204} \mathrm{~Pb}$. O ${ }^{204} \mathrm{~Pb}$ é escolhido por ser o único isótopo não radiogênico (não apresentando grandes variações em sua abundância ao longo do tempo), assim, as duas equações do decaimento de urânio são:

$$
\begin{aligned}
& \left(\frac{206 \mathrm{~Pb}}{204 \mathrm{~Pb}}\right) \mathrm{P}=\left(\frac{206 \mathrm{~Pb}}{204 \mathrm{~Pb}}\right) \mathrm{I}+\frac{238 \mathrm{U}}{204 \mathrm{~Pb}}\left(\mathrm{e}^{\lambda 238 t}-1\right) \\
& \left(\frac{207 \mathrm{~Pb}}{204 \mathrm{~Pb}}\right) \mathrm{P}=\left(\frac{207 \mathrm{~Pb}}{204 \mathrm{~Pb}}\right) \mathrm{I}+\frac{235 \mathrm{U}}{204 \mathrm{~Pb}}\left(\mathrm{e}^{\lambda 235 t}-1\right)
\end{aligned}
$$

Se for considerado um mineral que incorpora urânio, mas não incorpora chumbo no momento de sua formação, os membros intermediários das equações que se referem aos termos iniciais de chumbo podem ser removidos, desta forma as equações se tornam:

$$
\begin{aligned}
& { }^{206} \mathrm{~Pb}^{\star}={ }^{238} \mathrm{U}\left(\mathrm{e}^{\lambda 238 t}-1\right) \\
& { }^{207} \mathrm{~Pb}^{\star}={ }^{235} \mathrm{U}\left(\mathrm{e}^{\lambda 235 t}-1\right)
\end{aligned}
$$

onde $\mathrm{Pb}^{*}$ representa apenas o chumbo radiogênico. Passando os isótopos de urânio para o outro lado, tem-se:

$$
\frac{206 \mathrm{~Pb} *}{238 \mathrm{U}}=\left(\mathrm{e}^{\lambda 238 t}-1\right)
$$




$$
\frac{207 \mathrm{~Pb} *}{235 \mathrm{U}}=\left(\mathrm{e}^{\lambda 235 t}-1\right)
$$

Os minerais que permanecem como sistemas fechados para urânio e chumbo apresentam valores concordantes de $t$ quando suas composições isotópicas são substituídas nas últimas duas equações, desta forma quando valores concordantes são plotados graficamente, eles definem uma curva chamada concórdia (WETHERILL, 1956). Esta curva pode ser desenhada substituindo as constantes de decaimento e seus sucessivos valores de $t$ nas duas últimas equações, e plotando os resultados para cada $t$.

O zircão é atualmente o mineral mais utilizado para datação por U-Pb por sua ampla ocorrência, estando presente na maioria das rochas intermediárias à ácidas e por ser um mineral que tende a incorporar grandes concentrações de urânio e muito pouco de chumbo inicial não radiogênico. $\mathrm{O}$ zircão quando se cristaliza retém uma razão alta de $\mathrm{U} / \mathrm{Pb}$, juntamente com os isótopos filhos do decaimento de $\mathrm{U}$ e Th, podendo, desta forma, prover a idade de sua formação (HOSKIN; IRELAND, 2000). O pouco de chumbo que é incorporado durante a cristalização do mineral é chamado de 'chumbo comum' e existem correções que podem ser realizadas para minimizar a presença de chumbo não radiogênico no sistema. Essas correções podem ser feitas medindo a quantidade de ${ }^{204} \mathrm{~Pb}$ inicial e então utilizando a razão ${ }^{206} \mathrm{~Pb} / 204 \mathrm{~Pb}$ e ${ }^{207} \mathrm{~Pb} /{ }^{204} \mathrm{~Pb}$ de rocha-total para estimar as quantidades iniciais de ${ }^{206} \mathrm{~Pb} \mathrm{e}$ ${ }^{207} \mathrm{~Pb}$ incorporados pelo zircão. Essas quantidades são subtraídas das concentrações atuais de ${ }^{206} \mathrm{~Pb}$ e ${ }^{207} \mathrm{~Pb}$. No caso de cristais de zircão com quantidades muito baixas de chumbo comum, a correção pode ser feita estimando a concentração de chumbo comum a partir de um modelo geral de evolução terrestre de chumbo (DICKIN, 2005).

A maioria das amostras resultam em idades ${ }^{206} \mathrm{~Pb} /{ }^{238} \mathrm{U}$ e ${ }^{207} \mathrm{~Pb} / 235 \mathrm{U}$ discordantes, e essa discordância pode ser atribuída à perda de chumbo. Em certos casos, os dados discordantes apresentam-se alinhados e este alinhamento é chamado de discórdia. A dupla intersecção da curva concórdia pela reta discórdia resulta em duas idades de diferente significado geológico, a idade mais velha pode ser atribuída à cristalização do mineral e a mais jovem, a algum evento termal e deve ser confirmada por outros métodos de datação. No entanto, estas conclusões devem ser tomadas com precaução, na medida em que em uma população complexa de cristais de zircão, muitos podem refletir idades de herança. São vários os processos que levam à perda de chumbo, mas no geral são promovidos por metamictização.

\section{Preparação e análise}

As etapas de preparação das amostras foram realizadas no Laboratório de Separação do Centro de Pesquisas Geocronológicas (CPGeo) do IGc-USP, e seguiram os 
seguintes passos: (1) fragmentação das amostras para obtenção de fragmentos na ordem de poucos centímetros de diâmetro; (2) cominuição destes fragmentos em moinho de disco; (3) utilização de peneira vibratória para separação do pó nas granulações <100 mesh e <250 mesh; (4) utilização da mesa vibratória Wiffley para separação dos minerais pesado do material previamente peneirado e separado; (5) o material pesado, depois de seco, tem seus minerais magnéticos inicialmente separados por imã de mão e então o restante segue para o separador magnético do tipo Frantz; (6) o material restante - minerais pesados sem os magnéticos - segue para a separação por líquidos densos no qual se utiliza primeiramente o bromofórmio e por fim o iodeto. O material concentrado é então levado ao microscópio para a separação manual dos cristais de zircão com o auxílio de pinça de tungstênio. Os grãos separados são grudados em fita colante para a confecção dos discos de resina (mounts). Os mounts seguem para o polimento e realização de uma cobertura de carbono. A quantidade de grãos separados variou de aproximadamente 150 a 200 no caso de amostras de rochas metassedimentares, e em torno de 80 no caso das amostras de rochas metaígneas.

Para a seleção e classificação de cada cristal de zircão foram confeccionadas imagens de catodoluminescência. Essas imagens proporcionam a visualização dos diversos tipos de zoneamento existentes a partir da diferenciação por cor da quantidade de urânio cores escuras indicam porções com alto urânio enquanto que porções claras indicam baixo conteúdo de urânio. Os diversos tipos de zoneamento foram cuidadosamente descritos e classificados para que se pudesse distinguir núcleos herdados, cristais ígneos, metamórficos e sobrecrescimentos posteriores.

As análises geocronológicas por U-Pb foram realizadas em cristais de zircão detrítico de 7 amostras de rochas metassedimentares da Nappe Andrelândia (SNA-116, SNA-125, SNA-201, SNA-213, SNA-228, NESG-1434 e NESG-1446) e 3 da Nappe Liberdade (SNA169, SNA-172 E e SNA-180 A), e em grãos ígneos de zircão e metamórficos de 2 amostras de rochas metamórficas de protólito ígneo, da Nappe Liberdade (SNA-168 e SNA-205 B). Tais análises foram feitas no Centro de Pesquisas Geocronológicas do Instituto de Geociências da USP (CPGeo). Para este estudo foi utilizado um sistema de excimer laser ablation acoplado a um inductively coupled plasma mass spectrometer multicoletor da marca Neptune ${ }^{\mathrm{TM}}$.

A configuração, em ordem, dos coletores de massa foi: dois contadores de íons $\mathrm{IC}_{3} \mathrm{e}$ $\mathrm{IC}_{4}$ que analisam ${ }^{202} \mathrm{Hg}$ e ${ }^{204}(\mathrm{Hg}+\mathrm{Pb})$, um coletor low mass $\mathrm{L} 4$ que analisa ${ }^{206} \mathrm{~Pb}$ seguido por outro contador de íon IC6 que lê ${ }^{207} \mathrm{~Pb}$, um terceiro coletor low mass L3 analisa ${ }^{208} \mathrm{~Pb}$ e finalmente dois coletores high mass $\mathrm{H} 2$ e $\mathrm{H} 4$, que analisam ${ }^{232} \mathrm{Th}$ e ${ }^{238} \mathrm{U}$, respectivamente. Os parâmetros fixados do ICP-MS foram: energia de radiofrequência de $1100 \mathrm{~W}$, fluxo de gás (argônio) igual a $15 \mathrm{l} / \mathrm{min}$ para refrigeração, fluxo de argônio de 0,9l/min e fluxo de gás auxiliar (argônio) igual a 0,75 I/min e taxa de fluxo de gás da amostra igual a 0,6 I/min. Os 
parâmetros do laser foram: energia entre 5 e $6 \mathrm{~mJ}$, taxa de repetição de 5 a $6 \mathrm{~Hz}$, transportador do fluxo de gás (hélio) igual a 0,35 + 0,5 I/min e o diâmetro do spot do laser variou de 29 a $32 \mathrm{~mm}$ (SATO et al., 2009).

\section{Aplicação}

As diversas populações de cristais detríticos de zircão, separados de uma rocha (meta)sedimentar, podem ser definidas pela descrição de seus hábitos e formatos, pelas estruturas internas e pelas composições isotópicas de $\mathrm{U}-\mathrm{Pb}$ e $\mathrm{Lu}-\mathrm{Hf}$, ou mesmo pelas suas concentrações de elementos terras raras. Os grupos de idades de diferentes populações são definidos por limites superiores e inferiores, e serão considerados como um componente de proveniência aqueles que podem representar a idade relacionada à uma mesma fonte (ANDERSEN, 2005). Uma população de idade pode ser derivada de mais de uma fonte, e desta maneira se faz necessário outros tipos de investigação, como por exemplo a assinatura química e isotópica (Lu-Hf) dos cristais.

Os padrões de distribuição distintos de idades em cristais detríticos de zircão refletem o ambiente tectônico da bacia de sedimentação na qual eles foram depositados. Esses padrões podem ser controlados por três principais fatores: (i) volume de magma gerado em cada ambiente tectônico e seu potencial de preservação; (ii) a facilidade com que cristais de zircão magmáticos e detríticos de várias idades e origens distintas foram incorporados no registro sedimentar, e (iii) o registro e preservação de grãos antigos de zircão incorporados aos sedimentos. Estes fatores podem ser utilizados para distinguir o cenário tectônico ajudando a discernir entre ambientes convergentes e extensionais (CAWOOD; HAWKESWORTH; DHUIME, 2012).

Em rochas ígneas ou metaígneas é esperado que haja apenas uma população de idades de zircão, que poderia indicar a idade de cristalização da rocha ou mesmo um evento metamórfico, e assim a interpretação dos dados tende a ser simplificada, fazendo com que seja possível distinguir o conjunto de idades da formação da rocha, de dados com perda de chumbo ou cristais herdados. Já no caso de cristais detríticos de zircão, as idades discordantes não podem ser tratadas da mesma forma, já que é esperado que exista mais de uma população de idades e que estas reflitam diferentes fontes. Os dados discordantes poderiam representar mistura entre diferentes componentes, antigos e mais recentes, ambos com perdas de chumbo (NEMCHIN; CAWOOD, 2005).

Usualmente os dados de U-Pb são exibidos em diagramas concórdia, mas no caso de cristais detríticos a identificação objetiva das diversas populações é dificultada neste tipo de diagrama. Uma alternativa é a utilização de histogramas que destacam as idades, no entanto não informam sobre a precisão e erro de cada dado, além da dificuldade na seleção da quantidade e tamanho dos bins. Os diagramas da probabilidade da densidade (probability density plot) combinam essas informações, exemplificado na Figura 2-6 A, 
através da soma da distribuição gaussiana de cada dado individual, que é definida pela idade e seu erro (SIRCOMBE, 2000). Este método pode ser aplicado também para a comparação visual dos resultados das idades de zircão detrítico analisados com idades de possíveis fontes.

Como comparativo entre o espectro de dados de diferentes amostras, as idades podem ser tratadas no K-S test (Kolmogorov-Smirnov) para a comparação da distribuição dos diferentes intervalos graficamente (exemplo na Figura 2-6 B). Os dados são convertidos em uma função de distribuição cumulativa e o teste gera a probabilidade a partir da qual os picos de idades são traçados segundo a mesma distribuição. Valores próximos a 1,0 indicam que o espectro de idades são quase idênticos (BERRY et al., 2001).

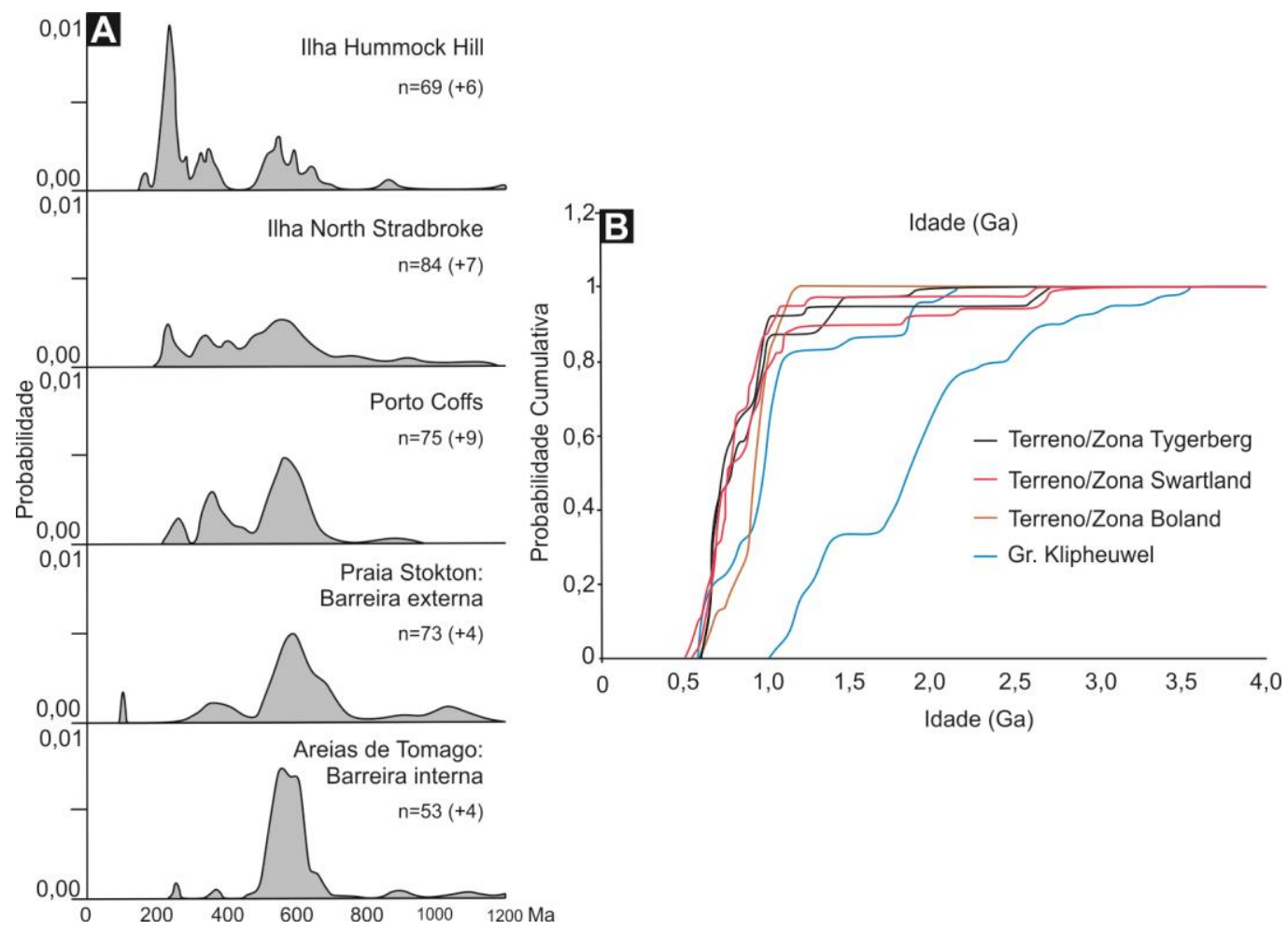

Figura 2-6. (A) Diagrama de distribuição da probabilidade das idades de zircão detrítico do litoral leste da Austrália. Extraído e modificado de Sircombe (2000); (B) Diagrama da distribuição cumulativa da densidade de probabilidade (K-S test) de zircão detrítico de várias amostras do Orógeno Saldania Ocidental. Extraído e modificado de Frimmel et al. (2013).

Dickinson e Gehrels (2009) promoveram um estudo a respeito da máxima idade de deposição através de diferentes abordagens das idades $\mathrm{U}-\mathrm{Pb}$ mais jovens. Os autores estudaram cinco modos de como seriam tratados ou quais dados seriam os mais robustos para a determinação da idade máxima de deposição: (i) utilização da idade mais jovem com $1 \sigma$ de incerteza; (ii) o pico gráfico mais jovem em histogramas de probabilidade, onde foi ignorado picos que continham apenas um dado; (iii) idade a partir da média ponderada do cluster mais jovem de dois ou mais grãos, com $1 \sigma$ de incerteza; (iv) idade a partir da média ponderada do cluster mais jovem de três ou mais grãos, com $2 \sigma$ de incerteza, e (v) idade 
calculada com o diagrama Youngest Detrital Zircon do Isoplot (LUDWIG, 2008). Foi concluído que a utilização das idades U-Pb mais jovens de grãos individuais é bastante adequada para determinação da idade máxima de deposição. Nas amostras utilizadas pelos autores, até a idade do zircão mais jovem é compatível com a idade de deposição em $90 \%$ dos casos testados. No entanto, no trabalho de Dehler et al. (2010) são utilizadas as idades resultantes a partir do conjunto de cristais de zircão mais jovens que estejam dentro das incertezas analíticas um do outro, e grãos isolados não são representativos o bastante para se determinar a máxima idade de deposição.

A junção entre tectônica, tipo de bacia e preenchimento sedimentar indica que a preservação de zircão detrítico é uma somatória entre a presença ou ausência de magmatismo sin-sedimentar, e a amplitude e proporção de diferentes idades registradas. $\mathrm{O}$ impacto destas variáveis pode ser graficamente exposto através da subtração da máxima idade de deposição das idades de cristalização dos cristais detríticos de zircão, exemplificado na Figura 2-7. Ambientes extensionais, incluindo intracratônicos, apresentam idade de cristalização (IC) - idade de deposição (ID) maiores que $150 \mathrm{Ma}$ nos 5\% dos cristais mais jovens, e todos os ambientes convergentes exibem IC - ID menores que 100 Ma nos 30\% dos cristais de zircão mais jovens (Figura 2-7) (CAWOOD; HAWKESWORTH; DHUIME, 2012).

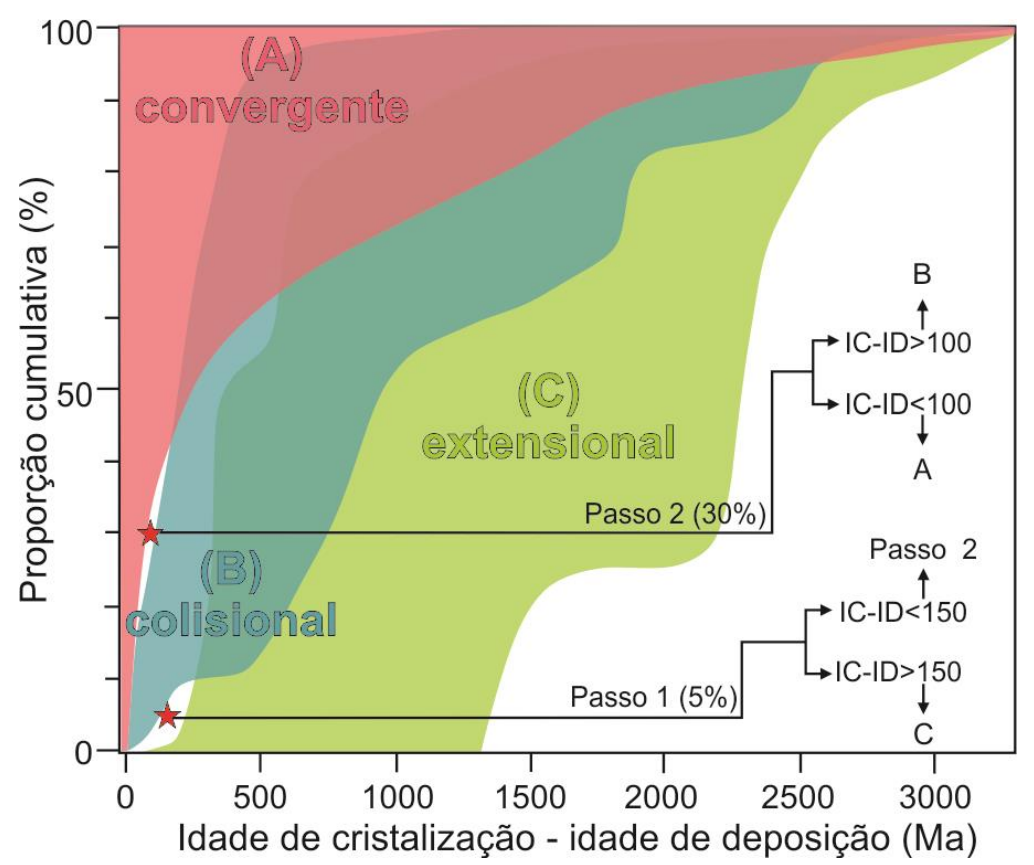

Figura 2-7. Diagrama da proporção cumulativa (\%) versus a idade de cristalização IC subtraída a idade de deposição ID (Ma) para os campo de baciais convergentes ( $A$, em rosa), colisionais ( $\mathrm{B}$, em azul) e extensionais (C, em verde). Extraído e modificado de Cawood, Hawkesworth e Dhume (2012).

Em estudos de datação de eventos metamórficos por U-Pb utilizando zircão, se faz necessário e indispensável a descrição dos cristais de zircão através de imagens de 
catodoluminescência, para que as diversas feições de cada grão seja individualizada. Estas feições podem ser tanto bordas metamórficas sobrecrescidas em cristais de zircão detríticos, como grãos metamórficos que foram (re)cristalizados a partir de um núcleo ígneo, que pode ou não estar preservado, como é observado no caso de rochas de maior grau, como eclogitos (BECKMAN et al., 2014). Em rochas máficas os cristais primários de zircão tendem a ser raros, enquanto que os metamórficos podem ser abundantes e terem sido formados em mais de um estágio do metamorfismo (HARLEY; KELLY; MÖLLER, 2007). Geralmente os sobrecrescimentos metamórficos de zircão apresentam razão Th/U mais baixas que as encontradas em cristais ígneos, e conteúdo de $U$ e Th reduzidos, de algumas centenas de ppm a um pouco menos de 10 ppm (RUBATTO; GEBAUER; COMPAGNONI, 1999).

\section{Tratamento e apresentação dos dados}

Os dados de U-Pb em zircão foram corrigidos através de programa com linguagem Python (SIQUEIRA; HOLLANDA; BASEI, 2014), e a presença de chumbo comum foi corrigida pelo ${ }^{204} \mathrm{~Pb}$. As idades utilizadas em todas as amostras foram as ${ }^{207} \mathrm{~Pb} /{ }^{206} \mathrm{~Pb}$, com erro em $2 \sigma$, seja para os dados de metamorfismo, idades de zircão detríticos jovens do Neoproterozoico ou até mesmo para os cristais ígneos herdados nas amostras de rocha metaígnea. A escolha deste critério deve-se a observação de que com as idades ${ }^{207} \mathrm{~Pb} /{ }^{206} \mathrm{~Pb}$, os clusters de dados geravam idades com erros compatíveis ao método LA-ICPMS, com valores de MSWD (Mean Square Weighted Deviation) menores ou próximos a 1,0.

\begin{tabular}{|c|c|c|c|c|c|c|}
\hline \multicolumn{2}{|r|}{ Unidade } & Amostra & $\begin{array}{c}\text { Quantidade } \\
\text { total de } \\
\text { Análises }\end{array}$ & $\begin{array}{c}\text { Quantidade } \\
\text { de dados } \\
\text { utilizados* }\end{array}$ & $\begin{array}{l}\text { Quantidade de } \\
\text { dados de } \\
\text { metamorfismo* }\end{array}$ & $\begin{array}{c}\text { Quantidade de } \\
\text { dados de zircão } \\
\text { detrítico** }\end{array}$ \\
\hline \multirow{9}{*}{ 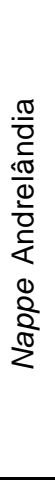 } & \multirow{6}{*}{$\begin{array}{l}\text { Unidade } \\
\text { Serra da } \\
\text { Boa Vista }\end{array}$} & NESG-1434 & 91 & 70 & 32 & 38 \\
\hline & & $\begin{array}{c}\text { NESG- } \\
1446+1447 \\
\end{array}$ & 77 & 62 & 52 & 10 \\
\hline & & SNA-116 & 58 & 56 & 0 & 56 \\
\hline & & SNA-125 & 85 & 65 & 14 & 51 \\
\hline & & SNA-228 & 64 & 57 & 0 & 57 \\
\hline & & SNA-213 & 64 & 59 & 0 & 59 \\
\hline & \multirow{3}{*}{$\begin{array}{l}\text { Unidade } \\
\text { Santo } \\
\text { Antônio }\end{array}$} & NESG-1010 & 129 & 120 & 23 & 97 \\
\hline & & NESG-1552 & 65 & 58 & 16 & 42 \\
\hline & & SNA-201 & 65 & 58 & 8 & 50 \\
\hline \multirow{5}{*}{$\begin{array}{l}\frac{0}{0} \\
\frac{\pi}{0} \\
\frac{0}{0} \\
\frac{0}{3} \\
0 \\
\frac{0}{2} \\
\frac{\pi}{2}\end{array}$} & \multirow{3}{*}{$\begin{array}{c}\text { Rochas } \\
\text { metassedi- } \\
\text { mentares }\end{array}$} & SNA-169 & 65 & 42 & 27 & 15 \\
\hline & & SNA-172 E & 78 & 70 & 11 & 59 \\
\hline & & SNA-180 A & 78 & 73 & 0 & 73 \\
\hline & \multirow{2}{*}{$\begin{array}{l}\text { Rochas } \\
\text { exóticas }\end{array}$} & SNA-168 & 40 & 38 & 0 & 38 \\
\hline & & SNA-205 B & 65 & 57 & 40 & 17 \\
\hline
\end{tabular}

Tabela 2-8. Resumo das quantidades de idades $\mathrm{U}-\mathrm{Pb}$ analisadas e utilizadas neste trabalho, destacando o número de análises em porções metamórficas ou ígneas do zircão.

* Quantidade de dados com concordância $100 \pm 10 \%$. 
** Quantidade de dados de zircão ígneo no caso das amostras exóticas à Nappe Liberdade (SNA-168 e SNA205B).

A porcentagem de corte em relação à concordância de cada análise foi de $100 \pm$ $10 \%$, e na Tabela 2-8 é possível observar a relação da quantidade de dados U-Pb gerados, a quantidade de idades utilizadas após o corte e a relação entre os dados metamórficos e os cristais detríticos. As amostras sublinhadas foram utilizadas somente para a discussão do metamorfismo, pela baixa quantidade de dados de zircão detrítico.

As idades de eventos metamórficos, proveniência e cristalização ígnea foram trabalhos separadamente, no entanto todos foram tratados através do software Isoplot/Ex® 4.11 (LUDWIG, 2008). As idades de proveniência foram utilizadas para gerar histogramas juntamente com a curva de densidade de probabilidade (probability density plot) para que os agrupamentos de idades fossem destacados. Diagramas de média ponderada (weighted average) foram confeccionados utilizando os grupos de idades destacadas pelo histograma, sendo utilizados aqueles que apresentaram valores de MSWD menores ou em torno de 1,0. Os diagramas concórdias foram utilizados no caso das rochas metaígneas da Nappe Liberdade (SNA-168 e SNA-205B) juntamente com os diagramas weighted average destacando as populações. Além dos histogramas dos dados de cada amostra, foi utilizado o K-S test (Kolmogorov-Smirnov) para a comparação visual das distribuições das idades entre as amostras metassedimentares.

Grupos de idades que resultam em MSWD > 1,0 sugerem que os dados utilizados provavelmente não são de uma mesma idade, enquanto que dados com MSWD $\leq 1,0$ indicam que os valores são estatisticamente uniformes e provavelmente todos os grãos apresentam a mesma idade (NEMCHIN; CAWOOD, 2005).

Para calcular as máximas idades de deposição foram utilizados os grupos de idades mais jovens que resultaram em idades com valores de MSWD $\leq 1,0$.

\subsubsection{Sistema isotópico Lu-Hf em zircão}

\section{Método}

O Lu, elemento mais pesado na série dos elementos terras raras, apresenta dois isótopos, ${ }^{175} \mathrm{Lu}$ e ${ }^{176} \mathrm{Lu}$, com abundâncias de $97,4 \%$ e 2,6\%, respectivamente. O ${ }^{176} \mathrm{Lu}$ decai para $0{ }^{176} \mathrm{Hf}$ através da emissão de partícula $\beta$, e para $0{ }^{176} \mathrm{Yb}$ através da captura de um elétron. O Hf apresenta seis isótopos, dentre os quais $0{ }^{176} \mathrm{Hf}$ perfaz apenas $5,2 \%$ do total. Por mais que não faça parte da série dos elementos terras raras, ele apresenta comportamento químico bastante semelhante ao do $\mathrm{Zr}$, resultando em um comportamento mais insolúvel, diferentemente de outros elementos que tendem a ser mais móveis como é o caso do Rb e Sr. Em cristais de zircão, a quantidade de $\mathrm{Hf}$ pode alcançar 10.000 ppm em 
rochas mais evoluídas, exatamente pelo fato de se assemelhar quimicamente ao $\mathrm{Zr}$ (HOSKIN; SCHALTEGGER, 2003).

O decaimento de ${ }^{176} \mathrm{Lu}$ para ${ }^{176} \mathrm{Hf}$ é descrita através da equação:

$$
{ }^{176} \mathrm{Hf}={ }^{176} \mathrm{Hf}_{\mathrm{l}}+{ }^{176} \mathrm{Lu}\left(\mathrm{e}^{\lambda t}-1\right)
$$

onde I refere-se à quantidade inicial de ${ }^{176} \mathrm{Hf}$ no sistema. Esta equação é dividida por ${ }^{177} \mathrm{Hf}$, para se obter a razão isotópica de Hf:

$$
\left(\frac{176 \mathrm{Hf}}{177 \mathrm{Hf}}\right)=\left(\frac{176 \mathrm{Hf}}{177 \mathrm{Hf}}\right) \mathrm{I}+\frac{176 \mathrm{Lu}}{177 \mathrm{Hf}}\left(\mathrm{e}^{\lambda t}-1\right)
$$

A determinação das taxas de decaimento de Lu e seus respectivos tempos de meiavida evoluíram principalmente a partir da década de oitenta, onde Tatsumoto et al. (1981) obtiveram, através de meteoritos acondríticos de 4,55 Ga de idade, uma meia-vida de 35,7 \pm 1,2 Ga equivalente a uma taxa de decaimento de $1,94 \times 10^{-11}$ ano ${ }^{-1}$ e razão ${ }^{176} \mathrm{Hf} /{ }^{177} \mathrm{Hf}$ inicial de $0,27978 \pm 9(2 \sigma)$. Mais tarde os valores de $37,3 \pm 0,1 \mathrm{Ga}$ de tempo de meia-vida e constante de decaimento de 1,86 $\pm 0,005 \times 10^{-11}$ ano-1 $^{-1}$ foram alcançados por Nir-El e Lavi (1998).

Patchett e Tatsumoto (1981) determinaram a composição do reservatório condrítico uniforme - CHUR (chondritic uniform resevoir) através da intersecção da isócrona do meteorito acondrito e a razão ${ }^{176} \mathrm{Lu} /{ }^{177} \mathrm{Hf}$ de 0,0334 obtida através de condritos carbonáceos, resultando na razão ${ }^{176} \mathrm{Hf} /{ }^{177} \mathrm{Hf}$ atual de 0,28286. Mais recentemente, através de análises por MC-ICP-MS, Blichert-Toft e Akbarède (1997) obtiveram a razão ${ }^{176} \mathrm{Hf} /{ }^{177} \mathrm{Hf}$ atual de 0,28277 \pm 3 .

As razões isotópicas de $\mathrm{Hf}$ podem ser descritas como um desvio, em partes por $10^{4}$, em relação à CHUR através da notação $\varepsilon$. No entanto, Bizzarro et al. (2003) obtiverem novos valores para a taxa de decaimento e tempo de meia-vida de 1,98 x 10 $0^{-11}$ ano-1 $^{-1}$ e 35,0 $\mathrm{Ga}$, respectivamente. Desta forma, a partir da nova isócrona, a razão isotópica inicial é de $0,27963 \pm 2$, o que acarreta em um deslocamento da curva CHUR em $3 \varepsilon$ em relação à original (DICKIN, 2005).

Patchett et al. (1981) foram um dos primeiros a relacionar as razões isotópicas iniciais de $\mathrm{Hf}$ como traçador de $\mathrm{Hf}$ mantélico através de rochas crustais de origem mantélica. Desta forma, o estudo isotópico de Hf avançou através das análises de cristais de zircão, mineral escolhido pelos fatos de que: (i) o Hf é um elemento importante na estrutura cristalina do zircão, e este mineral apresenta certa resistência à mobilidade do Hf; (ii) altas concentrações de Hf estão presentes no zircão, ocasionando em baixas razões Lu/Hf; (ii) por ser um mineral que normalmente já é analisado por U-Pb, é possível aliar uma idade à 
razão isotópica de $\mathrm{Hf}$, e (iv) efeitos como metamorfismo ou cristais herdados são revelados através dos dados de U-Pb (DICKIN, 2005). Em diagramas de evolução isotópica de Hf foram plotadas as razões iniciais de ${ }^{176} \mathrm{Hf} /{ }^{177} \mathrm{Hf}$ provindas de rochas ígneas derivadas do manto por Patchett et al. (1981), e praticamente todos os dados caírem sobre a linha de evolução condrítica.

\section{Preparação, análise e tratamento dos dados}

As análises foram realizadas no Centro de Pesquisas Geocronológicas (CPGeo) da USP, onde foi utilizado o mesmo LA-ICP-MS multicoletor Neptune ${ }^{\mathrm{TM}}$ empregado nas análises de U-Pb, assim como os mesmos mounts. Os cristais de zircão foram selecionados pela sua importância através das principais idades destacadas nos histogramas. Os spots do laser foram posicionados nas mesmas estruturas internas/zoneamentos datadas por $U$ $\mathrm{Pb}$, no intuito de se alicerçar as idades com a origem crustal ou juvenil das fontes. Foram analisados cristais de zircão de 8 amostras de rochas metassedimentares da Nappe Andrelândia (SNA-125, SNA-201, SNA-213, SNA-228, NESG-1434, NESG-1446, NESG1010 e NESG-1552) e duas da Nappe Liberdade (SNA-172 E e SNA-180 A), assim como cristais ígneos de zircão de das rochas metaígneas da Nappe Liberdade (SNA-168 e SNA$205 \mathrm{~B})$.

Os parâmetros fixados do ICP-MS e as configurações do laser foram: energia de 6 $\mathrm{mJ}$; taxa de repetição de $7 \mathrm{~Hz}$; fluxo de hélio no controlador de gás 1 (MCF1) igual a 0,25 $\mathrm{l} / \mathrm{min}$; fluxo de hélio no controlador de gás 2 (MCF2) igual a 0,5 I/min; $\mathrm{N}_{2}$ igual a 1,4 $\mathrm{ml} / \mathrm{min}$ e diâmetro do spot de $47 \mu \mathrm{m}$. Os filtros utilizados para a aquisição dos dados foram distribuídos da seguinte forma: quatro coletores low mass $L_{4}, L_{3}, L_{2}$ e $L_{1}$ que analisam ${ }^{171} Y b$, ${ }^{173} \mathrm{Yb},{ }^{174} \mathrm{Hf},{ }^{175} \mathrm{Lu}$, respectivamente; um coletor central $\mathrm{C}$ que examina ${ }^{176} \mathrm{Hf}$; e quatro coletores high mass $\mathrm{H}_{1}, \mathrm{H}_{2}, \mathrm{H}_{3}$ e $\mathrm{H}_{4}$ que identificam as quantidades de ${ }^{177} \mathrm{Hf},{ }^{178} \mathrm{Hf},{ }^{179} \mathrm{Hf}$ e ${ }^{181} \mathrm{Ta}$, respectivamente. Os padrões utilizados para correções internas das análises foi o padrão internacional GJ-1.

As aquisições de dados seguiram os seguintes procedimentos: análise de dois GJ-1, análise de um branco seguido por onze cristais de zircão e finalmente análise de mais dois GJ-1, por planilha. A quantidade de pontos realizados nas amostras variou de 6 (NESG1434) a 44 (NESG-1010), no entanto a maioria das amostras obtiveram de 22 a 28 pontos de análise.

\section{$\underline{\text { Aplicação }}$}

O zircão tipicamente se cristaliza a partir de melts ricos em sílica e em graus metamórficos de moderado à alto, estando presente em praticamente todas as rochas da crosta continental superior. Por conseguir reter sua integridade isotópica ao longo de diversos processos geológicos, ele consegue carregar suas informações químicas e 
isotópicas. É sabido que sedimentos de fontes conhecidas apresentam idade e composição isotópica de $\mathrm{Hf}$ que se espelham ao tipo de rocha de onde eles vieram. O fracionamento de Lu-Hf durante a fusão do manto é aproximadamente duas vezes maior que o de Sm-Nd, e a meia-vida de ${ }^{176} \mathrm{Lu}$ é menor que a de ${ }^{147} \mathrm{Sm}$, indicando que este método apresenta resolução maior na identificação de domínios mantélicos (HAWKESWORTH; KEMP, 2006). Sm e Nd são ETR com características químicas muito semelhantes, já o Lu é um ETR pesado e o Hf é um elemento de alta carga iônica (HFSE - High Field Strenght Element) o que implica que apresentam comportamentos distintos: Hf é mais incompatível que Lu durante os processos de fusão no manto, desta forma no começo da diferenciação, a crosta terrestre se enriqueceu em $\mathrm{Hf}$ e se tornou empobrecida em Lu, já o manto se tornou enriquecido em Lu e empobrecido em Hf (MATTEINI et al., 2010).

As razões isotópicas de $\mathrm{Hf}$ são uma medida da idade de residência crustal ou a média da idade na qual uma certa rocha, neste caso um cristal de zircão, se cristalizou e foi extraído de um específico reservatório mantélico (HAWKESWORTH; KEMP, 2006). Partindo de um reservatório mantélico uniforme primordial (CHUR - chondritic uniform resevoir) ou mesmo do manto depletado (DM - depleted mantle), tem-se que $\mathrm{Lu} / \mathrm{Hf}_{\text {crosta }}<\mathrm{Lu} / \mathrm{Hf}_{\mathrm{CHUR} / \mathrm{DM}} \mathrm{e}$ $\mathrm{Lu} / \mathrm{Hf}_{\text {manto }}>\mathrm{Lu} / \mathrm{Hf}_{\text {CHUR/DM }}$ (MATTEINI et al., 2010). Desta forma, amostras com valores da razão ${ }^{176} \mathrm{Hf} /{ }^{177} \mathrm{Hf}$ maiores que do condrito/manto empobrecido têm $\varepsilon \mathrm{Hf}$ positivos, enquanto que valores menores desta razão apresentam $\varepsilon \mathrm{Hf}$ negativo.

A Figura 2-8 ilustra esquematicamente a evolução isotópica de $\mathrm{Hf}$, na qual um episódio de fusão parcial do manto, em tempo $t_{1}$, resulta em caminhos divergentes de evolução de Hf para a nova crosta gerada (baixa razão Lu/Hf) e para o manto residual, com alta razão Lu/Hf (KINNY; MAAS, 2003). Apresentando razões baixas de Lu/Hf, qualquer zircão que se formar a partir desta crosta, irá preservar sua razão ${ }^{176} \mathrm{Hf} /{ }^{177} \mathrm{Hf}$ inicial, e através do tempo, irá divergir, em composição, de sua rocha hospedeira. No tempo $t_{2}$ uma variedade de possíveis fontes poderá contribuir para a crosta recém formada. Se totalmente derivada do manto empobrecido, o $\varepsilon \mathrm{Hf}$ inicial será positivo, no entanto a mistura com uma fonte não empobrecida ou enriquecida, como é o caso de contaminação pela crosta, poderá resultar em valores de $\varepsilon \mathrm{Hf}$ positivos baixos, zero ou negativos no momento de cristalização, dependendo da quantidade dos componentes. Quaisquer núcleos de zircão herdados em tempo $t_{2}$ será esperado que apresentem valores de $\varepsilon \mathrm{Hf}$ menores que a rocha hospedeira recém formada (KINNY; MAAS, 2003). 


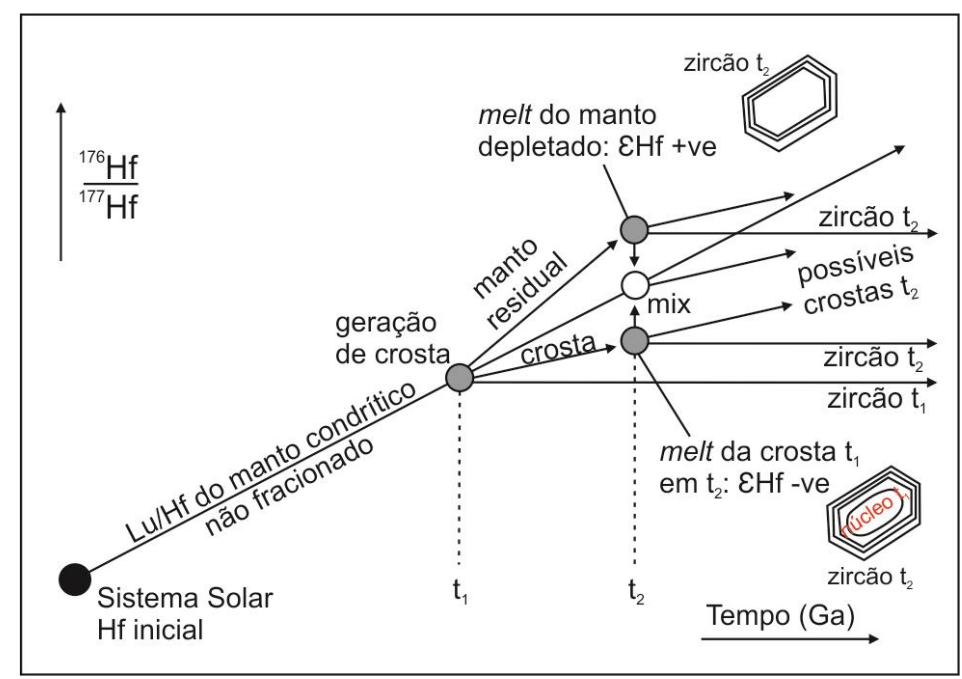

Figura 2-8. Diagrama esquemático da evolução isotópica de Hf, ilustrando como um episódio de fusão parcial no manto terrestre no tempo t1 resultaria em caminhos de evolução isotópica de Hf divergentes para a nova crosta formada (baixo Lu/Hf) e o manto residual (alto Lu/Hf). Retirado e modificado de Kinny e Maas (2003).

Além das composições de CHUR e DM, também pode ser utilizada a linha de evolução de Hf intitulada NC - New Crust (DHUIME; HAWKESWORTH; CAWOOD, 2011), que representa a composição de rochas de arcos de ilhas provenientes do manto depletado, mas com características distintas de sua fonte. As composições de arcos de ilhas podem representar melhor as razões isotópicas de novas crostas, já que apresentam contribuição isotópica de sedimentos subductados, resultando em razões isotópicas de $\mathrm{Hf}$ menores que a do manto depletado (DM). Desta forma o valor atual de $\varepsilon \mathrm{Hf}$ da curva New Crust é de 13,2 enquanto que a do Depleted Mantle é de 16,9. Sendo assim, idades modelo geradas a partir da curva NC resultariam em valores de no máximo 300 Ma mais jovens que as idades modelo TDM comumente utilizadas (Figura 2-9).

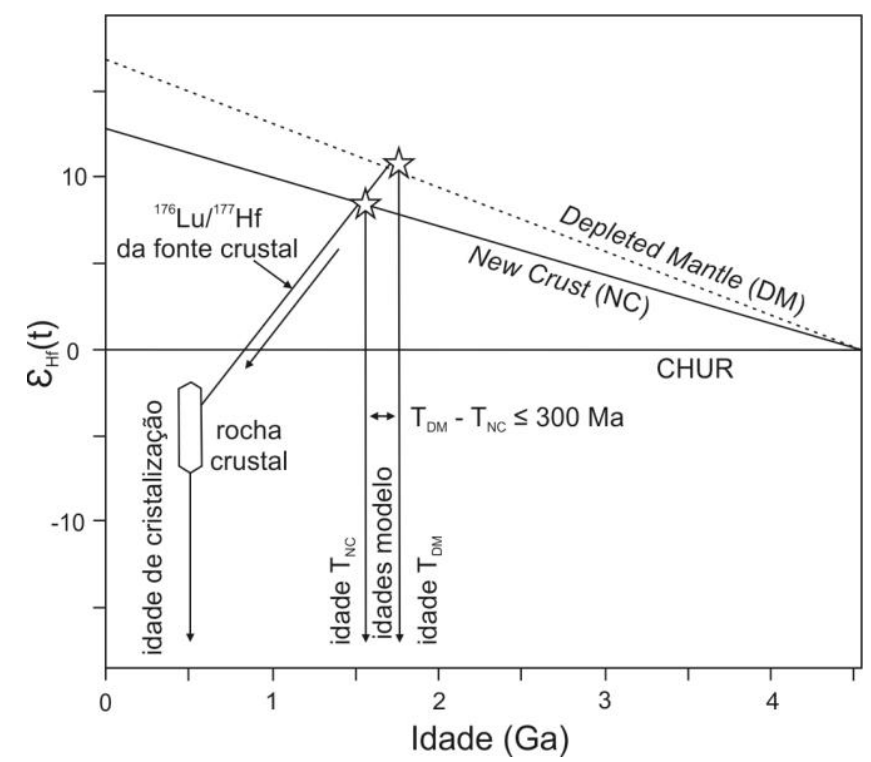

Figura 2-9. Diagrama de $\varepsilon \mathrm{Hf}(\mathrm{t})$ representando a evolução isotópica de $\mathrm{Hf}$ de Depleted Mantle (DM) e New Crust (NC), no qual está representado o $\varepsilon \mathrm{Hf}_{\mathrm{DM}}$ atual de $\sim 16,9$ e o $\varepsilon \mathrm{Hf}_{\mathrm{NC}}$ de 13,2. As idades modelo calculadas através 
de New Crust são geralmente mais jovens, no máximo $300 \mathrm{Ma}$, do que as idade modelo TDM. Figura retirada de Dhuime, Hawkesworth, Cawood (2011).

\subsection{Geoquímica elemental in situ em minerais}

\subsubsection{Elementos traço em zircão}

\section{Preparação, análise e tratamento dos dados}

Para as investigações de elementos traço em cristais de zircão foram utilizados os mesmos mounts das análises U-Pb e Lu-Hf, e de preferência foram escolhidos os grãos que já tivessem sido analisados por estes métodos e com espaço suficiente para a locação dos spots ou dos rasters. Os cristais de zircão escolhidos pertenciam tanto às amostras metassedimentares quanto ao granada-clinopiroxênio anfibolito retroeclogítico (SNA-205B) e ao quartzo-granada-cummingtonita fels (SNA-168). O objetivo deste estudo foi caracterizar quimicamente os grãos detríticos de zircão das diversas fontes encontradas nas amostras e os cristais do protólito ígneo das rochas metaígenas. O objetivo de analisar os cristais metamórficos de zircão do retroeclogito, foi para que, juntamente com os resultados de ETR dos grãos de granada, pudesse ser investigado suas correlações genéticas durante o metamorfismo de alta pressão.

As análises foram realizadas no Laboratório de Química e ICP - Geoanalítica da USP com o auxílio da responsável pelo laboratório Dra. Sandra Andrade, onde foi utilizado um laser ablation da New WaveTM UP-213/AF, que nas primeiras análises estava acoplado a um ICP-MS quadrupolo da Perkin Elmer/Sciex ${ }^{T M}$ Elan-6100/DRC e nas últimas análises acoplado a um ICP-MS I CAP Q 2013 da Thermo Scientific.

Os parâmetros do ICP-MS fixados durante as análises foram: fluxo de gás $\mathrm{He}$ e $\mathrm{Ar}$ igual a 0,25-0,48 I/min; fluxo de gás Ar do plasma igual a 0,48-0,70 l/min; fluxo de gás $\mathrm{Ar}$ auxiliar igual a 0,8-1,0 l/min; energia RF de 1250-1550 W. No laser, os parâmetros foram: taxa de repetição de $20 \mathrm{~Hz}$; energia do laser de $90 \%$ com $\sim 5 \mathrm{~J} / \mathrm{cm}^{2}$; velocidade de ablação de 1-2 $\mu \mathrm{m} / \mathrm{s}$; raster de $\sim 60 \mu \mathrm{m}$ de comprimento e spot de $25 \mu \mathrm{m}$ de diâmetro.

O material utilizado como padrão de qualidade foi o ZR-91500 da IAGeo Limited (sigla em inglês para Internetional Association of Geoanalysts), e os procedimentos de aquisição dos dados seguiram os seguintes passos: análise de dois ou três NIST-610, análise de seis amostras, um NIST-610, seis amostras novamente, ZR-91500 e finalmente análise de mais dois ou três NIST-610.

Os dados foram tratados juntos ao software Glitter 4.4.2 desenvolvido pela Geochemical Evolution and Metallogeny of Continents da Universidade Macquarie na Austrália, e todos os valores foram normalizados segundo o condrito $\mathrm{C} 1$ de Sun e McDonough (1989). 


\section{Aplicação}

O zircão, por ser um mineral relativamente resistente aos processos geológicos e por sua presença em diversos tipos de rocha, é usualmente utilizado como aquele que consegue registrar quimicamente suas características desde sua formação, não sofrendo grandes intervenções durante processos como erosão e deposição, e também gravando eventos metamórficos posteriores. Assim como a datação por U-Pb e a caracterização química de sua fonte por Lu-Hf, a composição dos elementos terras raras em zircão é mais uma ferramenta para a identificação de sua rocha parental (HOSKIN; IRELAND, 2000). A determinação de um tipo de rocha específico é relativamente complicada, já que há sobreposição das concentrações e dos padrões de elementos traços e terras raras nos cristais de zircão de diferentes litotipos, no entanto, é possível fazer uma estimativa do caráter químico da rocha-fonte do zircão em questão. A similaridade dos padrões de ETR em diversos tipos de rocha pode ser explicada pelo fato destes elementos serem altamente compatíveis com a estrutura do zircão. Os ETR de maiores números atômicos apresentam raios iônicos similares ao do $\mathrm{Zr}^{4+}$ o que induz uma preferência pela incorporação dos ETR pesados em relação aos leves, gerando um padrão enriquecido em ETR pesados e empobrecido em ETR leves (GRIMES et al., 2007). Por mais que a abundância de cristais de zircão seja baixa, eles efetivamente afetam o comportamento dos ETR durante a cristalização do magma (BELOUSOVA et al., 2002).

Belosouva et al. (2002) analisaram cristais de zircão de diversos tipos de rocha a fim de traçar o comportamento químico dos elementos traço, em zircão, em relação às diferentes rochas. As concentrações de $U$ e Th são bastante variáveis, de $0,1 \mathrm{ppm}$ a $1 \%$ de $\mathrm{U}$ e de $1 \mathrm{ppm}$ a $1 \%$ de Th, das quais as menores quantidades são encontradas em cristais de zircão provenientes de kimberlitos, enquanto que as maiores concentrações são observadas em rochas granitoides. As razões Th/U geralmente variam entre 0,1 e 1 , no entanto valores mais altos entre 100 e 1000 podem ser observados em sienitos e nefelina sienitos pegmatíticos, e em alguns casos esta razão pode alcançar valores de $10^{3}$ a $10^{4}$, como em grãos de zircão em carbonatitos. Quanto à presença de ETR, as rochas granitoides e os pegmatitos apresentam as maiores concentrações destes elementos, seguidas pelas rochas máficas (basaltos e diabásios). Os cristais de zircão de kimberlitos são os que apresentam menores concentrações de ETR dentre as rochas estudada pelos autores. O enriquecimento em ETR pesados, calculado a partir da razão $\mathrm{Yb}_{N} / \mathrm{Gd}_{N}$ (a notação N corresponde aos elementos já normalizados pelo condrito), indica que os pegmatitos apresentam os maiores valores e portanto exibem um padrão mais inclinado, em diagramas já normalizados pelo condrito, enquanto que rochas carbonatíticas e kimberlíticas podem apresentam padrões relativamente flat (Figura 2-10). 


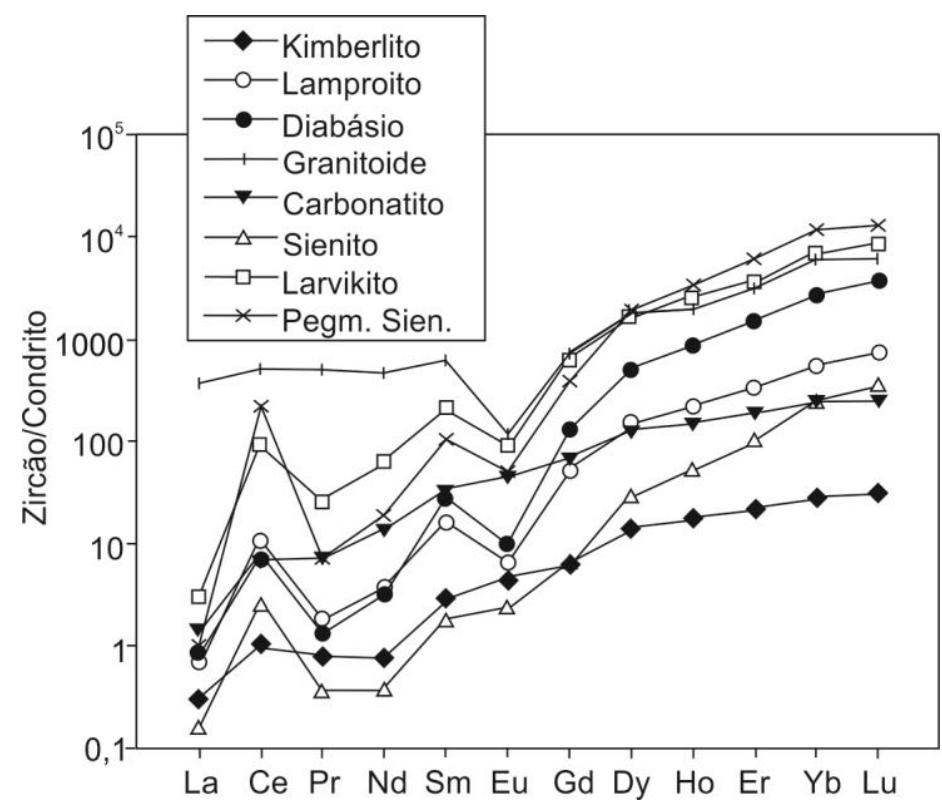

Figura 2-10. Diagrama spider com as concentrações de elementos terras raras, normalizados pelo condrito, de cristais de zircão de diversos tipos de rochas (BELOUSOVA et al., 2002).

As anomalias positivas de $\mathrm{Ce}\left(\mathrm{Ce}_{N} /\left(\mathrm{La}_{N}+\mathrm{Pr}_{N}\right) / 2\right)$ são mais evidentes e mais acentuadas em pegmatitos sieníticos, enquanto que anomalias positivas mais fracas são vistas em kimberlitos, carbonatitos e granitoides. O contrário pode ser observado no caso das anomalias negativas de $\mathrm{Eu}\left(\mathrm{Eu}_{\mathrm{N}} /\left(\mathrm{Sm}_{\mathrm{N}}+\mathrm{Gd}_{\mathrm{N}}\right) / 2\right)$, onde os kimberlitos e carbonatitos apresentam pouca ou nenhuma, e esta se torna mais proeminente nos casos de rochas mais félsicas e fracionadas (BELOUSOVA et al., 2002).

As anomalias de Ce serão governadas pela abundância de $\mathrm{Ce}^{4+}$ no melt e isto está relacionado à razão $\mathrm{Ce}^{4+} / \mathrm{Ce}^{3+}$ que é uma função da fugacidade de oxigênio. As anomalias pequenas ou não-existentes podem estar relacionadas com cristalização em condições mais redutoras. Já as anomalias de Eu, que existe tanto na forma 2+ como 3+ em magmas, são explicadas pela presença de plagioclásio antes ou durante a cristalização do zircão (HOSKIN; SCHALTEGGER, 2003).

O estudo da concentração e dos padrões dos elementos terras raras em zircão, além de ser mais uma ferramenta para indicar um tipo específico de litologia da rocha-fonte, serve também como indicador de condições metamórficas, quando as porções analisadas dos cristais são bordas sobrecrescidas ou quando os cristais são metamórficos. Como descrito em Hoskin e Black (2000), o termo 'zircão metamórfico' é utilizado para descrever os grãos que são formados sob condições metamórficas, podendo ser formados a partir de diferentes processos como (i) precipitação através de fluido durante fusão anatética; (ii) nucleação e cristalização sub-solidus (blastogênse) por difusão de $\mathrm{Zr}$ e Si liberados pelas reações metamórficas de quebra da maioria dos silicatos e fases acessórias; (iii) precipitação através de fluidos metamórficos aquosos, e (iv) recristalização a partir de um protólito de zircão. No entanto, o termo 'zircão metamórfico' stricto sensu é utilizado pra descrever aqueles que não 
são formados por precipitação através de fluido, e sim os cristais que são gerados pelos processos (ii) e (iv) descritos acima, e portanto tendem a não apresentar estruturas internas ou raramente um fraco zoneamento setorizado. No caso do mecanismo (iv), quando não completo, pode ser esperado a presença de um núcleo com zoneamento oscilatório envolto por uma porção sem zoneamento.

Através de um vasto banco de dados (GRIFFIN et al., 1997) foi possível construir árvores de classificação, através das concentrações de determinados elementos em zircão, utilizadas para a determinação diversos tipos de rocha-fonte (BELOUSOVA et al., 2002). A Figura 2-11 é um exemplo destes diagramas com um alto grau de probabilidade de acerto, no qual cristais de zircão provenientes de kimberlitos, carbonatitos, rochas máficas (diabásio e basalto), rochas sieníticas (sienitos e larvikitos) e Ne-sienitos pegmatíticos são reconhecidos com a probabilidade de acerto maior do que $80 \%$. Os cristais de zircão provenientes de granitoides, como grupo, são classificados com probabilidade maior que $75 \%$, já esta porcentagem cai quando a classificação é dividida pelo teor de $\mathrm{SiO}_{2}$, chegando a $49 \%$ de probabilidade para os granitoides com $70-75 \%$ de $\mathrm{SiO}_{2}$ e $63 \%$ para os granitoides com mais de $75 \%$ de $\mathrm{SiO}_{2}$. No entanto, este diagrama foi desenhado baseado em um determinado database e diferentes amostras podem resultar em mudanças tanto nas divisões baseadas nas concentrações dos elementos, quanto na ordem da classificação.

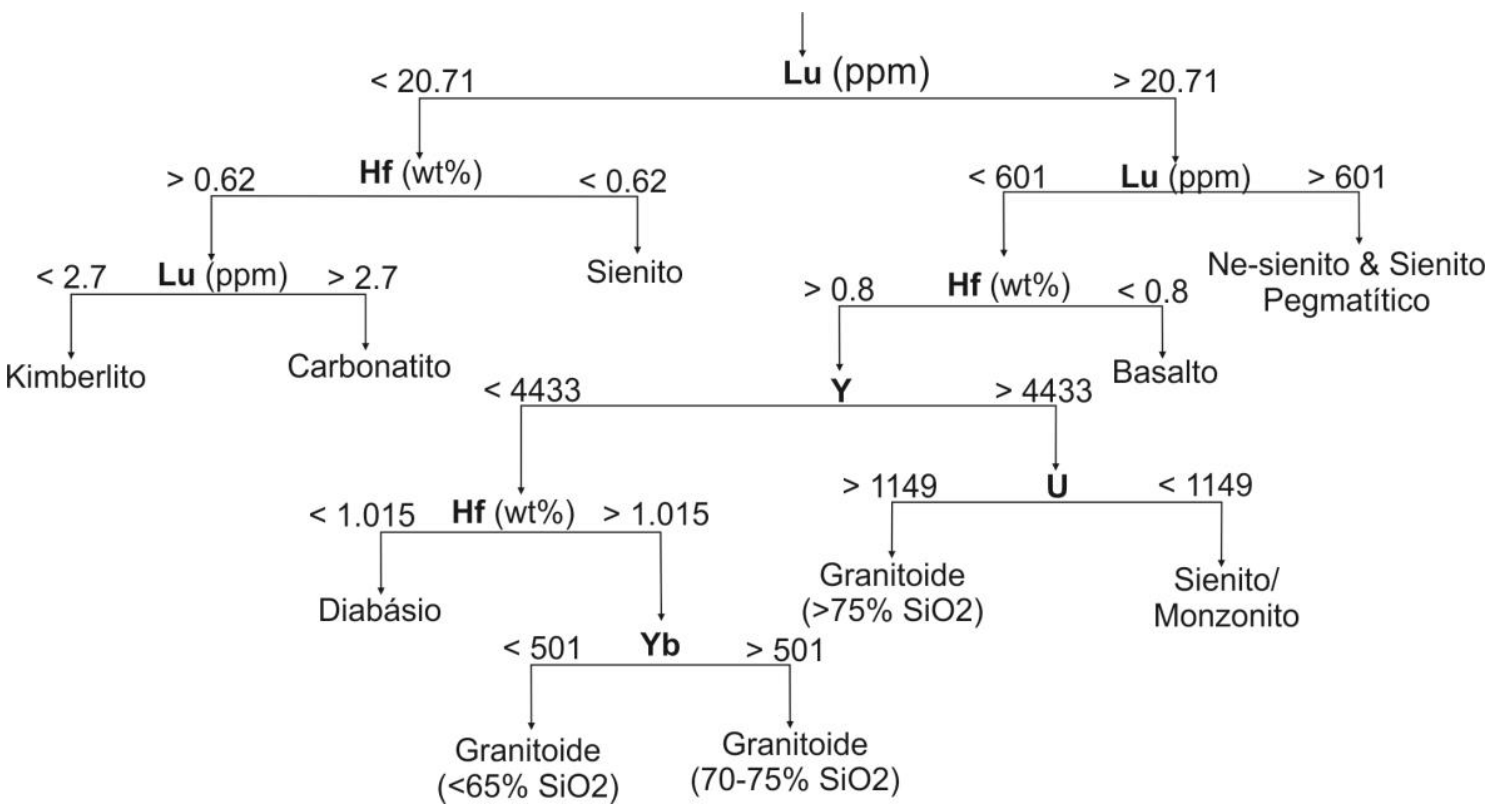

Figura 2-11. Árvore de classificação e regressão binária (BELOUSOVA et al., 2002) para a determinação de diferentes tipos de rocha como fonte de um determinado cristal de zircão.

A cristalização ou recristalização de cristal metamórfico de zircão pode ocorrer em um vasto intervalo de pressão e temperatura durante as etapas progressivas, pico metamórfico e retrogressivas. A concentração de ETR em zircão metamórfico pode refletir o crescimento concomitante dele com outras fases minerais como granada, gerando 
empobrecimento em ETR pesados, monazita, que resulta em empobrecimento em ETR leves e feldspatos, que resulta em anomalia negativa de Eu (RUBATTO, 2002). No caso desta dissertação, os cristais de zircão utilizados para o estudo do metamorfismo, através de suas concentrações e padrões de ETR, são provenientes do granada-clinopiroxênio anfibolito retroeclogítico (SNA-205 B). É entendido que rochas em fácies eclogito nunca apresentam feldspatos, monazita geralmente é ausente e granada está sempre presente. Granada e zircão são enriquecidos em ETR pesados e em $\mathrm{Y}$, desta forma o crescimento concomitante destas duas fases influenciará na composição um do outro (RUBATTO; HERMANN, 2007; RUBATTO, 2002).

Uma forma de comparar a coexistência entre duas fases, sólida e líquida ou mesmo duas fases minerais, é utilizar o coeficiente de partição (D) que calcula a preferência de um certo elemento entre duas fases. O coeficiente de partição é calculado através da equação ${ }^{i} D_{\alpha / \beta}=C_{i}^{\alpha} / C_{i}^{\beta}$, onde $C$ é a concentração do elemento $i$, e $\alpha$ e $\beta$ são as duas fases. Desta maneira pode-se calcular o coeficiente de partição de todos os ETR entre zircão e granada como forma de distinguir quais cristais, ou porções dos grãos de granada (núcleo ou borda) cresceram concomitantemente sob fácies eclogito. Se o zircão metamórfico crescer em equilíbrio com a granada é possível que ele exiba um padrão empobrecido em ETR pesados, ou até mesmo flat (RUBATTO, 2002).

\subsubsection{Elementos traço em granada}

\section{Preparação, análise e tratamento dos dados}

As análises de elementos traço em granada foram realizadas também no Laboratório de Química e ICP - Geoanalítica da USP onde foi utilizado o mesmo equipamento para as análises de elementos traço em zircão, descrito no item acima. Neste caso os materiais utilizados foram duas seções delgadas de $80 \mu \mathrm{m}$ de espessura do granada-clinopiroxênio anfibolito retroeclogítico das amostras SNA-205 B1 e SNA-205 B2, das quais foram escolhidas um cristal de granada em cada uma, onde foram feitas análises em seção transversal ao grão, analisando borda-núcleo-borda. O objetivo deste estudo foi identificar as porções dos cristais de granada que cresceram concomitante aos grãos metamórficos de zircão.

Os parâmetros fixados do ICP-MS foram os mesmos utilizados durante as análises de zircão, já os parâmetros do laser para a investigação de elementos traço em granada foram: taxa de repetição do laser de 10-20 Hz; energia de 83-87\% com 15 J/cm², no caso dos rasters, e $\sim 5 \mathrm{~J} / \mathrm{cm}^{2}$, no caso dos spots; velocidade de ablação de $1 \mu \mathrm{m} / \mathrm{s}$, raster de $\sim 80$ $\mu \mathrm{m}$ de comprimento e spot de $55 \mu \mathrm{m}$ de diâmetro.

O material utilizado como padrão de qualidade foi o vidro basáltico BHVO-2G da USGS (sigla em inglês para United States Geological Survey). Os procedimentos de 
aquisição de dados seguiram a seguinte ordem: análise de dois NIST-610, análise de seis amostras, um NIST-610, seguido por mais seis análises de amostra, dois BHVO-2G e finalmente mais três NIST-610.

Todos os dados obtidos foram tratados com o auxílio do software Glitter 4.4.2 desenvolvido pela Geochemical Evolution and Metallogeny of Continents da Universidade Macquarie na Austrália, e todos os valores foram normalizados pelo condrito C1 de Sun e McDonough (1989)

\section{Aplicação}

Os elementos traço são tidos como sendo menos móveis que os elementos maiores durante o metamorfismo, desta forma eles são utilizados, em especial os ETR, para investigações de seus comportamentos e mobilidade entre fases minerais sob condições metamórficas de alta pressão (LI et al., 2013). A granada é um mineral rico em ETR pesados e empobrecido em ETR leves, o que gera um padrão inclinado, em diagramas de suas concentrações normalizadas pelo condrito, mesmo que ocorra porções flat em cada um dos grupos de elementos (pesados e leves), como é o caso do exemplo da Figura 2-12 A.

Granada é um dos minerais mais utilizados como termobarômetro enquanto que o zircão é o melhor geocronômetro, desta forma se há comprovação de que exista coexistência entre eles em uma determinada rocha, como é o caso dos eclogitos, é possível anexar informações a respeito da idade ao grau metamórfico no qual estas duas fases foram geradas concomitantemente. Como descrito no item acima, ambas fases minerais são enriquecidas em ETR pesados e em $\mathrm{Y}$, o que acarretará na interferência da composição um do outro (RUBATTO; HERMANN, 2007; RUBATTO, 2002).
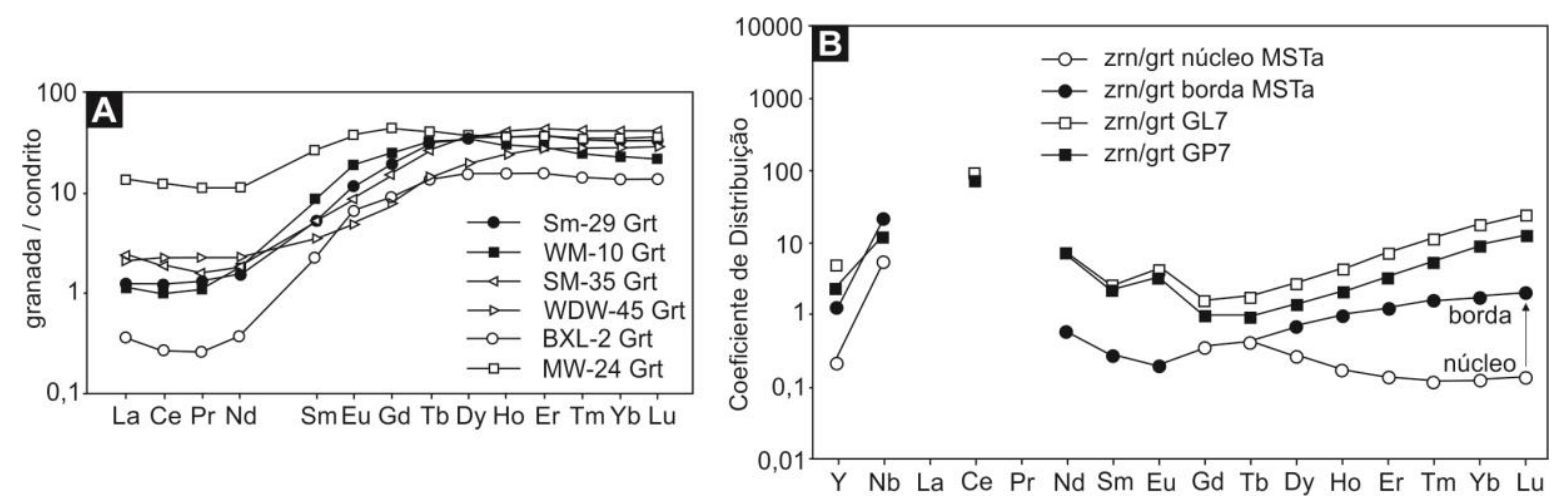

Figura 2-12. (A) Diagrama spider, normalizado pelo condrito, com as concentrações dos ETR dos cristais de granada analisados por Li et al. (2013): SM-29 e WM-10 referem-e à eclogitos associados à gnaisses, SM-35 e WDW-45 estão associados à mármores, e BXL-2 e MW-24 são eclogitos associados à rochas ultramáficas; (B) Diagrama dos coeficientes de partição/distribuição entre zircão e granada do eclogito (MSTa), do granulito (GP7) e do leucossoma coexistente (GL7), analisados por Rubatto (2002). 
O coeficiente de partição, ou de distribuição, é um indicativo de que duas fases minerais cresceram em equilíbrio, como no caso do eclogito descrito por Rubatto (2002), no qual o zircão cresceu em equilíbrio com a granada. Este coeficiente pode também apontar em qual estágio o zircão cresceu especialmente quando os grãos de granada apresentam zoneamento químico. A granada analisada pela autora referente a um eclogito, apresenta empobrecimento em $\mathrm{Ca}$ e enriquecimento em $\mathrm{MgO} /\left(\mathrm{MgO}_{+} \mathrm{FeO}_{\text {tot }}\right)$ do núcleo para a borda, o que sugere que o cristal cresceu durante o avanço do metamorfismo e que a borda rica em Mg represente a condição do pico metamórfico. Este mesmo zoneamento é observado nos elementos traço, com uma drástica diminuição em Ti, Y e ETR pesados do núcleo para a borda. É esperado que a composição química do zircão seja controlada pela formação de granada. Como previsto, o empobrecimento em ETR pesados nas bordas dos grãos metamórficos de zircão indica que esta porção foi recristalizada na presença de granada.

A Figura 2-12 B exibe os coeficientes de partição entre zircão e granada do trabalho de Rubatto (2002), que demonstra uma mudança entre os valores calculados com o núcleo e a borda da granada das amostras referentes ao eclogito: os coeficientes de partição para os ETR pesados calculados com as composições das bordas da granada estão em torno de uma unidade, indicando que houve distribuição quase que igualitária destes elementos entre o zircão e a granada. Isso demonstra que as bordas dos cristais de zircão foram formadas em equilíbrio com as bordas ricas em $\mathrm{Mg}$ da granada, apontando que isto ocorreu durante o pico metamórfico de alta pressão.

O objetivo então, de se analisar os cristais de granada da amostra do granadaclinopiroxênio anfibolito retroeclogítico e seus cristais metamórficos de zircão, é determinar, através do coeficiente de partição dos elementos traço, quais porções de ambos os minerais cresceram em equilíbrio.

\subsubsection{Elementos maiores e menores em granada}

\section{Preparação, análise e tratamento dos dados}

Os elementos maiores e menores foram investigados em dois cristais de granada, B1 e B2, da amostra SNA-205B (granada-clinopiroxênio anfibolito retroeclogítico) em seções delgadas de $80 \mu \mathrm{m}$ de espessura com revestimento de carbono. As análises foram realizadas no Instituto de Geociências da USP com o equipamento JXA-8530 F Jeol Superprobe, onde cada um dos cinco espectrômetros foram organizados para analisar um determinado elemento. O primeiro espectrômetro (TAP) analisou Si e Al, o segundo (Lif L) Mn e $\mathrm{Fe}^{2+}$, o terceiro (PET J) Ca, o quarto (Lif L) Ti e Cr e o último (TAP H) analisou Mg. Os parâmetros utilizados foram corrente de $2,0 \times 10^{-8} \mathrm{~A}$, voltagem de aceleração de $15 \mathrm{kV}$ e spot de $5 \mu \mathrm{m}$ de diâmetro. Os spots foram posicionados segundo uma linha irregular que atravessou borda-núcleo-borda de cada cristal de granada. 
Para o cálculo dos membros finais das granadas foi utilizado uma tabela cujas equações estavam baseadas em 24 oxigênios, como indicado por Deer, Howie e Zussman (2013), e os cálculos foram programados pela própria autora com auxílio do doutorando Pedro Augusto da Silva Rosa. A tabela foi testada através dos próprios dados disponíveis no livro citado acima.

\section{Aplicação}

A quantificação dos elementos maiores e menores em minerais como granada podem ser utilizados, além da composição mineral, para a determinação de zoneamentos químicos que possam estar relacionados a fatores como avanço, pico ou retrogressão metamórfica. O trabalho de Rubatto (2002) relaciona o zoneamento químico dos elementos maiores através do grão de granada de um eclogito, juntamente com a composição dos ETR em granada e zircão, para determinar qual porção do cristal se formou durante o pico metamórfico em fácies eclogito.

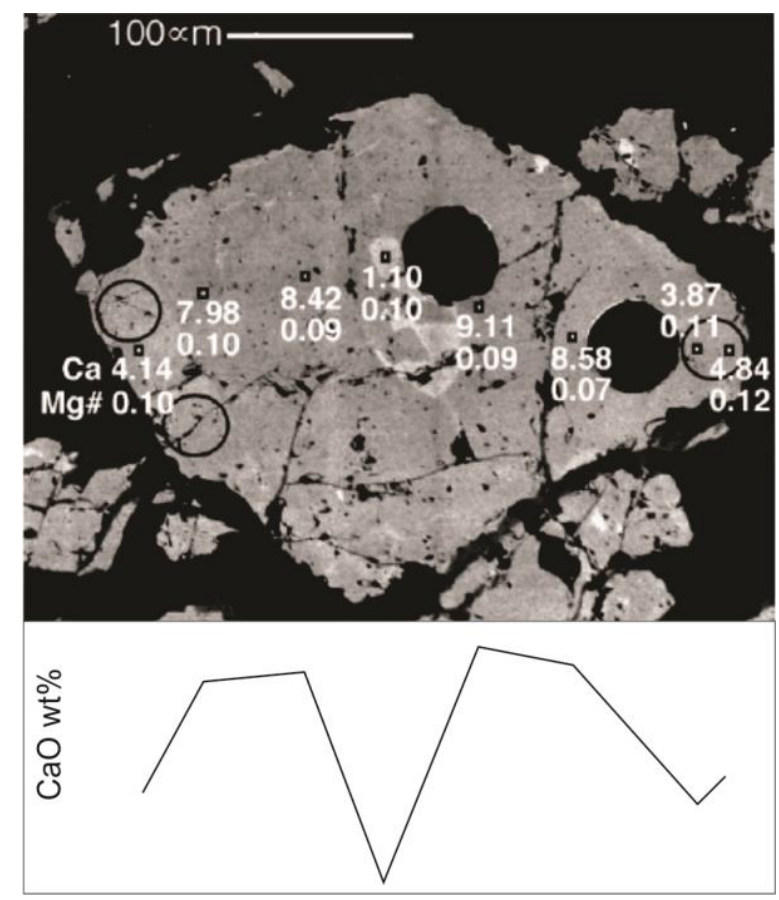

Figura 2-13. Imagem por elétron retroespalhado (BSE - backscattered eletron image) do cristal de granada do eclogito do trabalho de Rubatto (2002) juntamente com a localização e porcentagem em peso relativa das análises de $\mathrm{CaO}$ e $\mathrm{MgO} / \mathrm{MgO}+\mathrm{FeOtot}(\mathrm{Mg \#})$ por microssonda realizadas através do grão. Abaixo está o perfil do conteúdo de $\mathrm{Ca}$. O núcleo rico em Ca é provavelmente uma relíquia pré-metamorfismo alpino.

A Figura 2-13 exibe a imagem de elétron retroespalhado do cristal de granada analisado juntamente com o perfil do conteúdo de $\mathrm{Ca}$, indicando que o núcleo é enriquecido em $\mathrm{Ca}$ em relação às bordas (descontando o núcleo reliquiar pobre em $\mathrm{Ca}$ do prémetamorfismo alpino). A conclusão do trabalho dela é que, do núcleo para a borda, o cristal de granada tem seu conteúdo de $\mathrm{Ca}$ diminuído e de $\mathrm{MgO} / \mathrm{MgO}+\mathrm{FeO}_{\text {tot }}$ aumentado, e que 
este zoneamento também é observado nos ETR pesados que diminuem do núcleo para a borda. Desta forma é provável que a granada tenha crescido durante o avanço do metamorfismo e que a borda rica em Mg represente as condições de pico.

Assim como o trabalho citado acima, o objetivo desta dissertação, em relação aos elementos maiores e menores nos cristais de granada do retroeclogito, é tentar traçar uma relação da composição e zoneamento químico com a composição de ETR pesados e seus coeficientes de partição com o zircão para que seja tirada alguma conclusão em relação ao pico metamórfico ou sua retrogressão. 


\section{CAPÍTULO 3}

\section{O ORÓGENO BRASÍLIA MERIDIONAL}

A Província Tocantins é um extenso segmento originado da colagem orogênica Brasiliano-Pan Africana do Gondwana Ocidental e é subdividido em dois sistemas orogênicos. O Orógeno Araguaia, de estruturação N-S, compreende a porção mais setentrional da província. O Orógeno Brasília, estruturado em um arco de orientação NE-SW a partir do sul de Palmas (Tocantins) e NW-SE de Brasília ao sudeste do estado de Minas Gerais, pode ser segmentado em dois domínios: Brasília e Brasília Meridional, ambos com vergência principal para o Cráton São Francisco. A porção meridional do Orógeno Brasília encontra-se lateralmente alóctone sobre o extremo sul cratônico, para onde o transporte principal varia de E-NE para N-NE. A Faixa Paraguai é a extensão mais ocidental da província e também é subdividida em duas partes, norte e sul, de acordo com sua estruturação principal (Figura 3-1). A porção norte da Faixa Paraguai localiza-se na borda sul do Cráton Amazônico, enquanto que a porção sul abraça o Bloco Rio Apa e extende-se ao Bloco Paraguá (Faixas Sunsás e Rondoniano-San Ignácio - Bettencourt et al., (2010)) do Cráton Amazonas.

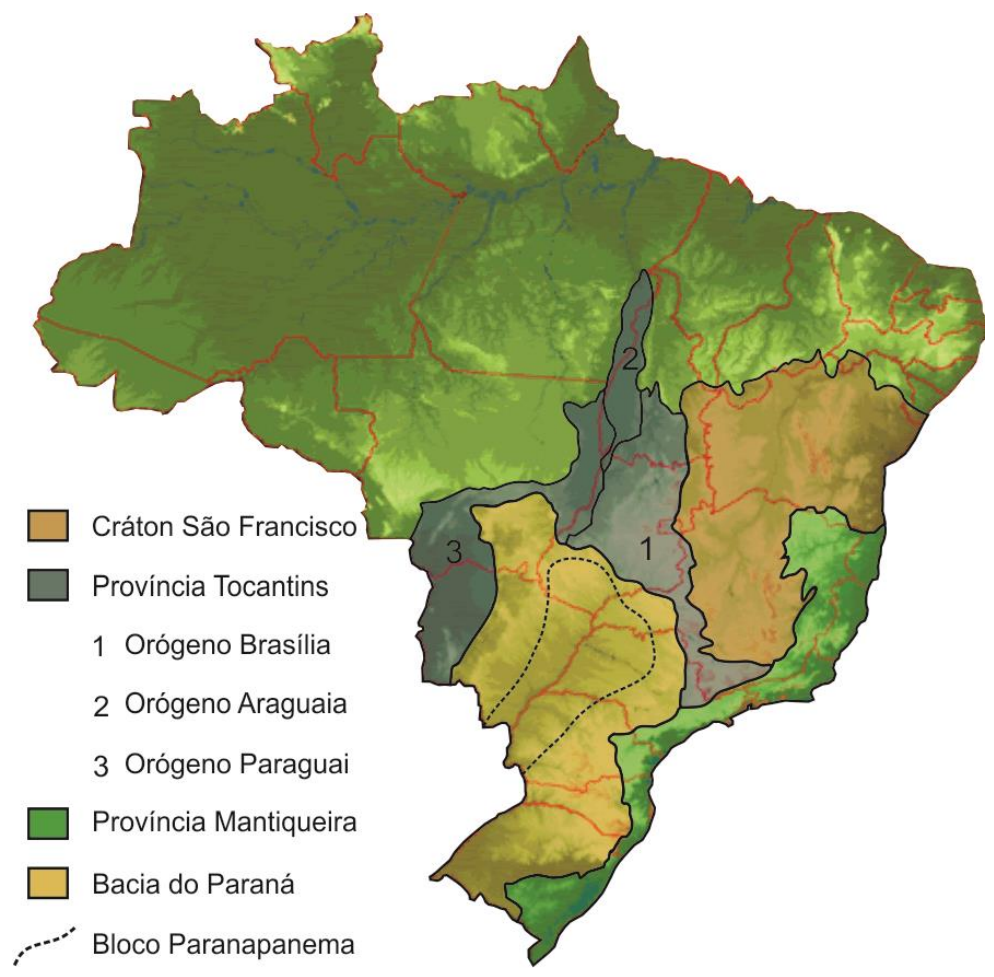

Figura 3-1. Mapa baseado nas principais províncias estruturais segundo Bizzi et al. (2003), com a localização do Bloco Paranapanema segundo Campos Neto et al. (2000). Imagem do relevo retirado de Brasil em revelo EMBRAPA.

A presença de sistemas de arcos insulares tonianos (PIMENTEL; FUCK, 1992; SAALMANN et al., 2006) a leste do Lineamento Transbrasiliano, sugere um grande oceano na margem sul-oriental do Cráton Amazonas. O oceano Farusiano-Goiás, largo e de longa- 
vida (cerca de 300 milhões de anos), poderia separar duas massas continentais: África (ou Gondwana) e Rodinia (ou Laurencia) (CORDANI; BRITO-NEVES; D'AGRELLA-FILHO, 2003; CORDANI et al., 2009; GANADE ARAUJO et al., 2012, 2014; KRÖNER; CORDANI, 2003). $\mathrm{Na}$ história diacrônica de fechamento deste oceano, a convergência entre as margens das placas São Francisco (margem passiva) e Paranapanema (margem ativa) resultou no Orógeno Brasília Meridional.

O Orógeno Brasília Meridional bordeia o limite sul do Cráton São Francisco, onde à ESE encontra, obliquamente, a Faixa Ribeira [sistema orogênico Mantiqueira de Campos Neto et al. (2000)] e à W-NW a Bacia do Paraná encobre seu limite ocidental. Ele é composto por uma pilha de nappes sin-metamórficas neoproterozoicas com vergência para o Cráton São Francisco exibindo um aumento do gradiente metamórfico de norte para os compartimentos mais centrais da faixa, em um padrão metamórfico geral invertido. A evolução do conhecimento geológico deste segmento do Orógeno Brasília tem possibilitado duas principais interpretações à respeito da sedimentação, metamorfismo e evolução tectônica da área. Inicialmente, até o final da década de 1980, as rochas metassedimentares da região foram relacionadas a uma única bacia deposicional denominada Complexo Algonquiano composto pelas sequências sedimentares Prados, Barroso, Carandaí e Série Andrelândia (EBERT, 1955, 1956, 1984). A partir do final da década de 1980, estas unidades foram separadas nos ciclos deposicionais Tiradentes, Lenheiro, Carandaí e Andrelândia (ANDREIS; RIBEIRO; PACIULLO, 1989) e mais adiante em Bacia São João Del Rei, Bacia Carandaí e Bacia Andrelândia (PACIULLO; RIBEIRO; ANDREIS, 1993; RIBEIRO et al., 1995; PACIULLO et al., 1996, 1998; TROUW; PACIULLO; RIBEIRO, 1998). Com o avanço das metodologias analíticas a partir dos anos 2000 , as intepretações dos dados divergiram dando início aos dois principais segmentos de pesquisa da área conhecidas hoje.

\subsection{A Megassequência Andrelândia}

Os ciclos deposicionais Tiradentes e Lenheiro (ANDREIS et al., 1989, RIBEIRO et al., 1990) teriam sido depositados sobre um embasamento relacionado à margem do Cráton São Francisco (TROUW et al., 2000) e separados, através de uma discordância angular (RIBEIRO; PACIULLO; ANDREIS, 1990) dos ciclos deposicionais Carandaí e Andrelândia (ANDREIS et al., 1989, RIBEIRO et al., 1990). Foram reconhecidas três bacias deposicionais (RIBEIRO et al., 1995) relacionadas aos quatro ciclos: Bacia São João Del Rei, que corresponde aos ciclos Tiradentes e Lenheiro, com idade entre 1,8 Ga e 1,3 Ga; Bacia Carandaí, que engloba o ciclo Carandaí, com idade entre 1,3 Ga e 1,0 Ga (RIBEIRO et al., 2013); e a Bacia Andrelândia, com idade entre 1,0 Ga e 0,6 Ga, referente ao ciclo deposicional Andrelândia. Estas bacias e respectivos ciclos foram divididas (RIBEIRO et al., 1990) em um domínio autóctone (domínio I), referente aos ciclos deposicionais Tiradentes, Lenheiro, Carandaí e parte do Andrelândia e 
dois domínios alóctones (domínios II e III), correspondentes ao embasamento e ao ciclo Andrelândia (Figura 3-2). Foi atribuída à diferença do transporte tectônico entre os domínios II, de E para W, e III, de SSE para NNW, à interferência da Faixa Ribeira no Orógeno Brasília Meridional (TROUW et al., 1994; TROUW et al., 2000, 2013; PETERNEL et al., 2005), resultando na Zona de Interferência composta pelo domínio III, deixando o domínio II como a continuidade meridional da geometria da Nappe Araxá-Canastra, que ocorre principalmente na porção setentrional segmento central do Orógeno Brasília.

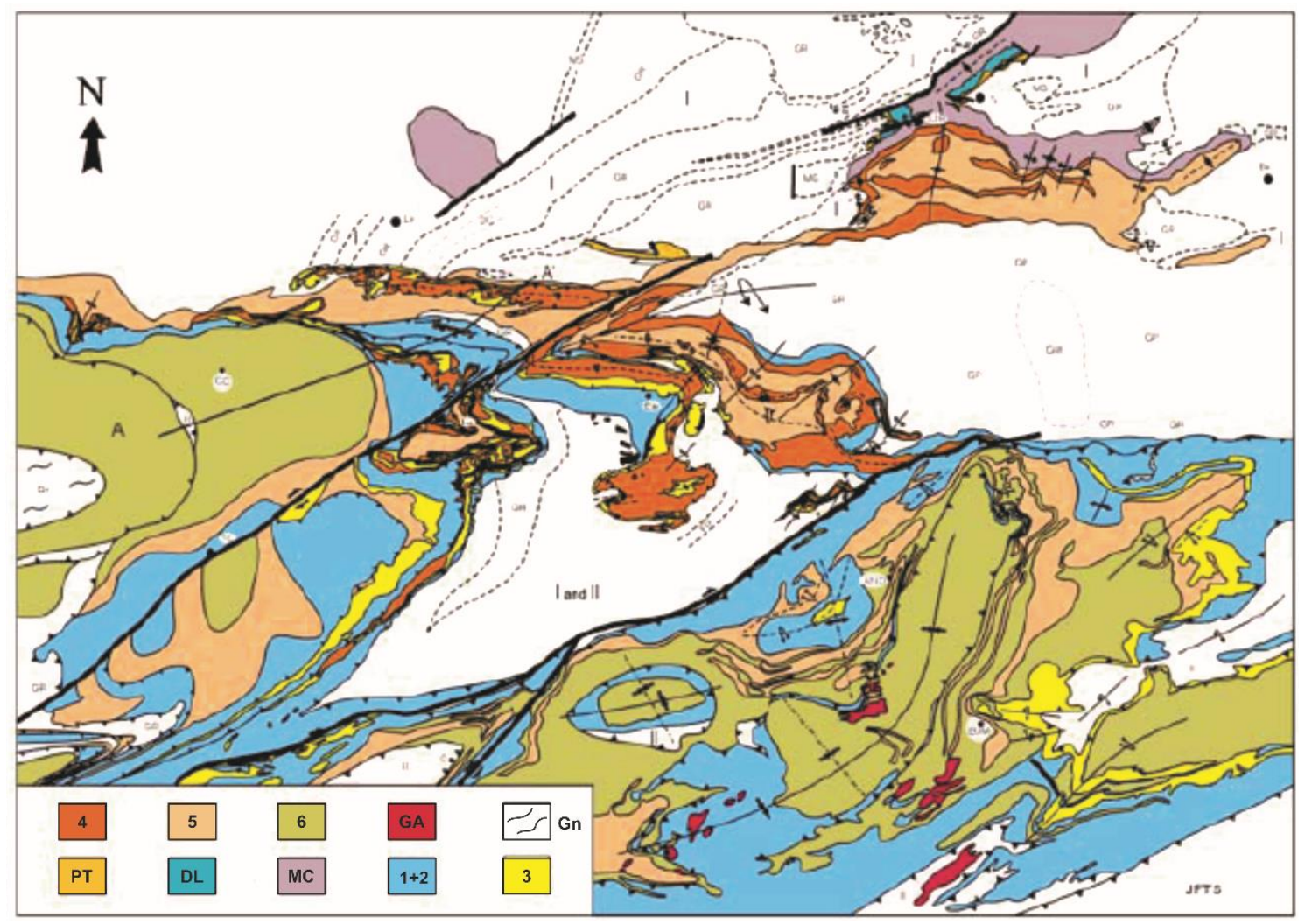

Figura 3-2. Mapa geológico da Megassequência Andrelândia (TROUW et al., 2002). Unidades do Embasamento (em branco): I-Faixas Greenstone; II-Complexo Gnáissico; GR-Granitoides; MG-Metagabro; MS-Supergrupo Minas; DC-Diorito Capivari; GP-Gnaisse Piedade; GM-Gnaisse Sienítico Matola. Unidades Proterozoicas: 1+2Paragnaisse com intercalações de anfibolitos, quartzitos e xistos; 3-Mica verde quartzito; 4-Filito/xisto cinzento com quartzitos subordinados; 5-Biotita filito/xistos finos; 6-Biotita xisto/gnaisses grossos com intercalações de anfibolitos, quartzitos, gonditos e rochas calciossilicáticas; PT-Plataforma Tiradentes; DL-Delta do Lenheiro; MCMegassequência Carandaí; Gn-Nappe Guaxupé.

A Bacia Andrelândia, conhecida como Megassequência Andrelândia (RIBEIRO et al., 1995), atualmente é dividida em duas sequências deposicionais separadas por uma discordância interna (TROUW et al., 2000). A Sequência Carrancas é composta pelas unidades $\mathrm{Na}_{1}, \mathrm{Na}_{2}, \mathrm{Na}_{3}$ e $\mathrm{Na}_{4}$ e teria idade toniana, e a Sequência Serra do Turvo é composta pelas unidades $\mathrm{Na}_{5}$ e $\mathrm{Na}_{6}$ e apresentaria idade criogeniana (Figura 3-3). A sequência de deposição destas unidades teria início na fase ritf da bacia e é representada por paragnaisses com intercalações de anfibolitos ( $\left.\mathrm{Na}_{1}\right)$; a evolução seria seguida por uma fase proto-oceânica 
responsável pela ocorrência de paragnaisses com intercalações de quartzitos, xistos e anfibolitos ( $\left.\mathrm{Na}_{2}\right)$; a unidade $\mathrm{Na}_{3}$ seria correspondente a uma para-sequência desenvolvida em plataforma estável e é representada por mica verde quartzitos com xistos subordinados; a máxima inundação da bacia seria representada pela unidade $\mathrm{Na}_{4}$ composta por filito/xistos grafitosos com intercalações de muscovita quartzitos; a evolução daria origem à depósitos regressivos e transgressivos relacionados à períodos glaciais e pós-glaciais representados por biotita xistos ricos em plagioclásio e quartzo $\left(\mathrm{Na}_{5}\right)$; e o topo da sequência seria representada por biotita xisto/gnaisses com intercalações de rochas calciossilicáticas e anfibolitos referentes à depósitos turbidíticos, pelágicos e hemipelágicos correspondentes à sedimentação distal e profunda pós fase proto-oceânica (Na6) (PACIULLO et al., 1998, 2000). A Figura 3-3 resume a coluna estratigráfica da Megassequência Andrelândia.

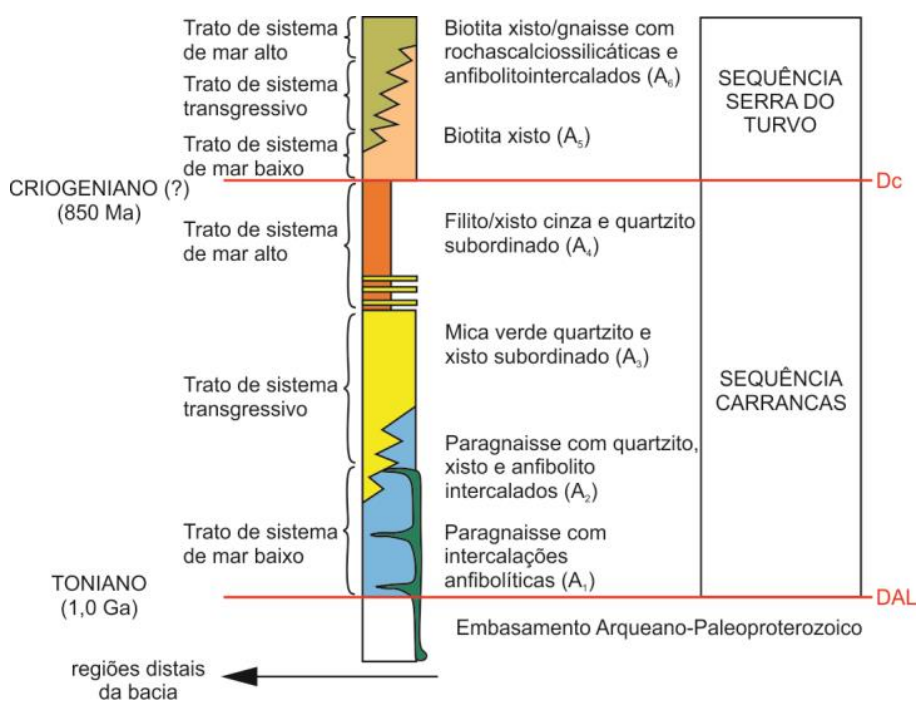

Figura 3-3. Estratigrafia da Megassequência Andrelândia segundo Trouw et al. (2002). Dc = desconformidade; DAL = discordância angular e litológica; $A_{1}$ à $A_{5}=$ associações de litofácies.

As rochas metassedimentares da região do sul do Orógeno Brasília são, portanto, denominadas Megassequência Andrelândia pelos autores acima citados, e correspondem à sedimentação em uma única bacia sedimentar localizada na margem passiva, referente à paleoplaca São Francisco-Congo. Da mesma forma, é considerado que grande parte da faixa, onde está localizada parte das associações de $A_{1}$ à $A_{6}$, faz parte de uma zona de interferência entre este orógeno e a Faixa Ribeira, estando localizada a zona de sutura referente à colisão Ribeira-Brasília na retaguarda das nappes que compõem a megassequência.

\subsection{O Orógeno Brasília Meridional}

$\mathrm{Na}$ outra visão e interpretação acerca do Orógeno Brasília Meridional, esta porção da Província Tocantins é compartimentada em três domínios principais: domínio interno, representado por rochas de altas temperaturas representantes do arco magmático e 
constituintes da Nappe Socorro-Guaxupé (CAMPOS NETO; CABY, 1999, 2000); domínio continental subductado, que é representado por rochas de altas pressões e constituintes do Terreno Andrelândia (CAMPOS NETO; CABY 1999, 2000; TROUW et al., 2000); e domínio externo de margem continental passiva representado pelo Sistema de Nappes Carrancas (TROUW et al., 2000) e Nappe Lima Duarte (CAMPOS NETO et al., 2004). Desta forma, a Nappe Socorro-Guaxupé e o Sistema de Nappes Andrelândia seriam correlacionáveis ao Bloco Paranapanema, margem ativa, enquanto que o Sistema de Nappes Carrancas e a Nappe Lima Duarte seriam representantes da margem passiva da paleoplaca São FranciscoCongo (CAMPOS NETO et al., 2011) (Figura 3-4). Xistos imaturos, semi-pelíticos a metawackes compõem uma série de depósitos sin-colisionais tipo flysch sobre a Nappe Carrancas, no domínio de margem passiva (WESTIN; CAMPOS NETO, 2013). Como embasamento destes domínios, ocorrem substratos alóctones arqueano-paleoproterozoicos que afloram em núcleos antiformais.

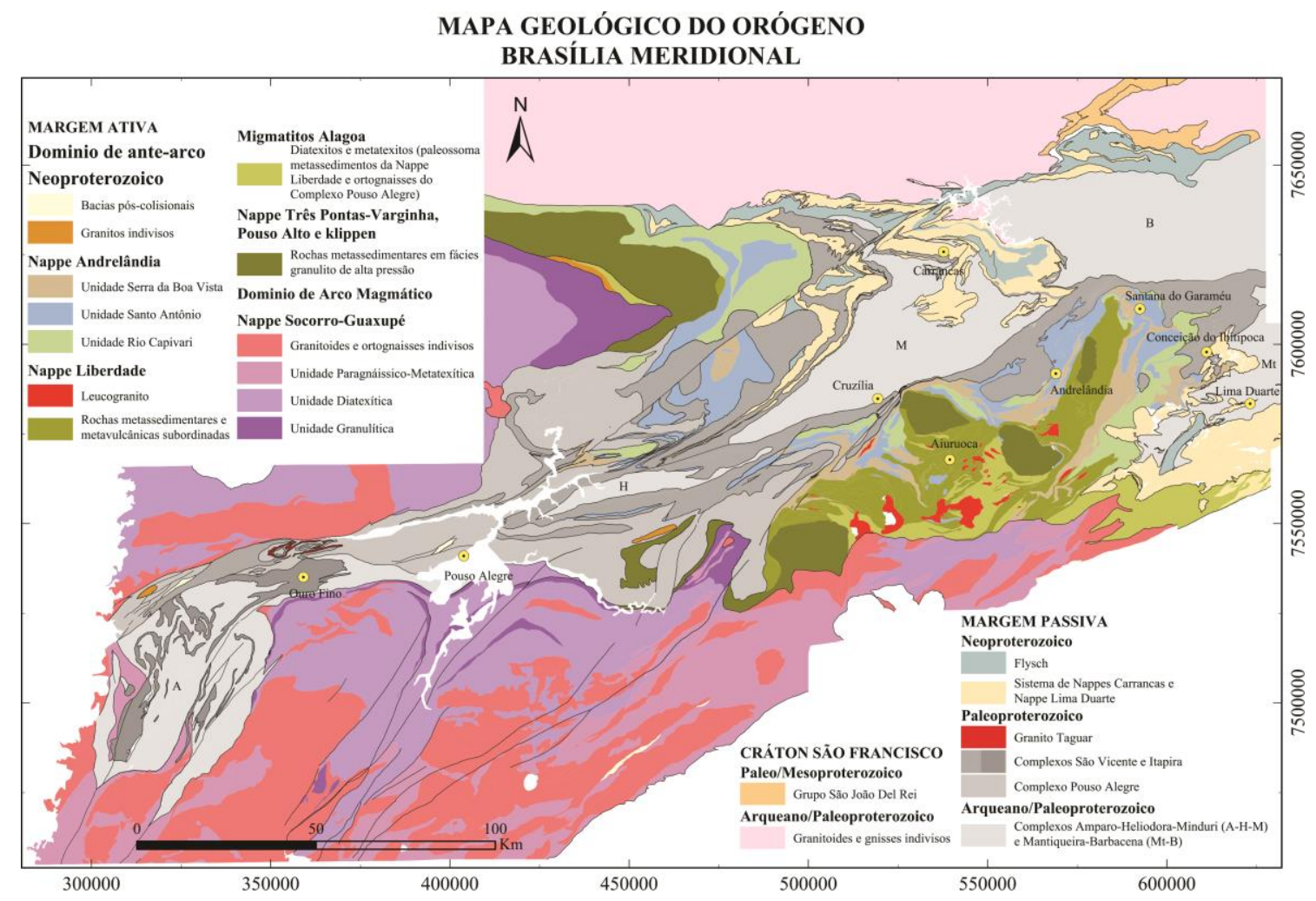

Figura 3-4. Mapa geológico do Orógeno Brasíla Meridional. Modificado de Campos Neto et al. (2010), Gengo (2014), Nunes et al. (2008), Paciullo et al. (2002), Quéméneur et al. (2002), Ribeiro et al. (2002), Trouw et al. (2008, 2002), Vinagre et al. (2014) e Westin et al. (2016).

Os complexos Amparo-Serra Negra, Heliodora-Minduri, Mantiqueira e Petúnia, correspondem a ortognaisses arqueanos, enquanto que o Complexo Pouso Alegre (CIOFFI et al., 2016), Paleoproterozoico juvenil, é representado por tonalito-granodiorito ortognaisses migmatíticos com associações de granitos porfiroclásticos e subordinadamente anfibolitos. Este complexo ocorre como substrato do Sistema de Nappes Andrelândia e cavalga o 
Complexo São Vicente. O Complexo São Vicente corresponde às unidades $\mathrm{Na}_{1}$ e $\mathrm{Na}_{2}$ de Paciullo et al. (2002), e é composto por duas associações de litofácies principais, uma composta por paragnaisses e outra por intercalações de paragnaisses com quartzitos, xistos, rochas calciossilicáticas, anfibolitos e rochas metaultramáficas subordinadas (TEIXEIRA, 2015; WESTIN et al., 2016).

\subsubsection{Domínio de Arco Magmático}

A Nappe Socorro-Guaxupé corresponde a uma lasca de aproximadamente $15 \mathrm{~km}$ de espessura de crosta inferior e intermediária representada pelas raízes do arco magmático continental construído através da subducção da crosta oceânica referente à paleoplaca São Francisco-Congo. As suítes plutônicas cálcio-alcalinas e valores negativos de $\varepsilon \mathrm{Nd}_{\mathrm{t}}$ indicam ambiente de margem continental ativa e acrescionária, com idades entre $670 \mathrm{Ma}$ e $625 \mathrm{Ma}$ (CAMPOS NETO; CABY, 1999; GENGO, 2014; SALAZAR MORA; CAMPOS NETO; BASEI, 2014; VINAGRE et al., 2014). É considerada como representante da extensão mais meridional do Arco Magmático de Goiás (LAUX, 2004; LAUX et al., 2004, 2005; PIMENTEL; FUCK; GIOIA, 2000), e é dividida em Unidade Granulítica Basal, Unidade Diatexítica Intermediária e Unidade Metatexítica Superior (CAMPOS NETO; CABY, 2000). As condições de metamorfismo que afetaram a Nappe Socorro-Guaxupé resultaram em extensa fusão sinorogênica observada em rochas migmatíticas presentes em diferentes níveis crustais. A existência de rampas laterais de alto ângulo separam a nappe em dois domínios principais: Guaxupé, ao norte, e Socorro, ao sul.

O Domínio Guaxupé apresenta, em sua base, rochas granulíticas enderbíticas à charno-enderbíticas com intercalações locais de gnaisses gabro-noríticos, referentes à Unidade Granulítica Basal (CAMPOS NETO; CABY, 2000). A porção intermediária, Unidade Diatexítica Intermediária, é representada por biotita-hornblenda diatexitos e biotita-granada diatexitos com fontes metaluminosas a peraluminosas e com enclaves de gnaisses kinzigíticos. E no topo da sequência, compondo a Unidade Metatexítica Superior, são encontrados metatexitos pelíticos e semi-pelíticos (CAMPOS NETO et al., 2004). Os eventos metamórficos gravados pelas rochas acima descritas, sob condições de ultra-alta temperatura, ocorreram a $625 \pm 5 \mathrm{Ma}$, datado através de U-Pb em zircão provenientes de granitos sin-orogênicos (JANASI, 1999; MARTINS; VLACH; JANASI, 2009; SALAZAR MORA; CAMPOS NETO; BASEI, 2014), com relaxamento térmico associado à colisão entre $615 \pm 16$ Ma e $612 \pm 3$ Ma (CAMPOS NETO et al., 2004). No Domínio Socorro, as delimitações entre as unidades mapeadas encontradas no Domínio Guaxupé nem sempre são perceptíveis e a Unidade Granulítica Basal comumente ocorre como lascas. As rochas que ocorrem nesse domínio podem ser divididas em dois principais grupos: ortognaisses metatexíticos e gnaisses diatexíticos (GENGO, 2014). 


\subsubsection{Domínio de Crosta Continental Subductada}

O Terreno Andrelândia ou Sistema de Nappes Andrelândia é representado por uma pilha metamórfica composta por três estruturas alóctones (CAMPOS NETO et al., 2007). O alóctono superior é constituído por metapelitos e metawackes metamorfisados sob condições de fácies granulito de alta pressão (CAMPOS NETO; CABY, 1999, 2000; CAMPOS NETO et al., 2007, 2010, 2004; DA MOTTA et al., 2010) da Nappe Três Pontas-Varginha (Pouso Alto e klippen associadas). O alóctono intermediário, Nappe Liberdade, é composto por uma sequência de mica xistos pelíticos com quartzitos e gnaisses calciossilicáticos subordinados, com blocos de rochas metabásicas retroeclogíticas. A Nappe Andrelândia, alóctono inferior deste sistema de nappes, é composta por metapelitos na base, seguidos por metawackes e, no topo, por uma sequência metapelito-psamítica.

As Nappes Três Pontas-Varginha, Pouso Alto e klippen associadas (Carvalhos, Aiuruoca e Serra da Natureza) correspondem aos segmentos que registraram as maiores temperaturas, e são representadas por granulitos de alta pressão. São rutilo-cianita-granadafeldspato potássico granulitos com níveis de plagioclásio e biotita e bancos de quartzitos, e subordinadamente ocorrem faixas de rochas máficas representadas por granadaclinopiroxênio quartzo granulitos, enstatita-granada-hornblenda granulitos, granada-biotitaplagioclásio gnaisses e escapolita-hornblenda-biotita gnaisse (CAMPOS NETO et al., 2010). As rochas metabásicas da Klippe Carvalhos comumente apresentam texturas importantes do metamorfismo retrogressivo marcadas por cristais de granada com coronas de intercrescimento entre hornblenda + plagioclásio \pm quartzo \pm minerais opacos, substituição parcial ou total de clinopiroxênio por hornblenda e intercrescimento de hornblenda e plagioclásio em torno de cristais de zoisita (CIOFFI, 2009). No entanto o pico metamórfico calculado é de no mínimo 850-900 ํ e 12 kbar de pressão, o que indica que estas rochas foram submetidas a condições de, ou próximas de, profundidades mantélicas relacionada a um ambiente de subducção. A trajetória P-T de descompressão de sentido horário, apresenta pico bárico em $15 \mathrm{kbar}$ com temperatura de $800^{\circ} \mathrm{C}$. Esta condição de metamorfismo em alta pressão apresenta idade de $618 \mathrm{Ma}$ (idade U-Pb por TIMS em monazita proveniente de paragnaisses) (CAMPOS NETO et al., 2010; CIOFFI, 2009; CIOFFI et al., 2012).

A Nappe Liberdade (TROUW et al., 2000) é predominantemente composta por rochas metassedimentares pelíticas com lentes de quartzitos, anfibolitos, metawackes, gnaisses calciossilicáticos, rochas máficas e ultramáficas. Boudins de rochas retroeclogíticas ocorrem restritas na base da estrutura e indicam metamorfismo em $680^{\circ} \mathrm{C}$ a profundidades de até 60 km (CAMPOS NETO et al., 2011). Segundo Santos et al. (2004), as rochas metapelíticas e os retroeclogitos provavelmente experimentaram as mesmas trajetórias $\mathrm{P}-\mathrm{T}$ a partir de $650^{\circ} \mathrm{C}$ a 12 kbar, durante a descompressão. Alguns metapelitos apresentam metamorfismo em 
profundidades mais rasas, a 5,6 kbar de pressão, e temperaturas mais altas, de $834{ }^{\circ} \mathrm{C}$, enquanto que o pico metamórfico dos retroeclogitos ocorreu em temperaturas de ca. $675^{\circ} \mathrm{C}$ e 17,5 kbar de pressão (CAMPOS NETO; CABY, 1999).

A Nappe Andrelândia é compartimentada em três unidades litoestratigráficas, que da base para o topo são: Xisto Rio Capivari, composto por uma série predominantemente metapelítica com raras intercalações de rochas metapsamíticas e metamáficas, sendo sua litologia principal granada-cianita xistos porfiroblásticos; Xisto Santo Antônio (TROUW et al., 1983) que é composto por metawackes onde o litotipo predominante é um granada-biotitaplagioclásio-quartzo xisto homogêneo de textura predominante granoblástica; e o Xisto Serra da Boa Vista, onde ocorrem rochas metapsamíticas compostas por muscovita quartzitos e muscovita-quartzo xistos, com lentes de quartzitos e cianita-muscovita-quartzo xistos porfiroblásticos (Figura 3-5).

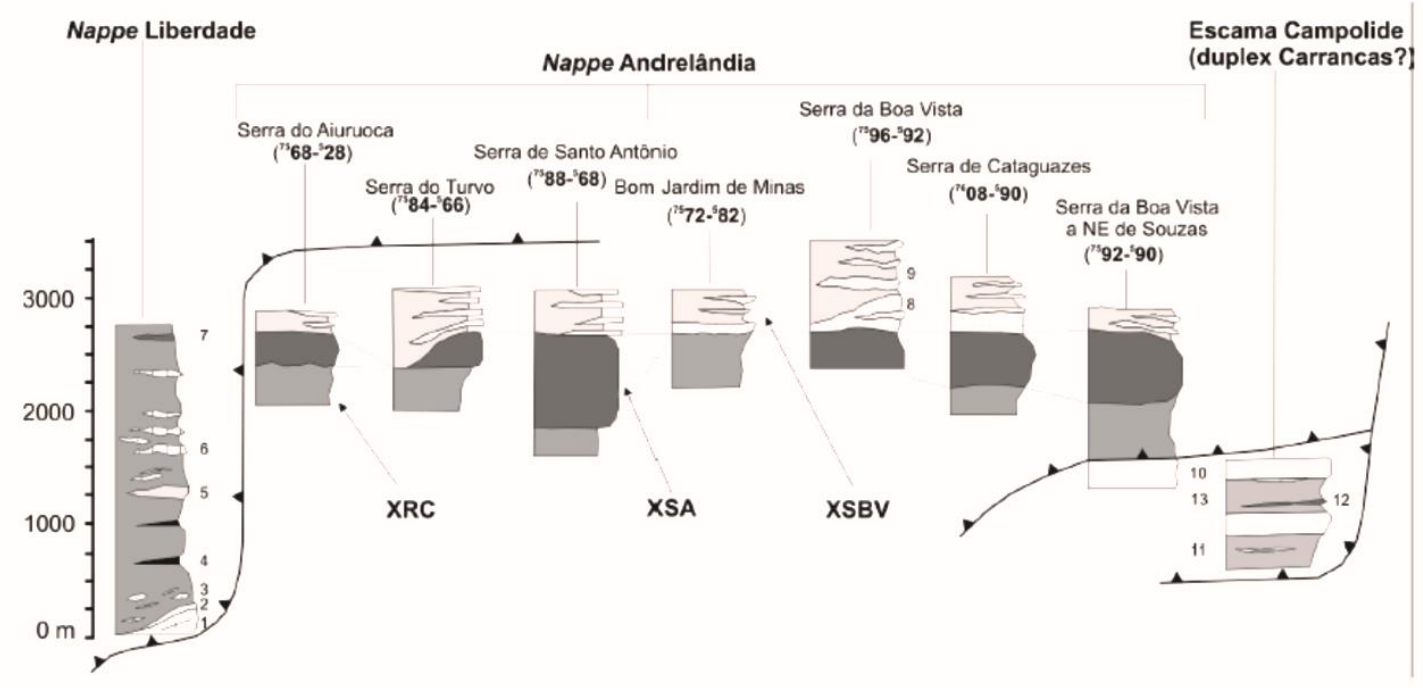

Figura 3-5. Estratigrafia do Sistema de Nappes Andrelândia (CAMPOS NETO et al., 2007). XRC-Xisto Rio Capivari; XSA-Xisto Santo Antônio; XSBV-Xisto Serra da Boa Vista.

\subsubsection{Domínio de Margem Continental Passiva}

O domínio de margem continental passiva é representado pelas rochas do Sistema de Nappes Carrancas e pela Nappe Lima Duarte, que é cavalgada a SE pela Nappe Andrelândia e ambas cavalgam o Grupo Carrancas. Sobre as unidades do Sistema de Nappe Carrancas ocorre a Unidade Biotita Xisto (TROUW et al. 1980) tipo flysch, originalmente mapeada como continuação do Xisto Santo Antônio, unidade intermediária da Nappe Andrelândia (TEIXEIRA, 2011; WESTIN; CAMPOS NETO, 2013).

A Nappe Lima Duarte é composta por quartzitos miloníticos de granulação bastante grossa, onde ortoquartzitos são mais comuns que quartzitos imaturos, representados por lascas de aproximadamente $750 \mathrm{~m}$ de espessura, imbricados com sillimanita-granada-biotita 
gnaisses migmatíticos com intercalações raras de gnaisses calciossilicáticos. Na retaguarda da estrutura são predominantes os biotita gnaisses e granada-biotita gnaisses homogêneos. A unidade basal da Nappe Lima Duarte é composta por gnaisses finamente bandados com intercalações de quartzitos micáceos, granada-estaurolita-muscovita xistos e sillimanita xistos. A unidade intermediária é representada por biotita gnaisses bandados, granada-biotitamuscovita xistos homogêneos e hornblenda gnaisses, localmente com intercalações de quartzitos micáceos, mica xistos, sillimanita xistos e gnaisses bandados. $O$ topo da estrutura é composta por níveis basais mais quartzosos que gradam para termos mais micáceos no topo. É constituída por quartzitos micáceos, gnaisses bandados com níveis anfibolíticos, quartzo xistos e raramente rochas calciossilicáticas (ROCHA, 2011).

O Sistema de Nappes Carrancas é composto por quatro escamas de cavalgamento: Nappe Luminárias, Klippe Carrancas, Alóctone Serra da Bandeira e Alóctone Madre de Deus, que compõem a pilha metassedimentar do sistema. Na região de Carrancas-Itumirim o sistema é composto por uma Unidade Quartzítica Inferior (Formação São Tomé das Letras), Formação Campestre e Unidade Quarztítica Superior (COUTINHO, 2012; WESTIN; CAMPOS NETO, 2013). A unidade basal é composta por muscovita verde quartzitos que variam de quartzitos puros à muscovita xistos. A unidade intermediária é composta por quartzitos intercalados a filitos/xistos com cloritóide, cianita e localmente granada em presença de grafita e muscovita (fácies xisto verde) ou em presença de granada e estaurolita (fácies anfibolito). 


\section{CAPÍTULO 4}

\section{SEGMENTO ORIENTAL DO SISTEMA DE NAPPES ANDRELÂNDIA}

O segmento oriental do Sistema de Nappes Andrelândia compreende uma pilha metamórfica composta por três alóctones principais, sub-horizontais, que preservam uma espessura de aproximadamente 4.500 metros (CAMPOS NETO et al., 2007). Da base para a o topo, a Nappe Andrelândia (TROUW et al., 2000) corresponde a uma lasca de aproximadamente 1500 metros de espessura que repousa, frontalmente, sobre o Sistema de Nappes Carrancas e lateralmente, sobre a Nappe Lima Duarte. Encontra-se sob a Nappe Liberdade (CAMPOS NETO et al., 2007). Ela é composta por uma coluna litoestratigráfica com metapelitos na base, metawackes intermediários e uma sequência discordante e superior metapelito-psamítica. A Nappe Andrelândia registra um caminhamento metamórfico de alta pressão, sob condições de cerca de $680^{\circ} \mathrm{C}$ de temperatura e 12 kbar de pressão (SANTOS; CAMPOS NETO; GROHMANN, 2004).

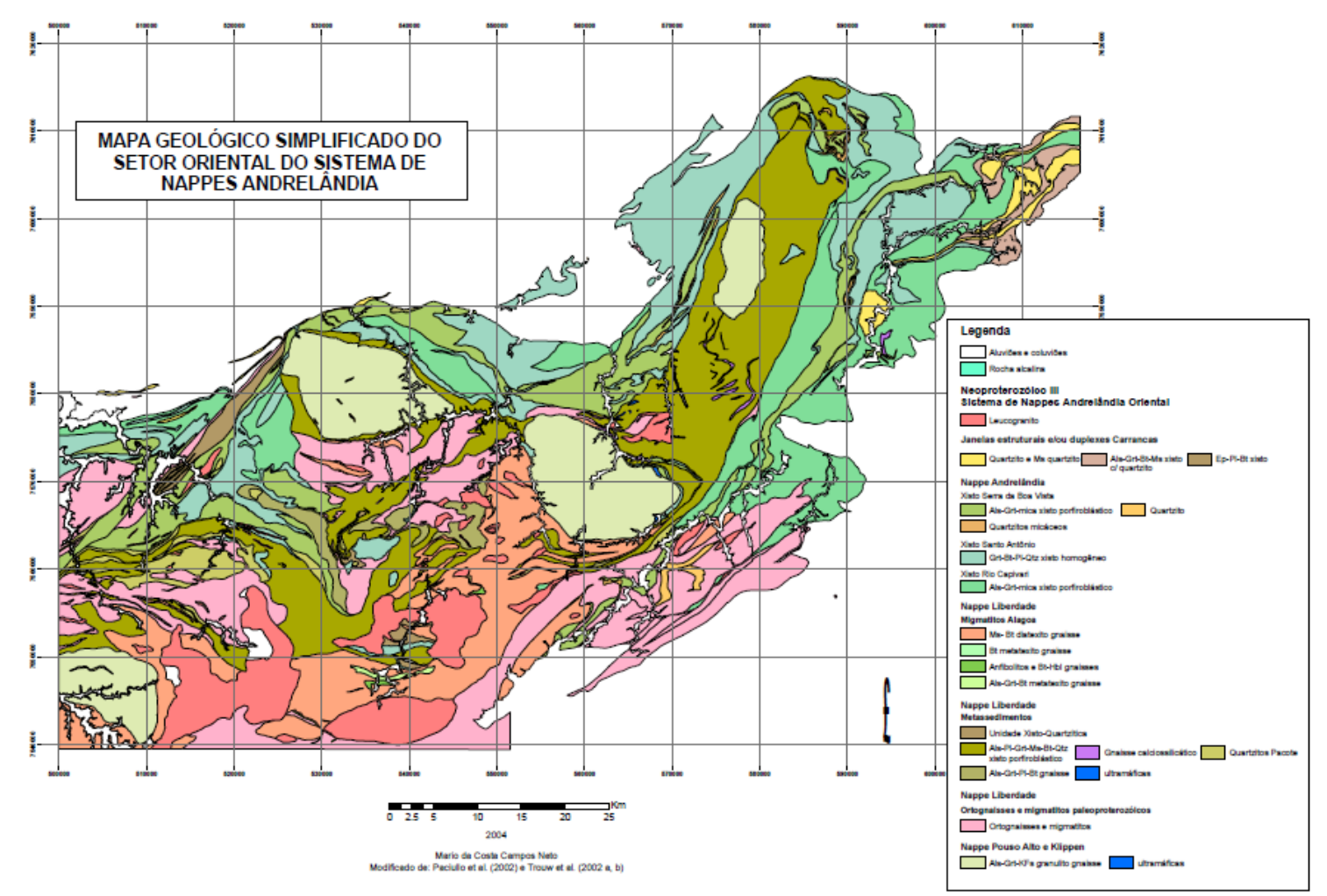

Figura 4-1. Mapa geológico do setor oriental do Sistema de Nappes Andrelândia (CAMPOS NETO et al., 2007).

A Nappe Liberdade (TROUW et al., 2000), alóctono intermediário, é constituída por uma espessa sequência metapelítica, com metapsamitos e gnaisses calciossilicáticos subordinados, metamorfisada sob fácies anfibolito de alta pressão e contendo lascas restritas de rochas metabásicas retroeclogíticas e metaultramáficas. Este segmento teria registrado o soterramento de crosta continental em zona de subducção em profundidades 
de cerca de $60 \mathrm{~km}$ (CAMPOS NETO; CABY, 1999). Ortognaisses paleoproterozoicos profundamente anatéticos constituem a infraestrutura do alóctono (CAMPOS NETO et al., 2007). A Nappe Pouso Alto e klippen associadas, no topo deste sistema de nappes, expõem rochas metapelíticas em fácies granulito de alta pressão (TROUW et al., 1998) com leucogranitos associados, cujo registro do metamorfismo encontra-se a $825-900^{\circ} \mathrm{C}$ de temperatura e 12-15 kbar de pressão (CAMPOS NETO et al., 2010, 2004; CAMPOS NETO; CABY, 2000). A Figura 4-1 exibe o mapa geológico do setor oriental do Sistema de Nappes Andrelândia.

\subsection{Nappe Andrelândia}

A coluna litoestratigráfica que constitui o pacote metamórfico da Nappe Andrelândia é constituída por três unidades litológicas distintas e mapeáveis, que da base para o topo são: Unidade Rio Capivari, Unidade Santo Antônio e Unidade Serra da Boa Vista. A Unidade Rio Capivari compreende uma série metassedimentar pelítica com ocorrências esparsas de rochas metapsamíticas e metamáficas, cuja base, desconhecida, é um dos planos de deslocamento da nappe. As rochas metapelíticas são micaxistos porfiroblásticos ricos em porfiroblastos de granada e cianita, com biotita e muscovita. O quartzo supera o plagioclásio, que também pode ocorrer na forma de porfiroblastos. Agrupam-se, respectivamente, em texturas lepidoblásticas descontínuas e granoblásticas, estas, no geral lenticulares, definindo microlithons de um bandamento diferenciado- $S_{2}$. Como fases acessórias são encontrados monazita, zircão, apatita, ilmenita e rutilo, este último ocorre como inclusões na granada, ou como porfiroblastos até decimétricos. Sillimanita e estaurolita ocorrem como fases tardias na $S_{2}$, registrando a descompressão e resfriamento da pilha alóctone (CAMPOS NETO et al., 2007, 2011).

\subsubsection{Unidade Santo Antônio}

O Xisto Santo Antônio (TROUW et al., 1983), ou Unidade Santo Antônio, aflora em grandes lajes tanto no segmento ocidental quanto no norte-oriental da nappe, e em sua área-tipo, na Serra de Santo Antônio, a espessura máxima alcança cerca de 850 metros. Ocorre em grandes sinformes transpressivos relativamente apertados e fortemente inclinados (Figura 4-3 A). Esta unidade pode ocorrer localmente em klippen, como a Klippe Pico do Papagaio em Aiuruoca (CAMPOS NETO et al., 2007, 2011), indicando um sistema em duplex. A principal litologia da Unidade Santo Antônio é um metawacke com esparsas ocorrências de rochas metapsamíticas e metamáficas. Um granada-biotita-plagioclásioquartzo xisto, geralmente homogêneo, é a rocha dominante, ocorrendo variações com presença de cianita, muscovita, sillimanita e estaurolita. $O$ pacote metamórfico registra, na 
área-tipo, um gradiente metamórfico invertido, com estaurolita na base da estrutura e fusão parcial, em presença de cianita e/ou sillimanita no topo, com leucossomas de composição leucotonalíticos (TEIXEIRA, 2008). Na Klippe Pico do Papagaio ocorrem lâminas e vênulas granoblásticas e lenticulares, paralelas a $\mathrm{S}_{2}$, ricas em plagioclásio e/ou quartzo, envolvidas por selvedges de biotita. Lentes de anfibolitos ocorrem como intercalações subordinadas.

No front do Sistema de Nappes Andrelândia, a Unidade Santo Antônio pode ocorrer protomilonítica com foliação formada por pares SC com recristalização de biotita e muscovita, assim como por ribbons de quartzo (LIMA, 2013). Os cristais de granada ocorrem como porfiroblastos pre-, sin- a tardi-cinemáticos. Na mesma região, as rochas comumente ocorrem dobradas e cisalhadas indicando movimentação principal para $\sim \mathrm{N}$ (Figura 4-2).
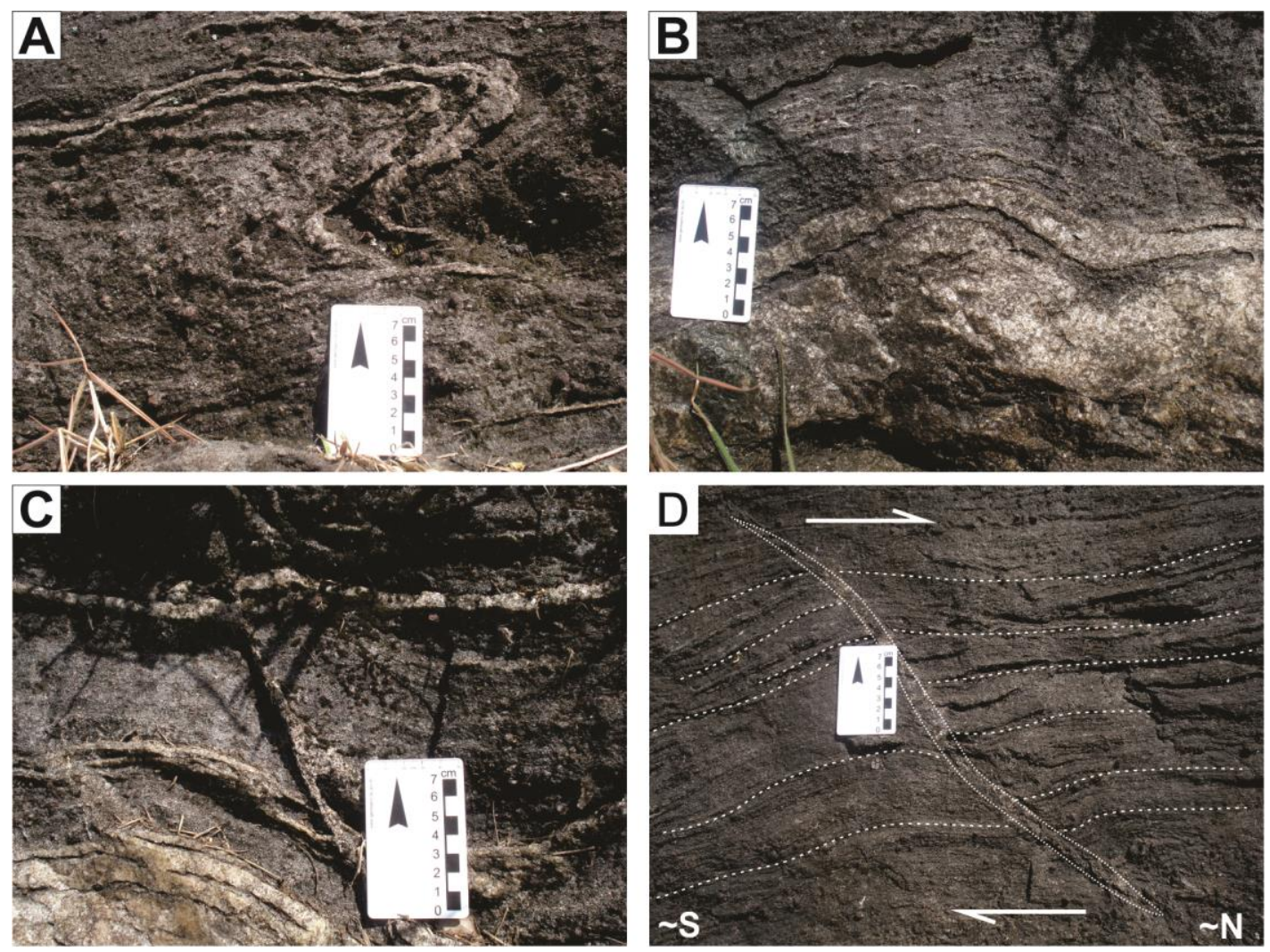

Figura 4-2. (A) Dobra parasita assimétrica de flanco superior sustentada por vênulas de quartzo; (B) Camadas granoblásticas centimétricas à decimétricas dobradas em dobras suaves; (C) Falha inversa com rejeito centimétrico em vênulas de quartzo; (D) Fenda de tração preenchida por vênula de quartzo com foliação adjacente levemente defletida. Fotos do afloramento NESG-1010 (LIMA, 2013), coordenadas: 591771/7609604.

Os metawackes apresentam condições de fusão em presença de muscovita em torno de 650-670 ํ $\mathrm{C}$ sob pressões de 10-13 kbar no topo na estrutura a NE de Andrelândia, confirmando que houve fusão parcial durante o pico metamórfico (TEIXEIRA, 2008). 


\subsubsection{Metawackes}

A leste de Andrelândia a Unidade Santo Antônio ocorre como um granadamuscovita-cianita-biotita-plagioclásio-quartzo xisto com estaurolita, turmalina e clorita de textura granoblástica e coloração cinza, com biotita homogeneamente distribuída e vênulas estiradas, subcentimétricas, quartzo-feldspáticas de granulação médio-grossa, intensamente dobradas e crenuladas, envoltas por selvedges de biotita. Possui porfiroblastos poiquiloblásticos de granada, que ocorrem em todos os domínios texturais da rocha, sobretudo nas lâminas descontínuas lepidoblásticas. Cianita e estaurolita ocorrem subordinadamente.

As vênulas de quartzo e de quartzo e plagiocásio são granobásticas e podem conter granada e biotita acessórias; cianita e estaurolita raras. A textura é granoblástica interlobada, com os bordas cheias de reentrâncias e apenas localmente retilíneas nos cristais de quartzo. Possuem extinção ondulante e fábrica de forma orientada na foliação $S_{2}$. Os cristais de plagioclásio, geminados ou não, estão saussuritizados. Os contatos entre os grãos também são interlobados.

As lâminas lepidobásticas, que no geral ocorrem como selvedges de até $3 \mathrm{~mm}$, apresentam cristais de biotita idioblásticos a xenoblásticos, grossos e com inclusões de monazita, zircão e rutilo. Subordinadamente ocorrem, nessa lâminas lepidobásticas, muscovita, cianita, estaurolita, granada, clorita, turmalina, plagioclásio e quartzo.

Ao sul de Andrelândia, na Serra de Santo Antônio, área-tipo da unidade, o metawacke ocorre como um cianita-muscovita-granada-plagioclásio-biotita-quartzo xisto porfiroblástico com estaurolita e turmalina, na forma de grandes lajes de coloração escura (Figura 4-3 A). Estas lajes apresentam rugosidade conferida por cristais subcentimétricos de granada e por fitas de quartzo de granulação média, que no geral estão dobradas. A granulação predominante da rocha é fina-média com porfiroblastos de granada homogeneamente distribuídos. Vênulas de quartzo na $S_{2}$, dobradas, podem apresentar, nas charneiras, uma recristalização orientada de quartzo definindo uma xistosidade $\mathrm{S}_{3}$ (Figura 4-3 B, C, D e E). 

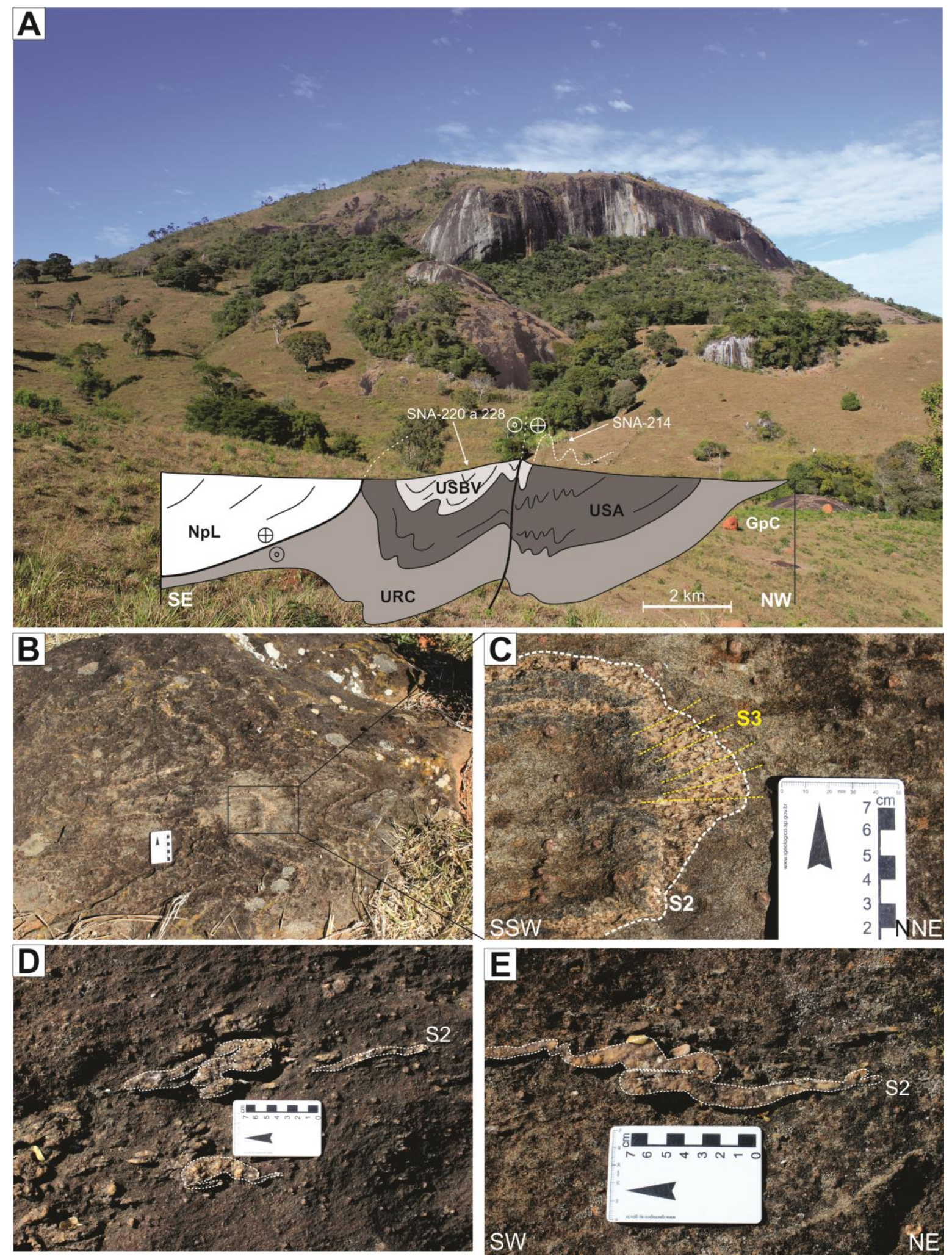

Figura 4-3. (A) Afloramento na área-tipo do Unidade Santo Antônio, na Serra de Santo Antônio com a seção geológica da serra, ilustrando as unidades da Nappe Andrelândia em sinformes transpressivos de alta inclinação. NpL-Nappe Liberdade; USBV-Unidade Serra da Boa Vista; USA-Unidade Santo Antônio; URC-Unidade Rio Capivari; GpC-Grupo Carrancas (CAMPOS NETO et al., 2007); (B) Disposição geral da superfície do afloramento com vênulas de quartzo dobradas; (C) Destaque para a foliação $S_{2}$, dobrada, marcada por vênula de quartzo, com fábrica de forma dos cristais em disposição de $S_{3}$ convergente; (D) e (E) Vênulas de quartzo $S_{2}$ dobradas e cavalgadas. Coordenadas: 570551/7591158. 
Ao microscópio o cianita-muscovita-granada-plagioclásio-biotita-quartzo xisto porfiroblástico com estaurolita e turmalina exibe bandas escalonadas e extensionais de cisalhamento marcadas por cristais de biotita e raramente muscovita (Figura 4-4 A e B). Os porfiroblastos de granada apresentam inclusões passivas de quartzo e de minerais opacos, que definem uma foliação interna por vezes em continuidade com a foliação externa, o que indica porfiroblastos cedo- à sin-cinemáticos (Figura 4-4 A). A foliação externa amolda assimetricamente os porfiroblastos, definindo zonas de sombra de pressão em degrau (Figura 4-5 A).

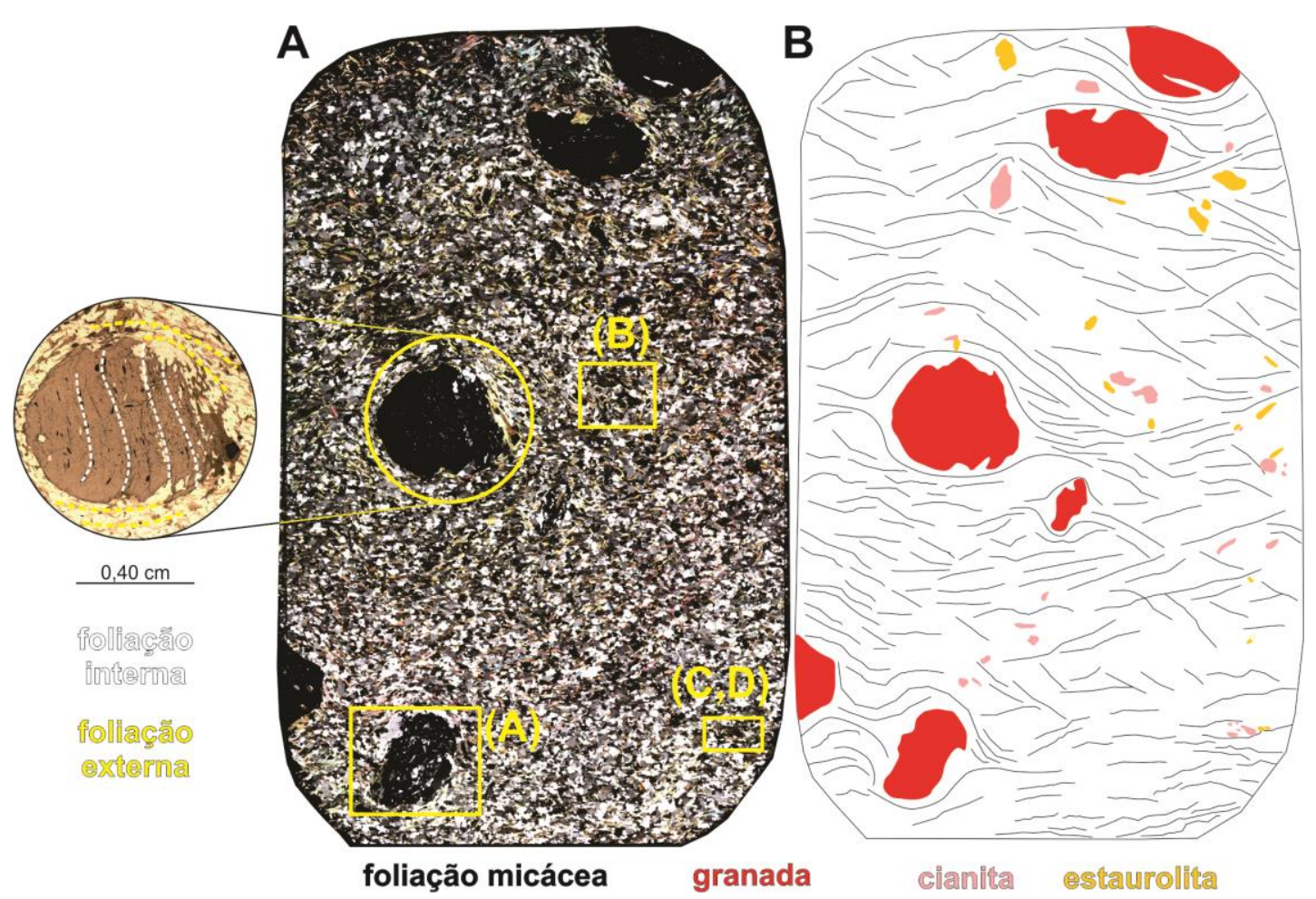

Figura 4-4. (A) Fotomicrografia da seção delgada completa (lado maior com $4 \mathrm{~cm}$ de comprimento), com a localização das fotomicrografias da Figura 4-5 (polarizador cruzado). Detalhe para o porfiroblastos de granada que exibe uma foliação interna em continuação com a foliação externa, indicando portanto que seu crescimento se deu de forma cedo- à sin-cinemática; (B) Interpretação das principais estruturas e minerais da seção delgada. Imagens referentes à amostra SNA-214.

Os cristais de cianita ocorrem dispersos pela lâmina em cristais isolados, ou em pequenos aglomerados nas proximidades de cristais de estaurolita (Figura 4-5 B) e são subidioblásticos à xenoblásticos. Os cristais de estaurolita, subidioblásticos, possuem um forte pleocroísmo do marrom claro ao amarelo. A cianita possui bordas corroídas e irregulares, em relação aos cristais de estaurolita, de tendência idioblástica. Quando em contato, a estaurolita invade a cianita (Figura 4-5 C e D).

A textura granoblástica é equigranular e de granulação fina, cristais de plagioclásio ocorrem com uma discreta geminação da lei da albita. 


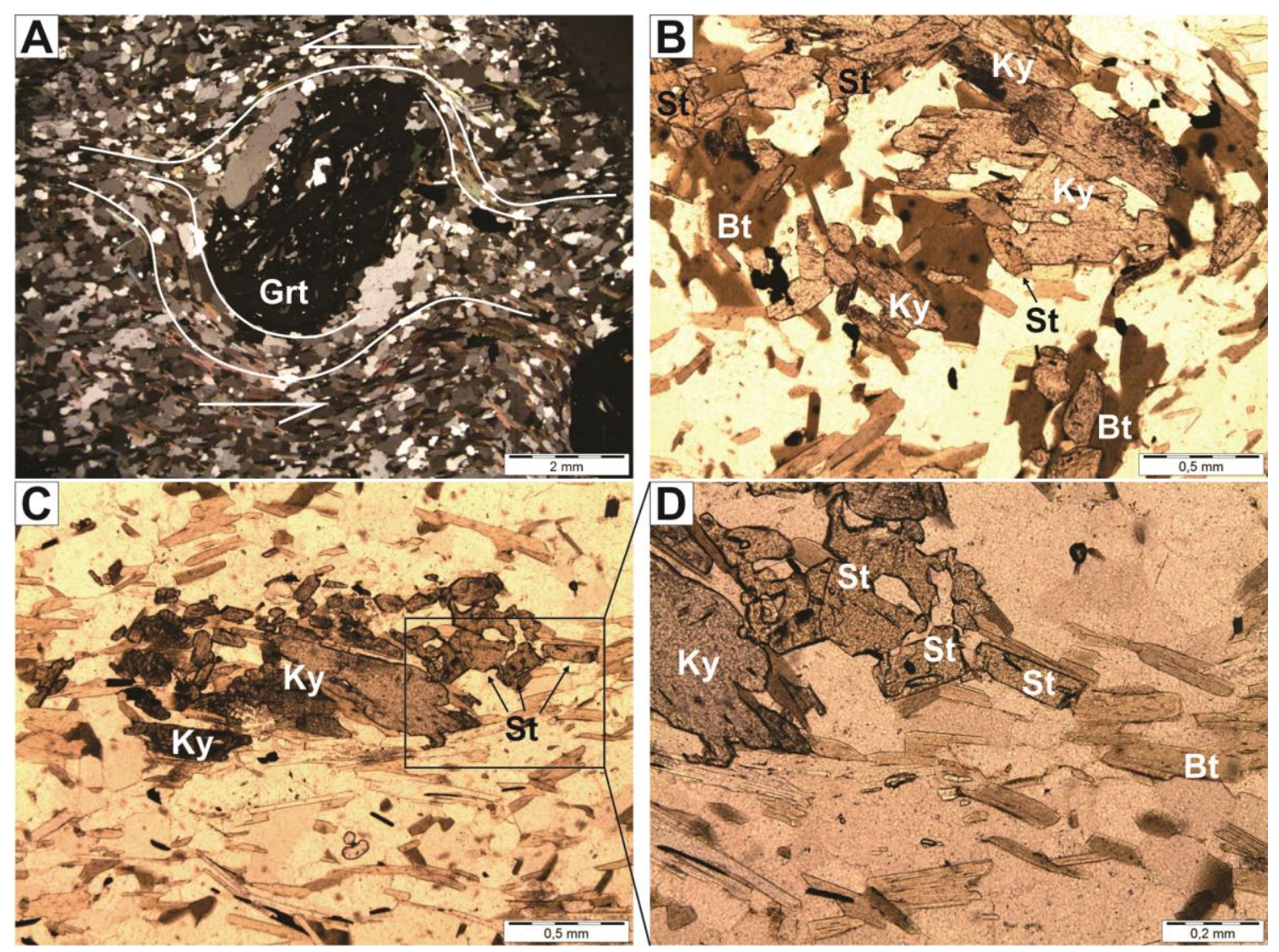

Figura 4-5. (A) Porfiroblasto de granada em forma de indicador cinemático, indicando topo para a esquerda (polarizador cruzado); (B) e (C) Cristais de cianita junto à aglomerados de pequenos cristais de estaurolita (polarizador descruzado); (D) Cristal de cianita com bordas corroídas, aparentemente sendo invadida por cristais de estaurolita (polarizador descruzado). Fotomicrografias referentes à amostra SNA-214.

Na Klippe Pico do Papagaio a litologia é um granada-biotita-plagioclásio-quartzo xisto porfiroblástico com cianita e sillimanita, constituída por porções essencialmente granoblásticas ricas em quartzo, e em menor quantidade plagioclásio e biotita, e porções granolepidoblásticas, mais frequentes, compostas por biotita, plagioclásio, quartzo, minerais opacos, apatita, zircão, sillimanita, cianita, rutilo e porfiroblastos de granada. Os cristais de quartzo frequentemente apresentam texturas em bulging, gravando resfriamento posterior ao pico metamórfico, já em fácies xisto verde (Figura 4-6 A). Os cristais de sillimanita nesta localidade, são bastante comuns e ocorrem geralmente nos interstícios entre cristais de quartzo e plagioclásio na forma de aglomerados decussados compostos por finas agulhas (Figura 4-6 B) ou orientadas segundo a foliação. 

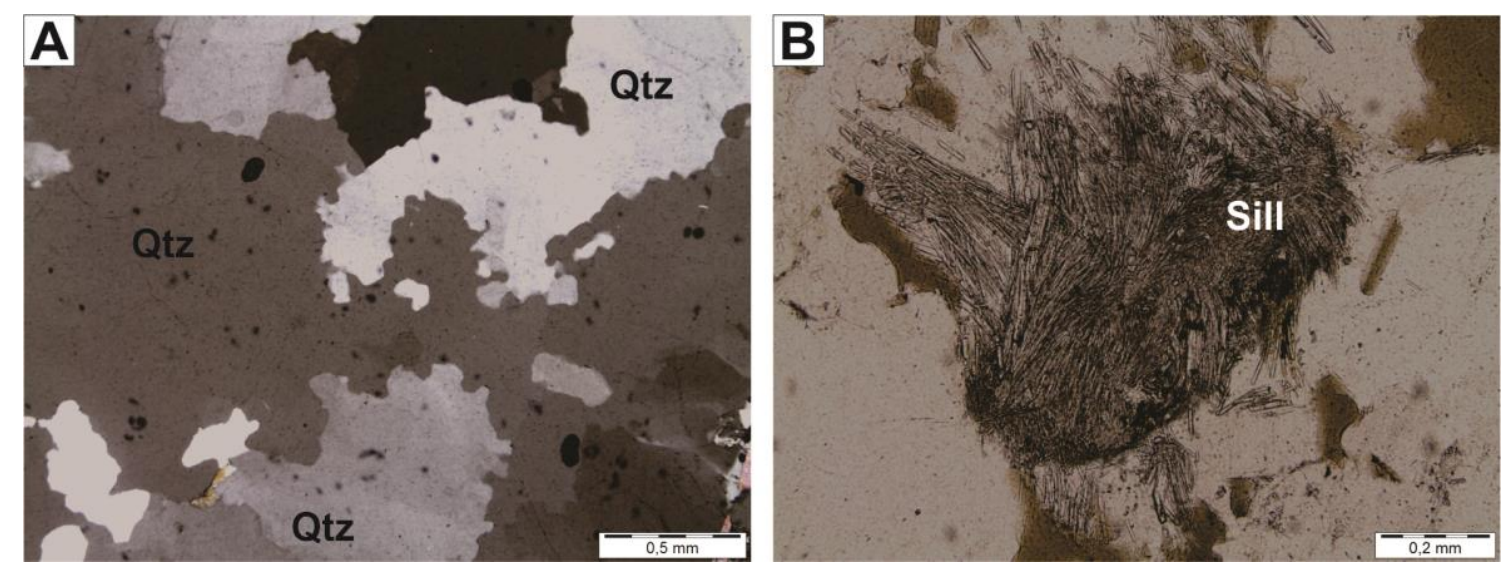

Figura 4-6. (A) Cristais de quartzo com avanço de borda/bulging e extinção em domínios de subgrãos (polarizador cruzado); (B) Agulhas decussadas de sillimanita em aglomerados (polarizador descruzado). Fotomicrografias referentes à amostra SNA-201.

\subsubsection{Anfibolitos}

Os anfibolitos ocorrem como lentes métricas intercaladas aos metawackes, localmente boudinadas podendo exibir estrutura xistosa. Ao microscópio trata-se de titanitaepidoto-clinozoisita anfibolito com foliação marcada pela orientação da textura nematoblástica inequigranular seriada. A hornblenda é a fase mineral predominante com contorno serrilhados geralmente bordeadas por finos cristais de quartzo. Podem exibir prováveis texturas simplectíticas de exsolução com o crescimento de cristais de quartzo finos ou vermiformes (Figura 4-7 A). A clinozoisita perfaz cerca de $10-15 \%$ do volume da rocha, apresenta formas arredondadas e ovais, podendo exibir eventualmente núcleos de epidoto com birrefringência mais amarelada e aureolas de clinozoisita. Os cristais de epidoto são um tanto mais raros que os de clinozoisita e apresentam formatos menos homogêneos. Zoisita ocorre como porfiroblastos alongados. Os grãos de titanita estão geralmente orientados segundo a foliação marcada pela textura nematoblástica e ocorrem homogeneamente distribuídos por toda a rocha.

O plagioclásio ocorre geralmente como cristais xenoblásticos um tanto mais finos que os de hornblenda, podem ocorrer geminados ou não, e eventualmente exibem inclusões arredondadas de quartzo (Figura 4-7 B). Os cristais de quartzo ocorrem como finos grãos geralmente nos entornos dos cristais de hornblenda. Eventualmente são observados leitos vermiformes como "piscinas" de material fundido residual, parcialmente recristalizado por rotação de sub-grãos, cujos cristais, em sua maioria, guardam ainda a mesma direção óptica. 

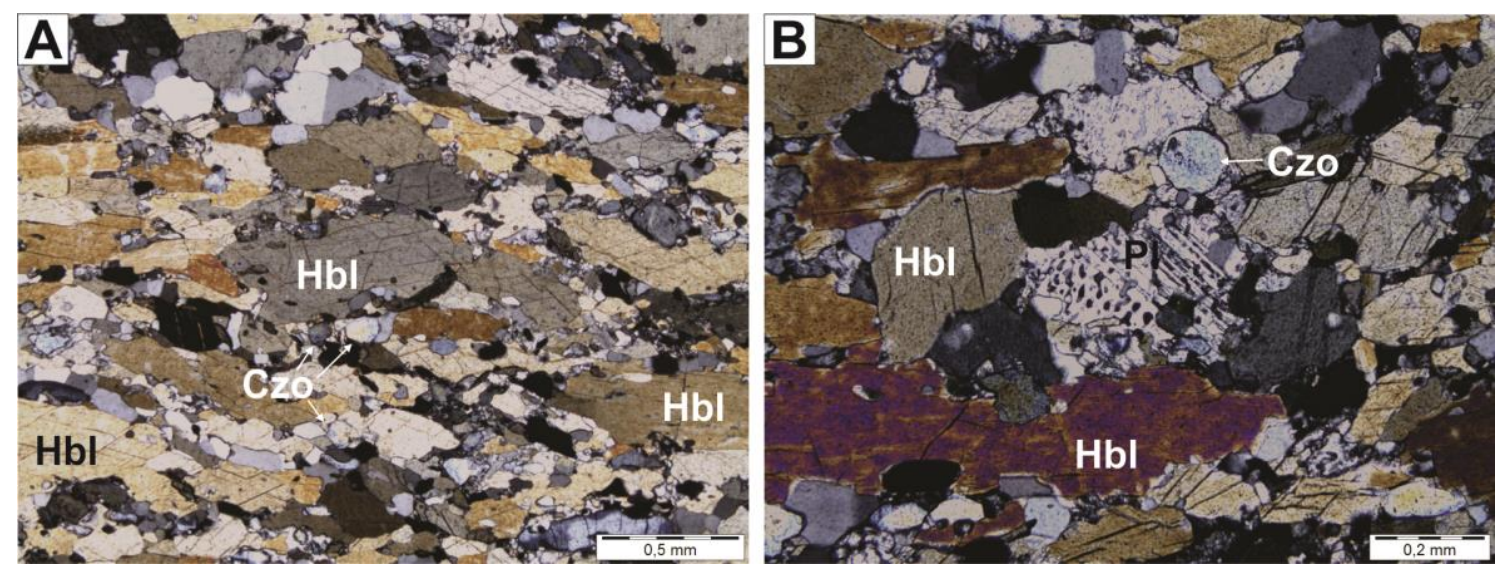

Figura 4-7. (A) Orientação da textura nematoblástica gerada pelos cristais de hornblenda (polarizador cruzado); (B) Textura de intercrescimento entre quartzo e plagioclásio (polarizador cruzado). Fotomicrografias referentes à amostra NESG-1552.

A associação hornblenda + plagioclásio é típica de fácies anfibolito, e a ausência de granada e de clinopiroxênio limita as condições em menores pressões e menores temperaturas, respectivamente. A presença de epidoto evidencia condições superiores à de fácies xisto verde. No entanto, as texturas de intercrescimento e a presença de quartzo vermiforme ao redor de hornblenda pode evidenciar condições de fusão parcial.

\subsubsection{Unidade Serra da Boa Vista}

A Unidade Serra da Boa Vista apresenta espessura que pode ultrapassar 800 metros, com topo desconhecido, e ocorre principalmente sobre a Unidade Santo Antônio, mas pode repousar diretamente sobre a Unidade Rio Capivari em algumas localidades. No segmento setentrional desta unidade, é observado, da base para o topo, rochas metapsamíticas compostas por muscovita quartzitos e muscovita-quartzo xistos, ambos com lentes de ortoquartzitos e com intercalações esparsas de cianita-granada-muscovita-quartzo xistos porfiroblásticos. Na porção superior da unidade, afloram (clorita)-cianita-granadabiotita-muscovita xistos porfiroblásticos que localmente apresentam estaurolita e porfiroblastos decimétricos de rutilo. Intercala camadas métricas de quartzitos (CAMPOS NETO et al., 2007).

Nas serras de Cataguases e Santana, nas proximidades de Santana do Garambéu, Lima (2013) descreve a presença de muscovita quartzitos e ortoquartzitos que constituem ambas as serras, com intercalações de níveis metapelíticos a estaurolita, cianita, granada, biotita e muscovita. A leste da Serra da Cataguases ocorre contato tectônico, marcado por falha normal tardi-foliação $S_{2}$, com a Unidade Santo Antônio. Já nos dois flancos da Serra de Santana o contato tectônico se dá através do cavalgamento cedo- $D_{3}$. Ainda na Serra de Cataguases, a Unidade Serra da Boa Vista ocorre deformada em dobras abertas com planoaxial de alto ângulo mergulhando para NW. 
Na Serra da Boa Vista, localidade-tipo da unidade, ocorre uma sucessão de dobras exibindo eixos com caimento que variam de sub-horizontais à ângulos moderados e planoaxiais geralmente com alto mergulho, e que eventualmente são rompidas por rampas de cavalgamento, onde a Unidade Santo Antônio aflora geralmente no intrado de dobras antiformes (Figura 4-8).

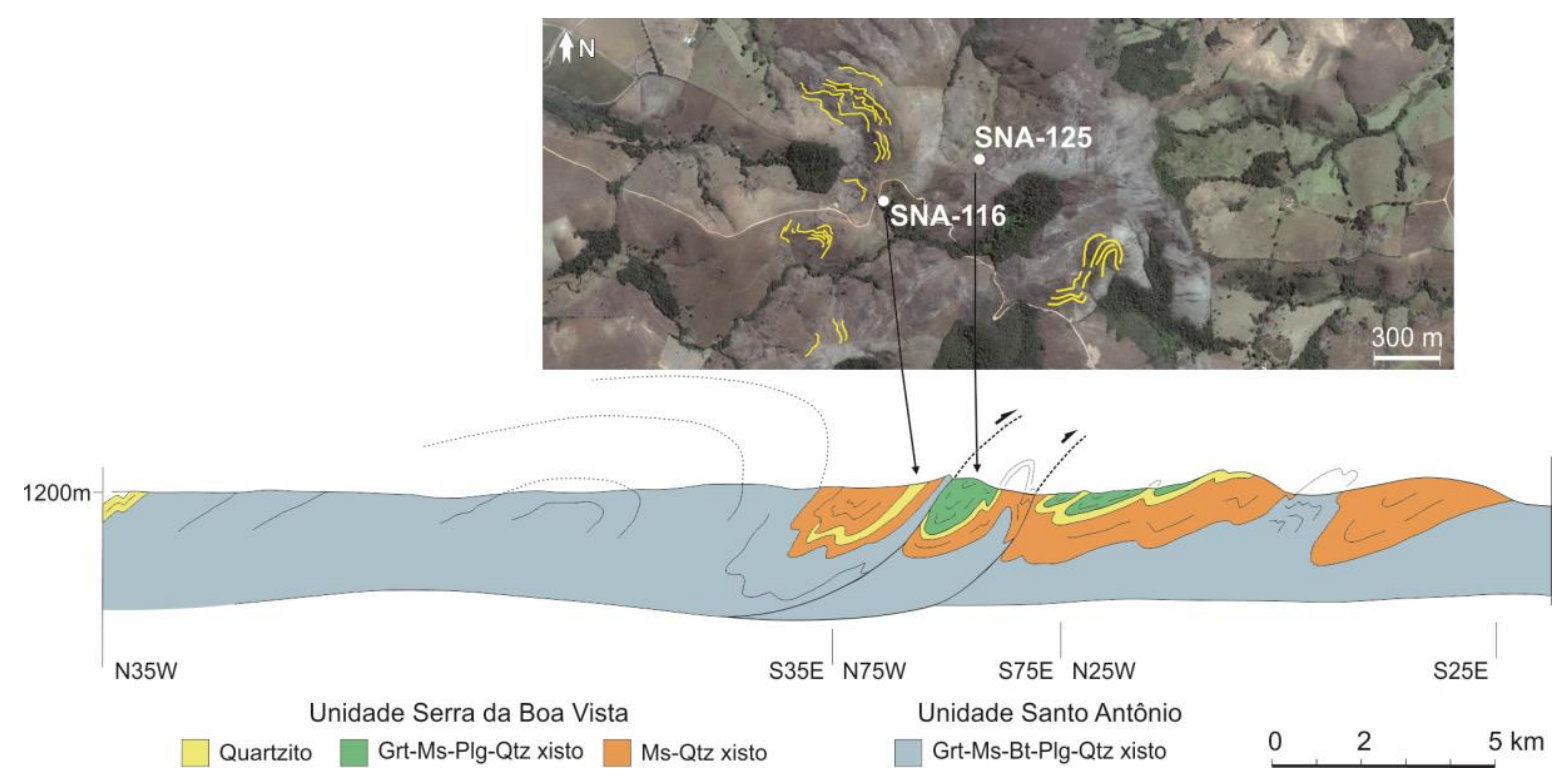

Figura 4-8. Seção geológica transversal à Serra da Boa Vista, norte-noroeste de Sousa, com a localização de dois afloramentos cujas amostras foram analisadas, provenientes da Unidade Serra da Boa Vista.

\subsubsection{Metapelitos}

As rochas metapelíticas da Unidade Serra da Boa Vista apresentam pequenas variações mineralógicas, principalmente em relação à presença, ou ausência, de sillimanita, cianita, estaurolita e turmalina, e quanto ao volume variável de granada, biotita e muscovita. Os tipos de afloramento que apresentam essas litologias são um tanto distintos, desde lajes abauladas de coloração escura à lápides com foliação bastante proeminente. Geralmente os afloramentos apresentam textura superficial rugosa provinda da grande quantidade de porfiroblastos de granada e/ou cianita subcentimétricos (Figura 4-9).

Três dos granada-biotita-sillimanita-muscovita-quartzo xistos porfiroblásticos com cianita e turmalina que ocorrem ao sul-sudoeste de Andrelândia, na Serra de Santo Antônio, apresentam grande semelhança textural e mineralógica, com pequenas diferenças no volume de biotita, sillimanita e cianita (SNA-223, SNA-225 e SNA-227). 

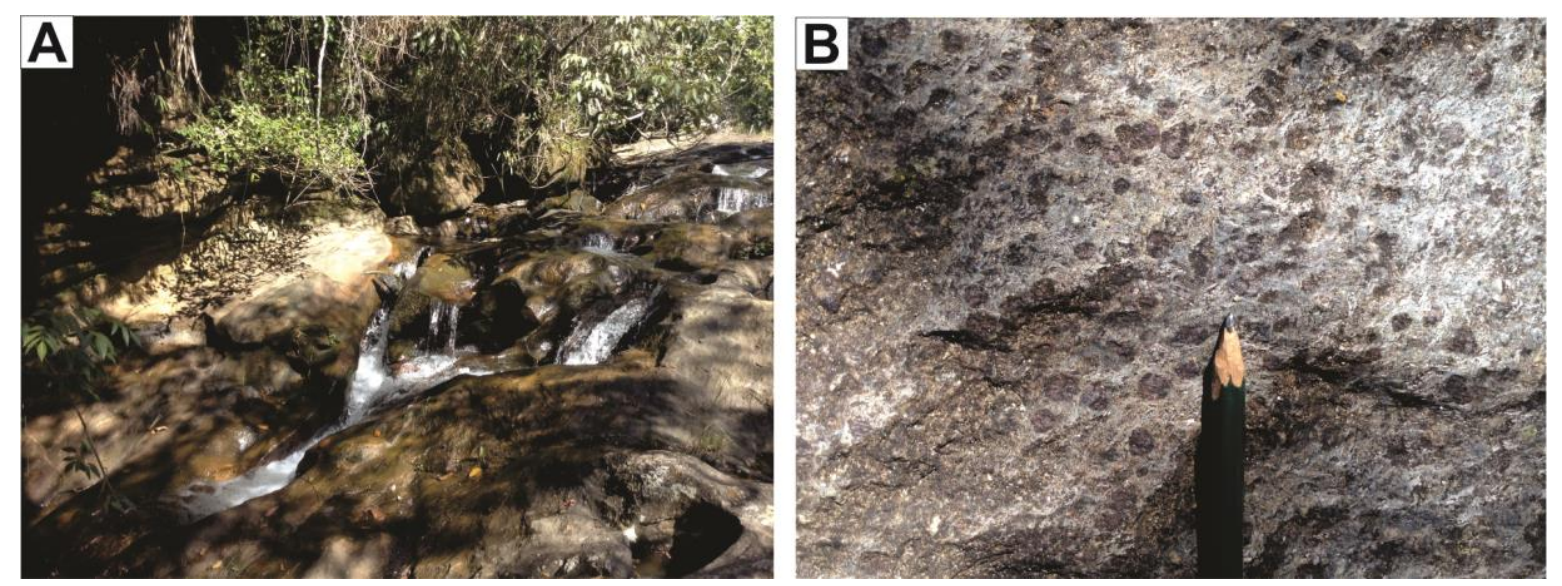

Figura 4-9. (A) Afloramento em curso d'água da amostra SNA-225; (B) Detalhe para a textura superficial do afloramento e presença de porfiroblastos de granada bem distribuídos. Coordenadas: 568733 / 7584612.

Estes xistos ocorrem na forma de lajes abauladas de coloração escura e apresentam granulação que varia de média à grossa, com presença de porfiroblastos de granada subcentimétricos. Podem ocorrer porções mais granoblásticas de granulação grossa compostas principalmente por quartzo e feldspato, assim como veios de quartzo em forma de amêndoa. Nos afloramentos em que as litologias são mais ricas em cianita, é possível observar os cristais a olho nu, mesmo que sejam bem finos. Em algumas localidades é possível encontrar, soltos no solo, cristais centimétricos de cianita, fragmentos de cianititos com cristais que chegam a alcançar em torno de 10 centímetros de comprimento, assim como fragmentos de cristais de rutilo de aproximadamente 5 centímetros. A rocha do afloramento SNA-227 ocorre bastante crenulada, com a presença de grande quantidade de veios de quartzo dobrados e crenulados juntos à foliação. A quantidade de biotita neste afloramento é reduzida em relação aos pontos SNA-223 e SNA-225. 


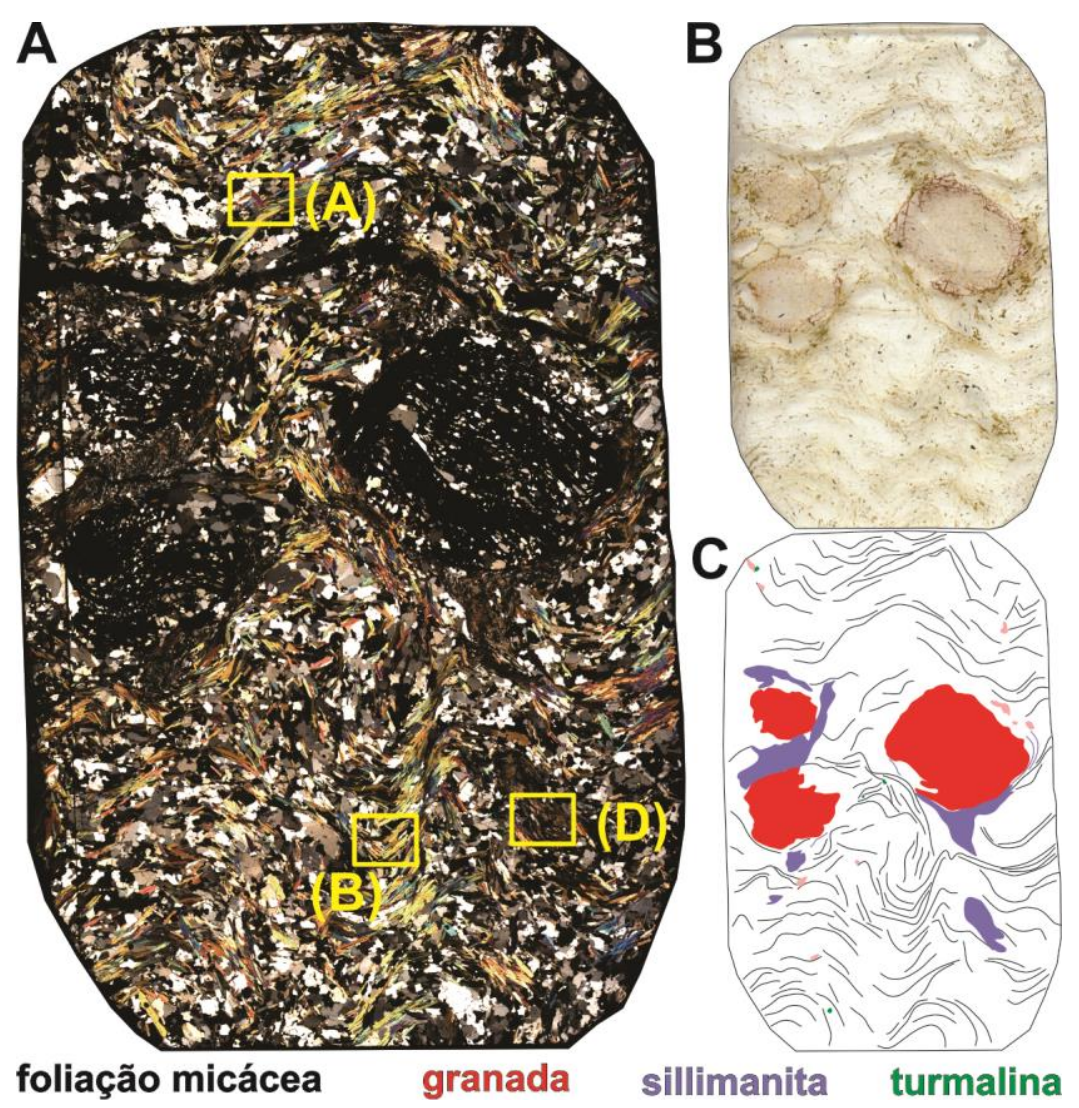

Figura 4-10. (A) Fotomicrografia da seção delgada completa (lado maior com $4 \mathrm{~cm}$ de comprimento), com a localização das fotomicrografias da Figura 4-11 (polarizador cruzado); (B) Imagem escaneada da lâmina; (C) Interpretação das principais estruturas e minerais encontrados. Todas imagens são referentes à lâmina da amostra SNA-227.

Microscopicamente estas litologias apresentam foliação marcada por cristais de muscovita subidioblástica e, em menor quantidade, por biotita xenoblástica e eventualmente sillimanita. Esta foliação principal ocorre geralmente dobrada desarmonicamente em dobras assimétricas e, onde ocorrem os flancos mais longos, elas tendem a ser mais fechadas do que nas porções onde os flancos são mais curtos (Figura 4-10). Em algumas zonas de charneiras ocorrem arcos poligonais formados por cristais de muscovita. É possível observar também outras direções de crescimento posterior de muscovita, por vezes posicionadas segundo o plano-axial destas dobras (Figura 4-11 A, B e C). Aglomerados de finas agulhas de sillimanita ocorrem ao longo de certas porções da foliação, podendo estar ou não, orientadas (Figura 4-11 D), assim como nas bordas de porfiroblastos de granada perfazendo pequenas zonas de sombra de pressão. É comum, nesses aglomerados, a ocorrência de biotita onde possivelmente está ocorrendo alguma reação de substituição, aparentemente da biotita pela sillimanita. Os cristais de cianita apresentam geralmente algumas inclusões de quartzo e de minerais opacos, mas ocorrem dois cristais específicos, que por mais que ocorram estas inclusões, eles estão bem formados e com as faces retilíneas preservadas. 

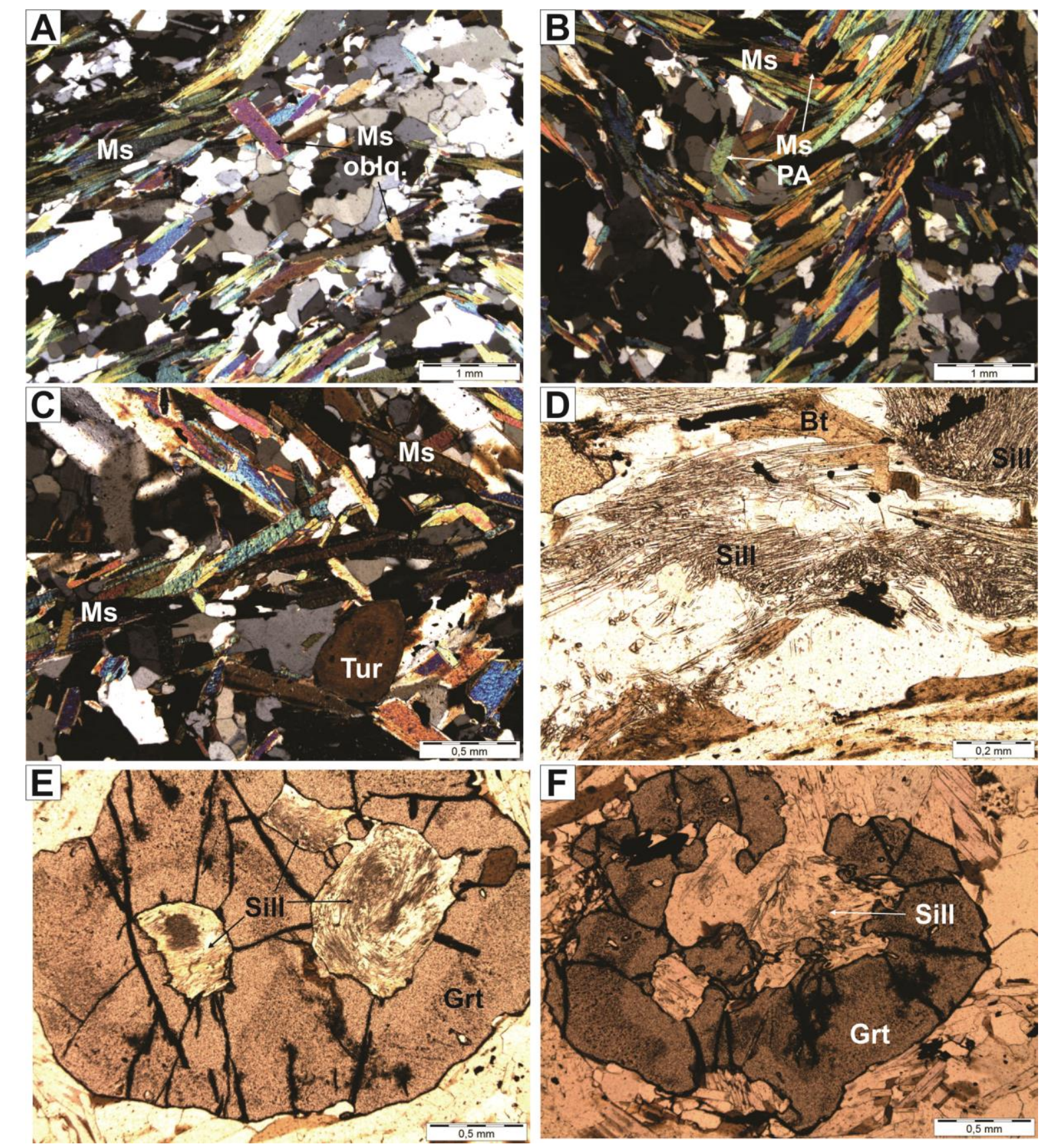

Figura 4-11. (A) Cristais de muscovita dispostos obliquamente à foliação micácea principal (polarizador cruzado); (B) Cristais de muscovita plano-axiais das dobras preservadas como arcos poligonais da foliação principal (polarizador cruzado); (C) Possível reação de substituição entre sillimanita e biotita (polarizador descruzado); (D) Arcos poligonais formados por cristais de muscovita (polarizador cruzado); (E) e (F) Finos cristais de sillimanita aprisionados no interior dos porfiroblastos de granada (polarizador descruzado). Fotomicrografias $A$, B e D são referentes à lâmina da amostra SNA-227, já as fotomicrografias C, E e F são referentes à amostra SNA-223.

Os porfiroblastos de granada variam de subidioblásticos à xenoblásticos e apresentam bastante inclusões de grãos de quartzo principalmente e, em menor quantidade, de cristais de minerais opacos e biotita. Alguns porfiroblastos podem exibir bordas livres de inclusões sugerindo que estas porções cresceram sobre a foliação micácea. Três porfiroblastos apresentam inclusões, em seus centros, compostas por bolsão quartzoso com finas agulhas de sillimanita, sugerindo que a granada começou a crescer tardiamente na 
trajetória metamórfica da foliação $S_{2}$, sob condições onde a sillimanita estava estável (Figura 4-11 E e F). A maioria das inclusões que chegam a gerar uma foliação interna, eventualmente em $S$, não apresentam continuidade com a foliação externa indicando seus caráteres cedo-cinemáticos. Uma observação interessante é que a foliação interna de três porfiroblastos apresentam a mesma direção, indicando que os porfiroblastos não foram deformados posteriormente (Figura 4-12).

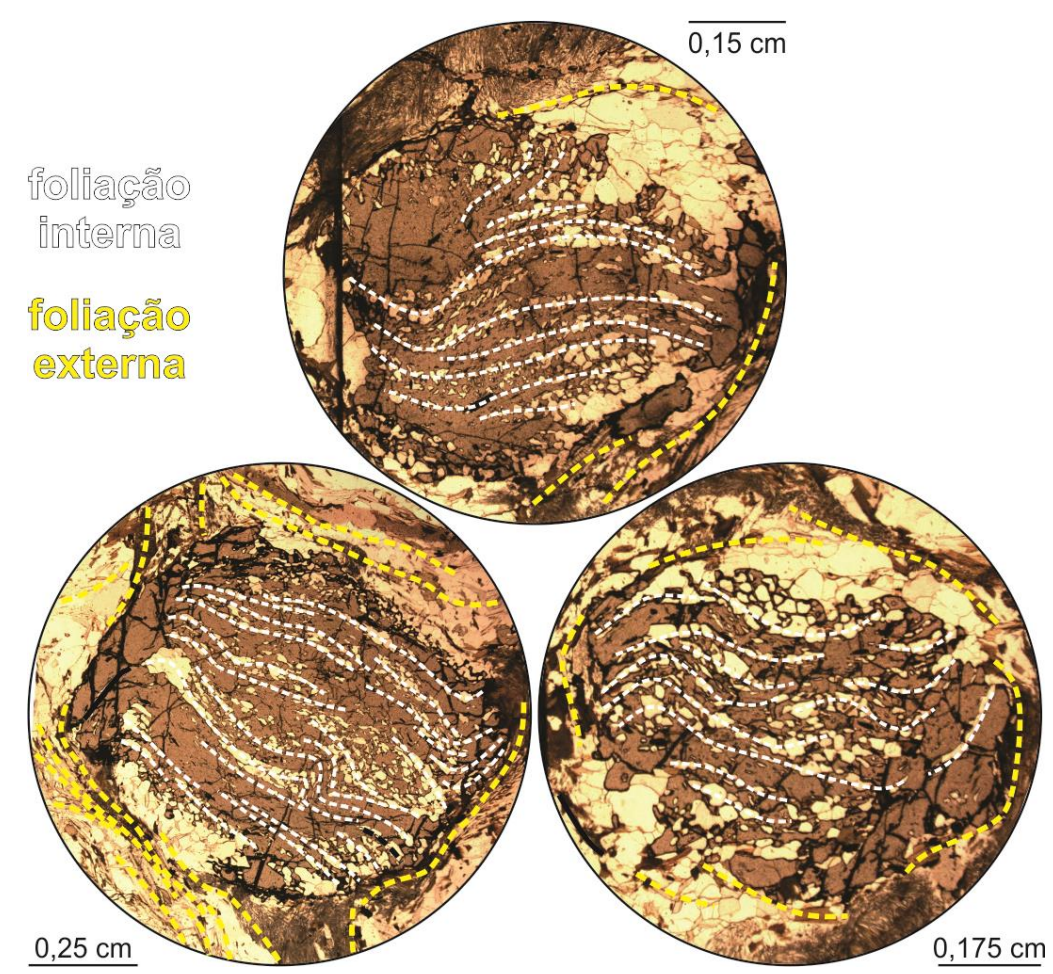

Figura 4-12. Porfiroblastos de granada cujas foliações internas compostas por inclusões não apresentam continuação com a foliação externa. Notar que as bordas dos cristais tendem a apresentar menor quantidades de inclusões, indicando que podem ter crescido em momentos distintos.

Também na Serra de Santo Antônio, um biotita-granada-muscovita-quartzo xisto porfiroblástico com turmalina (SNA-228) exibe texturas bastante semelhantes aos demais metapelitos, no entanto não é observada a presença de sillimanita e nem de cianita. Neste afloramento a quantidade de granada é um pouco menor e a rocha torna-se mais quartzosa. Em algumas porções é possível observar níveis de quartzitos no intrado de dobras antiformes assimétricas de meio comprimento de onda métrico.

Petrograficamente este xisto exibe foliação bem marcada por cristais de muscovita e em menor quantidade, biotita, que ocorre dobrada ora em dobras abertas de amplitude bem pequena, ora em dobras mais fechadas com amplitude maior (Figura 4-13 A e B). Quando a foliação se aproxima dos porfiroblastos de granada, ela se torna mais rica em biotita. Nas zonas de charneira, os grãos não estão dobrados e sim formam arcos poligonais bem marcados (Figura 4-13 C). Os cristais de biotita geralmente ocorrem mais próximos dos porfiroblastos de granada. São subidioblásticos e apresentam pleocroísmo bem visível do 
bege claro ao vermelho amarronzado. Em algumas porções parece que a biotita está substituindo a muscovita, mas também ocorrem texturas que podem indicar o contrário.
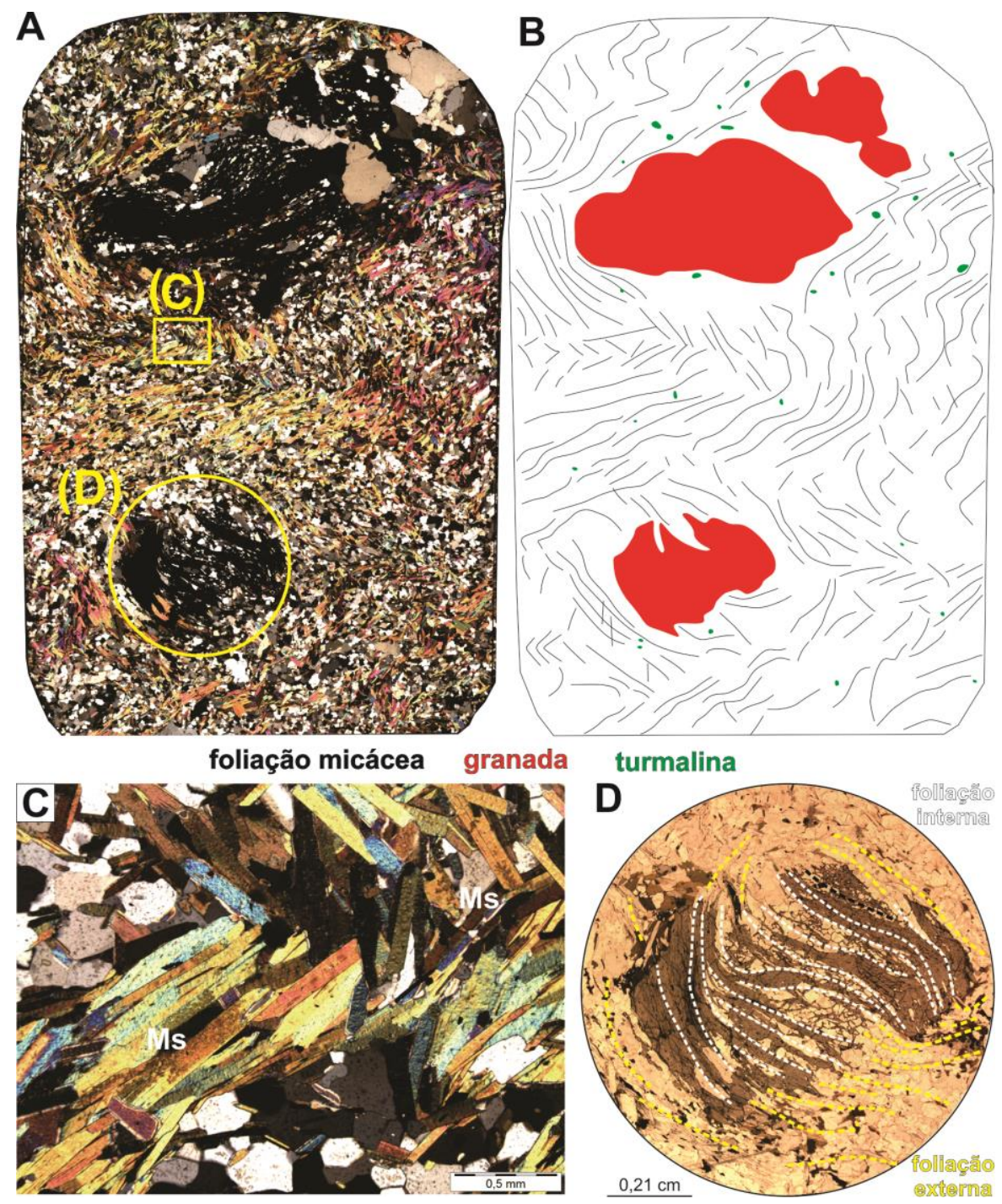

Figura 4-13. (A) Fotomicrografia da seção delgada completa (lado maior com $4 \mathrm{~cm}$ de comprimento), com a localização das fotomicrografias C e D (polarizador cruzado); (B) Interpretação das principais estruturas e minerais encontrados; (C) Arcos poligonais formados por cristais de muscovita (polarizador cruzado); (D) Porfiroblasto de granada cuja foliação interna apresenta continuação com a externa.

Os porfiroblastos de granada apresentam foliação interna constituída por cristais de quartzo e por minerais opacos ripiformes. Em um dos porfiroblastos a foliação interna não apresenta continuação com a foliação externa, sendo este cedo-cinemático. Já outro cristal de granada, a foliação interna apresenta continuação com a externa, indicando que ele é sin-cinemático (Figura 4-13 D).

Já à leste de Andrelândia a rocha é um granada-estaurolita-biotita-plagioclásiomuscovita-quartzo xisto com turmalina e cianita (SNA-125). Macroscopicamente a rocha apresenta um bandamento diferenciado bem desenvolvido, definido pela alternância de bandas lenticulares de textura granoblástica, espessas de $3 \mathrm{~mm}$, e bandas lepidoblásticas 
de até $1 \mathrm{~mm}$ de espessura. Microscopicamente é possível distinguir duas feições principais, porções granoblásticas ricas em quartzo e plagioclásio e porções essencialmente lepidoblásticas, mais finas. Estas duas feições apresentam contatos irregulares e descontínuos, sendo normalmente gradacionais entre si.

As porções granoblásticas quartzo-feldspáticas dessa rocha destacam-se do resto da lâmina na forma de bandas de $\sim 4,5 \mathrm{~mm}$ de espessura, ocorrem principalmente na forma de uma dobra isoclinal, mascarada pela orientação dos grossos cristais de quartzo e plagioclásio e por finas agulhas de micas. Ocorrem também, em menor volume, cristais de biotita e muscovita. Os grãos de quartzo apresentam-se normalmente fraturados e com finas linhas de inclusões fluidas. Medem em média 3,0 mm e não possuem extinção homogênea. As bordas dos cristais, nesta parte da rocha, tendem a ser irregulares, por mais que possam ocorrer também contatos retilíneos. Pontualmente é possível observar o avanço de borda entre cristais de quartzo (Figura 4-14 A). Os grãos de plagioclásio tendem a ser um pouco menores que os de quartzo, medindo em média 1,2 mm, sendo muito rara ou incipiente, a presença de geminação. Alguns cristais apresentam-se levemente saussuritizados enquanto outros apresentam grande volume de inclusões e ocorrem bastante fraturados (Figura 4-14 B).
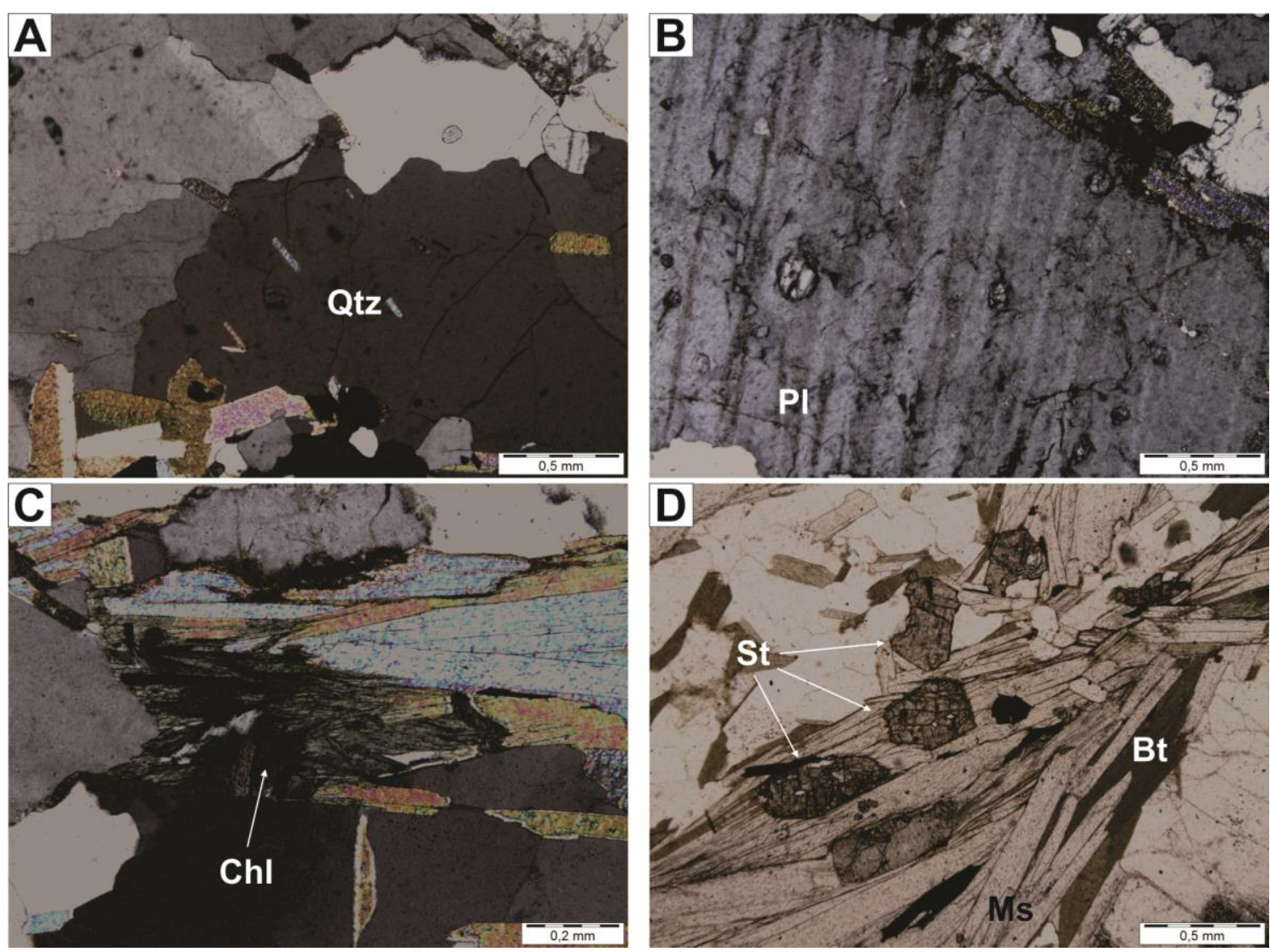

Figura 4-14. (A) Cristais de quartzo com bordas irregulares sugerindo provável avanço de borda (polarizador cruzado); (B) Grão de plagioclásio saussuritizado e bastante fraturado, com geminação incipiente (polarizador cruzado); (C) Cristais de clorita (polarizador cruzado); (D) Cristais de estaurolita subidioblásticos e fraturados (polarizador descruzado). Fotomicrografias referentes à amostra SNA-125. 
As porções lepidoblásticas são caracterizadas por uma granulação média dos minerais micáceos e juntamente com os grãos de muscovita e biotita, ocorrem cristais de estaurolita, granada, e em menor quantidade, de turmalina, cianita e clorita (Figura 4-14 C). Os cristais de muscovita são idioblásticos e são a fase mineral com granulação mais grossa, podendo medir até $5,0 \mathrm{~mm}$ de comprimento, e marcam bem uma foliação dobrada onde, como foliação plano-axial, correm grãos mais finos desta mesma fase mineral. Os grãos de biotita variam de subidioblásticos a xenoblásticos e são menores que os de muscovita, medindo em média 1,0 $\mathrm{mm}$. Os cristais de estaurolita variam de subidioblásticos a xenoblásticos, possuem um grande número de inclusões arredondadas de quartzo e de minerais opacos. São grãos grossos que chegam a medir até 2,7 $\mathrm{mm}$ de comprimento (Figura 4-14 D). Já os cristais de cianita são bastante finos, medindo em média 0,3 mm de comprimento. Os grãos de granada são raros porém grossos, medindo em torno de $2,5 \mathrm{~mm}$. São xenoblásticos e possuem inclusões de minerais opacos.

\subsubsection{Metapsamitos}

Os afloramentos descritos referentes às porções metapsamíticas da Unidade Serra da Boa Vista apresentam duas distinções marcantes entre eles: a presença de biotita e a ocorrência de granada. Dois afloramentos, um à leste (SNA-116) e outro ao sul (SNA-224) de Andrelândia são representados por muscovita quartzitos muito semelhantes petrograficamente. O muscovita quartzito do ponto SNA-116 ocorre em contato com a Unidade Santo Antônio enquanto que o do afloramento SNA-224 ocorre na forma de barras de aproximadamente quatro metros de largura intercaladas ao granada-biotita-muscovitaquartzo xisto porfiroblástico com turmalina, sillimanita e cianita (SNA-223). Os cristais de muscovita neste ponto estão bem orientados e geram uma foliação com mergulho de alto ângulo, onde são observáveis dobras assimétricas de flanco superior indicando que a charneira estaria para SSE.

Microscopicamente a foliação destes quartzitos é marcada por finos cristais de muscovita e pela orientação dos lados maiores dos cristais de quartzo. A granulação finamédia é conferida pelos cristais de quartzo mais grossos que o restante dos minerais, enquanto que os grãos de muscovita e de minerais opacos apresentam granulação que varia de fina à muito fina (Figura 4-15 A e B). Os formatos dos cristais de quartzo são bastante irregulares, com bordas sinuosas, cheias de reentrâncias. A extinção dos grãos de quartzo são na maioria praticamente homogêneas, no entanto alguns cristais apresentam extinção em subgrãos.

À NE de Seritinga, a litologia aflorante é um biotita-muscovita quartzito com granada (SNA-213). Neste ponto, na encosta de um pequeno morro, há uma laje escura de um 
biotita-quartzo-plagioclásio xisto com granada pertencente à Unidade Santo Antônio, e acima dele, alguns poucos metros, ocorre uma intercalação métrica de quartzitos, granada quartzitos, cianita-granada-muscovita-quartzo xistos assim como o biotita-muscovita quartzito com granada.

Petrograficamente a foliação desta rocha é marcada por finos cristais de muscovita e biotita e pela orientação dos maiores eixos dos cristais de quartzo. A granulação dos grãos de quartzo variam de fina a média, e quanto maiores os cristais, mais irregulares são suas formas e suas bordas tendem a ser mais entrecortadas, repletas de reentrâncias. Os grãos maiores apresentam extinção ondulante e em alguns é possível distinguir domínios de subgrãos (Figura 4-15 C), enquanto que os cristais mais finos tendem a apresentar extinção homogênea. Na seção delgada ocorre apenas um porfiroblastos de granada, bastante alterado e cominuído.

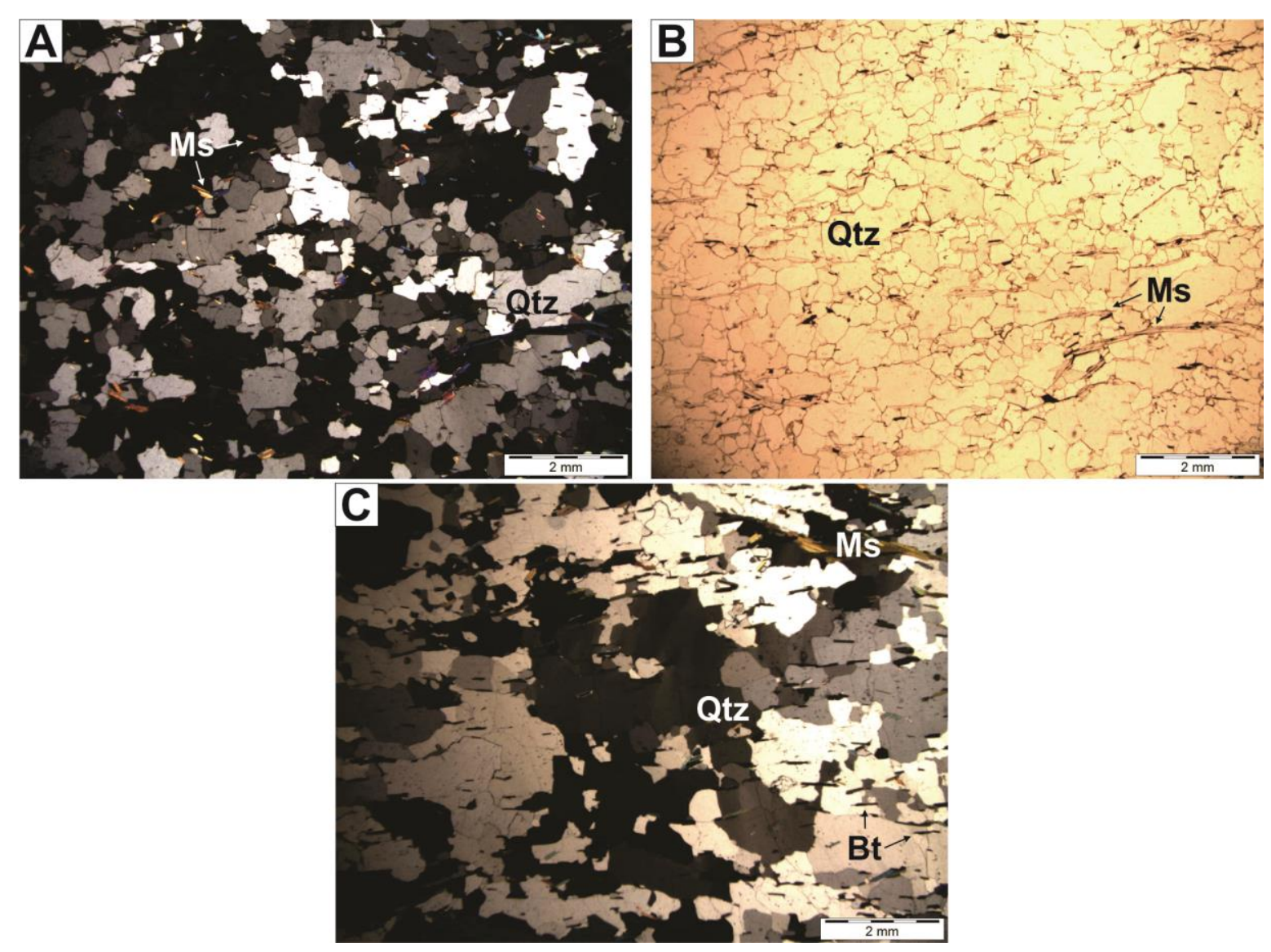

Figura 4-15. (A) Textura geral do muscovita quartzito do afloramento SNA-224, exibindo foliação marcada pela orientação dos cristais de muscovita e pela orientação dos eixos maiores dos cristais de quartzo (polarizador cruzado); (B) Mesma fotomicrografia, agora com polarizador descruzado; (C) Extinção em domínios de subgrãos dos cristais de quartzo do muscovita quartzito do afloramento SNA-213 (polarizador cruzado). 


\subsection{Nappe Liberdade}

A Nappe Liberdade é dominada por rochas metapelíticas com ocorrência subordinadas de fácies pelito-grafitosas, psamo-pelíticas, psamíticas e wackes, enquanto que de maneira mais frequente ocorrem gnaisses e rochas calciossilicáticas, assim como lascas de rochas metamáficas, metaultramáficas, fels manganesíferos e ferríferos. Os ortognaisses ocorrem como fatias contínuas no interior do alóctono, e em seu front ocorre como lascas menos espessas, e compreendem hornblenda-biotita gnaisses e biotita gnaisses granodiorito-tonalíticos com bandamento; gnaisses com bandamento que varia de decimétrico à métrico entre biotita tonalito gnaisses, biotita-hornblenda gnaisses e biotita anfibolitos; muscovita-biotita gnaisses com granada bandados a estromáticos; biotita diatexitos de composição leuco-tonalítica eventualmente com enclaves máficos (CAMPOS NETO et al., 2007, 2011).

Os Migmatitos Alagoa compreendem um conjunto de rochas diatexíticas e metatexíticas cortados por corpos de leucogranitos. As litologias frequentemente encontradas desta unidade são biotita diatexitos e metatexitos, estes com mesossoma de biotita granodiorito gnaisse. Os anfibolitos encontrados ocorrem como scholens e boudins em faixas de dezenas de metros. Diatexitos com granada com estruturas em schillieren e diatexitos estromáticos com alternância de leucossoma branco e melanossoma biotítico também ocorrem. Sob os Migmatitos Alagoa, ou sob os ortognaisses, ocorre um pacote não muito espesso, de aproximadamente 200 metros, de muscovita quartzitos que gradam para ortoquartzitos e para muscovita-quartzo xistos, podendo estar intercalados a micaxistos com granada e sillimanita, na porção mais traseira da nappe (CAMPOS NETO et al., 2007, 2011).

O pacote dominante na Nappe Liberdade são os micaxistos que podem alcançar 3000 metros de espessura, onde o litotipo principal é um rutilo-(ilmenita-sillimanita)-cianitagranada-plagioclásio-muscovita-biotita xisto porfiroblástico, que pode gradar para porções mais quartzosas, apresentando caráter mais gnáissico com bandamento félsico rico em quartzo e plagioclásio. Intercalados a este, podem ocorrer lascas frequentes de gnaisses calciossilicáticos nos quais predominam um (granada, rutilo, ilmenita)-titanita-diopsídiohornblenda gnaisse. Da mesma maneira, ocorrem anfibolitos, granada anfibolitos e clinopiroxênio-granada anfibolitos na forma de lentes e boudins. De forma mais restrita, e principalmente no front da nappe, ocorrem xistos grafitosos pouco espessos e sequências ferro-manganesíferas na forma de corpos métricos (CAMPOS NETO et al., 2007, 2011).

As rochas metaultramáficas e os anfibolitos retroeclogíticos são pontuais e mais frequentes nas proximidades do contato tectônico basal da estrutura. Carbonato-talcoantofilita fels com olivina, clorita fels porfiroblásticos e flogopita-clorita xistos afloram como lentes de dezenas de metros de espessura, na forma de matacões e blocos nos arredores 
da Serra da Garça (MEIRA, 2005). Os anfibolitos retroeclogíticos ocorrem como boudins métricos e lentes, com granadas porfiroblásticas e texturas metamórficas reliquiares de fácies eclogito a onfacita (CAMPOS NETO; CABY, 1999). A trajetória de descompressão destes eclogitos é evidenciada por coronas de intercrescimento entre plagioclásio e hornblenda que envolvem os cristais de granada, assim como pela substituição de onfacita por intercrescimentos entre diopsídio-quartzo-plagioclásio. Ambas texturas são consideradas como representantes de uma rápida exumação (CAMPOS NETO; CABY, 1999; SANTOS; CAMPOS NETO; GROHMANN, 2004).

A Nappe Liberdade exibe um processo de exumação acompanhado por intenso estiramento e boudinagem que resultaram em uma extensa pilha de estruturas anticlinais, onde os indicadores cinemáticos $\sin -S_{2}$ (plano-axiais de dobras recumbentes) são coerentes com o transporte regional para NE, como indicado na Figura 4-16 (CAMPOS NETO et al., 2007)
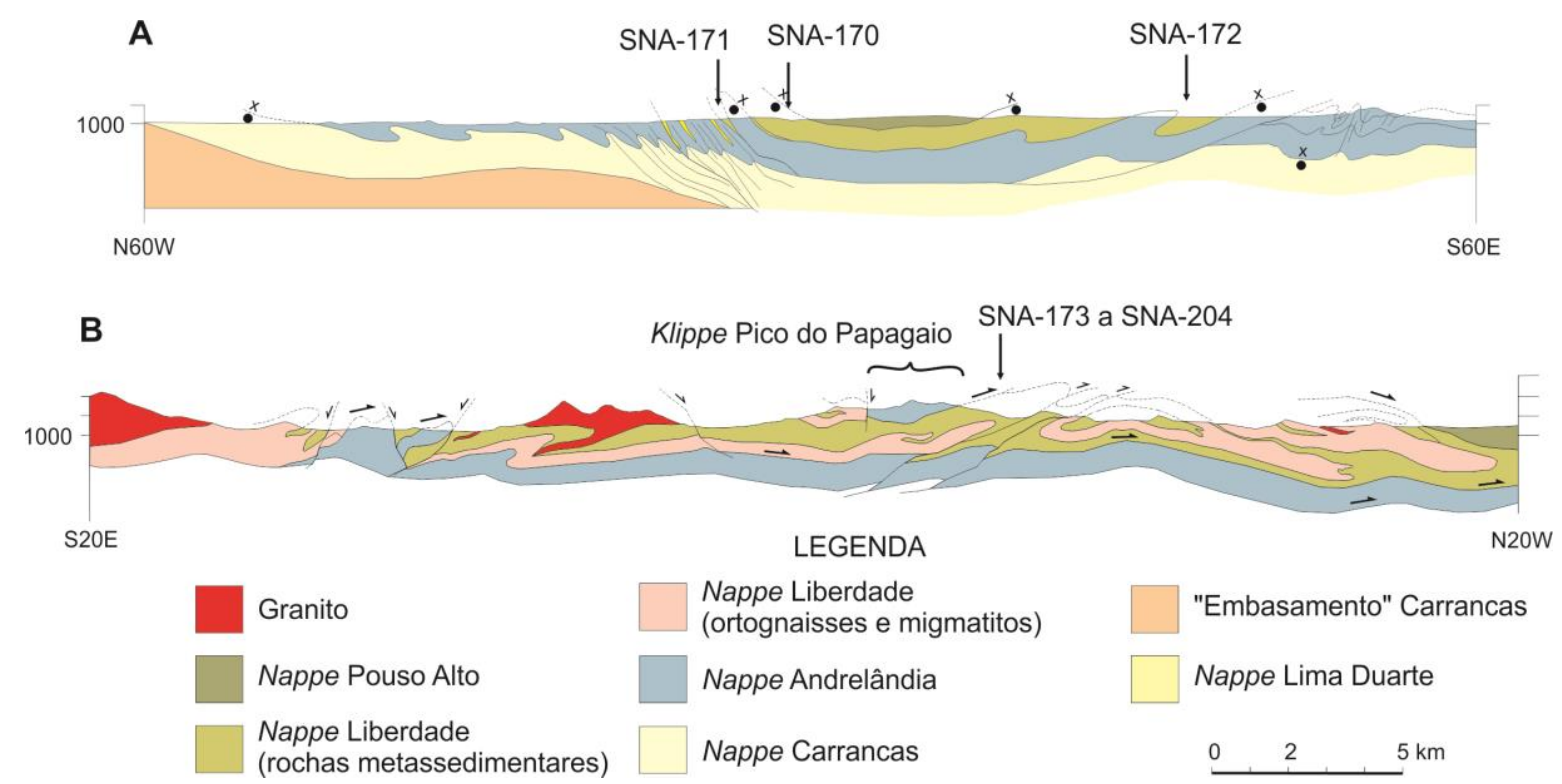

Figura 4-16. Seções geológicas do Sistema de Nappes Andrelândia Oriental (CAMPOS NETO et al., 2007) com a posição de algumas afloramentos e amostras estudadas, ambas localizadas na retaguarda do sistema de nappes.

\subsubsection{Rochas metassedimentares}

As rochas metassedimentares da Nappe Liberdade frequentemente ocorrem como xistos porfiroblásticos com presença comum de granada, cianita e estaurolita, e como fases acessórias turmalina, rutilo e minerais opacos. As foliações marcadas pela textura lepidoblástica, composta por muscovita e biotita, podem ocorrer crenuladas e com cristais marcando arcos poligonais mimetizando dobras $D_{2}$, por vezes dobradas em dobras $D_{3}$ orientadas segundo a $S_{3}$. A estaurolita é tardi- a pós- $S_{2}$ chegando à sin- $S_{3}$ em alguns casos 
(TEIXEIRA, 2008). Os porfiroblastos de granada em sua maioria são cedo-S 2 , podendo em alguns casos, ocorrer como sin- ou pós-S $S_{2}$.

As rochas descritas apresentam variações composicionais relativamente sutis dentre as mesmas litologias. À norte de Arantina ocorre um granada-biotita-muscovita-quartzo xisto porfiroblástico com estaurolita e cianita (SNA-172 A) enquanto que na Serra do Pico do Papagaio (SNA-175 e SNA-197) e ao sul de Andrelândia (SNA-169) aparentemente esta mesma litologia ocorre como um granada-cianita-biotita-muscovita-plagioclásio-quartzo xisto porfiroblástico com estaurolita, aqui com presença de porfiroblastos de plagioclásio centimétricos, fase mineral ausente na primeira litologia (Figura 4-17).
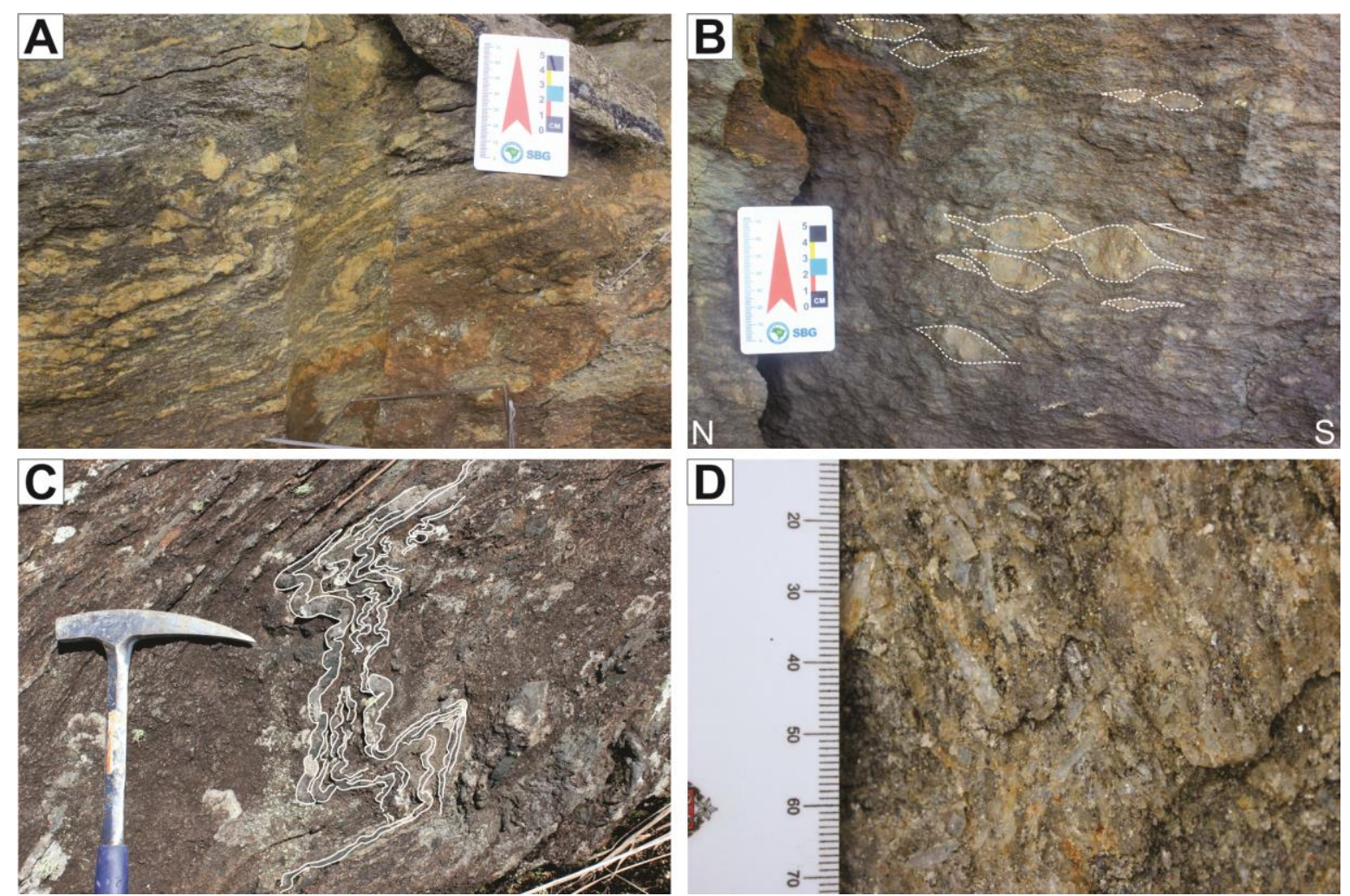

Figura 4-17. (A) Estrutura geral do afloramento SNA-169, com porções granoblásticas dobradas e (B) porfiroblastos de plagioclásio como indicadores cinemáticos exibindo movimentação sinistral com topo para o norte; (C) Vênulas de quartzo em dobras intrafoliais do afloramento SNA-197; (D) Detalhe para os cristais de cianita orientados no plano da foliação no afloramento SNA-169.

O granada-cianita-biotita-muscovita-plagioclásio-quartzo xisto porfiroblástico com estaurolita apresenta granulação média, em alguns pontos é bastante micácea, já em outros a rocha tende a ser mais quartzosa, e é possível perceber níveis descontínuos ricos em cristais de cianita tanto incolores quanto azuladas. Os cristais de granada apresentam formas bastante arredondadas e coloração lilás, e em algumas partes da rocha são encontrados cristais bastante grossos de plagioclásio em formato de indicadores cinemáticos, que chegam a medir aproximadamente $3 \mathrm{~cm}$, principalmente no afloramento SNA-169 (Figura 4-17 A e B). No afloramento SNA-169 esta rocha ocorre associada a 
xistos com turmalina e turmalinitos, a ser descrito no próximo item, e no ponto SNA-175 ele ocorre intercalado à camadas de muscovita quartzitos. No afloramento SNA-197 são facilmente observáveis vênulas de espessura subcentimétricas descontínuas dobradas em pequenas dobras relativamente apertadas e assimétricas (Figura 4-17 C). Dentre os três afloramentos é o único no qual não foi observado estaurolita em lâmina. Neste ponto, esta litologia ocorre como intercalações métricas em meio a um quartzito micáceo na subida da serra nas proximidades do Retiro dos Pedros. Já o granada-biotita-muscovita-quartzo xisto porfiroblástico com estaurolita macroscopicamente se assemelha a um gnaisse pelo grande volume de minerais granoblásticos. Na superfície do afloramento se destacam bandas granoblásticas de espessura centimétrica assim como porfiroblastos de granada de coloração avermelhada. 

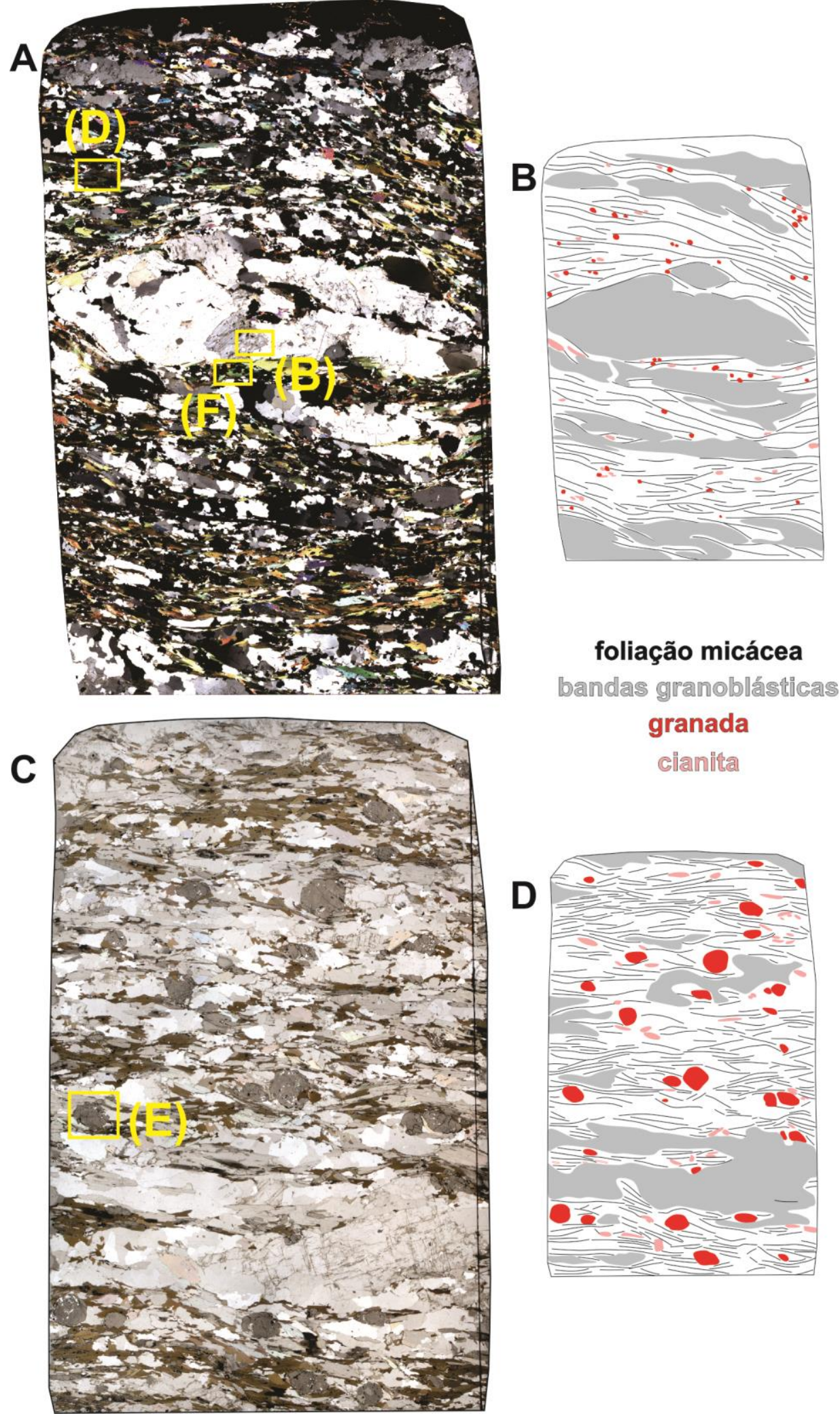

Figura 4-18. (A) Fotomicrografia da seção delgada completa (lados maiores com $4 \mathrm{~cm}$ de comprimento), da amostra SNA-169, com a localização de algumas das fotomicrografias da Figura 4-19 (polarizador cruzado); (B) Interpretação das principais estruturas e minerias da lâmina SNA-169; (C) Fotomicrografia da seção delgada completa da amostra SNA-175, com a localização de algumas das fotomicrografias da Figura 4-19 (polarizador descruzado); (D) Interpretação das principais estruturas e minerais da lâmina SNA-175. 
Petrograficamente as amostras são compostas por uma intercalação caótica de bandas granoblásticas com bandas nematolepidoblásticas, onde geralmente ocorrem os porfiroblastos de granada, ambas completamente descontínuas com formatos irregulares e disformes que ocorre de maneira arrítmica e despadronizada (Figura 4-18). A espessura dessas porções é muito irregular e em alguns locais não é possível determinar seus limites, e sob luz natural, nota-se que a textura geral da rocha é milonítica As bandas nematolepidoblásticas são compostas principalmente por muscovita e biotita, mas ocorrem também porfiroblastos de granada, e como acessórios, minerais opacos, estaurolita, cianita, clorita, rutilo, apatita, e zircão (Figura 4-19 C e D). As porções que exibem textura granoblástica são ora compostas por quartzo e plagioclásio (SNA-169, SNA-175 e SNA197), ora 98\% por quartzo (SNA-172A) com poucas ocorrências de biotita e muscovita. Os cristais de quartzo apresentam bordas bastante irregulares e extinção em subgrãos (Figura 4-19 A), e os cristais de plagioclásio, quando ocorrem, estão geralmente geminados e apresentam forte saussuritização (Figura 4-19 B).

Os porfiroblastos de granada ocorrem sempre onde a foliação lepidoblástica é mais rica em biotita e um pouco mais espessa, e apresentam formatos que variam de arredondados a alongados, orientados segundo a foliação. Pode-se dividi-los em três famílias: (i) porfiroblastos pouco fraturados e com raras inclusões, possivelmente sendo tardi- à pós-cinemáticos (Figura 4-19 F); (ii) porfiroblastos com inclusões, podendo ou não gerar foliação interna, que não exibe continuação com a foliação externa, indicando crescimento cedo-cinemático (Figura 4-19 E); e (iii) porfiroblastos com foliação interna gerada pelas inclusões e que, aparentemente, mantém continuação com a foliação externa, demonstrando caráter sin-cinemático. 

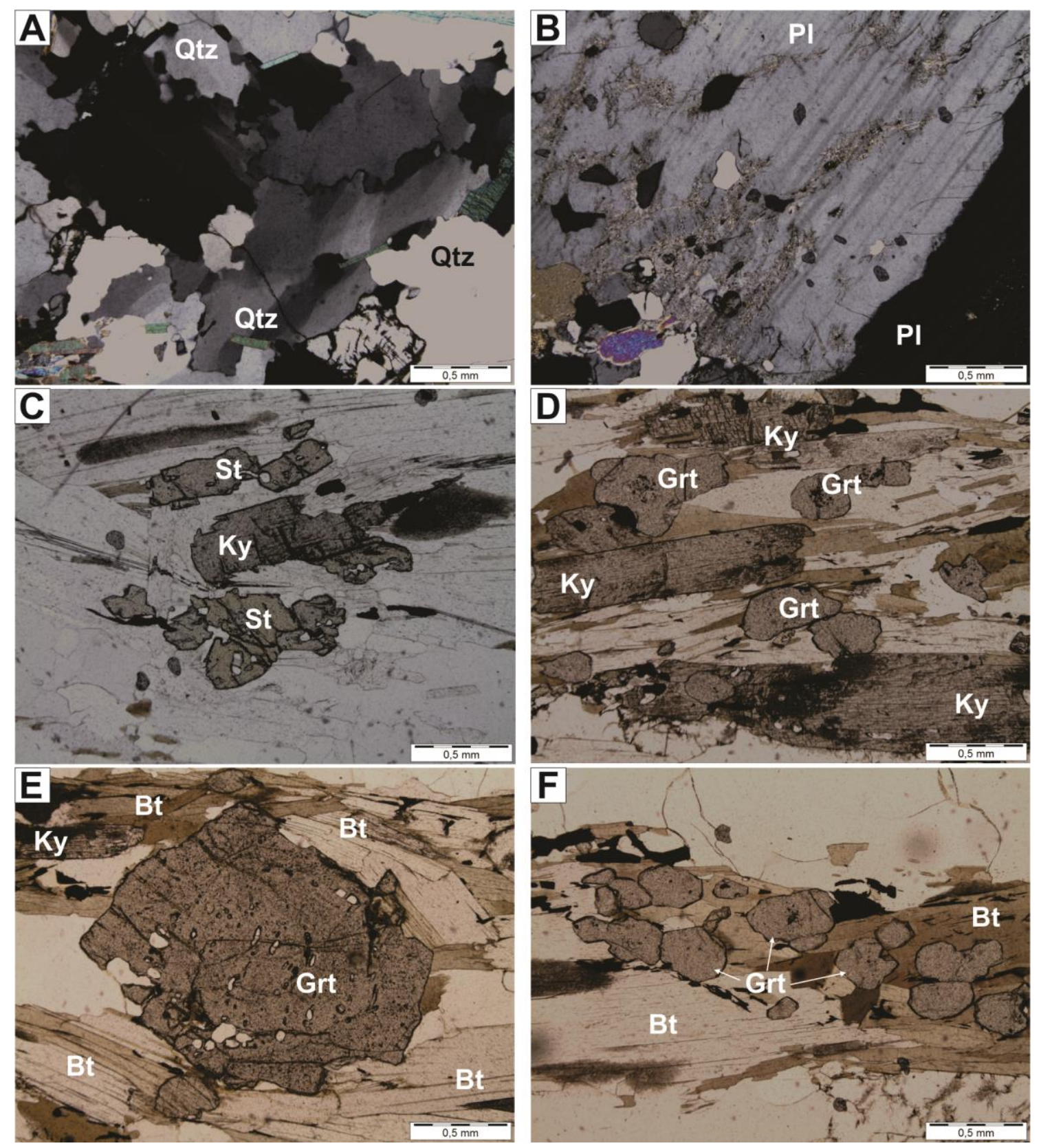

Figura 4-19. (A) Grãos de quartzo com bordas irregulares e extinção em domínios de subgrãos da lâmina SNA197 (polarizador cruzado); (B) Cristal de plagioclásio geminado e saussuritizado da lâmina SNA-169 (polarizador cruzado); (C) Cristais de cianita e estaurolita como fases acessórias (polarizador descruzado); (SNA-172A) (D) Minerais constituintes das bandas nematolepidoblásticas da lâmina SNA-169 (polarizado descruzado); (E) Porfiroblasto de granada da lâmina SNA-175 cuja foliação interna não apresenta continuidade com a foliação externa (polarizador descruzado); (F) Cristais de granada quase sem inclusões, crescidos sobre a foliação essencialmente lepidoblástica da lâmina SNA-169 (polarizador descruzado).

No mesmo afloramento ao sul de Andrelândia, onde há o granada-cianita-biotitamuscovita-plagioclásio-quartzo xisto porfiroblástico com estaurolita, ocorre uma pequena zona de cisalhamento preenchida por um filão de quartzo associado a um turmalinito muito fino. Esta zona de cisalhamento ocorre rompendo o flanco de uma dobra próximo da região da charneira, onde a foliação é subvertical, já abaixo do filão de quartzo a foliação encontrase subhorizontal. Os turmalinitos encontram-se em várias porções da rocha, 
preferencialmente junto à concentrações quartzosas, cortando a foliação metamórfica. Nos locais do afloramento onde ocorrem grande quantidade de turmalina e turmalinitos, a rocha torna-se um turmalina-granada-biotita-plagioclásio-muscovita-quartzo xisto com estaurolita (SNA-169A).

Microscopicamente essa amostra apresenta ora uma intercalação perceptível entre bandas granoblásticas quartzo-feldspáticas com bandas lepidoblásticas de biotita e muscovita, ora cristais desorientados dos minerais micáceos juntos aos grãos de quartzo e feldspato. Ocorrem, de forma aleatória, cristais de granada, estaurolita, megacristais de turmalina, e eventualmente pequenos cristais de estaurolita xenoblásticos (Figura 4-20 A). Os megacristais de turmalina são frutos de eventos hidrotermais, correm geralmente associados às bandas lepidoblásticas e ora estão orientados segundo a foliação marcada pelos cristais de muscovita e biotita, ora ocorrem de forma decussada. São grãos xenoblásticos, com pleocroísmo bastante forte do bege claro ao verde alaranjado. Podem ocorrer com inclusões de zircão, minerais opacos, granada, muscovita, e quartzo (Figura 4-20 B, C e D).
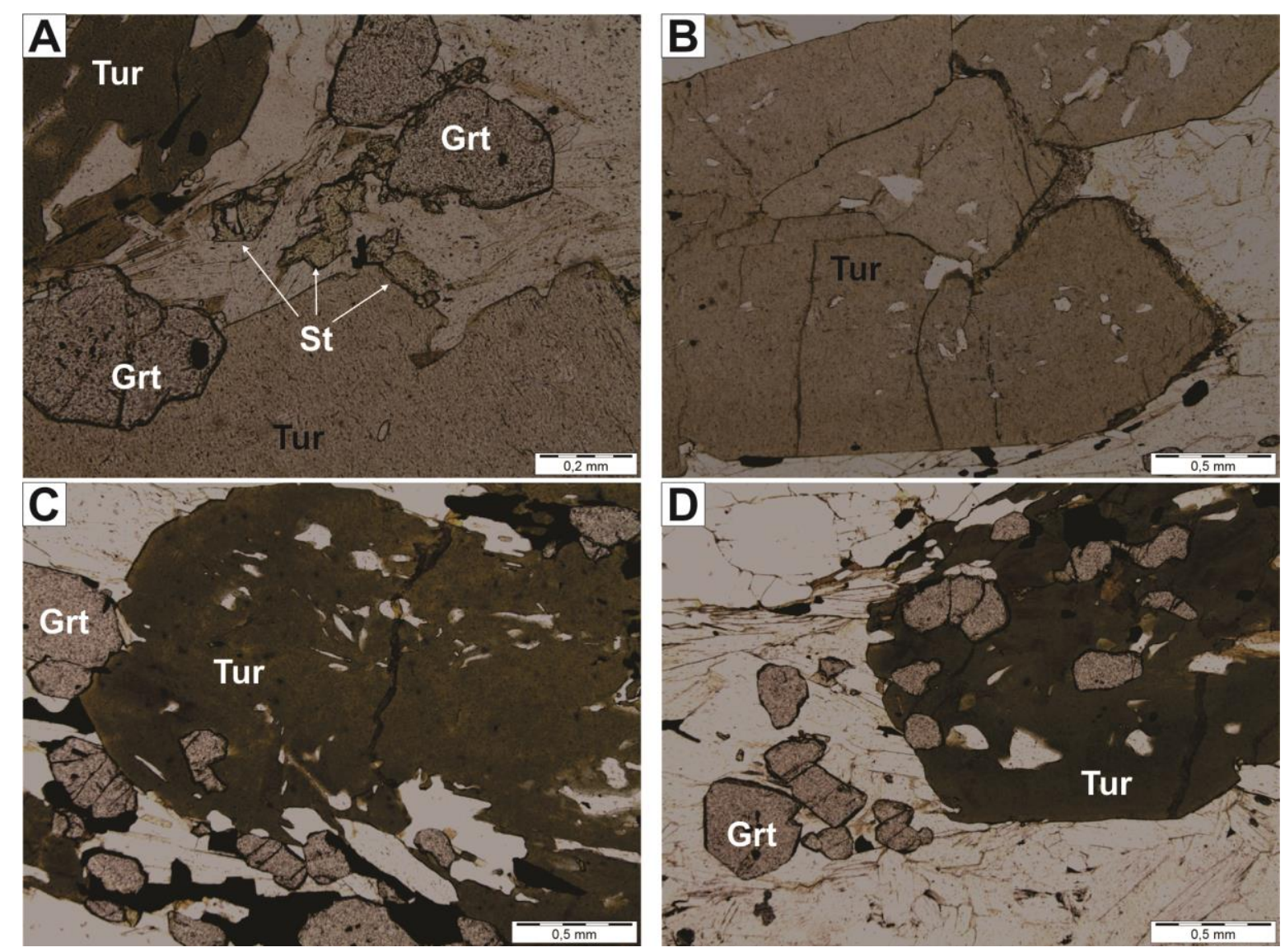

Figura 4-20. (A) Pequenos cristais xenoblásticos de estaurolita dispostos aleatoriamente entre os grãos de granada e turmalina (polarizador descruzado); (B), (C) e (D) Megacristais de turmalina com inclusões de quartzo, granada e grãos de minerais opacos, e ocorrem ao longo de toda a seção delgada (polarizador descruzado). 
Na subida para o Retiro dos Pedros, porção norte da Serra do Pico do Papagaio, além dos xistos descritos anteriormente, ocorre um granada-biotita-muscovita-plagioclásiofeldspato potássico-quartzo xisto porfiroblástico (SNA-180 B e SNA-181), no entanto ali próximo (SNA-182 à SNA-184) e no corte da estrada de ferro Oeste de Minas, ao norte de Arantina (SNA-172 E), a mesma litologia ocorre sem a presença de granada, e torna-se um muscovita-biotita-plagioclásio-quartzo xisto com feldspato potássico, agora metatexítico. Os leucossomas gerados apresentam formatos de sigmoides que variam de centimétricos à decimétricos e ao longo dos afloramentos é possível distinguir pares S-C bem preservados (Figura 4-21 A e B).

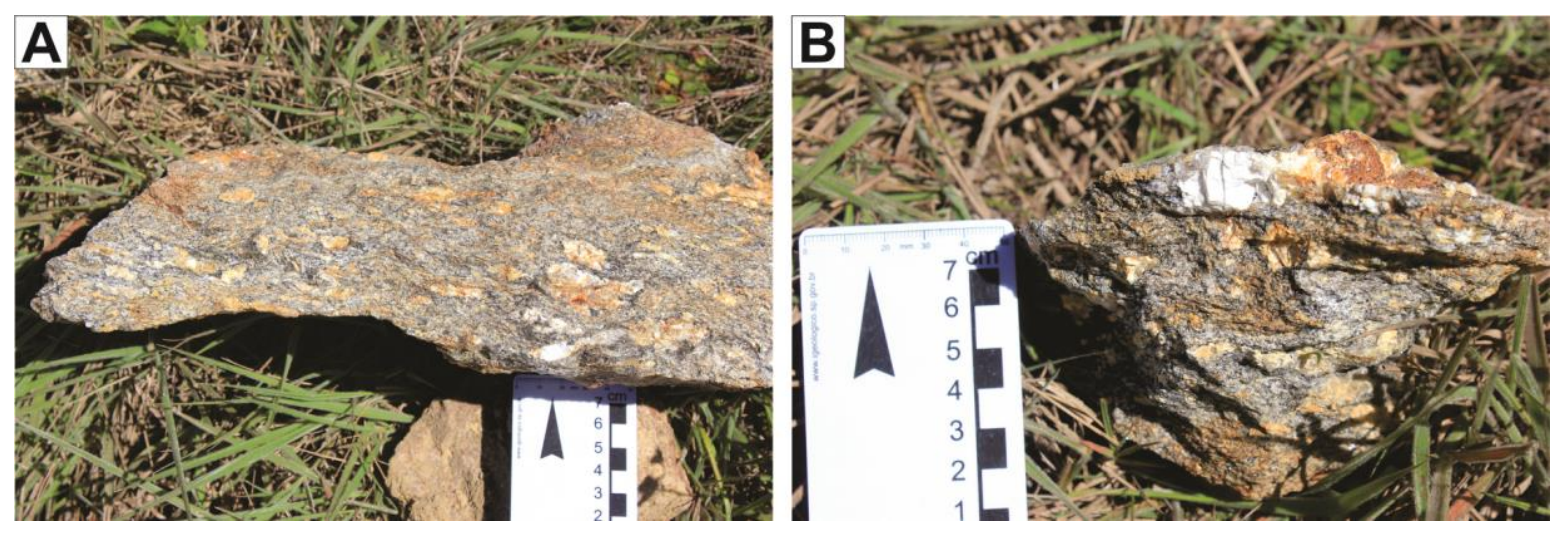

Figura 4-21. (A) e (B) Textura macroscópica geral do granada-biotita-muscovita-plagioclásio-feldspato potássicoquartzo xisto porfiroblástico do afloramento SNA-180. Coordenadas: 532280/7564361.

Petrograficamente a amostra deste xisto apresenta leitos finos de textura lepidoblástica completamente descontínuos e irregulares compostos principalmente por muscovita e biotita, intercalados caoticamente a leitos granoblásticos quartzo-feldspáticos um pouco mais espessos (Figura 4-22). As bandas granoblásticas são compostas $70 \%$ por quartzo e o restante é distribuído pelo volume de feldspato potássico e plagioclásio, e em menor quantidade ocorrem raros grãos dispersos de mineral carbonático. As bandas lepidoblásticas são compostas principalmente por muscovita e biotita, ocorrendo como minerais acessórios grãos dispersos de apatita, clinozoisita, granada, mineral carbonático, zircão e clorita. Na lâmina ocorre apenas um porfiroblasto de granada que mede $1,5 \mathrm{~cm}$, no entanto se apresenta completamente alterado e com bordas completamente difusas, mesmo assim, cristais menores de granada ocorrem dispersos pela lâmina. 

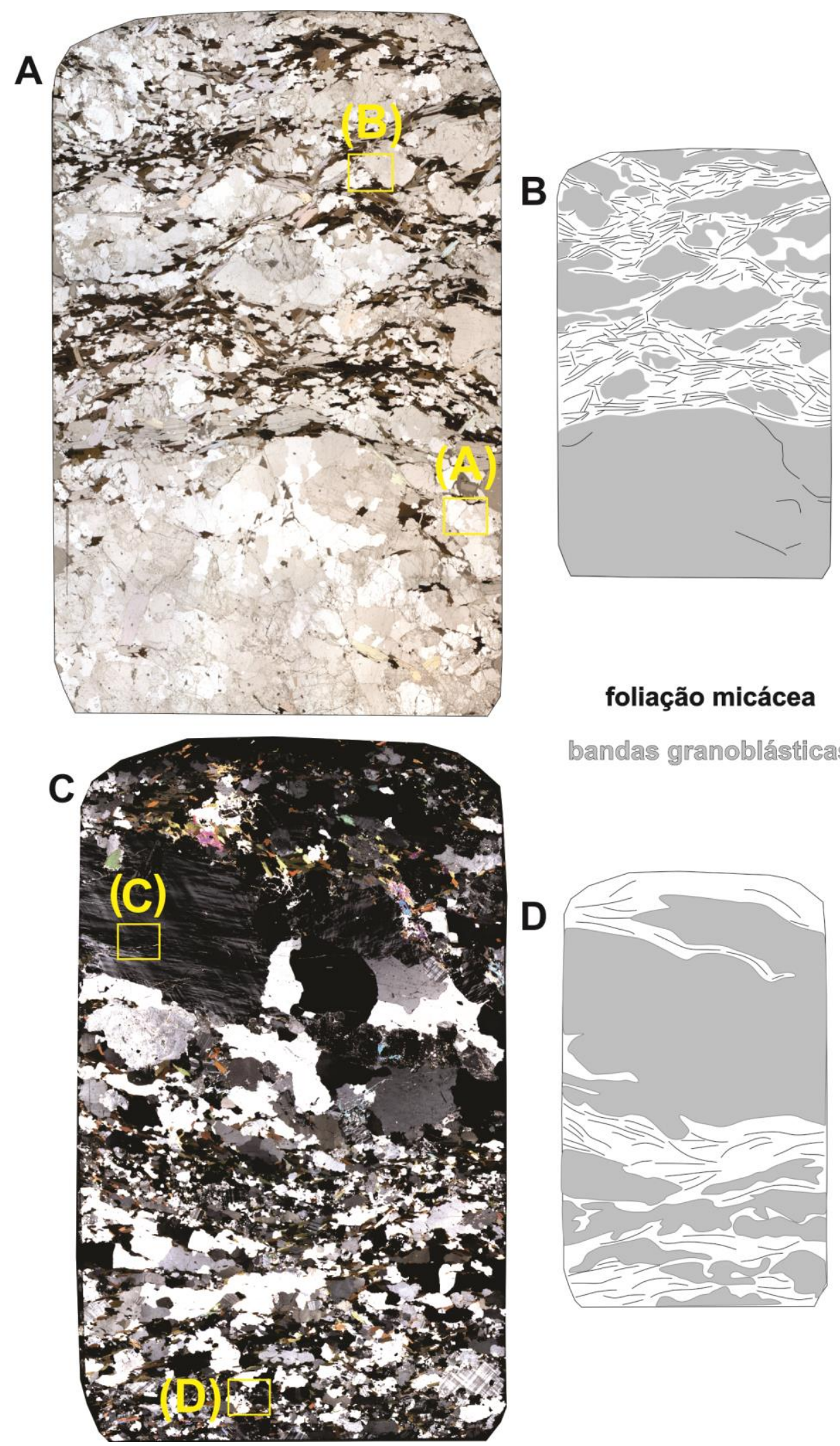

Figura 4-22. (A) Fotomicrografia da seção delgada completa (lados maiores com $4 \mathrm{~cm}$ de comprimento), da amostra SNA-182, com a localização de algumas das fotomicrografias da Figura 4-23 (polarizador descruzado); (B) Interpretação das principais estruturas e texturas da lâmina SNA-182; (C) Fotomicrografia da seção delgada completa da amostra SNA-172 E, com a localização de algumas das fotomicrografias da Figura 4-23 (polarizador cruzado); (D) Interpretação das principais estruturas e texturas da lâmina SNA-172 E. 
A variação do xisto sem granada e metatexítico exibe leucossoma de textura granoblástica bastante grossa composta principalmente por quartzo e em menor volume plagioclásio e feldspato alcalino com geminação em grade visível (Figura 4-23 A, B e C), ocorrendo também, de forma rara, cristais de biotita, muscovita e aglomerados de finos cristais de carbonato. Alguns bolsões de leucossoma apresentam formatos semelhantes à sigmóides delimitados pelos minerais micáceos. Nestas porções da rocha, nas bordas de alguns cristais de feldspato potássico, é observada a presença de mirmequita (Figura 4-23 D). O restante da rocha exibe uma intercalação irregular e descontínua entre bandas granoblásticas compostas por quartzo, plagioclásio e feldspato alcalino, e bandas lepidoblásticas compostas essencialmente por biotita e muscovita, e em menor volume clorita, apatita, minerais opacos e zircão. Ainda assim ocorrem camadas lepidoblásticas relativamente finas compostas essencialmente por biotita e muscovita.
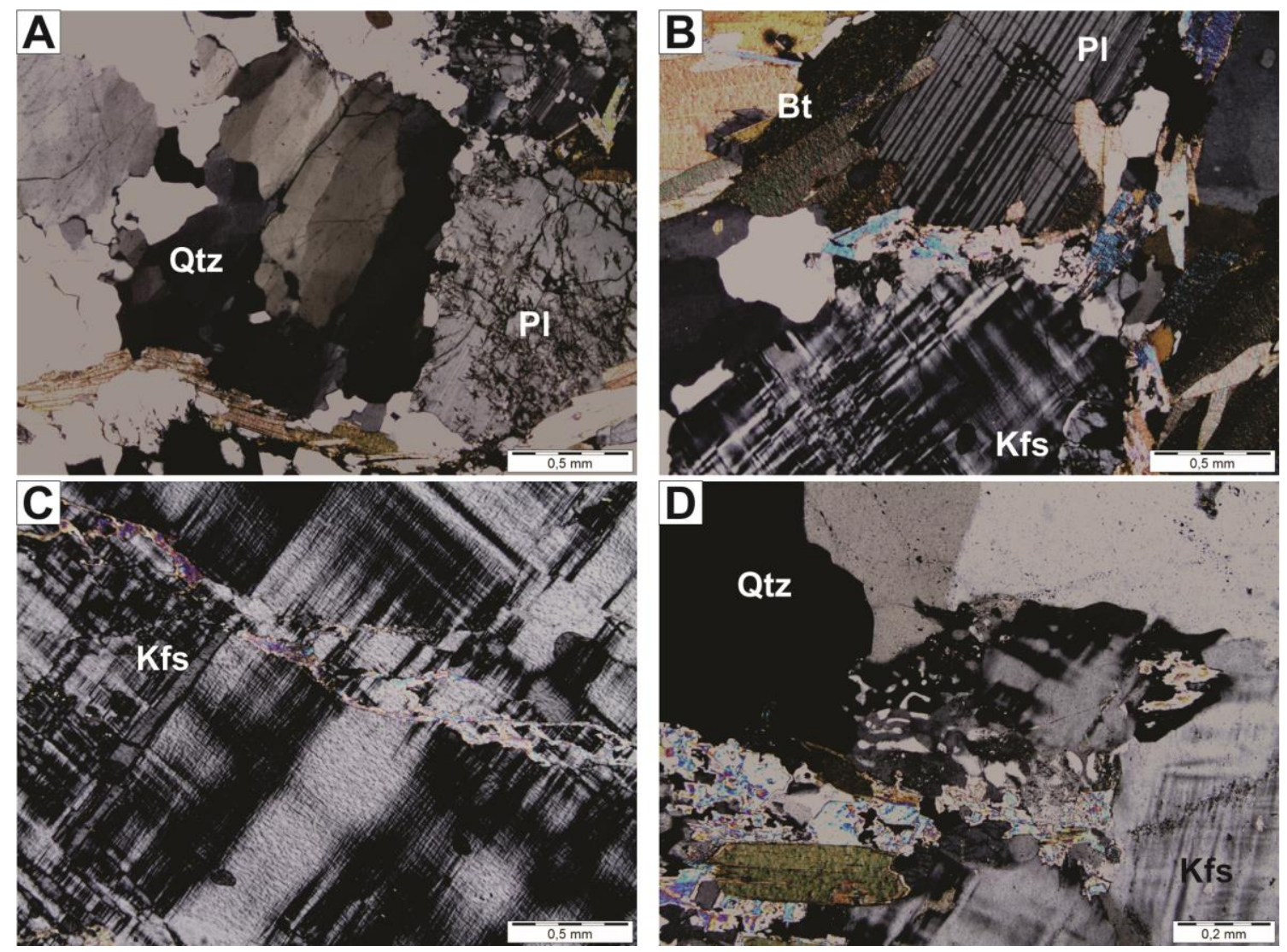

Figura 4-23. (A) Grão de quartzo com extinção heterogênea em domínios de subgrãos da lâmina SNA-182 (polarizador cruzado); (B) Cristais de plagioclásio e feldspato potássico no leucossoma da lâmina SNA-182 (polarizador cruzado); (C) Porfiroblasto de feldspato potássico da lâmina SNA-172 E (polarizador cruzado); (D) Presença de mirmequita próxima dos contatos entre cristais de quartzo e feldspato potássico na lâmina SNA-172 E (polarizador cruzado).

Intercalado aos granada-cianita-biotita-muscovita-plagioclásio-quartzo xistos porfiroblásticos com estaurolita na subida da Serra do Pico do Papapagio, o muscovita quartzito (SNA-180A) ocorre como camadas métricas. Macroscopicamente pode-se dizer 
que apresenta granulação fina, coloração avermelhada e que os cristais de quartzo estão bem recristalizados. Em algumas porções do afloramento são observados leitos mais ricos em minerais micáceos onde eventualmente podem ser encontrados porfiroblastos de granada.

Ao microscópio essa rocha apresenta textura granoblástica caracterizada por uma grande massa quartzítica com finos cristais de muscovita orientados segundo uma direção preferencial e marcando uma foliação principal (Figura 4-24 A). Os grãos de quartzo em sua grande maioria são equidimensionais e medem em média 0,5 mm. Ocorrem alguns cristais um pouco maiores e alongados tendo seu eixo principal de elongação orientados segundo a foliação, paralelos à direção de crescimento dos cristais de muscovita. As bordas destes grãos, em alguns locais, são em cúspide e lobados, e a grande maioria dos cristais apresenta extinção em subgrãos que pode ou não estar paralela à foliação (Figura 4-24 B). Os cristais de muscovita são subidioblásticos com a presença de alguns xenoblásticos. Medem em média 0,5 mm de comprimento e 0,4 $\mathrm{mm}$ de largura. Estão todos orientados na mesma direção, marcando visivelmente os planos de foliação.
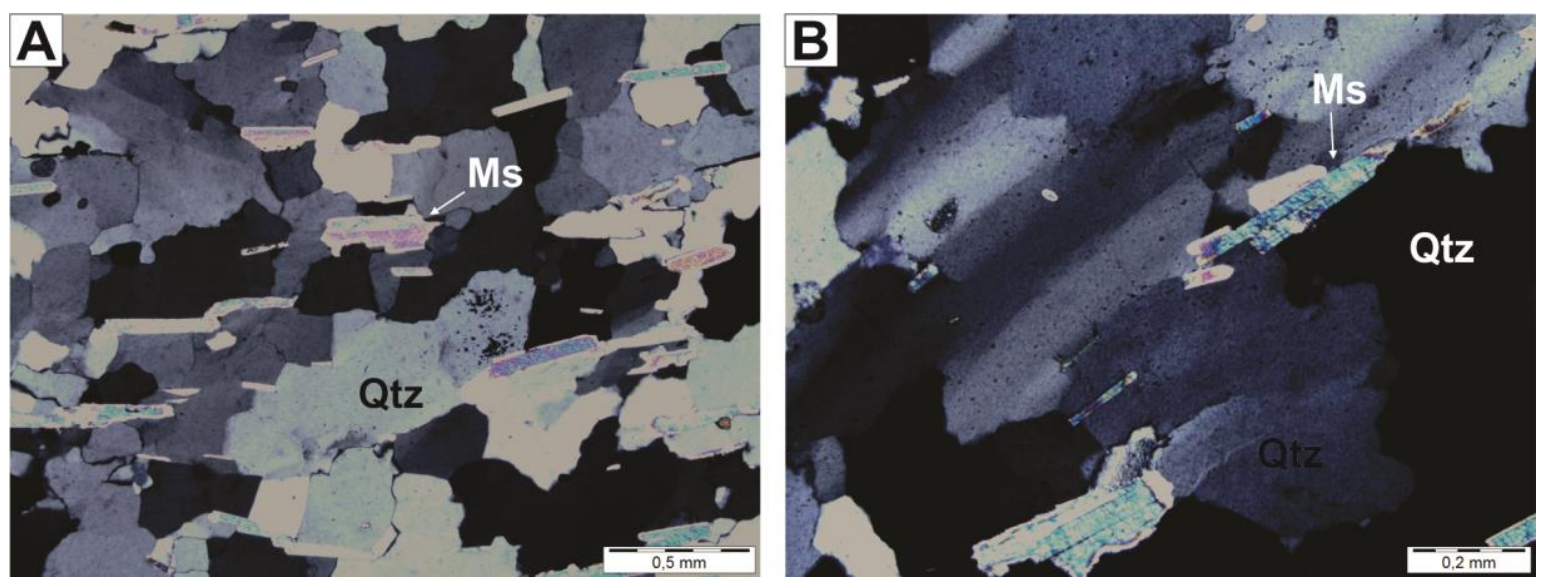

Figura 4-24. (A) Orientação dos cristais de muscovita marcando a foliação principal do muscovita quartzito (polarizador cruzado); (B) Grão de quartzo com extinção em subgrãos paralela à foliação marcada pela orientação dos cristais de muscovita (polarizador cruzado).

\subsubsection{Rochas calciossilicáticas}

As rochas calciossilicáticas descritas da Nappe Liberdade (SNA-170 e SNA-17) ocorrem como blocos soltos, nas proximidades de um túnel da estrada de ferro Oeste de Minas. Macroscopicamente os blocos apresentam aspecto maciço, sem foliação proeminente, de coloração cinza claro com veios decimétricos de quartzo de granulação grossa manteados por concentrações de cristais de biotita também de granulação grossa que chegam a medir $2 \mathrm{~cm}$ de espessura. Ao microscópio foram identificadas duas litologias distintas, um titanita-granada-biotita-anfibólio gnaisse calciossilicático com carbonato (SNA- 
170 A) e um titanita-epidoto-carbonato-escapolita-diopsídio gnaisse calciossilicático (SNA$170 \mathrm{~B})$.

O titanita-granada-biotita-anfibólio gnaisse calciossilicático com carbonato apresenta estrutura bandada, com intercalação caótica e despadronizada de bandas ricas em cristais orientados de biotita e anfibólio (Figura 4-25 A), e bandas compostas por quartzo e plagioclásio. Além de biotita e anfibólio, a banda lepidonematoblástica é composta por granada, carbonato, titanita, clinozoisita e apatita (Figura 4-25 B). Esta banda compõe a maior parte da lâmina, apresenta granulação mais grossa e por ela é possível observar uma foliação bem marcada. Mesmo nesta banda há uma certa diferença de composição de porções para porções, onde ocorre variância no volume de anfibólio e biotita. As porções granoblásticas da rocha são compostas apenas por quartzo e plagioclásio (Figura 4-25 C), e não apresentam continuidade lateral, ocorrendo de maneira bastante disforme e descontínua.

Diferentemente da litologia descrita acima, o titanita-epidoto-carbonato-escapolitadiopsídio gnaisse calciossilicático, assim como o observado macroscopicamente, apresenta aspecto maciço pela distribuição aparentemente homogênea de todos os minerais ao longo de toda a lâmina. Esta rocha é composta principalmente por diopsídio, escapolita e carbonato, e em menor volume, quartzo, plagioclásio, titanita, clinozoisita, epidoto e biotita.

Os cristais de diopsídio apresentam coloração bege amarronzada e estão ligeiramente fraturados. As cores de birrefringência variam de bege a tons mais quentes como verde, azul e laranja. Os formatos são bastante irregulares, e as bordas nunca são retilíneas. Podem ocorrer com várias inclusões de grãos de quartzo, escapolita, titanita e carbonato. É possível observar uma certa orientação dos cristais de diopsídio, porém isso não é o bastante para gerar uma foliação proeminente na rocha.

Os cristais de escapolita são incolores mas apresentam relevo maior do que os grãos de quartzo e plagioclásio. Apresentam cores de birrefringência bastante variável, do bege ao verde amarelado e rosa. Seus formatos também são bastante irregulares, que variam de praticamente equidimensionais até levemente alongados, e geralmente se apresentam fraturados. Os cristais de carbonato ocorrem na forma de um conjunto de grãos grossos nos quais é possível observar suas direções de clivagem (Figura 4-25 D), ou podem ocorrer nos interstícios dos cristais de escapolita e de diopsídio. 

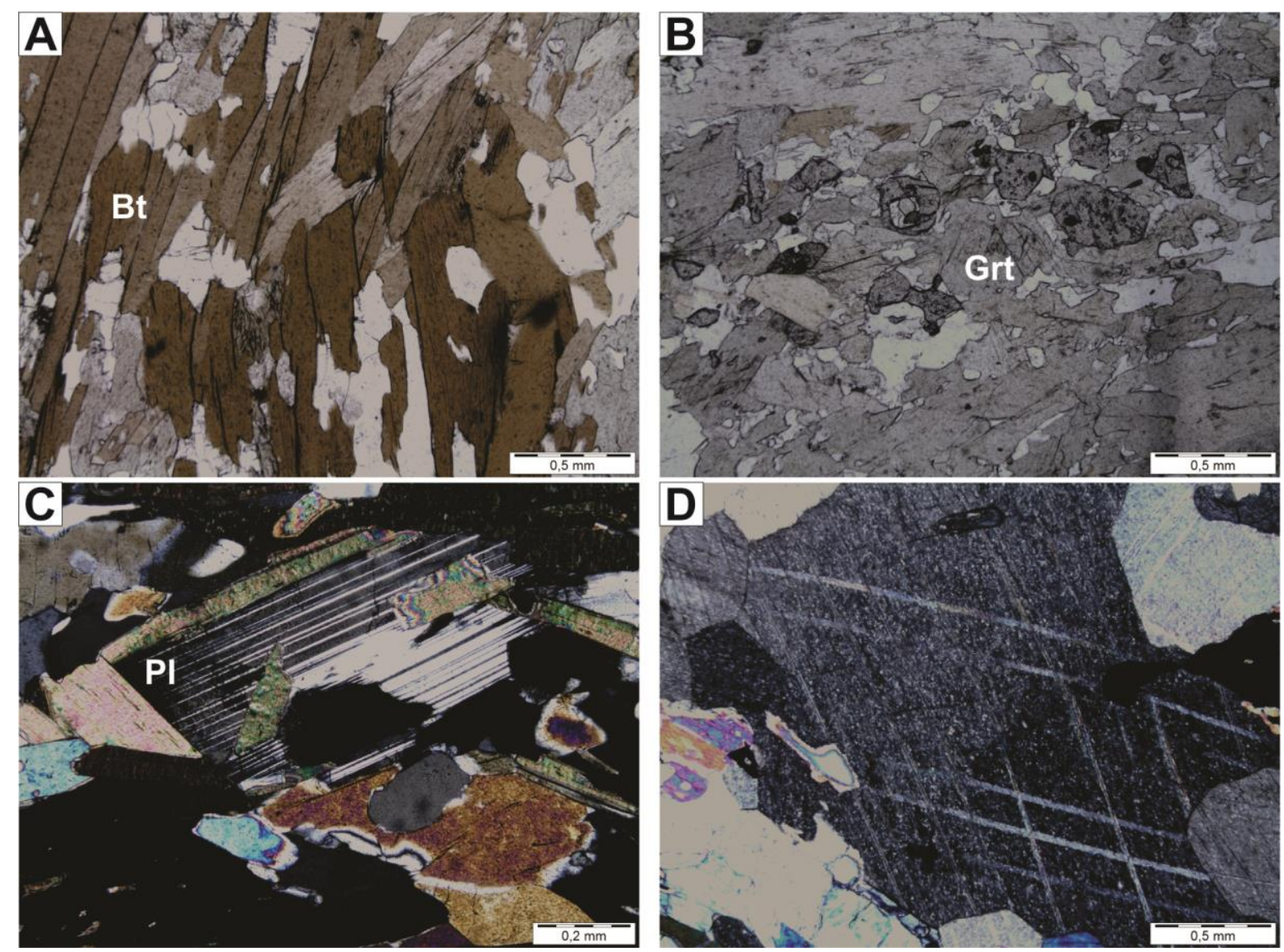

Figura 4-25. (A) Porções ricas em biotita de granulação mais grossa na lâmina SNA-170 A (polarizador descruzado); (B) Níveis ricos em cristais de granada na lâmina SNA-170 A (polarizador descruzado); (C) Grão de plagioclásio com geminação lei da albita bastante proeminente na lâmina SNA-170 A (polarizador cruzado); (D) Cristal de carbonato com as duas direções de clivagem bem marcadas na lâmina SNA-170 B (polarizador cruzado).

\subsubsection{Rochas metabásicas}

Os titanita-epidoto anfibolitos metatexíticos foram descritos nos afloramentos SNA171 e SNA-172. No corte da estrada de ferro (SNA-172) é possível observar que estes anfibolitos ocorrem intercalados a gnaisses entre os quais os contatos são sub-horizontais, retilíneos e bem marcados.

Petrograficamente as amostras desta litologia são compostas por intercalações irregulares, descontínuas e em diferentes proporções de bandas ricas em anfibólio com bandas compostas principalmente por plagioclásio, e em menor quantidade por quartzo. Nas bandas com textura nematoblástica os cristais de anfibólio tendem a estar orientados segundo uma direção preferencial de elongação, já nas bandas granoblásticas os grãos tendem a ser mais equidimensionais. Em uma das lâminas, é possível distinguir bolsões de leucossoma compostos $85 \%$ por quartzo e o restante por plagioclásio, e essas intercalações de bandas granoblásticas e bandas nematoblásticas perfazem o mesossoma. 
As bandas nematoblásticas são constituídas aproximadamente de $70 \%$ de hornblenda, aproximadamente $10 \%$ de epidoto e de titanita e o restante é dividido por pequenos volumes de clinozoisita, biotita, apatita e raramente clinopiroxênio. Apresentam granulação geral maior que as bandas granoblásticas. Os cristais de hornblenda apresentam coloração verde claro, com pleocroísmo do verde amarelado ao verde claro, e variam de subidioblásticos a xenoblásticos com bordas em sua maioria irregulares (Figura 4-26 A e B). A grande parte dos cristais encontra-se orientados, porém ocorrem alguns grãos crescidos em outras orientações. É comum encontrar inclusões arredondadas de quartzo (Figura 4-26 C). Os cristais de epidoto geralmente apresentam cores que variam do quase incolor ao marrom claro, com cores de birrefringência arco-íris e formatos que variam de arredondados a pequenos prismas. Os cristais de titanita apresentam formatos que variam entre alongados, losangulares, disformes e ovais. São típicos cristais de coloração amarronzada e birrefringência marrom claro com textura chamuscada.

As bandas granoblásticas são constituídas principalmente por plagioclásio (Figura 4-26 D) e em menor volume por quartzo, e em algumas lâminas foi possível observar a presença discreta de minerais carbonáticos (Figura 4-26 E). Estas bandas podem ou não apresentar continuidades laterais, ou apenas ocorrer como bolsões irregulares e sem continuação. O leucossoma, diferentemente das bandas granoblásticas do mesossoma, é constituído principalmente por quartzo, ocorrendo em menor teor, cristais de plagioclásio. Esta porção da rocha apresenta granulação grossa e é facilmente diferenciável das bandas granoblásticas que constituem o restante da rocha (Figura 4-26 F). 

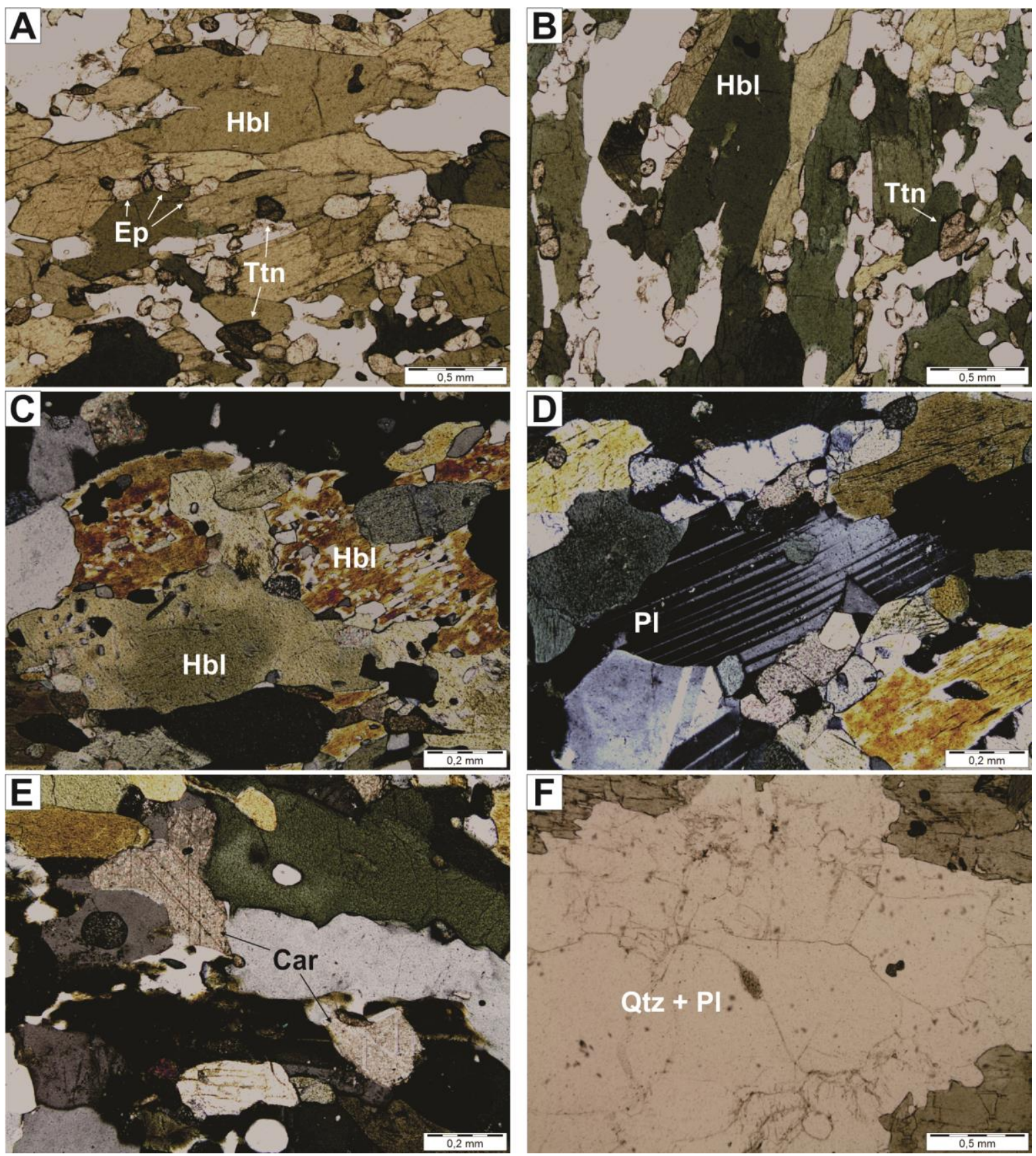

Figura 4-26. (A) e (B) Pleocroísmo do verde amarelado ao verde musgo dos cristais de hornblenda na lâmina SNA-172 D (polarizador descruzado); (C) Cristal de hornblenda com inclusões arredondadas de quartzo na lâmina SNA-171 B (polarizador cruzado); (D) Grão de plagioclásio geminado com terminação em lança na lâmina SNA-172 B (polarizador cruzado); (E) Cristais de carbonato espalhados pela lâmina SNA-172 D (polarizador cruzado); (F) Porções granoblásticas espessas constituídas de quartzo e plagioclásio na lâmina SNA-172 B (polarizador cruzado).

\subsubsection{Granada-clinopiroxênio anfibolito retroeclogítico e quartzo-granada-} cummingtonita xisto/fels

O granada-clinopiroxênio anfibolito retroeclogítico foi descrito no afloramento SNA205 e no SNA-208, próximo à rodovia MG-494 que liga os municípios de Andrelândia e Arantina e a oeste de Arantina, respectivamente. A rocha é bastante densa e dura, e ocorre 
na forma de blocos relativamente arredondados e concentrados em uma área de uma espécie de pasto ou próximo de áreas de plantação de eucalipto. No afloramento SNA-205, junto aos blocos do granada-clinopiroxênio anfibolito ocorrem fragmentos decimétricos de turmalinitos, assim como lajes de um cianita-granada-muscovita-quartzo xisto porfiroblástico, já próximo do afloramento SNA-208 foram observados blocos de rochas metaultramáficas.

Macroscopicamente o granada-clinopiroxênio anfibolito exibe granulação média à média-grossa proferida principalmente pelos cristais de granada, que eventualmente apresentam coronas de coloração clara compostas principalmente por plagioclásio (Figura 4-27 A). Alguns blocos, ou porções destes blocos, apresentam maiores densidades de cristais de granada nos quais a granulação se torna um pouco mais fina, já em outros a densidade é diminuída e a granulação dos grãos de granada é suavemente maior (Figura 4-27 B e C, respectivamente).
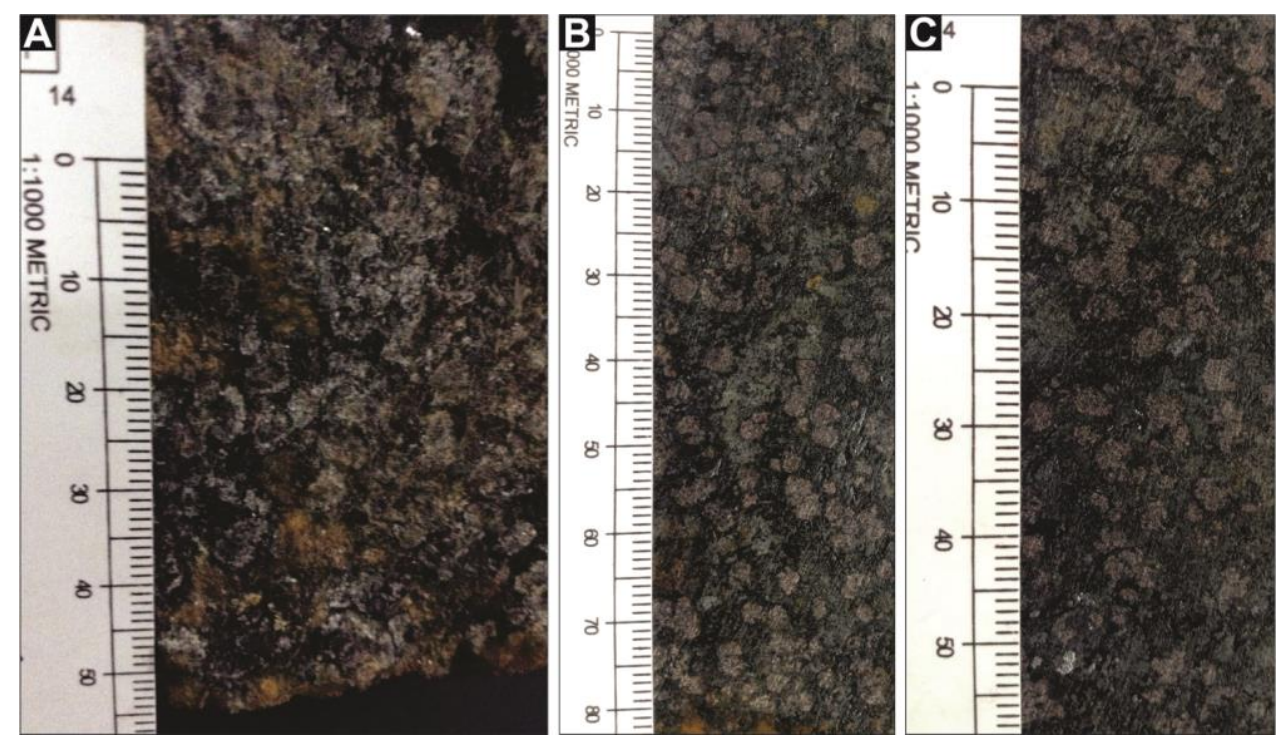

Figura 4-27. (A) Amostra de mão da amostra SNA-205B, exibindo a capa de alteração da qual são visíveis as coronas esbranquiçadas ricas em plagioclásio no em torno dos cristais de granada; (B) Amostra de mão já serrada exibindo uma grande densidade de cristais de granada, aqui com granulação um pouco mais fina e em (C) com granulação um pouco mais grossa e cristais mais espaçados.

Petrograficamente o granada-clinopiroxênio anfibolito apresenta granulação geral média-grossa, com estrutura maciça e cristais de granada bem distribuídos por toda a lâmina. É composta principalmente por hornblenda e granada, e em menor volume clinopiroxênio e plagioclásio, com presença de quartzo em algumas porções. Titanita, rutilo e ilmenita constituem juntos aproximadamente $5 \%$ da rocha, e como acessório ocorre apatita.

Os cristais de granada geralmente apresentam muitas inclusões, e grosseiramente podem ser divididos em dois grupos: aqueles que apresentam um grande volume de inclusões em todo o cristal, se assemelhando a uma textura poiquiloblástica, e aqueles que 
apresentam grande volume de inclusões principalmente em seus núcleos, tendendo a ser um tanto mais límpidos em suas bordas. Os formatos dos grãos também variam de xenoblásticos a subidioblásticos, nos quais ainda é possível observar as principais faces dos cristais, mesmo que não retilíneas. Em torno de todos os grãos é observado uma corona de plagioclásio que geralmente não permite que os cristais grossos de hornblenda do resto da rocha entre em contato com os grãos de granada (Figura 4-28). Estas coronas podem também serem constituídas por crescimento simplectítico entre plagioclásio e hornblenda. As inclusões presentes, de hornblenda, plagioclásio, quartzo, ilmenita, titanita e rutilo, ou até mesmo bolsão de simplectito de hornblenda com plagioclásio (Figura 4-29 A), não apresentam nenhum tipo de orientação.

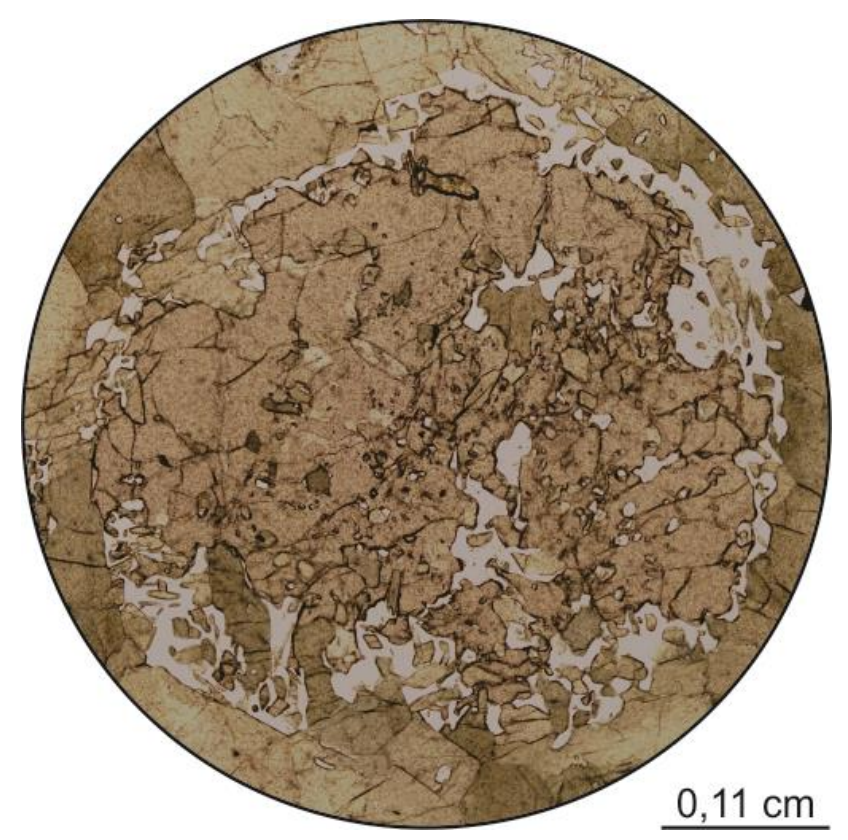

Figura 4-28. Porfiroblasto de granada com corona principalmente de plagioclásio e eventualmente por crescimento simplectítico de hornblenda com plagioclásio (polarizador descruzado).

Os cristais de titanita, rutilo e ilmenita ocorrem quase que sempre um relacionado ao outro: o comum encontrado nesta rocha é titanita substituindo núcleos de ilmenita, e mais raramente podem ocorrer cristais de rutilo junto à ilmenita, sendo substituídos por titanita (Figura 4-29 C e D). Isso pode ser observado tanto como inclusões em cristais de granada como dispersos pela lâminas, nas proximidades dos grãos de anfibólio. Em alguns locais é possível observar o que se assemelha ao intercrescimento entre ilmenita e plagioclásio (Figura 4-29 B).

Os cristais de hornblenda apresentam um pleocroísmo sutil do bege ao verde amarelado e geralmente constituem um mosaico com contatos tríplices entre eles. Os formatos dos grãos variam, a maioria tende a ser equidimensional no entanto podem ocorrer cristais com um lado maior. Por vezes pode-se encontrar inclusões arredondadas de 
plagioclásio ou quartzo, e em alguns locais é possível observar textura simplectítica entre hornblenda e plagioclásio (Figura 4-29 E e F).

Os cristais de clinopiroxênio apresentam coloração cinza levemente esverdeada e cor de birrefringência cinza escuro e amarelada. Sem exceções, eles ocorrem como simplectitos com plagioclásio (Figura 4-29 E e F) ou sendo substituídos por hornblenda com texturas também simplectítica. Os cristais de plagioclásio que crescem junto ao clinopiroxênio podem apresentar formatos arredondados ou até mesmo formatos mais alongados como ripas, orientadas segundo a direção preferencial de clivagem do piroxênio. Todos os cristais são xenoblásticos, mas no geral tendem a apresentar granulação mais grossa que os grãos de anfibólio.

Os grãos de plagioclásio ocorrem principalmente como coronas no entorno dos cristais de granada e na forma de simplectitos junto à hornblenda, e apresentam granulação mais fina que o restante da rocha, podendo ou não estarem geminados. Em menor quantidade os grãos de plagioclásio estão presentes nas texturas simplectíticas com o clinopiroxênio, na maioria com formatos arredondados. A presença de quartzo é um pouco mais restrita, ocorrendo apenas como bolsões distribuídos aleatoriamente pela lâmina, apresentando granulações bastante variadas, geralmente com extinção ondulantes e por vezes sendo observável alguns domínios de subgrãos.

As variações que ocorrem entre as lâminas descritas desta litologia está na diferença da granulação que pode eventualmente ser mais fina, na quantidade presente dos minerais, ora sendo mais rica em plagioclásio e quartzo e mais pobre em clinopiroxênio ou apresentando menores teores de granada. Um destaque pode ser feito para a seção delgada SNA-205 A1, na qual, diferentemente das demais, grande parte dos cristais de anfibólio apresentam um lado maior e tendem a estar orientados todos segundo uma mesma direção gerando uma foliação, por mais discreta que ela seja.

A amostra descrita do afloramento SNA-208 é igual às demais no quesito composição mineral, só que nesta, a quantidade de clinopiroxênio é maior e sempre ocorre em textura simplectítica com o plagioclásio. A granulação da rocha é a mais fina entre todas. É bastante rica em granada e diferentemente das demais lâminas, nesta rocha os cristais de granada são subidioblásticos e mais bem formados, em contraste com os cristais xenoblásticos poiquilíticos, com maior densidade de inclusões apenas em seus núcleos, permitindo que suas bordas ainda estejam relativamente preservadas. 

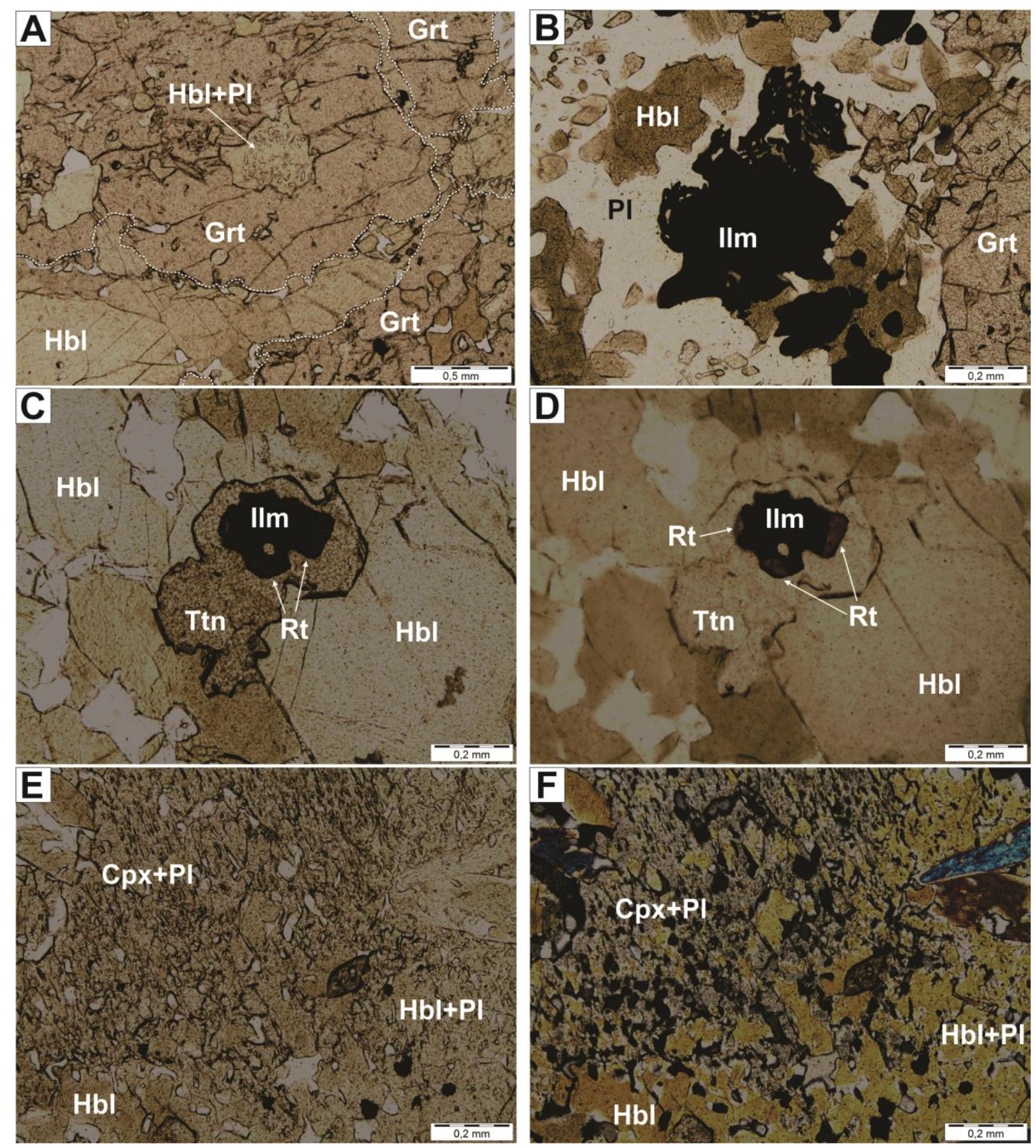

Figura 4-29. (A) Porfiroblasto de granada com inclusão de bolsão mostrando crescimento simplectítico entre hornblenda e plagioclásio (polarizador descruzado); (B) Textura semelhante ao intercrescimento de ilmenita e plagioclásio (polarizador descruzado); (C) Aparente substituição de ilmenita por rutilo, e ambos por titanita (polarizador descruzado); (D) Mesma fotomicrografia, com polarizado descruzado e com conversor de luz; (E) Textura simplectítica de clinopiroxênio e plagioclásio e entre hornblenda e plagioclásio (polarizador descruzado); (F) Mesma fotomicrografia, agora com polarizador cruzado.

O quartzo-granada-cummingtonita fels foi descrito no afloramento a NW de Aiuruoca (SNA-168), na Rodovia BR-267, entre a saída para Cruzília e a saída para Aiuruoca. Nesta localidade a rocha apresenta granulação grossa e estrutura maciça, no entanto, à SSW de Andrelândia, no afloramento SNA-218 localizado na Serra do Turvo, a mesma litologia foi amostrada mas com granulação mais fina e aspecto foliado bem marcado por finas bandas 
granoblásticas e leitos ricos em granada. A Figura 4-30 exibe esquemas das duas lâminas descritas.
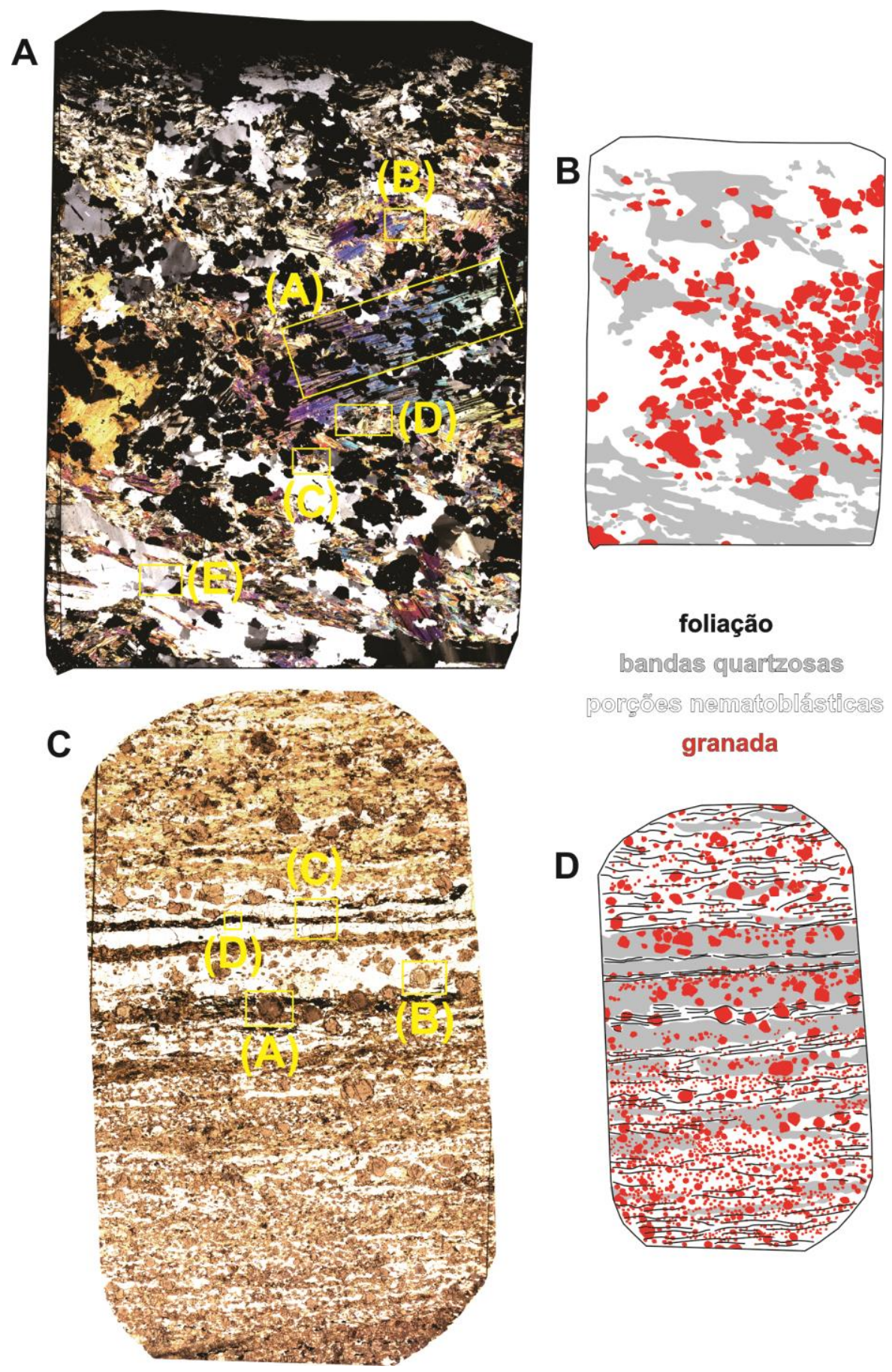

Figura 4-30. (A) Fotomicrografia da seção delgada completa (lados maiores com $4 \mathrm{~cm}$ de comprimento), da amostra SNA-168, com a localização de algumas das fotomicrografias da Figura 4-31 (polarizador cruzado); (B) Interpretação das principais estruturas e texturas da lâmina SNA-168; (C) Fotomicrografia da seção delgada completa da amostra SNA-218, com a localização de algumas das fotomicrografias da Figura 4-31 (polarizador descruzado); (D) Interpretação das principais estruturas e texturas da lâmina SNA-218.

Ao microscópio foi possível observar que grande parte da lâmina SNA-168 apresenta estrutura maciça, porém em um dos cantos ocorre uma pequena intercalação entre bandas 
nematoblásticas e bandas granoblásticas. A rocha é bastante rica em cummingtonita cujos cristais encontram-se geminados e apresentam duas colorações distintas de birrefringência, um grupo, geralmente dos cristais mais grossos, apresentam birrefringência em tons de azul, enquanto que os grãos mais finos e que podem ocorrer de forma fibrorradial, apresentam coloração amarela (Figura 4-31 A, B e C). Em relação a ordem de crescimento dos minerais é possível dizer que os cristais com birrefringência azul se formaram antes, e depois se cristalizaram os grãos de granada e os cristais de anfibólio com birrefringência amarela. Em certas porções é possível observar que os grãos de anfibólio, principalmente aqueles fibrorradiados, estão sendo substituídos por Mg-clorita, com birrefringência acinzentada (Figura 4-31 D).

Os cristais de granada apresentam cor amarronzada levemente avermelhada, com formatos irregulares que ocorrem geralmente espalhados pela lâmina, junto aos cristais de anfibólio e raramente sobre a porção quartzosa. Eles apresentam inclusões de quartzo e clorita (muito raro) e fraturas preenchidas por material avermelhado (talvez biotita), no entanto certos grãos são límpidos e não apresentam inclusões. Os cristais de quartzo ocorrem em diversas granulações, medindo de $0,2 \mathrm{~mm}$ até $7,0 \mathrm{~mm}$, com formatos bastante irregulares e com bordas normalmente bem entrecortadas, abauladas, com pequenas protuberâncias arredondadas. Alguns contatos sugerem bulging (Figura 4-31 E). A grande parte dos grãos apresenta extinção ondulante e trilhas de inclusões fluídas. 

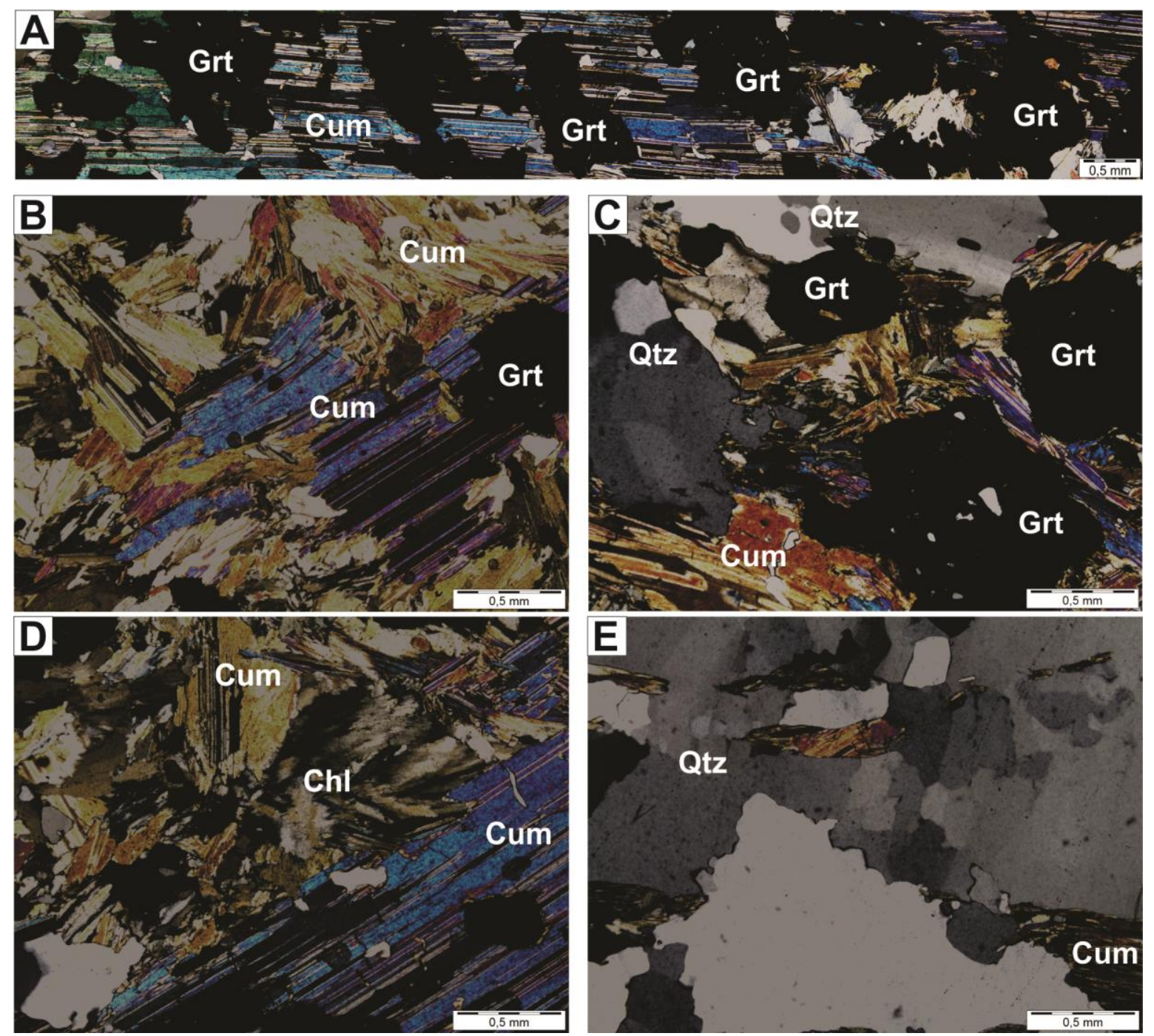

Figura 4-31. (A) Grande cristal de anfibólio geminado com birrefringência azul, medindo em torno de 7,0 mm (polarizador cruzado); (B) Diferença na cor de birrefringência das duas gerações de anfibólio (polarizador cruzado); (C) Cristais de anfibólio de birrefringência amarela fibrorradiais (polarizador cruzado); (D) Substituição de anfibólio por clorita (polarizador cruzado); (E) Contatos irregulares e extinção em domínios de subgrãos dos cristais de quartzo (polarizador cruzado).

À SSW de Andrelândia, no afloramento SNA-218, a quantidade de granada supera a quantidade de anfibólio, tonando a rocha um quartzo-cummingtonita-granada xisto, que diferentemente da mesma litologia descrita acima, ocorre uma foliação bem marcada tanto pela orientação de cristais de anfibólio, como pela disposição dos ribbons e bandas de quartzo. É bastante rica em granada, que ocorre tanto na forma de pequenos cristais, que podem ocorrer em grandes densidades em certas porções, como porfiroblastos mais homogeneamente espalhados pela lâmina. A rocha pode ser dividida em porções essencialmente granoblásticas, onde ocorrem grãos de quartzo e em menor quantidade de granada, e porções essencialmente nematoblásticas ricas em cummingtonita com geminação bastante visível. Além destes minerais é possível observar cristais de minerais opacos e de apatita. 
Os cristais de granada geralmente ocorrem bastante alterados, com ou sem a presença de inclusões, mas sempre bordeados com uma alteração laranja avermelhada, mas sempre variando de xenoblásticos à subidioblásticos. Alguns cristais aparentemente cresceram sobre a foliação rica em cummingtonita, já outros cresceram em um estágio anterior, onde é possível observar a foliação amoldando estes grãos (Figura 4-32 A). Um cristal específico de granada apresenta borda esqueletal, tipo atol, sobrecrescendo a matriz quartzosa (Figura 4-32 B). Os cristais de anfibólio apresentam uma geminação bastante proeminente que ocorre em praticamente todos os grãos (ver as fotomicrografias da figura anterior). Assim com o caso da granada, a grande maioria ocorre alterada, com bordas alaranjadas que visivelmente aumentam o relevo dos cristais. Os grãos de anfibólio tendem a ocorrer orientados segundo a foliação principal, paralelo à direção dos ribbons e bandas ricas em quartzo. Na grande maioria dos grãos é possível observar apenas uma direção de clivagem bem marcada, mas em certos grãos é visível as duas direções de clivagens distintas, que podem até conferir ao grão um formato em losango.

As bandas granoblásticas tendem a ser mais retilíneas onde ocorrem os ribbons e os grãos mais grossos de quartzo (Figura 4-32 C), já estas porções tendem a ter seus limites mais mais irregulares e serem descontínuas, com cristais finos de quartzo, onde há maior presença de anfibólio e granada. Nos ribbons praticamente todos os cristais apresentam extinção em domínios de subgrãos e bordas bastante irregulares e cheias de reentrânceas, já os grãos finos de quartzo mais dispersos tendem a apresentar extinção homogênea e formatos um tanto mais equidimensionais. Em alguns locais das bandas granoblásticas a alteração alaranjada nas bordas dos grãos também está presente. Nas bordas de onde ocorrem as principais bandas granoblásticas há uma alta densidade de minerais opacos principalmente substituindo os grãos de anfibólio (Figura 4-32 D), podendo haver também alguns cristais dispersos destes minerais opacos, com formatos bastante irregulares 

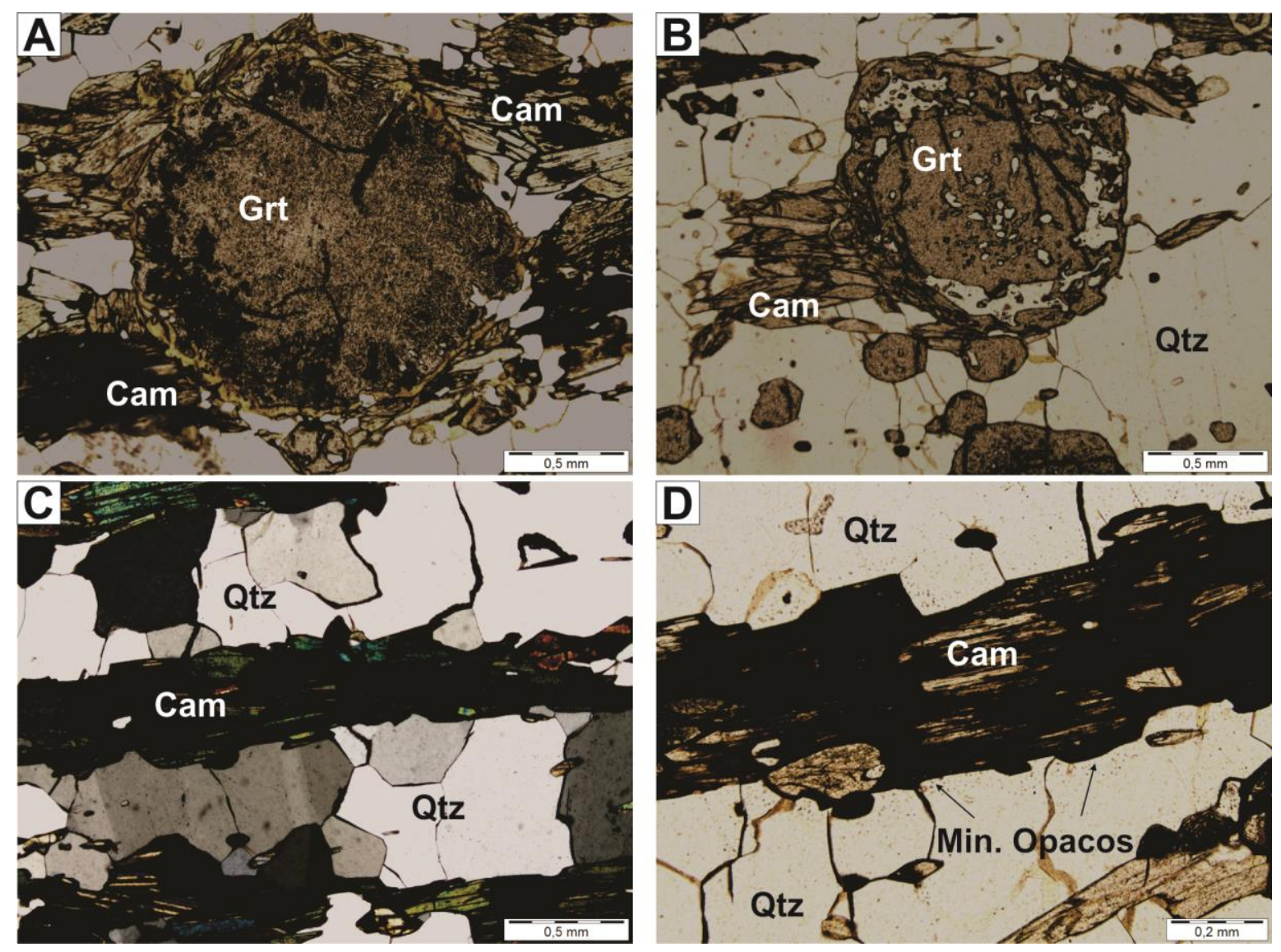

Figura 4-32. (A) Foliação marcada por grãos de anfibólio defletindo ao redor de cristal de granada (polarizador descruzado); (B) Cristal de granada tipo atol, com inclusões de quartzo (polarizador descruzado); (C) Ribbons de quartzo recristalizados separados por finas bandas nematoblásticas (polarizador cruzado); (D) Substituição de anfibólio por minerais opacos (polarizador descruzado). 


\section{CAPÍTULO 5}

\section{PROVENIÊNCIA SEDIMENTAR}

A proveniência sedimentar das rochas metamórficas (fácies anfibolito médiosuperior) das nappes Liberdade e Andrelândia, do Sistema de Nappes Andrelândia Ocidental, será abordada através de seus caráteres químicos e isotópicos - composição de elementos maiores, menores e ETR em rocha total, ETR em mineral, sistemas Sm-Nd e Rb$\mathrm{Sr}$ em rocha-total e U-Pb e Lu-Hf em zircão. Através destes aspectos, as diferentes composições serão confrontadas afim de se estabelecer correlações e pontuar as diferenças que existem entre elas, desta forma, podendo-se traçar a configuração paleogeográfica do ambiente de deposição de cada unidade. Dados de elementos maiores e menores em metawackes do Sistema de Nappes Carrancas, também gerados por este trabalho, serão utilizados como comparativo. Os dados U-Pb das amostras de sigla NESG foram obtidos por Lima (2013). As tabelas que reúnem todos os dados gerados de elementos traço e ETR em rocha-total, U-Pb, Lu-Hf e ETR em zircão estão apresentadas do Anexo II ao Anexo VI.

\subsection{Geoquímica elemental em rocha-total}

\subsubsection{Elementos maiores, menores e traço}

Os elementos maiores, menores e traço foram analisados em 15 amostras de duas unidades da Nappe Andrelândia, Unidade Santo Antônio e Unidade Serra da Boa Vista, e nas rochas metassedimentares da Nappe Liberdade.

\begin{tabular}{|c|c|c|c|c|c|c|c|c|c|c|c|c|}
\hline \multicolumn{3}{|c|}{ Unidades e amostras } & SiO2 & TiO2 & Al2O3 & $\mathrm{Fe} 2 \mathrm{O} 3$ & MnO & $\mathrm{MgO}$ & $\mathrm{CaO}$ & $\mathrm{Na} 2 \mathrm{O}$ & K2O & P2O5 \\
\hline \multirow{6}{*}{ 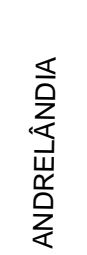 } & \multirow{5}{*}{$\begin{array}{l}\text { Unidade Serra } \\
\text { da Boa Vista }\end{array}$} & NESG-1434 & 59,65 & 1,121 & 19,13 & 8,99 & 0,118 & 2,29 & 1,42 & 1,68 & 3,42 & 0,118 \\
\hline & & NESG-1447 & 66,33 & 0,981 & 16,19 & 7,09 & 0,056 & 1,30 & 0,63 & 1,56 & 3,18 & 0,102 \\
\hline & & SNA-225 & 66,38 & 1,223 & 17,62 & 6,43 & 0,156 & 1,05 & 0,09 & 0,44 & 3,73 & 0,054 \\
\hline & & SNA-228 & 72,68 & 1,085 & 14,21 & 3,17 & 0,028 & 0,74 & 0,31 & 0,27 & 4,01 & 0,072 \\
\hline & & SNA-213 & 92,32 & 0,182 & 4,01 & 0,58 & 0,006 & $<0,01$ & $<0,01$ & $<0,02$ & 1,32 & 0,006 \\
\hline & \multirow{5}{*}{$\begin{array}{c}\text { Unidade Santo } \\
\text { Antônio }\end{array}$} & NESG-1010 2A & 70,40 & 0,950 & 12,87 & 6,53 & 0,108 & 1,92 & 1,28 & 1,39 & 2,80 & 0,152 \\
\hline \multirow{4}{*}{$\frac{\omega}{\frac{\omega}{0}}$} & & \begin{tabular}{|l} 
NESG-1010 2B \\
\end{tabular} & 63,60 & 0,837 & 15,24 & 6,61 & 0,095 & 3,46 & 3,73 & 2,46 & 2,46 & 0,196 \\
\hline & & SNA-201 & 64,83 & 0,831 & 15,02 & 6,97 & 0,119 & 3,39 & 2,40 & 2,56 & 2,26 & 0,207 \\
\hline & & SNA-214 & 62,57 & 0,858 & 16,48 & 7,20 & 0,102 & 3,32 & 2,16 & 2,56 & 2,79 & 0,208 \\
\hline & & NESG-1552 & 48,31 & 1,224 & 16,64 & 11,30 & 0,171 & 6,97 & 11,68 & 0,63 & 0,57 & 0,098 \\
\hline \multirow{5}{*}{ 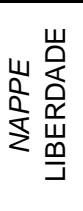 } & \multirow{5}{*}{$\begin{array}{l}\text { Rochas metas } \\
\text { sedimentares }\end{array}$} & SNA-169 & 61,37 & 1,344 & 16,46 & 9,68 & 0,088 & 1,64 & 0,88 & 0,96 & 3,13 & 0,445 \\
\hline & & SNA-172E & 70,20 & 0,717 & 13,35 & 4,64 & 0,075 & 1,30 & 2,24 & 2,46 & 3,52 & 0,204 \\
\hline & & SNA-175 & 57,49 & 0,994 & \begin{tabular}{|l|}
20,96 \\
\end{tabular} & 9,42 & 0,146 & 2,66 & 0,35 & 0,77 & 4,55 & 0,109 \\
\hline & & SNA-170 & 45,22 & 0,427 & 9,27 & 3,97 & 0,103 & 8,43 & 25,13 & 1,02 & 0,17 & 0,178 \\
\hline & & SNA-170D & 47,42 & 2,828 & 14,27 & 12,25 & 0,166 & 5,59 & 11,39 & 2,60 & 0,87 & 0,324 \\
\hline
\end{tabular}

Tabela 5-1. Resumo dos dados dos elementos maiores e menores das rochas, principalmente metassedimentares e um anfibolito, das unidades Santo Antônio e Serra da Boa Vista, ambos da Nappe Andrelândia e rochas metassedimentares da Nappe Liberdade. 
A Tabela 5-1 resume as concentrações dos elementos maiores e menores analisadas das rochas metassedimentares estudadas.

Os índices de intemperismo químico (CIA) são maiores nas rochas da Unidade Serra da Boa Vista com valores que variam de 67,89 à 78,16, com média de 72,01 para as rochas metapelíticas e de 73,04 para a rocha metapsamítica. Esses valores indicam uma alteração química mais eficaz e uma reciclagem dos depósitos sedimentares. Os metawackes da Unidade Santo Antônio exibem valores menores de CIA, entre 53,04 e 62,74, com média de 58,27, diferindo da Unidade Serra da Boa Vista. Nos metawackes, a atuação do intemperismo químico não foi intensa e esses valores indicam rápida sedimentação e diagênese em um cenário de alteração física, comparável aos ambientes orogênicos (Figura 5-1). O anfibolito desta mesma unidade apresenta valor de CIA $(42,10)$ compatível com o campo das rochas basálticas de ambientes orogênicos (Figura 5-1).

A maioria das rochas metapelíticas da Nappe Liberdade apresentam valores de CIA relativamente altos, entre 71,48 e 75,43, mesclados com uma amostra de valor baixo, de 52,81 . As amostras com valores de CIA mais elevados podem indicar que seus sedimentos sofreram longos períodos de alteração química em detrimento da física, ou simplesmente momentos de quiescência tectônica. Já a rocha com valor de CIA extremamente baixo e razão $\mathrm{Th} / \mathrm{Sc}$ alto, aponta para uma maior contribuição de fonte enriquecida em ambiente tectonicamente instável.

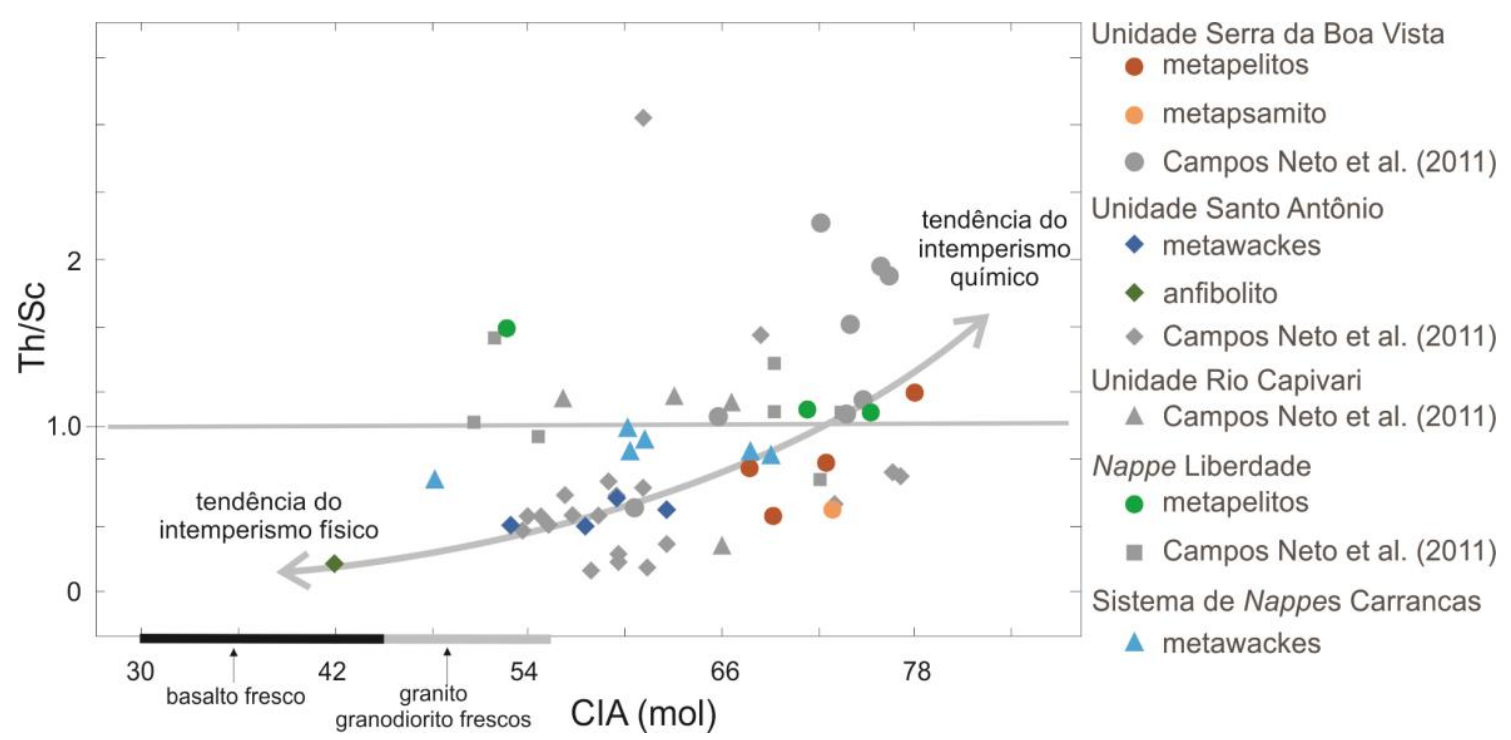

Figura 5-1. Diagrama de Th/Sc versus CIA (Chemical Index of Alteration - McLennan et al. (1995), modificado de Nesbitt e Young (1982) e Taylor e McLennan (1985)). Os dados em cinza foram retirados de Campos Neto et al. (2011).

Os metawackes do Sistema de Nappes Carrancas (WESTIN; CAMPOS NETO, 2013) tendem a apresentar valores de CIA e da razão Th/Sc mais elevados que os metawackes da Unidade Santo Antônio, o que indica provavelmente ambiente de sedimentação e 
composições de rochas-fonte distintos. As rochas metassedimentares da Unidade Rio Capivari não foram aqui estudadas, no entanto Campos Neto et al. (2011) admitem que seus valores de CIA e de Th/Sc encontram-se no trend da alteração química do restante das rochas estudadas.

Sendo assim, as assinaturas químicas dos metawackes da Unidade Santo Antônio estão relacionadas a rápidas taxas de deposição, correlacionáveis à áreas tectonicamente ativas e proximidade com a fonte, enquanto que os metawackes do Sistema de Nappes Carrancas podem representar depósitos mais distais. As demais rochas metassedimentares resultam de maior reciclagem sedimentar, com maiores taxas de alteração química em possíveis depósitos distais à área-fonte.

O diagrama Th/U versus Th da Figura 5-2 A ilustra os campos de crosta superior e fontes mantélicas. As amostras da Unidade Santo Antônio ocorrem muito próximas do campo delimitado para fontes mantélicas empobrecidas em meio aos sedimentos de margem ativa de McLennan et al. (1993), assim como duas amostras da Unidade Serra da Boa Vista. O restante das amostras da Unidade Serra da Boa Vista e todas da Nappe Liberdade apresentam concentrações de Th maiores e maiores razões Th/U indicando fontes na crosta superior. Os dados do metawackes do Sistema de Nappes Carrancas exibem composições distintas da Unidade Santo Antônio, apresentando maior afinidade com a crosta continental superior.
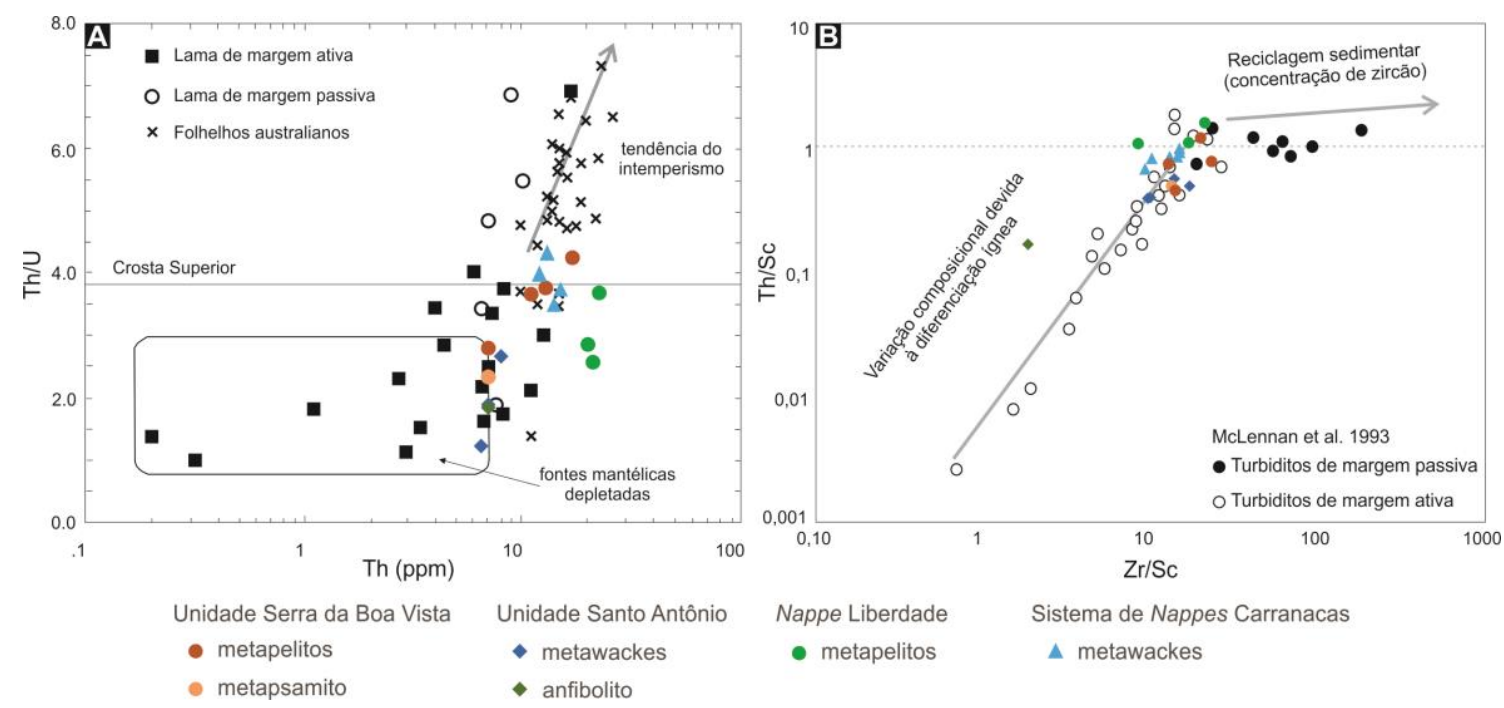

Figura 5-2. (A) Diagrama Th/U versus Th (ppm) de McLennan et al. (1993) com os dados das rochas aqui estudadas. Para comparação foram plotados dados de sedimentos de margens ativa e passiva e de folhelhos australianos de McLennan et al (1983); (B) Diagrama de Th/Sc versus Zr/Sc com os dados deste trabalho e como comparativo os dados dos turbiditos de margem ativa e passiva retirados de McLennan et al. (1993).

A razão $\mathrm{Zr} / \mathrm{Sc}$ é um traçador de enriquecimento em zircão dos sedimentos, relacionando o papel da concentração de minerais pesados na seleção dos sedimentos (MCLENNAN, 1989). Quanto maior for a razão Zr/Sc mais selecionado serão os sedimentos 
podendo apresentar maiores concentrações de minerais pesados, no entanto, se a fonte em potencial já for empobrecida em zircão é improvável que um sedimento, mesmo que bem selecionado, enriqueça-se em neste mineral. A Figura 5-2 B mostra que sedimentos de margens passivas tendem a apresentar maior seleção, o que leva à maiores concentrações de minerais pesados, já em ambientes de margem ativa esta seleção é menos expressiva e as razões $\mathrm{Zr} / \mathrm{Sc}$ são menores. Os dados das rochas metassedimentares estudadas neste trabalho encontram-se no range dos turbiditos de margem ativa de McLennan et al. (1993), com a maioria das rochas da Unidade Santo Antônio e uma da Nappe Liberdade demonstrando menores valores de $\mathrm{Zr} / \mathrm{Sc}$. Valores progressivamente maiores desta razão são encontrados nas rochas da Unidade Serra da Boa Vista e o restante das da Nappe Liberdade. O anfibolito da Unidade Santo Antônio indica fontes pouco diferenciadas e empobrecida em zircão.

Os dados dos metawackes do Sistema de Nappes Carrancas exibem valores variáveis de ambas as razões, no geral com valores de $\mathrm{Zr} / \mathrm{Sc}$ mais altos que os metawackes da Unidade Santo Antônio, no entanto encontram-se sobre o trend da composição de sedimentos de margem ativa

\subsubsection{Padrões dos elementos terras raras}

Os ETR normalizados pelo condrito (Figura 5-3) das amostras de rochas metassedimentares da Unidade Serra da Boa Vista apresentam padrão de forte enriquecimento em ETR leves em relação aos pesados, com fracionamento geral dos elementos (razão $L a_{N} / Y_{b_{N}}$ ) que varia entre 3,56 à 12,99 para as rochas metapelíticas, exceto uma amostra com razão em 22,87, comparável à rocha metapsamítica $(20,13)$. A média dos valores de enriquecimento em ETR das rochas metapelíticas é de 9,78 muito semelhante ao de PAAS (9,73). O enriquecimento em ETR leves, calculado por $\mathrm{La}_{\mathrm{N}} \mathrm{S} \mathrm{S}_{\mathrm{N}}$, é bastante semelhante entre todas as rochas, variando entre 3,41 e 4,99, sendo comparáveis com os de PAAS, NASC e ES (4,38, 3,62 e 3,63, respectivamente). As anomalias negativas de Eu estão presentes (Figura 5-3 A) e exibem valores entre 0,62 e 0,94, já as de Ce são menos expressivas, variando de pouco positivas à pouco negativas, entre 0,75 e 1,17. Pode-se notar que a maioria das amostras apresentam anomalias positivas de Gd (Tabela 5-2). 


\begin{tabular}{|c|c|c|c|c|c|}
\hline Unidade & $\begin{array}{l}\text { Tipo de } \\
\text { rocha }\end{array}$ & \begin{tabular}{|c|}
$\begin{array}{c}\text { Fracionamento } \\
\text { dos ETR } \\
(\mathrm{La} / \mathrm{Yb})_{\mathrm{N}}\end{array}$ \\
\end{tabular} & $\begin{array}{c}\text { Enriquecimento } \\
\text { em ETR leves } \\
(\mathrm{La} / \mathrm{Sm})_{\mathrm{N}}\end{array}$ & $\begin{array}{c}\text { Anomalia de Eu } \\
\mathrm{Eu} /[(\mathrm{Sm}+\mathrm{Gd}) / 2]_{\mathrm{N}}\end{array}$ & $\begin{array}{l}\text { Anomalia de Ce } \\
\mathrm{Ce} /[(\mathrm{La}+\operatorname{Pr}) / 2]_{\mathrm{N}}\end{array}$ \\
\hline \multirow{8}{*}{ 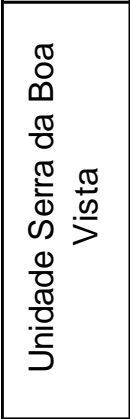 } & \multirow{7}{*}{ metapelitos } & 22,87 & 4,99 & 0,68 & 0,75 \\
\hline & & 9,42 & 3,92 & 0,63 & 1,04 \\
\hline & & 8,22 & 3,81 & 0,66 & 1,06 \\
\hline & & 7,79 & 3,44 & 0,63 & 1,17 \\
\hline & & 12,99 & 3,57 & 0,62 & 1,13 \\
\hline & & 3,56 & 3,41 & 0,97 & 1,09 \\
\hline & & 3,6 & 3,59 & 0,94 & 1,02 \\
\hline & metapsamito & 20,13 & 4,12 & 0,68 & 0,91 \\
\hline \multirow{8}{*}{ 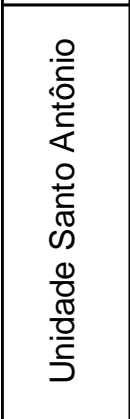 } & \multirow{6}{*}{ metawackes } & 9,88 & 3,89 & 0,68 & 0,94 \\
\hline & & 7,66 & 3,08 & 0,75 & 0,83 \\
\hline & & 7,05 & 2,99 & 0,71 & 0,82 \\
\hline & & 8,52 & 3,03 & 0,71 & 0,83 \\
\hline & & 8,78 & 3,06 & 0,73 & 0,83 \\
\hline & & 9,25 & 2,98 & 0,7 & 0,98 \\
\hline & \multirow{2}{*}{ anfibolitos } & 1,29 & 1,18 & 1,02 & 0,99 \\
\hline & & 1,22 & 1,11 & 0,68 & 0,59 \\
\hline \multirow{5}{*}{ 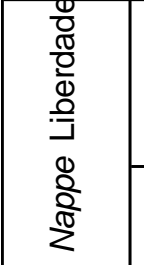 } & \multirow{3}{*}{ metapelitos } & 10,55 & 3,53 & 0,58 & 1,07 \\
\hline & & 16,37 & 3,17 & 0,44 & 0,98 \\
\hline & & 10,09 & 3,54 & 0,55 & 1,04 \\
\hline & \multirow{2}{*}{$\begin{array}{l}\text { calcios- } \\
\text { silicática }\end{array}$} & 8,55 & 3,9 & 0,67 & 0,92 \\
\hline & & 6,85 & 2,37 & 0,58 & 0,95 \\
\hline
\end{tabular}

Tabela 5-2. Resumo dos parâmetros calculados dos elementos terras raras em rocha-total, em sua maioria metassedimentares, das amostras estudadas.

Os metawackes da Unidade Santo Antônio são mais empobrecidos em ETR do que as rochas metassedimentares da Unidade Serra da Boa Vista e da Nappe Liberdade, principalmente nos ETR leves. O fracionamento geral dos elementos tende a ser mais constante e maior do que nas rochas descritas acima, variando entre 7,05 e 9,88. No entanto o enriquecimento em ETR leves é menor, estando entre 2,98 e 3,89. As anomalias negativas de Eu estão presentes, mas são menos pronunciadas do que as encontradas na Unidade Serra da Boa Vista, variando entre 0,68 e 0,73. As anomalias de Ce são fracamente negativas, contrastando com as demais unidades. Semelhante a unidade superior da Nappe Andrelândia, os metawackes apresentam anomalias positivas de Gd. O anfibolito apresenta um fracionamento totalmente distinto das rochas metassedimentares: as razões de $\mathrm{LaN}_{N} / \mathrm{Yb}_{N}$ variam apenas entre 1,22 e 1,29, conferindo um padrão praticamente flat de seus elementos normalizados pelo condrito (Figura 5-3 B). O enriquecimento em ETR leves também é o menor, entre 1,11 e 1,18, com as anomalias negativas de Ce mais pronunciadas chegando a 0,59, e anomalias de Eu que variam de pouco positivas à pouco negativas. É enriquecido em todos os ETR, sendo comparável ao E-MORB, no entanto 
apresenta razão $\mathrm{LaN}_{N} / \mathrm{Sm}_{\mathrm{N}}$ maior que 1,00 e anomalia de Ce, distinguindo-o do padrão basáltico.

As rochas metapelíticas da Nappe Liberdade apresentam fracionamento dos ETR maior que as rochas calciossilicáticas, entre 10,09 e 16,37 com média de 12,34, sendo maiores que os de PAAS, NASC e ES. O enriquecimento nos ETR leves é menor que os encontrados nas rochas da Unidade Serra da Boa Vista, entre 3,17 e 3,54. As anomalias negativas de Eu são as mais pronunciadas entre todas as rochas metassedimentares aqui estudadas, com valores entre 0,44 e 0,67, enquanto que as anomalias de Ce são mais imperceptíveis e variam entre 0,92 e 1,07 (Figura 5-3 C).

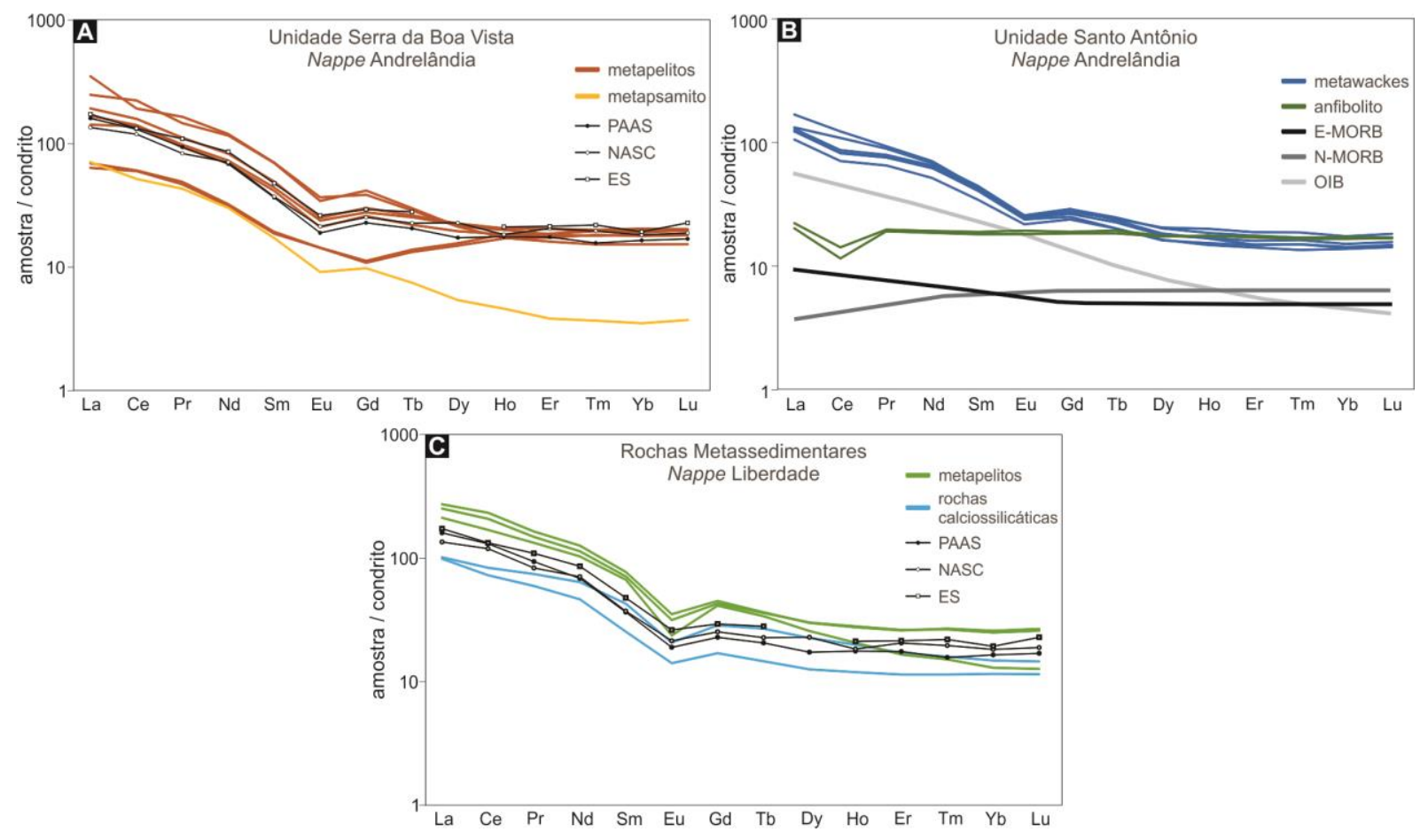

Figura 5-3. (A) Diagrama dos ETR normalizados pelo condrito das rochas metassedimentares da Unidade Serra da Boa Vista; (B) Diagrama dos ETR normalizados pelo condrito das rochas da Unidade Santo Antônio; (C) Diagrama dos ETR normalizados pelo condrito das rochas metassedimentares da Nappe Liberdade. Condrito utilizado para normalização foi o C1 de Sun e McDonough (1989).

Anomalias negativas de Eu são encontradas em todos os sedimentos/rochas sedimentares pós-arqueanas e a única exceção importante que não apresenta empobrecimento em Eu são alguns sedimentos vulcanogênicos depositados em bacias de ante-arco, de arcos vulcânicos, derivados principalmente de rochas andesíticas. Rochas ígneas derivadas do manto geralmente não exibem anomalias de Eu e este fato pode ser atribuído à adição ou remoção tardia do feldspato ou por alteração hidrotermal. Baseado nos padrões de ETR em rocha-total, padrão flat e sem anomalia negativa de Eu, do anfibolito encontrado na Unidade Santo Antônio, pode-se dizer que sua rocha parental tinha 
composição semelhante à andesítica e estava associada a arcos vulcânicos e bacias de ante-arco.

\subsection{Sistema isotópico U-Pb em cristais detríticos de zircão}

\subsubsection{Nappe Andrelândia}

\subsubsection{Unidade Serra da Boa Vista}

Os cristais detríticos de zircão dos metapelitos (SNA-125, SNA-228, NESG-1434) da unidade superior da Nappe Andrelândia apresentam dois grupos de granulações entre 90 $\mu \mathrm{m}$ e $295 \mu \mathrm{m}$, e $120 \mu \mathrm{m}$ e $170 \mu \mathrm{m}$ de comprimento dependendo da amostra (Figura 5-4). São grãos prismáticos com bordas arredondadas e com a ocorrência de zoneamento setorizado e oscilatório, com raros grãos claros, homogêneos, no entanto todos apresentam sobrecrescimentos metamórficos cinza escuros (em imagens de catodoluminescência), de alto urânio. Alguns núcleos herdados são facilmente observáveis. Os cristais de zircão encontrados na amostra de quartzito micáceo (SNA-116) são ovoides ou fragmentos com formatos ovalados, com raros prismas de bordas arredondadas, ocorrendo em granulações que variam de $145 \mu \mathrm{m}$ a $290 \mu \mathrm{m}$. O zoneamento oscilatório é a feição mais comum. A amostra de um granada-biotita-muscovita quartzito (SNA-213), que se encontra na base da unidade, no contato com a Unidade Santo Antônio, exibe uma população de grãos ovoides e prismas arredondados com zoneamento oscilatório de $68 \mu \mathrm{m}$ a $170 \mu \mathrm{m}$ de comprimento, e em menor volume são observados cristais com zoneamento setorizado. 


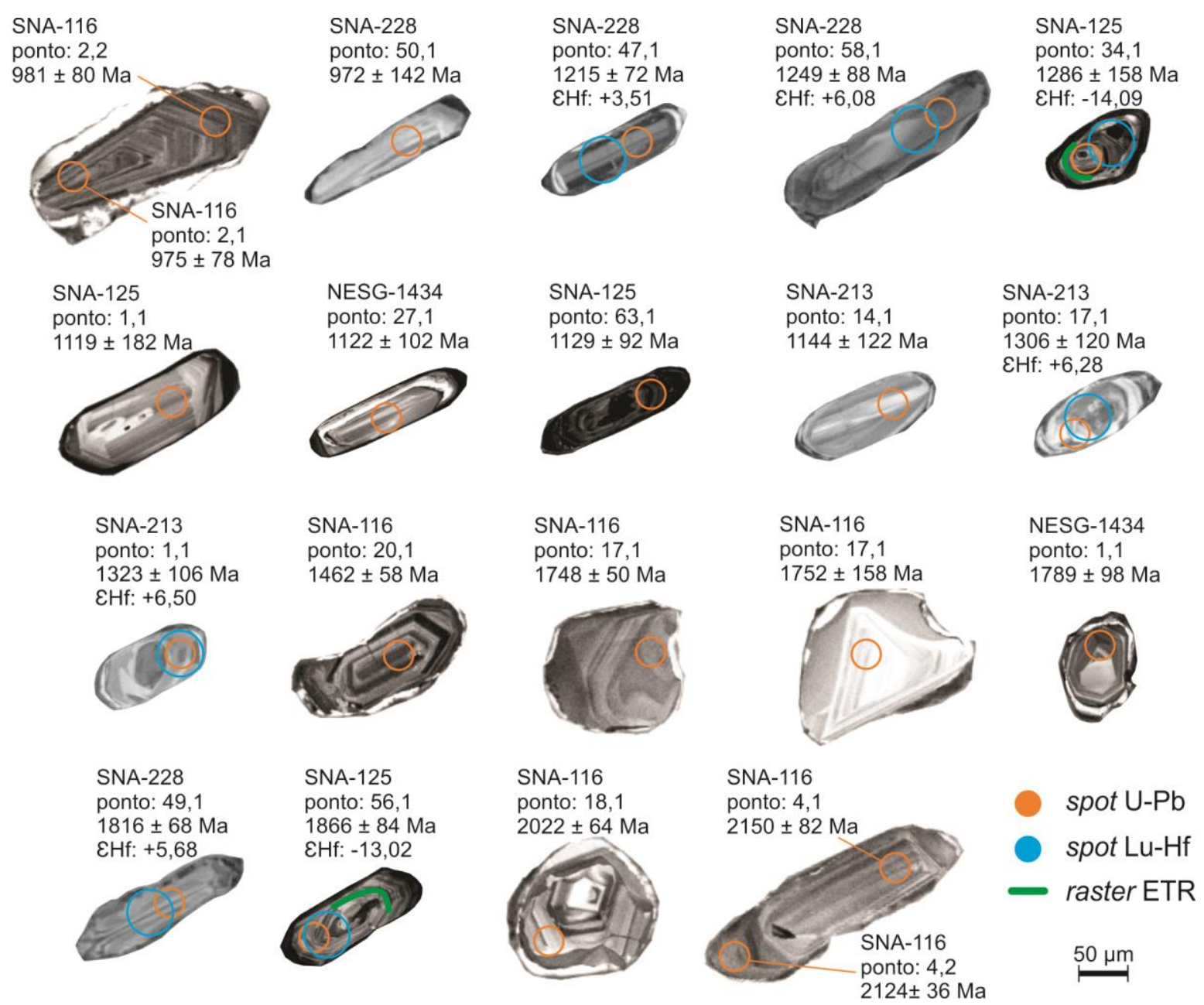

Figura 5-4. Exemplos de cristais de zircão provenientes da Unidade Serra da Boa Vista, analisados através das amostras SNA-116, SNA-125, SNA-213, SNA-228 e NESG-1434. Parte dos cristais da amostra NESG-1434 foram analisados por LIMA (2013). Idades ${ }^{207} \mathrm{~Pb} /{ }^{206} \mathrm{~Pb}$ erros em $2 \sigma$.

Os dados U-Pb em zircão exibem praticamente os mesmos conjuntos de idades em todas as amostras, as mais jovens encontram-se no início do Toniano, e as mais antigas no fim do Riaciano (exceto a amostra SNA-116). Embora a maioria das idades sejam observadas na maioria das amostras, alguns gaps podem estar presentes (Figura 5-5).

Os conjuntos de idades mais jovens, que englobam o início do Toniano ao início do Esteniano, resultaram em valores que variam de $924 \pm 37 \mathrm{Ma}$ (SNA-228) a 1177 $\pm 66 \mathrm{Ma}$ (NESG-1434). O restante dos conjuntos de dados resultaram em idades gradativamente mais velhas, por todo Mesoproterozoico, com valores estatísticos preferenciais de idade em 1,21-1,28 Ga e 1,37-1,48 Ga, com exceção das amostras SNA-116 e NESG-1434. As idades de proveniência no Paleoproterozoico encontram-se no Estateriano (1,73-1,76 Ga) e no Orosiriano (1,80-1,97 Ga); valores no Riaciano são raros (2,07 e 2,14 Ga) e no Sideriano e Neo-Mesosarqueano negligenciáveis (salvo para a amostra SNA-116). 
A

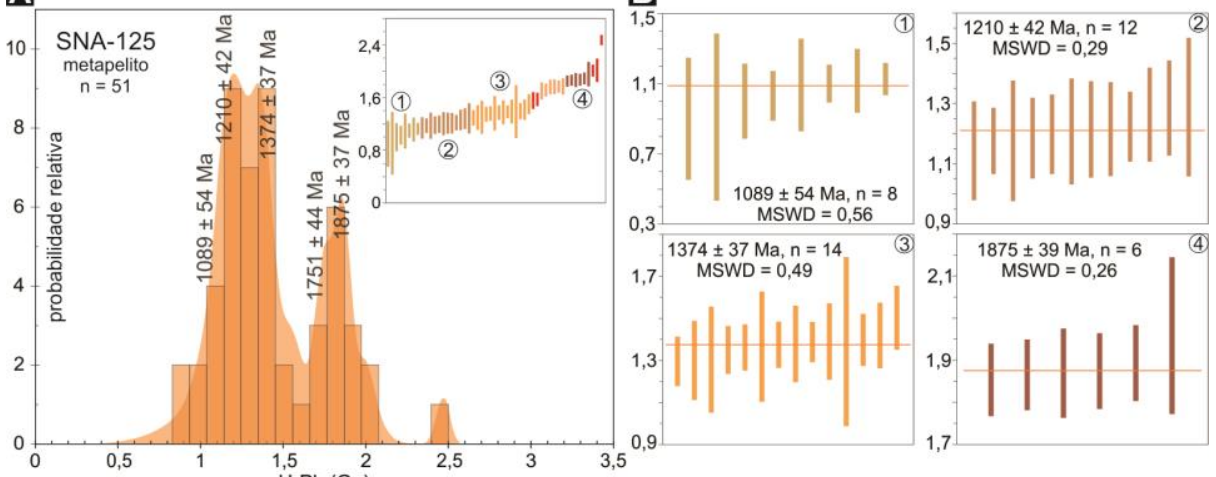

C

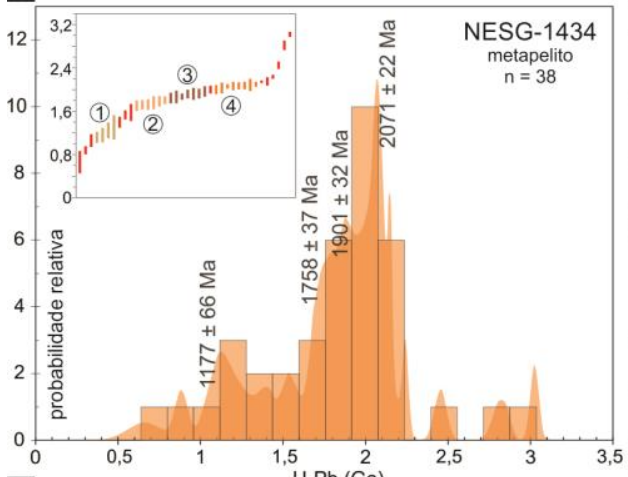

E

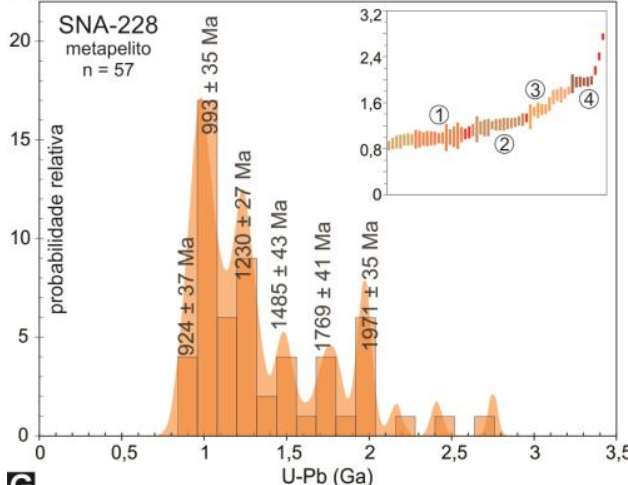

G
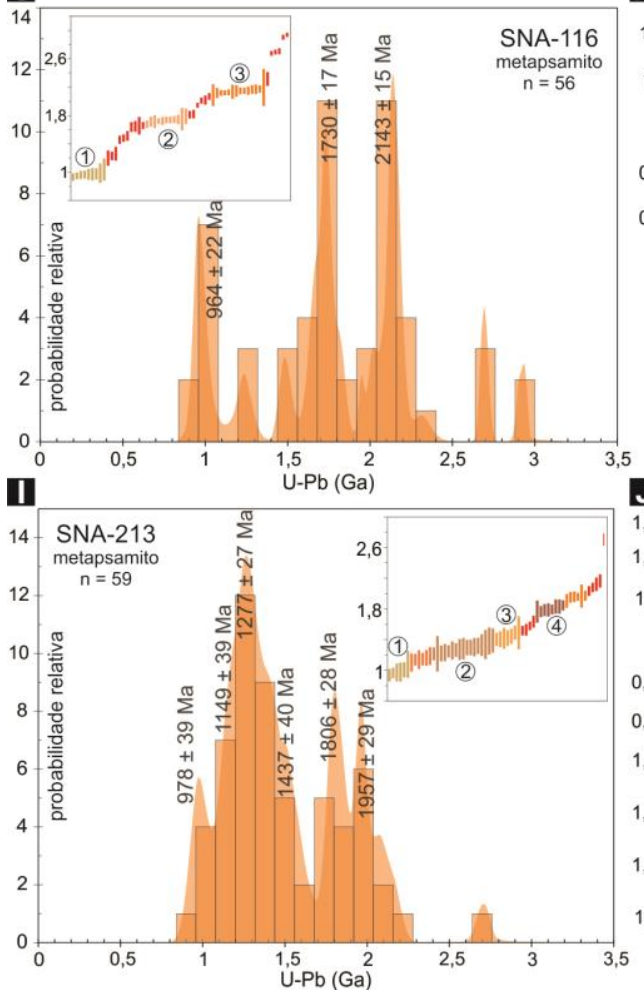

D

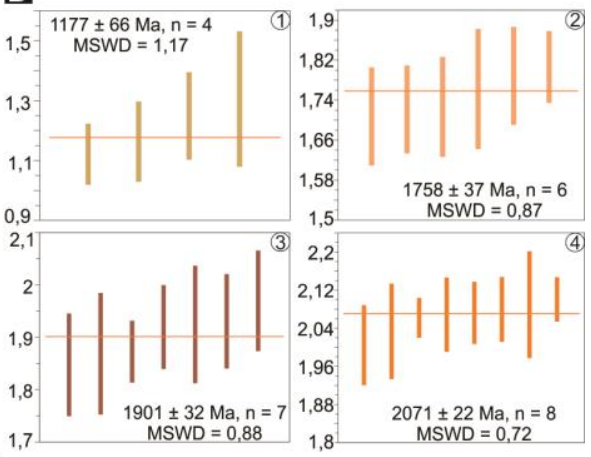

F

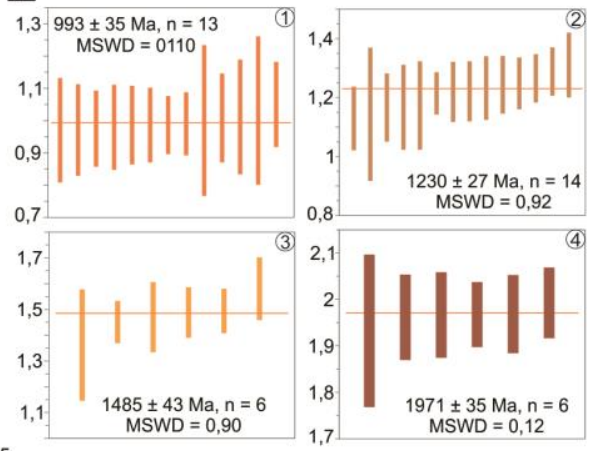

H

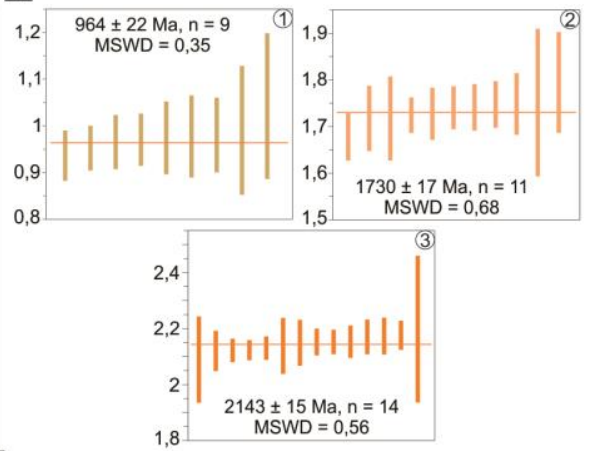

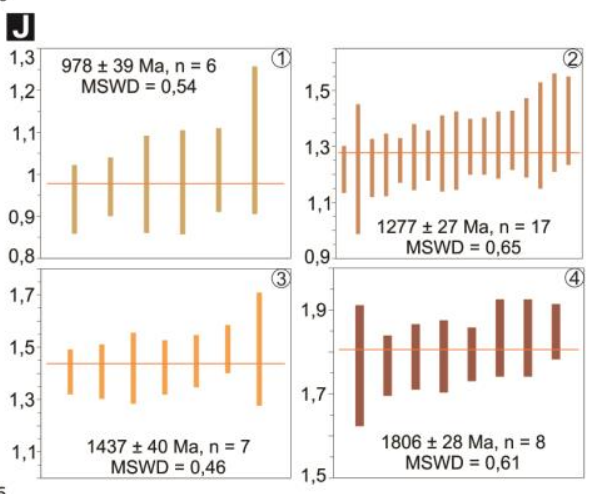


Figura 5-5. Diagramas A, C, E, G e I são histogramas de densidade de idades ${ }^{207} \mathrm{~Pb} /{ }^{206} \mathrm{~Pb}$ das rochas metassedimentares da Unidade Serra da Boa Vista da Nappe Andrelândia, em cada um notar o diagrama weighted average geral com todos os dados; Diagramas B, D, F, H e J são diagramas weighted average com as idades resultantes dos principais conjuntos de dados destacados tanto pelos picos dos histogramas quanto pela heterogeneidade dos diagramas weighted average com todos os dados.

\subsubsection{Unidade Santo Antônio}

Os grãos detríticos de zircão das amostras de metawackes da unidade intermediária da Nappe Andrelândia (Unidade Santo Antônio), SNA-201 e NESG-1010 apresentam comprimento entre $90 \mu \mathrm{m}$ e $175 \mu \mathrm{m}$, são em sua maioria ovoides ou fragmentos arredondados, e prismas com pontas arredondadas sem nenhum cristal prismático bipiramidal preservado (Figura 5-6). O zoneamento oscilatório prevalece com ocorrência, em menor quantidade, de grãos com zoneamento setorizado, no entanto todos os cristais apresentam, mesmo que com pouca espessura, sobrecrescimentos metamórficos homogêneos tanto claros como escuros. A amostra do anfibolito NESG-1552, apresenta cristais prismáticos, longos ou curtos, de pontas arredondadas com zoneamento oscilatório e setorizado, e comprimento entre $100 \mu \mathrm{m}$ e $270 \mu \mathrm{m}$, com raros núcleos herdados de zoneamento convoluto. Comumente são observados sobrecrescimentos metamórficos homogêneos claros, de baixo urânio. 


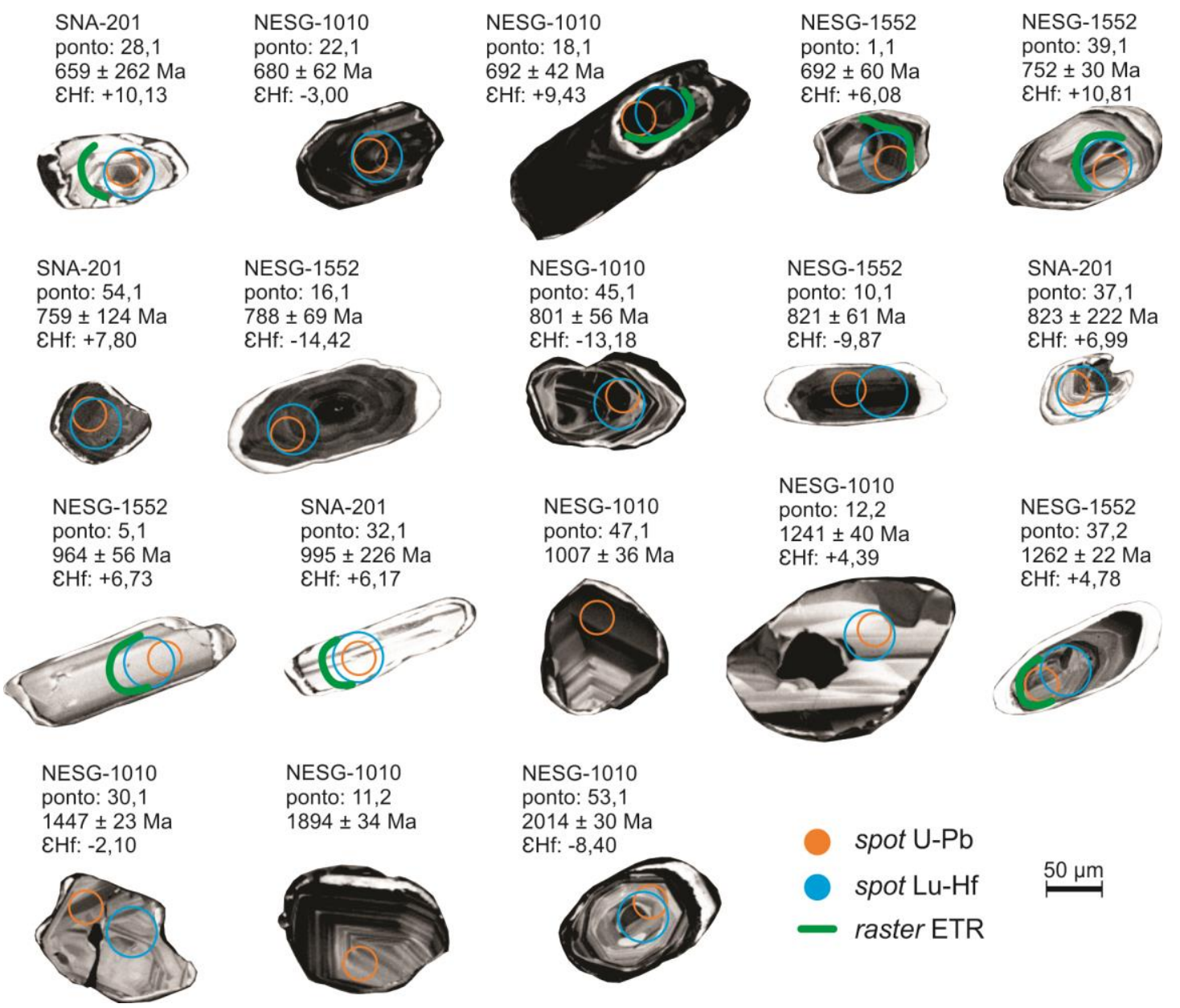

Figura 5-6. Exemplos de cristais de zircão provenientes da Unidade Santo Antônio, analisados através das amostras SNA-201, NESG-1010 e NESG-1552. Idades ${ }^{207} \mathrm{~Pb} /{ }^{206} \mathrm{~Pb}$ e erros em $2 \sigma$.

Os dados de U-Pb obtidos para esta unidade são, em sua maioria, do Neoproterozoico, e valores no Mesoproterozoico estão presentes na amostra NESG-1010 e mais raramente na NESG-1552. Apenas a amostra NESG-1010 possui dados no Paleoproterozoico (Figura 5-7). Todos os dados, separadamente por amostra, foram plotados em diagramas weighted average e resultaram em valores altos de MSWD, indicando a existência de mais de um grupo de idades. Os grupos de dados que se concentram no Neoproterozoico, encontradas nas três amostras, exibem intervalos entre $682 \pm 56$ e $699 \pm 30 \mathrm{Ma}, 764 \pm 44$ e $785 \pm 9 \mathrm{Ma}, 805 \pm 9$ e $838 \pm 59 \mathrm{Ma}$ e entre $940 \pm 41$ e $957 \pm 18 \mathrm{Ma}$. Do Mesoproterozoico estes intervalos se dão entre $1005 \pm 14 \mathrm{Ma}, 1242 \pm 12 \mathrm{e}$ $1262 \pm 19 \mathrm{Ma}$ e $1437 \pm 15 \mathrm{Ma}$. Os dados mais antigos, dos quais foi possível obter idades resultantes, estão restritos à amostra NESG-1010 e ocorrem todas no Orosiriano, entre $1884 \pm 12 \mathrm{Ma}$ e $2030 \pm 27 \mathrm{Ma}$, no entanto são resultados com MSWD entre 1,14 e 1,5. 


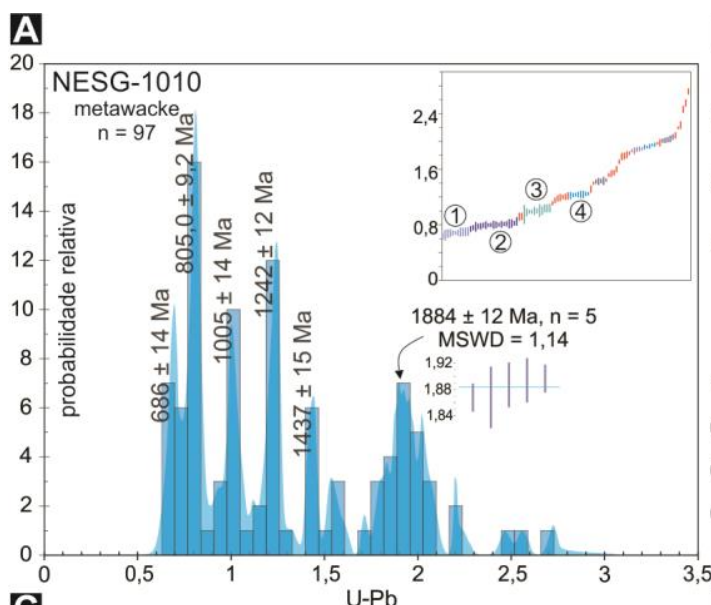

B
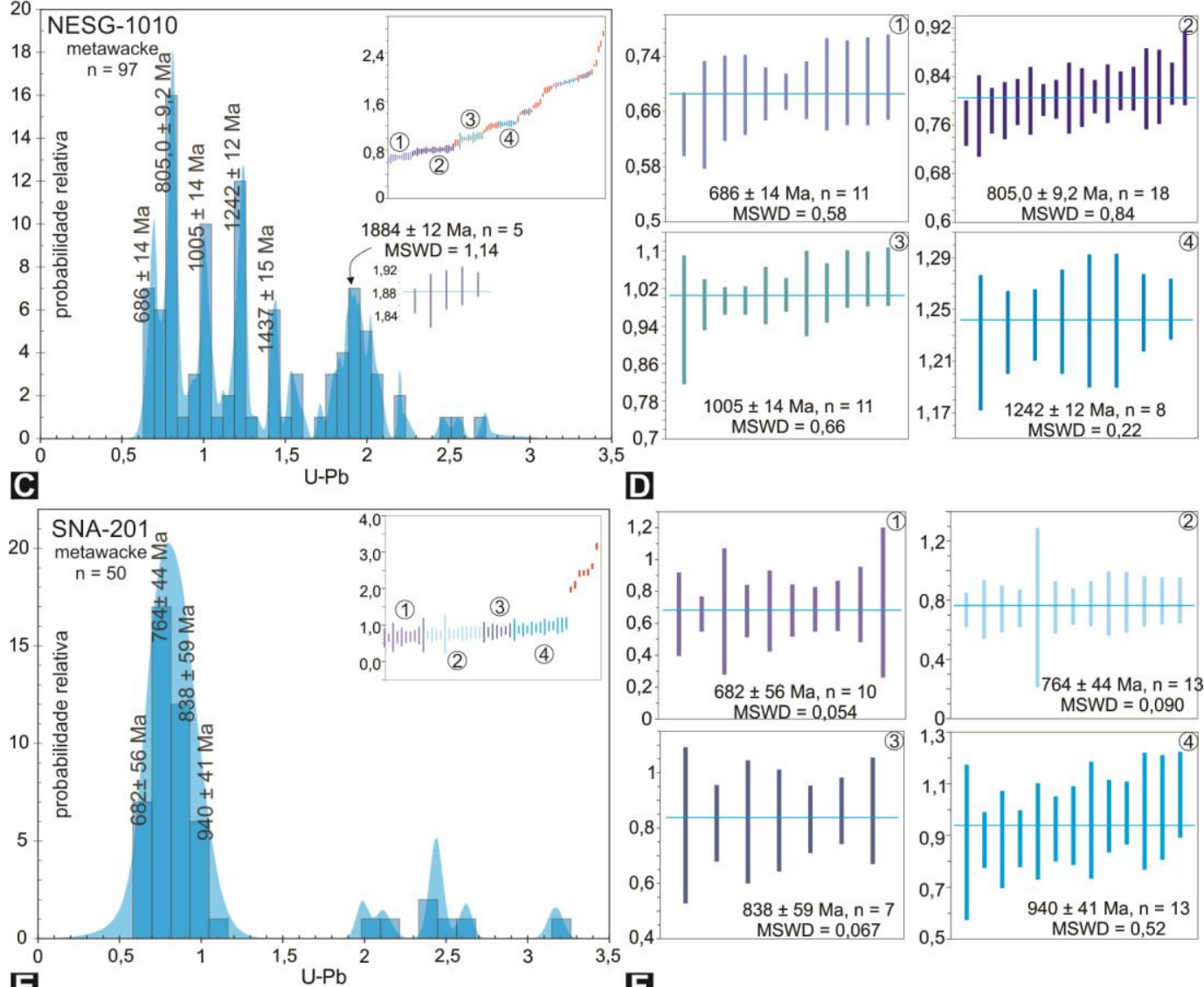

目
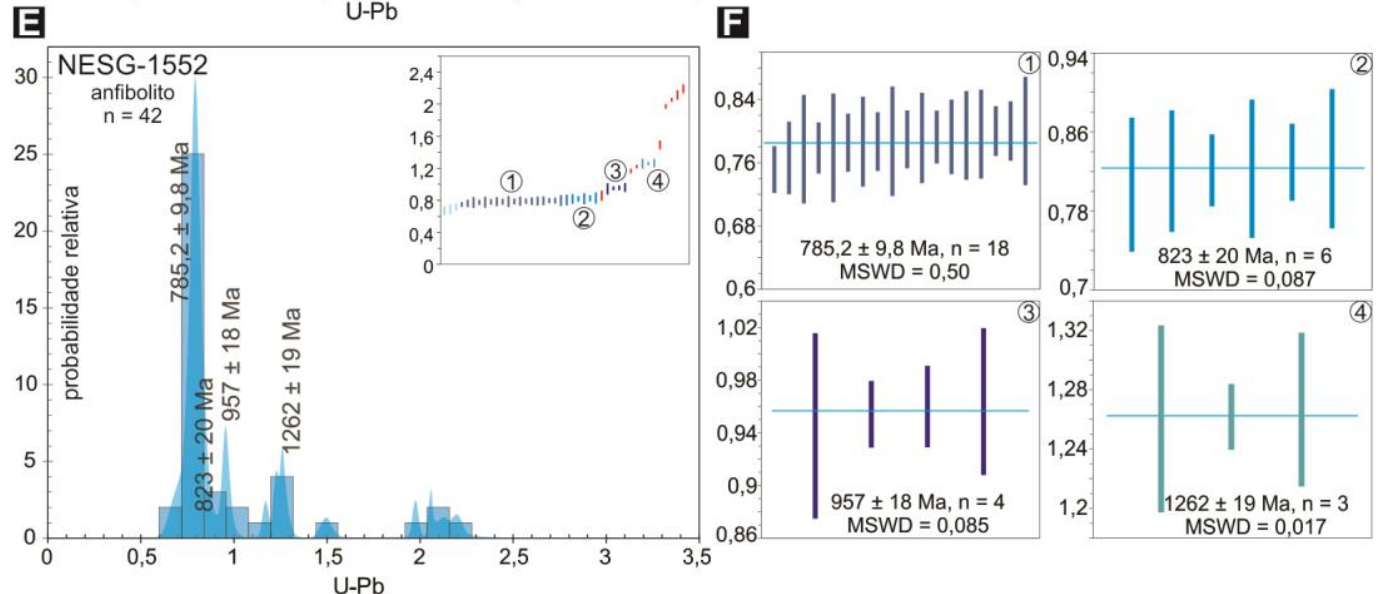

Figura 5-7. Diagramas A, C e E são histogramas de densidade de idades ${ }^{207} \mathrm{~Pb} /{ }^{206} \mathrm{~Pb}$ das rochas da Unidade Santo Antônio da Nappe Andrelândia, em cada um notar o diagrama weighted average geral com todos os dados; Diagramas B, D e F são diagramas weighted average com as idades resultantes dos principais conjuntos de dados destacados tanto pelos picos dos histogramas quanto pela heterogeneidade dos diagramas weighted average com todos os dados.

Os cristais detríticos de zircão da Unidade Santo Antônio são dominantemente do Neoproterozoico Criogeniano (ca. 0,68 Ga), fim-Toniano (ca. 0,78 Ga), Toniano $(0,8$ a 0,84 $\mathrm{Ga})$ e Eo-Toniano (0,95 a 1,0 Ga).

Uma comparação entre as idades obtidas neste trabalho, com aquelas de Trouw (2008), Santos (2011) e Belém et al. (2011) é apresentada na Figura 5-8. É destacável a densidade de dados no Neoproterozoico para todas as amostras. 


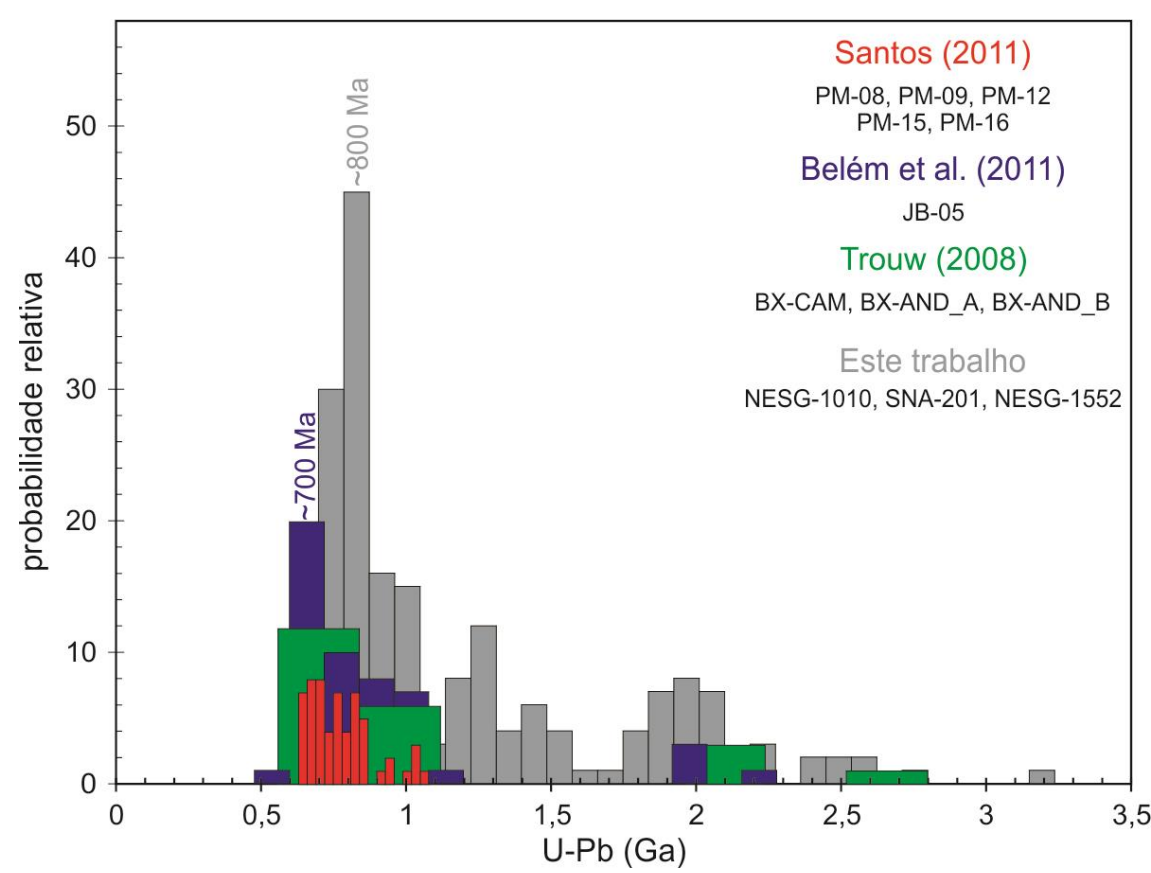

Figura 5-8. Histograma de densidade de idades U-Pb com os dados de amostras da Unidade Santo Antônio dos trabalhos de Santos (2011), Belém et al. (2011) e Trouw (2008) juntamente com os resultados obtidos neste trabalho.

Aliando a Figura 5-8 com os dados da Tabela 5-3 fica evidente a grande densidade de idades, em todas as amostras da Unidade Santo Antônio estudadas pelos diversos autores, no Neoproterozoico entre $\sim 650 \mathrm{Ma} \mathrm{e} \sim 950 \mathrm{Ma}$, com pico principal mais jovem que $800 \mathrm{Ma}$. As quantidades de cristais do Mesoproterozoico e do Paleoproterozoico são ínfimas, sendo cristais do Arqueano negligenciáveis.

Sendo assim as principais fontes da Unidade Santo Antônio seriam rochas de idade neoproterozoica mais novas que $800 \mathrm{Ma}$ e com pico observado entre 680-780 Ma, com idades também importantes do início do Neoproterozoico entre 850 Ma e $950 \mathrm{Ma}$. 


\begin{tabular}{|c|c|c|c|c|}
\hline Amostra & $\begin{array}{c}\text { Idades } \\
\text { Idas }\end{array}$ & \multicolumn{3}{|c|}{ Idades ígneas (Ma) } \\
\hline \multicolumn{5}{|c|}{ Santos (2011) } \\
\hline PM-08 & - & $\begin{array}{c}645,7 \pm 10,9 \\
670,8 \pm 7,9 \\
701,3 \pm 6,4 \\
702,1 \pm 7,2\end{array}$ & $\begin{array}{c}769,7 \pm 10,5 \\
800,6 \pm 8,1 \\
827,2 \pm 9,1\end{array}$ & $\begin{array}{l}857,5 \pm 21,5 \\
907,6 \pm 19,9 \\
945,6 \pm 10,0\end{array}$ \\
\hline PM-09 & $\begin{array}{l}605,3 \pm 7,0 \\
625,9 \pm 6,8\end{array}$ & $\begin{array}{c}531,9 \pm 12,3 \\
565,5 \pm 7,5 \\
591,4 \pm 7,3 \\
625,9 \pm 6,8 \\
632,8 \pm 5,5 \\
633,2 \pm 10,5 \\
646,6 \pm 6,4\end{array}$ & $\begin{array}{c}646,9 \pm 8,5 \\
651,2 \pm 7,4 \\
670,16,1 \\
672,7 \pm 9,3 \\
681,0 \pm 7,5 \\
682,8 \pm 6,5 \\
728,5 \pm 10,2\end{array}$ & $\begin{array}{c}730,0 \pm 9,4 \\
753,8 \pm 8,8 \\
833,3 \pm 13,2 \\
1026,4 \pm 11,5 \\
1046,8 \pm 12,9 \\
1068,6 \pm 30,7\end{array}$ \\
\hline PM-12 & - & $\begin{array}{l}651,3 \pm 14,9 \\
705,4 \pm 19,6 \\
710,7 \pm 22,6 \\
759,7 \pm 16,9 \\
760,6 \pm 12,1\end{array}$ & $\begin{array}{l}765,0 \pm 31,6 \\
765,2 \pm 30,2 \\
808,4 \pm 22,0 \\
808,8 \pm 33,8\end{array}$ & $\begin{array}{r}830,8 \pm 21,0 \\
863,8 \pm 21,0 \\
995,7 \pm 15,5 \\
1035,6 \pm 21,9\end{array}$ \\
\hline PM-15 & - & $\begin{array}{c}687,3 \pm 17,6 \\
688,5 \pm 6,5 \\
706,5 \pm 11,7\end{array}$ & $\begin{array}{c}712,7 \pm 10,3 \\
770,0 \pm 9,6 \\
784,7 \pm 10,6\end{array}$ & $\begin{array}{l}832,5 \pm 7,8 \\
846,0 \pm 8,0\end{array}$ \\
\hline PM-16 & $570,2 \pm 25,9$ & $\begin{array}{l}682,0 \pm 11,1 \\
707,8 \pm 21,8 \\
714,6 \pm 15,4 \\
720,9 \pm 11,7 \\
\end{array}$ & $\begin{array}{l}741,7 \pm 9,7 \\
816,8 \pm 8,5 \\
821,3 \pm 9,0 \\
829,5 \pm 9,5 \\
\end{array}$ & $\begin{array}{c}842,0 \pm 7,0 \\
857,7 \pm 7,9 \\
946,4 \pm 17,3\end{array}$ \\
\hline \multicolumn{5}{|c|}{ Belém et al. $(2011)^{\star}$} \\
\hline JB-05 & - & $\begin{array}{l}637,6 \pm 8,7 \\
676,7 \pm 8,7 \\
\end{array}$ & $\begin{array}{l}711 \pm 15 \\
772 \pm 12 \\
\end{array}$ & $\begin{array}{c}969 \pm 13 \\
1974 \pm 45\end{array}$ \\
\hline \multicolumn{5}{|c|}{ Trouw (2008) } \\
\hline BX-CAM & - & $\begin{array}{c}675,8 \pm 7,6 \text { (c.a.) } \\
692,1 \pm 9,2 \\
\end{array}$ & $\begin{array}{l}798,3 \pm 11,6 \\
832,4 \pm 11,1 \\
\end{array}$ & $1973,5 \pm 10,1$ \\
\hline BX-AND_A & $595,0 \pm 5,8$ (c.a.) & $\begin{array}{l}643,5 \pm 3,9 \\
685,5 \pm 8,9 \\
\end{array}$ & $\begin{array}{l}733,6 \pm 9,2 \\
746,4 \pm 4,8 \\
\end{array}$ & $\begin{array}{c}958,4 \pm 16,0 \\
2615 \pm 38 \\
\end{array}$ \\
\hline BX-AND_B & $\begin{array}{c}55,7 \pm 13,4 \\
593,5 \pm 16,0 \\
598,3 \pm 14,5 \\
605,7 \pm 14,5 \\
627,6 \pm 15,2 \\
\end{array}$ & $\begin{array}{l}752,2 \pm 18,1 \\
800,3 \pm 19,3\end{array}$ & $\begin{array}{l}841,5 \pm 21,7 \\
931,2 \pm 10,0\end{array}$ & $\begin{array}{c}1090,3 \pm 21,4 \\
1987,5 \pm 9,4\end{array}$ \\
\hline \multicolumn{5}{|c|}{$\operatorname{Lima}(2013)^{\star}$} \\
\hline NESG-1010 & $634 \pm 14$ & $\begin{array}{c}686 \pm 14 \\
805,0 \pm 9,2\end{array}$ & $\begin{array}{l}1005 \pm 14 \\
1242 \pm 12 \\
\end{array}$ & $\begin{array}{l}1437 \pm 15 \\
1884 \pm 12 \\
\end{array}$ \\
\hline NESG-1552 & $611 \pm 18$ & $\begin{array}{c}699 \pm 30 \\
785,2 \pm 9,8\end{array}$ & $\begin{array}{l}823 \pm 20 \\
957 \pm 18\end{array}$ & $1262 \pm 19$ \\
\hline \multicolumn{5}{|c|}{ este trabalho* } \\
\hline SNA-201 & $625 \pm 71$ & $\begin{array}{l}682 \pm 56 \\
764 \pm 44\end{array}$ & $838 \pm 59$ & $940 \pm 41$ \\
\hline
\end{tabular}

Tabela 5-3. Resumo de todas as idades encontradas por Santos (2011), Belém et al. (2011), Trouw (2008), Lima (2013) e por este trabalho para a Unidade Santo Antônio. (c.a.) = concordia age; ${ }^{*}=$ idades resultantes geradas a partir de um conjunto de dados através de diagramas weighted average com erro em $2 \sigma$; o restante são os resultados de cada cristal de zircão com erro em $1 \sigma$.

\subsubsection{Nappe Liberdade}

Os cristais detríticos de zircão encontrados nas rochas metapelítica e metapsamítica da Nappe Liberdade são predominantemente ovoides e prismas com pontas arredondadas, 
apresentando zoneamento oscilatório e setorizado, e em menor volume ocorrem prismas com pontas arredondadas e zoneamento convoluto com núcleos de baixo urânio (brancos e homogêneos em imagens de catodoluminescência). Os cristais detríticos podem ser divididos em três grupos distintos a partir de suas granulações: um grupo apresenta comprimento que varia de $75 \mu \mathrm{m}$ a $160 \mu \mathrm{m}$, outro de $97 \mu \mathrm{m}$ a $233 \mu \mathrm{m}$ e por último, de 155 $\mu \mathrm{m}$ a $255 \mu \mathrm{m}$ (Figura 5-9).
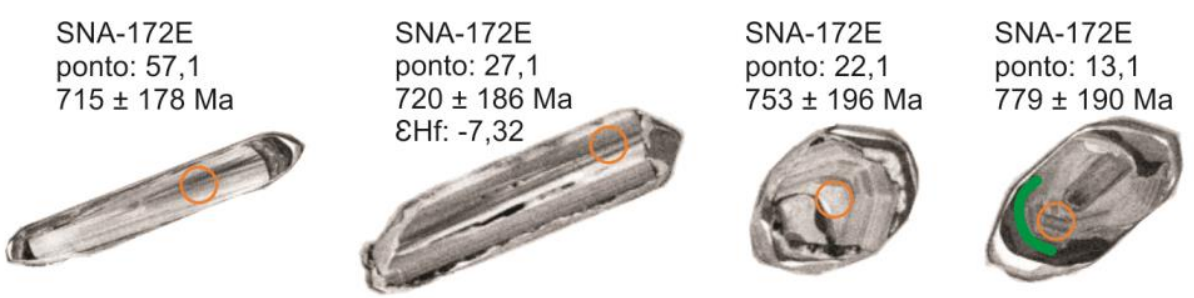

SNA-172E ponto: 39,1
$784 \pm 164 \mathrm{Ma}$
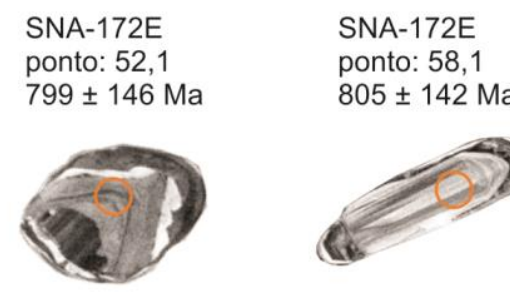

\section{SNA-172E}

ponto: 3,1 $805 \pm 142 \mathrm{Ma}$

$866 \pm 372 \mathrm{Ma}$ EHf: $-7,32$
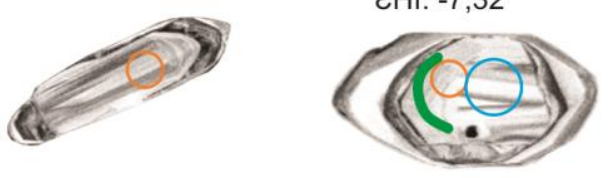

\section{SNA-180A} ponto: 7,1 $1119 \pm 80 \mathrm{Ma}$
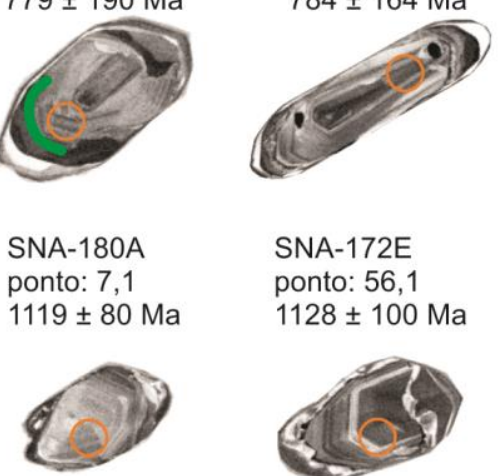

SNA-172E ponto: 56,1 $1128 \pm 100 \mathrm{Ma}$

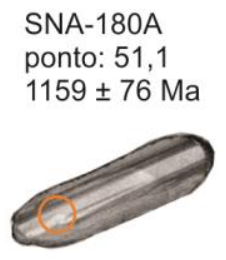

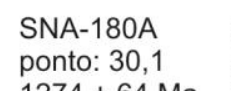

\section{SNA-180A}

ponto: 60,1 $1274 \pm 64 \mathrm{Ma} \quad 1236 \pm 58 \mathrm{Ma}$ EHf: $+1,40$
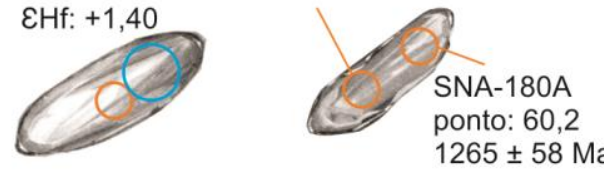

\section{SNA-180A} ponto: 32,1 $1330 \pm 52 \mathrm{Ma}$

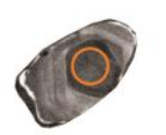

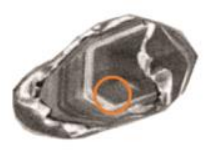

SNA-180A ponto: 3,1 $1476 \pm 92 \mathrm{Ma}$ $\varepsilon H f:-9,49$

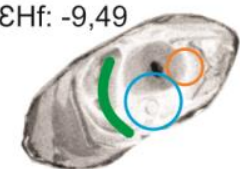

spot U-Pb spot Lu-Hf raster ETR $50 \mu \mathrm{m}$

Figura 5-9. Exemplos de cristais de zircão provenientes das rochas metassedimentares da Nappe Liberdade, analisados através das amostras SNA-172E e SNA-180A. Idades ${ }^{207} \mathrm{~Pb} / 206 \mathrm{~Pb}$ e erros em $2 \sigma$.

Os dados de $\mathrm{U}-\mathrm{Pb}$ dos cristais detríticos de zircão das rochas metassedimentares desta unidade são distintos e variam de uma amostra para outra: o metapelito exibe idades mais jovens restritas ao Neoproterozoico. Idades mais antigas são mais frequentes no metapsamito, que variam do final do Paleoproterozoico ao final do Mesoproterozoico (Figura 5-10).

Os cristais detríticos do metapelito (75\% dos dados concordantes) geram uma idade de $791 \pm 28 \mathrm{Ma}(\mathrm{n}=44)$ com probabilidade de 1,0 e MSWD de 0,34 . Os poucos dados que existem do Mesoproterozoico e Paleoproterozoico (cada um dos conjuntos corresponde a apenas $12 \%$ dos dados concordantes) resultaram em idades de $1093 \pm 57 \mathrm{Ma}(\mathrm{n}=5)$ e $1864 \pm 39 \mathrm{Ma}(\mathrm{n}=6)$. 
As idades dos cristais detríticos da amostra metapsamítica apresentam uma maior densidade no Mesoproterozoico (68\% dos dados concordantes). As cinco idades que ocorrem neste período são do Esteniano (1095 \pm 30 Ma e $1162 \pm 31 \mathrm{Ma})$, do Ectasiano (1240 $\pm 19 \mathrm{Ma}$ e $1330 \pm 25 \mathrm{Ma})$ e do Calimiano (1515 $\pm 20 \mathrm{Ma}$ ). Idades no Estateriano (1766 $\pm 18 \mathrm{Ma})$ e no Orosiriano (1865 $\pm 26 \mathrm{Ma})$ correspondem a $23 \%$ dos dados concordantes, sendo que uma moda secundária em $1864 \pm 39$ Ga está presente também no metapelito.
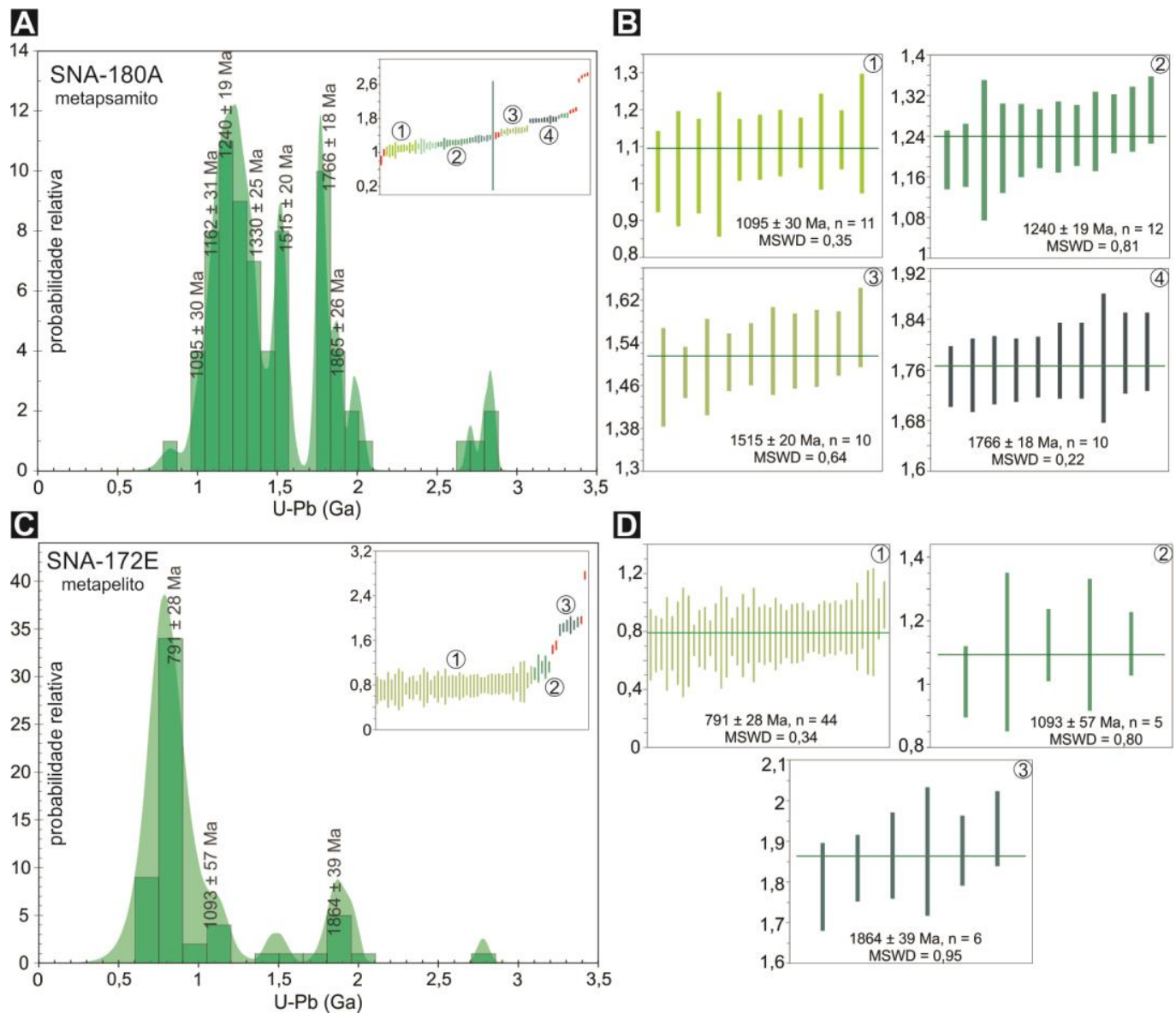

Figura 5-10. Diagramas A e C são histogramas de densidade de idades ${ }^{207} \mathrm{~Pb} /{ }^{206} \mathrm{~Pb}$ das rochas metassedimentares da Nappe Liberdade, em cada um notar o diagrama weighted average geral com todos os dados; Diagramas B e D são diagramas weighted average com as idades resultantes dos principais conjuntos de dados destacados tanto pelos picos dos histogramas quanto pela heterogeneidade dos diagramas weighted average com todos os dados.

\subsection{Geoquímica isotópica em rocha-total}

As rochas (meta)sedimentares são uma mistura de fontes distintas e desta forma suas idades-modelo $\mathrm{T}_{\mathrm{DM}}$ resultam em uma mistura de diversas composições. As idadesmodelo maiores que a idade da rocha indicam uma mistura mais significativa de fontes mais antigas. Valores de $\varepsilon \mathrm{Nd}$ positivos indicam uma parcela maior de contribuição juvenil, enquanto que valores negativos indicam maior volume de material crustal. Na Figura 5-11 A 
encontram-se os dados $\varepsilon \mathrm{Nd}_{\mathrm{t}}$ versus idade para as rochas metassedimentares das unidades estudadas, assim como alguns dados de rochas metabásicas da Nappe Liberdade.

Os metawackes da Unidade Santo Antônio são os que apresentam idades-modelo mais jovens entre todas as rochas metassedimentares. Variam de 1,16 Ga a 1,40 Ga, indicando material juvenil acrescido às fonte tanto no Neoproterozoico quanto no Mesoproterozoico. Já as rochas metassedimentares da Unidade Serra da Boa Vista e da Nappe Liberdade exibem uma história isotópica completamente distinta, com idades modelos mais antigas, entre 1,80 Ga e 2,28, com duas exceções, indicando uma mistura importante de fontes mais antigas.

Os valores de $\varepsilon \mathrm{Nd}_{\mathrm{t}}$, para qualquer idade, tendem ser sempre mais positivos - ou menos negativos - nas rochas da Unidade Santo Antônio que os demais valores encontrados nas rochas das demais unidades, com exceção das rochas metabásicas da Nappe Liberdade, que eventualmente encontram-se no mesmo trend do Santo Antônio.
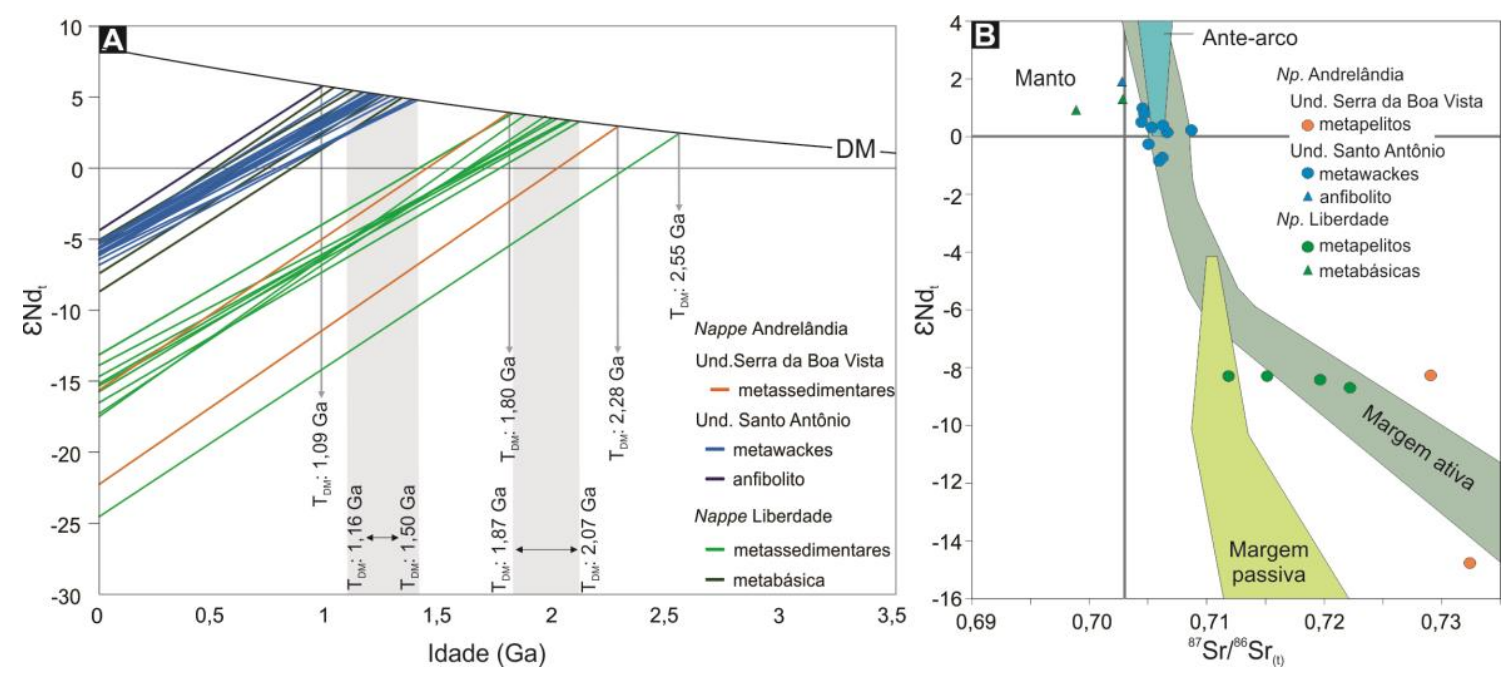

Figura 5-11. (A) Diagrama de $\varepsilon N d$ versus idade das rochas metassedimentares, e de algumas rochas metabásicas, das unidades estudadas. As setas e os campos em cinza destacam as idades-modelo $\mathrm{T}_{\mathrm{DM}}$, ou seus intervalos, para cada unidade; (B) Diagrama $\varepsilon N d(t)$ versus ${ }^{87} \mathrm{Sr} /{ }^{86} \mathrm{Sr}(\mathrm{t})$ com as delimitações de alguns ambientes tectônicos e os dados das amostras estudadas plotados. (t) Unidade Serra da Boa Vista = 0,68 Ga; ( $\mathrm{t}$ ) Unidade Santo Antônio = 0,68 Ga; (t) Nappe Liberdade = 0,79 Ga.

As relações entre os valores de $\varepsilon{N d_{t}}_{t}$ e as razões isotópicas de ${ }^{87} \mathrm{Sr}^{86} \mathrm{Sr}_{\mathrm{t}}$ podem ser utilizadas como traçadores gerais do ambiente tectônico. As amostras da Unidade Santo Antônio possuem razões isotópicas características de rochas de arco vulcânico pouco evoluído a juvenil (Figura 5-11 B). As demais associações litológicas identificam-se, a priori, com um campo de margem ativa. A relação entre $\varepsilon \mathrm{Nd}_{\mathrm{t}}$ versus $\mathrm{Th} / \mathrm{Sc}$ sugere a distinção entre componentes félsicos e máficos das diversas idades, e a Figura 5-12 sugere que as rochas da Unidade Serra da Boa Vista e da Nappe Liberdade apresentam componentes importantes de fontes na crosta continental superior e mais antiga do que as rochas da Unidade Santo Antônio, com $\varepsilon \mathrm{Nd}_{\mathrm{t}}$ menos negativos. 


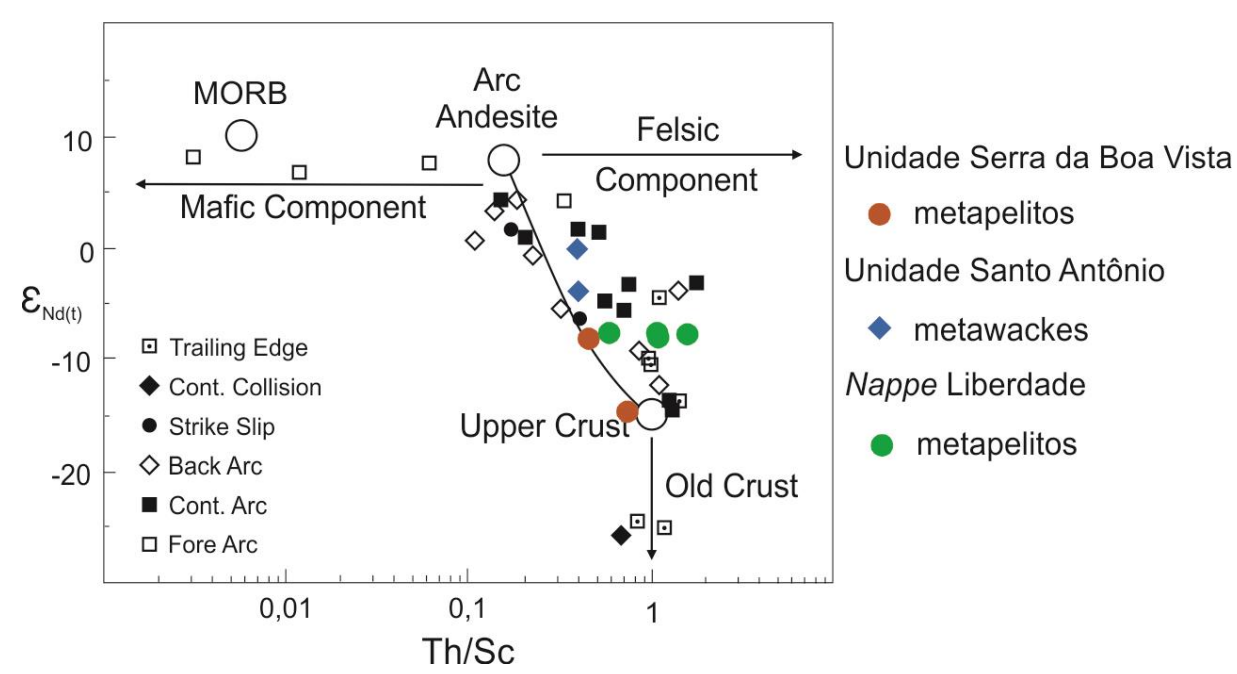

Figura 5-12. Diagrama de $\varepsilon N d_{(t)}$ versus $\mathrm{Th} / \mathrm{Sc}$ ressaltanto os componentes félsicos, máficos (MCLENNAN et al., 1990) e os campos referentes à composições de MORB, crosta superior e crosta antiga além das composições típicas de vários reservatórios geoquímicos (TAYLOR; MCLENNAN, 1985). (t) Unidade Serra da Boa Vista = 0,68 $\mathrm{Ga}$; (t) Unidade Santo Antônio = 0,68 Ga; (t) Nappe Liberdade = 0,79 Ga.

\subsection{Sistema isotópico Lu-Hf em cristais detríticos de zircão}

\subsubsection{Nappe Andrelândia}

\subsubsection{Unidade Serra da Boa Vista}

Cristais detríticos de zircão oriundos de uma área fonte com características magmáticas juvenis ou pouco evoluídas encontram-se dominantemente no Mesoproterozoico. Idades individuais entre $\sim 1,21$ e 1,34 Ga possuem predominantemente $\varepsilon \mathrm{Hf}$ entre -2 e +8 , aproximando-se da evolução isotópica linear $(\mathrm{NC})$ de $\mathrm{Hf}$ dos arcos insulares juvenis modernos (New Crust de DHUIME; HAWKESWORTH; CAWOOD, 2011). A razão isotópica decresce à valores entre 0 e 3 positivos nas idades individuais de zircão entre 1,38 e 1,49 Ga (Figura 5-13).

No Paleoproterozoico Estateriano e Orosiriano, cristais detríticos oriundos de áreas fontes juvenis também estão evidenciados pelas razões isotópicas positivas, entre 0,5 e 5,7. No fim-Esteniano ao Neoproterozoico Eo-Toniano $(1,18-0,98 \mathrm{Ga})$ as áreas-fontes magmáticas pouco evoluídas foram mais restritas. De cerca de 19 idades individuais, 4 encontram-se entre 0 e 2,5. Nas demais, predominam os valores de $\varepsilon \mathrm{Hf}$ entre -7,0 e -0,4. 


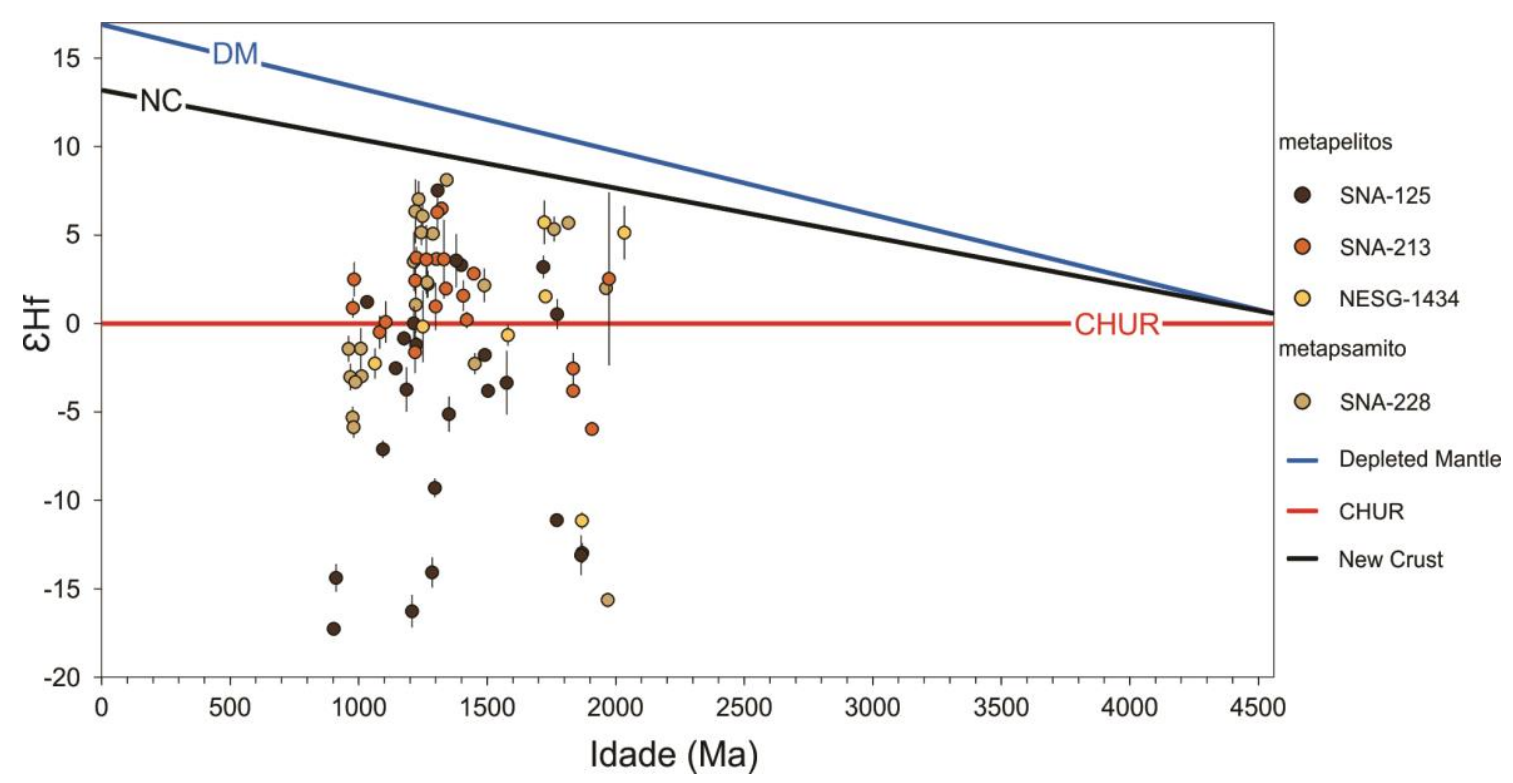

Figura 5-13. Diagrama de $\varepsilon \mathrm{Hf}$ versus idade com as composições isotópicas das amostras de rochas metassedimentares da Unidade Serra da Boa Vista, pertencente à Nappe Andrelândia, plotadas.

Razões isotópicas negativas ocorrem em todos os conjuntos de idades e em menor proporção no Mesoproterozoico. A média crustal das razões ${ }^{176} \mathrm{Lu} /{ }^{177} \mathrm{Hf}$ admitida em 0,015 (VERVOOT; BLICHERT-TOFT, 1999) permite estimar as idades-modelo DM (Depleted Mantle) ou NC (New Crust) e expressa os principais períodos de geração de crosta. Os cristais detríticos de zircão de idades fim-Esteniano ao eo-Toniano, com $\varepsilon \mathrm{Hf}$ positivo, alinham-se, na razão $\mathrm{Lu} / \mathrm{Hf}$ de 0,015 , com os valores de características juvenis do Ectasiano-Esteniano, indicando uma $T_{N C}$ em 1,35-1,65 Ga. Essa relação sugere que os processos magmáticos do Eo-Neoproterozoico resultaram da reciclagem de material adicionado à crosta entre 1,35 e 1,65 Ga.

Os cristais de zircão do início do Toniano com $\varepsilon \mathrm{Hf}$ negativo alinham-se, na razão $\mathrm{Lu} / \mathrm{Hf}$ de 0,015, com cristais do Ectasiano, Calimiano e Estateriano de $\varepsilon \mathrm{Hf}$ positivo e resultam em idade-modelo $T_{N C}$ de 1,70-1,96 Ga, sendo assim os cristais tonianos de zircão com afinidade crustal podem ter evoluído a partir de material juvenil eo-estaterianoorosiriano. Os cristais mesoproterozoicos com $\varepsilon \mathrm{Hf}$ essencialmente negativo alinham-se, da mesma forma, com cristais do Paleoproterozoico de $\varepsilon \mathrm{Hf}$ positivo e geram idades $\mathrm{T}_{\mathrm{NC}}$ de 2,0$2,9 \mathrm{Ga}$.

No entanto, se as idades-modelo fossem baseadas na evolução isotópica do Depleted Mantle, os cristais de zircão mais jovens exibiriam idades-modelo $\mathrm{T}_{\mathrm{DM}}$ aproximadamente $150 \mathrm{Ma}$ mais antigas que as idades $\mathrm{T}_{\mathrm{NC}}$, e um pouco menos de $100 \mathrm{Ma}$ mais antigas que as idades $T_{\mathrm{NC}}$ no caso dos cristais de zircão mais antigos. 


\subsubsection{Unidade Santo Antônio}

Metawackes da Unidade Santo Antônio devem, em parte, representar uma suíte vulcanoclástica oriunda de magma essencialmente juvenil no intervalo de idade Criogeniano-Toniano (660-810 Ma). A evidência está nas razões isotópicas de Hf para essas idades que se encontram próximas, ou entre, as curvas de evolução New Crust e Depleted Mantle (Figura 5-14).

Um outro conjunto de cristais de zircão de metawackes e do anfibolito, também no Criogeniano-Toniano (660-810 Ma), possuem $\varepsilon H f$ entre +3,6 e +9,1 e admitem idadesmodelo $\mathrm{T}_{\mathrm{NC}}$ entre 1,0-1,25 Ga. Para essas idades as razões isotópicas próximas ao reservatório condrítico (CHUR) admitem idades-modelo $T_{N C}$ no Mesoproterozoico entre 1,3 e 1,6 Ga e compartilham a evolução dos cristais juvenis de idade 1,0 e 1,25 Ga.

Os cristais de zircão dos metawackes e sobretudo do anfibolito de idade no Toniano e com $\varepsilon \mathrm{Hf}$ ente -7 e -2 admitem idades-modelo $\mathrm{T}_{\mathrm{NC}}$ entre 1,6 e 2,0 Ga, compartilhadas pela razão isotópica positiva de cristais de idade no Calimiano. Os cristais do Toniano de maior residência na crosta, $\varepsilon \mathrm{Hf}$ entre -9 e -14 , são sobretudo do anfibolito e admitem um $T_{N C}$ no intervalo de 2,2-2,6 Ga, compartilhado pelos cristais de idade no Orosiriano, com $\varepsilon \mathrm{Hf}$ superior a próximos ao CHUR.

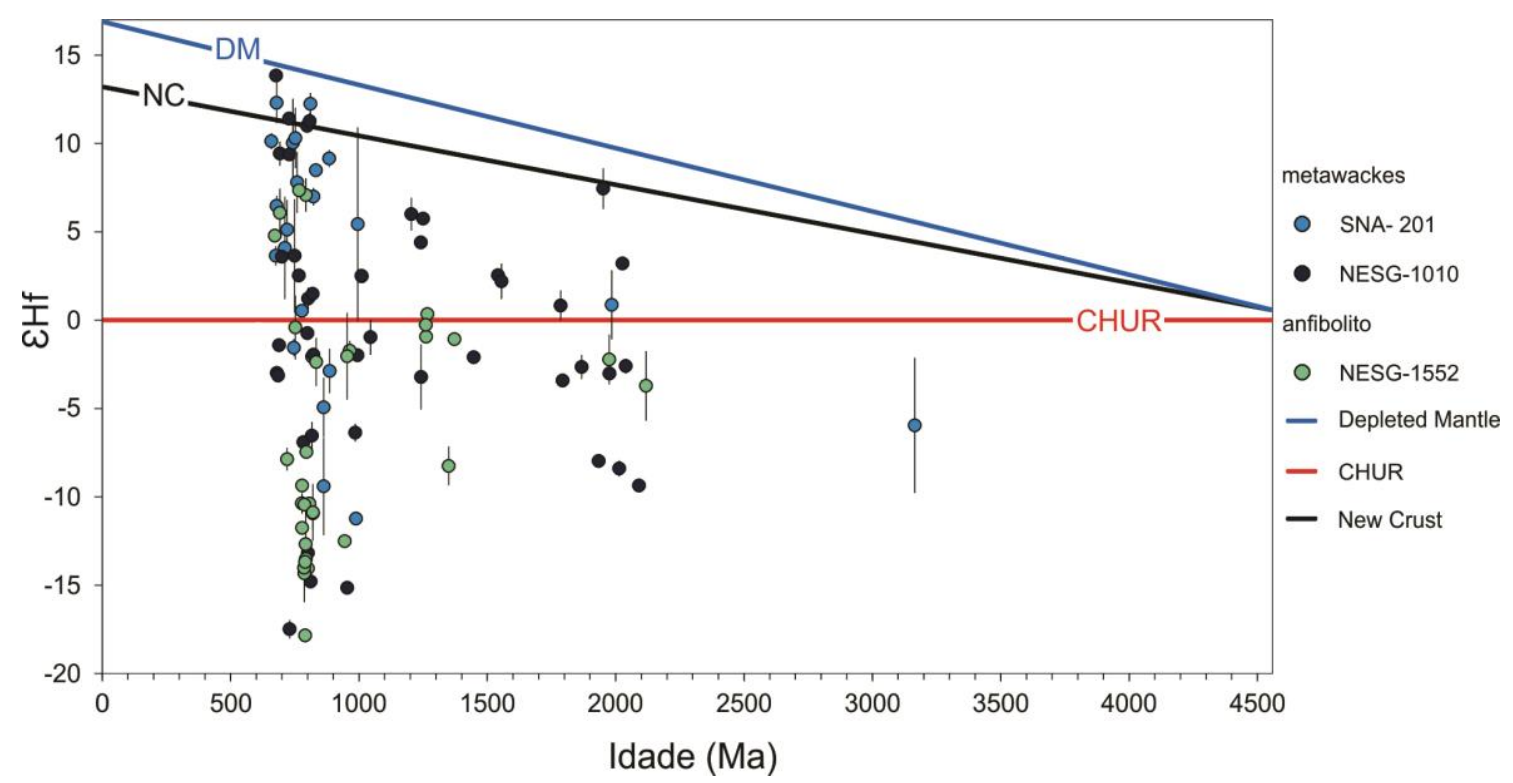

Figura 5-14. Diagrama de $\varepsilon \mathrm{Hf}$ versus idade com as composições isotópicas das amostras de rochas metassedimentares da Unidade Santo Antônio, pertencente à Nappe Andrelândia, plotadas.

As idades-modelo $T_{D M}$ para os cristais de zircão mais jovens e com $\varepsilon \mathrm{Hf}$ positivos são bastante próximas das próprias idades de cristalização. Quanto mais positivo é o $\varepsilon \mathrm{Hf}$ destas amostras, menor é a diferença entre as idades do zircão e $T_{\mathrm{DM}}$, indicando uma breve evolução isotópica de Hf para os cristais de zircão com idades U-Pb entre $660 \mathrm{Ma}$ e 880 Ma. O intervalo de tempo entre a extração do magma de um reservatório mantélico e a 
cristalização do cristal de zircão foi relativamente baixo. Sendo assim, estes cristais de zircão confirmam sua gênese em rochas vulcânicas de arco insular intraoceânico.

\subsubsection{Nappe Liberdade}

As rochas analisadas da Nappe Liberdade não apresentam grandes influências diretas de magmas juvenis em suas fontes. Entre 1,0-1,3 $\mathrm{Ga}$, onde os únicos dados positivos de $\varepsilon \mathrm{Hf}$ ocorrem, as razões isotópicas variam de $-5,7 \mathrm{a}+4$, indicando que neste intervalo de tempo a fonte poderia ser composta por rochas intermediárias (Figura 5-15).

Fontes essencialmente crustais encontram-se em todo o Neoproterozoico que ficam evidenciadas pelos valores de $\varepsilon \mathrm{Hf}$ entre -2 a -15 . No Calimiano e Orosiriano a razão isotópica concentra-se entre -3 e -9 , sugerindo fontes crustais também nestes períodos.

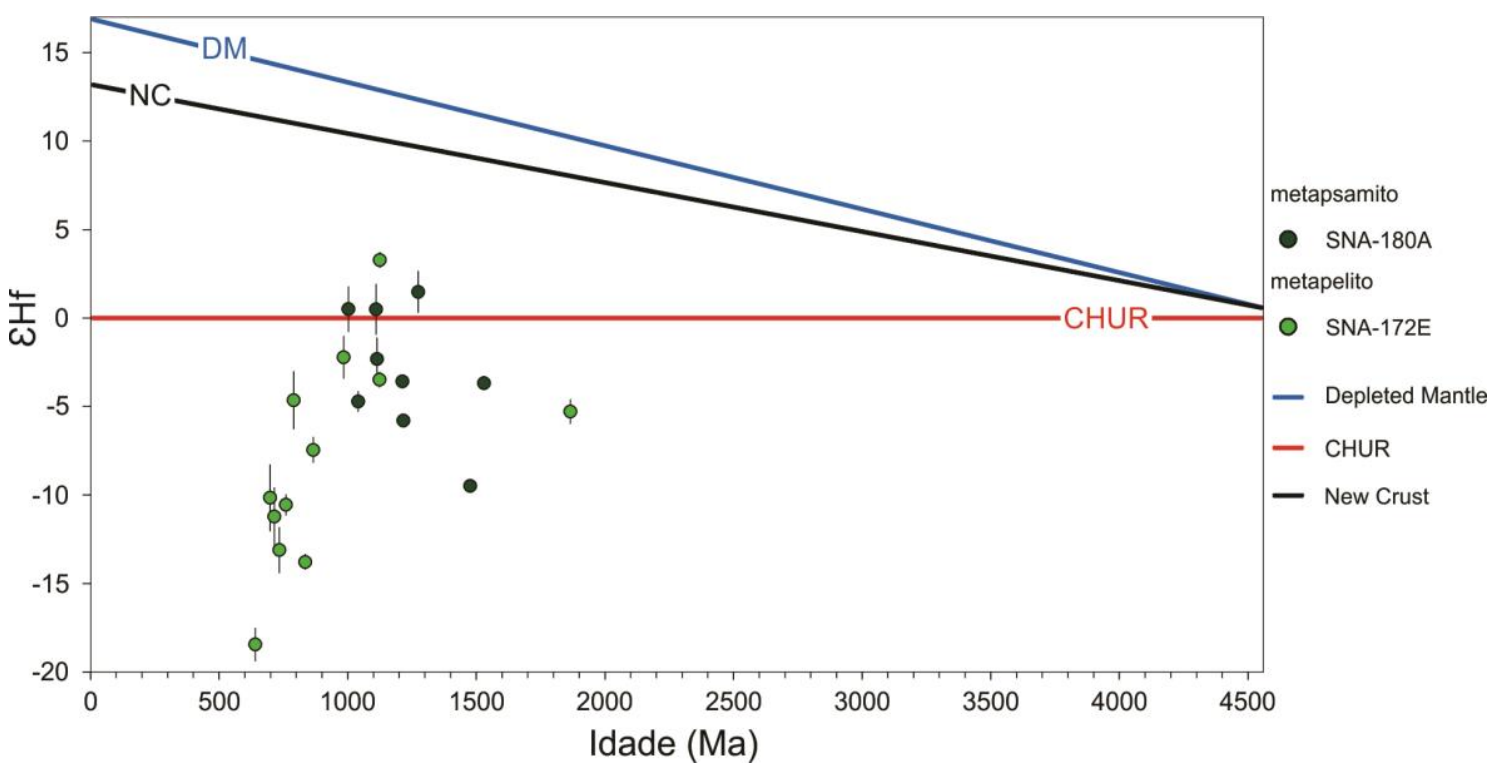

Figura 5-15. Diagrama de $\varepsilon \mathrm{Hf}$ versus idade com as composições isotópicas das amostras de rochas metassedimentares da Nappe Liberdade plotadas.

Os cristais do Esteniano-Ectasiano (1,0-1,3 Ga) com $\varepsilon \mathrm{Hf}$ positivos alinham-se, na razão $\mathrm{Lu} / \mathrm{Hf}$ de 0,015, com cristais, tanto do Esteniano $(\sim 1,0 \mathrm{Ga})$ com $\varepsilon \mathrm{Hf}$ de -3 , quanto do Toniano $(\sim 0,8 \mathrm{Ga})$ com $\varepsilon \mathrm{Hf}$ de -5 , e todo este conjunto exibe idades-modelo $\mathrm{T}_{\mathrm{NC}}$ de 1,551,85 Ga ( $T_{D M}$ de 1,7-2,0 Ga), sugerindo que para estes cristais a evolução isotópica iniciouse de um manto depletado no Calimiano-Estateriano-Orosiriano. Já os cristais com $\varepsilon \mathrm{Hf}$ entre -7 e -15 do Neoproterozoico e os de $\varepsilon \mathrm{Hf}$ entre -3 e - 6 do Mesoproterozoico, alinham-se na mesma razão 0,015 e resultam em idades-modelo $T_{N C}$ de 1,9-2,4 Ga ( $T_{D M}$ de 2,05-2,50 Ga), sugerindo que ambos os conjuntos apresentam evolução a partir de um mesmo reservatório no manto empobrecido entre o Orosiriano e o Sideriano. 


\subsection{Elementos terras raras em cristais detríticos de zircão}

Algumas análises de lantânio, praseodímio, neodímio, samário, európio e gadolínio não foram utilizadas por estarem abaixo do limite de quantificação (3,3 x limite de detecção).

\subsubsection{Nappe Andrelândia}

\subsubsection{Unidade Serra da Boa Vista}

Os padrões de ETR de cristais detríticos de zircão da Unidade Serra da Boa Vista são bastante semelhantes em todos os intervalos de idade, e no geral apresentam-se enriquecidos em ETR pesados, com anomalias negativas de Eu e positivas de $\mathrm{Ce}$ perceptíveis (Figura 5-16 A).

A Tabela 5-4 reúne os parâmetros calculados para os principais intervalos de idades cujos cristais de zircão foram analisados. Cristais do Toniano-Esteniano (924-1089 Ma) apresentam as menores concentrações, em ppm, de ETR entre todos os conjuntos analisados. Os enriquecimentos em ETR pesados são bastante variáveis e apresentam média $\mathrm{Yb}_{N} / G_{N}$ 10,96, com anomalias negativas de Eu, com média de 0,26 bastante acentuadas, enquanto que as positivas de Ce tendem a ser mais brandas $f B$ ). Os grãos do Esteniano-Ectasiano (1149-1277 Ma) são os que apresentam baixas concentrações médias por análise e os menores enriquecimentos em ETR pesados, com média $\mathrm{Yb}_{\mathrm{N}} / \mathrm{Gd}_{\mathrm{N}}$ de 8,39. As anomalias negativas de Eu e as positivas de Ce são ambas acentuadas (Figura 5-16 C). 

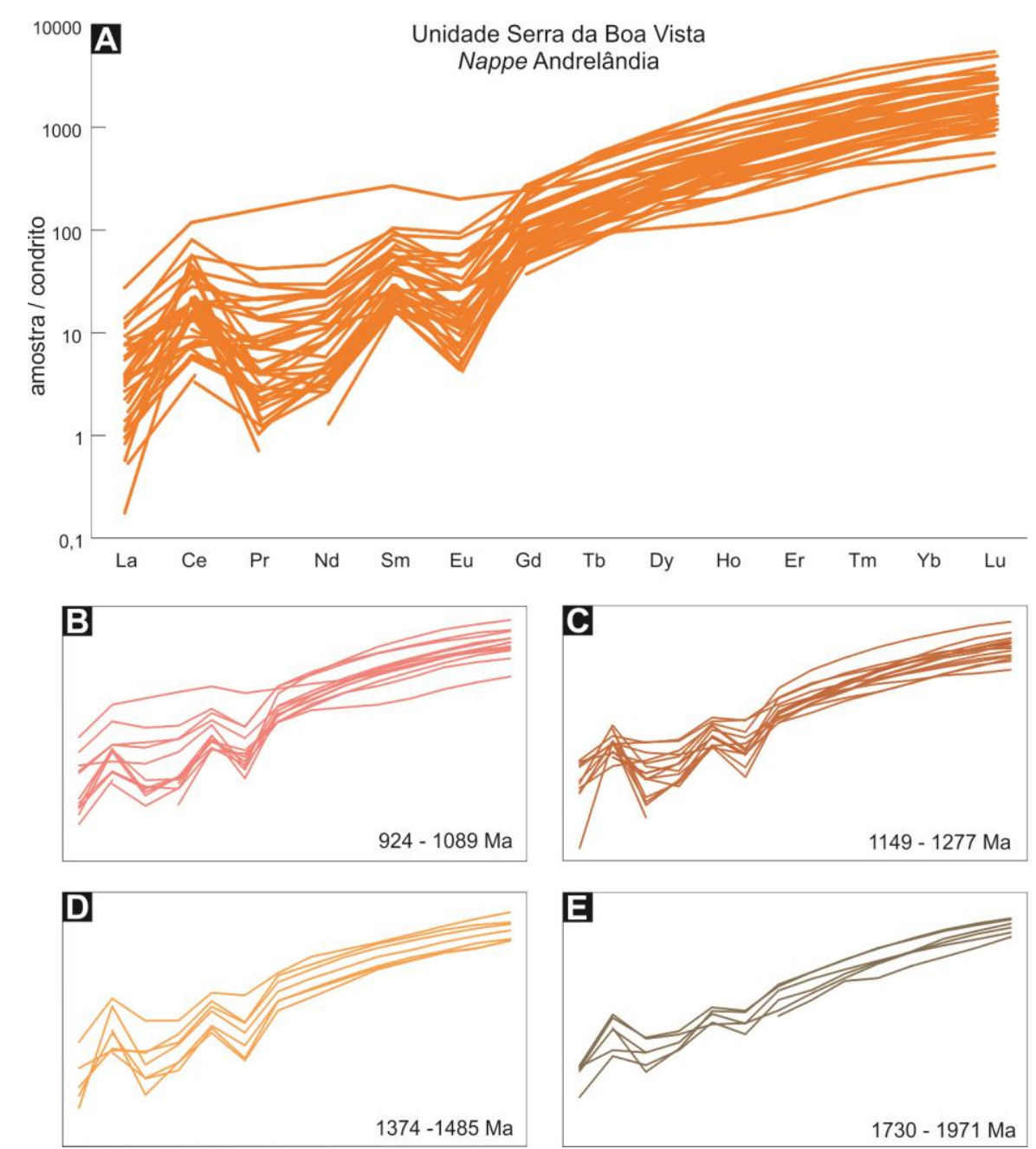

Figura 5-16. (A) Diagrama dos padrões da concentração dos ETR de todos os cristais de zircão analisados das rochas metassedimentares da Unidade Serra da Boa Vista; (B) Diagrama com os dados dos cristais de zircão com idades entre 924-1089 Ma; (C) Diagrama com os dados dos cristais de zircão com idades entre 1149-1277 Ma; (D) Diagrama com os dados dos cristais de zircão com idades entre 1374-1485 Ma; (E) Diagrama com os dados dos cristais de zircão com idades entre 1730-1971 Ma. Elementos normalizados pelo condrito C1 de Sun e McDonough (1989).

Grãos de zircão do Ectasiano-Calimiano (1374-1485 Ma) são os que tendem a apresentar enriquecimento relativamente brando em ETR pesados, com $\mathrm{Yb}_{N} / \mathrm{Gd}_{\mathrm{N}}$ entre 0,07 e 16,50. As anomalias negativas de Eu e as positivas de Ce são as mais acentuadas, com médias de 0,23 e 8,58, respectivamente (Figura 5-16 D). Já os cristais mais antigos analisados, do Estateriano-Orosiriano (1730-1971 Ma) são destacáveis do restante por apresentarem os maiores enriquecimentos em ETR pesados, as menores anomalias negativas de Eu e positivas de Ce, com médias de 0,50 e 3,05, respectivamente (Figura 5-16 E). 


\begin{tabular}{|c|c|c|c|c|c|}
\hline Idade (Ma) & $\begin{array}{c}\text { Qntde. de } \\
\text { análises }\end{array}$ & $\begin{array}{c}\text { Média da } \\
\text { qntd. de } \\
\text { ETR }(\mathrm{ppm})\end{array}$ & $\begin{array}{c}\text { Enriquecimento } \\
\text { em ETR pesados } \\
(\mathrm{Yb} / \mathrm{Gd}) \mathrm{N}\end{array}$ & $\begin{array}{c}\text { Anomalia de Eu } \\
\text { Eu/[(Sm+Gd)/2]N }\end{array}$ & $\begin{array}{c}\text { Anomalia de Ce } \\
\text { Ce/[(La+Pr)/2]N }\end{array}$ \\
\hline $924-1089$ & 7 & 842,47 & $\begin{array}{c}0,05 \text { a } 22,78 \\
\text { média }=10,96\end{array}$ & $\begin{array}{c}0,06 \text { a } 0,78 \\
\text { média }=0,26\end{array}$ & $\begin{array}{c}1,16 \text { a } 10,24 \\
\text { média }=3,82\end{array}$ \\
\hline $1149-1277$ & 14 & 880,23 & $\begin{array}{c}0,03 \text { a } 24,24 \\
\text { média }=8,39\end{array}$ & $\begin{array}{c}0,14 \text { a } 0,67 \\
\text { média }=0,32\end{array}$ & $\begin{array}{c}1,21 \text { a } 49,48 \\
\text { média }=8,29\end{array}$ \\
\hline $1374-1485$ & 7 & 976,74 & $\begin{array}{c}0,07 \text { a } 16,50 \\
\text { média }=9,01\end{array}$ & $\begin{array}{c}0,12 \text { a } 0,52 \\
\text { média }=0,23\end{array}$ & $\begin{array}{c}1,44 \text { a } 24,78 \\
\text { média }=8,58\end{array}$ \\
\hline $1730-1971$ & 7 & 996,98 & $\begin{array}{c}0,07 \text { a 31,91 } \\
\text { média }=15,91\end{array}$ & $\begin{array}{c}0,31 \text { a } 0,73 \\
\text { média }=0,50\end{array}$ & $\begin{array}{c}1,47 \text { a 4,58 } \\
\text { média }=3,05\end{array}$ \\
\hline
\end{tabular}

Tabela 5-4. Resumo dos parâmetros calculados em relação aos Elementos Terras Raras das amostras analisadas referentes à Unidade Serra da Boa Vista, da Nappe Andrelândia.

Comparativamente aos padrões das amostras das demais unidades estudadas, os cristais de zircão da Unidade Serra da Boa Vista tendem a apresentar os menores enriquecimentos em ETR pesados e as anomalias negativas de Eu mais acentuadas.

Pelos padrões observados dos ETR normalizados pelo condrito (Figura 5-16) podese dizer que todos os cristais de zircão encontrados nas amostras da Unidade Serra da Boa Vista apresentam anomalias negativas de Eu condizentes com a cristalização na presença de plagioclásio, cuja estabilidade se dá acima de aproximadamente $40 \mathrm{~km}$ de profundidade. Desta maneira as prováveis fontes destes cristais de zircão devem ter sido formadas em profundidades mais rasas que $40 \mathrm{~km}$.

Na árvore de discriminação de rocha-fonte de Belousova et al. (2002) da Figura 5-17, a grande maioria dos cristais detríticos, do início do Neoproterozoico ao Paleoproterozoico, estão plotados nos membros que se referem à granitoides (probabilidade de acerto de mais de $75 \%$ ) e em menor quantidade, indicam que a segunda fonte principal seriam rochas máficas de composição semelhante à de um diabásio (probabilidade de acerto de mais de $80 \%)$. Apenas um cristal referente do Ectasiano indicou que sua fonte poderia ser uma rocha basáltica (probabilidade de acerto de mais de $80 \%$ ), e outro cristal do Ectasiano e um do Toniano demonstraram que sua fonte poderia ser uma rocha carbonatítica (probabilidade de acerto de mais de 80\%). No entanto, vale ressaltar que segundo Belousova et al. (2002), o padrão dos cristais de zircão provenientes de rochas carbonatíticas não apresentam anomalias negativas de $\mathrm{Eu}$, divergindo do que é observado em todas as análises aqui apresentadas. 


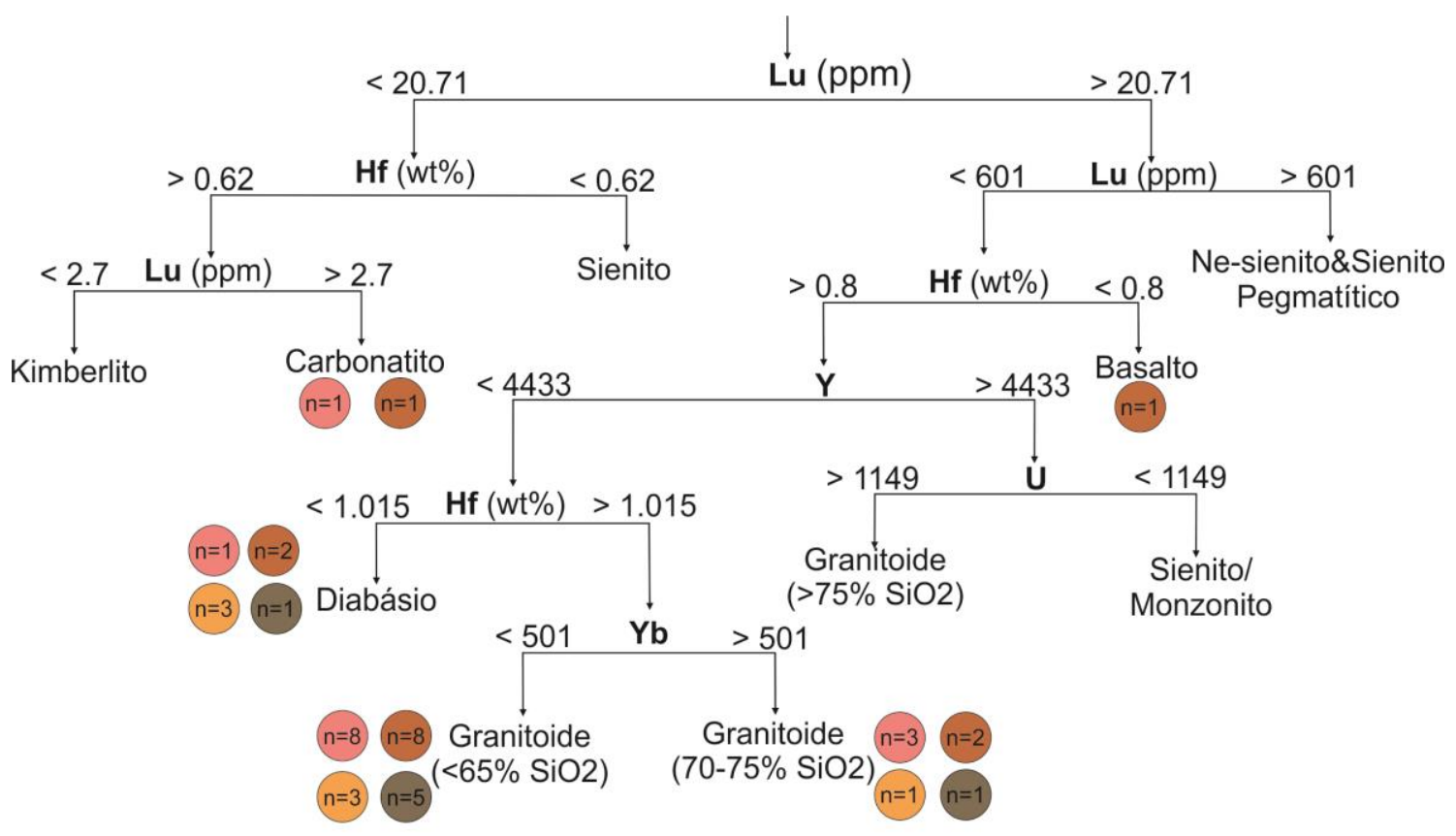

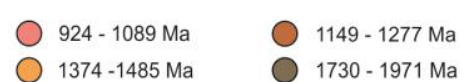

Figura 5-17. Árvore de classificação e regressão para o reconhecimento de cristais de zircão provenientes de diversos tipos de rocha retirado de Belousova et al. (2002), com os dados dos cristais detríticos de zircão das rochas da Unidade Serra da Boa Vista. Cada cor indica uma idade e os números inseridos nas formas indicam a quantidade de dados com o mesmo resultado.

Segundo a mesma árvore classificatória, um destaque pode ser feito para os $75 \%$ dos cristais do Ectasiano-Calimiano (1374-1485 Ma) que indicam fonte de composição básica, semelhante à diabásica.

No diagrama da Figura 5-18 A, grande parte dos cristais de zircão são compatíveis com ambiente de arco magmático e crosta continental com fontes possivelmente de composições mais félsicas, no entanto, novamente, um destaque é feito para os grãos do Ectasiano-Calimiano (1374-1485 Ma), de cor laranja no diagrama, que apresentam maiores concentrações de $\mathrm{Y}$ e menores razões $\mathrm{U} / \mathrm{Yb}$ e caminham para composições mais máficas. Segundo o diagrama da Figura 5-18 B quase que a total composição dos cristais são plotados em campos referentes à fontes félsicas - granodioritos, tonalitos, aplitos e leucogranitos - enquanto que apenas um cristal do Ectasiano-Calimiano encontra-se em campos referentes à composições mais máficas.

Observando em conjunto os dois diagramas da Figura 5-18 pode-se dizer que a grande maioria dos cristais de zircão, não importando a idade, encontram-se próximos aos campos referentes às rochas félsicas continentais podendo estar em ambiente de arco magmático. 


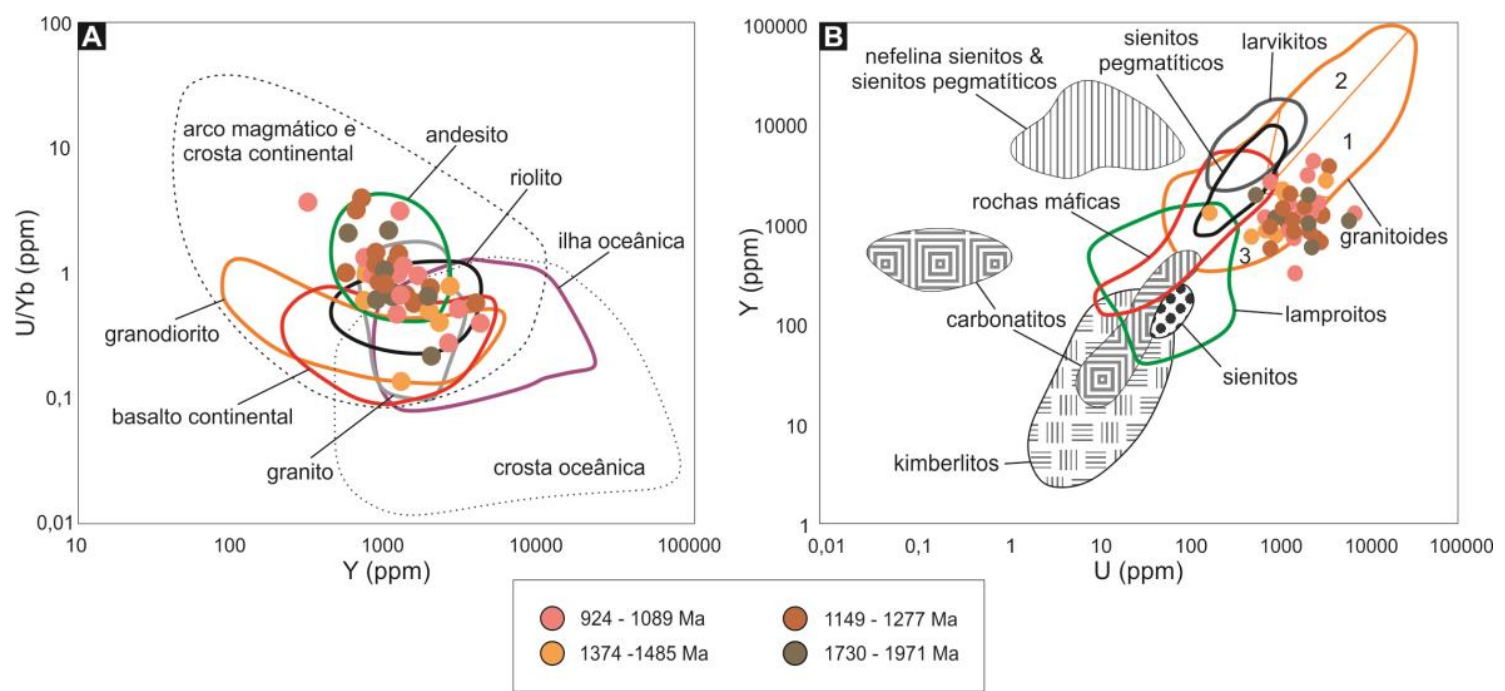

Figura 5-18. Diagrama U/Yb versus $\mathrm{Y}$ (ambos em ppm) com os campos de arco magmático e crosta continental e crosta oceânica de Grimes et al. (2007), os demais campos foram retirados de Teixeira (2015) que compilou os dados disponibilizados por GEOROC; (B) Diagrama Y versus U (ambos em ppm) discriminante para diversos tipos de rocha retirado de_Belousova et al. (2002), onde os campos em 'granitoides' correspondem à (1) aplitos e leucogranitos, (2) granitos e (3) granodioritos e tonalitos. Os dados em ambos os diagramas correspondem aos cristais detríticos de zircão das rochas referentes à Unidade Serra da Boa Vista, onde cada cor corresponde a um intervalo de idade.

Sendo assim, é provável que as fontes dos cristais de zircão da Unidade Serra da Boa Vista, além de apresentarem idades que variam do início do Neoproterozoico ao final do Paleoproterozoico, foram formadas em profundidades menores que $40 \mathrm{~km}$ e que a maioria delas seja de composição félsica, podendo ocorrer influências de rochas de composição máfica, principalmente nos intervalos do fim-Ectasiano e Ectasiano-Calimiano.

\subsubsection{Unidade Santo Antônio}

Os padrões de ETR dos cristais da Unidade Santo Antônio são relativamente semelhantes entre os diferentes grupos de idades, no entanto são destacáveis padrões com pequenas anomalias de Eu e Ce (Figura 5-19 A). A Tabela 5-5 exibe os parâmetros calculados a partir das concentrações de ETR nos cristais de zircão analisados.

Cristais do Ediacarano-fim Toniano (682-699 Ma) apresentam diferentes graus de enriquecimento em ETR pesados, de 1,72 à 32,29, assim como anomalias negativas de Eu variáveis entre 0,03 e 0,69 (Figura 5-19 B). Os grãos do fim-Toniano (764-785 Ma) são os menos enriquecidos em ETR pesados, e suas anomalias negativas de Eu são bastante variáveis, ocorrendo padrões com anomalias proeminentes $(0,20)$ e padrões com anomalias fracas $(0,74)$. Da mesma forma as anomalias positivas de Ce $(1,06$ à 7,90$)$ variam de proeminentes à discretas (Figura 5-19 C). 

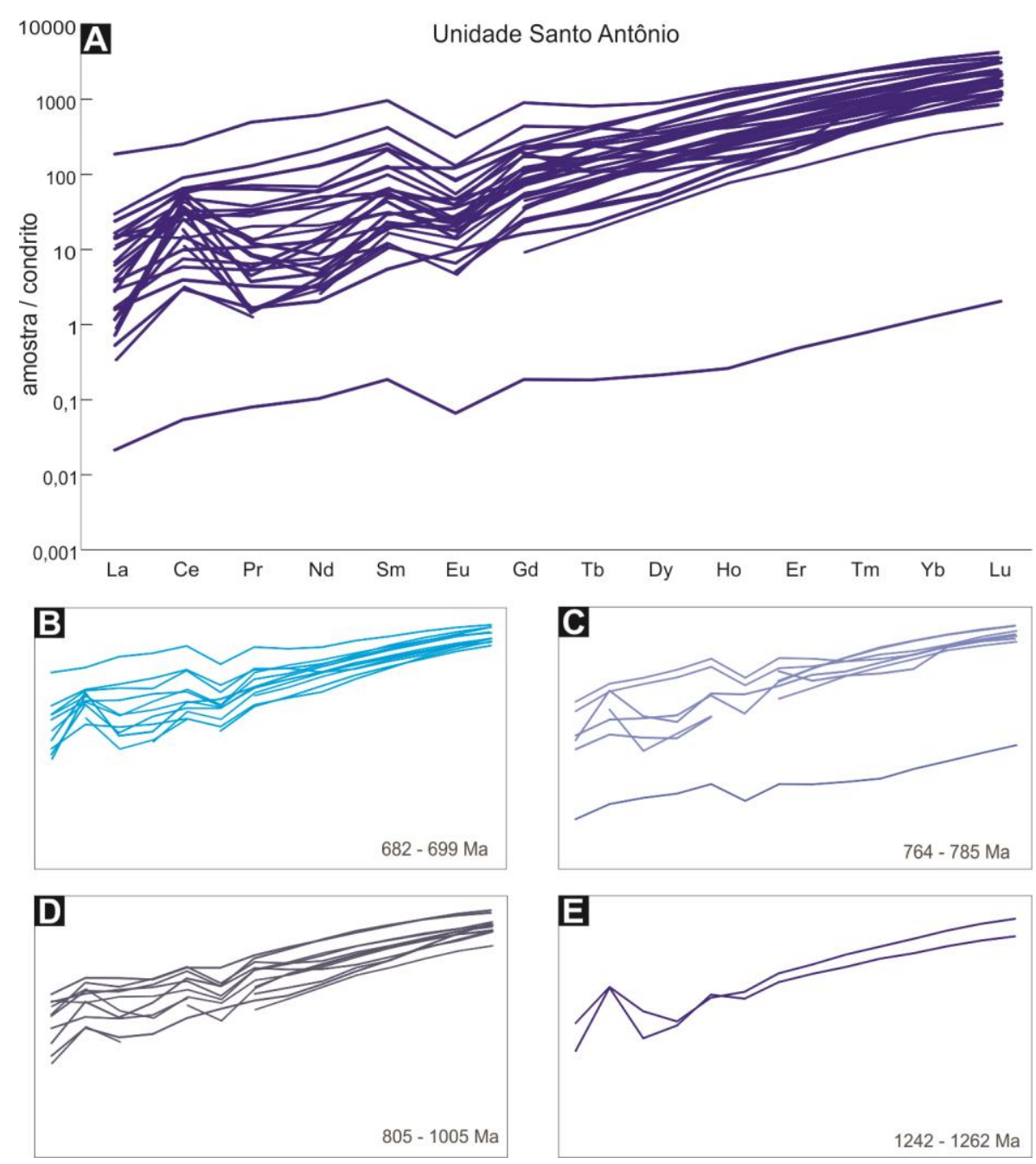

Figura 5-19. (A) Diagrama dos padrões da concentração dos ETR de todos os cristais de zircão analisados das rochas metassedimentares da Unidade Santo Antônio; (B) Diagrama com os dados dos cristais de zircão com idades entre 682-699 Ma; (C) Diagrama com os dados dos cristais de zircão com idades entre 764-785 Ma; (D) Diagrama com os dados dos cristais de zircão com idades entre 805-1005 Ma; (E) Diagrama com os dados dos cristais de zircão com idades entre 1242-1262 Ma. Elementos normalizados pelo condrito C1 de Sun e McDonough (1989).

Os cristais do Toniano (805-1005 Ma), diferentemente dos grãos do intervalo de idades anterior, são os mais enriquecidos em ETR pesados (média $Y b_{N} / G_{N}$ de 22,03). Alguns cristais apresentam anomalias negativas de Eu proeminentes $(0,20)$ enquanto que em outros, estas anomalias são imperceptíveis $(0,89)$. As anomalias positivas de $\mathrm{Ce}$, por mais variáveis que sejam, são baixas (Figura 5-19 D). O intervalo de idades mais antigo cujos cristais foram analisados é do Ectasiano (1242-1262 Ma). Estes grãos apresentam pequenas anomalias negativas de Eu $(0,51)$ e as maiores anomalias positivas de $\mathrm{Ce}$ da unidade (Figura 5-19 E). 


\begin{tabular}{|c|c|c|c|c|c|}
\hline Idade (Ma) & $\begin{array}{c}\text { Qntde. de } \\
\text { análises }\end{array}$ & $\begin{array}{c}\text { Média da } \\
\text { qntd. de } \\
\text { ETR }(\mathrm{ppm})\end{array}$ & $\begin{array}{c}\text { Enriquecimento } \\
\text { em ETR pesados } \\
(\mathrm{Yb} / \mathrm{Gd}) \mathrm{N}\end{array}$ & $\begin{array}{c}\text { Anomalia de } \mathrm{Eu} \\
\mathrm{Eu} /[(\mathrm{Sm}+\mathrm{Gd}) / 2] \mathrm{N}\end{array}$ & $\begin{array}{c}\text { Anomalia de Ce } \\
\mathrm{Ce} /[(\mathrm{La}+\mathrm{Pr}) / 2] \mathrm{N}\end{array}$ \\
\hline $682-699$ & 13 & 804,5 & $\begin{array}{c}1,72 \text { a } 32,29 \\
\text { média }=16,33\end{array}$ & $\begin{array}{c}0,03 \text { a } 0,69 \\
\text { média }=0,34\end{array}$ & $\begin{array}{c}0,74 \text { a } 16,45 \\
\text { média }=5,23\end{array}$ \\
\hline $764-785$ & 8 & 912,69 & $\begin{array}{c}3,04 \text { a } 26,50 \\
\text { média }=14,4\end{array}$ & $\begin{array}{c}0,20 \text { a } 0,74 \\
\text { média }=0,38\end{array}$ & $\begin{array}{c}1,06 \text { a } 7,90 \\
\text { média }=2,36\end{array}$ \\
\hline $805-1005$ & 12 & 808,55 & $\begin{array}{c}0,03 \text { a } 60,36 \\
\text { média }=22,03\end{array}$ & $\begin{array}{c}0,20 \text { a } 0,89 \\
\text { média }=0,39\end{array}$ & $\begin{array}{c}0,79 \text { a } 4,37 \\
\text { média }=2,30\end{array}$ \\
\hline $1242-1262$ & 2 & 699,54 & $\begin{array}{c}13,02 \text { a } 21,30 \\
\text { média }=17,16\end{array}$ & $\begin{array}{c}0,50 \text { a } 0,53 \\
\text { média }=0,51\end{array}$ & $\begin{array}{c}6,05 \text { a } 31,1 \\
\text { média }=18,58\end{array}$ \\
\hline
\end{tabular}

Tabela 5-5. Resumo dos parâmetros calculados em relação aos Elementos Terras Raras das amostras estudadas da Unidade Santo Antônio, da Nappe Andrelândia.

$\mathrm{Na}$ Unidade Santo Antônio ocorrem a maior parte dos cristais de zircão analisados com as menores anomalias de Eu. São os grãos mais empobrecidos em ETR e com as menores anomalias positivas de Ce. Grande parte das análises individuais também apresenta padrões menos enriquecidos em ETR pesados, tendendo à linhas menos inclinadas.

As presença de anomalias negativas de Eu são consistentes com rochas formadas em profundidades relativamente rasas, no entanto alguns cristais de zircão exibem padrões cujas anomalias são quase imperceptíveis, podendo estar associadas à rochas onde a presença de plagioclásio, principal causador de anomalias negativas de Eu em zircão, não fosse uma fase mineral importante.

A Figura 5-20 exibe a árvore de classificação de rocha-fonte de Belousova et al. (2002) na qual é possível observar que $80 \%$ dos dados da Unidade Santo Antônio exibe afinidade com rochas granitoides e em menor quantidade (11\%) com rochas de composição máfica. Apenas três cristais exibem afinidade com rochas kimberlíticas, sieníticas e carbonatíticas, no entanto, neste mesmo trabalho, os cristais de zircão provenientes de destas rochas não exibiriam anomalias de Eu, fato que é observado, mesmo que sutil, na grande maioria dos cristais de zircão aqui estudados. 


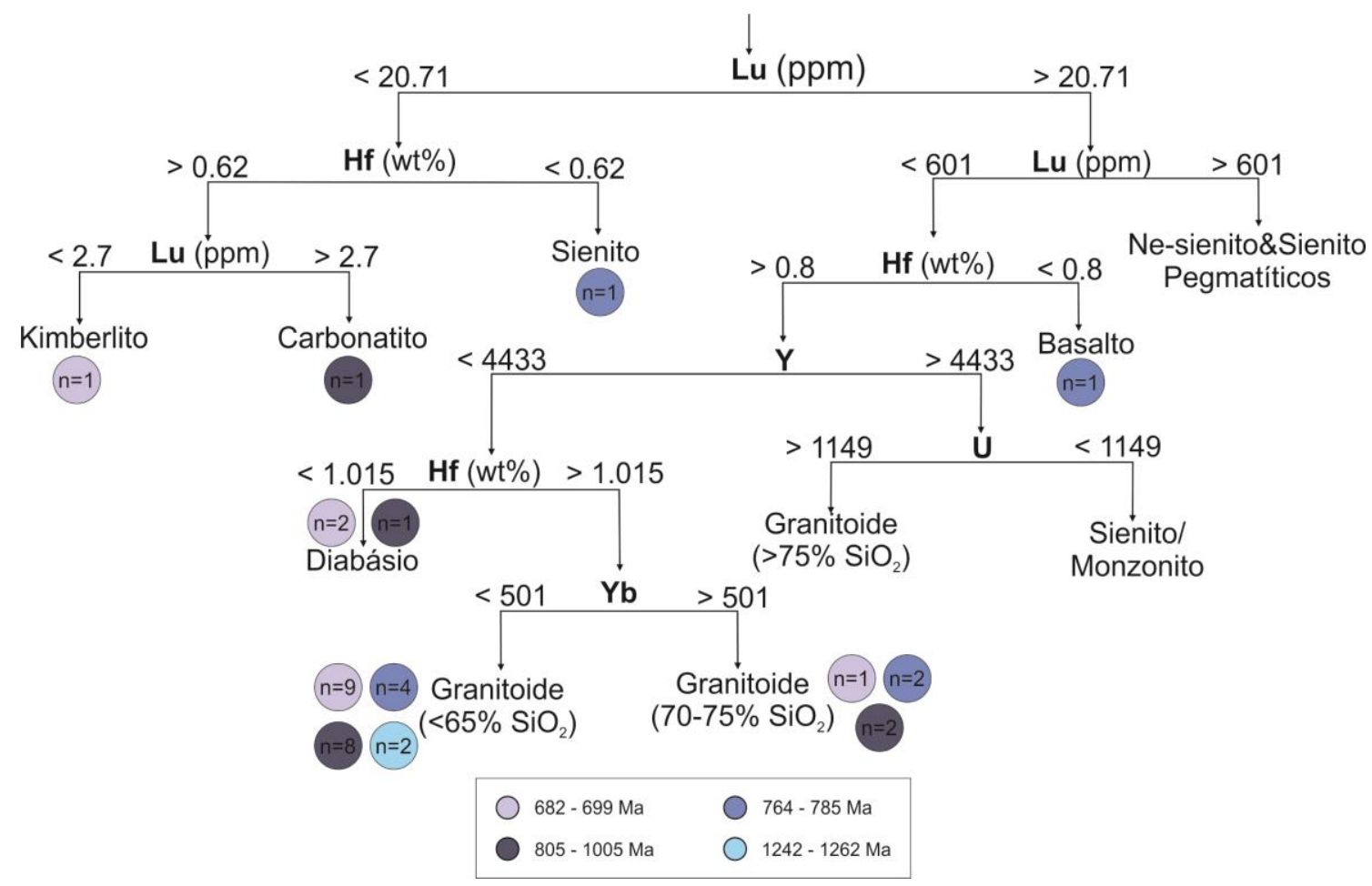

Figura 5-20. Árvore de classificação e regressão para o reconhecimento de cristais de zircão provenientes de diversos tipos de rocha retirado de Belousova et al. (2002), com os dados dos cristais de zircão das rochas da Unidade Santo Antônio. Cada cor indica uma idade e os números inseridos nas formas indicam a quantidade de dados com o mesmo resultado.

Pode-se perceber que, além da influência maioritária de rochas granitoides como fonte principal, a presença de outros tipos de rocha como fonte secundária ocorre somente nas idades mais jovens que $\sim 970 \mathrm{Ma}$.

O diagrama da Figura 5-21 A, com ambientes tectônicos e litologias distintos, sugere que os cristais de zircão da Unidade Santo Antônio tenham afinidade com ambiente de arco magmático e crosta continental, principalmente os grãos do Toniano (805-1005 Ma) com as maiores razões $\mathrm{U} / \mathrm{Yb}$ e as menores concentrações de $\mathrm{Y}$. O diagrama da Figura 5-21 B indica que os cristais de zircão apresentam compatibilidade com fontes granodioríticas, tonalíticas e rochas máficas. 


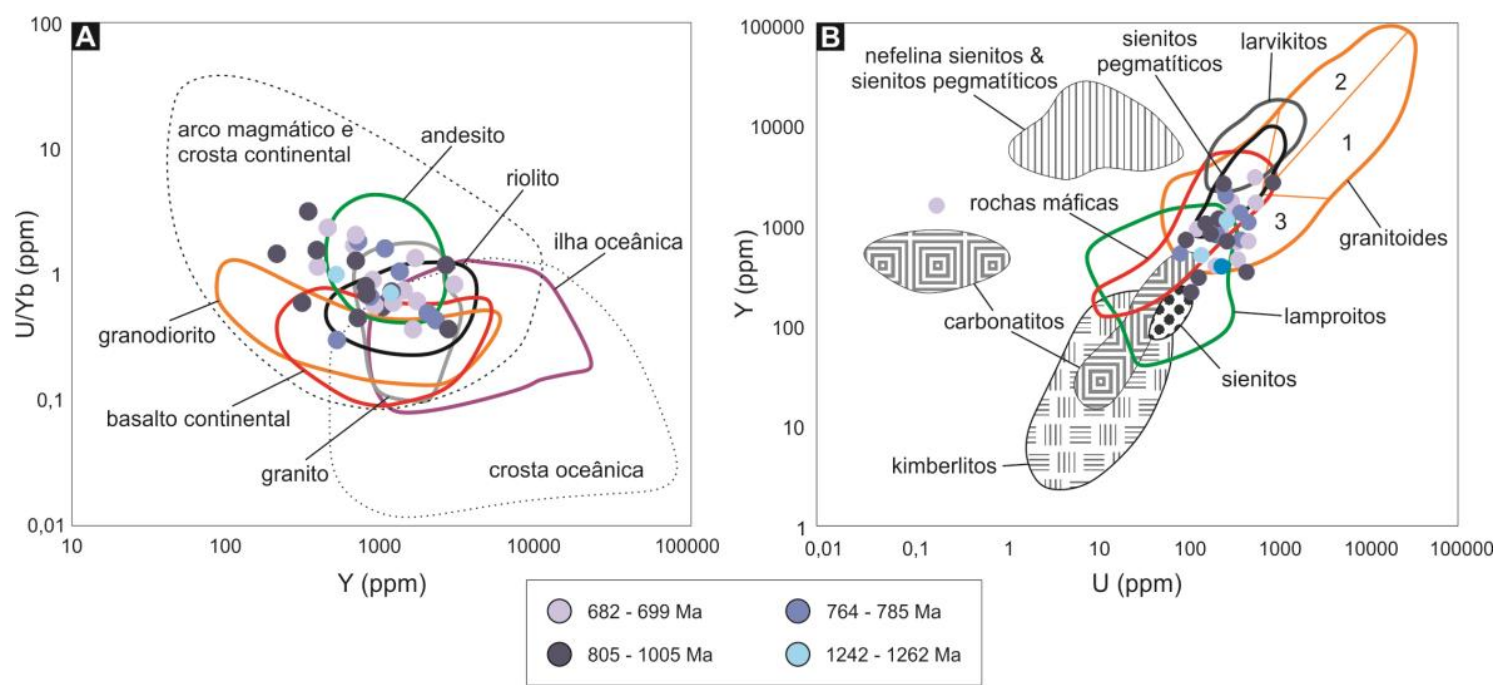

Figura 5-21. Diagrama U/Yb versus $\mathrm{Y}$ (ambos em ppm) com os campos de arco magmático e crosta continental e crosta oceânica de Grimes et al. (2007), os demais campos foram retirados de Teixeira (2015) que compilou os dados disponibilizados por GEOROC; (B) Diagrama $Y$ versus $U$ (ambos em ppm) discriminante para diversos tipos de rocha retirado de Belousova et al. (2002), onde os campos em 'granitoides' correspondem à (1) aplitos e leucogranitos, (2) granitos e (3) granodioritos e tonalitos. Os dados em ambos os diagramas correspondem aos cristais de zircão das rochas referentes à Unidade Santo Antônio, onde cada cor corresponde a um intervalo de idade.

Desta forma pode-se dizer que os cristais de zircão das três amostras da Unidade Santo Antônio indicam rochas granitoides como fonte principal associadas à rochas máficas possivelmente relacionadas à ambientes de arco magmático, onde a maioria tivesse se formado a profundidades menores do que $40 \mathrm{~km}$.

\subsubsection{Nappe Liberdade}

Os cristais de zircão das rochas metassedimentares da Nappe Liberdade, em geral, apresentam padrões enriquecidos em ETR pesados com anomalias negativas de Eu e positivas de Ce proeminentes (Figura 5-22). A Tabela 5-6 reúne os parâmetros calculados através das concentrações de ETR para os cristais de zircão desta unidade.

Grãos do Toniano (791 Ma) apresentam as maiores concentrações de ETR por análise, são os mais enriquecidos em ETR pesados e seus padrões apresentam tanto anomalias negativas quanto positivas de Eu. No entanto as anomalias positivas de Ce são praticamente imperceptíveis (Figura 5-22 B). Do Esteniano-Ectasiano (1093-1240 Ma), e Calimiano (1515 Ma) os cristais de zircão apresentam enriquecimento em ETR pesados semelhantes, com médias de $\mathrm{Yb}_{\mathrm{N}} / \mathrm{Gd}_{\mathrm{N}}$ entre 15,50 e 16,65, e com anomalias negativas de Eu relativamente a altas $(0,08)$ e baixas $(0,63)$, respectivamente. O mesmo ocorre com as anomalias positivas de Ce, que variam de proeminentes a quase imperceptíveis (Figura 5-22 C e D). 

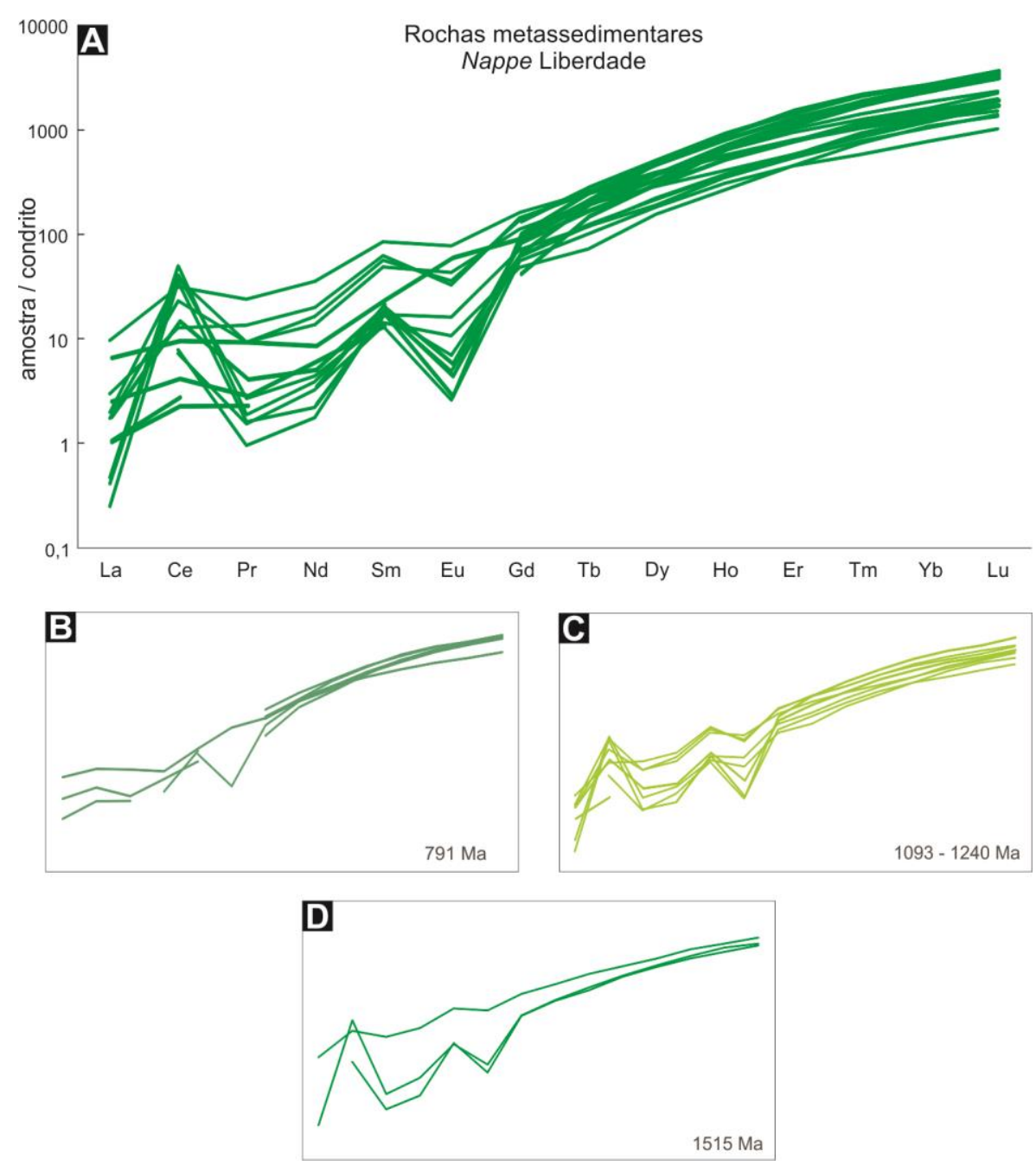

Figura 5-22. (A) Diagrama dos padrões da concentração dos ETR de todos os cristais de zircão analisados das rochas metassedimentares da Nappe Liberdade; (B) Diagrama com os dados dos cristais de zircão com idades entre $791 \mathrm{Ma}$; (C) Diagrama com os dados dos cristais de zircão com idades entre 1093-1240 Ma; (D) Diagrama com os dados dos cristais de zircão com idades entre $1515 \mathrm{Ma}$. Elementos normalizados pelo condrito $\mathrm{C} 1 \mathrm{de}$ Sun e McDonough (1989).

Comparativamente com as demais unidades, os padrões do ETR nos cristais de zircão das rochas metassedimentares da Nappe Liberdade apresentam os maiores enriquecimentos em ETR pesados, com anomalias positivas de Ce e negativas de Eu importantes.

Todas as análises possuem características e padrões típicos de rochas ígneas crustais pelo empobrecimento em ETR leves em relação aos pesados, anomalias negativas de Eu e anomalias positivas de Ce. As análises do intervalo do Toniano, mesmo que exibam baixíssimos valores de anomalias positivas de Ce e anomalia positiva de Eu, também se encaixam nestas características, que é suportada pela assinatura isotópica crustal de Lu-Hf. 


\begin{tabular}{|c|c|c|c|c|c|}
\hline Idade (Ma) & $\begin{array}{c}\text { Qntde. de } \\
\text { análises }\end{array}$ & $\begin{array}{c}\text { Média da } \\
\text { qntd. de } \\
\text { ETR }(\mathrm{ppm})\end{array}$ & $\begin{array}{c}\text { Enriquecimento } \\
\text { em ETR pesados } \\
(\mathrm{Yb} / \mathrm{Gd}) \mathrm{N}\end{array}$ & $\begin{array}{c}\text { Anomalia de Eu } \\
\text { Eu/[(Sm+Gd)/2]N }\end{array}$ & $\begin{array}{c}\text { Anomalia de Ce } \\
\mathrm{Ce} /[(\mathrm{La}+\mathrm{Pr}) / 2] \mathrm{N}\end{array}$ \\
\hline 791 & 6 & 1331,88 & $\begin{array}{c}13,59 \text { a } 36,91 \\
\text { média }=31,09\end{array}$ & $\begin{array}{c}0,10 \text { a } 1,04 \\
\text { média }=0,57\end{array}$ & $\begin{array}{c}1,20 \text { a } 1,55 \\
\text { média }=1,37\end{array}$ \\
\hline $1093-1240$ & 8 & 842,01 & $\begin{array}{c}12,83 \text { a } 36,91 \\
\text { média }=16,65\end{array}$ & $\begin{array}{c}0,08 \text { a } 0,54 \\
\text { média }=0,29\end{array}$ & $\begin{array}{c}1,20 \text { a } 37,31 \\
\text { média }=12,57\end{array}$ \\
\hline 1515 & 3 & 781,09 & $\begin{array}{c}9,28 \text { a } 20,16 \\
\text { média }=15,50\end{array}$ & $\begin{array}{c}0,12 \text { a } 0,63 \\
\text { média }=0,31\end{array}$ & $\begin{array}{c}1,86 \text { a } 42,19 \\
\text { média }=20,15\end{array}$ \\
\hline
\end{tabular}

Tabela 5-6. Resumo dos parâmetros calculados em relação aos Elementos Terras Raras das amostras SNA172E e SNA-180A da Nappe Liberdade.

Os padrões de ETR em zircão detrítico das rochas metassedimentares da Nappe Liberdade podem indicar que suas principais fontes se formaram em profundidades menores que $40 \mathrm{~km}$ devido à presença de anomalias negativas de Eu associadas à presença de plagioclásio, cujo campo de estabilidade se dá em menores profundidades.

A árvore de classificação de rochas-fonte de Belousova et al. (2002) indica que as principais fontes dos sedimentos das rochas aqui discutidas eram granitoides (Figura 5-23), no entanto um terço dos cristais do Calimiano sugere fonte com afinidade máfica.

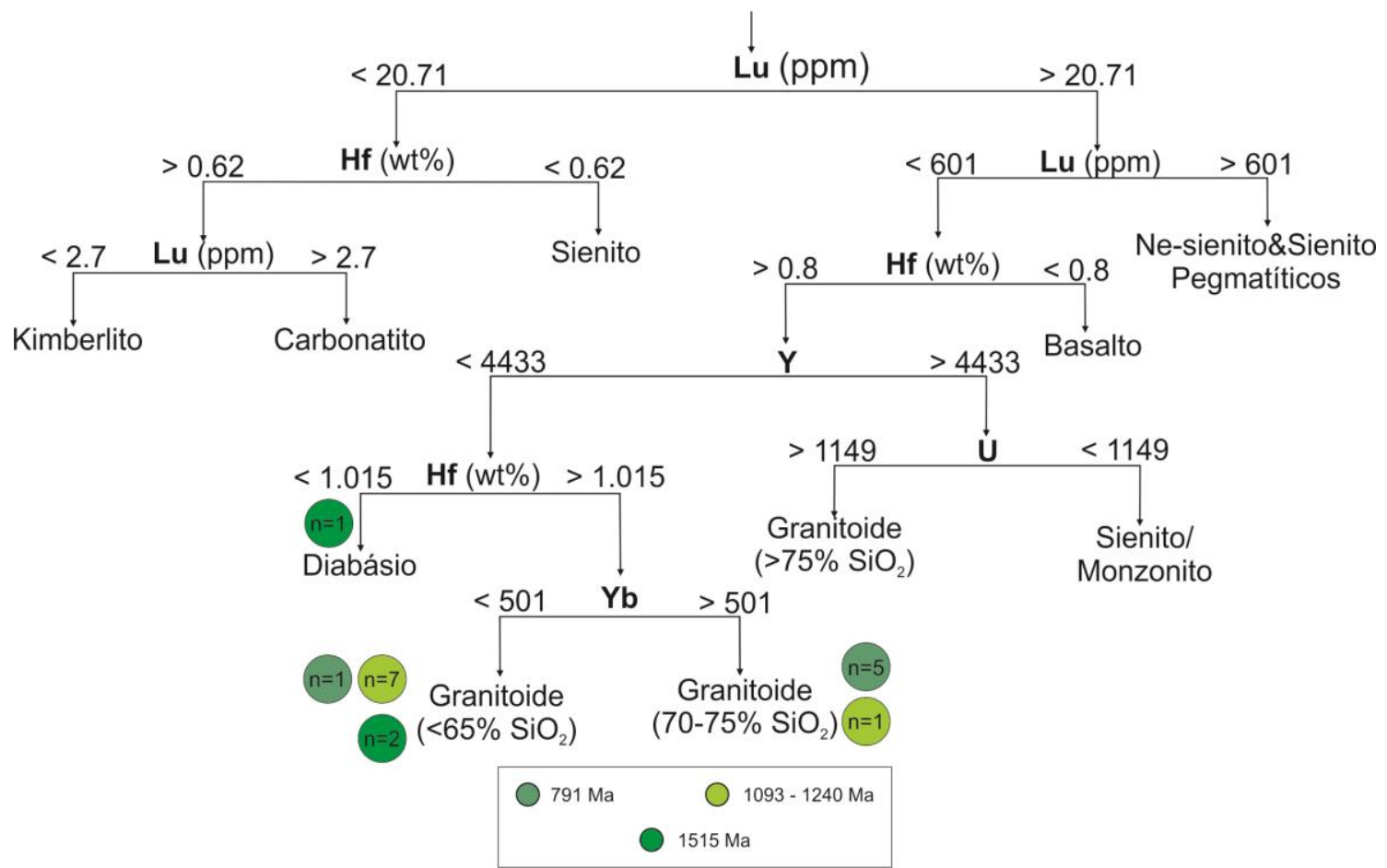

Figura 5-23. Árvore de classificação e regressão para o reconhecimento de cristais de zircão provenientes de diversos tipos de rocha retirado de Belousova et al. (2002), com os dados dos cristais de zircão detríticos das rochas da Nappe Liberdade. Cada cor indica uma idade e os números inseridos nas formas indicam a quantidade de dados com o mesmo resultado.

A partir dos diagramas de discriminação da Figura 5-24 pode-se dizer que as principais fontes dos sedimentos estariam relacionadas à arco magmático e crosta 132 
continental, com composições que variariam entre andesítica, riolítica, granítica e de composições mais máficas.

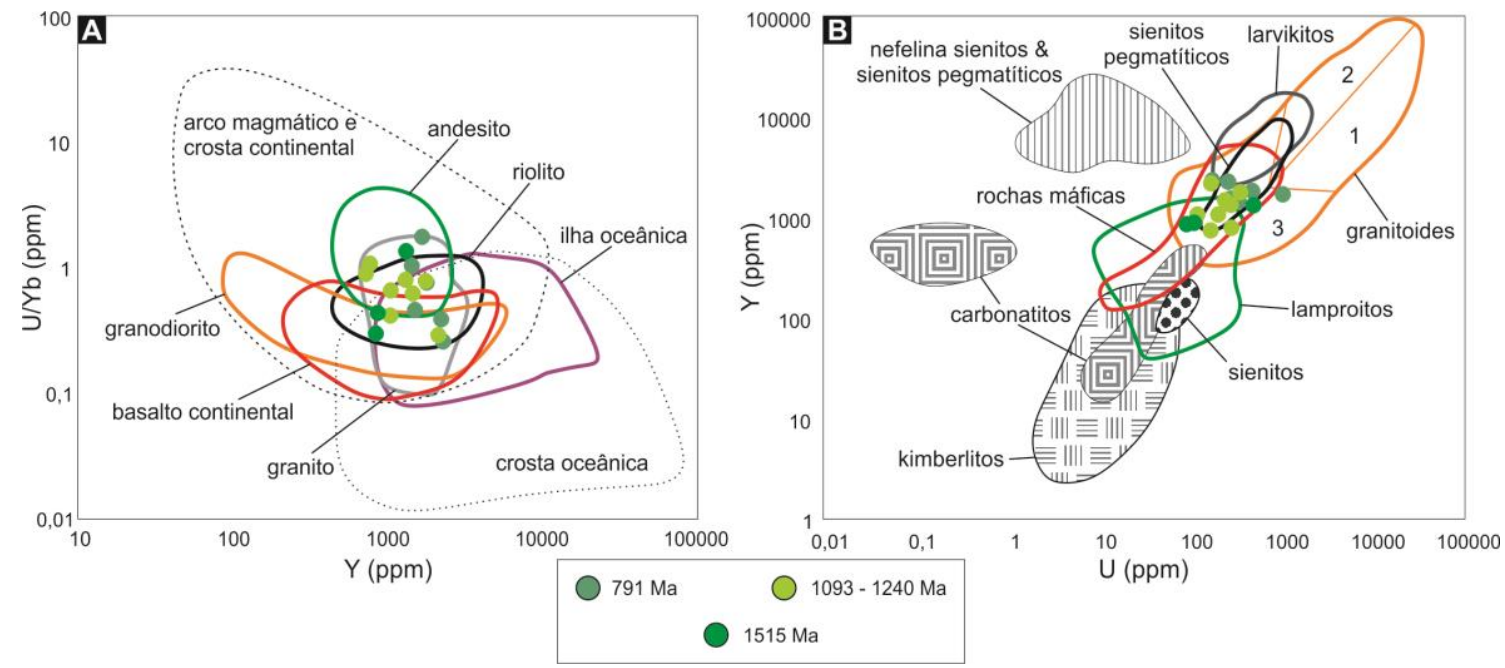

Figura 5-24. (A) Diagrama $\mathrm{U} / \mathrm{Yb}$ versus $\mathrm{Y}$ (ambos em ppm) com os campos de arco magmático e crosta continental e crosta oceânica de Grimes et al. (2007), os demais campos foram retirados de Teixeira (2015) que compilou os dados disponibilizados por GEOROC; (B) Diagrama Y versus $U$ (ambos em ppm) discriminante para diversos tipos de rocha retirado de Belousova et al. (2002), onde os campos em 'granitoides' correspondem à (1) aplitos e leucogranitos, (2) granitos e (3) granodioritos e tonalitos. Os dados em ambos os diagramas correspondem aos cristais de zircão detríticos das rochas metassedimentares da Nappe Liberdade, onde cada cor corresponde a uma idade e cada formato à uma amostra.

Sendo assim, os cristais de zircão analisados da Nappe Liberdade indicam que suas rochas-fontes principais teriam afinidade mais félsica, formadas em profundidades não maiores que $40 \mathrm{~km}$ e possivelmente relacionadas à ambientes de arco magmático.

\subsection{Idades máximas de sedimentação (IMS)}

As idades máximas de sedimentação podem ser abordadas pela idade mais jovem resultante do conjunto de dados mais novos, com MSWD menor ou igual a 1 (que será tratada como IMS-conjunto), ou a idade do cristal individual concordante (100\%) mais jovem (que será tratadam como IMS-individual). A Tabela 5-7 exibe os dados através destas duas abordagens, e para efeito de discussão foram inseridas tanto as idades ${ }^{207} \mathrm{~Pb} /{ }^{206} \mathrm{~Pb}$ como as ${ }^{206} \mathrm{~Pb} /{ }^{238} \mathrm{U}$. Primeiramente será discutido a idade máxima de sedimentação por unidade e então uma comparação entre as IMS e o que isto poderia significar em termos tectônicos. 


\begin{tabular}{|c|c|c|c|c|c|c|}
\hline \multirow{2}{*}{\multicolumn{2}{|c|}{ Unidade/Amostra }} & \multirow{2}{*}{ rocha } & \multicolumn{2}{|c|}{$207 / 206(\mathrm{Ma})$} & \multicolumn{2}{|c|}{ 206/238 (Ma) } \\
\hline & & & conjunto & individual & conjunto & individual \\
\hline \multirow{5}{*}{ 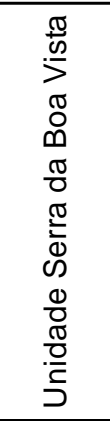 } & SNA-125 & \multirow{3}{*}{ metapelito } & $\begin{array}{c}1089 \pm 54 \\
(n=8)\end{array}$ & $1129 \pm 92$ & $\begin{array}{c}977 \pm 16 \\
(n=4)\end{array}$ & $1133 \pm 16$ \\
\hline & SNA-228 & & $\begin{array}{c}924 \pm 37 \\
(n=7)\end{array}$ & $967 \pm 106$ & $\begin{array}{c}947 \pm 7 \\
(n=7)\end{array}$ & $969 \pm 20$ \\
\hline & $\begin{array}{c}\text { NESG- } \\
1434\end{array}$ & & $\begin{array}{c}1114 \pm 66 \\
(n=3)\end{array}$ & $\begin{array}{c}885 \pm 70 \\
(101 \%)\end{array}$ & (2) & $\begin{array}{c}896 \pm 18 \\
(101 \%)\end{array}$ \\
\hline & SNA-116 & \multirow{2}{*}{ metapsamito } & $\begin{array}{c}964 \pm 22 \\
(n=9)\end{array}$ & $966 \pm 58$ & $\begin{array}{c}924 \pm 9 \\
(n=2)\end{array}$ & $975 \pm 16$ \\
\hline & SNA-213 & & $\begin{array}{c}978 \pm 39 \\
(\mathrm{n}=6)\end{array}$ & $1105 \pm 118$ & $\begin{array}{c}901 \pm 10 \\
(n=2)\end{array}$ & $1112 \pm 24$ \\
\hline \multirow{3}{*}{ 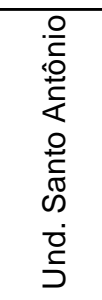 } & SNA-201 & \multirow[b]{2}{*}{ metawacke } & $\begin{array}{c}682 \pm 56 \\
(n=10)\end{array}$ & $660 \pm 110$ & $\begin{array}{c}632 \pm 16 \\
(n=2)\end{array}$ & $663 \pm 14$ \\
\hline & $\begin{array}{c}\text { NESG- } \\
1010\end{array}$ & & $\begin{array}{c}686 \pm 14 \\
(n=11)\end{array}$ & $680 \pm 62$ & $\begin{array}{c}687 \pm 3 \\
(n=6)\end{array}$ & $\begin{array}{c}681 \pm 8 \\
648 \pm 8 \\
(99 \%)\end{array}$ \\
\hline & $\begin{array}{c}\text { NESG- } \\
1552\end{array}$ & anfibolito & $\begin{array}{c}699 \pm 30 \\
(n=3)\end{array}$ & $672 \pm 57$ & - & $672 \pm 16$ \\
\hline \multirow{2}{*}{ 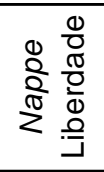 } & SNA-172E & metapelito & $\begin{array}{c}791 \pm 28 \\
(n=44)\end{array}$ & $756 \pm 122$ & $\begin{array}{c}718 \pm 11 \\
(n=2)\end{array}$ & $761 \pm 14$ \\
\hline & SNA-180A & metapsamito & $\begin{array}{c}1095 \pm 30 \\
(n=11)\end{array}$ & $1119 \pm 80$ & $\begin{array}{c}1038 \pm 12 \\
(n=4)\end{array}$ & $1125 \pm 28$ \\
\hline
\end{tabular}

Tabela 5-7. Resumo das idades máximas de sedimentação (IMS) das rochas metassedimentares estudadas. Observar que tanto para as idades ${ }^{207} \mathrm{~Pb} /{ }^{206} \mathrm{~Pb}$ como para as ${ }^{206} \mathrm{~Pb} /{ }^{238} \mathrm{U}$, foram inseridos os dados provenientes do grupo de idades mais jovem assim como a idade do cristal individual mais jovem. As idades resultantes de um conjunto de dados foram geradas a partir de diagramas weighted average com MSWD menor que 1,0. As idades individuais correspondem à concordância de 100\%, exceto três que estão destacadas com suas respectivas concordâncias (99\% ou 101\%).

Em todas as amostras as idades através de conjuntos ${ }^{206} \mathrm{~Pb} /{ }^{238} \mathrm{U}$ são mais jovens do que as ${ }^{207} \mathrm{~Pb} /{ }^{206} \mathrm{~Pb}$, no entanto quando se olha para as idades do cristal individual mais jovem, esta relação é inversa. É possível observar também que os erros, todos em $2 \sigma$, são consideravelmente menores nas idades ${ }^{206} \mathrm{~Pb} /{ }^{238} \mathrm{U}$ do que nas ${ }^{207} \mathrm{~Pb} /{ }^{206} \mathrm{~Pb}$, no entanto a representatividade do dado ${ }^{206} \mathrm{~Pb} /{ }^{238} \mathrm{U}$ é menor. Um exemplo é o caso da amostra SNA172E: a idade resultante de um conjunto de dados ${ }^{207} \mathrm{~Pb} /{ }^{206} \mathrm{~Pb}(791 \pm 28 \mathrm{Ma})$ é sustentada por 44 dados, enquanto que a ${ }^{206} \mathrm{~Pb} /{ }^{238} \mathrm{U}(718 \pm 11 \mathrm{Ma})$, apenas por dois.

As amostras da Unidade Serra da Boa Vista apresentam IMS-conjunto ${ }^{207} \mathrm{~Pb} /{ }^{206} \mathrm{~Pb}$ entre $924 \pm 37 \mathrm{Ma}$ e $1114 \pm 66 \mathrm{Ma}$ e IMS-individual ${ }^{207} \mathrm{~Pb} /{ }^{206} \mathrm{~Pb}$ entre $885 \pm 70 \mathrm{Ma}(101 \%$ de concordância) e $1129 \pm 92 \mathrm{Ma}$. Já as IMS-conjunto ${ }^{206} \mathrm{~Pb} /{ }^{238} \mathrm{U}$ ocorrem entre $901 \pm 10 \mathrm{Ma}$ e $977 \pm 16 \mathrm{Ma}$ enquanto que no caso das IMS-individual ${ }^{206} \mathrm{~Pb} / 238 \mathrm{U}$ este intervalo está entre $896 \pm 18$ Ma (101\% de concordância) e $1133 \pm 16$ Ma.

As amostras da Unidade Santo Antônio apresentam IMS-conjunto ${ }^{207} \mathrm{~Pb} /{ }^{206} \mathrm{~Pb}$ entre $682 \pm 56 \mathrm{Ma}$ e $699 \pm 30$ e IMS-individual ${ }^{207} \mathrm{~Pb} /{ }^{206} \mathrm{~Pb}$ entre $660 \pm 110 \mathrm{Ma}$ e $680 \pm 62 \mathrm{Ma}$, apresentando intervalos de praticamente $20 \mathrm{Ma}$ nos dois grupos. As idades IMS-conjunto ${ }^{206} \mathrm{~Pb} /{ }^{238} \mathrm{U}$ ocorrem entre $632 \pm 16 \mathrm{Ma}$ e $687 \pm 3 \mathrm{Ma}$, enquanto que as IMS-individual 
${ }^{206} \mathrm{~Pb} /{ }^{238} \mathrm{U}$ variam entre $663 \pm 14 \mathrm{Ma}$ e $681 \pm 8$. Neste caso os intervalos entre os grupos é de $55 \mathrm{Ma}$ e $18 \mathrm{Ma}$, respectivamente. Trouw (2008), Santos (2011) e Belém et al. (2011) também descrevem cristais de zircão unitários com idades em torno de $633 \mathrm{Ma}$ e $645 \mathrm{Ma}$, no entanto são idades ${ }^{206} \mathrm{~Pb} /{ }^{238} \mathrm{U}$ que comumente resultam em valores mais jovens, como exibido na tabela anterior, e que são também observados neste trabalho. Trouw (2008) descreve, em uma de suas amostras, uma idade concórdia de $675 \pm 7 \mathrm{Ma}$, obtida através de um grupo dos seis cristais mais jovens de zircão. Já outra amostra exibe um cristal de zircão com idade concordante de $643 \pm 4 \mathrm{Ma}$, no entanto não foi concluído, através de imagem de catodoluminesência, se a porção do cristal datada era de cristalização ígnea ou metamórfica, e concluiu que pode ser interpretada tanto como um evento metamórfico precoce quanto idade de cristalização da fonte ígnea.

No caso das rochas metassedimentares analisadas da Nappe Liberdade há uma grande variação nas IMS que é um reflexo das próprias populações distintas de idades discutidas anteriormente. A rocha metapelítica (SNA-172E) apresenta IMS-conjunto ${ }^{207} \mathrm{~Pb} /{ }^{206} \mathrm{~Pb}$ de $791 \pm 28 \mathrm{Ma}$ e IMS-cononjunto ${ }^{206} \mathrm{~Pb} /{ }^{238} \mathrm{U}$ de $718 \pm 11 \mathrm{Ma}$ (variação de 70 Ma), já a idade IMS-individual ${ }^{207} \mathrm{~Pb} /{ }^{206} \mathrm{~Pb}$ é de $756 \pm 122 \mathrm{Ma}$ enquanto que a IMS-individual ${ }^{206} \mathrm{~Pb} /{ }^{238} \mathrm{U}$ é de $761 \pm 14 \mathrm{Ma}$ (variação de apenas $5 \mathrm{Ma}$ ). No caso da rocha metapsamítica (SNA-180A) as idades provenientes de conjunto de dados são de $1095 \pm 30 \mathrm{Ma}$ $\left({ }^{207} \mathrm{~Pb} /{ }^{206} \mathrm{~Pb}\right)$ e $1038 \pm 12 \mathrm{Ma}\left({ }^{206} \mathrm{~Pb} /{ }^{238} \mathrm{U}\right)$, enquanto que as idades do cristal individual mais jovem são de $1119 \pm 80 \mathrm{Ma}\left({ }^{207} \mathrm{~Pb} /{ }^{206} \mathrm{~Pb}\right)$ e $1125 \pm 28 \mathrm{Ma}\left({ }^{206} \mathrm{~Pb} /{ }^{238} \mathrm{U}\right)$, com intervalos de 57 Ma e $6 \mathrm{Ma}$, respectivamente.

Para resultados mais consistentes foram consideradas as idades geradas a partir de conjunto de dados da razão ${ }^{207} \mathrm{~Pb} /{ }^{206} \mathrm{~Pb}$. Desta forma a máxima idade de deposição das rochas da Unidade Serra da Boa Vista encontra-se no Toniano, há 0,92 Ga. Para as rochas metassedimentares da Nappe Liberdade a máxima idade de sedimentação encontra-se no fim-Toniano, há 0,79 Ga. A Unidade Santo Antônio possui uma IMS no Criogeniano, há 0,68 Ga.

A idade máxima de sedimentação baseada em idades mais jovens de cristalização de zircão detrítico, pode indicar que (i) a bacia de sedimentação não recebeu sedimentos de rochas cristalizadas posteriormente, indicando o fechamento de seu ciclo, ou que (ii) a bacia continuou recebendo sedimentos das mesmas fontes e não houve interferência de fontes mais jovens, havendo continuidade na sedimentação na bacia. O intervalo entre a máxima idade de deposição e a idade de fechamento da bacia, deve ser relativamente pequeno para que a interpretação (ii) seja verdadeira. Se este intervalo for muito grande, é improvável que a região onde se encontrava a bacia de sedimentação não tenha sofrido nenhum tipo de movimentação tectônica que poderia aproximar fontes de idades mais jovens.

Segundo a coluna estratigráfica proposta para a região, a Unidade Serra da Boa Vista, com idade máxima de sedimentação no início do Toniano $(0,92 \mathrm{Ga})$, encontra-se no 
topo da estrutura da Nappe Andrelândia, sobre a Unidade Santo Antônio, que apresenta idade máxima de sedimentação no Criogeniano $(0,68 \mathrm{Ga})$. A partir dos dados anteriormente apresentados e discutidos em relação a $\mathrm{Lu}-\mathrm{Hf}$ e $\mathrm{Sm}-\mathrm{Nd}$, é provável que as idades mais jovens encontradas na Unidade Santo Antônio estejam relacionadas às atividades de magmatismo de arco vulcânico continental, arcos insulares e à rochas plutônicas tonianocriogenianas referentes à margem convergente acrescionária. Sendo assim, é provável que as rochas fontes, mais antigas, da Unidade Serra da Boa Vista tenham sido expostas posteriormente à deposição principal da Unidade Santo Antônio, e que as rochas magmáticas relacionadas ao arco estivessem mais distais, inativas, ou mesmo parcialmente erodidas na época da sedimentação da Unidade Serra da Boa Vista. Já a assinatura de LuHf dos cristais de zircão mais jovens, do Toniano, da Nappe Liberdade, indicam fontes crustais para estes grãos.

\section{7 caráter ígneo ou vulcanoclástico do anfibolito na Unidade Santo Antônio}

A amostra NESG-1552 é um titanita-epidoto-clinozoisita anfibolito e sua composição de ETR em rocha-total é comparável à de E-MORB. No entanto, os resultados de U-Pb e Lu-Hf em zircão, podem indicar que a interpretação para a gênese desta rocha é distinta. A densidade principal de dados U-Pb encontra-se no Toniano, com idade resultante de $785 \pm$ $9 \mathrm{Ma}(\mathrm{n}=18)$, enquanto que o restante dos dados variam do início do Criogeniano (699 \pm 30 Ma com $n=3$ ) ao Toniano (823 $\pm 20 \mathrm{com} n=6)$, e do Riaciano ( 2,1 Ga, sem idade resultante).

Em anfibolitos de protólito ígneo podem ser encontrados mais de um grupo de idade U-Pb em cristais de zircão, geralmente estando associados à contaminação ou grãos herdados durante a evolução ígnea do protólito. Esta amostra apresenta pelo menos seis grupos menores, além da idade principal de $785 \pm 9$ Ma. Todas estas idades são observadas nas demais rochas metassedimentares da Unidade Santo Antônio, inclusive a máxima idade de sedimentação.

Quanto aos dados de Lu-Hf em zircão, a idade de $785 \pm 9$ Ma apresenta valores de $\varepsilon \mathrm{Hf}$ entre $-0,41$ e $-14,05$ em sua maioria, com apenas dois dados em torno de +7 . A idade mais jovem encontrada exibe valores positivos de $\varepsilon \mathrm{Hf}$ entre 4,78 e 6,07 , e os demais cristais de zircão exibem valores negativos entre $-0,26$ e -12,51.

Se o protólito desta rocha for ígneo, uma possível explicação para a presença de populações de cristais de zircão com as mesmas idades encontradas nas rochas metassedimentares da mesma unidade, seria a contaminação com sedimentos não consolidados durante a intrusão do protólito máfico. O padrão de ETR em rocha-total apresenta anomalias de Eu imperceptíveis, típicas de rochas ígneas máficas, porém a existência de anomalias de Ce visíveis pode indicar o contrário. Sendo assim, foi feita a 
escolha de discutir seus dados juntamente com as rochas metassedimentares, no entanto não há resposta definitiva para a gênese do protólito desta rocha. 


\section{CAPÍTULO 6}

ROCHAS EXÓTICAS À BACIA DE SEDIMENTAÇÃO

Os comportamentos químicos do granada-clinopiroxênio anfibolito retroeclogítico e do quartzo-granada-cummingtonita fels/xisto, encontrados na Nappe Liberdade, foram estudados através de análises geoquímicas elementais de elementos maiores, menores, traço e terras raras em rocha-total (Anexo II), geoquímica isotópica, sistemas Sm- $\mathrm{Nd}$ e $\mathrm{Rb}$ $\mathrm{Sr}$, em rocha-total (Anexo III), geoquímica isotópica, U-Pb e Lu-Hf, em zircão (anexos IV e V) e geoquímica elemental de elementos terras raras em zircão (Anexo VI). Os resultados obtidos foram comparados com os encontrados na literatura para que se pudesse compreender melhor a gênese destas rochas e suas afinidades.

\subsection{Geoquímica elemental em rocha-total}

\subsubsection{Elementos maiores e menores}

A Tabela 6-1 resume as concentrações dos elementos maiores e menores das rochas exóticas a bacia de sedimentação.

\begin{tabular}{|c|c|c|c|c|c|c|c|c|c|c|c|}
\hline \multicolumn{2}{|c|}{ Rochas e amostras } & SiO2 & TiO2 & Al2O3 & Fe2O3 & MnO & MgO & CaO & Na2O & K2O & P2O5 \\
\hline \multirow{4}{*}{$\begin{array}{c}\text { Anfibolitos } \\
\text { retroeclogíticos }\end{array}$} & SNA-205 A3 & 49,54 & 0,726 & 15,31 & 10,68 & 0,183 & 7,97 & 12,35 & 1,69 & 0,13 & 0,053 \\
\cline { 2 - 11 } & SNA-205 A4 & 50,32 & 0,731 & 14,44 & 10,93 & 0,169 & 8,64 & 12,25 & 1,64 & 0,13 & 0,054 \\
\cline { 2 - 11 } & SNA-205 A5 & 49,72 & 0,977 & 16,65 & 11,39 & 0,169 & 6,35 & 12,16 & 1,95 & 0,20 & 0,072 \\
\cline { 2 - 11 } & SNA-205 B2 & 50,25 & 1,364 & 11,06 & 15,94 & 0,232 & 8,21 & 10,36 & 1,25 & 0,08 & 0,115 \\
\cline { 2 - 10 } & SNA-208 & 49,70 & 0,846 & 14,58 & 11,87 & 0,186 & 8,48 & 12,30 & 1,59 & 0,35 & 0,057 \\
\hline \multirow{4}{*}{$\begin{array}{c}\text { Rochas } \\
\text { metanulcânicas }\end{array}$} & \multirow{2}{*}{ SNA-168 } & 48,84 & 0,245 & 8,24 & 34,15 & 2,560 & 5,25 & 1,11 & 0,03 & $<0,01$ & 0,084 \\
\cline { 2 - 10 } & 48,70 & 0,245 & 8,23 & 34,07 & 2,550 & 5,24 & 1,10 & 0,03 & $<0,01$ & 0,084 \\
\cline { 2 - 10 } & \multirow{2}{*}{ SNA-218 } & 58,17 & 0,279 & 7,76 & 27,07 & 1,799 & 1,94 & 1,66 & $<0,02$ & $<0,01$ & 0,141 \\
\cline { 2 - 10 } & 58,60 & 0,280 & 7,89 & 27,30 & 1,813 & 1,96 & 1,67 & $<0,02$ & $<0,01$ & 0,142 \\
\hline
\end{tabular}

Tabela 6-1. Resumo dos dados dos elementos maiores e menores dos granada-clinopiroxênio anfibolitos retroeclogíticos e dos quartzo-granada-cummingtonita fels/xistos.

Os granada-clinopiroxênio anfibolitos retroeclogíticos apresentam composição compatível com protólito basáltico de afinidade tholeíitica (Figura 6-1) e são quimicamente comparáveis às rochas metabásicas encontradas nas sequências metavulcanossedimentares, principalmente Votuverava e Perau, do Terreno Apiaí (CAMPANHA et al., 2015; FALEIROS et al., 2011). 


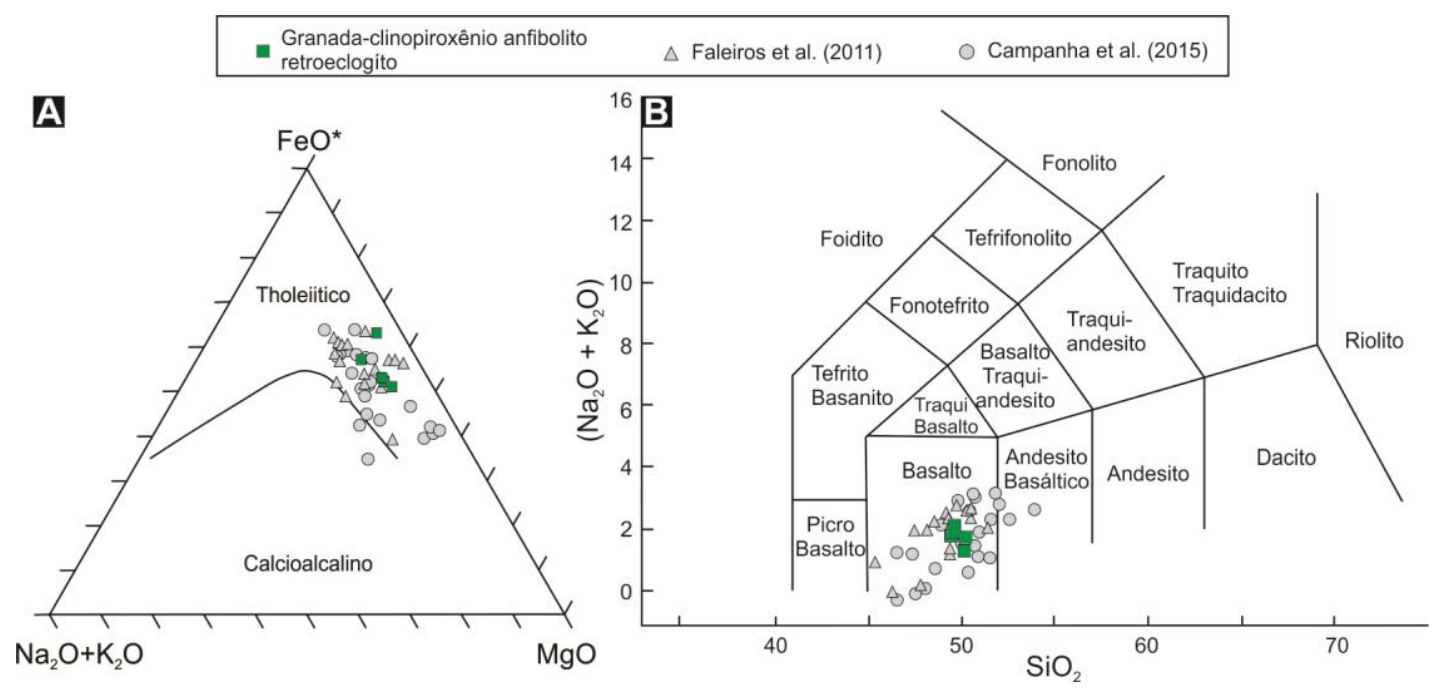

Figura 6-1. (A) Diagrama AFM destacando os campos de composição tholeiitica e calcioalcalina (IRVINE; BARAGAR, 1971). Em verde os dados dos granada-clinopiroxênio anfibolitos retroeclogíticos; (B) Diagrama $\left(\mathrm{Na}_{2} \mathrm{O}+\mathrm{K}_{2}\right)$ versus $\mathrm{SiO}_{2}$ com os campos das composições de rochas vulcânicas (LE BAS et al., 1986). Dados em cinza foram retirados de Faleiros et al. (2011) e Campanha et al. (2015), e correspondem à rochas metabásicas encontradas sequências metavulcanossedimentares do Terreno Apiaí.

\subsubsection{Elementos terras raras}

As amostras dos anfibolitos retroeclogíticos apresentam fracionamento dos ETR bastante baixo entre 1,19 e 1,88, conferindo ao diagrama normalizado pelo condrito (Figura 6-2) um aspecto grosseiramente flat. O enriquecimento em ETR leves é bastante baixo e praticamente não observável, já que as razões $\mathrm{La}_{N} / S m_{N}$ variam de 1,00 à 1,54 . As anomalias de Eu variam de pouco negativas à pouco positivas entre 0,82 e 1,14, enquanto que as anomalias de Ce variam de pouco negativas à neutra, entre 0,61 e 1,00, com uma exceção na qual é possível distinguir as anomalias negativa de Ce e de Eu. O padrão geral pode ser comparável ao de E-MORB (enriquecido) pelo enriquecimento em ETR leves. Todos estes parâmetros estão resumidos na Tabela 6-2.

\begin{tabular}{|c|c|c|c|c|}
\hline \multirow{2}{*}{ Tipo de rocha } & $\begin{array}{c}\text { Fracionamento } \\
\text { dos ETR }(\mathrm{La} / \mathrm{Yb})_{\mathrm{N}}\end{array}$ & $\begin{array}{c}\text { Enriquecimento em } \\
\text { ETR leves }(\mathrm{La} / \mathrm{Sm})_{\mathrm{N}}\end{array}$ & $\begin{array}{c}\text { Anomalia de Eu } \\
\text { Eu/[(Sm+Gd }) / 2]_{\mathrm{N}}\end{array}$ & $\begin{array}{c}\text { Anomalia de Ce } \\
\mathrm{Ce} /[(\mathrm{La}+\mathrm{Pr}) / 2]_{\mathrm{N}}\end{array}$ \\
\hline \multirow{2}{*}{$\begin{array}{c}\text { Rochas } \\
\text { metavulcânicas }\end{array}$} & 8,09 & 4,26 & 0,69 & 0,66 \\
\cline { 2 - 5 } & 6,96 & 3,49 & 0,70 & 0,94 \\
\hline \multirow{4}{*}{$\begin{array}{c}\text { Anfibolitos } \\
\text { retroeclogíticos }\end{array}$} & 1,56 & 1,29 & 1,03 & 0,97 \\
\cline { 2 - 5 } & 1,68 & 1,33 & 0,99 & 0,91 \\
\cline { 2 - 5 } & 1,52 & 1,32 & 1,14 & 0,93 \\
\cline { 2 - 5 } & 1,53 & 1,32 & 1,14 & 0,93 \\
\cline { 2 - 5 } & 1,88 & 1,54 & 0,82 & 0,61 \\
\cline { 2 - 5 } & 1,19 & 1,00 & 1,00 & 1,00 \\
\hline
\end{tabular}

Tabela 6-2. Resumo dos parâmetros calculados dos elementos terras raras em rocha total para as rochas, em sua maioria metassedimentares, estudadas. 
As rochas metavulcânicas apresentam padrão completamente distinto das rochas anfibolíticas discutidas acima, com maior fracionamento geral dos ETR e maior enriquecimento em ETR leves. As anomalias de Eu e Ce são todas negativas, variando de 0,69-0,70, e 0,66-0,94, respectivamente.

Os padrões dos ETR em rocha-total das amostras dos anfibolitos retroeclogíticos também são comparáveis aos padrões encontrados nas rochas metabásicas que ocorrem no Grupo Votuverava (CAMPANHA et al., 2015; FALEIROS et al., 2011).

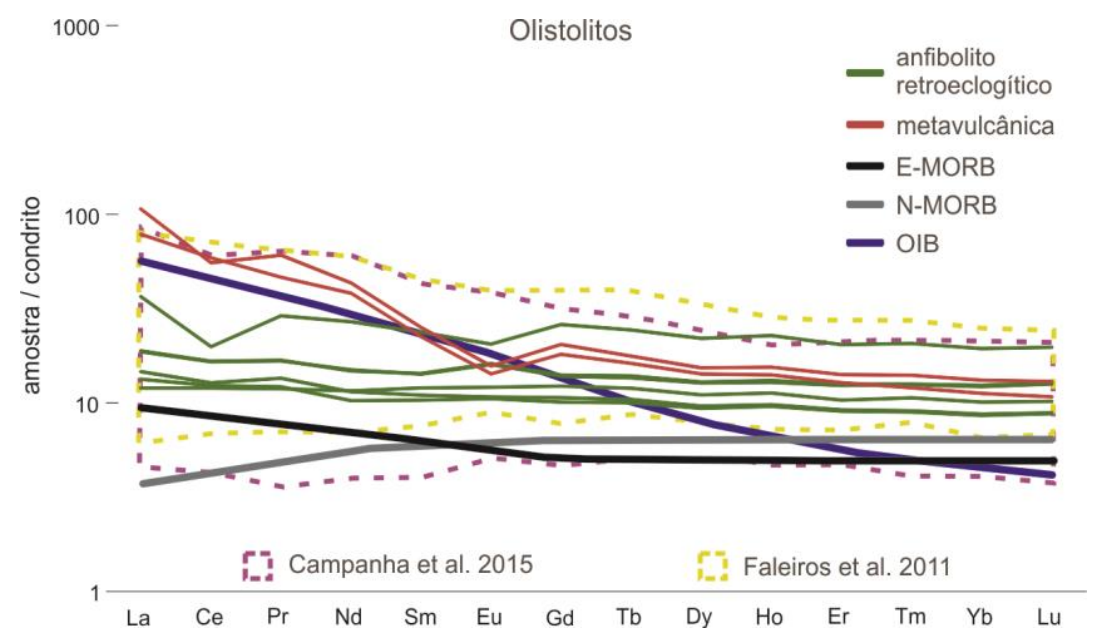

Figura 6-2. Diagrama dos ETR normalizados pelo condrito das rochas exóticas à bacia de sedimentação estudada: em vermelho as rochas metavulcanossedimentares e em verde as rochas anfibolíticas retroeclogíticas. Como comparação estão plotadas tanto as composições de rochas tipo E- e N- MORB, OIB e as composições das rochas metabásicas que ocorrem no Grupo Votuverava, Terreno Apiaí (CAMPANHA et al., 2015; FALEIROS et al., 2011).

\subsection{Sistema isotópico U-Pb em cristais de zircão}

A rocha metabásica retroeclogítica e a rocha metavulcânica possuem populações bastante semelhantes de cristais de zircão, uma (SNA-168) apresenta duas populações: grãos prismáticos retangulares com zoneamento setorizado de $185 \mu \mathrm{m}$ a $365 \mu \mathrm{m}$ de comprimento, assim como cristais prismáticos com zoneamento oscilatório mais finos e raros. A outra amostra (SNA-205B) apresenta três diferentes populações: uma é composta por cristais arredondados de $50 \mu \mathrm{m}$ a $110 \mu \mathrm{m}$ de comprimento, com espessos sobrecrescimentos metamórficos de alto urânio em volta de pequenos núcleos préexistentes com zoneamento oscilatório; outra população exibe cristais prismáticos retangulares alongados de $140 \mu \mathrm{m}$ a $350 \mu \mathrm{m}$ de comprimento e zoneamento setorizado com sobrecrescimentos de baixo urânio; enquanto que a última população apresenta grãos em prismas de $70 \mu \mathrm{m}$ a $184 \mu \mathrm{m}$ de comprimento com pontas arredondadas e zoneamento oscilatório, com sobrecrescimentos metamórficos, de baixo urânio, de $9 \mu \mathrm{m}$ a $35 \mu \mathrm{m}$ de 
espessura. Estas últimas duas populações da amostra SNA-205B são morfologicamente idênticas às duas que ocorrem na amostra SNA-168 (Figura 6-3).

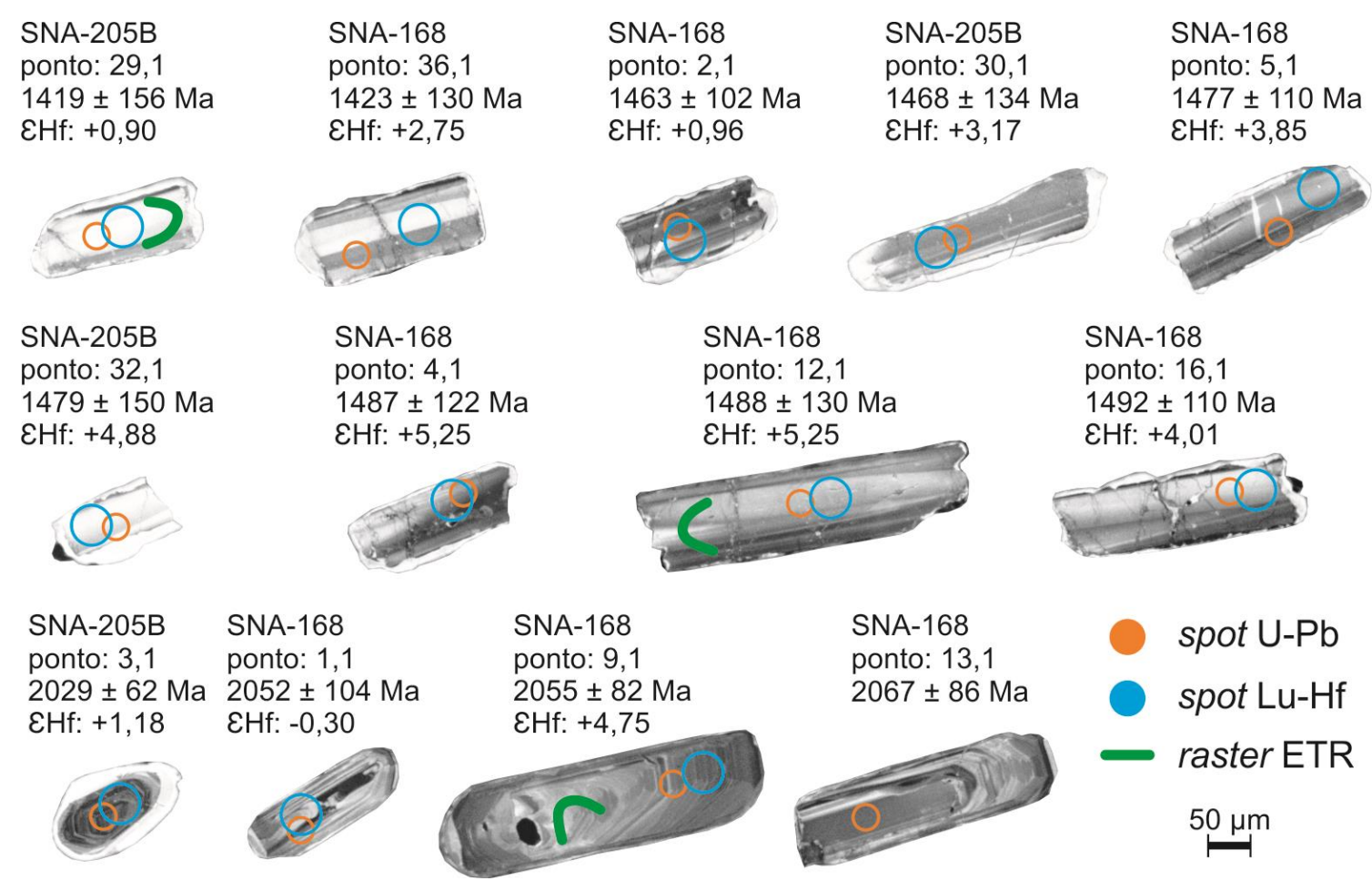

Figura 6-3. Exemplo de cristais de zircão datados das amostras do anfibolito retroeclogítico e da rocha metavulcanossedimentar.

Os dados de $\mathrm{U}-\mathrm{Pb}$ resultaram em dois clusters de idades muito semelhantes em ambas as amostras, com as mesmas morfologias de cristais de zircão. O quartzo-granadagrunerita/cummingtonita fels (SNA-168) exibe $87 \%$ de seus dados concordantes no Mesoproterozoico que resultou em uma idade de $1463 \pm 17 \mathrm{Ma}$, obtida nos cristais retangulares alongados com zoneamento setorizado, em diagrama concordia (Figura 6-4 B). O restante dos dados proveu uma idade de $2039 \pm 37 \mathrm{Ma}$, obtida nos grãos prismáticos com pontas arredondadas e zoneamento oscilatório (Figura 6-4 C).

O granada-clinopiroxênio anfibolito retroeclogítico (SNA-205B) apresenta os mesmos dois conjuntos de dados do Mesoproterozoico e Paleoproterozoico encontrados no fels, e as idades para esta rocha resultaram em $1480 \pm 43$ Ma e $2055 \pm 30 \mathrm{Ma}$, em cristais prismáticos retangulares alongados e prismas com pontas arredondadas, e zoneamento oscilatório, respectivamente (Figura 6-4 E e F, respectivamente). 

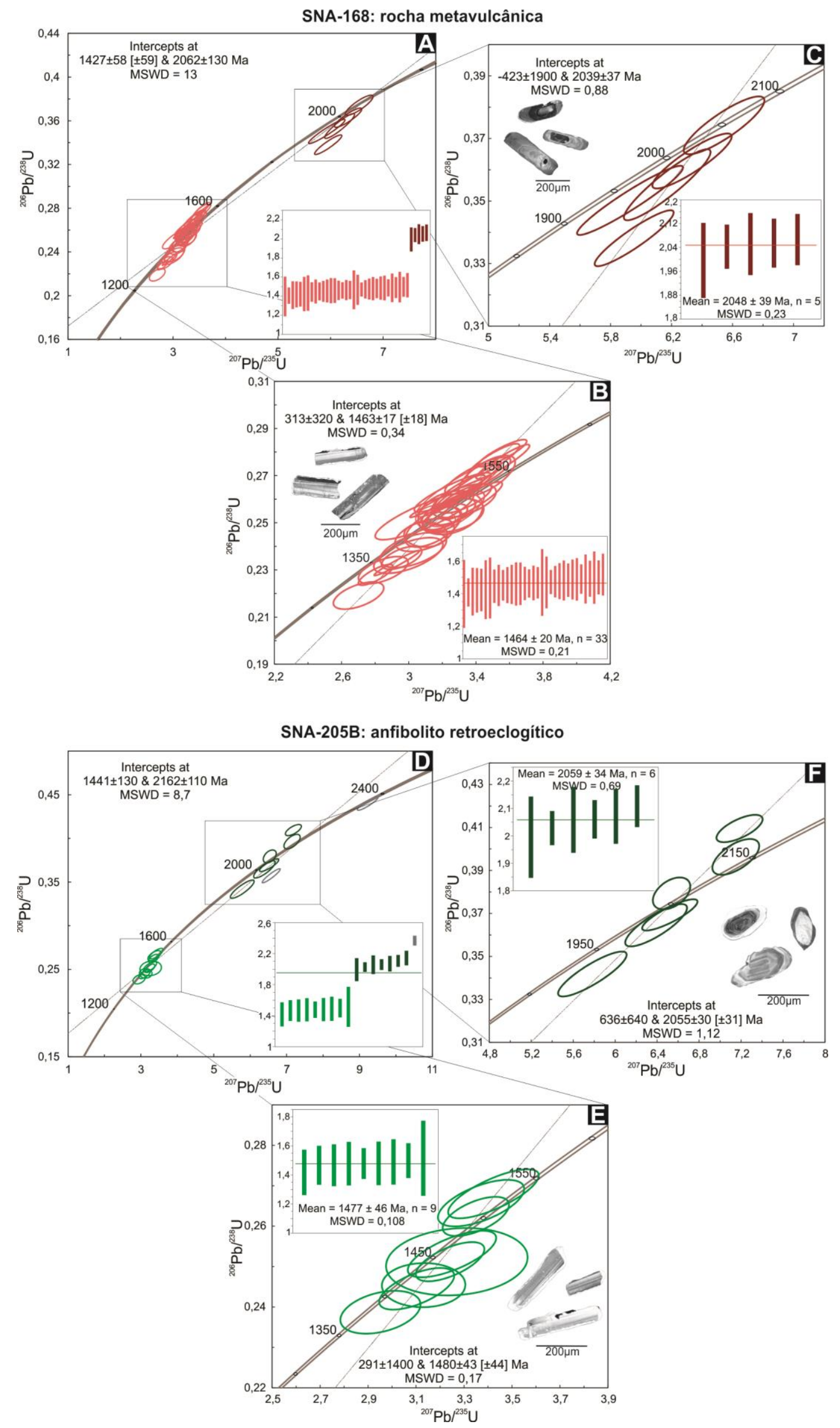

Figura 6-4. (A) Diagrama concordia com todos os dados plotados com intercepto inferior em $1427 \pm 58 \mathrm{Ma}$ e intercepto superior de $2062 \pm 130$ Ma da amostra SNA-168, detalhe para o diagrama weighted average; (B) 
Diagrama concordia com os dados do Mesoproterozoico resultando em uma idade de $1463 \pm 17 \mathrm{Ma}$, detalhe para o diagrama weighted average que resultou em $1464 \pm 20 \mathrm{Ma}$; (C) Diagrama concordia com os dados do Paleoproterozoico resultando em uma idade de $2039 \pm 37 \mathrm{Ma}$, detalhe para o diagrama weighted average que resultou em $2048 \pm 39 \mathrm{Ma}$; (D) Diagrama concordia com todos os dados plotados com intercepto inferior em $1441 \pm 130 \mathrm{Ma}$ e intercepto superior de $2162 \pm 110 \mathrm{Ma}$ da amostra SNA-205B, detalhe para o diagrama weighted average; (E) Diagrama concordia com os dados do mesoproterozoico resultando em uma idade de $1480 \pm 43$ $\mathrm{Ma}$, detalhe para o diagrama weighted average que resultou em $1477 \pm 46 \mathrm{Ma}$; (F) Diagrama concordia com os dados do paleoproterozoico resultando em uma idade de $2055 \pm 30 \mathrm{Ma}$, detalhe para o diagrama weighted average que resultou em $2059 \pm 34 \mathrm{Ma}$.

\subsection{Geoquímica isotópica em rocha-total}

As rochas metabásicas retroeclogíticas e a rocha metavulcânica, apresentam as mesmas tipologias de zircão assim como os mesmos grupos de idades. Quanto aos valores de $\varepsilon N d_{t}$ e seus caráteres isotópicos, elas diferem e bastante. O retroeclogito apresenta contribuição juvenil importante do final do Paleoproterozoico ao início do Neoproterozoico, com idade-modelo $\mathrm{T}_{\mathrm{DM}}$ de 1,63 $\mathrm{Ga}$, e apresenta $\varepsilon \mathrm{Nd}_{\mathrm{t}}$ positivo na idade da rocha de $1480 \pm$ 43 Ma. Já a rocha metavulcânica exibe contribuição juvenil restrita ao intervalo entre aproximadamente 1,80 Ga e sua idade-modelo $\mathrm{T}_{\mathrm{DM}}$ de 2,18 Ga. A idade de $1463 \pm 17 \mathrm{Ma}$, principal moda de idades encontrada, apresenta $\varepsilon \mathrm{Nd}_{\mathrm{t}}$ negativo, indicando que seu protólito recebeu contribuição crustal importante (Figura 6-5).

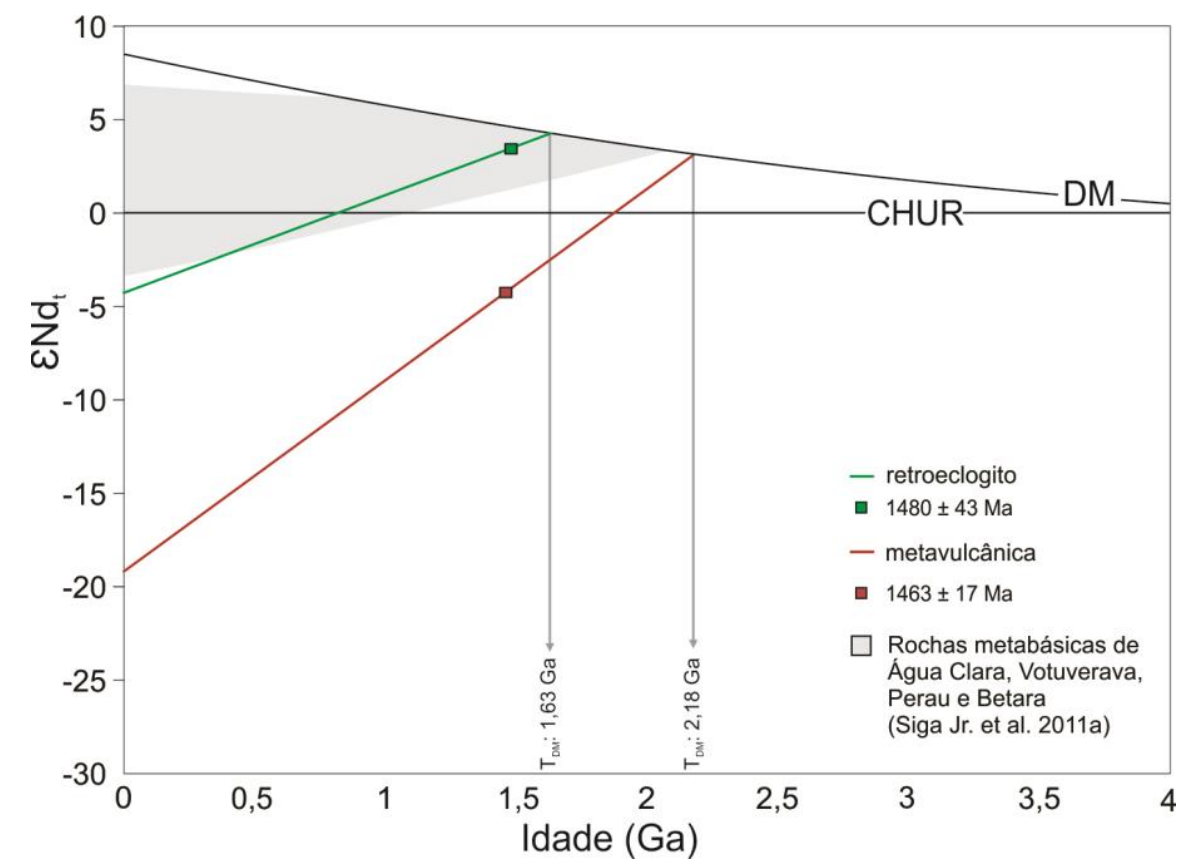

Figura 6-5. Diagrama $\varepsilon N d_{t}$ versus idade para as rochas exóticas à bacia de sedimentação: um anfibolito retroeclogítico e uma rocha metavulcanossedimentar. Como comparação está plotado o campo das composições de rochas metabásicas encontradas nas sequências Água Clara, Votuverava, Perau e Betara retirada de Siga Jr et al. (2011a). (t) anfibolito retroeclogítico = 1480; (t) rocha metavulcânica $=1460$. 
As amostras de rochas metabásicas encontradas em meio à sequências metavulcanossedimentares do Terreno Apiaí, analisadas por (SIGA JR et al., 2011a), apresentam idades modelo $\mathrm{T}_{\mathrm{DM}}$ entre $1664 \mathrm{Ma}$ e $1783 \mathrm{Ma}$, bastante semelhantes à idade encontrada no anfibolito retroeclogítico.

$\mathrm{Na}$ interpolação entre os dados isotópicos de $\varepsilon \mathrm{Nd}_{t}$ e ${ }^{87} \mathrm{Sr} /{ }^{86} \mathrm{Sr}$ (Figura 6-6 A), assim como $\varepsilon \mathrm{Nd}_{\mathrm{t}}$ e razão Th/Sc (Figura 6-6 B), têm se que o protólito do retroeclogito proveio de um ambiente de margem ativa, com caráter depletado, possivelmente em ambiente de forearc. A rocha metavulcânica igualmente se formou em ambiente orogênico, mas com contribuição crustal importante.
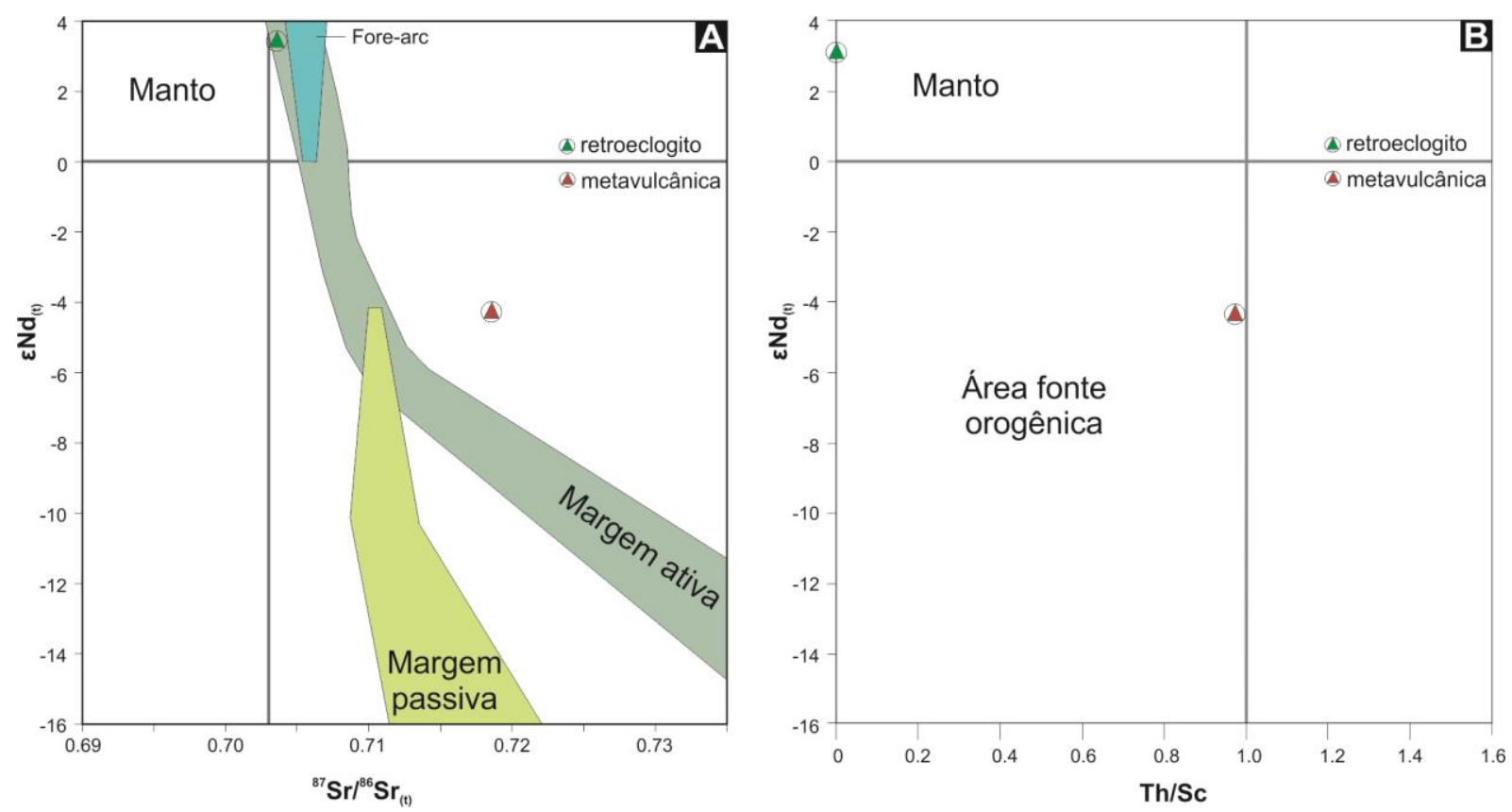

Figura 6-6. (A) Diagrama $\varepsilon N d_{t}$ versus ${ }^{87} \mathrm{Sr} /{ }^{86} \mathrm{Srt}$ e (B) Diagrama $\varepsilon N d_{t}$ versus $\mathrm{Th} / \mathrm{Sc}$ com as delimitações de alguns ambientes tectônicos e os dados das amostras estudadas plotados.

\subsection{Sistema isotópico Lu-Hf em cristais de zircão}

A rocha metabásica e a metavulcânica apresentam, além da coincidência de idades, uma assinatura isotópica de Lu-Hf em zircão semelhante. As idades do Mesoproterozoico, que resultaram em $1463 \pm 17 \mathrm{Ma}(S N A-168)$ e $1480 \pm 43 \mathrm{Ma}$ (SNA-205B), apresentam valores de $\varepsilon \mathrm{Hf}_{\mathrm{t}}$ que variam de $+0,48 \mathrm{a}+6,32$ e $-1,03 \mathrm{a}+5,43$, respectivamente, indicando que há contribuição juvenil importante, no entanto com contaminação crustal. As idades herdadas do Paleoproterozoico de $2039 \pm 37$ Ma (SNA-168) e $2055 \pm 30$ Ma (SNA-205B) apresentam valores de $\varepsilon \mathrm{Hf}_{\mathrm{t}}$ que variam de $-0,31 \mathrm{a}+4,75$ e $-0,53$ a $+4,55$, respectivamente (Figura 6-7). 


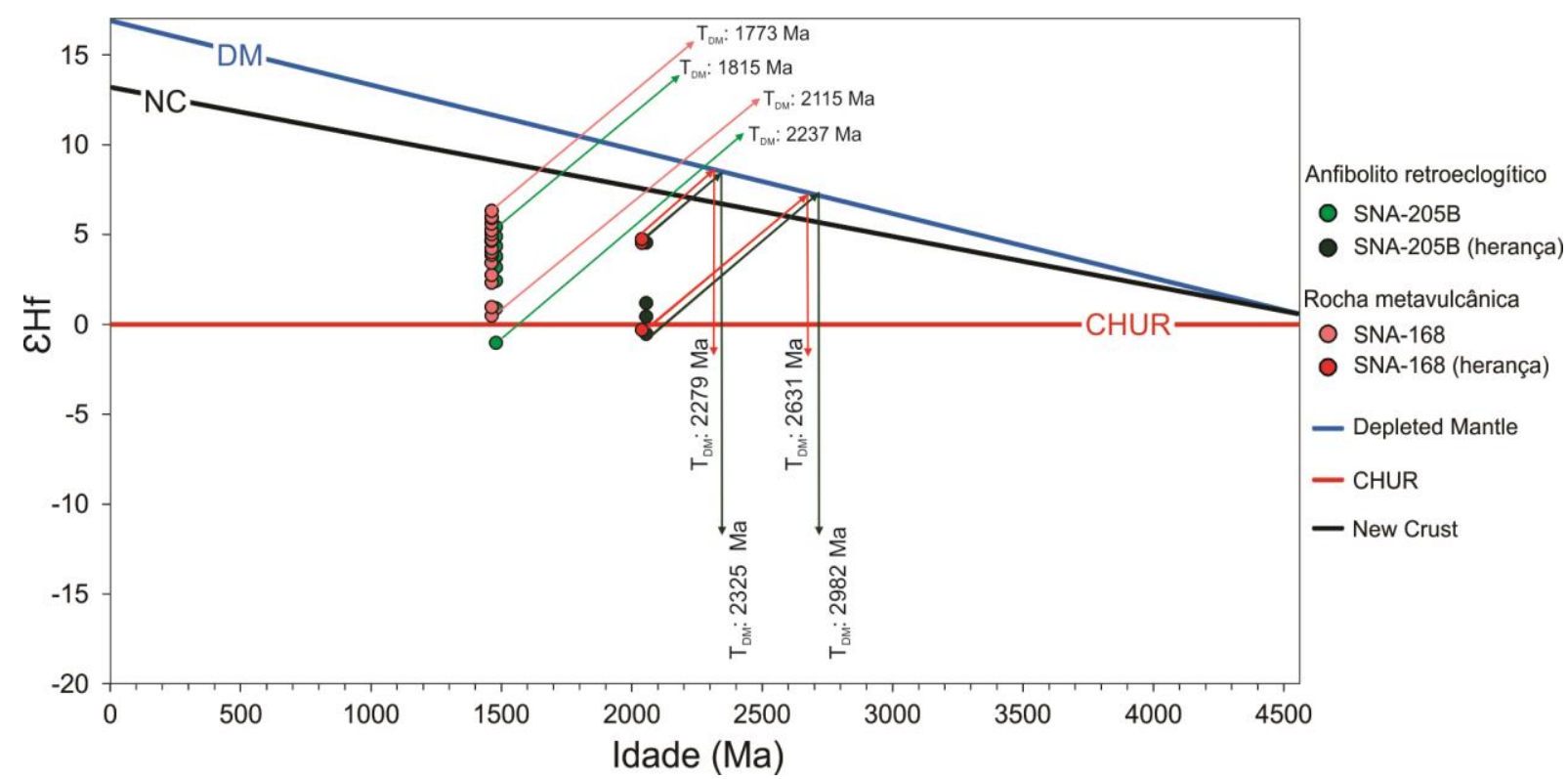

Figura 6-7. Diagrama $\varepsilon \mathrm{Hf}_{\mathrm{t}}$ versus idade com os dados de $\varepsilon \mathrm{Hf}$ plotados em relação às idades de cristalização dos cristais da rocha e herdados. Para a amostra SNA-205B os valores de $\varepsilon \mathrm{Hf}$ foram calculados para $1480 \pm 43 \mathrm{Ma}$ e $2055 \pm 30 \mathrm{Ma}$, enquanto que para a rocha metavulcânica (SNA-168) as idades foram $1463 \pm 17$ Ma e $2039 \pm 37$ Ma.

Idades-modelo calculadas a partir de New Crust, os dados mesoproterozoicos apresentam $\mathrm{T}_{\mathrm{NC}}$ de 1,65-2,10 Ga enquanto que as idades paleoproterozoicas apresentam TNC de 2,18-2,35 Ga. Para os mesmo intervalos as idades-modelo TDM são de 1,77-2,23 Ga e de 2,27-2,98 Ga. As Figura 6-8 A e B exibem histogramas com as idades U-Pb e as idades-modelo $\mathrm{T}_{\mathrm{DM}}$ do retroeclogito e da rocha metavulcânica, respectivamente.

As médias das idades-modelo $\mathrm{T}_{\mathrm{DM}}$ provenientes dos cristais de zircão do mesoproterozoico são de 1974 Ma (retroeclogito) e de 1894 Ma (rocha metavulcânica), respectivamente, desta forma indicando que houve um intervalo de aproximadamente 450 Ma entre o início da evolução isotópica do Hf a partir de sua extração de um reservatório empobrecido até sua retenção através da cristalização destes cristais de zircão. Já as médias das idades-modelo $T_{\mathrm{DM}}$ encontradas através dos cristais paleoproterozoicos são de 2508 Ma (retroeclogito) e de 2407 Ma (rocha metavulcânica), o que indica que houve um intervalo de aproximadamente $450 \mathrm{Ma}$, no caso do retroeclogito, e de $360 \mathrm{Ma}$ para a rocha metavulcânica, entre o início da evolução química da rocha parental destes cristais herdados até sua efetiva cristalização. 

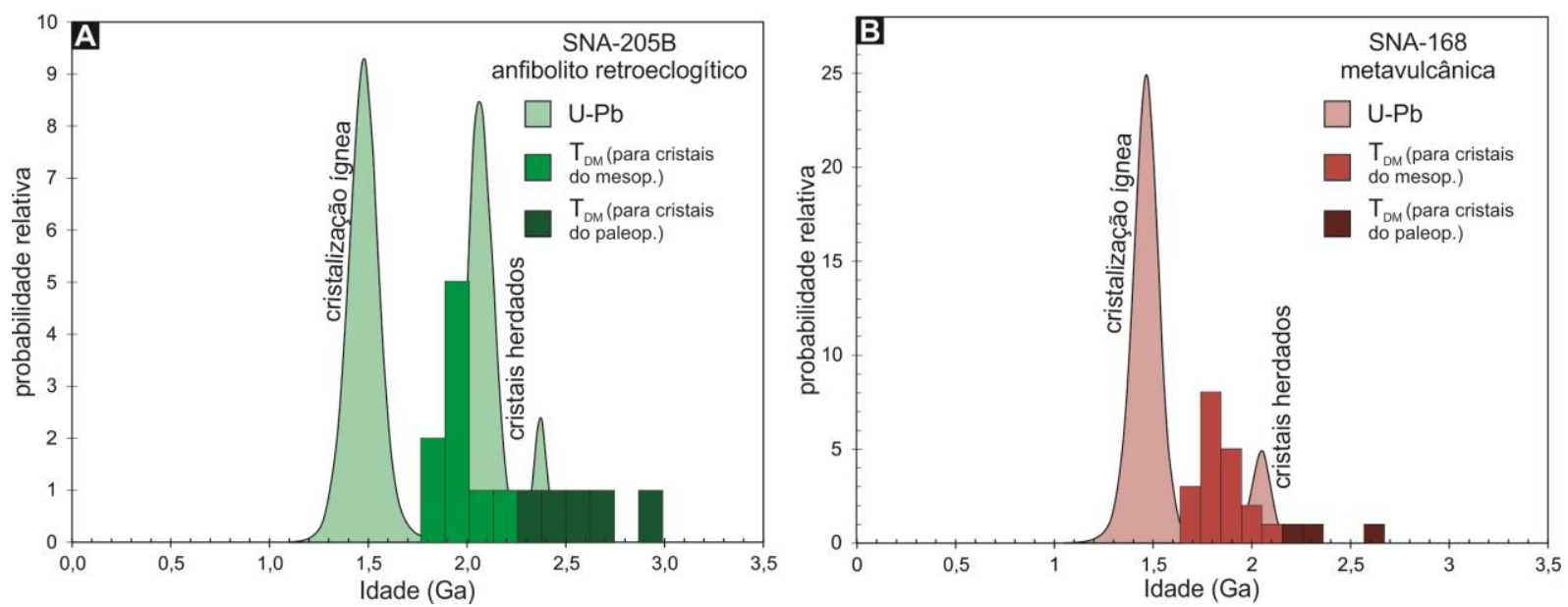

Figura 6-8. (A) Histograma das idades U-Pb e TDM da amostra do anfibolito retroeclogito; (B) Histograma das idades U-Pb e TDM da amostra da rocha metavulcanossedimentar.

\subsection{Elementos terras raras em cristais de zircão}

Análises de certos elementos em alguns cristais não foram utilizadas por não estarem dentro do limite de quantificação (3,3 x limite de detecção), que eram, em sua maioria, análises de lantânio, praseodímio e neodímio (Tabela 6-3).

\begin{tabular}{|c|c|c|c|c|c|c|}
\hline \multicolumn{7}{|c|}{ ZIRCÃO } \\
\hline Amostra & $\begin{array}{l}\text { Idade } \\
\text { (Ma) }\end{array}$ & $\begin{array}{l}\text { Quantidade } \\
\text { de análises }\end{array}$ & $\begin{array}{c}\text { Média da } \\
\text { concentração } \\
\text { de ETR (ppm) }\end{array}$ & $\begin{array}{c}\text { Enriquecimento } \\
\text { em ETR pesados } \\
\text { (Yb/Gd)N }\end{array}$ & $\begin{array}{l}\text { Anomalia de Eu } \\
\mathrm{Eu} /[(\mathrm{Sm}+\mathrm{Gd}) / 2] \mathrm{N}\end{array}$ & $\begin{array}{l}\text { Anomalia de Ce } \\
\mathrm{Ce} /[(\mathrm{La}+\mathrm{Pr}) / 2] \mathrm{N}\end{array}$ \\
\hline \multirow{2}{*}{ 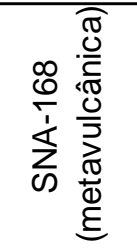 } & $1463 \pm 17$ & 11 & 5,16 & $13,96-36,18$ & $0,27-0,47$ & $3,28-9,62$ \\
\hline & $2039 \pm 37$ & 3 & 6,21 & $13,74-19,02$ & 0,47 & $3,62-113,75$ \\
\hline \multirow{2}{*}{ 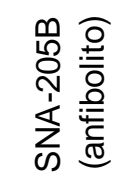 } & $1480 \pm 43$ & 8 & 5,1 & $1,37-32,19$ & $1,81,0,30-0,49$ & $\begin{array}{c}0,36,1,61- \\
14,29\end{array}$ \\
\hline & $2055 \pm 30$ & 2 & 5,54 & 18,08 e 18,11 & 1,78 & 5,85 e 35,21 \\
\hline
\end{tabular}

Tabela 6-3. Resumo dos parâmetros calculados em relação aos Elementos Terras Raras em zircão do anfibolito retroeclogítico e da rocha metavulcânica.

Em todos os quatro intervalos de idades, as concentrações dos ETR encontradas foram bastante baixas comparativamente com os cristais detríticos das rochas metassedimentares analisadas, variando entre 5,10 ppm e 6,21 ppm. O enriquecimento em ETR pesados é bastante semelhante nas idades mesoproterozoicas, variando entre 13,96 e 36,18 , no entanto, duas análises do anfibolito retroeclogítico exibem valores mais baixos, de 1,37 e 3,05, que são as duas que se destacam do conjunto homogêneo na Figura 6-9 B. Quanto às anomalias de Eu, a grande maioria dos dados resultaram em anomalias 
negativas entre 0,27 e 0,49, no entanto, também na amostra do retroeclogito, ocorre uma anomalia positiva de Eu com valor de 1,81. As anomalias de Ce, todas positivas, variam entre 0,36 e 14,29 .

As idades do paleoproterozoico apresentam enriquecimentos em ETR pesados homogêneos, enquanto que as anomalias de Eu são bastante distintas: na amostra da rocha metavulcânica (SNA-168) a anomalia é negativa com valor de 0,47 , já na do anfibolito retroeclogítico a anomalia de Eu é positiva em 1,78, já as anomalias positivas de Ce variam de 3,62 à 24,31 .
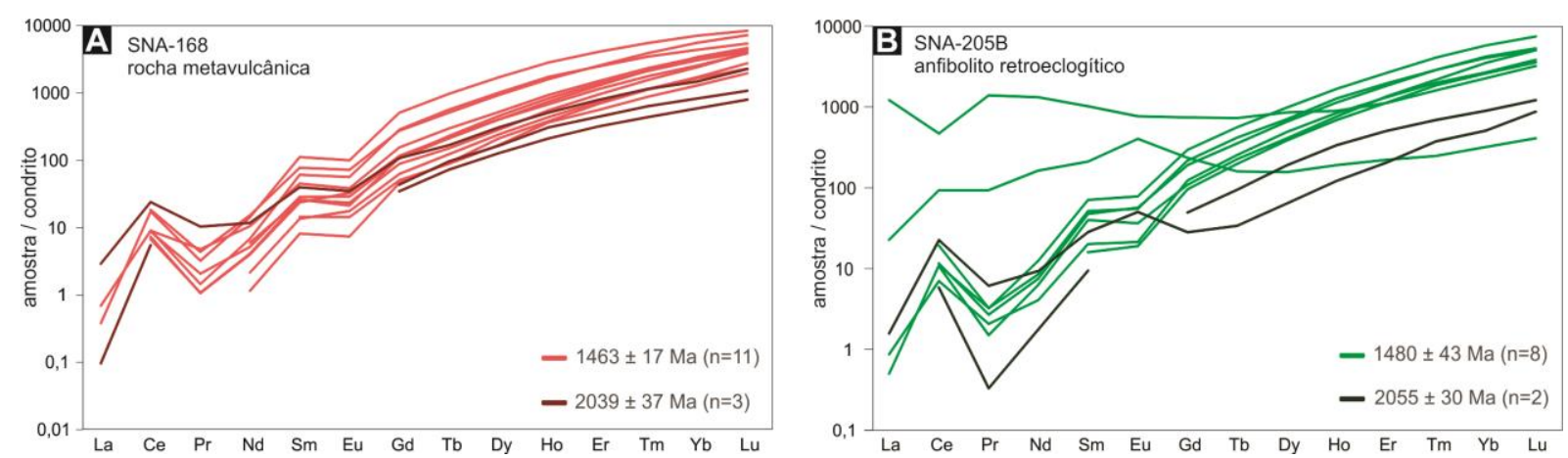

Figura 6-9. (A) Diagrama dos padrões da concentração dos Elementos Terras Raras da rocha metavulcânica e (B) do anfibolito retroeclogítico. Todos os elementos foram normalizados pelo condrito $\mathrm{C} 1$ de Sun e McDonough (1989). 


\section{CAPÍTULO 7}

\section{METAMORFISMO}

As investigações acerca do metamorfismo no qual foram submetidas as rochas estudadas, foram realizadas através de análises U-Pb e Lu-Hf (anexos IV e V, respectivamente) em sobrecrescimentos metamórficos de zircão e composição de elementos terras raras (Anexo $\mathrm{VI}$ ) nestes cristais, assim como análises de ETR e elementos maiores em granada (anexos VII e VIII). Os resultados obtidos foram confrontados com dados apresentados na literatura para que se pudesse discutir as idades e o comportamento destes elementos em zircão e granada, durante os principais eventos metamórficos de subducção e colisão continental.

\subsection{Metamorfismo de alta pressão}

\subsubsection{Aspectos petrográficos e condições de metamorfismo}

O granada-clinopiroxênio anfibolito retroeclogítico possui texturas que indicam substituição de uma paragênese de maior pressão, condizentes com fácies eclogito. Ocorre crescimento vermicular entre clinopiroxênio, provável diopsídio, quartzo e plagioclásio, o que poderia indicar substituição de cristais de onfacita. Coronas de plagioclásio em torno dos cristais de granada assim como texturas coroníticas entre titanita, rutilo e ilmenita também foram observadas. A hornblenda pode ocorrer em intercrescimento simplectítico com o plagioclásio nas texturas coroníticas em volta da granada, ou substituindo o diopsídio. A paragênese atual da rocha é constituída por granada + anfibólio + plagioclásio + ilmenita + titanita \pm quartzo condizente com fácies anfibolito, o clinopiroxênio se encontra em desequílibrio textural sendo substituído por hornblenda. Tais texturas são bastante semelhantes às descritas por Zhao et al. (2001) em retroeclogitos (granulitos de alta pressão retrometamorfisados) do Complexo Hengshan na China; por Santos et al. (2009), Reginato (2009) e Ancelmi et al. (2013) em retroeclogitos do Domínio Ceará Central da Província Borborema, assim como por Campos Neto e Caby (1999), Santos et al (2004) e por Pinheiro (2013) em retroeclogitos do Orógeno Brasília.

Algumas reações retrometamórficas podem ser sugeridas para a formação das texturas observadas:

(1) A formação de coronas de plagioclásio em volta dos cristais de granada pode ser descrita por granada + clinopiroxênio + quartzo $+\mathrm{H}_{2} \mathrm{O} \rightarrow$ plagioclásio + anfibólio e/ou granada + clinopiroxênio + rutilo + quartzo $+\mathrm{H}_{2} \mathrm{O} \rightarrow$ anfibólio + ilmenita + plagioclásio, marcando o início da descompressão (Figura 7-1 A); 
(2) A quebra da onfacita pode estimular o crescimento simplectítico entre diopsídio e plagioclásio (Figura 7-1 B e C), que é descrita pela reação: onfacita $\rightarrow$ diopsídio + plagioclásio (MYSEN; GRIFFIN, 1973), podendo ser gerada uma paragênese condizente com fácies granulito de alta pressão composta por granada + diopsídio + plagioclásio + quartzo + rutilo \pm anfibólio (PATTINSON, 2003);

(3) O surgimento de hornblenda, como coronas em cristais de granada ou substituindo 0 diopsídio, pode ser descrito pela reação: granada + diopsídio + plagioclásio $+\mathrm{H}_{2} \mathrm{O} \rightarrow$ anfibólio (Figura 7-1 B e C);

(4) A estabilizadação da paragênese atual da rocha, condizente com fácies anfibolito, pode ser escrita por granada + plagioclásio + quartzo $+\mathrm{H}_{2} \mathrm{O} \rightarrow$ granada $_{2}+$ plagioclásio (An) + anfibólio.
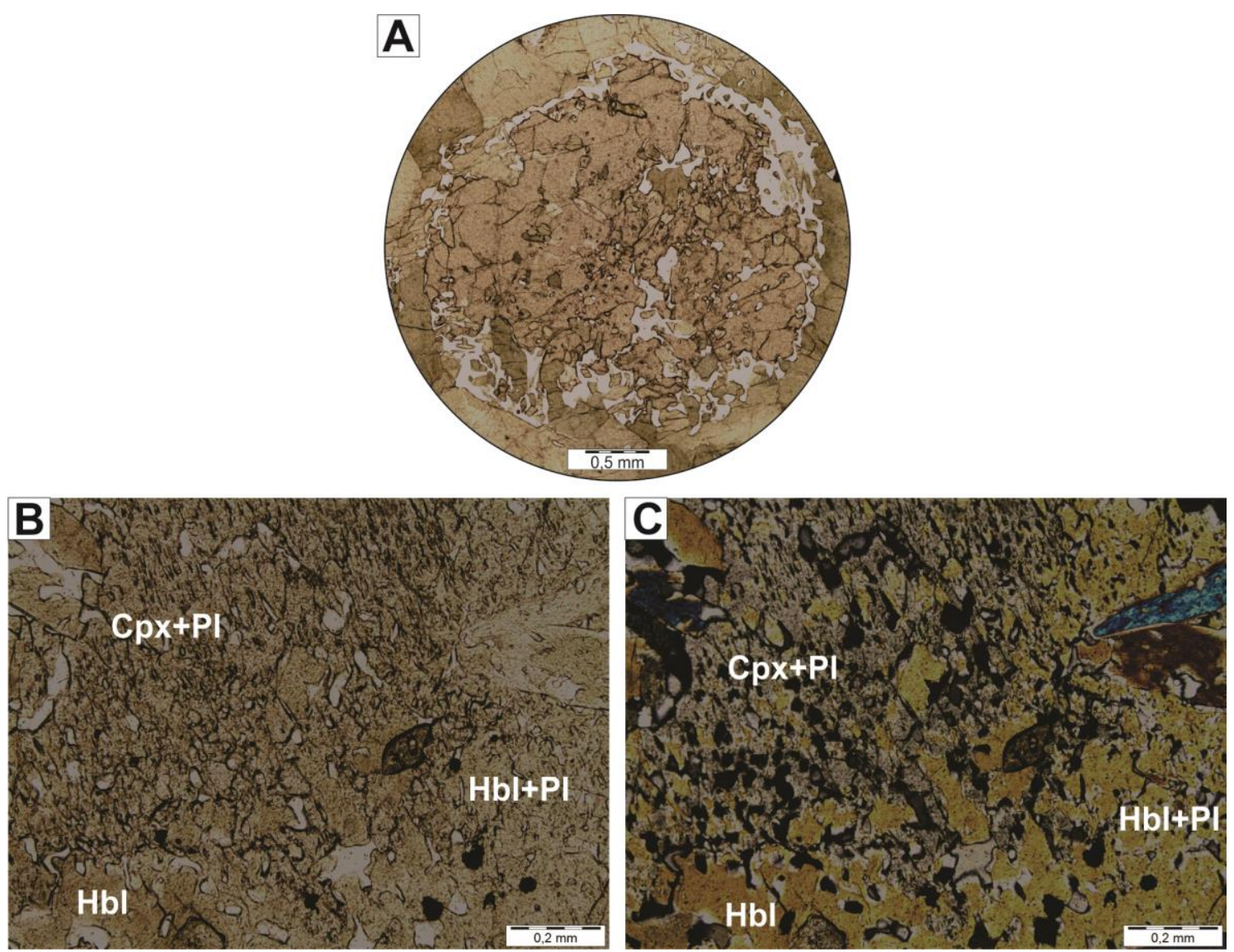

Figura 7-1. (A) Fotomicrografia com polarizador descruzado de corona de plagioclásio em torno da granada evidenciando a reação (1); (B) Fotomicrografia com polarizador descruzado exibindo crescimento simplecítico entre diopsídio e plagioclásio (reação 2), entre hornblenda e plagioclásio e a substituição de diopsídio + plagioclásio por hornblenda (reação 3); (C) Mesma fotomicrografia, agora com polarizador cruzado.

\subsubsection{Morfologia dos cristais de zircão metamórficos}

Os cristais de zircão de idades neoproterozoicas apresentam formatos que variam de arredondados à ovoides nos quais seus domínios internos, sob imagens de 
catodoluminescência (Figura 7-2) são de coloração cinza escura (altas concentrações de urânio) e possuem fraco zoneamento irregular e disforme. A grande parte destes cristais não exibe núcleos herdados, no entanto, núcleos de cristais brancos a cinza claros, localmente com zoneamento setorial também ocorrem (Figura 7-2). Desta forma, através das imagens de catodoluminescência, pode-se dizer que os cristais metamórficos sobrecresceram a partir de pequenos núcleos de zircão do protólito ígneo.

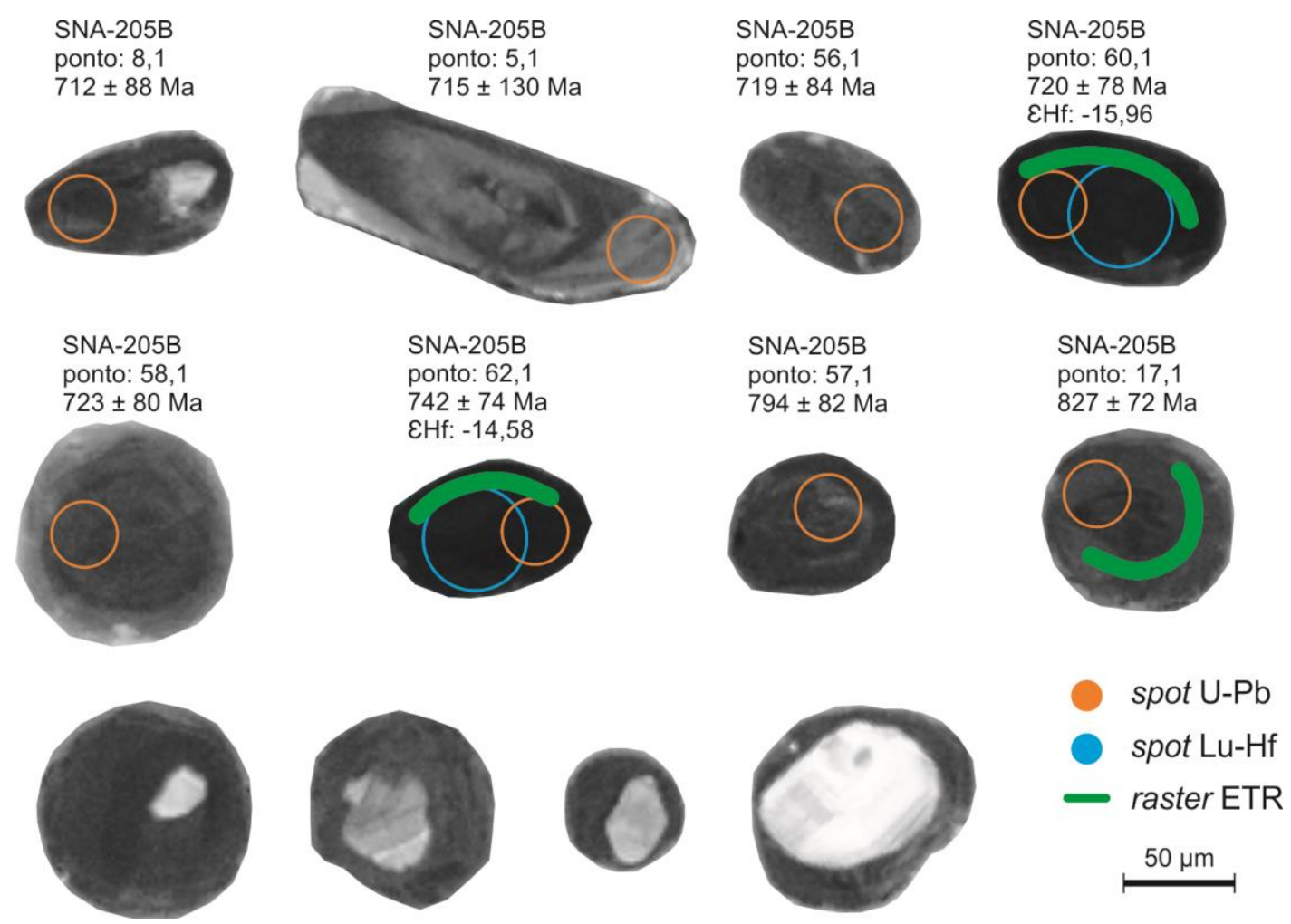

Figura 7-2. Exemplos de cristais de zircão, analisados ou não, cujos sobrecrescimentos metamórficos são tidos como representantes do metamorfismo de alta pressão registrado pela amostra SNA-205B (granadaclinopiroxênio anfibolito retroeclogítico). Idades ${ }^{207} \mathrm{~Pb} /{ }^{206} \mathrm{~Pb}$ com erro em $2 \sigma$.

Um único cristal datado do Neoproterozoico apresenta forma prismática alongada (ponto 5,1 na Figura 7-2) que se assemelha aos cristais ígneos do protólito, no entanto o zoneamento interno deste grão já se assemelha aos dos grãos metamórficos escuros.

\subsubsection{Idade do evento metamórfico de alta pressão}

A partir dos cristais/sobrecrescimentos metamórficos de zircão datados por U-Pb um conjunto de 20 pontos resultou em uma idade média, em diagrama weighted average, de $761 \pm 18 \mathrm{Ma}$ (Figura 7-3) com MSWD de 0,71. Esta idade foi adquirida em cristais principalmente arredondados de zircão do granada-clinopiroxênio anfibolito. Outro conjunto de dados resultou em uma idade mais jovem, de $612 \pm 24 \mathrm{Ma}$, que será discutida posteriormente. 
SNA-205B: Grt-cpx anfibolito retroeclogítico

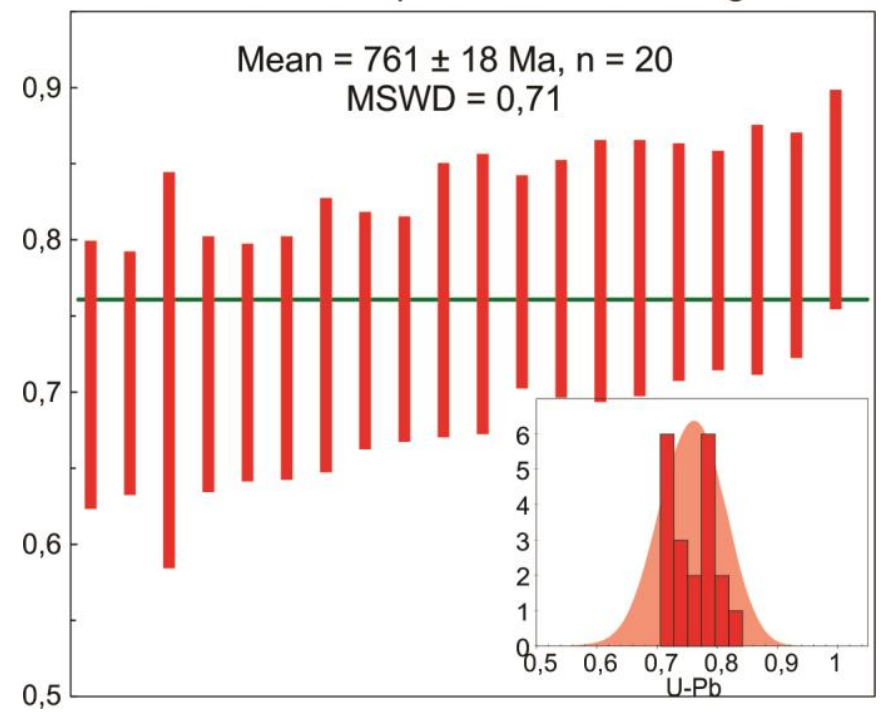

Figura 7-3. Diagrama weighted average cuja idade resultante é de $761 \pm 18 \mathrm{Ma}$ a partir de 20 pontos analisados em diferentes cristais metamórficos de zircão.

Dados mais jovens para a idade do metamorfismo de alta pressão em retroeclogitos análogos foram encontradas por outros autores: $673 \pm 57$ Ma (TROUW, 2008) intercepto inferior a partir de 9 dados, com intercepto superior de $1470 \pm 41$ e MSWD de 6,6 (amostra CTV4-CR22); $678 \pm 29 \mathrm{Ma}$ (RENO et al., 2009) como idade concórdia a partir de quatro dados (amostra 05b-13-13); e $669 \pm 25$ Ma (CAMPOS NETO et al., 2011), a partir de cinco dados em diagrama Tera-Wasserburg (amostra NESG-140). Na amostra aqui analisada estas idades não ocorrem.

\subsubsection{Razão Th/U e elementos terras raras em zircão}

As razões Th/U dos cristais arredondados de zircão, com zoneamento interno não visível e de coloração escura indicando alta concentração de urânio, são baixas, entre 0,004 à 0,029 (Figura 7-4). Os cristais com idades individuais mais jovens, que resultaram em 612 $\pm 24 \mathrm{Ma}$, tendem a apresentar razões Th/U maiores do que aqueles, neoproterozoicos mais antigos (entre 700 e $800 \mathrm{Ma}$ ), com idade resultante de $761 \pm 18 \mathrm{Ma}$. É grande a diferença na razão Th/U entre os cristais neoproterozoicos e os cristais do protólito ígneo e herdados (ver Capítulo 6), onde as menores razões Th/U são de 0,224 e chegam a alcançar 0,773. 


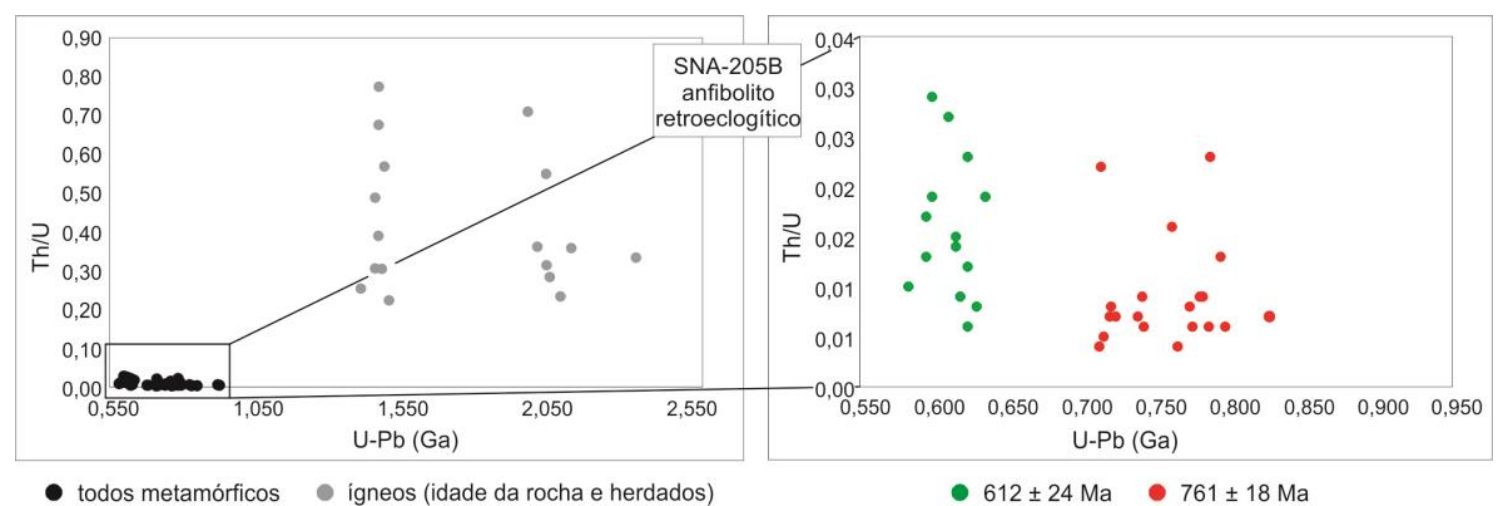

Figura 7-4. Razão Th/U versus idade U-Pb dos cristais de zircão da amostra SNA-205B referente ao anfbolito retroeclogítico exótico à bacia de sedimentação. À esquerda o detalhe somente das razões Th/U dos cristais metamórficos, em verde os grãos que resultaram em idade de $612 \pm 24 \mathrm{Ma}$, e em vermelho os que resultaram em $761 \pm 18 \mathrm{Ma}$.

Os cristais neoproterozoicos apresentam padrão dos ETR bastante distinto dos encontrados nos grãos com idades do protólito e herdados. São visivelmente mais empobrecidos em ETR pesados, com razões $\mathrm{Yb}_{N} / \mathrm{Gd}_{N}$ que podem demonstrar leve enriquecimento, entre 1,43 e 3,42, e leve empobrecimento, entre 0,45 e 0,74 (Figura 7-5), enquanto que as razões $\mathrm{Yb}_{N} / \mathrm{Gd}_{N}$ dos cristais do protólito e herdados apresentam média de 18,16. As anomalias de Eu são fracamente negativas entre 0,47 e 0,91 e uma análise possui anomalia positiva de 1,09 . As anomalias de Ce também são bastante distintas, ocorrendo anomalias positivas entre 1,01 e 3,92 e uma negativa de 0,63 (Tabela 7-1).

\begin{tabular}{|c|c|c|c|c|c|c|}
\hline Amostra & $\begin{array}{c}\text { Idade } \\
(\mathrm{Ma})\end{array}$ & $\begin{array}{c}\text { Quantidade } \\
\text { de análises }\end{array}$ & $\begin{array}{c}\text { Média da } \\
\text { concentração } \\
\text { de ETR }(\mathrm{ppm})\end{array}$ & $\begin{array}{c}\text { Enriquecimento } \\
\text { em ETR pesados } \\
(\mathrm{Yb} / \mathrm{Gd}) \mathrm{N}\end{array}$ & $\begin{array}{c}\text { Anomalia de Eu } \\
\mathrm{Eu} /[(\mathrm{Sm}+\mathrm{Gd}) / 2] \mathrm{N}\end{array}$ & $\begin{array}{c}\text { Anomalia de Ce } \\
\mathrm{Ce} /[(\mathrm{La}+\mathrm{Pr}) / 2] \mathrm{N}\end{array}$ \\
\hline $\begin{array}{c}\text { SNA- } \\
\text { 205B }\end{array}$ & $761 \pm 18$ & 5 & 7,82 & $\begin{array}{c}1,43-3,42, \\
0,45-0,74\end{array}$ & $1,09,0,47-0,91$ & $0,63,1,01-3,92$ \\
\hline
\end{tabular}

Tabela 7-1. Parâmetros calculados a partir das análises dos ETR em zircão metamórfico do granadaclinopiroxênio anfibolito retroeclogítico (SNA-205 B).

No geral as análises destes cristais tendem a apresentar padrões mais horizontalizados (Figura 7-5) quando comparado com as demais, com um leve empobrecimento nos ETR médios e pesados, o que acaba gerando um padrão levemente convexo ao diagrama, para estes elementos. 


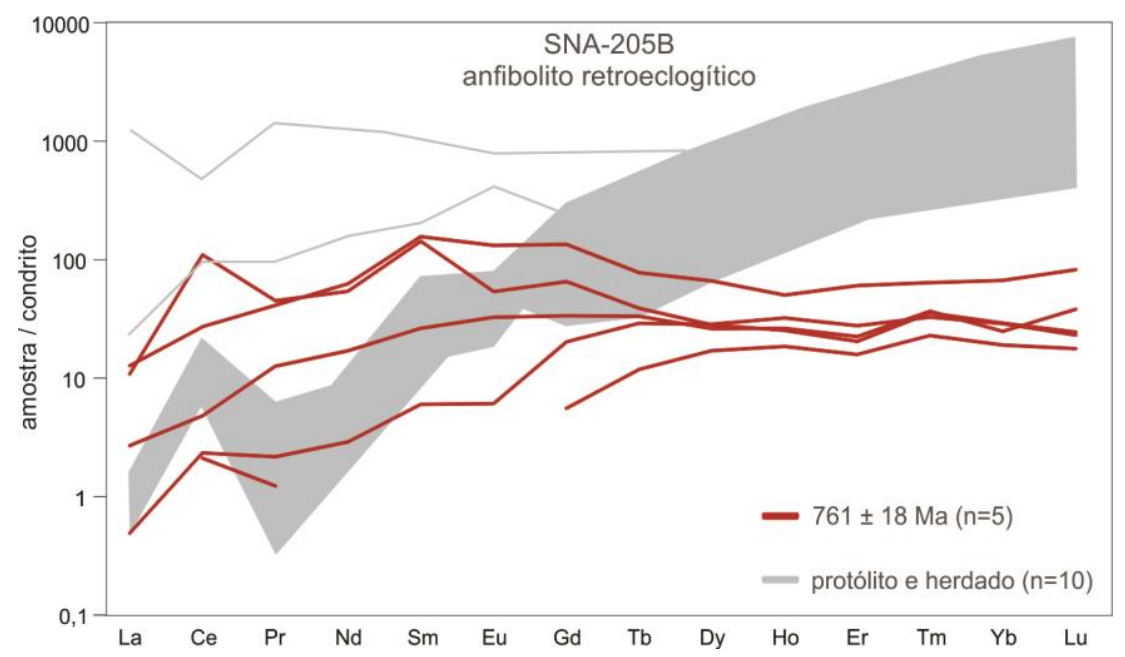

Figura 7-5. Diagrama spider dos elementos terras raras em zircão metamórfico do granada-clinopiroxênio anfibolito retroeclogítico.

É provável que os cristais e sobrecrescimentos metamórficos se formaram a partir de cristais de zircão preexistentes. A comparação entre os novos grãos e os antigos (empobrecimento em ETR pesados e menores anomalias negativas de Eu nos cristais metamórficos) indica sobrecrescimentos metamórficos formados durante recristalização subsolidus (HOSKIN; BLACK, 2000) e que os cristais do protólito se desenvolveram na ausência de granada ou outra fase mineral rica em ETR pesados (RUBATTO, 2002). O padrão relativamente mais horizontal dos cristais metamórficos de altas pressões se difere dos típicos padrões de grãos magmáticos ou de alta temperatura. As anomalias negativas de Eu são maiores em grãos ígneos ou em presença de melt, e são relativamente reduzidas com a redução da temperatura no metamorfismo (RUBATTO, 2002).

\subsubsection{Sistema isotópico Lu-Hf em cristais metamórficos de zircão}

Os cristais metamórficos de zircão apresentam razões ${ }^{176} \mathrm{Lu} /{ }^{177} \mathrm{Hf}$ entre $0,000008 \mathrm{e}$ 0,000209 , menores do que os cristais do protólito e os herdados $(0,000214$ à 0,005075$)$. As razões ${ }^{176} \mathrm{Hf} /{ }^{177} \mathrm{Hf}$ tendem a ser mais semelhantes, variam de 0,281777 à 0,281974 nos cristais metamórficos, entre 0,281955 e 0,282120 nos cristais do protólito e entre 0,281493 e 0,281607 nos cristais herdados (Figura 7-6).

Em condições de alta pressão há um aumento do coeficiente de partição do zircão (HAZEN; FINGER, 1979) o que pode explicar o aumento do conteúdo de Hf em cristais metamórficos cristalizados nestas condições. Aqui é observado que as razões ${ }^{176} \mathrm{Lu} /{ }^{177} \mathrm{Hf}$ são as menores no caso dos cristais metamórficos, fato que pode ser justificado pelo aumento da quantidade de $\mathrm{Hf}$ e a diminuição de Lu durante a cristalização em pressões mais altas. As razões ${ }^{176} \mathrm{Hf} /{ }^{177} \mathrm{Hf}$ dos cristais metamórficos são semelhantes ou um pouco mais baixas que as encontradas nos grãos do protólito, o que pode indicar que os novos cristais se formaram a partir da recristalização ou precipitação in-situ através da dissolução 
dos cristais da rocha. Se esta razão fosse maior nos cristais metamórficos, a explicação seria de que os grãos pudessem ter herdado estes elementos de minerais ricos em Lu/Hf, como granada e xenotima, pois somente cristais com altas razões de Lu/Hf conseguem produzir grandes quantidades de ${ }^{176} \mathrm{Hf}$ após uma evolução de longo tempo (CHEN; NI; XIE, 2007).

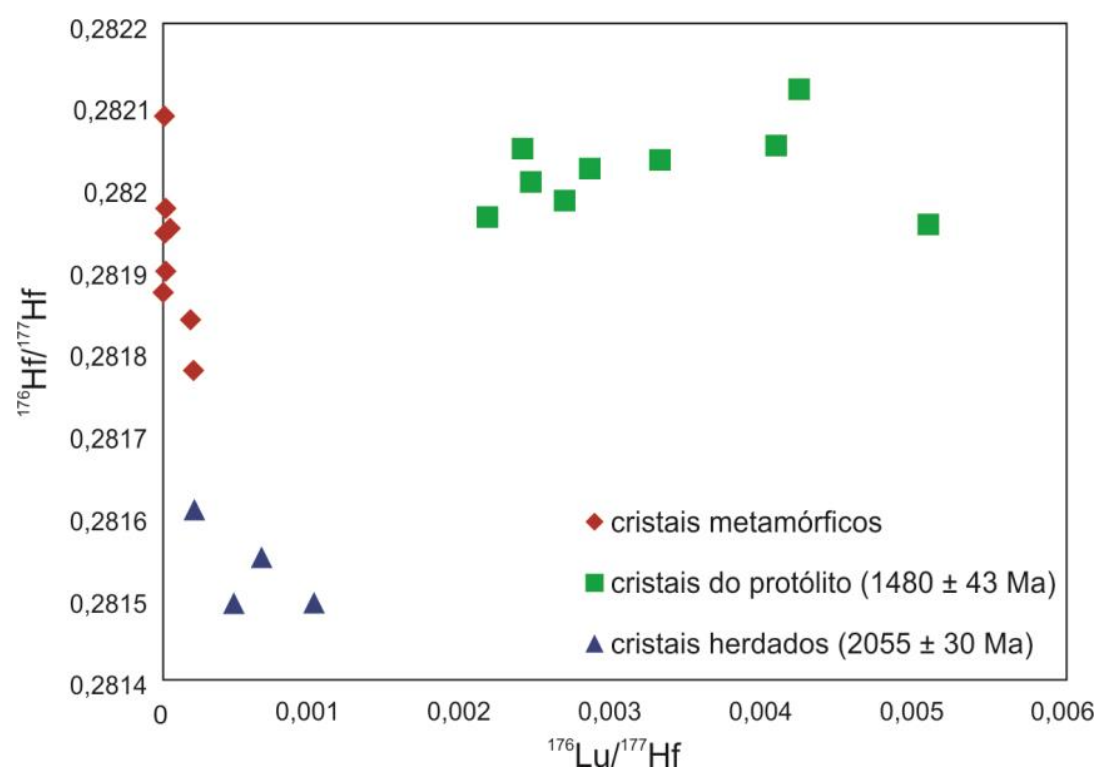

Figura 7-6. Diagrama ${ }^{176} \mathrm{Hf} /{ }^{177} \mathrm{Hf}$ versus ${ }^{176} \mathrm{Lu} /{ }^{177} \mathrm{Hf}$ com todos as razões isotópicas dos cristais de zircão da amostra do anfibolito retroeclogítico. Notar que os cristais metamórficos apresentam as menores razões de ${ }^{176} \mathrm{Lu} /{ }^{177} \mathrm{Hf}$.

\subsubsection{Elementos maiores em granada}

A partir das análises pontuais dos elementos maiores dos cristais de granada SNA205 B1 e B2, é possível dizer que ambos os cristais são ricos no membro almandina, com FeO total constituindo mais de $50 \%$ de seu conteúdo. A composição da granada B1 é $\operatorname{Alm}_{54,47-59,68} \operatorname{Grs}_{21,52-31,73} \operatorname{Prp}_{9,85-17,63} \mathrm{Sp}_{0,51-5,93}$ e a da granada B2 Alm $_{55,97-61,37} \operatorname{Grs}_{22,78-31,94} \operatorname{Prp}_{10,34-}$ ${ }_{17,70} \mathrm{Sp}_{0,56-2,87}$ (Figura 7-7). Não há grandes diferenças composicionais entre bordas e núcleo, mas observa-se um empobrecimento na molécula almandina do núcleo para a borda na granada $\mathrm{B} 1$, o que tende a ser o contrário na granada $\mathrm{B} 2$, enquanto que para a molécula grossulária os dois núcleos são empobrecidos. Sendo assim a composição média do núcleo da granada B1 é $\operatorname{Alm}_{57,80} \operatorname{Grs}_{24,62} \operatorname{Prp}_{15,15} \mathrm{Sp}_{2,42}$ e de sua borda é $\operatorname{Alm}_{57,05} \operatorname{Grs}_{27,72} \operatorname{Prp}_{13,22} \mathrm{Sp}_{2,02}$. Já no caso da granada B2 a média das composições é $\operatorname{Alm}_{56,95} \operatorname{Grs}_{23,54} \operatorname{Prp}_{17,32} \mathrm{Sp}_{2,19}$ para 0 núcleo e $\operatorname{Alm}_{58,29} \operatorname{Grs}_{26,35} \operatorname{Prp}_{13,84} \mathrm{Sp}_{1,51}$ para as bordas. 

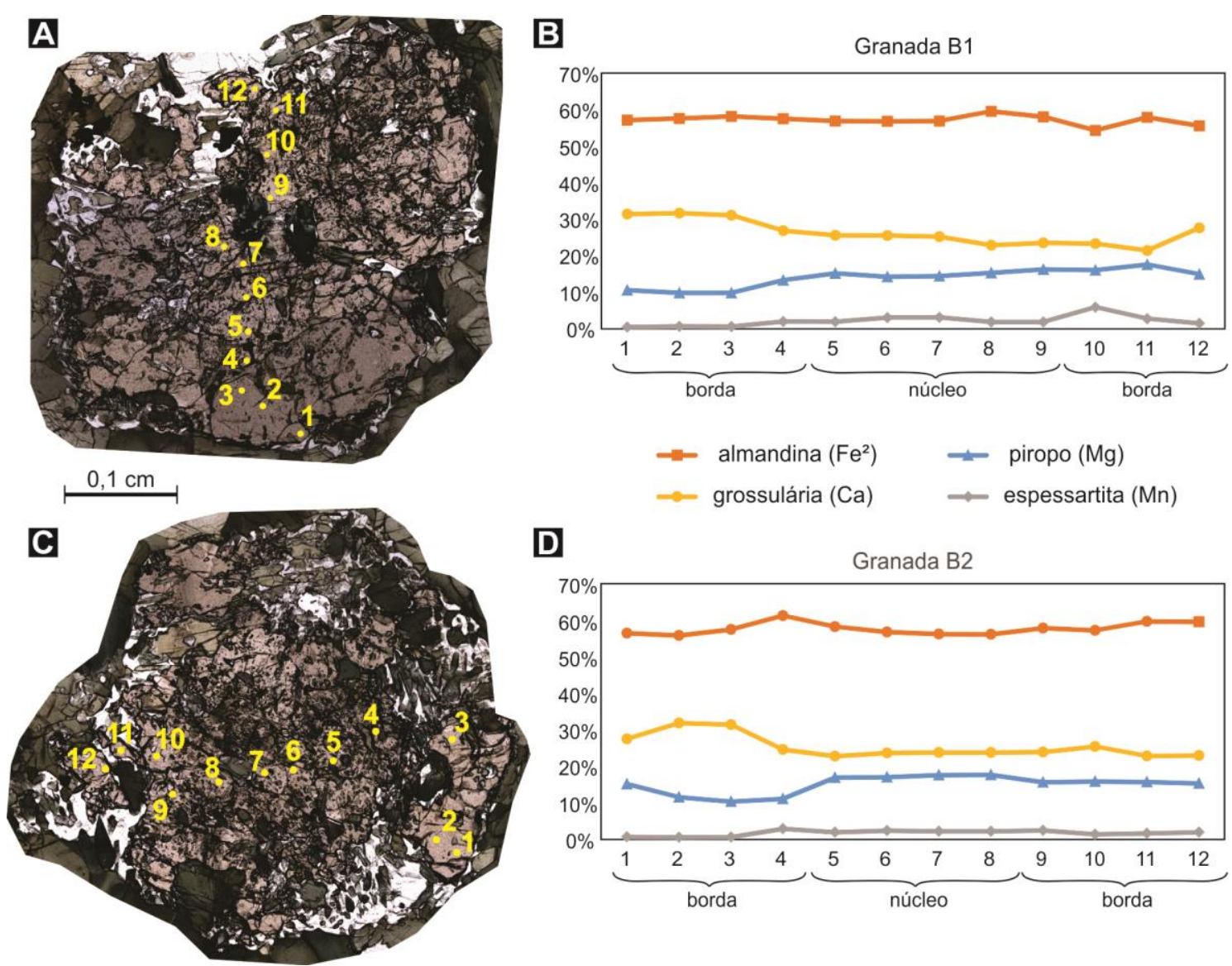

D

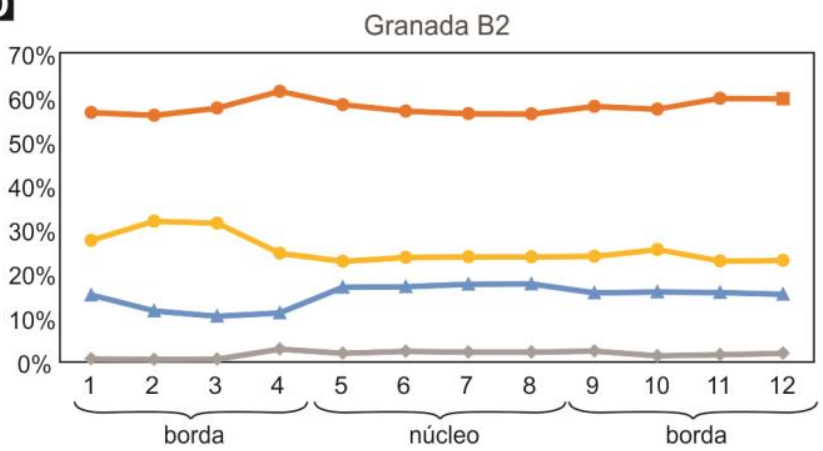

Figura 7-7. (A) Fotomicrografia com polarizar descruzado da granada SNA-205 B1 com a posição dos pontos analisados tanto por microssonda quanto por LA-ICP-MS; (B) Diagrama da composição de cada ponto analisado segundo os quatro membros finais: piropo, almandina, espessartita e grossulária da granada SNA-205 B1; (C) Fotomicrografia com polarizar descruzado da granada SNA-205 B2 com a posição dos pontos analisados tanto por microssonda quanto por LA-ICP-MS; (D) Diagrama da composição de cada ponto analisado segundo os quatro membros finais: piropo, almandina, espessartita e grossulária da granada SNA-205 B2.

Em relação aos óxidos dos elementos separadamente, em porcentagem de peso, as diferenças químicas entre núcleo e borda são mais facilmente observadas (Figura 7-8). Os núcleos tendem a ser mais empobrecidos em $\mathrm{CaO}$ e mais enriquecidos em $\mathrm{MgO}$, assim como na razão $\mathrm{MgO} /(\mathrm{MgO}$ + FеОтот), e em $\mathrm{MnO}$ do que as bordas. Já em relação ao FеOтот não é possível distinguir porções mais enriquecidas ou empobrecidas, haja visto as mudanças bruscas na composição de ponto à ponto (Figura 7-8 B). 


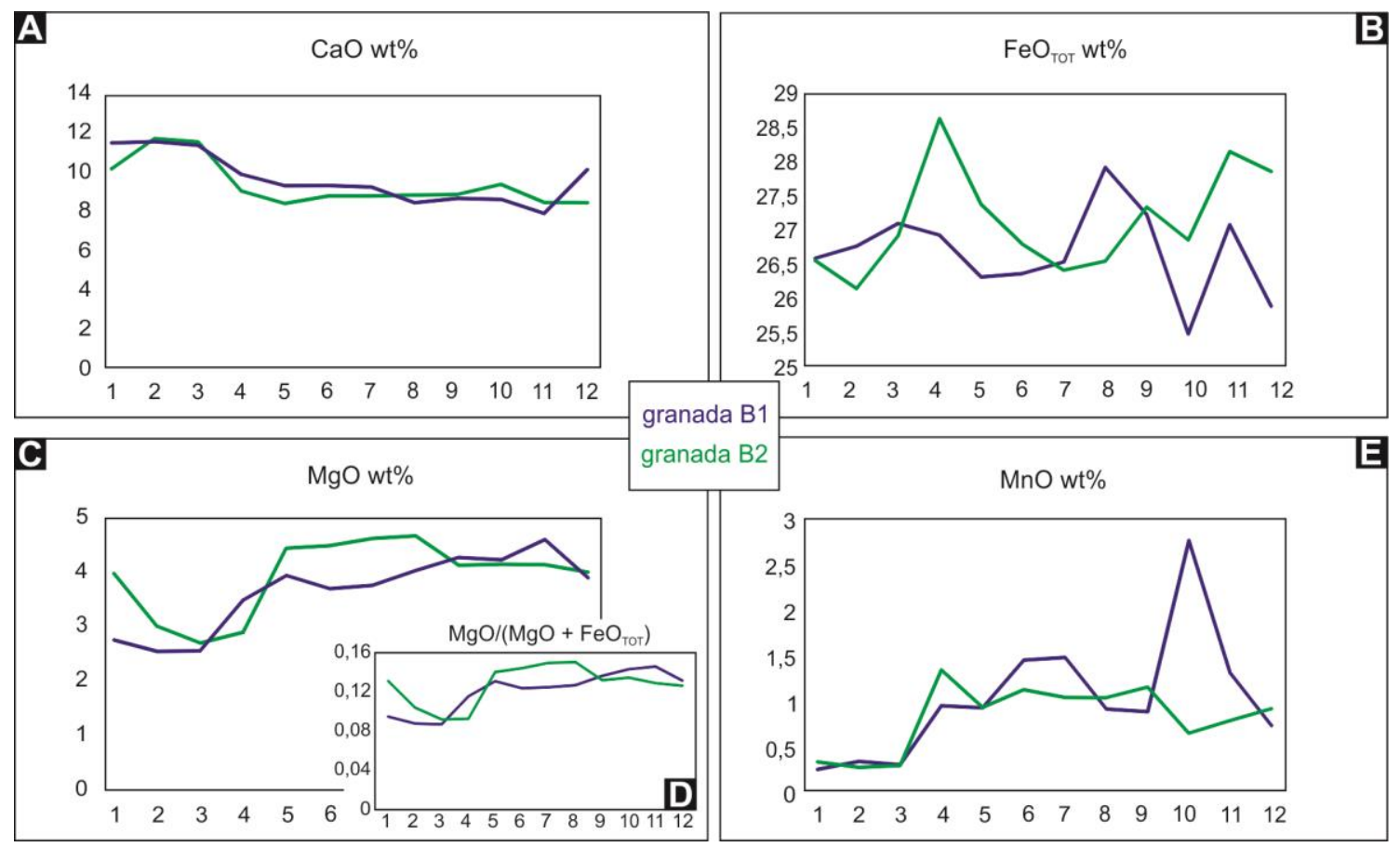

Figura 7-8. (A) Diagrama da porcentagem em peso de $\mathrm{CaO}$ nos diversos pontos analisados de ambas as granadas; (B) Diagrama da porcentagem em peso de FеОтот nos diversos pontos analisados de ambas as granadas; (C) Diagrama da porcentagem em peso de $\mathrm{MgO}$ nos diversos pontos analisados de ambas as granadas; (D) Diagrama de $\mathrm{MgO} /(\mathrm{MgO}$ + FеОтот) nos diversos pontos analisados de ambas as granadas. (E) Diagrama da porcentagem em peso de $\mathrm{MnO}$ nos diversos pontos analisados de ambas as granadas.

\subsubsection{Elementos terras raras em granada}

As análises de ETR foram realizadas em dois cristais de granada da amostra SNA205B totalizando 12 análises em cada cristal em seções borda-núcleo-borda. A maioria das análises, principalmente as dos ETR leves, exibiram concentrações medidas menores que o limite de quantificação (3,3 x limite de detecção), no entanto elas foram plotadas nos diagramas mas não serão utilizadas para calcular o fracionamento dos ETR e nem o enriquecimento em ETR leves. A Tabela 7-2 resumo todos parâmetros calculados em relação aos ETR nestes dois cristais de granada.

\begin{tabular}{|c|c|c|c|c|c|c|}
\hline \multicolumn{7}{|c|}{ GRANADA } \\
\hline \multicolumn{2}{|c|}{ Amostra } & $\begin{array}{l}\text { Local do } \\
\text { cristal }\end{array}$ & $\begin{array}{l}\text { Qntde. de } \\
\text { análises }\end{array}$ & $\begin{array}{c}\text { Média da } \\
\text { concentração de }\end{array}$ & $\begin{array}{l}\text { Enriquecimento em } \\
\text { ETR pesados }\end{array}$ & $\begin{array}{c}\text { Anomalia de Eu } \\
\mathrm{Eu} /[(\mathrm{Sm}+\mathrm{Gd}) / 2] \mathrm{N}\end{array}$ \\
\hline \multirow{4}{*}{ 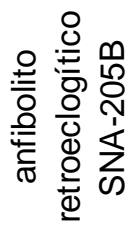 } & \multirow{2}{*}{$\bar{\infty}$} & borda & 7 & 373,48 & $1,83-7,99,31,37$ & 0,59 \\
\hline & & núcleo & 5 & 43,66 & $0,55-0,76,15,12$ & 0,69 e 0,70 \\
\hline & \multirow[t]{2}{*}{ N } & borda & 8 & 29,24 & $0,54-0,99,1,07-7,78$ & $0,49-0,76$ \\
\hline & & núcleo & 4 & 45,63 & $0,63-0,93,2,75$ & $0,75-0,83$ \\
\hline
\end{tabular}

Tabela 7-2. Resumo dos parâmetros calculados em relação aos Elementos Terras Raras em granada das amostras SNA-205B 1 e SNA-205B 2, exóticas à bacia de sedimentação estudada. 
A borda da granada B1 apresenta média de concentração em ETR por análise de 373,48 ppm, no entanto, das 7 análises realizadas, duas exibiram quantidades muito maiores de 1201,86 ppm e 1310,52 ppm, já as demais variaram entre 9,44 ppm e 28,88 ppm, com média de 20,39 ppm. O núcleo apresenta média de 43,66ppm por análise, sendo mais consistente pois as concentrações não ultrapassam a casa dos 90 ppm. A borda apresenta enriquecimento em ETR pesados com variações razoáveis entre 1,83 e 7,99, com um dado exibindo razão $\mathrm{Yb}_{N} / \mathrm{Gd}_{N}$ de 31,37 , enquanto que 0 núcleo apresenta empobrecimento em ETR pesados na maioria das análises, com razão $\mathrm{Yb}_{N} / \mathrm{Gd}_{\mathrm{N}}$ entre 0,55 e 0,76 . As anomalias negativas de Eu são maiores nas bordas do que nos núcleos (Figura 7-9 A).

A granada B2 apresenta características semelhantes (Figura 7-9 B). As análises realizadas nas bordas apresentam média de 29,24 ppm de concentração de ETR por análise, mais empobrecidas que o núcleo, que apresenta média de 45,63 ppm. Apenas duas análises em 8, na borda, exibem empobrecimento em ETR pesados, com razão $\mathrm{Yb}_{N} / \mathrm{Gd}_{N}$ de0,54 e 0,99, enquanto que as demais análises apresentam razões entre 1,07 e 7,78, demonstrando o enriquecimento visível em ETR pesados. No caso das análises no núcleo, três dados exibem empobrecimento nos ETR pesados e apenas uma análise apresenta fraco enriquecimento. As anomalias de Eu tendem a ser menores nas bordas do que nos núcleos.

Desta forma, as bordas dos cristais de granada analisados apresentam menores concentrações de ETR do que os núcleos, com enriquecimento em ETR pesados e anomalias negativas de Eu mais proeminentes. Já os núcleos tendem a apresentar empobrecimento em ETR pesados e anomalias negativas de Eu menos pronunciadas (Figura 7-9).
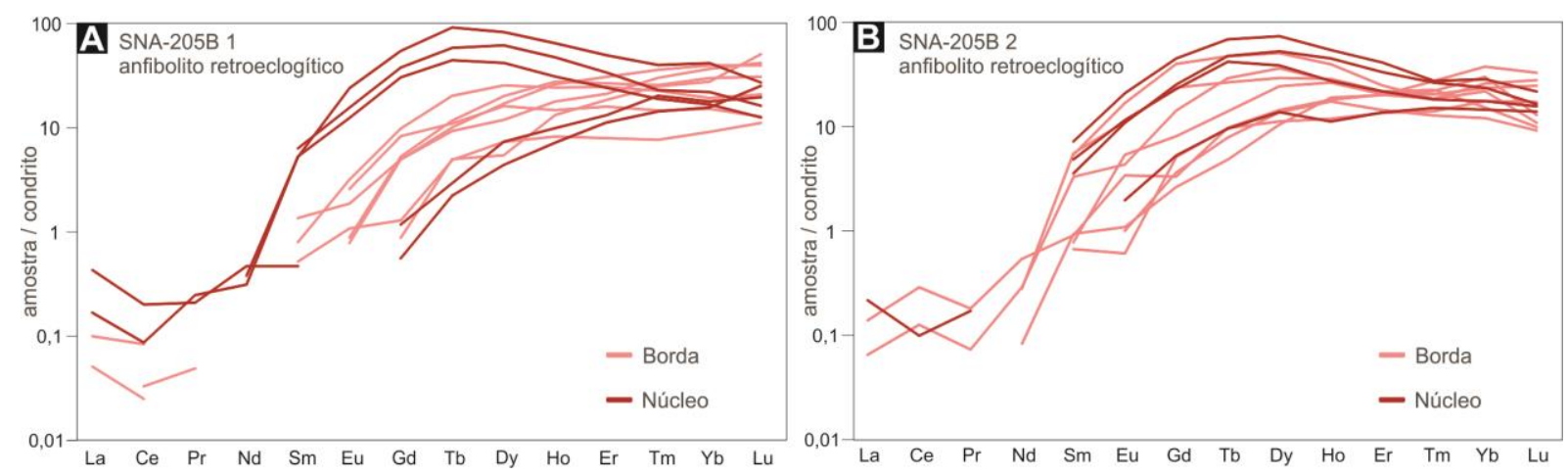

Figura 7-9. (A) Diagrama dos padrões da concentração dos ETR das bordas e núcleos dos cristais de granada B1 e (B) da granada B2 analisados da amostra SNA-205B. Os ETR foram normalizados pelo condrito C1 de Sun e McDonough (1989). 
Há um zoneamento na composição de ETR nos cristais de granada onde, do núcleo para a borda, há um empobrecimento considerável na concentração dos ETR médios (Sm, $\mathrm{Eu}, \mathrm{Gd}$ e Tb) e pesados (Dy, Ho, Er, Tm, Yb e Lu), sendo os núcleos sempre mais enriquecidos em ETR médios e pesados do que as bordas (Figura 7-10).

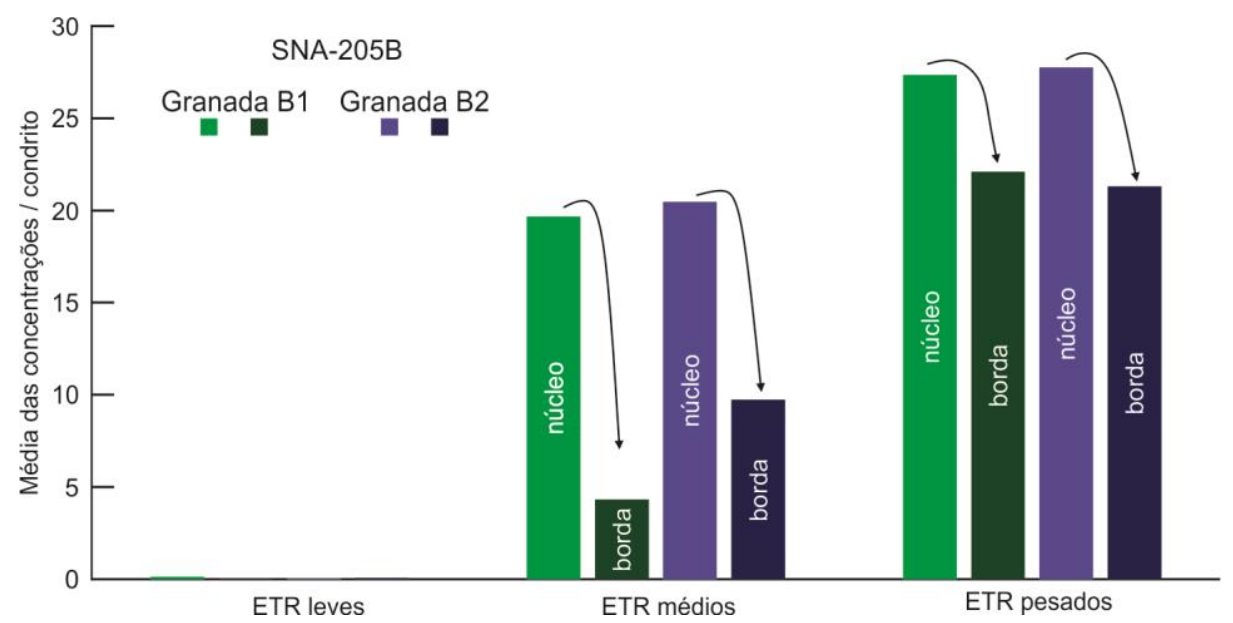

Figura 7-10. Diagrama da média da concentração, normalizada pelo condrito, dos ETR leves, médios e pesados do núcleo e borda dos dois cristais B1 e B2 de granada analisados da amostra SNA-205B. Notar que os núcleos de ambos os grãos são mais enriquecidos em ETR médios e pesados do que as bordas.

Desta forma pode-se dizer que as granadas aqui analisadas são do tipo almandina, e apresentam núcleos enriquecidos em MgO, MnO, ETR médios e pesados e empobrecidos em $\mathrm{CaO}$ em relação às bordas.

\subsection{8 coeficiente de partição de ETR entre zircão metamórfico e granada}

Para o cálculo dos coeficientes de partição entre zircão e granada ( ${ }^{E T R} D_{Z R / G R T}$ ) foram utilizados todos os ETR, no entanto o foco está voltado para os ETR pesados (ETRP) na medida em que as análises dos ETR leves em granada apresentaram altos erros. Os ${ }^{E T R P} D_{\text {ZR/GRT }}$ foram calculados através da comparação entre a média das composições do núcleo e da borda dos cristais de granada, com as composições dos cristais metamórficos individuais de zircão (Figura 7-11 A e C). A média das composições de núcleo e borda das granadas também foram utilizadas no cálculo com a média das composições de zircão que resultaram na idade neoproterozoica mais antiga, de $761 \pm 18$ Ma discutida no item 7.1.3 deste capítulo (Figura 7-11 B e D).

Os valores de ${ }^{E T R} D_{Z R / G R T}$ são dependentes da temperatura: para temperaturas mais altas $(\sim 1000 \stackrel{\circ}{\circ})$ estes valores são próximos de um, enquanto que em temperaturas mais baixas os ETR pesados favorecem o zircão em relação à granada, entre $800-850{ }^{\circ} \mathrm{C}$ (RUBATTO; HERMANN, 2007). 

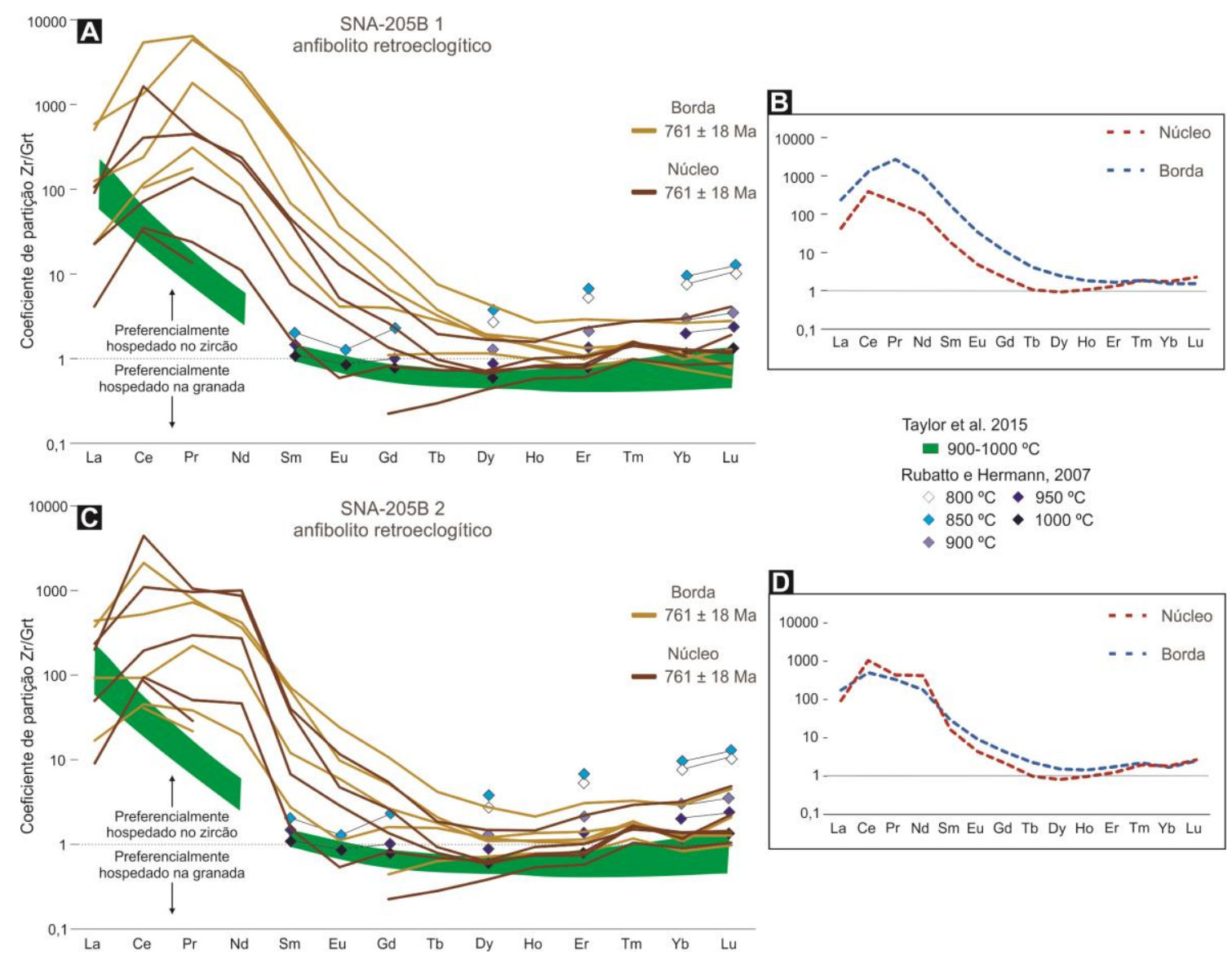

Figura 7-11. (A) e (C) Diagramas de coeficiente de partição zircão/granada entre os cristais metamórficos individuais de zircão e as porções internas e externas de dois grãos de granada do granada-clinopiroxênio anfibolito retroeclogítico (SNA0205B), como comparação estão plotados os dados obtidos através de estudo experimental de Rubatto e Hermann (2007), realizado a 20 kbar de pressão e Taylor et al. (2015) realizado a 7 kbar de pressão; (B) e (D) Diagramas do coeficiente de partição entre a média da composição dos cristais de zircão de $761 \pm 18$ Ma e a média das porções (núcleo e borda) dos grãos de granada.

Os valores de ${ }^{E T R P} D_{Z R / G R T}$ são relativamente distintos quando comparados entre as porções internas e externas da granada: geralmente estes valores são mais baixos entre zircão/núcleo (Figura 7-11 B e D), e tendem a ser um pouco mais elevadas entre zircão/borda. Os ETR pesados aparentemente favoreceram os núcleos da granada em relação ao zircão, enquanto que nas bordas a tendência é contrária.

Com o cálculo do coeficiente de partição entre zircão metamórfico e as porções dos grãos de granada é possível traçar a relação entre o crescimento de ambos os minerais principalmente através dos elementos terras raras pesados (ETRP), já que os dois minerais em questão são comumente enriquecidos neles. Valores maiores que 1 indicam que um certo elemento é preferencialmente hospedado no zircão, enquanto que valores menores indicam o oposto. Espera-se que, se o cristal metamórfico de zircão tenha se cristalizado no mesmo período da formação da granada, os valores de coeficiente de partição ${ }^{E T R P} D_{\text {ZR/GRT }}$ estejam próximos de 1. O empobrecimento em ETR pesados dos cristais de zircão metamórficos demonstrado aqui, diferentemente dos grãos ígneos, indica que o crescimento 
destes grãos/sobrecrescimentos se deu em presença de granada, assim como descrito por Rubatto (2002). Sendo assim, é possível dizer que os cristais metamórficos cresceram concomitantemente aos núcleos das granadas aqui estudadas, o que indica que seus núcleos se formaram mais próximos das condições de alta pressão do que suas bordas.

Através de estudos experimentais (RUBATTO; HERMANN, 2007; TAYLOR et al., 2015) constataram que é quanto maior a temperatura, mais os ETR médios e pesados favorecem a granada em relação ao zircão, e aparentemente, em temperaturas entre 900$1000^{\circ} \mathrm{C}$, estes mesmo elementos tendem a favorecer a granada em pressões mais baixas, como no caso de Taylor et al. (2015) no qual o estudo foi realizado a 7 kbar de pressão. Em pressões mais altas, como no caso do estudo de Rubatto e Hermann (2007) realizado a 20 kbar, neste mesmo intervalo de temperatura, os ETR médios e pesados favorecem um pouco menos a granada, mesmo que os valores de ${ }^{E T R M / P} D_{Z R / G R T}$ estejam próximos da unidade. Sendo assim, é possível observar a semelhança (Figura 7-11 A e C) entre os valores de ${ }^{E T R M / P} D_{Z R / G R T}$ do retroeclogito aqui estudado com os valores experimentalmente gerados a $900-950{ }^{\circ} \mathrm{C}$ e $12 \mathrm{kbar}$ (RUBATTO; HERMANN, 2007).

As assinaturas geoquímicas de ETR e seus coeficientes de partição com a granada metamórfica indicam que a idade de $761 \pm 18$ Ma está relacionada a estágios de exumação de evento metamórfico de alta pressão. Esse evento, na Nappe Liberdade, foi admitido sob condições báricas de $17 \mathrm{kbar}$ e $\mathrm{T}$ entre $650^{\circ}-700^{\circ} \mathrm{C}$ e descreve uma trajetória de descompressão isotérmica para condições de fácies anfibolito (CAMPOS NETO; CABY, 1999; SANTOS et al, 2004).

\subsection{Metamorfismo de colisão e migração de nappes}

\subsubsection{Condições do metamorfismo de colisão}

As rochas metassedimentares das nappes Andrelândia e Liberdade foram submetidas a metamorfismo fácies anfibolito-anfibolito superior, com alguns dos metapelitos da Nappe Liberdade indicando o metamorfismo de maior temperatura pela presença de feldspato potássico proveniente da quebra da muscovita (ver Capítulo 4). Estas rochas apresentam paragênese do pico metamórfico constituída por biotita + feldspato potássico \pm cianita, indicando temperaturas próximas de $770^{\circ} \mathrm{C}$ sob altas pressões. Algumas outras litologias possuem estaurolita retrometamórfica e estaurolita progressiva foi descrita por Santos et al. (2004).

Os metawackes da Unidade Santo Antônio apresentam assembleia mineral constituída por biotita + granada + plagioclásio + quartzo \pm cianita \pm sillimanita \pm estaurolita, com indícios de que no metamorfismo retrogressivo, parte desta assembleia foi parcialmente consumida para geração de sillimanita e estaurolita, na medida em que observa-se cristais 
de cianita corroídos aparentemente invadidos por estaurolita. O anfibolito desta mesma unidade, exibe assembleia típica de fácies anfibolito, constituída essencialmente por hornblenda + plagioclásio + epidoto; a presença de "piscinas" vermiformes de quartzo no entorno de cristais de hornblenda com bordas irregulares pode indicar fusão parcial.

Os metapelitos da Unidade Serra da Boa Vista apresentam geralmente assembleias minerais constituídas por quartzo + plagioclásio + muscovita + biotita + granada \pm sillimanita \pm cianita \pm estaurolita ( \pm clorita). Também observa-se o consumo da cianita pela sillimanita e estaurolita indicando uma trajetória de resfriamento e descompressão. A clorita é magnesiana, retrogressiva e consome muscovita e/ou biotita (Fe-Clorita progressiva é descrita inclusa em granadas).

\subsubsection{Razão Th/U em sobrecrescimento metamórfico de zircão}

As razões Th/U foram utilizadas em conjunto com a descrição da tipologia do zircão sob imagem de catodoluminescência. Na Figura 7-12 estão reunidas as razões Th/U versus idade U-Pb das amostras das rochas metassedimentares. A maioria dos sobrecrescimentos metamórficos possuem razões Th/U menores que 0,10 no entanto em amostras da Nappe Liberdade (SNA-169 e SNA-172E) poucas razões podem alcançar 0,45. As menores razões são próximas de 0,002. As médias das razões para cada amostra variam de 0,058 para a amostra SNA-169 da Nappe Liberdade e 0,008 para a amostra SNA-125 da Unidade Serra da Boa Vista.
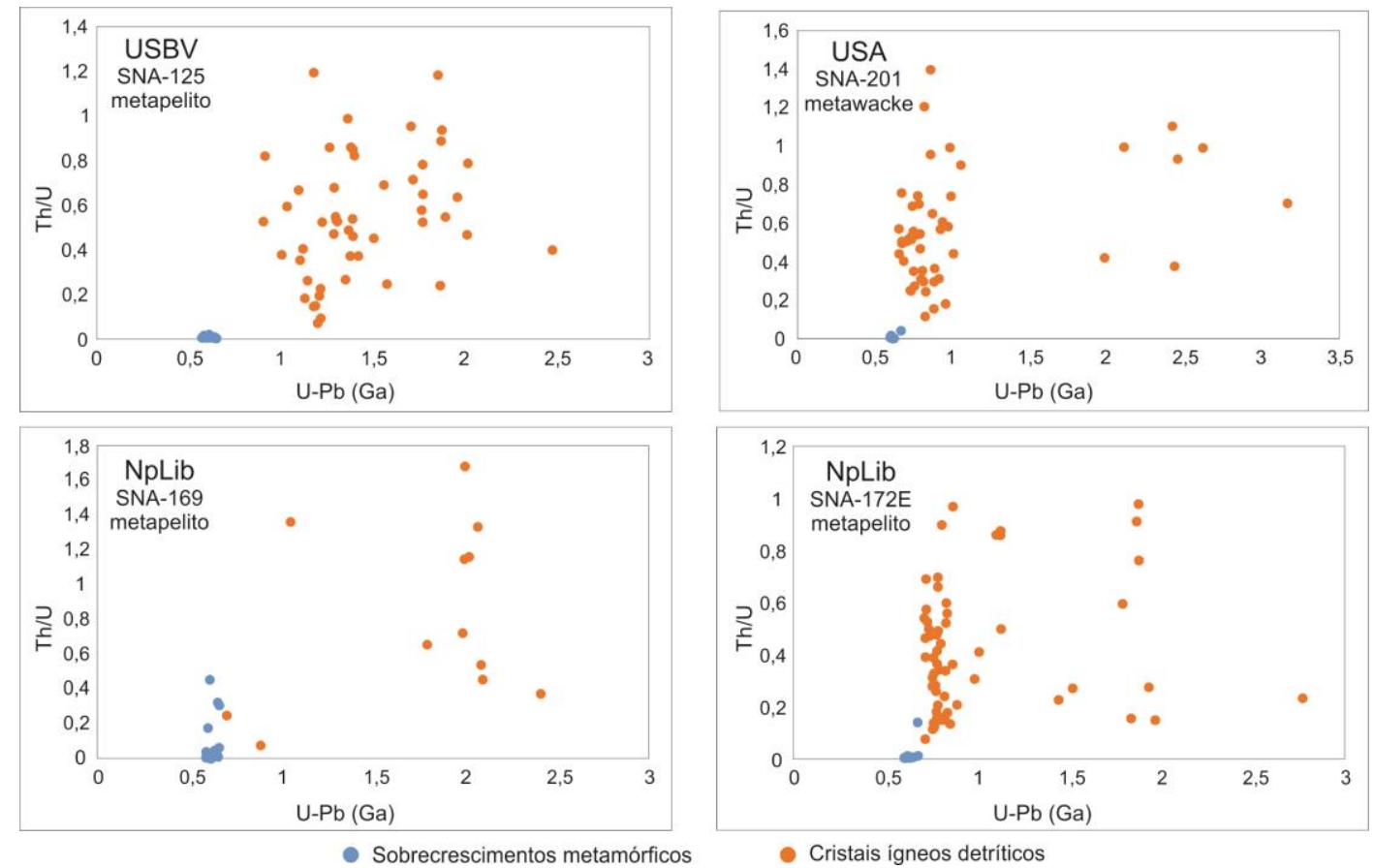

Figura 7-12. Razões Th/U versus idade U-Pb dos cristais de zircão provenientes das rochas metassedimentares que apresentaram sobrecrescimentos metamórficos analisados nos quais proveram as concentrações de Th e $U$ para tal cálculo. USBV = Unidade Serra da Boa Vista; USA = Unidade Santo Antônio; NpLib = Nappe Liberdade. 
7.2.3 Idades do evento metamórfico relacionado a migração de nappes sin-colisão

As idades do metamorfismo foram obtidas nos sobrecrescimentos metamórficos dos cristais de zircão em 9 de 14 amostras utilizadas para datação U-Pb. As idades resultantes através de conjuntos de dados, tratados em diagramas weighted average (Figura 7-13), são

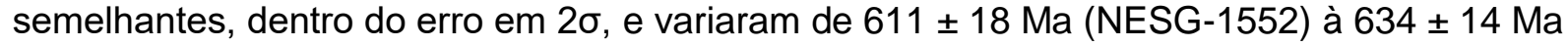
(NESG-1010), ambas na Unidade Santo Antônio.

A amostra do granada-clinopiroxênio anfibolito retroeclogítico além de ter gravado idades do metamorfismo de alta pressão, também possue cristais de zircão com idade de $612 \pm 24 \mathrm{Ma}$ (Figura 7-13), relacionada ao metamorfismo sin-colisão.
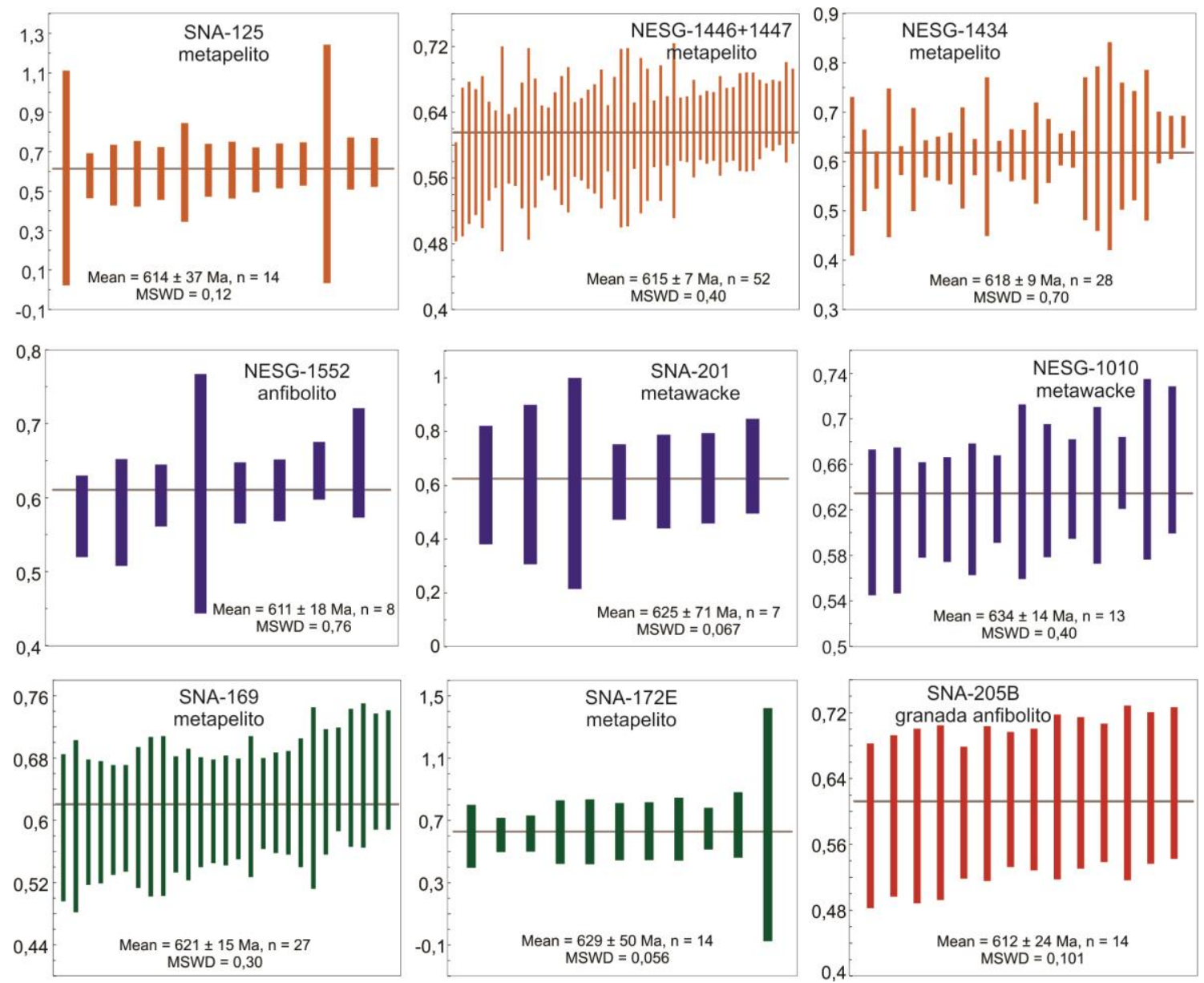

Figura 7-13. Diagramas weighted average com as idades ${ }^{207} \mathrm{~Pb} / 206 \mathrm{~Pb}$ resultantes dos conjuntos de sobrecrescimentos metamórficos em zircão. Em laranja as amostras da Unidade Serra da Boa Vista; em azul as amostras da Unidade Santo Antônio; em verde as amostras das rochas metassedimentares da Nappe Liberdade e em vermelho a amostra do granada-clinopiroxênio anfibolito retroeclogítico exótico à bacia de sedimentação. 


\section{CAPÍTULO 8}

\section{DISCUSSÕES E CONCLUSÕES}

\subsection{Ambiente de sedimentação e possíveis áreas-fonte}

As rochas da Unidade Serra da Boa Vista e da Nappe Liberdade apresentam valores relativamente altos de índice do intemperismo químico, indicando que a maior parte de suas fontes esteve sob as ações de alteração química durante longos períodos de tempo e pode estar relacionada à rochas mais antigas ou mais facilmente alteráveis. Com valores menores, as rochas da Unidade Santo Antônio, com CIA entre 53 e 62, sugerem uma história diferente de sedimentação que indica rápida erosão e soterramento dos sedimentos. A química dos metawackes do Sistema de Nappes Carrancas (WESTIN; CAMPOS NETO, 2013), com CIA principalmente entre 60 e 67, sugerem uma evolução sedimentar distinta àquela dos metawackes da Unidade Santo Antônio, indicando maiores taxas de alteração química (Figura 5-1).

Os elementos traço sugerem que as fontes dos sedimentos das rochas da Unidade Serra da Boa Vista e da Nappe Liberdade eram predominantemente crustais de composições intermediárias à ácidas, enquanto que as fontes da Unidade Santo Antônio seriam mais empobrecidas, com contribuição importante de rochas derivadas diretamente do manto. Os padrões de ETR de todas as rochas estudadas apresentam anomalias negativas de Eu condizente com sedimentos pós-Arqueanos provenientes de rochas ígneas cristalizadas em profundidades menores do que $40 \mathrm{~km}$ (Figura 5-3). O anfibolito da Unidade Santo Antônio exibe padrão flat de ETR médios e pesados, sem anomalias significantes de $\mathrm{Eu}$, o que pode evidenciar sedimentos de bacia em ambiente de arco, com fonte preferencialmente andesítica (Figura 5-3 C).

Nas relações entre Th/U versus Th, Th/Sc versus $\mathrm{Zr} / \mathrm{Sc}$, $\varepsilon N d_{t}$ versus ${ }^{87} \mathrm{Sr}^{86} \mathrm{Sr}_{\mathrm{t}}$ e $\varepsilon \mathrm{Nd}_{\mathrm{t}}$ versus $\mathrm{Th} / \mathrm{Sc}$, todas as amostras registram uma assinatura de margem ativa o que sugere um ambiente de deposição tectonicamente instável e orogênico, a partir da erosão de rochas crustais antigas (Unidade Serra da Boa Vista), com influência de rochas de arco magmático diferenciado (Nappe Liberdade) e de rochas empobrecidas de arco magmático continental e de arco de insular intraoceânico (Unidade Santo Antônio) (Figuras 5-2 e 5-11).

As rochas-fonte da Unidade Serra da Boa Vista apresentam idades mais antigas que o Toniano, com densidades importantes de idades no Mesoproterozoico (1089-1277 Ma e 1374-1485 Ma), no Estateriano-Orosiriano (1730-1971 Ma) e no Riaciano (2071-2143 Ma). Em todos os intervalos, os cristais de zircão exibem valores de $\varepsilon \mathrm{Hf}$ positivos e negativos e anomalias negativas de Eu, com destaque para o intervalo de 1089-1277 Ma e de 1374$1485 \mathrm{Ma}$ quando valores de $\varepsilon \mathrm{Hf}$ alcançam $+7,03$ e +8,12, e anomalias de Eu de 0,78 e 0,52, respectivamente. Os resultados de geoquímica isotópica em rocha-total indicam mistura de 
fontes mantélicas empobrecidas, entre 1,5-2,28 Ga, com rochas crustais para os sedimentos desta unidade, com valores negativos de $\varepsilon \mathrm{Nd}_{680}$ (entre $-8,23$ e $-14,75$ ) e razões ${ }^{87} \mathrm{Sr} /{ }^{86} \mathrm{Sr}$ altas $(0,72898$ a 0,73242$)$ (Tabela 8-1).

\begin{tabular}{|c|c|c|c|c|c|c|c|}
\hline \multirow{2}{*}{$\begin{array}{c}\text { Idade } \\
\text { U-Pb (Ma) }\end{array}$} & \multicolumn{3}{|c|}{ Lu-Hf (mineral) } & \multirow{2}{*}{$\begin{array}{c}\text { Elementos } \\
\text { Terras Raras } \\
\text { Anomalia de } \\
\text { Eu }\end{array}$} & \multicolumn{3}{|c|}{$\begin{array}{c}\text { Geoquímica isotópica em rocha- } \\
\text { total }\end{array}$} \\
\hline & $\varepsilon \mathrm{Hf}$ & $\mathrm{T}_{\mathrm{DM}}(\mathrm{Ma})$ & $\mathrm{T}_{\mathrm{NC}}(\mathrm{Ma})$ & & $\varepsilon N d$ & $\mathrm{~T}_{\mathrm{DM}}(\mathrm{Ma})$ & ${ }^{87} \mathrm{Sr} /{ }^{86} \mathrm{Sr}$ \\
\hline \multicolumn{8}{|c|}{ UNIDADE SERRA DA BOA VISTA - Nappe Andrelândia } \\
\hline $924-1089$ & $-17,31 \mathrm{a}+2,50$ & 1728 a 2691 & $1450-2300$ & 0,08 a 0,39 & \multirow{5}{*}{$\begin{array}{c}-8,23 \\
a \\
-14,75\end{array}$} & \multirow{5}{*}{$\begin{array}{c}1798 \\
a \\
2282\end{array}$} & \multirow{5}{*}{$\begin{array}{c}0,72898 \\
a \\
0,73242\end{array}$} \\
\hline $1149-1277$ & $-16,15 a+7,03$ & 1492 a 3222 & $1350-2900$ & 0,06 a 0,78 & & & \\
\hline $1374-1485$ & $-9,27 a+8,12$ & 1966 a 2669 & $1500-2550$ & 0,12 a 0,52 & & & \\
\hline $1730-1971$ & $-15,62 a+5,72$ & 1991 a 3534 & $1800-3200$ & 0,31 a 0,65 & & & \\
\hline $2071-2143$ & $-5,14$ & 2268 & 2000 & - & & & \\
\hline \multicolumn{8}{|c|}{ UNIDADE SANTO ANTÔNIO - Nappe Andrelândia } \\
\hline $682-699$ & $-3,14 a+13,84$ & 743 a 2101 & $<1900$ & 0,03 a 0,69 & \multirow{7}{*}{$\begin{array}{c}-4,00 \\
a \\
+0,98\end{array}$} & \multirow{7}{*}{$\begin{array}{c}1164 \\
a \\
1540\end{array}$} & \multirow{7}{*}{$\begin{array}{c}0,69851 \\
a \\
0,70870\end{array}$} \\
\hline $764-785$ & $-17,48 a+11,90$ & 832 a 2547 & $<2350$ & 0,20 a 0,74 & & & \\
\hline $805-1005$ & $-14,79 a+12,24$ & 872 a 2722 & $<2550$ & 0,20 a 0,89 & & & \\
\hline $1242-1262$ & $-3,22 a+5,47$ & 1628 a 2193 & $1350-1900$ & 0,50 a 0,53 & & & \\
\hline 1437 & $-2,1$ & 2280 & 2000 & - & & & \\
\hline $1884-1938$ & $-7,97 a+7,45$ & 2638 a 3026 & $2450-1900$ & - & & & \\
\hline 2030 & $-8,40 a+3,21$ & 2387 a 3115 & $2100-1950$ & - & & & \\
\hline \multicolumn{8}{|c|}{ ROCHAS METASSEDIMENTARES - Nappe Liberdade } \\
\hline 791 & $-15,63$ a $-2,27$ & 1866 a 2606 & $1650-2400$ & 0,10 a 1,04 & \multirow{4}{*}{$\begin{array}{c}-9,11 \\
a \\
-7,30\end{array}$} & \multirow{4}{*}{$\begin{array}{c}1925 \\
a \\
2111\end{array}$} & \multirow{4}{*}{$\begin{array}{c}0,71194 \\
a \\
0,72213\end{array}$} \\
\hline $1093-1240$ & $-5,75 a+3,35$ & 1585 a 2253 & $1300-2100$ & 0,05 a 0,54 & & & \\
\hline 1515 & $-9,49$ a $-3,67$ & 2447 a 2751 & $2250-2500$ & 0,12 a 0,63 & & & \\
\hline $1766-1864$ & $-5,28$ & 2782 & 2500 & 0,04 & & & \\
\hline
\end{tabular}

Tabela 8-1. Resumo dos principais registros isotópicos e químicos das rochas metassedimentares estudadas. As idades aqui plotadas referem-se às idades resultantes em de diagrama weighted average.

A Unidade Santo Antônio tem a maior densidade de idades no Criogeniano-TonianoEsteniano, cujos cristais de zircão apresentam valores de $\varepsilon \mathrm{Hf}$ positivos no intervalo mais jovem (682-699 Ma) com valores ente $+4,10$ e $+13,84$, e igualmente positivos e negativos ($14,79 \mathrm{a}+12,24)$ nas idades tonianas (764-785 Ma e 805-1005 Ma). As idades-modelo Hf$\mathrm{T}_{\mathrm{DM}}$ mais jovens em cada um destes intervalos assemelham-se às idades de cristalização dos cristais, e a maioria dos dados encontram-se sobre a linha de evolução isotópica de New Crust, sugerindo um intervalo de tempo pequeno para a evolução isotópica a partir do manto empobrecido, compatível com sedimentos provindos da erosão de arcos insulares ou de rochas vulcanoclásticas do arco (Figura 8-1 A). As demais fontes desta unidade apresentam idades no Ectasiano (1242-1262 Ma), Calimiano (1437 Ma) e Orosiriano (1884- 
$1938 \mathrm{Ma}$ e $2030 \mathrm{Ma}$ ), com valores de $\varepsilon \mathrm{Hf}$ menos positivos. A geoquímica isotópica em rocha-total de $\mathrm{Sm}-\mathrm{Nd}$ e $\mathrm{Rb}-\mathrm{Sr}$ sugere mistura entre fontes crustais e rochas empobrecidas a partir dos valores pouco negativos a pouco positivos de $\varepsilon \mathrm{Nd}_{680}$ (entre $-4,00$ e $+0,98$ ) e baixos valores de ${ }^{87} \mathrm{Sr} /{ }^{86} \mathrm{Sr}$ (entre 0,69851 e 0,70870) (Tabela 8-1).

A área-fonte mais jovem da Nappe Liberdade apresenta idades toniana (791 Ma) com valores de $\varepsilon \mathrm{Hf}$ essencialmente negativos. Já as demais fontes desta unidade apresentam idades que predominam no Esteniano-Ectasiano (1093-1240 Ma), EctasianoCalimiano (1330-1515 Ma) e Estateriano-Orosiriano (1766-1864 Ma). Todos estes intervalos exibem valores de $\varepsilon \mathrm{Hf}$ negativos, com exceção das idades do Esteniano-Ectasiano, com valores que alcançam +3,35 (Figura 8-1 A). A geoquímica isotópica de $\mathrm{Sm}-\mathrm{Nd}$ e Rb-Sr em rocha-total, sugere mistura de fontes essencialmente crustais, com valores negativos de $\varepsilon \mathrm{Nd}_{790}$ (entre $-7,30$ a $-9,11$ ) e razões isotópicas de ${ }^{87} \mathrm{Sr} /{ }^{86} \mathrm{Sr}$ encontram-se entre $0,71194 \mathrm{e}$ 0,72213 (Tabela 8-1).

As concentrações de ETR em zircão detrítico mostram distintos padrões para cada unidade (Figura 8-1 B), sugerindo fontes diferentes principalmente entre a Unidade Santo Antônio e as demais. A Unidade Santo Antônio exibe os padrões menos enriquecidos em ETR pesados, sugerindo cristalização de zircão concomitante à outras fases minerais ricas em ETR pesados, como granada. Nos cristais de zircão desta unidade também são observadas as menores anomalias negativas de Eu e positivas de Ce. Já a Unidade Serra da Boa Vista e a Nappe Liberdade apresentam padrões mais inclinados com enriquecimento em ETR pesados em relação aos leves, e anomalias negativas de Eu e positivas de Ce. A média das concentrações de ETR por análise é menor nas da Unidade Santo Antônio do que nas demais.
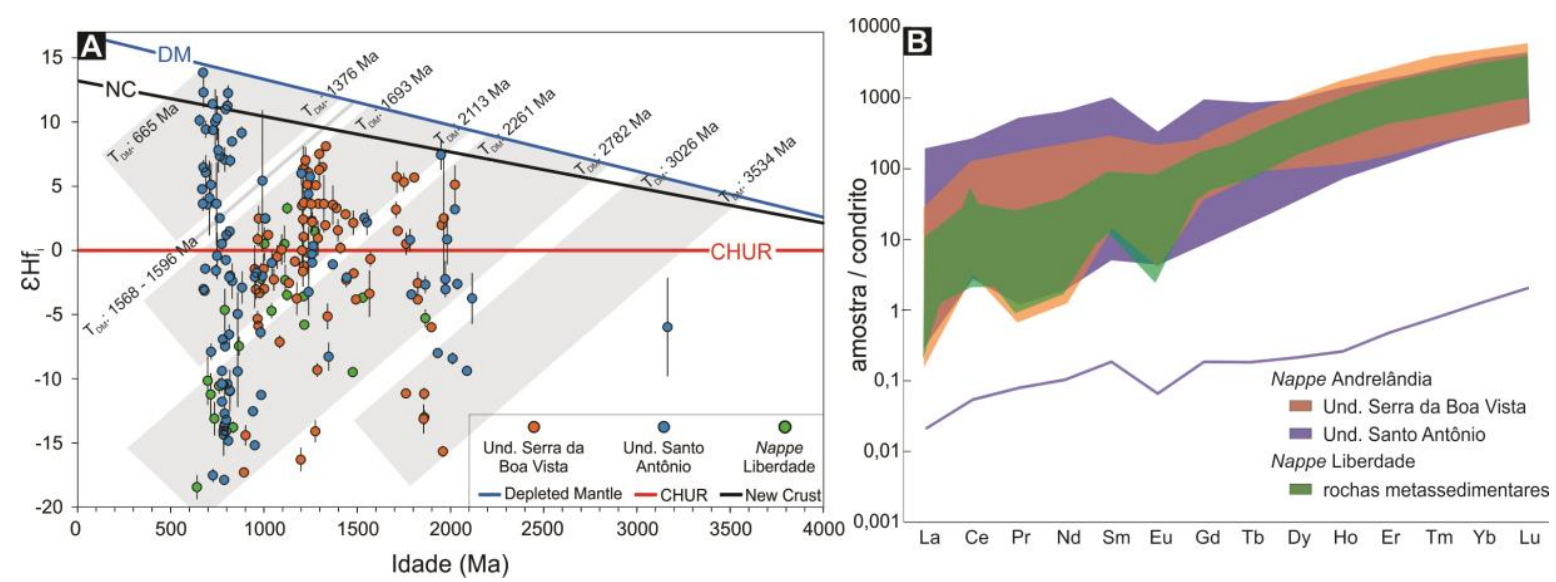

Figura 8-1. (A) Diagrama $\varepsilon \mathrm{Hf}$ versus idade das três unidades estudadas; (B) Diagrama dos padrões dos elementos terras raras de cada uma das três unidades.

A composição isotópica de Sm-Nd da Unidade Santo Antônio (Figura 8-2 A), com $\varepsilon \mathrm{Nd}_{680}$ entre -4,00 e +0,98 e idades-modelo $\mathrm{T}_{\mathrm{DM}}$ entre $1164 \mathrm{Ma}$ e $1540 \mathrm{Ma}$, é a mesma 
obtida por Santos (2011) para os metawackes das nappes superiores (Andrelândia, Carmo da Cachoeira e Liberdade, $\varepsilon N d_{t}$ entre $+0,04$ e $+1,75$, T $T_{D M}$ entre $1089 \mathrm{Ma}$ e $1278 \mathrm{Ma}$ e $\varepsilon N d$ atual entre -5 e -7). Os demais metawackes analisados por Santos (2011) apresentam padrões e comportamentos isotópicos que diferem dos acima descritos. Os metawackes da estrutura autóctone e das nappes inferiores apresentam, em sua maioria, idades modelo no Estateriano (1624-1698 Ma), $\varepsilon N d_{t}$ negativos (entre -4,84 e -5,40) e $\varepsilon N d$ atual entre -10 e -14. Essas rochas compartilham a assinatura de $\mathrm{Nd}$ dos metawackes do Sistema de Nappes Carrancas (TEIXEIRA, 2011; WESTIN; CAMPOS NETO, 2013). A partir destes comportamentos isotópicos é possível distinguir e individualizar dois conjuntos de rochas com evoluções distintas: metawackes do Sistema de Nappes Andrelândia, com $\varepsilon N d_{t}$ pouco positivo a pouco negativo e com idades modelo mais jovens que o Calimiano; metawackes com $\varepsilon \mathrm{Nd}_{\mathrm{t}}$ negativo e idades $\mathrm{T}_{\mathrm{DM}}$ que variam do Calimiano ao Mesoarqueano, referente aos demais.

A composição isotópica de $\mathrm{Nd}$ dos metawackes da Nappe Andrelândia, Unidade Santo Antônio, assemelha-se às composições dos arcos de Mara Rosa e Anicuns (Figura 8-2 B).
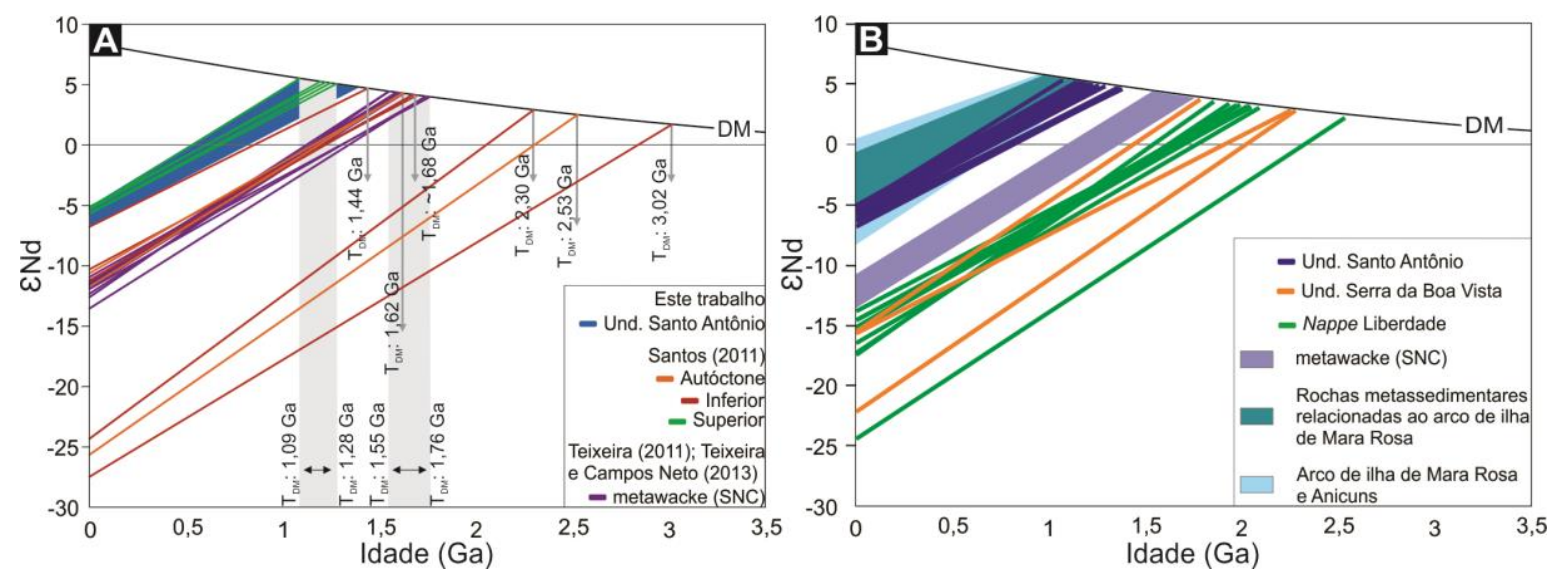

Figura 8-2. (A) Diagrama $\varepsilon N d t$ versus idade $(\mathrm{Ga})$ com os dados da Unidade Santo Antônio das amostras aqui estudadas, das amostras analisadas por Santos (2011), assim como os resultados referentes ao metawackes do Sistema de Nappes Carrancas (SNC) (TEIXEIRA, 2011; WESTIN; CAMPOS NETO, 2013); (B) Diagrama $\varepsilon N d_{t}$ versus idade $(\mathrm{Ga})$ das três unidades analisadas, dos metawackes do Sistema de Nappes Carrancas (SNC) (TEIXEIRA, 2011; WESTIN; CAMPOS NETO, 2013) e das rochas do arco de ilha de Mara Rosa e Anicuns (FUCK et al., 2014; JUNGES; PIMENTEL; MORAES, 2002; LAUX et al., 2004, 2005; MATTEINI et al., 2010; PIMENTEL; FUCK; GIOIA, 2000; PIMENTEL et al., 1997).

O fim da sedimentação da Unidade Santo Antônio se deu a partir de 680 Ma (idade resultante a partir do conjunto de cristais de zircão mais jovens), e por mais que as idades mais jovens da Unidade Serra da Boa Vista sejam do Toniano ( 920 Ma), ela encontra-se estratigraficamente no topo da estrutura alóctone, indicando que sua sedimentação foi posterior a deposição da Unidade Santo Antônio (camada intermediária), e portanto após 
$680 \mathrm{Ma}$. As amostras da Nappe Liberdade apontam que o fim da sedimentação foi posterior que $790 \mathrm{Ma}$.

A relação entre as idades de cristalização de zircão e as idades máximas de sedimentação obtidas em diagramas weigthed average são exibidas na Figura 8-3 (CAWOOD; HAWKESWORTH; DHUIME, 2012), e corroboram com a hipótese de que a Unidade Santo Antônio e a rocha metapelítica da Nappe Liberdade foram depositadas em ambiente convergente (idade de cristalização - idade de deposição < $150 \mathrm{Ma}$ ). No entanto, para as amostras da Unidade Serra da Boa Vista e para a rocha metapsamítica da Nappe Liberdade, segundo o diagrama confeccionado por Cawood, Hawkesworth e Dhuime (2012) a partir de um banco de dados específicos, as idades de cristalização subtraída nas idades de deposição resultaram em valores maiores que $200 \mathrm{Ma}$, o que segundo estes autores configurariam bacias de ambientes extensionais ou margens passivas. Essas relações contradizem o que todos os outros dados sugerem.

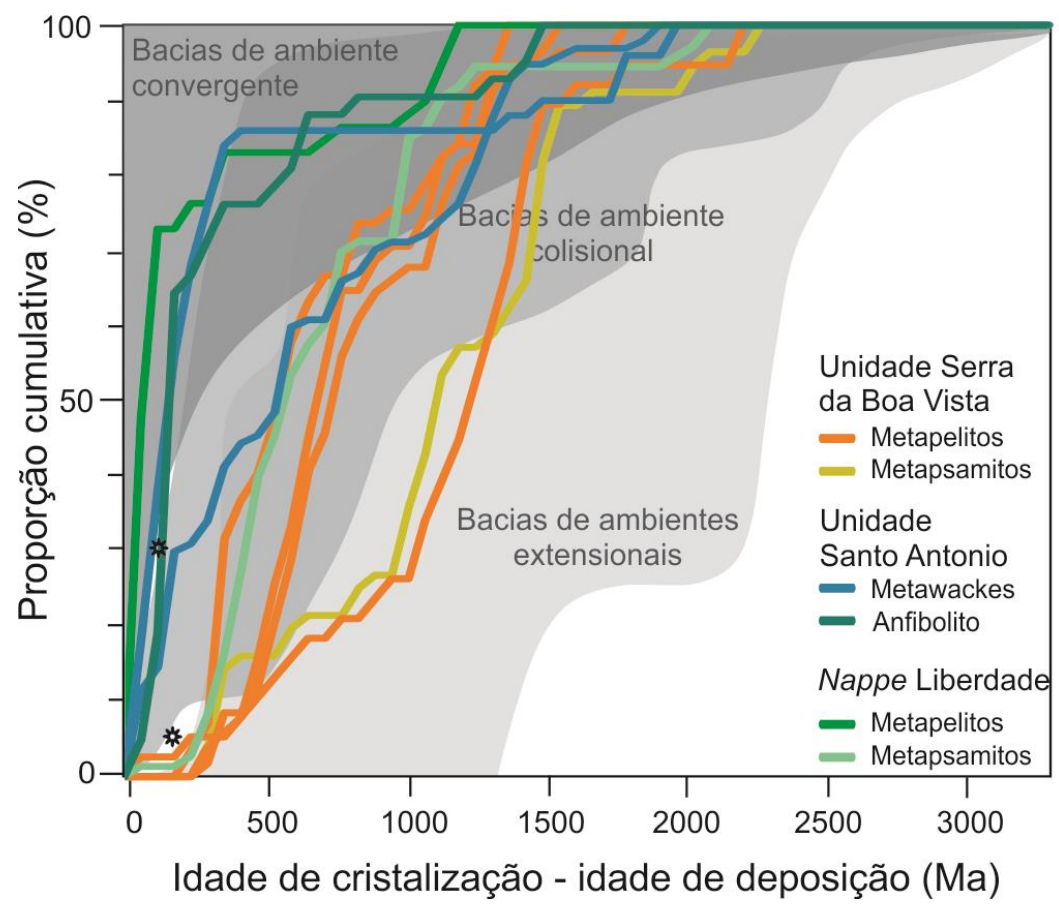

Figura 8-3. Diagrama da Idade de cristalização - idade de sedimentação (IS) versus proporção cumulativa (CAWOOD; HAWKESWORTH; DHUIME, 2012). ID Unidade Serra da Boa Vista e Unidade Santo Antônio = 680 Ma e ID Nappe Liberdade $=790 \mathrm{Ma}$.

O predomínio de idades mais jovens, do Criogeniano e Criogeniano-Toniano, está nas rochas da Unidade Santo Antônio (em azul na Figura 8-4) e na rocha metapelítica da Nappe Liberdade (em verde na Figura 8-4), no entanto é notável a distinta evolução isotópica do $\mathrm{Hf}$ para os cristais de zircão, nestes intervalos de idade, entre as duas unidades. Quando a Unidade Santo Antônio evidencia detritos vulcanoclásticos contemporâneos a um arco vulcânico intraoceânico de fonte em manto empobrecido, o conjunto de idades entre ca. 690 e 860 Ma na Nappe Liberdade indica área-fonte evoluída, a 
partir de idades-modelo no Paleoproterozoico, provavelmente relacionada a um arco vulcânico continental (margem continental ativa). Diferentemente, as rochas da Unidade Serra da Boa Vista e a rocha metapsamítica da Nappe Liberdade indicam fontes mais antigas que o Toniano (em laranja e verde claro na Figura 8-4 A), sem influência de arcos magmáticos neoproterozoicos como visto nas rochas anteriores. Fontes do EstenianoEctasiano (1093-1277 Ma) para as três unidades, e do Estateriano-Orosiriano (1730-1971 Ma) para as duas unidades da Nappe Andrelândia, apresentam características isotópicas empobrecidas, indicando influência de rochas máficas nestas idades. Influência máfica também ocorre no intervalo do Ectasiano-Calimiano para a Unidade Serra da Boa Vista (1374-1485 Ma com $\varepsilon \mathrm{Hf}$ de até $+8,12)$.
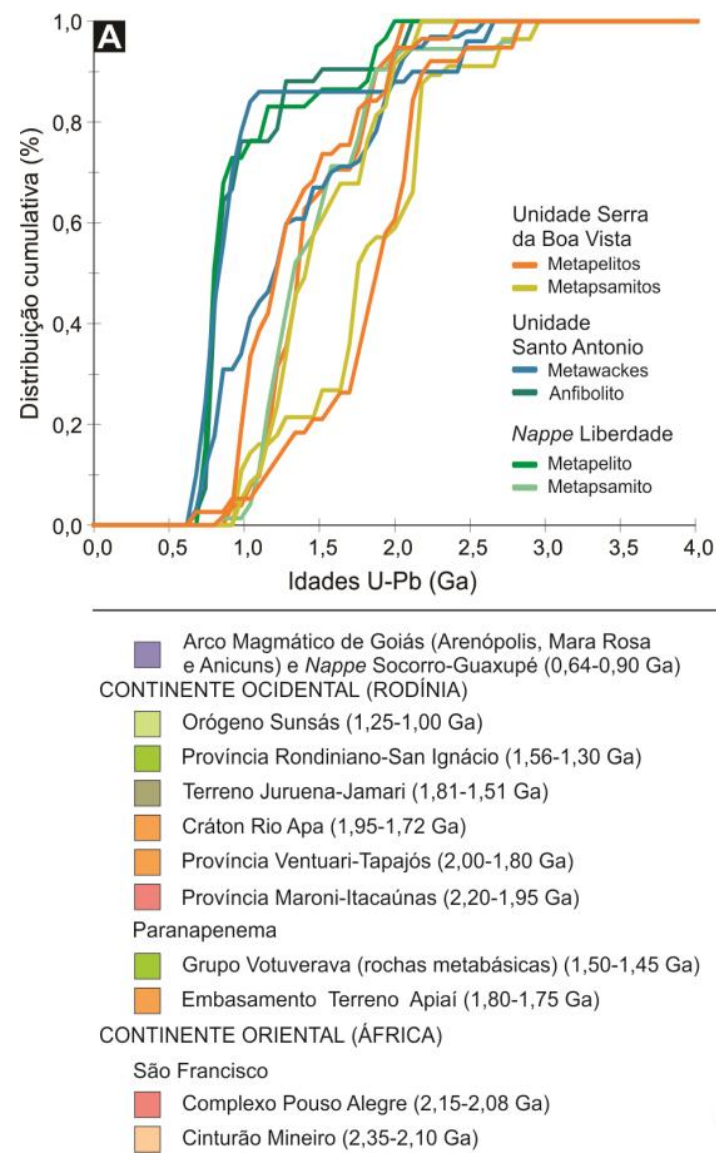

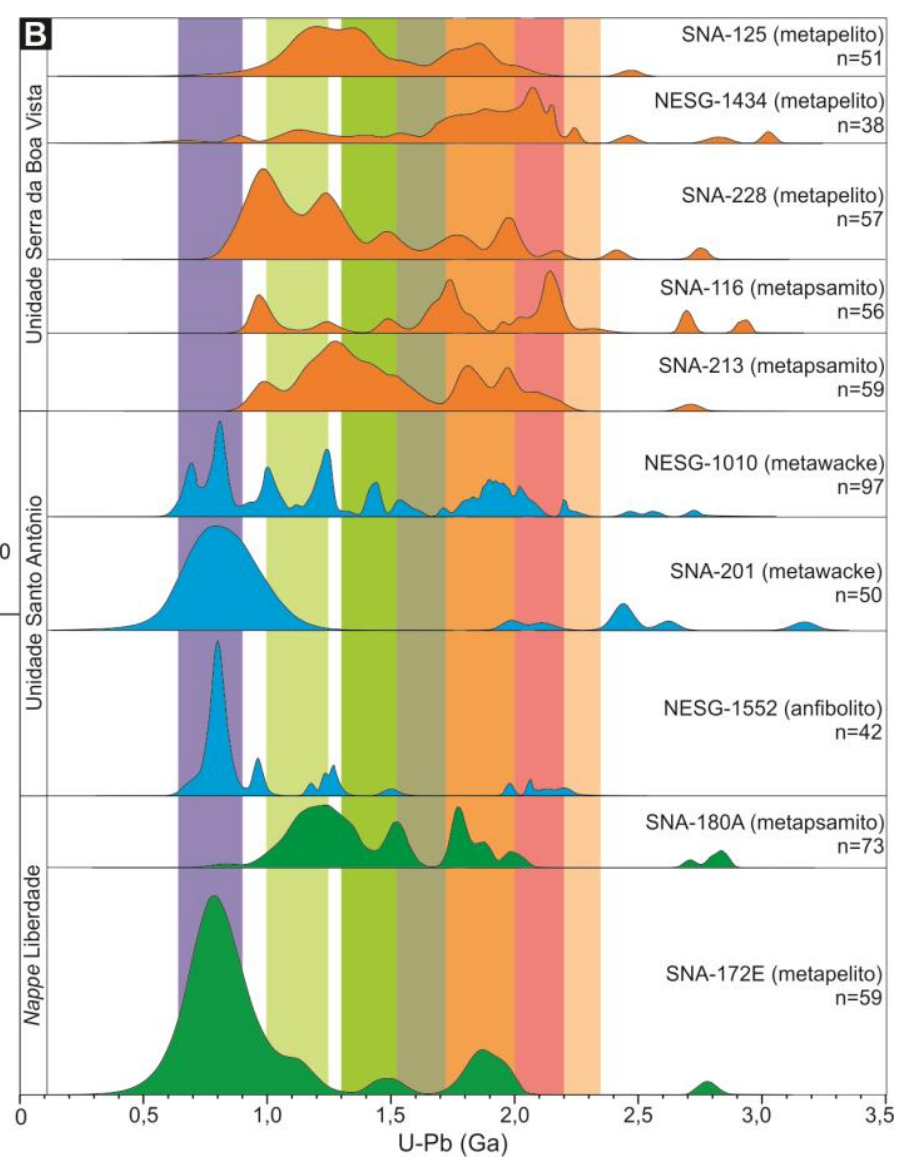

Figura 8-4. (A) Diagrama da idade versus distribuição cumulativa e (B) histograma das idades de todas as amostras da três unidades estudadas juntamente com os intervalos de idades das possíveis áreas-fonte dos sedimentos. Arco Mgamático de Goiás (Arenópolis, Mara Rosa e Anicuns) (LAUX et al., 2004, 2005; PIMENTEL; FUCK; GIOIA, 2000; PIMENTEL; HEAMAN; FUCK, 1991; PIMENTEL et al., 1997); Nappe Socorro-Guaxupé (DUFFLES et al., 2016; GENGO, 2014; VINAGRE et al., 2014); Orógeno Sunsás (TEIXEIRA et al., 2010); Província Rondoniano-San Ignácio (BETTENCOURT et al., 2010; TEIXEIRA et al., 2010); Terreno JuruenaJamari (SCANDOLARA et al., 2016); Cráton Rio Apa (CORDANI et al., 2010a; FALEIROS et al., 2016); províncias Ventuari-Tapajós e Maroni Itacaúnas (CORDANI; TEIXEIRA, 2007); rochas metabásicas do Grupo Votuverava (CAMPANHA et al., 2015; FALEIROS et al., 2011; SIGA JR et al., 2011a); Embasamento do Terreno Apiaí (SIGA JR et al., 2011b, 2011c); Complexo Pouso Alegre (CIOFFI et al., 2016; WESTIN et al., 2016); Cinturão Mineiro (TEIXEIRA et al., 2015). 
As idades neoproterozoicas no Criogeniano-Toniano são encontradas nas rochas dos arcos insulares de Arenópolis, Mara Rosa, Anicuns-Itaberaí, no arco magmático continental de Goiás e na Nappe Socorro-Guaxupé (DUFFLES et al., 2016; GENGO, 2014; LAUX, 2004; LAUX et al., 2005; PIMENTEL; FUCK; GIOIA, 2000; PIMENTEL; HEAMAN; FUCK, 1991; PIMENTEL et al., 1997; VINAGRE et al., 2014) (Figura 8-4).

Idades de 0,10-1,25 Ga, encontradas em cristais detríticos de composição isotópica de fonte intermediária à empobrecida, são idades tipo-Grenville e coincidem com as encontradas no Orógeno Sunsás, enquanto que as idades entre 1,30-1,50 Ga são observadas na Província Rondoniano-San Ignácio (BETTENCOURT et al., 2010; TEIXEIRA et al., 2010) e em rochas dos terrenos Jamari, Jauru e Juruena (SCANDOLARA et al., 2016, in press; TEIXEIRA et al., 2010). Estas observações posicionam o Cráton Amazônico junto ao paleocontinente Rodínia, enquanto que a existência de arcos insulares intraoceânicos do Arco Magmático de Goiás (0,9-1,0 Ga) sugere que um grande oceano separava, entre outros, Amazônia e São Francisco enquanto que o núcleo de Rodínia se formava, entre Laurentia e Oeste África-Amazônia (CORDANI et al., 2010b) (Figura 8-4).

O anfibolito retroeclogítico e a rocha metavulcânica, com idades de cristalização ígnea entre 1,45-1,48 Ga, sugerem correlação às rochas metabásicas do Grupo Votuverava do Terreno Apiaí (CAMPANHA et al., 2015; FALEIROS et al., 2011; SIGA JR et al., 2011a), onde as idades e as tipologias de cristais de zircão se assemelham (Figura 8-4).

Idades do Calimiano ao Orosiriano (1,55-1,75 Ga) não representam densidades importantes em grande parte das amostras, no entanto ocorrem em todas as unidades e podem ser observadas no Terreno Jamari-Juruena (SCANDOLARA et al., 2016, in press). Já no intervalo entre 1,70-2,00 Ga, a densidade de dados é importante, principalmente nas Unidade Serra da Boa Vista e nas rochas metassedimentares da Nappe Liberdade, e em menor expressão na Unidade Santo Antônio, sendo encontradas no embasamento do Terreno Apiaí (CAMPANHA et al., 2015; FALEIROS et al., 2011; SIGA JR et al., 2011a), no Cráton Rio Apa (FALEIROS et al., 2016) e na Província Ventuari-Tapajós (CORDANI; TEIXEIRA, 2007) (Figura 8-4).

Para os cristais de zircão do Orosiriano-Riaciano $(2,00-2,35)$, restritos às unidades Serra da Boa Vista e Santo Antônio, são sugeridas três principais áreas-fonte, duas no continente oriental São Francisco-África: Complexo Pouso Alegre (CIOFFI et al., 2016; WESTIN et al., 2016) e Cinturão Mineiro (TEIXEIRA et al., 2015); e uma no continente ocidental Rodínia: Província Maroni-Itacaúnas CORDANI; TEIXEIRA, 2007) (Figura 8-4). A alta densidade de cristais com idades neste intervalo na Unidade Serra da Boa Vista sugere sedimentação sin-colisional com influência do Cráton São Francisco como fonte para parte de seus sedimentos. 


\subsection{Metamorfismo de alta pressão e evolução da subducção}

Os retroeclogitos da base da Nappe Liberdade, estudados nesta Dissertação, não preservam as fases minerais de crescimento sob alta pressão, como onfacita, descrita por Campos Neto e Caby (1999). Entretanto exibem feições texturais sugestivas de paragênese pretérita em condições de fácies eclogito recristalizada em fácies anfibolito, são elas: coronas de plagioclásio em torno de cristais de granada indicando a descompressão; cristalização simplectítica entre plagioclásio + quartzo + diopsídio, sugerindo a substituição de cristais de onfacita, ou de clinopiroxênio de alto Al e Si; cristalização de hornblenda, em texturas simplectíticas com plagioclásio, ou substituindo o diopsídio.

Os cristais de zircão em sua maioria são arredondados e ovoides com alto urânio, sem zoneamento e raramente são visíveis núcleos herdados de cristais ígneos preexistentes, a partir dos quais sobrecresceram. Estes grãos apresentam razões Th/U extremamente baixas $(0,004-0,029)$, são pobres em ETR, exibem fraco enriquecimentos à fraco empobrecimentos em ETR pesados (razão $\mathrm{Yb}_{N} / \mathrm{Gd}_{N}$ entre 3,42 a 0,45) e menores anomalias negativas de $\mathrm{Eu}$, que diferem dos cristais do protólito ígneo (ver Figura 7-5). $\mathrm{O}$ empobrecimento observado em ETR pesados e as menores anomalias negativas de Eu sugerem recristalização subsolidus (HOSKIN; BLACK, 2000) e que eles se desenvolveram em presença de fases minerais ricas em ETR pesados, como granada. Estes cristais metamórficos de zircão apresentam razões ${ }^{176} \mathrm{Hf} /{ }^{177} \mathrm{Hf}$ semelhantes aos do protólito, sugerindo recristalização ou precipitação in-situ, a partir de cristais preexistentes (CHEN; NI; XIE, 2007).

Os grãos de granada desta rocha são do tipo almandina com núcleos enriquecidos em $\mathrm{MgO}, \mathrm{MnO}$ e empobrecidos em $\mathrm{CaO}$ em relação às suas bordas (Figuras 7-9 e 7-10). Eles apresentam núcleos mais enriquecidos em ETR, com padrão empobrecido em ETR pesados e menores anomalias negativas de Eu. As bordas dos cristais usualmente apresentam enriquecimento em ETR pesados e maiores anomalias negativas de Eu (Figura 7-6).

O coeficiente de partição ${ }^{E T R} D_{Z R / G R T}$ próximo a 1 sugere que houve crescimento concomitante entre zircão e núcleo da granada, enquanto que valores maiores foram observados entre zircão/borda, ilustrando o favorecimento dos ETR pesados ao zircão. $O$ empobrecimento em ETR pesados dos cristais de zircão e o coeficiente de partição entre zircão e granada indicam que o crescimento concomitante se deu quando da cristalização do núcleo da granada, portanto no início da descompressão (figura 7-7). 
A

Cristalização ígnea $1,46-1,48 \mathrm{Ga}$
B

Cristalização metamórfica $\sim 760 \mathrm{Ma}$
C

Cristalização metamórfica tardia $\sim 612 \mathrm{Ma}$

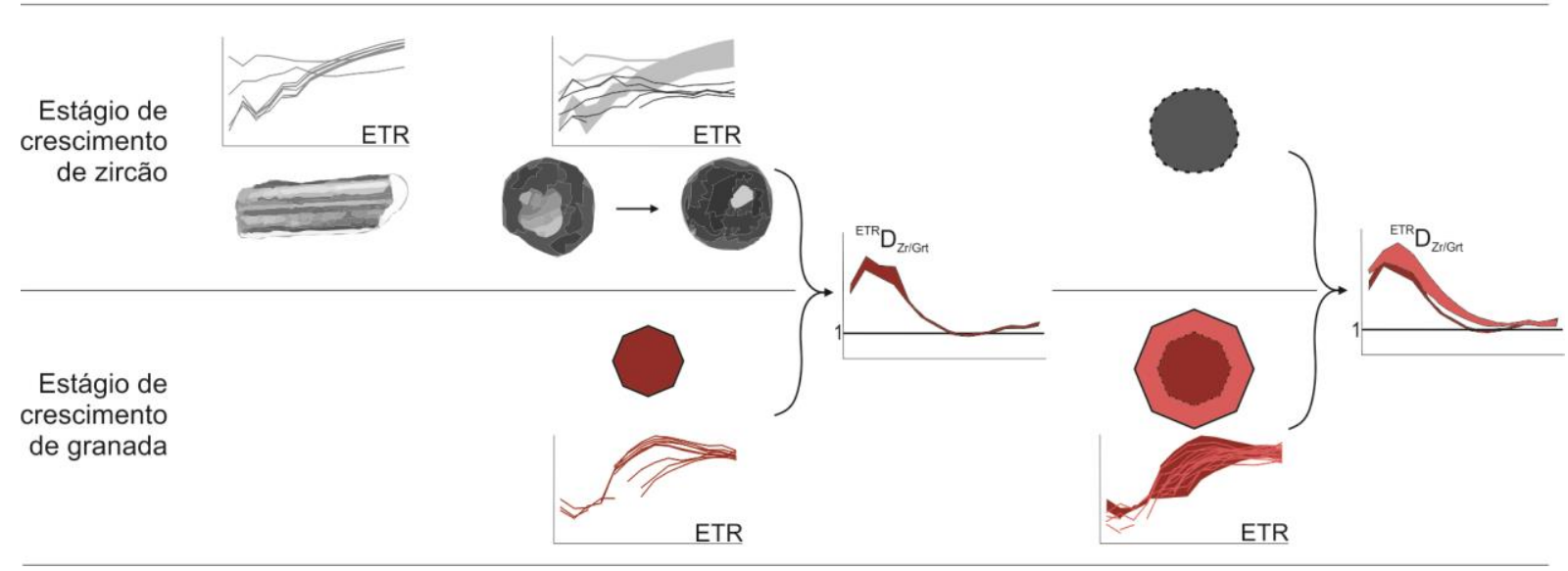

Figura 8-5. Diagrama esquemático da evolução da assinatura de elementos terras raras nos cristais de zircão e de granada da amostra do retroeclogito. Em (A) a assinatura de ETR nos cristais de zircão do protólito ígneo na ausência de granada; em (B) ocorre a recristalização dos cristais de zircão do protólito concomitante ao crescimento de granada, ambos em fácies eclogito em $761 \mathrm{Ma}$, notar o empobrecimento em ETR pesados dos cristais de zircão e de granada, assim como o diagrama do coeficiente de partição que ilustra valores próximos a 1; Em (C) há recristalização das bordas dos cristais de granada possivelmente concomitante a cristalização de bordas de cristais de zircão em metamorfismo de menor grau, em $612 \mathrm{Ma}$, notar o diagrama de ETR da granada ainda depletado em ETR pesados, já no diagrama do coeficiente de partição é possível notar maior preferência dos ETRP em relação ao zircão (valores maiores que 1).

As idades U-Pb dos cristais de zircão resultaram em $761 \pm 18$ Ma (Figura 7-11) e indicam subducção ativa de segmentos continentais no final do Toniano. Outras idades de retroeclogitos da Nappe Liberdade em $673 \pm 57 \mathrm{Ma}$ (TROUW, 2008), de $678 \pm 29 \mathrm{Ma}$ (RENO et al., 2009) e de $669 \pm 25$ Ma (CAMPOS NETO et al., 2011) indicam a continuidade do metamorfismo de alta pressão até a metade do Criogeniano.

\subsection{Metamorfismo de colisão e a migração do sistema de nappes}

O metamorfismo impresso nas rochas metassedimentares das nappes Andrelândia e Liberdade aqui estudadas não ultrapassou temperaturas de $770 \stackrel{\circ}{ }{ }^{\circ}$ (BATISTA, 2015; CAMPOS NETO et al., 2004; DA MOTTA et al., 2010; SANTOS; CAMPOS NETO; GROHMANN, 2004), em condições de fácies anfibolito superior, mas atingiram condições suficientes para recristalização de sobrecrescimentos metamórficos nas bordas dos cristais de zircão. Estes sobrecrescimentos apresentam, em grande parte, razões $\mathrm{Th} / \mathrm{U}$ abaixo de 0,10, no entanto cristais de duas amostras alcançaram valores de 0,45 (Figura 7-12).

As idades metamórficas colisionais, por U-Pb em zircão, variam entre $611 \pm 18 \mathrm{Ma} \mathrm{e}$ $634 \pm 14 \mathrm{Ma}$ e sugerem que a colisão teve início na passagem do Criogeniano para o Ediacarano. 
As idades $\mathrm{U}-\mathrm{Pb}$ em monazita, que evidenciam o processo de migração de nappes sin-metamorfismo, é de $618 \mathrm{Ma}$ em granada-cianita granulito da Klippe Carvalhos (CAMPOS NETO et al., 2011; CIOFFI, 2009), 611 Ma em granada-cianita-biotita-muscovita xisto da Nappe Liberdade e 606-611 Ma em granada-biotita-plagioclásio-quartzo xisto da Nappe Andrelândia. Idades de $606 \pm 1,4 \mathrm{Ma}$ e $603 \pm 2,2 \mathrm{Ma}$ também foram encontradas em metawackes em fácies anfibolito da Unidade Santo Antônio (CAMPOS NETO et al., 2011). Progressivamente mais jovens, ocorrem as idades no Sistema de Nappes Carrancas e na Nappe Lima Duarte de $590 \pm 2,8 \mathrm{Ma}, 573,5 \pm 2,9 \mathrm{Ma}$ (CAMPOS NETO et al., 2011) e 575$580 \mathrm{Ma}$ (VALERIANO et al. 2004; MACHADO et al. 1996).

Desta maneira, é possível dizer que as idades de colisão foram diacrônicas nos diversos segmentos do Orógeno Brasília Meridional, evidenciando assim a migração do sistema de nappes para leste.

\subsection{Anfibolito retroeclogítico e a rocha metavulcânica - conexão com o Terreno Apiaí?}

O granada-clinopiroxênio anfibolito retroeclogítico corresponde à série tholeiitica rica em FeO e MgO, e de composição basáltica (tabela 6-1 e Figura 6-1). No entanto, para a rocha metavulcânica (quartzo-granada-cummingtonita fels/xisto) sua origem vulcânica, vulcânica hidrotermalisada ou vulcanossedimentar não foi ainda estabelecida.

As composições de ETR do anfibolito apresentam padrões flats em sua maioria, com anomalias de Eu que variam de pouco positivas a pouco negativas, com pouco enriquecimento em ETR leves, assemelhando-se ao padrão de MORB enriquecido. A rocha metavulcância apresenta padrão distinto do acima descrito: com anomalias negativas de Eu e de Ce e enriquecimento em ETR leves na ordem de 4 (tabela 6-2 e Figura 6-2).

Se quimicamente essas rochas são diferentes, as suas populações e idades de cristais ígneos de zircão são as mesmas. Cristais retangulares prismáticos com zoneamento setorizado resultaram em idades, a partir de diagramas concordias, de $1463 \pm 17 \mathrm{Ma}$ (metavulcânica) e $1480 \pm 43$ Ma (anfibolito). Essa população, a mais recorrente em ambas as amostras, é semelhante aos cristais descritos por Campanha et al. (2015) em rochas metabásicas do Grupo Votuverava, Terreno Apiaí. Nestes cristais os formatos, estruturas internas e idades são as mesmos. A outra população de cristais encontrada é composta por grãos prismáticos com terminações arredondadas e zoneamento oscilatório. Estes cristais resultaram em idades de $2039 \pm 37$ Ma (metavulcânica) e $2055 \pm 30$ Ma (anfibolito). Esta população foi considerada como sendo herdada pelos protólitos (Figuras 6-4 e 6-5).

As idades ígneas de cristalização destas rochas são mais antigas que as máximas idades de sedimentação das rochas metassedimentares nas quais estão inseridas (790 Ma), sugerindo uma colocação tectônica, como blocos olistolísticos. 
A evolução isotópica de $\mathrm{Nd}$ difere entre estas rochas. A rocha metavulcânica sugere contribuição juvenil no Orosiriano-Riaciano $(1,80 \mathrm{Ga}$ a 2,18 Ga, esta última sendo a idade $\mathrm{T}_{\mathrm{DM}}$ ) com $\varepsilon \mathrm{Nd}_{1460}$, em $1,46 \mathrm{Ga}$, negativo na ordem de -5 . Enquanto que o anfibolito retroeclogítico sugere contribuição mais importante de rochas empobrecidas do fimEstateriano ao Toniano, com idade-modelo de 1,63 $\mathrm{Ga}$ e $\varepsilon \mathrm{Nd}_{1460}$ positivo na ordem de +4 , em 1,48 Ga (Figura 6-6). Esta idade modelo coincide com as encontradas por Siga Jr. et al. (2011a) em rochas metabásicas de sequências metavulcanossedimentares do Terreno Apiaí.

As relações entre $\varepsilon \mathrm{Nd}_{1460}$ versus ${ }^{87} \mathrm{Sr} /{ }^{86} \mathrm{Sr}$ e $\varepsilon \mathrm{Nd}_{1460}$ versus $\mathrm{Th} / \mathrm{Sc}$ sugerem origem do protólito do anfibolito retroeclogítico em margem ativa provavelmente em ambiente de forearc, enquanto que a o protólito da rocha metavulcânica registra assinatura crustal e enriquecida (Figura 6-7). As composições isotópicas de Hf nos cristais ígneos de zircão, para as duas rochas, indicam valores positivos de $\varepsilon \mathrm{Hf}$ tanto para as idades do Calimiano $(1463 \pm 17 \mathrm{Ma}$ e $1480 \pm 43 \mathrm{Ma})$ quanto para as idades do Orosiriano-Riaciano (2039 \pm 37 Ma e $2055 \pm 30 \mathrm{Ma}$ ) (Figura 6-8).

Os padrões de ETR em zircão ígneo são semelhantes entre as duas populações, assim como de uma amostra para outra: baixas concentrações de ETR e proeminente enriquecimento em ETR pesados. Um destaque é feito para as anomalias de Eu e Ce nos cristais do anfibolito, podendo ocorrer tanto positivas quanto negativas (Tabela 6-3 e Figura 6-10).

Sendo assim, é possível traçar uma correlação entre o protólito ígneo do granadaclinopiroxênio anfibolito retroeclogítico e a rocha metavulcânica com as rochas metabásicas do Grupo Votuverava do Terreno Apiaí. Campanha et al. (2015) interpretam as rochas metabásicas deste grupo como um magmatismo máfico associado a uma faixa calimiana, em ambiente de back-arc de orógeno acrescionário, envolvido em uma colisão no Esteniano, provavelmente relacionada a aglutinação de Rodínia.

\subsection{Evolução tectônica da margem ativa do Bloco Paranapanema}

A individualização de segmentos paleogeográficos associados a convergência de placas durante o Toniano (850-790 Ma) é evidenciada pelas idades de proveniência sedimentar dos cristais detríticos de zircão das rochas metassedimentares da Unidade Santo Antônio e da Nappe Liberdade. Atividades vulcânicas relacionadas a um sistema de arcos insulares intraoceânicos é encontrada no registro químico e isotópico dos metawackes da Unidade Santo Antônio, enquanto que um arco magmático em margem continental ativa, nas rochas da Nappe Liberdade.

O sistema de arcos insulares deveria corresponder aos arcos de Anicuns e Mara Rosa (LAUX et al., 2004, 2005; PIMENTEL; FUCK; BOTELHO, 1999; PIMENTEL; HEAMAN; 
FUCK, 1991; PIMENTEL et al., 1997), enquanto que a margem continental ativa deveria corresponder à borda do Bloco Paranapanema (arco magmático continental de Goiás e Nappe Socorro-Guaxupé) (Figura 8-6 A).

O registro nos detritos sedimentares do vulcanismo de ambiente convergente indicam que suas atividades perduraram, tanto no arco insular, quanto na margem continental ativa, até o Criogeniano, há $660 \mathrm{Ma}$. Rochas retroeclogíticas, em blocos tectônicos na Nappe Liberdade, possuem idades entre 760 e 670 Ma, e indicam também uma longa vida para o processo de subducção sob a margem ativa (Figura 8-6 B). A Nappe Socorro-Guaxupé, segmento da margem continental ativa, possui granitoides cálcioalcalinos no final deste período (DUFFLES et al., 2016; GENGO, 2014; VINAGRE et al., 2014).

A partir dos cristais individuais mais jovens de zircão encontrados na Unidade Santo Antônio, e das idades gravadas em sobrecrescimentos metamórficos nos metassedimentos, é sugerido o início da colisão entre 660 e 640 Ma. A ausência de detríticos provenientes dos arcos magmáticos neoproterozoicos e a presença de idades de zircão detrítico no Riaciano, com provável fonte no bloco continental São Francisco, sugerem sedimentação flysch sincolisional para a Unidade Serra da Boa Vista (Figura 8-6 C).

As idades dos sobrecrescimentos metamórficos em zircão e em cristais de monazita indicam no Ediacarano (635-610 Ma) a migração sin-colisional do sistema de nappes da margem ativa. Neste período, depósitos colisionais tipo flysch seriam depositados sobre a margem passiva (Figura 8-6 D). As prováveis áreas-fonte destes sedimentos estariam, em parte, na erosão do interior orogênico montanhoso (WESTIN; CAMPOS NETO, 2013).

O metamorfismo gravado em rochas do Sistema de Nappes Carrancas na margem passiva, entre 590 Ma (VALERIANO et al., 2004), e 573 Ma e 590 Ma (CAMPOS NETO et al., 2011), sugerem que em 600-580 Ma o metamorfismo e a migração das nappes alcançaria os segmentos da margem passiva, deformando os depósitos flysch (Figura 8-6 E). Um adelgaçamento litosférico, no domínio do antigo arco magmático, Nappe SocorroGuaxupé, é evidenciado pelo plutonismo sub-alcalino do tipo-A (JANASI et al., 2009). O modelo de extrusão de segmentos das rochas metamórficas de alta pressão do canal de subducção foi baseado em Warren et al. (2008).

Figura 8-6. Esquema paleogeográfico da evolução subducção-colisão entre os blocos Paranapanema (Prp) e São Francisco (SF) ao longo do Neoproterozoico. 
(A) 850 - 790 Ma: magmatismo de arco insular e início de magmatismo de arco continental

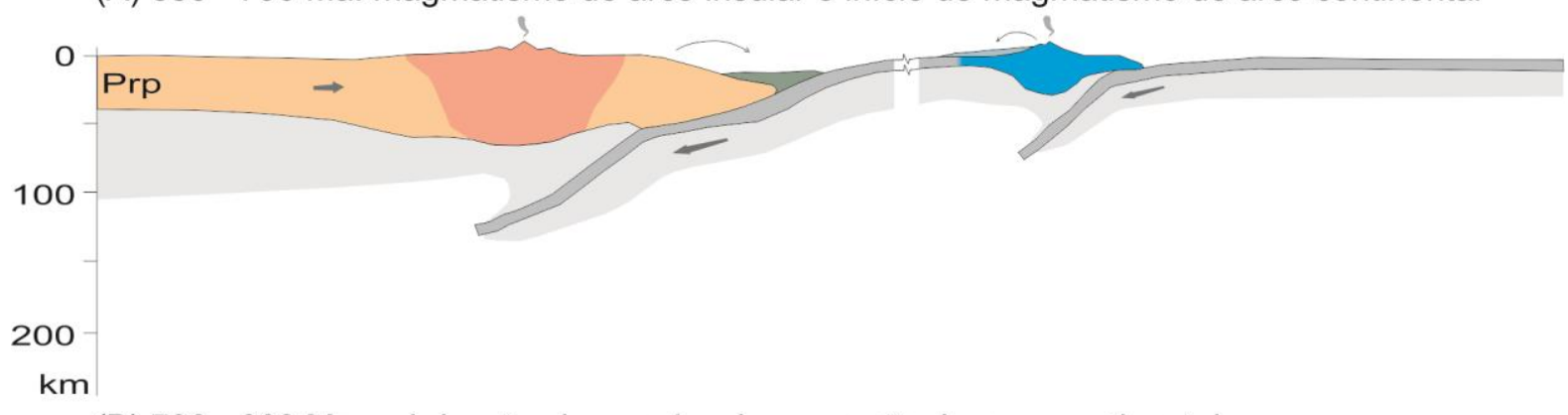

(B) 790 - 660 Ma: subducção do arco insular e erosão do arco continental
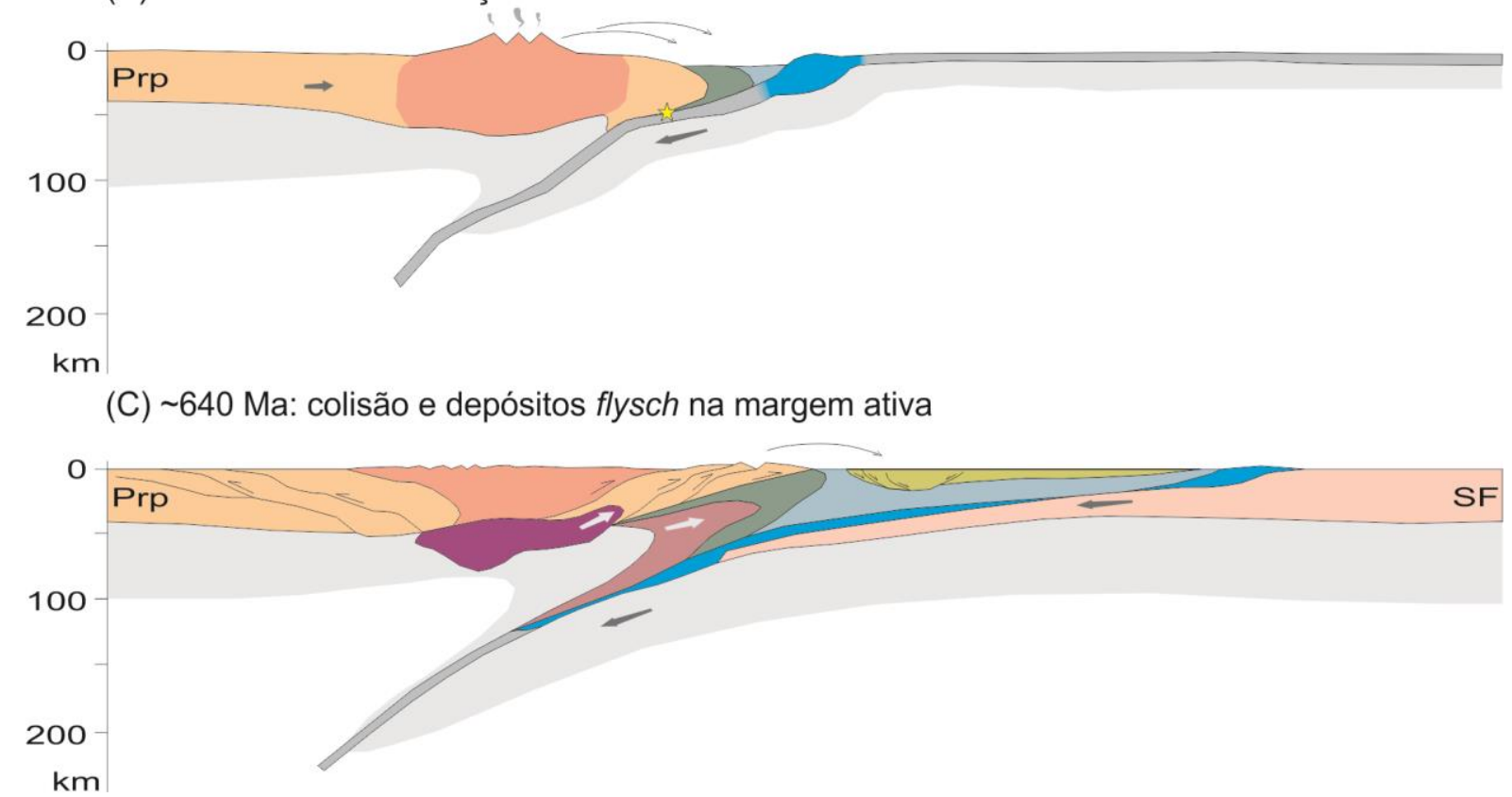

(D) 625 - 610 Ma: migração do sistema de nappes e depósitos flysch na margem passiva

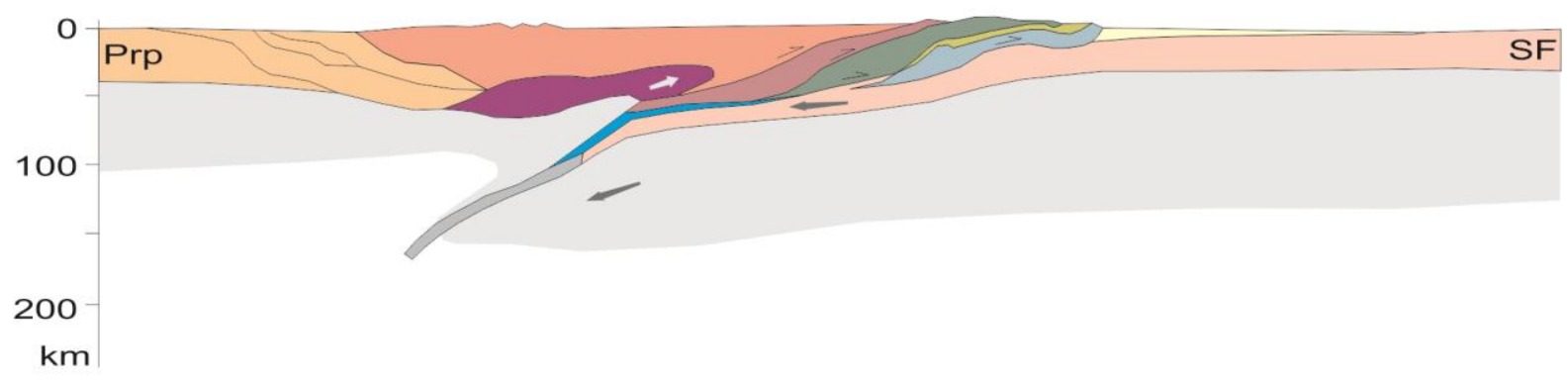

(E) 600 - $580 \mathrm{Ma}$ : nappes da margem passiva e adelgaçamento da litosfera do arco

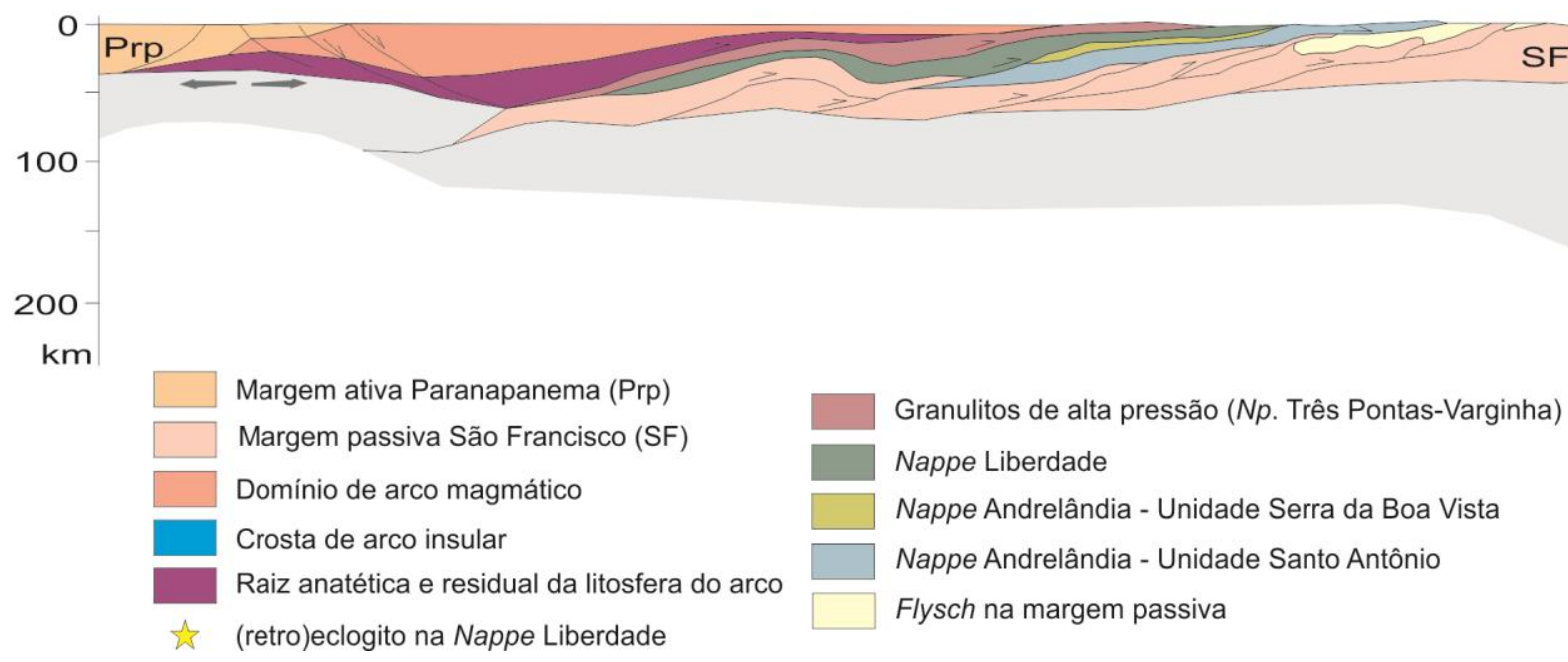




\section{CONCLUSÕES FINAIS}

- Ambiente tectônico de sedimentação e possíveis áreas-fonte: a Unidade Santo Antônio sugere sedimentação em ambiente convergente intraoceânico, com contribuição vulcânica e erosão direta de arco insular (provavelmente tipo Mara Rosa e Anicuns); as rochas metassedimentares da Nappe Liberdade apontam para sedimentos provindos de arco magmático continental (edificado na margem ativa) e erosão do embasamento da margem ativa (Paranapanema - bloco continental ocidental - Rodínia); já a Unidade Serra da Boa Vista sugere sedimentação sin-colisional, com áreas-fonte no continente ocidental e no continente colidente oriental (África).

- Máxima idade de sedimentação: para as rochas metassedimentares da Nappe Liberdade, a máxima idade de sedimentação é de 790 Ma. Para a Unidade Santo Antônio foi em torno de $680 \mathrm{Ma}$, enquanto que a unidade superior, Serra da Boa Vista, que não mais registra as atividades magmáticas neoproterozoicas, foi provavelmente depositada entre $680 \mathrm{Ma}$ e $635 \mathrm{Ma}$ (idade mais antiga para o metamorfismo de colisão).

- Bloco Paranapanema e suas afinidades Rodínia: populações de cristais detríticos de zircão entre 0,10-1,35 Ga sugerem área-fonte tipo-Grenville, enquanto que aquelas entre 1,30-1,55 Ga sugerem fontes tipo-Rondoniano-San Ignácio. A população entre 1,80-1,75 Ga presente em todas as unidades é encontrada no embasamento do Terreno Apiaí; o mesmo para as rochas retroeclogítica e metavulcânica semelhantes, na idade $(1,46-1,48$ $\mathrm{Ga}$ ) e na forma e estrutura interna dos cristais ígneos de zircão, às metabásicas do Grupo Votuverava.

- Metamorfismo de alta pressão: as idades de metamorfismo de alta pressão sugerem subducção de porção continental da margem ativa entre 760-670 Ma, com cristalização de zircão metamórfico concomitante ao crescimento dos núcleos de granada durante a descompressão.

- Colisão continental e migração do sistema de nappes: a colisão/subducção continental da margem passiva São Francisco (bloco continental oriental - África) contra Paranapanema (bloco continental ocidental - Rodinia) deve ter ocorrido entre os registros mais jovens, nos metawackes da Unidade Santo Antônio, da atividade vulcânica juvenil em ambiente de arco intraoceânico (660-645 Ma) e a idade mais antiga para o metamorfismo, na foliação S2, associado a migração do sistema de nappes de margem ativa (635-600 Ma). 


\section{Referências bibliográficas}

ANCELMI, M. F. et al. Geologia da Faixa Eclogítica de Forquilha, Domínio Ceará Central, noroeste da Província Borborema. Brazilian Journal of Geology, v. 43, n. 2, p. 235-252, 2013.

ANCELMI, M. F. et al. Provenance of metasedimentary rocks from the Cear_a Central Domain of Borborema Province, NE Brazil: implications for the significance of associated retrograded eclogites. Journal of South American Earth Sciences, v. 58, p. 82-99, 2015.

ANDERSEN, T. Detrital zircons as tracers of sedimentary provenance: Limiting conditions from statistics and numerical simulation. Chemical Geology, v. 216, n. 3-4, p. 249-270, 2005.

ANDREIS, R. R.; RIBEIRO, A.; PACIULLO, F. V. P. Ciclos deposicionais no Proterozoico das folhas Barbacena e Divinópolis (setor sul), 1:250.000, Minas Gerais: base para a interpretação da evolução das bacias sedimentares. In: I Simpósio de Geologia do Sudeste - Anais..., Rio de Janeiro, 1989.

ASSUMPÇÃO, M. et al. Intraplate seismicity in SE Brazil: stress concentration in lithospheric thin spots. Geophysical Journal International, v. 159, n. 1, p. 390-399, 2004.

ASSUMPÇÃO, M. et al. Upper mantle anisotropy in SE and Central Brazil from SKS splitting: Evidence of asthenospheric flow around a cratonic keel. Earth and Planetary Science Letters, v. 250, n. 1-2, p. 224-240, 2006.

ASSUMPÇÃO, M. et al. Crustal thickness map of Brazil: Data compilation and main features. Journal of South American Earth Sciences, v. 43, p. 74-85, 2013.

ARTHAUD, M. H.; FUCK, R. A.; DANTAS, E. L.; SANTOS, T. J. S.; CABY, R.; ARMSTRONG, R. The Neoproterozoic Ceará Group, Ceará Central domain, NE Brazil: Depositional age and provenance of detrital material. New insights from U-Pb and Sm-Nd geochronology. Journal of South American Earth Sciences, v. 58, p. 223-237, 2015.

BATISTA, L. A. Geração e transporte de fundidos em semi-pelitos: modelagem com dados de campo e pseudosseções. Dissertação de Mestrado, Universidade de São Paulo, 2015.

BECKMAN, V. et al. Metamorphic zircon formation at the transition from gabbro to eclogite in Trollheimen-Surnadalen, Norwegian Caledonides. Geological Society, London, Special Publications, v. 390, n. 1, p. 403-424, 2014.

BELÉM, J. et al. Bacia precursora versus bacias orogênicas : exemplos do Grupo Andrelândia com base em datações U-Pb ( LA-ICP-MS ) em zircão e análises litoquímicas. Geonomos, v. 19, n. 2, p. 224-243, 2011.

BELOUSOVA, E. et al. Igneous zircon: trace element composition as an indicator of source rock type. Contributions to Mineralogy and Petrology, v. 143, n. 5, p. 602-622, 2002. 
BERGER, J. et al. Continental subduction recorded by Neoproterozoic eclogite and garnet amphibolites from Western Hoggar (Tassendjanet terrane, Tuareg Shield, Algeria). Precambrian Res. 247, p. 139-158, 2014.

BERGER, J.; CABY, R.; LIÉGOIS, J. P.; MERCIER, J. C.; DEMAIFFE, D. Deep inside a Neoproterozoic intra-oceanic arc: growth, differentiation and exhumation of the Amalaoulaou complex (Gourma, Mali). Contrib. Mineral. Petrol. 162, p. 773-796, 2011.

BERRY, R. F. et al. A North American provenance for Neoproterozoic to Cambrian sandstones in Tasmania? Earth and Planetary Science Letters, v. 192, n. 2, p. 207-222, 2001.

BETTENCOURT, J. S. et al. The Rondonian-San Ignacio Province in the SW Amazonian Craton: An overview. Journal of South American Earth Sciences, v. 29, n. 1, p. 28-46, 2010.

BIZZARRO, M., BAKER, J. A., HAACK, H., ULFBECK, D., ROSING, M. Early history of Earth's crust-mantle system inferred from hafnium isotopes in chondrites. Nature v. 421, p. 9313, 2003.

BIZZI, L. A.; SCHOBBENHAUS, C.; VIDOTTI, R. M.; GONÇALVES, J. H. (ed). Geologia, tectônica e recursos minerais do Brasil. Brasília: CPRM-SBG, 2003.

BLICHERT-TOFT, J., ALBAR`EDE, F. The Lu-Hf isotope geochemistry of chondrites and the evolution of the mantle-crust system. Earth Planet. Sci. Lett. v. 148, 243-58, 1997.

BOSCH, D.; BRUGUIER, O.; CABY, R.; BUSCAIL, F.; HAMMOR, D. Orogenic development of the Adrar des Iforas (Tuareg Shield, NEMali): New geochemical and geochronological data and geodynamic implications. Journal of geodynamics, v. 96, p. 104-130, 2016.

BRINKMAN, G. A., ATEN, A. H.W. AND VEENBOER, J. T. Natural radioactivity of K-40, Rb 87 and Lu-176. Physica, v. 31, 1305-19, 1965.

BRITO NEVES, B. B.; FUCK, R. A. The Neoproterozoic evolution of the basement of the South-American platform. Journal of South American Earth Sciences, v. 47, p. 72-89, 2013. CABY, R. Nature and evolution of Neoproterozoic ocean-continent transition: Evidence from the passive margin of the West African craton in NE Mali. Journal of African Earth Sciences, v. 91, p. 1-11, 2014.

CABY, R.; BRUGUIER, O.; FERNANDES, L.; HAMMOR, D.; BOSCH, D.; MECHATI, M.; LAOUAR, R.; OUABADI, A.; ABDALLAH, N.; DOUCHET, C. Metamorphic diamonds in a garnet megacryst from the Edough Massif (northereastern Algeria). Recognition and geodynamic consequences. Tectonophysics, v. 637, p. 341-353, 2014.

CABY, R.; MONIÉ, R. Neoproterozoic subductions and differential exhumation of western Hoggar (southwest Algeria): new structural, petrological and geochronological evidence. Journal of African Earth Sciences, v. 37, p. 269-293, 2003.

CAMPANHA, G. A. C. et al. Geochemistry and age of mafic rocks from the Votuverava Group, southern Ribeira Belt, Brazil: Evidence for 1490Ma oceanic back-arc magmatism. Precambrian Research, v. 266, p. 530-550, 2015. 
CAMPOS NETO, M. C.; CABY, R. Neoproterozoic high-pressure metamorphism and tectonic constraint from the nappe system south of the Sao Francisco Craton, southeast Brazil. Precambrian Research, v. 97, n. 1-2, p. 3-26, 1999.

CAMPOS NETO, M. C.; CABY, R. Lower crust extrusion and terrane accretion in the Neoproterozoic nappes of southeast Brazil: petrologic and structural constraints. Tectonics, v. 19, n. 4, p. 669-687, 2000.

CAMPOS NETO, M. C. Orogenic Systems from Southwestern Gondwana - an approach to Brasiliano-Pan African Cycle and Orogenic Collage in Southeastern Brazil. Tectonic Evolution of South America, Rio de Janeiro, p. 335-365, 2000.

CAMPOS NETO, M. C. et al. Migração de Orógenos e Superposição de Orogêneses: Um Esboço da Colagem Brasiliana no Sul do Cráton do São Francisco, SE - Brasil. Geologia USP - Serie Cientifica, v. 4, n. 1, p. 13-40, 2004.

CAMPOS NETO, M. C. et al. Sistema de nappes Andrelândia, setor oriental : litoestratigrafia e posição estratigráfica. Revista Brasileira de Geociências, v. 37, n. 4-suplemento, p. 47-60, 2007.

CAMPOS NETO, M. C. et al. Structural and metamorphic control on the exhumation of high-P granulites: The Carvalhos Klippe example, from the oriental Andrelândia Nappe System, southern portion of the Brasília Orogen, Brazil. Precambrian Research, v. 180, n. 3-4, p. 125-142, 2010.

CAMPOS NETO, M. C. et al. Orogen migration and tectonic setting of the Andrelândia Nappe system: An Ediacaran western Gondwana collage, south of São Francisco craton. Journal of South American Earth Sciences, v. 32, n. 4, p. 393-406, 2011.

CAWOOD, P. A.; HAWKESWORTH, C. J.; DHUIME, B. Detrital zircon record and tectonic setting. Geology, v. 40, n. 10, p. 875-878, 2012.

CHEN, D.; NI, T.; XIE, L. Zircon Hf isotope composition of metamorphic eclogite from Xindian, Dabie Terrain. Science in China Series D: Earth Sciences, v. 50, n. 7, p. 1013-1020, 2007.

CHOPIN, C. Coesite and pure pyrope in high-grade blueschists of the Western Alps: a fi rst record and some consequences. Contributions to Mineralogy and Petrology 86: 107118, 1984.

CIOFFI, C. R. Geologia dos granulitos de alta pressão da Klippe Carvalhos, extensão sul da Faixa Brasília. [s.I.] Universidade de São Paulo, 2009.

CIOFFI, C. R. et al. Geochemical signatures of metasedimentary rocks of high-pressure granulite facies and their relation with partial melting: Carvalhos Klippe, Southern Brasília Belt, Brazil. Journal of South American Earth Sciences, v. 40, p. 63-76, 2012.

CIOFFI, C. R. et al. Paleoproterozoic continental crust generation events at 2.15 and $2.08 \mathrm{Ga}$ in the basement of the southern Brasília Orogen, SE Brazil. Precambrian Research, v. 275, p. 176-196, 2016. 
CONDIE, K.C. Continental growth during formation of Rodinia at 1.35-0.9 Ga. Gondwana Research, v. 4, 5-16, 2001.

CONDIE, K.C. Supercontinents, superplumes and continental growth: the Neoproterozoic record. Geological Society, London, Special Publications, v. 206, 1-21, 2003.

CORDANI, U. G.; BRITO-NEVES, B. B.; D’AGRELLA-FILHO, M. S. From Rodinia to Gondwana: a review of the Available Evidence from South America. Gondwana Research, v. 6 , n. 2, p. 275-283, 2003.

CORDANI, U. G., TEIXEIRA, W. Proterozoic accretionary belts in the Amazonian Craton. Geological Society of America, memoir 200, p. 297-320, 2007.

CORDANI, U. G. et al. The position of the Amazonian Craton in supercontinents. Gondwana Research, v. 15, n. 3-4, p. 396-407, 2009.

CORDANI, U. G. et al. The rio apa craton in mato grosso do sul (brazil) and northern paraguay: Geochronological evolution, correlations and tectonic implications for rodinia and gondwana. American Journal of Science, v. 310, n. 9, p. 981-1023, 2010a.

CORDANI, U. G. et al. On the origin and tectonic significance of the intra-plate events of Grenvillian-type age in South America: A discussion. Journal of South American Earth Sciences, v. 29, n. 1, p. 143-159, 2010b.

CORDANI, U. G. et al. The significance of the Transbrasiliano-Kandi tectonic corridor for the amalgamation of West Gondwana. Brazilian Journal of Geology, v. 43, p. 583-597, 2013. COUTINHO, L. Estrutura , litoestratigrafia e metamorfismo do Grupo Carrancas na frente orogênica da Faixa Brasília Meridional. Dissertação de Mestrado, Universidade de São Paulo, 2012.

DA MOTTA, R. G. et al. Reconstrução e comparação de trajetórias P-T no sistema de nappes andrelândia, sul da faixa brasília, MG. Geologia USP - Serie Cientifica, v. 10, n. 3, p. 7996, 2010.

DAVIS, D.W., GRAY, J. AND CUMMING, G. L. Determination of the 87Rb decay constant. Geochim. Cosmochim. Acta, v. 41, 1745-9, 1977.

DAVIS, P. B.; WHITNEY, D. L. Petrogenesis and structural petrology of high-pressure metabasalt pods, Sivrihisar, Turkey. Contributions to Mineralogy and Petrology, v. 156, n. 2, p. 217-241, 2008.

DEER, W. A., HOWIE, R. A., ZUSSMAN, J. An introduction to rock-forming minerals. Mineralogical Society, 3rd ed., p. 498, 2013.

DEHLER, C. M. et al. Maximum depositional age and provenance of the Uinta Mountain group and big cottonwood formation, northern Utah: Paleogeography of rifting western Laurentia. Bulletin of the Geological Society of America, v. 122, n. 9-10, p. 1686-1699, 2010.

DEPAOLO, D. J. Neodymium isotopes in the Colorado Front Range and crust-mantle evolution in the Proterozoic. Journal of Chemical Information and Modeling, v. 291, p. 193-196, 1981. 
DEPAOLO, D. J.; WASSERBURG, G. J. Nd isotopic variations and petrogenetic models. Geophysical Research Letters, v. p. 249-252, 1976.

DEPAOLO, D. J.; WASSERBURG, G. J. Petrogenetic mixing models and $\mathrm{Nd}$-Sr isotopic patterns. Geochimica et Cosmochimica Acta, v. 43, n. 4, p. 615-627, 1979.

DHUIME, B.; HAWKESWORTH, C.; CAWOOD, P. When Continents Formed. Science, v. 331, p. 154-155, 2011.

DICKIN, A. Radiogenic Isotope Geology. Cambridge, 2 ed. 2005.

DICKINSON, W. R.; GEHRELS, G. E. Use of U-Pb ages of detrital zircons to infer maximum depositional ages of strata: A test against a Colorado Plateau Mesozoic database. Earth and Planetary Science Letters, v. 288, n. 1-2, p. 115-125, 2009.

DICKINSON, W. R.; SUCZEK, C. Plate tectonics and sandstone composition. American Association of Petroleum Geologists Bulletin, 1979.

DUFFLES, P. et al. U-Pb age of detrital zircon from the Embu sequence, Ribeira belt, Se Brazil. Precambrian Research, v. 278, p. 69-86, 2016.

EBERT, H. Pesquisas geológicas na parte sudeste de Minas Gerais, Relatório Anual do Diretor - Divisão de Geologia e Mineralogia - Ano de 1955. [s.I: s.n].

EBERT, H. Pesquisas geológicas na parte sudeste de Minas Gerais, Relatório Anual do Diretor - Divisão de Geologia e Mineralogia - Ano de 1956. [s.l: s.n].

EBERT, H. (in memorian). Aspectos principais da geologia da região de São João Del rei, estado de Minas Gerais. In: Sâo Paulo - SP: Sociedade Brasileira de Geologia - Núcleo São Paulo, p. 1-71, 1984.

EMBRAPA - Empresa Brasileira de Pesquisa Agropecuária. Brasil em Relevo. Disponível em $<$ http://www.relevobr.cnpm.embrapa.br/>

ENNIH, N.; LIÉGEOIS, J-P. The boundaries of the West African craton, with special reference to the basement of the Moroccan metacratonic Anti-Atlas belt. Geological Society, London, Special Publications, v. 297, p. 1-17, 2008.

FALEIROS, F. M. et al. Geoquímica e Petrogênese de Metabasitos do Grupo Votuverava (Terreno Apiaí, Cinturão Ribeira Meridional ): evidências de uma bacia retroarco Calimiana. Geologia USP - Série Científica, v. 11, n. 2, p. 135-155, 2011.

FALEIROS, F. M. et al. Zircon U-Pb ages of rocks from the Rio Apa Cratonic Terrane (Mato Grosso do Sul, Brazil): New insights for its connection with the Amazonian Craton in preGondwana times. Gondwana Research, v. 34, p. 187-204, 2016.

FENG, M.; ASSUMPÇÃO, M.; VAN DER LEE, S. Group-velocity tomography and lithospheric S-velocity structure of the South American continent. Physics of the Earth and Planetary Interiors, v. 147, n. 4, p. 315-331, 2004.

FLYNN, K. F. and Glendenin, L. E. Half-life and $\beta$ spectrum of Rb87. Phys. Rev. 116, 744-8, 1959. 
FRIMMEL, H. E. et al. A new lithostratigraphic subdivision and geodynamic model for the PanAfrican western Saldania Belt, South Africa. Precambrian Research, v. 231, p. 218-235, 2013.

FRUGIS, G. L. Proveniência dos metassedimentos das nappes Andrelândia e Liberdade na região de Aiuruoca - MG. Trabalho de Conclusão de Curso, Universidade de São Paulo, 2013.

FUCK, R. A.; BRITO NEVES, B. B.; SCHOBBENHAUS, C. Rodinia descendants in South America. Precambrian Research, v. 160, n. 1-2, p. 108-126, 2008.

GANADE ARAUJO, C. E. et al. U-Pb detrital zircon provenance of metasedimentary rocks from the Ceará Central and Médio Coreaú Domains, Borborema Province, NE-Brazil: Tectonic implications for a long-lived Neoproterozoic active continental margin. Precambrian Research, v. 206-207, p. 36-51, 2012.

GANADE ARAUJO, C. E. et al. Ediacaran 2,500-km-long synchronous deep continental subduction in the West Gondwana Orogen. Nature communications, v. 5, p. 5198, 2014. GENGO, R. M. Petrologia de ortognaisses e granitóides do Domínio Socorro, Nappe Socorro-Guaxupé, Seção Extrema-Camanducaia. Dissertação de Mestrado, Universidade de São Paulo, 2014.

GEOROC. Geochemistry of rocks of the oceans and continents. Disponível em: $<$ http://georoc.mpch-mainz.gwdg.de/georoc/>.

GILOTTI, J. A. The realm of ultrahigh-pressure metamorphism. Elements, v. 9, n. 4, p. 255260, 2013.

GRIFFIN, W. L. et al. Statistical techniques for the classification of chromites in diamond exploration samples. Journal of Geochemical Exploration, v. 59, n. 3, p. 233-249, 1997. GRIMES, C. B. et al. Trace element chemistry of zircons from oceanic crust: A method for distinguishing detrital zircon provenance. Geology, v. 35, n. 7, p. 643, 2007.

HAMILTON, P. J., O'NIONS, R. K., BRIDGWATER, D. AND NUTMAN, A. Sm-Nd studies of Archean metasediments and metavolcanics fromWest Greenland and their implications for the Earth's early history. Earth Planet. Sci. Lett. 62, 263-72, 1983.

HARLEY, S. L.; KELLY, N. M.; MÖLLER, A. Zircon behaviour and the thermal history of mountain belts. Elements, v. 3, n. 1, p. 25-30; DOI: 10.2113/gselements.3.1.25, 2007.

HARLOW, G. E.; DAVIES, R. M. Diamonds. Elements, v. 1, p. 67-70, 2005.

HASKIN, L. A., WIELDEMAN, T. R., FREY, F. A., COLLINS, K. A., KEEDY, C. R., HASKIN, M. A. Rare Earths in sediments. Journal of Geophysical Research, v. 71, n. 24, p. 60916105, 1966.

HAUGHTON, P. D. W.; TODD, S. P.; MORTON, A. C. Sedimentary provenance studies. Geological Society, London, Special Publications, v. 57, n. 1, p. 1-11, 1991. 
HAWKESWORTH, C. J.; KEMP, A. I. S. Using hafnium and oxygen isotopes in zircons to unravel the record of crustal evolution. Chemical Geology, v. 226, n. 3-4, p. 144-162, 2006.

HAZEN, R. M.; FINGER, L. M. Crystal structure and compressibility of zircon at high pressure. American Mineralogist, v. 64, p. 196-201, 1979.

HOSKIN, P. W. O.; BLACK, L. P. Metamorphic zircon formation by solid-state recrystallization of protolith igneous zircon. Journal of Metamorphic Geology, v. 18, n. 4, p. 423-439, 2000.

HOSKIN, P. W. O.; IRELAND, T. R. Rare earth element chemistry of zircon and its use as a provenance indicator Rare earth element chemistry of zircon and its use as a provenance indicator. Geology, v. 28, n. 7, p. 627-630, 2000.

HOSKIN, P. W. O.; SCHALTEGGER, U. The Composition of Zircon and Igneous and Metamorphic Petrogenesis. Reviews in Mineralogy and Geochemistry, v. 53, p. 27-62, 2003.

IRVINE; T.; BARAGAR, W. A guide to the chemical classification of the common volcanic rocks. Canadian Journal of Earth Sciences, v. 8, p. 523-548, 1971.

JAFFEY, A. H., FLYNN, K. F., GLENDENIN, L. E., BENTLEY, W. C. AND ESSLING, A. M. Precision measurement of the half-lives and specific activities of U235 and U238. Phys. Rev.C v. 4, 1889-907, 1971.

JANASI, V. A. Petrogênese de granitos crustais da nappe de empurrão SocorroGuaxupé (SP-MG): uma contribuição da geoquímica elemental e isotópica. 1999. Tese de Livre Docência - Instituto de Geociências, Universidade de São Paulo, 1999. JANASI, V. A.; VLACH, S. R. F.; CAMPOS NETO, M. C.; ULBRICH, H. H. G. J. Associated A-Type subalkaline and high-K calc-alkaline granites in the Itu Granite Province, Southeastern Brazil: Petrological and tectonic significance. Canadian Mineralogist, v. 47, p. $1505-1526,2009$

JOHANSSON, A. Baltica, Amazonia and the SAMBA connection-1000 million years of neighbourhood during the Proterozoic? Precambrian Research, v. 175, n. 1-4, p. 221234, 2009.

JOHANSSON, A. From Rodinia to Gondwana with the "SAMBA" model-A distant view from Baltica towards Amazonia and beyond. Precambrian Research, v. 244, n. 1, p. 226-235, 2014.

JUNGES, L.; PIMENTEL, M.; MORAES, R. DE. Nd isotopic study of the Neoproterozoic Mara Rosa Arc , central Brazil: implications for the evolution of the Brası. Precambrian Research, v. 117, p. 101-118, 2002.

KINNY, P. D.; MAAS, R. Lu - Hf and Sm - Nd isotope systems in zircon THE Lu - Hf ISOTOPE SYSTEM IN NATURE. Reviews in Mineralogy \& Geochemistry, v. 53, n. 1, p. 327-341, 2003. 
KRETZ, R. Symbols for rock-forming minerals. American Mineralogist, v. 68, p. 277-279, 1983.

KRÖNER, A.; CORDANI, U. African, southern Indian and South American cratons were not part of the Rodinia supercontinent: Evidence from field relationships and geochronology. Tectonophysics, v. 375, n. 1-4, p. 325-352, 2003.

KRÖNER, A.; CORDANI, U. African, southern Indian and South American cratons were not part of the Rodinia supercontinent: Evidence from field relationships and geochronology. Tectonophysics, v. 375, n. 1-4, p. 325-352, 2003.

LAUX, J. H. Evolução do Arco Magmático de Goiás com base em dados geocronológicos U-Pb e Sm-Nd . Tese de Doutorado, Universidade de Brasilia, 2004.

LAUX, J. H. et al. Mafic magmatism associated with the Goiá magmatic arc in the Anicuns region, Goiás central Brazil: Sm - Nd isotopes and new ID-TIMS and SHIMP U-Pb data. Journal of South American Earth Sciences, v. 16, n. 7, p. 615-630, 2004.

LAUX, J. H. et al. Two neoproterozoic crustal accretion events in the Brasília belt, central Brazil. Journal of South American Earth Sciences, v. 18, n. 2, p. 183-198, 2005.

LE BAS, M. J.; LE MAITRE, R. W.; STRECKEISEN, A.; ZANETTIN, B. A chemical classification of volcanic rocks based on the total alkali-silica diagram. Journal of Petrology, v. 27, p. 745-750, 1986.

LESQUER, A. et al. SIGNIFICATION STRUCTURALE DES ANOMALIES De tres nombreuses datations radiomktriques sur le Precambrien du Bresil ont permis de definir plusieurs orogeneses et de distinguer zones cratoniques et zones mobiles. Dans 1 ' Etat du Minas Gerais, des etudes re. Tectonophysics, v. 76, p. 273-293, 1981.

LI, Z.X., BOGDANOVA, S.V., COLLINS, A.S., DAVIDSON, A., DE WAELE, B., R.E. ERNST, R.E., FITZSIMONS, I.C.W., FUCK, R.A., GLADKOCHUB, D.P., JACOBS, J., KARLSTROM, K.E., LU, S., NATAPOV, L.M., PEASE, V., PISAREVSKY, S.A., THRANE, K., VERNIKOVSKY, V. Assembly, configuration, and break-up history of Rodinia: a synthesis. Precambrian Research, v. 160, 179-210, 2008.

$\mathrm{LI}$, J. et al. REE concentrations of garnet and omphacite in eclogites from the Dabie Mountain, central China. Chinese Journal of Geochemistry, v. 32, n. 1, p. 85-94, 2013.

LIMA, R. B. EVOLUÇÃO TECTÔNICA DA FRENTE DA NAPPE ANDRELÂNDIA: ORÓGENO BRASÍLIA MERIDIONAL. Dissertação de Mestrado, Universidade de São Paulo, 2013.

LUDWIG, K. R. User' s Manual for Isoplot 3.70. Berkeley Geochronology Center Special Publication, v. 26, n. 4, p. 77, 2008.

MACHADO, N., VALLADARES, C., HEILBRON, M., VALERIANO, C. U-Pb geochronology of central Ribeira belt (Brazil) and implications for the evolution of the Brazilian Orogeny. Precambrian Research, v. 79, 347-361, 1996. 
MANTOVANI, M. S. M. et al. Delimitation of the paranapanema proterozoic block: A geophysical contribution. Episodes, v. 28, n. 1, p. 18-22, 2005.

MANTOVANI, M. S. M.; BRITO-NEVES, B. B. The Paranapanema lithospheric block: Its importance for Proterozoic (Rodinia, Gondwana) supercontinent theories. Gondwana Research, v. 8, n. 3, p. 303-315, 2005.

MANTOVANI, M. S. M.; BRITO NEVES, B. B. DE. Chapter 7.1 The Paranapanema Lithospheric Block: Its Nature and Role in the Accretion of Gondwana. Developments in Precambrian Geology, v. 16, n. C, p. 257-272, 2009.

MANTOVANI, M. S. M.; DE FREITAS, S. R. C.; SHUKOWSKY, W. Tidal gravity anomalies as a tool to measure rheological properties of the continental lithosphere: Application to the South American Plate. Journal of South American Earth Sciences, v. 14, n. 1, p. 1-14, 2001.

MARTINS, L; VLACH, S. R. F.; JANASI, V. A. Reaction microtextures of monazite: correlation between chemical and age domains in the Nazaré Paulista migmatite, SE Brazil. Chemical Geology, V. 261, P. 271-285, 2009.

MASSONNE, H-J. Constructing the pressure-temperature path of ultra-high pressure rocks. Elements, v. 9, p. 267-272, 2013.

MATTEINI, M. et al. Combined U-Pb and Lu-Hf isotope analyses by laser ablation MC-ICPMS: Methodology and applications. Anais da Academia Brasileira de Ciencias, v. 82, n. 2, p. 479-491, 2010.

MATTEINI, M. et al. In situ zircon U-Pb and $\mathrm{Lu}-\mathrm{Hf}$ isotope systematic on magmatic rocks: Insights on the crustal evolution of the Neoproterozoic Goiás Magmatic Arc, Brasília belt, Central Brazil. Gondwana Research, v. 17, n. 1, p. 1-12, 2010.

MEIRA, V. T. Integração metamórfica e estrutural da Serra de Santo Antônio: Neoproterozoico da borda sul do Cráton do São Francisco. Trabalho de Conclusão de Curso, Instituto de Geociências, Universidade de São Paulo, 2005.

MCLENNAN, S. M. Rare Earth elements in sedimentary rocks: influence of provenance and sedimentary processes. Mineralogical Society of America Reviews in Mineralogy, v. 21, p. 169-200, 1989.

MCLENNAN, S. M., TAYLOR, S. R. Sedimentary rocks and crustal evolution: tectonic setting and secular trends. The Journal of Geology, v. 99, p. 1-21, 1991.

MCLENNAN, S. M. et al. Geochemical and Nd-Sr isotopic composition of deep-sea turbidites: Crustal evolution and plate tectonic associations. Geochimica et Cosmochimica Acta, v. 54, n. 7, p. 2015-2050, 1990.

MCLENNAN, S. M. et al. Geochemical approaches to sedimentation, provenance, and tectonicsGeological. Society of America Special Paper, v. 284, p. 21-40, 1993. 
MCLENNAN, S. M. et al. Early Proterozoic crustal evolution: Geochemical and Nd $\square \mathrm{Pb}$ isotopic evidence from metasedimentary rocks, southwestern North America. Geochimica et Cosmochimica Acta, v. 59, n. 6, p. 1153-1177, 1995.

MORI, P. E. et al. Development of a fused glass disc xrf facility and comparison with the pressed powdes pellet technique at Instituto de Geociencias, Sao Paulo University. Revista Brasileira de Geociências, v. 29, n. 3, p. 441-446, 1999.

MYSEN, B.; GRIFFIN, W. L. Pyroxene Stoichiometry and Breakdown of Omphacite. American Mineralogist, v. 58, n. 1-2, p. 60-63, 1973.

NANCE, W. B., TAYLOR, S. R. Rare earth element patterns and crustal evolution -I. Australian post-Archean sedimentary rocks. Geochimica et Cosmochimica Acta, v. 40, p. 1539-1551, 1976.

NAVARRO, M. S., ANDRADE, S., ULBRICH, H., GOMES, C. B., GIRARDI, V. A. V. The direct determination of rare earth elements in basaltic and related rocks using ICP-MS: testing the efficiency of microwave oven sample decomposition procedures. Geostandars and Geoanalytical Research, v. 32, n. 2, p. 167-180, 2008.

NEAL, C. R.; TAYLOR, L. A. A negative Ce anomaly in a peridotite xenolith: evidence for crustal recycling into the mantle or mantle metasomatism. Geochimica et Cosmochimica Acta, v. 53, p. 1035-1040, 1989.

NEMCHIN, A. A.; CAWOOD, P. A. Discordance of the U-Pb system in detrital zircons: Implication for provenance studies of sedimentary rocks. Sedimentary Geology, v. 182, n. 1-4, p. 143-162, 2005.

NESBITT, H. W.; YOUNG, G. M. Early Proterozoic climates and plate motions inferred from major element chemistry of lutites. Nature, v. 299, p. 715-717, 1982.

NEUMANN, W., HUSTER, E. Discussion of the 87Rb halflife determined by absolute counting.

Earth Planet. Sci. Lett. v. 33, 277-88, 1976.

NICOLAYSEN, L. O. Graphic interpretation of discordant age measurements on metamorphic rocks. Ann. N.Y. Acad. Sci. v. 91, 198-206, 1961.

NIR-EL, Y., LAVI, N. Measurement of the half-life of 176Lu. Appl. Radiat. Isot. V. 49, 1653$5,1998$.

NUNES, R. P. M., TROUW, R. A. J., CASTRO, E. O. Mapa Geológico - Varginha. 2008.

PACIULlO, F. V. P.; FONSECA, A. C.; ANDREIS, R. R.; RIBEIRO, A.; TROUW, R. A.; WIEDEMANN, C. M. Contribuição à geologia do sul de Minas Gerais edição das folhas 1:50.000 Itumirim, Itutinga, Madre de Deus, Luminárias, Minduri e Andrelândia. Anuário do Instituto de Geociências, v. 19, p. 123-142, 1996.

PACIULLO, F. V. P.; RIBEIRO, A.; ANDREIS, R. R. Reconstrução de uma bacia fragmentada: o caso do Ciclo Deposicional Andrelândia. In: II Simpósio do Cráton do São Francisco Anais..., Salvador, 1993. 
PACIULLO, F. V. P.; RIBEIRO, A.; ANDREIS, R. R.; TROUW, R. A. J. Sedimentary, igneous and termo-tectonic events in the folded belts at the Southern border of the São Francisco Craton. In: $14^{\text {th }}$ International Conference on Basement Tectonics - Abstracts..., Anais..., Ouro Preto, 1998.

PACIULLO, F. V. P.; RIBEIRO, A.; ANDREIS, R. R.; TROUW, R. A. J. The Andrelândia Basil, a Neoproterozoic intraplate continental margim, Southern Brasília Belt, Brazil. Revista Brasileira de Geociências, v. 30, n. 1, p. 200-202, 2000

PACIULlO, F. V. P., TROUW, R. A. J., RIBEIRO, A., SIMOES, L. A., LOPES R. M. Mapa Geológico - Folha Andrelândia. 2002.

PAPANASTASSIOU, D. A., WASSERBURG, G. J. Rb-Sr ages of lunar rocks from the Sea of Tranquillity. Earth Planet. Sci. Lett. v. 8, 1-19, 1970.

PATCHETT, P. J., KOUVO, O., HEDGE C. E., TATSUMOTO M. Evolution of continental crust and mantle heterogeneity: evidence from Hf isotopes. Contrib. Mineral. Petrol. v. 78, 27997, 1981.

PATCHETT, P. J., TATSUMOTO, M. Lu/Hf in chondrites and definition of a chondritic hafnium growth curve. Lunar Planet. Sci. v. 12, 822-4, 1981.

PATTINSON, D. R. M. Petrogenetic significance of orthopyroxene-free garnet + clinopyroxene + plagioclase +- quartz-bearing metabasites with respect to the amphibolite and granulite facies. Journal of Metamorphic Geology, v. 21, p. 21-34, 2003.

PIMENTEL, M. M. et al. The Mara Rosa Arch in the Tocantins Province: further evidence for Neoproterozoic crustal accretion in Central Brazil. Precambrian Research, v. 81, n. 3-4, p. 299-310, 1997.

PIMENTEL, M. M.; FUCK, R. A. Neoproterozoic crustal accretion in central Brasil. Geology, v. 20, p. 375-379, 1992.

PIMENTEL, M. M.; FUCK, R. A.; BOTELHO, N. F. Granites and the geodynamic history of the Neoproterozoic Brasilia belt, Central Brazil: A review. Lithos, v. 46, n. 3, p. 463-483, 1999.

PIMENTEL, M. M.; FUCK, R. A.; GIOIA, S. M. C. L. The Neoproterozoic Goiás Magmatic Arc, Central Brazil : a review and new Sm-Nd isotopic data. Revista Brasileira de Geociencias, v. 30 , n. 1, p. 35-39, 2000.

PIMENTEL, M. M.; HEAMAN, L.; FUCK, R. A. Zircon and sphene U-Pb geochronology of Upper Proterozoic volcanic-arc rock units from southwestern Goiás, central Brazil. Journal of South American Earth Sciences, v. 4, n. 4, p. 295-305, 1991.

PINHEIRO, M. A. Geologia e petrogênese de corpos máfico- ultramáficos da Faixa Brasília Sul, borda sul do Cráton São Francisco - MG. Tese de Doutorado, Universidade Federal de Ouro Preto, 2013.

PISAREVSKY, S. A. et al. Mesoproterozoic paleogeography: Supercontinent and beyond. Precambrian Research, v. 244, p. 207-225, 2014. 
PETERNEL, R.; TROUW, R. A. J.; SCHIMITT, R. da S. Interferência entre duas faixas móveis Neoproterozoicas: o caso das faixas Brasília e Ribeira no sudeste do Brasil. Revista Brasileira de Geociências, v. 35, p. 297-310, 2005.

QUÉMÉNEUR, J. J. G., RIBEIRO, A., PACIULLO, F. V. P., HEILBRON, M., TROUW, R. A. J., VALENÇA, J. G., NOCE, C. M. Mapa Geológico - Folha Lavras. 2002.

REGINATO, R. A. Petrografia das Rochas Metabásicas de Alta Pressão do Domínio Ceará Central , Província Borborema , Nordeste do Brasil Petrografia das Rochas Metabásicas de Alta Pressão do Domínio Ceará Central , Província Borborema , Nordeste do Brasil. Trabalho de Conclusão de Curso, Universidade Estadual de Campinas, 2009.

RENO, B. L. et al. Eclogite-high-pressure granulite metamorphism records early collision in

West Gondwana: new data from the Southern Brasilia Belt, Brazil. Journal of the Geological Society, v. 166, n. 6, p. 1013-1032, 2009.

RIBEIRO, A.; PACIULLO, F. V. P.; ANDREIS, R. R. Evolução policíclica ao sul do Cráton do Sâo Francisco: análise da região de Sâo João Del Rei e Andrelândia, MG. In: XXXVI Congresso Brasileiro de Geologia - Anais..., Natal, 1990.

RIBEIRO, A., PACIULLO, F. V. P., NOCE, C. M., VALERIANO, C. M., VALENÇA, J. G., ÁVILA, C. A., TROUW, R. A. J., SILVA, M. A. Mapa Geológico - Folha São João del Rei. 2002.

RIBEIRO, A.; TEIXEIRA, W.; DUSSIN, I. A.; ÁVILA, C. A.; NASCIMENTO, D. U-Pb LA-ICPMS detrital zircon ages of the São João del Rei and Carandaí basins: New evidence of intermitente Proterozoic rifting in the São Francisco paleocontinent. Gondwana Research, v. 24, p. 713-726, 2013.

RIBEIRO, A.; TROUW, R. A. J.; ANDREIS, R. R.; PACIULlO, F. V. P.; VALENÇA, J. G. Evolução das bacias Proterozoicas e o termo-tectonismo Brasiliano na margem sul do Cráton do Sâo Francisco. Revista Brasileira de Geociências, v. 25, n. 4, p. 235-248, 1995.

ROCHA, B. C. MAPEAMENTO DA FOLHA VIRGÍNIA - MG, GEOCRONOLOGIA U-Pb (SHRIMP) EM ZIRCÕES E INTERPRETAÇÃO GEOTECTÔNICA. Dissertação de Mestrado, Universidade de São Paulo, 2011.

ROCHA, M. P.; SCHIMMEL, M.; ASSUMPÇÃO, M. Upper-mantle seismic structure beneath

SE and Central Brazil from P- and S-wave regional traveltime tomography. Geophysical Journal International, v. 184, n. 1, p. 268-286, 2011.

ROGERS, J. J. W., SANTOSH, M. Configuration of Columbia, a Mesoproterozoic Supercontinent. Gondwana Research, v. 5, 5-22, 2002.

RUBATTO, D. Zircon trace element geochemistry: partition with garnet and the link between $\mathrm{U}-\mathrm{Pb}$ ages and metamorphism. Chemical Geology, v. 184, p. 123-138, 2002. 
RUBATTO, D.; GEBAUER, D.; COMPAGNONI, R. Dating of eclogite-facies zircons: The age of Alpine metamorphism in the Sesia-Lanzo Zone (Western Alps). Earth and Planetary Science Letters, v. 167, n. 3-4, p. 141-158, 1999.

RUBATTO, D.; HERMANN, J. Experimental zircon/melt and zircon/garnet trace element partitioning and implications for the geochronology of crustal rocks. Chemical Geology, v. 241, n. 1-2, p. 38-61, 2007.

SAALMAN, K.; REMUS, M. V. D.; HARTMANN, L. A. Tectonic evolution of the Neoproterozoic São Grabriel Block, souther Brazil: constraints on Brasiliano orogenic evolution of the Rio de la Plata cratonix margin. Journal of South American Earth Sciences, v. 21, p. 204227, 2006.

SALAZAR MORA, C. A.; CAMPOS NETO, M. D. C.; BASEI, M. A. S. Syn-collisional lower continental crust anatexis in the Neoproterozoic Socorro-Guaxup?? Nappe System, southern Brasília Orogen, Brazil: Constraints from zircon U-Pb dating, Sr-Nd-Hf signatures and whole-rock geochemistry. Precambrian Research, v. 255, n. P3, p. 847-864, 2014.

SANTOS, L. P.; CAMPOS NETO, M. DA C.; GROHMANN, C. H. Metamorphic path constrained by metapelitic rocks from the inner Aiuruoca-Andrelândia nappe, south of the São Francisco craton, SE Brazil. Journal of South American Earth Sciences, v. 16, n. 8, p. 725-741, 2004.

SANTOS, P. DE S. GEOCRONOLOGIA, ÁREA FONTE E AMBIENTE TECTÔNICO DA UNIDADE SANTO ANTÔNIO - MEGASSEQUÊNCIA ANDRELÂNDIA. Dissertação de Mestrado, Universidade Federal do Rio de Janeiro, 2011.

SANTOS, T. J. S. et al. Relics of eclogite facies assemblages in the Ceará Central Domain, NW Borborema Province, NE Brazil: Implications for the assembly of West Gondwana. Gondwana Research, v. 15, n. 3-4, p. 454-470, 2009.

SATO, K. et al. In Situ Isotopic Analyses of $U$ and Pb in Zircon by Remotely Operated SHRIMP II , and Hf by LA-ICP-MS : an Example of Dating and Genetic Evolution of Zircon by $176 \mathrm{Hf}$ / $177 \mathrm{Hf}$ from the Ita Quarry in the Atuba Complex, SE Brazil. Geologia USP - Serie Cientifica, v. 9, p. 61-69, 2009.

SCANDOLARA, J. E. et al. Paleo-Mesoproterozoic arc-accretion along the southwestern margin of the Amazonian craton: the Juruena Accretionary Orogen and implications for Columbia reconstruction. Journal of South American Earth Sciences, 2016.

SIGA JR, O. et al. Calymmian (1.50-1.45 Ga) magmatic records in Votuverava and Perau sequences, south-southeastern Brazil: Zircon ages and $\mathrm{Nd}-\mathrm{Sr}$ isotopic geochemistry. Journal of South American Earth Sciences, v. 32, n. 4, p. 301-308, 2011 a.

SIGA JR, O. et al. Extensional and colisional magmatic records in the Apiaí Terrane, SouthSoutheastern Brazil: Integration of Geochronological U-Pb Zircon Ages. Geologia USP Serie Cientifica, v. 11, n. 3, p. 149-175, 2011 b. 
SIGA JR, O. et al. Geology and geochronology of the Betara region in south-southeastern Brazil: Evidence for possible Statherian (1.80-1.75Ga) and Calymmian (1.50-1.45 Ga) extension events. Gondwana Research, v. 19, n. 1, p. 260-274, $2011 \mathrm{c}$.

SIQUEIRA, R., HOLLANDA, M. H. B., BASEI, M. A. S. A novel approach to (LA-ICP-MS acquired) U-Th-Pb data processing. In: $9^{\text {th }}$ South American Symposium on Isotope Geology - SSAGI, São Paulo, Brasil. Programa e resumos, p. 306, 2014.

SIRCOMBE, K. N. Quantitative comparison of large sets of geochronological data using multivariate analysis: A provenance study example from Australia. Geochimica et Cosmochimica Acta, v. 64, n. 9, p. 1593-1616, 2000.

SMITH, D. C. Coesite in clinopyroxene in the Caledonides and its implications for geodynamics. Nature, 310: 641-644, 1984.

SOBOLEV N. V., SHATSKY V. S. Diamond inclusions in garnets from metamorphic rocks: a new environment for diamond formation. Nature, 343: 742-756, 1990

SCHREINER, G.D. L. Comparison of the Rb-87/Sr-87 ages of the red granite of the Bushveld complex from measurements on the total rock and separated mineral fractions. Proc. Roy. Soc. Lond. v. 245, 112-17, 1958.

SUN, S. -S.; MCDONOUGH, W. F. Chemical and isotopic systematics of oceanic basalts: implications for mantle composition and processes. Geological Society, London, Special Publications, v. 42, n. 1, p. 313-345, 1989.

TATSUMOTO, M., UNRUH, D. M. AND PATCHETT, P. J. U-Pb and Lu-Hf systematics of Antarctic meteorites. Nat. Inst. Polar Res. Tokyo, 1981.

TAYLOR, S. R.; MCLENNAN, S. M. The continental crust: its composition and evolution. Oxford: Blackwell Scientific, 1985.

TAYLOR, R. J. M. et al. Experimental determination of REE partition coefficients between zircon, garnet and melt: A key to understanding high-T crustal processes. Journal of Metamorphic Geology, v. 33, n. 3, p. 231-248, 2015.

TEIXEIRA, A. W. Influência da pilha de nappes na trajetória metamórfica da Nappe Andrelândia, borda sul do Cráton São Francisco. Tranalho de Conclusão de Curso, Universidade de São Paulo, 2008.

TEIXEIRA, A. W. O Grupo Carrancas e a frente da Nappe Andrelândia na borda sul do Cráton do São Francisco proveniência sedimentar e implicações tectônicas. Dissertação de Mestrado, Universidade de São Paulo, 2011.

TEIXEIRA, A. W. DEPÓSITOS OROGÊNICOS E BACIA EXTENSIONAL: 0 EMBASAMENTO METASSEDIMENTAR E A COBERTURA DA MARGEM PASSIVA NO ORÓGENO BRASÍLIA MERIDIONAL. Tese de Doutorado, Universidade de São Paulo, 2015.

TEIXEIRA, W. et al. A review of the tectonic evolution of the Sunsás belt, SW Amazonian

Craton. Journal of South American Earth Sciences, v. 29, n. 1, p. 47-60, 2010. 
TEIXEIRA, W. et al. A juvenile accretion episode (2.35-2.32Ga) in the Mineiro belt and its role to the Minas accretionary orogeny: Zircon $\mathrm{U}-\mathrm{Pb}-\mathrm{Hf}$ and geochemical evidences. Precambrian Research, v. 256, p. 148-169, 2015.

TOHVER, E.; D'AGRELLA-FILHO, M. S.; TRINDADE, R. I. F. Paleomagnetic record of Africa and South America for the 1200-500 Ma interval, and evaluation of Rodinia and Gondwana assemblies. Precambrian Research, v. 147, n. 3-4, p. 193-222, 2006.

TROMPETTE R. Geology of Western Gondwana (2000-500 Ma). Pan-African-Brasiliano aggregation of South America and Africa. A.A. Balkema, Rotterdam, 350 pp, 1994.

TROUW, C. C. MAPEAMENTO DA FOLHA VIRGÍNIA - MG, GEOCRONOLOGIA U-Pb (SHRIMP) EM ZIRCÕES E INTERPRETAÇÃO GEOTECTÔNICA. Tese de Doutorado, Universidade do Rio de Janeiro, 2008.

TROUW, R. A. J.; HEILBRON, M.; RIBEIRO, A.; PACIULLO, F. V. P.; VALERIANO, C. M.; ALMEIDA, J. C. H.; TUPINAMBÁ, M.; ANDREIS, R. R. The central segmento of the Ribeira Belt. In: CORDANI, U. G.; MILANI, E. J.; THOMAZ FILHO, A.; CAMPOS, D. A. (Ed). Tectonic Evolution of South America. 1st. Ed. Rio de Janeiro: 31 International Geological Congress. p. 335-365, 2000.

TROUW, R. A. J., NUNES, R. P. M., TROUW, C. C., MATOS, G. C. Mapa Geológico - Folha Itajubá. 2008.

TROUW, R. A. J.; PACIULLO, F. V. P.; RIBEIRO, A. A Faixa Alto Rio Grande reinterpretada como zona de interferência entre a Faixa Brasília e a Faixa Ribeira. In: XXXVIII Congresso Brasileiro de Geologia - Boletim de resumos..., Anais..., Balneário de Camburiú, 1994.

TROUW, R. A. J.; PACIULLO, F. V. P.; RIBEIRO, A. Tectonic significance of Neoproterozoic high-pressure granulites in Southern Minas Gerais. In: $14^{\text {th }}$ International Conference on Basement Tectonics - Abstracts..., Anais..., Ouro Preto, 1998.

TROUW, R. A. J.; PACIUllO, F. V. P.; RIBEIRO, A.; BITTAR, S.; ALMEIDA, J. C. H. Mapa geológico - Folha Caxambu. COMIG - Companhia Mineradora de Minas gerais, 2002.

TROUW, R. A. J.; PETERNEL, R.; RIBEIRO, A.; HEILBRON, M.; VINAGRE, R.; DUFFLES, P.; TROUW, C. C.; FONTAINHA, M.; KUSSAMA, H. H. A new interpretation for the interference zone between the Southern Brasília belt and central Ribeira belt, SE Brazil. Journal of South American Earth Sciences, v. 48, p. 43-57, 2013.

TROUW, R. A. J.; RIBEIRO, A.; PACIULLO, F. V. P. Evolução estrutural e metamórfica de uma área a SE de Lavras - Minas Gerais. In: XXXI Congresso Brasileiro de Geologia Anais..., Balneário de Camburiú. SBG, 1980.

TROUW, R. A. J.; RIBEIRO, A.; PACIULLO, F. V. P. Geologia estrutural dos grupos São João Del Rei, Carrancas e Andrelândia, sul de Minas Gerais. Anais da Academia Brasileira de Ciências, v. 55, n. 1, p. 71-85, 1983.

VALERIANO, C.M., MACHADO, N., SIMONETTI, A., VALLADARE, C.S., SEER, H.J., SIMÕES, L.S.A. U-Pb geochronology of the southern Brasilia belt (SE-Brazil): sedimentary 
provenance, Neoproterozoic orogeny and assembly of West Gondwana. Precambrian Research, v. 130, 27-55. 2004.

VERVOOT, J. D.; BLICHERT-TOFT, J. Evolution of the depleted mantle: Hf isotope evidence from juvenile rocks through time. Geochimica et Cosmochimica Acta, v. 63, p. 533-556, 1999.

VINAGRE, R., TROUW, R. A. J., MENDES, J. C., DUfFLES, P., PETERNEL, R., MATOS, G. New evidence of a magmatic arc in the southern Brasília Belt Brazil: the Serra da Água Limpa batholith (Socorro-Guaxupé Nappe). South American Earth Sciences, v. 54, 120139, 2014.

WARREN, C. J., BEAUMONT, C., JAMIESON, R. A. Modelling tectonic styles and ultra-high pressure (UHP) rock exhumation during the transition from oceanic subduction to continental collision. Earth and Planetary Science Letters, v. 267, p. 129-145, 2008.

WESTIN, A.; CAMPOS NETO, M. D. C. Provenance and tectonic setting of the external nappe of the Southern Brasília Orogen. Journal of South American Earth Sciences, v. 48, p. 220-239, 2013.

WESTIN, A. et al. A paleoproterozoic intra-arc basin associated with a juvenile source in the Southern Brasilia Orogen: application of U-Pb and $\mathrm{Hf}-\mathrm{Nd}$ isotopic analyses to provenance studies of complex areas. Precambrian Research, v. 276, p. 178-193, 2016.

WETHERILL, G.W. Discordant uranium-lead ages. Trans. Amer. Geophys. Union, v. 37, 320-7, 1956.

ZHAO, G. et al. High-Pressure Granulites (Retrograded Eclogites) from the Hengshan Complex, North China Craton: Petrology and Tectonic Implications. Journal of Petrology, v. 42, n. 6, p. 1141-1170, 2001.

ZHAO, G., SUN, M., WILDE, S.A., LI, S. A Paleo-Mesoproterozoic supercontinent: assembly, growth and breakup. Earth Science Review, v. 67, 91-123, 2004. 
ANEXO I

Mapa geológico de pontos 
MAPA GEOLÓGICO DO ORÓGENO BRASÍLIA MERIDIONAL

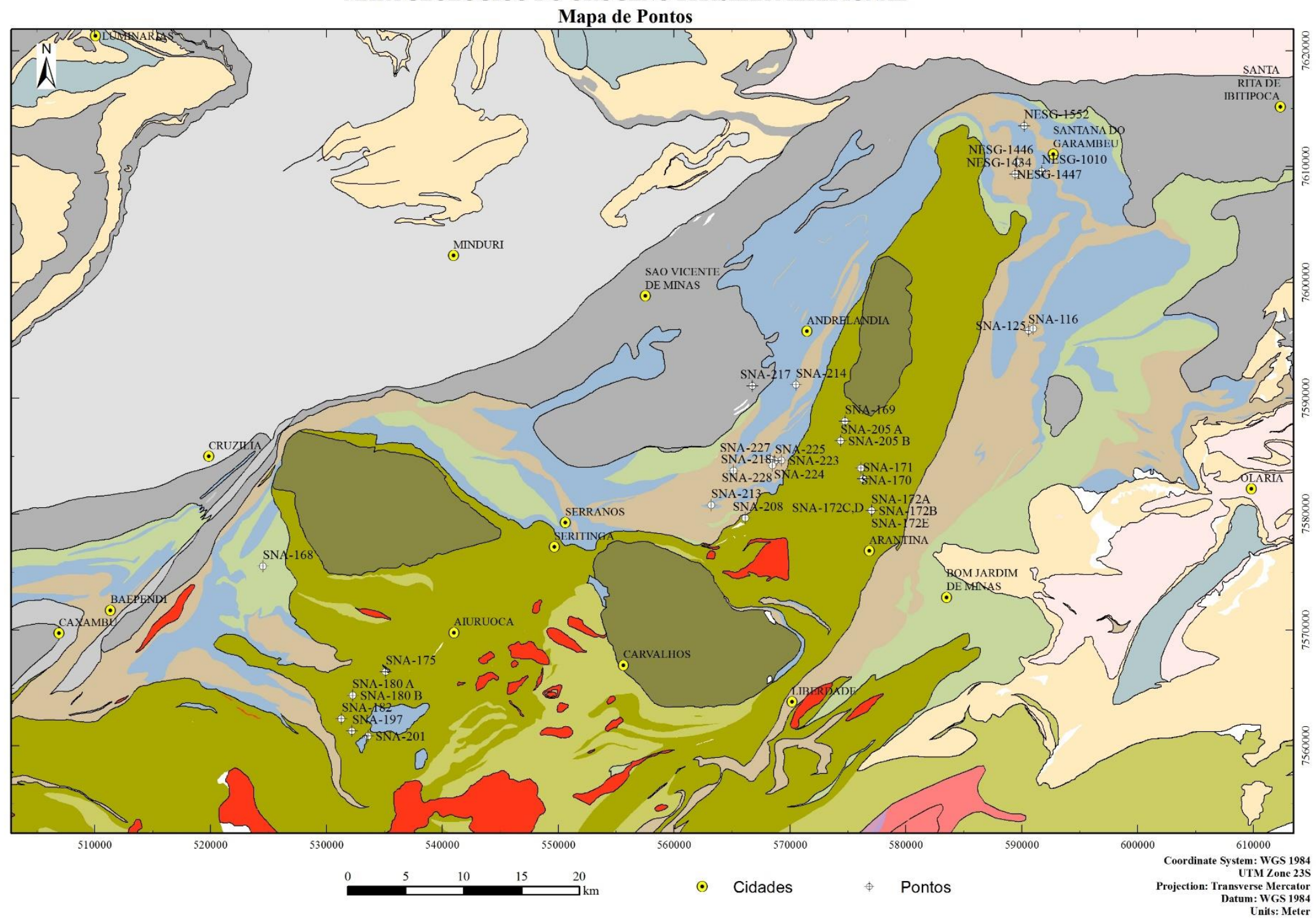


LEGENDA

MARGEM ATIVA

Dominio de ante-arco

Nappe Andrelândia Neoproterozoico

Unidade Serra da Boa Vista

Unidade Santo Antônio

Unidade Rio Capivari

Nappe Liberdade

Leucogranito

Rochas metassedimentares $\mathrm{e}$

Migmatitos Alagoa

Diatexitos e metatexitos (paleosson

metassedimentos da Nappe

Liberdade e ortognaisses do
Complexo Pouso Alegre)
Nappe Três Pontas-Varginha,

Pouso Alto e klippen

Rochas metassedimentares em fácies
granulito de alta pressão

Dominio de Arco Magmático

Nappe Socorro-Guaxupé

Granitoides e ortognaisses indivisos
CRÁTON SÃO FRANCISCO

Arqueano/Paleoproterozoico

$$
\text { Granitoides e gnisses indivisos }
$$

MARGEM PASSIVA

Neoproterozoico

Sistema de Nappes Carrancas

leoproterozoico

Complexos São Vicente e Itapira Complexo Pouso Alegre

Arqueano/Paleoproterozoico

Complexos Amparo-Heliodora-Minduri (A-H-M) 
ANEXO II

Geoquímica elemental em rocha-total

(Elementos traço por FRX e traços e terras raras por LA-ICP-MS) 


\begin{tabular}{|c|c|c|c|c|c|c|c|c|c|c|c|c|}
\hline & $\begin{array}{l}\text { NESG- } \\
10102 \mathrm{~A}\end{array}$ & $\begin{array}{l}\text { NESG- } \\
10102 \mathrm{~B}\end{array}$ & $\begin{array}{c}\text { NESG- } \\
1552\end{array}$ & $\begin{array}{l}\text { SNA- } \\
201\end{array}$ & $\begin{array}{c}\text { NESG- } \\
1434\end{array}$ & $\begin{array}{c}\text { NESG- } \\
1447\end{array}$ & $\begin{array}{c}\text { SNA- } \\
169\end{array}$ & $\begin{array}{l}\text { SNA- } \\
172 \mathrm{E}\end{array}$ & $\begin{array}{l}\text { SNA- } \\
175\end{array}$ & $\begin{array}{c}\text { SNA- } \\
168\end{array}$ & $\begin{array}{l}\text { SNA- } \\
170\end{array}$ & $\begin{array}{l}\text { SNA- } \\
\text { 170D }\end{array}$ \\
\hline \multicolumn{13}{|c|}{ FRX } \\
\hline $\mathrm{Ba}$ & 437 & 511 & 117 & 450 & 701 & 500 & 558 & 611 & 612 & 22 & 72 & 883 \\
\hline $\mathrm{Ce}$ & 56 & 71 & 59 & 38 & 99 & 81 & 84 & 106 & 87 & 41 & $<35$ & 74 \\
\hline Co & 17 & 19 & 51 & 21 & 24 & 13 & 11 & 14 & 21 & 35 & 8 & $<6$ \\
\hline $\mathrm{Cr}$ & 275 & 108 & 274 & 98 & 119 & 157 & 99 & 38 & 108 & 32 & 43 & 105 \\
\hline $\mathrm{Cu}$ & 52 & 19 & 21 & 61 & 48 & 49 & 53 & 8 & 21 & 46 & $<5$ & 39 \\
\hline $\mathrm{Ga}$ & 15 & 18 & 17 & 16 & 25 & 23 & 21 & 17 & 27 & 10 & 11 & 28 \\
\hline La & 33 & $<28$ & $<28$ & 29 & 66 & $<28$ & 45 & 43 & 36 & $<28$ & 30 & 35 \\
\hline $\mathrm{Nb}$ & 15 & 10 & $<9$ & 9 & 18 & 16 & 20 & 14 & 16 & 9 & 12 & 11 \\
\hline $\mathrm{Nd}$ & 39 & $<14$ & 26 & 13 & 52 & 21 & 44 & 56 & 30 & 22 & 18 & 32 \\
\hline $\mathrm{Ni}$ & 46 & 65 & 86 & 62 & 51 & 34 & 40 & 25 & 35 & 32 & 21 & 76 \\
\hline $\mathrm{Pb}$ & 10 & 13 & 11 & 6 & 19 & 14 & 13 & 13 & 20 & 33 & 23 & 15 \\
\hline $\mathrm{Rb}$ & 83 & 96 & 14 & 66 & 169 & 141 & 130 & 164 & 222 & $<3$ & 7 & 125 \\
\hline Sc & $<14$ & 17 & 41 & 16 & 17 & 15 & 18 & $<14$ & 19 & $<14$ & 26 & 14 \\
\hline $\mathrm{Sr}$ & 114 & 199 & 81 & 181 & 179 & 132 & 115 & 138 & 72 & 14 & 239 & 224 \\
\hline Th & $<7$ & $<7$ & $<7$ & 7 & 13 & $<7$ & 20 & 23 & 21 & 17 & 16 & 60 \\
\hline$U$ & $<3$ & 4 & 4 & 5 & 3 & 3 & 7 & 6 & 8 & 19 & 17 & 50 \\
\hline $\mathrm{V}$ & 96 & 133 & 292 & 152 & 122 & 113 & 133 & 51 & 146 & 53 & 46 & 55 \\
\hline$Y$ & 30 & 25 & 32 & 28 & 26 & 38 & 44 & 41 & 39 & 32 & 24 & 21 \\
\hline $\mathrm{Zn}$ & 83 & 103 & 82 & 101 & 126 & 87 & 96 & 60 & 131 & 182 & 72 & 138 \\
\hline $\mathrm{Zr}$ & 240 & 173 & 76 & 157 & 218 & 214 & 304 & 295 & 163 & 96 & 108 & 186 \\
\hline \multicolumn{13}{|c|}{ LA-ICP-MS } \\
\hline $\mathrm{Rb}$ & 85,7 & 94,3 & 9,74 & 71,4 & 156 & 130 & 140 & 167 & 252 & 0,10 & 5,60 & 39,9 \\
\hline $\mathrm{Sr}$ & 112 & 192 & 81,0 & 186 & 174 & 128 & 113 & 140 & 73,4 & 10,4 & 229 & 261 \\
\hline$Y$ & 29,4 & 23,3 & 28,6 & 30,6 & 25,9 & 33,1 & 38,9 & 30,8 & 42,1 & 28,5 & 21,7 & 31,1 \\
\hline $\mathrm{Zr}$ & 256 & 161 & 51,6 & 143 & 242 & 258 & 229 & 178 & 156 & 54,0 & 95,0 & 102 \\
\hline $\mathrm{Nb}$ & 16,2 & 10,4 & 3,51 & 11,6 & 21,1 & 17,8 & 27,5 & 18,8 & 21,9 & 3,79 & 14,1 & 15,0 \\
\hline Cs & 3,89 & 6,12 & 1,00 & 4,21 & 8,10 & 5,49 & 3,96 & 6,72 & 13,0 & 0,04 & 0,36 & 0,38 \\
\hline $\mathrm{Ba}$ & 469 & 509 & 85,4 & 471 & 673 & 494 & 586 & 634 & 653 & 1,96 & 51,6 & 277 \\
\hline $\mathrm{La}$ & 39,8 & 25,0 & 5,26 & 29,1 & 83,1 & 45,7 & 64,6 & 50,3 & 59,7 & 18,5 & 23,4 & 24,1 \\
\hline $\mathrm{Ce}$ & 75,0 & 43,3 & 8,67 & 50,0 & 118 & 97,0 & 143 & 104 & 127 & 35,9 & 44,5 & 51,1 \\
\hline $\operatorname{Pr}$ & 8,83 & 6,18 & 1,87 & 7,18 & 15,6 & 10,6 & 15,6 & 12,6 & 14,1 & 4,40 & 5,65 & 7,06 \\
\hline $\mathrm{Nd}$ & 32,9 & 24,0 & 8,97 & 28,9 & 55,8 & 38,7 & 58,9 & 48,2 & 53,1 & 17,8 & 21,7 & 29,9 \\
\hline Sm & 6,60 & 5,25 & 2,89 & 6,29 & 10,7 & 7,54 & 11,8 & 10,2 & 10,9 & 3,43 & 3,88 & 6,55 \\
\hline $\mathrm{Eu}$ & 1,43 & 1,26 & 1,12 & 1,41 & 2,14 & 1,46 & 2,04 & 1,37 & 1,83 & 0,82 & 0,82 & 1,20 \\
\hline $\mathrm{Gd}$ & 5,94 & 4,89 & 3,89 & 5,65 & 7,92 & 6,20 & 9,26 & 8,48 & 8,81 & 3,71 & 3,50 & 5,86 \\
\hline $\mathrm{Tb}$ & 0,92 & 0,75 & 0,73 & 0,90 & 1,08 & 0,98 & 1,36 & 1,27 & 1,35 & 0,61 & 0,55 & 1,00 \\
\hline Dy & 5,12 & 4,15 & 4,45 & 5,20 & 5,40 & 5,72 & 7,60 & 6,52 & 7,64 & 3,62 & 3,20 & 5,74 \\
\hline Ho & 1,05 & 0,84 & 0,99 & 1,13 & 0,98 & 1,17 & 1,56 & 1,17 & 1,59 & 0,80 & 0,68 & 1,13 \\
\hline $\mathrm{Er}$ & 2,92 & 2,34 & 2,89 & 3,11 & 2,67 & 3,37 & 4,31 & 2,74 & 4,34 & 2,12 & 1,89 & 2,83 \\
\hline $\mathrm{Tm}$ & 0,43 & 0,34 & 0,43 & 0,48 & 0,39 & 0,51 & 0,69 & 0,39 & 0,67 & 0,31 & 0,29 & 0,41 \\
\hline $\mathrm{Yb}$ & 2,89 & 2,34 & 2,92 & 2,96 & 2,61 & 3,48 & 4,39 & 2,20 & 4,24 & 1,91 & 1,96 & 2,52 \\
\hline Lu & 0,43 & 0,36 & 0,43 & 0,46 & 0,39 & 0,51 & 0,68 & 0,32 & 0,66 & 0,27 & 0,29 & 0,37 \\
\hline $\mathrm{Hf}$ & 7,22 & 4,58 & 1,83 & 3,71 & 6,88 & 7,35 & 6,01 & 4,69 & 4,10 & 1,39 & 2,43 & 2,58 \\
\hline $\mathrm{Pb}$ & 14,1 & 14,8 & 7,82 & 12,2 & 21,3 & 18,6 & 13,6 & 22,8 & 25,1 & 9,88 & 17,6 & 8,72 \\
\hline Th & 11,0 & 6,87 & 0,29 & 6,19 & 16,1 & 15,0 & 20,0 & 17,7 & 18,9 & 2,98 & 6,99 & 1,24 \\
\hline U & 2,19 & 1,55 & 0,08 & 2,07 & 2,20 & 3,34 & 2,73 & 3,60 & 3,46 & 0,50 & 3,66 & 0,31 \\
\hline
\end{tabular}


SNA-214 SNA-213 SNA-225 SNA-228 SNA-205 A3(2) SNA-205 A4 SNA-205 A5 SNA-205 B2 SNA-208 SNA-218 C-561 C-562B C-571 C-572 C-573 C-574

\begin{tabular}{|c|c|c|c|c|c|c|c|c|c|c|c|c|c|c|c|c|}
\hline \multicolumn{17}{|c|}{ FRX } \\
\hline $\mathrm{Ba}$ & 560 & 274 & 666 & 591 & $<37$ & $<37$ & 90 & $<37$ & 63 & $<37$ & 385 & 273 & 412 & 405 & 434 & 382 \\
\hline $\mathrm{Ce}$ & 53 & $<35$ & 88 & $<35$ & $<35$ & $<35$ & $<35$ & $<35$ & $<35$ & 38 & 79 & 53 & 83 & 79 & 83 & 70 \\
\hline Co & 23 & $<6$ & 15 & 15 & 44 & 45 & 44 & 80 & 50 & 13 & 18 & $<6$ & 20 & 18 & 21 & 19 \\
\hline $\mathrm{Cr}$ & 99 & 16 & 87 & 88 & 298 & 316 & 116 & 201 & 289 & 51 & 86 & 33 & 83 & 86 & 101 & 85 \\
\hline $\mathrm{Cu}$ & 45 & $<5$ & 9 & 18 & 82 & 115 & 128 & 274 & 163 & 9 & 40 & 8 & 33 & 27 & 36 & 25 \\
\hline $\mathrm{Ga}$ & 21 & $<9$ & 24 & 18 & 13 & 13 & 16 & 15 & 15 & $<9$ & 23 & $<9$ & 21 & 20 & 25 & 22 \\
\hline $\mathrm{La}$ & $<28$ & $<28$ & 42 & $<28$ & $<28$ & $<28$ & $<28$ & $<28$ & $<28$ & 28 & 73 & $<28$ & 45 & 43 & 38 & 42 \\
\hline $\mathrm{Nb}$ & 12 & $<9$ & 23 & 23 & $<9$ & $<9$ & $<9$ & $<9$ & $<9$ & 9 & 16 & 9 & 15 & 16 & 16 & 15 \\
\hline $\mathrm{Nd}$ & 24 & $<14$ & 36 & $<14$ & $<14$ & $<14$ & $<14$ & 26 & $<14$ & 32 & 46 & 19 & 37 & 32 & 33 & 28 \\
\hline $\mathrm{Ni}$ & 63 & $<5$ & 23 & 16 & 128 & 138 & 94 & 173 & 121 & 5 & 50 & 7 & 44 & 41 & 49 & 46 \\
\hline $\mathrm{Pb}$ & 28 & 8 & 25 & 21 & $<4$ & 4 & $<4$ & 5 & $<4$ & 9 & 17 & 13 & 26 & 18 & 18 & 14 \\
\hline $\mathrm{Rb}$ & 99 & 45 & 153 & 127 & $<3$ & $<3$ & 3 & $<3$ & 6 & $<3$ & 163 & 85 & 157 & 136 & 144 & 138 \\
\hline Sc & 14 & $<14$ & $<14$ & $<14$ & 44 & 43 & 37 & 46 & 47 & $<14$ & $<14$ & $<14$ & 19 & 14 & 18 & 14 \\
\hline $\mathrm{Sr}$ & 182 & 12 & 94 & 133 & 131 & 102 & 164 & 58 & 140 & 4 & 91 & 10 & 195 & 147 & 65 & 164 \\
\hline Th & 8 & 7 & 17 & 11 & $<7$ & $<7$ & $<7$ & $<7$ & $<7$ & 14 & 12 & 9 & 13 & 13 & 15 & 12 \\
\hline$U$ & $<3$ & 3 & 4 & $<3$ & $<3$ & $<3$ & $<3$ & $<3$ & $<3$ & 3 & 3 & 3 & 3 & 3 & 4 & 3 \\
\hline V & 143 & 14 & 115 & 109 & 256 & 264 & 283 & 374 & 299 & 45 & 124 & 20 & 121 & 107 & 146 & 116 \\
\hline$Y$ & 30 & 6 & 30 & 24 & 15 & 15 & 21 & 36 & 17 & 27 & 37 & 16 & 33 & 32 & 30 & 33 \\
\hline $\mathrm{Zn}$ & 121 & 6 & 90 & 45 & 72 & 75 & 70 & 137 & 85 & 80 & 109 & 17 & 110 & 93 & 116 & 103 \\
\hline $\mathrm{Zr}$ & 194 & 187 & 279 & 324 & 47 & 47 & 60 & 89 & 51 & 64 & 182 & 242 & 176 & 209 & 183 & 202 \\
\hline
\end{tabular}


ANEXO III

Geoquímica isotópica em rocha-total

(Sistemas Sm-Nd e Rb-Sr) 


\begin{tabular}{|c|c|c|c|c|c|c|c|c|c|c|}
\hline & $\mathrm{Sm}$ & $\mathrm{Nd}$ & ${ }^{147} \mathrm{Sm} /{ }^{144} \mathrm{Nd}$ & ${ }^{143} \mathrm{Nd} /{ }^{144} \mathrm{Nd}$ & $\varepsilon(0)$ & $f_{S m / N d}$ & $\mathrm{~T}_{\mathrm{DM}}(\mathrm{Ma})$ & $\varepsilon(\mathrm{TDM})$ & $\mathrm{T}_{1}$ & $\varepsilon(\mathrm{t})$ \\
\hline NESG-1010 & 6,12 & 30,96 & 0,11951 & 0,51209 & $-10,70$ & $-0,39$ & 1540 & 4,47 & 680 & $-4,00$ \\
\hline SNA-169 & 11,80 & 58,90 & 0,12115 & 0,51183 & $-15,74$ & $-0,38$ & 1997 & 3,50 & 790 & $-8,71$ \\
\hline SNA-170 & 10,20 & 48,20 & 0,12797 & 0,51189 & $-14,67$ & $-0,35$ & 2058 & 3,38 & 790 & $-8,27$ \\
\hline SNA-172E & 10,90 & 53,10 & 0,12413 & 0,51186 & $-15,18$ & $-0,37$ & 2014 & 3,47 & 790 & $-8,42$ \\
\hline SNA-175 & 10,20 & 48,20 & 0,12797 & 0,51189 & $-14,67$ & $-0,35$ & 2058 & 3,38 & 790 & $-8,27$ \\
\hline SNA-180B & 10,90 & 53,10 & 0,12413 & 0,51186 & $-15,18$ & $-0,37$ & 2014 & 3,47 & 790 & $-8,42$ \\
\hline SNA-172D & 6,55 & 29,90 & 0,13247 & 0,51238 & $-5,09$ & $-0,33$ & 1249 & 5,14 & 790 & 0,89 \\
\hline NESG-1434 & 11,81 & 64,92 & 0,11000 & 0,51150 & $-22,26$ & $-0,44$ & 2283 & 2,94 & 680 & $-14,75$ \\
\hline NESG-1447 & 7,76 & 42,05 & 0,11161 & 0,51184 & $-15,62$ & $-0,43$ & 1799 & 3,90 & 680 & $-8,24$ \\
\hline SNA-168 & 3,43 & 17,80 & 0,11652 & 0,51165 & $-19,19$ & $-0,41$ & 2183 & 3,13 & 1460 & $-4,26$ \\
\hline
\end{tabular}

\begin{tabular}{|c|c|c|c|c|c|c|c|c|c|c|}
\hline & $\mathrm{Rb}$ & $\mathrm{Sr}$ & $1 / \mathrm{Sr}$ & $\mathrm{Sr}^{87} / \mathrm{Sr}^{86}$ & $\mathrm{Rb}^{87} / \mathrm{Sr}^{86}$ & $\mathrm{~T}(\mathrm{Ma})$ & $\left(\mathrm{Sr}^{87} / \mathrm{Sr}^{86}\right)_{0}$ & & constantes & \\
\hline NESG-1010 & 174,90 & 188,90 & 0,00529 & 0,72456 & 2,68413 & 680 & 0,69851 & 1,00193 & 0,00729 & 2,89340 \\
\hline SNA-201 & 71,40 & 186,00 & 0,00538 & 0,71585 & 1,11188 & 680 & 0,70506 & 1,00107 & 0,00976 & 2,89340 \\
\hline SNA-169 & 140,00 & 113,00 & 0,00885 & 0,75969 & 3,60408 & 790 & 0,72214 & 1,00539 & 0,01517 & 2,89340 \\
\hline SNA-170 & 5,60 & 229,00 & 0,00437 & 0,71584 & 0,07083 & 790 & 0,71510 & 1,00107 & 0,15298 & 2,89340 \\
\hline SNA-172E & 167,00 & 140,00 & 0,00714 & 0,75585 & 3,46872 & 790 & 0,71970 & 1,00501 & 0,01466 & 2,89340 \\
\hline SNA-175 & 252,00 & 73,40 & 0,01362 & 0,81659 & 10,04306 & 790 & 0,71194 & 1,01101 & 0,01111 & 2,89340 \\
\hline SNA-172D & 39,90 & 261,00 & 0,00383 & 0,70355 & 0,44226 & 790 & 0,69894 & 0,99986 & $-0,00328$ & 2,89340 \\
\hline NESG-1434 & 104,98 & 179,07 & 0,00558 & 0,74895 & 1,70360 & 680 & 0,73242 & 1,00433 & 0,02580 & 2,89340 \\
\hline NESG-1447 & 146,21 & 138,59 & 0,00722 & 0,75876 & 3,06872 & 680 & 0,72899 & 1,00530 & 0,01752 & 2,89340 \\
\hline SNA-168 & 0,10 & 10,40 & 0,09615 & 0,71913 & 0,02786 & 1460 & 0,71855 & 1,00139 & 0,50733 & 2,89340 \\
\hline
\end{tabular}




\section{ANEXO IV}

Sistema isotópico U-Pb em zircão

(LA-ICP-MS) 
AMOSTRA SNA-116: metapsamito (Unidade Serra da Boa Vista - Nappe Andrelândia)

\begin{tabular}{|c|c|c|c|c|c|c|c|c|c|c|c|c|c|c|c|c|c|c|c|c|c|}
\hline Spot & 07/235 & 1sigma & 206/238 & 1sigma & Zorrel. & $238 / 206$ & 1sigma & 207/206 & 1sigma & 208/206 & 1sigma & $\begin{array}{c}\% \\
\text { Com.Pb }\end{array}$ & $\begin{array}{c}\mathrm{ppm} \\
\mathrm{Pb}\end{array}$ & $\begin{array}{l}\text { ppm } \\
\text { Th }\end{array}$ & $\stackrel{\mathrm{ppm}}{\mathrm{U}}$ & $\mathrm{Th} / \mathrm{U}$ & $\begin{array}{c}T \\
206 / 238\end{array}$ & $\begin{array}{c}1 \\
\text { sigma }\end{array}$ & $\begin{array}{c}T \\
207 / 206\end{array}$ & $\begin{array}{c}1 \\
\text { sigma }\end{array}$ & $\begin{array}{c}\% \\
\text { Conc. }\end{array}$ \\
\hline \multicolumn{22}{|c|}{ M135 } \\
\hline 1,1 & 7,4621 & 0,1279 & 0,3994 & 0,004 & 0,92 & 2,5038 & 0,0253 & 0,1355 & 0,0024 & 0,1387 & 0,0121 & 0,23 & 30,6 & 29,1 & 64,6 & 0,451 & 2,166 & 0,019 & 2,171 & 0,031 & 99 \\
\hline 1,2 & 7,3194 & 0,122 & 0,3954 & 0,0038 & 0,83 & 2,5288 & 0,0245 & 0,1342 & 0,0023 & 0,132 & 0,0046 & 0,21 & 48,3 & 46,9 & 102,2 & 0,459 & 2,148 & 0,018 & 2,154 & 0,029 & 99 \\
\hline 2,1 & 1,5931 & 0,0303 & 0,1613 & 0,0014 & 0,86 & 6,1987 & 0,055 & 0,0716 & 0014 & 0,2079 & 0,0079 & 4,15 & 55,8 & 187 & 274,7 & 0,68 & 0,964 & 0,008 & 0,975 & ,039 & 98 \\
\hline 2,2 & 1,6345 & 0,0321 & 0,165 & 0,0015 & 0,74 & 6,0589 & 0,0555 & 0,0718 & 0,0014 & 0,1662 & 0,0056 & 0,12 & 66,2 & 200 & 341 & 0,585 & 0,985 & 0,008 & 0,981 & 0,04 & 100 \\
\hline 3,1 & 11,7209 & 0,1553 & 0,4645 & 0,0034 & 0,85 & 2,1526 & 0,0158 & 0,183 & 0,002 & 0,1564 & 0,019 & 0,71 & 143,4 & 100 & 238,5 & 0,42 & 2,46 & 0,015 & 2,68 & 0,017 & 91 \\
\hline 3,2 & 12,3413 & 0,1436 & 0,4839 & 0,0032 & 0,99 & 2,0667 & 0,0135 & 0,185 & 0,0018 & 0,0757 & 0,0049 & 0,12 & 348,8 & 169 & 581,6 & 0,291 & 2,544 & 0,014 & 2,698 & 0,017 & 94 \\
\hline 3,3 & 13,4403 & 0,1857 & 0,5231 & 0,0043 & 0,99 & 1,9116 & 0,0158 & 0,1863 & 0,0024 & 0,1098 & 0,0048 & 0,41 & 134,6 & 88,3 & 218,3 & 0,405 & 2,712 & 0,018 & 2,71 & 0,021 & 100 \\
\hline 4,1 & 4,0953 & 0,1142 & 0,2914 & 0,0043 & 0,47 & 3,432 & 0,0512 & 0,1019 & 0,0034 & 0,3554 & 0,0445 & 0,67 & 18,7 & 52,7 & 47,6 & 1,107 & 1,648 & 0,022 & 1,66 & 0,062 & 99 \\
\hline 5,1 & 4,9381 & 0,0843 & 0,3211 & 0,003 & 0,86 & 3,1139 & 0,0291 & 0,1115 & 0,0019 & 0,2584 & 0,0132 & & 60,5 & 153 & 137,3 & 1,113 & 1,795 & 0,015 & 1,824 & 0,03 & 98 \\
\hline 5,2 & 5,094 & 0,0781 & 0,3327 & 0,0028 & 0,83 & 3,0055 & 0,0251 & 0,111 & 0,0016 & 0,2329 & 0,004 & 0,25 & 81,8 & 170 & 194,4 & 0,872 & 1,852 & 0,013 & 1,816 & 0,027 & 101 \\
\hline 6,1 & 1,4945 & 0,0185 & 0,1542 & 0,001 & 1 & 6,4851 & 0,0413 & 0,0703 & 0,0009 & 0,5662 & 0,4635 & 0,97 & 153,2 & 1353 & 755,3 & 1,792 & 0,924 & 0,006 & 0,937 & 0,027 & 98 \\
\hline 6,2 & 1,6923 & 0,0254 & 0,1717 & 0,0013 & 0,85 & 5,824 & 0,043 & 0,0715 & 0,001 & 0,1448 & 0,0024 & 0 & 127,4 & 340 & 643,1 & 0,528 & 1,021 & 0,007 & 0,971 & 0,028 & 105 \\
\hline 7,1 & 1,5889 & 0,1025 & 0,1747 & 0,0041 & 0,47 & 5,7237 & 0,1338 & 0,066 & 0,0049 & 0,0741 & 0,042 & 0,68 & 24,9 & 54,5 & 128,4 & 0,425 & 1,038 & 0,022 & 0,805 & 0,15 & 128 \\
\hline 8,1 & 7,1442 & 0,2754 & 0,4003 & 0,0086 & 0,73 & 2,4979 & 0,0534 & 0,1294 & 0,0058 & 0,3779 & 0,0325 & 1,11 & 18,7 & 53,9 & 31,9 & 1,688 & 2,171 & 0,039 & 2,09 & 0,077 & 103 \\
\hline 9,1 & 8,6388 & 0,225 & 0,4243 & 0,0068 & 0,54 & 2,3566 & 0,0378 & 0,1477 & 0,0042 & 0,1628 & 0,011 & 0,6 & 27,9 & 29,4 & 50,6 & 0,581 & 2,28 & 0,031 & 2,319 & 0,049 & 98 \\
\hline 10,1 & 2,1618 & 0,0465 & 0,1906 & 0,0021 & 0,78 & 5,247 & 0,0568 & 0,0823 & 0,0019 & 0,1618 & 0,0525 & 6,83 & 34,1 & 55 & 168,6 & 0,326 & 1,125 & 0,011 & 1,252 & 0,048 & 89 \\
\hline 11,1 & 7,7977 & 0,473 & 0,4107 & 0,0142 & 0,38 & 2,4351 & 0,0842 & 0,1377 & 0,0101 & 0,1285 & 0,0385 & 2,31 & & 6,8 & 16,8 & 0,407 & 2,218 & 0,065 & 2,199 & 0,131 & 100 \\
\hline 12,1 & 1,692 & 0,0501 & 0,17 & 0,0022 & 0,79 & 5,8809 & 0,0766 & 0,0722 & 0,0023 & 0,1587 & 0,0186 & 0,21 & 34,9 & 114 & 188,9 & 0,603 & 1,012 & 0,012 & 0,991 & 0,069 & 102 \\
\hline 13,1 & 1,6046 & 0,0257 & 0,1632 & 0,0015 & 0,95 & 6,1256 & 0,0551 & 0,0713 & 0,001 & 0,1908 & 0,1604 & 0,79 & 171,4 & 354 & 983 & 0,36 & 0,975 & 0,008 & 0,966 & 0,029 & 100 \\
\hline 14,1 & 7050 & 0,187 & 0,3848 & 0,0059 & 0,56 & 2,5989 & 0,04 & 0,1331 & 0,0038 & 0,1054 & 0,0111 & 0,46 & 22,9 & 18,5 & 51,1 & 0,362 & 2,099 & 0,028 & 2,139 & 0,05 & 98 \\
\hline 15,1 & 3,5635 & 0,0673 & 0,2737 & 0,0028 & 0,93 & 3,6537 & 0,0376 & 0,0944 & 0,0017 & 0,1594 & 0,0058 & 0,27 & 68,8 & 117 & 225 & 0,521 & 1,56 & 0,014 & 1,517 & 0,034 & 102 \\
\hline 16,1 & 4,446 & 0,0844 & 0,3064 & 0,0033 & 0,99 & 3,2637 & 0,0347 & 0,1052 & 0,002 & 0,1335 & 0,0311 & 0,14 & 60,6 & 87,9 & 184,5 & 0,476 & 1,723 & 0,016 & 1,718 & 0,035 & 100 \\
\hline 17,1 & 4,4705 & 0,167 & 0,3024 & 0,0057 & 0,72 & 3,3065 & 0,062 & 0,1072 & 0,0046 & 0,3229 & 0,0204 & 0,45 & 20,9 & 56,7 & 50,7 & 1,118 & 1,703 & 0,028 & 1,752 & 0,079 & 97 \\
\hline 18,1 & 6,4238 & 0,109 & 0,3741 & 0,0038 & 1 & & 0,0271 & & & & & 0,18 & 88,9 & 255 & 167,4 & 1,522 & 2,049 & 0,018 & 2,022 & 0,032 & 101 \\
\hline 19,1 & 6,3005 & 0,0899 & 0,3686 & 0,0033 & 0,98 & 2,7128 & 0,024 & 0,124 & 0,0015 & 0,1407 & 0,0011 & 0,08 & 253,9 & 297 & 586,8 & 0,505 & 2,023 & 0,015 & 2,014 & 0,022 & 100 \\
\hline
\end{tabular}




\begin{tabular}{|c|c|c|c|c|c|c|c|c|c|c|c|c|c|c|c|c|c|c|c|c|c|}
\hline 20,1 & 3,305 & 0,0544 & 0,2613 & 0,0025 & 0,97 & 3,827 & 0,0362 & 0,0917 & 0,0014 & 0,0972 & 0,0139 & 0,55 & 89,4 & 108 & 303,2 & 0,356 & 1,496 & 0,013 & 1,462 & 0,029 & 102 \\
\hline 21,1 & 6,487 & 0,0949 & 0,3671 & 0,0034 & 0,9 & 2,7243 & 0,0256 & 0,1282 & 0,0018 & 0,1234 & 0,0135 & 0,36 & 126,9 & 159 & 292,3 & 0,542 & 2,016 & 0,016 & 2,073 & 0,024 & 97 \\
\hline 22,1 & 4,8839 & 0,1397 & 0,3228 & 0,0053 & 0,84 & 3,0979 & 0,0505 & 0,1097 & 0,0033 & 0,3057 & 0,0339 & 0,04 & 74,4 & 175 & 170,9 & 1,025 & 1,803 & 0,025 & 1,795 & 0,054 & 100 \\
\hline 23,1 & 4,5391 & 0,08 & 0,3077 & 0033 & 0,92 & 3,2502 & 0,0344 & 0,107 & 0,0019 & 0,3271 & 0,0116 & 0,33 & 25,1 & 69,8 & 63,2 & 1,104 & 1,729 & 0,016 & 1,749 & 0,033 & 98 \\
\hline 24,1 & 6,8385 & 0,1283 & 0,3765 & 0,0046 & 0,9 & 2,6562 & 0,0322 & 0,1317 & 0,0027 & 0,1088 & 0,0054 & 0,8 & 30,1 & 25,8 & 69,2 & 0,373 & 2,06 & 0,021 & 2,121 & 0,036 & 97 \\
\hline 25,1 & 4,62 & 0,1036 & 0,3186 & 0,0041 & 0,86 & 3,1391 & 0,0402 & 0,1052 & 0,0026 & 0,3916 & 0,0302 & 0,13 & 58,4 & 207 & 130,5 & 1,588 & 1,783 & 0,02 & 1,718 & 0,045 & 103 \\
\hline 25,2 & 4,5727 & 0,0727 & 0,3135 & 0,003 & 0,89 & 3,1893 & 0,0309 & 0,1058 & 0,0016 & 0,4178 & 0,0092 & 0,16 & 100,6 & 359 & 226 & 1,588 & 1,758 & 0,015 & 1,728 & 0,028 & 101 \\
\hline \multicolumn{22}{|c|}{ M245 } \\
\hline 1,1 & 1,6174 & 0,0302 & 0,1636 & 0,0018 & 0,98 & 6,1141 & 0,0675 & 0,0717 & 0,0015 & 0,214 & 0,0181 & 1,17 & 39,5 & 132 & 227,2 & 0,58 & 0,977 & 0,01 & 0,978 & 0,044 & 99 \\
\hline 2,1 & 7,1322 & 0,0984 & 0,3856 & 0,0041 & 0,97 & 2,5932 & 0,0279 & 0,1341 & 0,0018 & 0,2041 & 0,0323 & 0,15 & 58,7 & 71 & 126,6 & 0,561 & 2,102 & 0,019 & 2,153 & 0,024 & 97 \\
\hline 2,2 & 7,1864 & 0,1044 & 0,3886 & 0,0037 & 0,99 & 2,5736 & 0,0246 & 0,1341 & 0,0017 & 0,163 & 0,0087 & 0,15 & 46,9 & 56,9 & 103,8 & 0,548 & 2,116 & 0,017 & 2,153 & 0,022 & 98 \\
\hline 3,1 & 2,3851 & 0,0592 & 0,2155 & 0,0031 & 0,9 & 4,6404 & 0,0674 & 0,0803 & 0,0022 & 0,1589 & 0,0117 & 0,52 & 28,2 & 68,3 & 120,4 & 0,567 & 1,258 & 0,017 & 1,204 & 0,054 & 104 \\
\hline 4,1 & 8,2151 & 0,1874 & 0,4449 & 0,0078 & 0,98 & 2,2479 & 0,0397 & 0,1339 & 0,0031 & 0,1415 & 0,0113 & 0,17 & 57,8 & 71,1 & 131,9 & 0,539 & 2,372 & 0,035 & 2,15 & 0,041 & 110 \\
\hline 4,2 & 6,914 & 0,0911 & 0,3801 & 0,0033 & 0,99 & 2,6312 & 0,0228 & 0,1319 & 0,0014 & 0,0824 & 0,0036 & 0,15 & 90,8 & 55,8 & 212,7 & 0,263 & 2,077 & 0,015 & 2,124 & 0,018 & 97 \\
\hline 5,1 & 6,8602 & 0,0836 & 0,3773 & 0,0036 & 0,97 & 2,6506 & 0,0252 & 0,1319 & 0,0016 & 0,1252 & 0,0052 & 0,45 & 82,4 & 81,7 & 186,6 & 0,438 & 2,064 & 0,017 & 2,123 & 0,021 & 97 \\
\hline 5,2 & 7,2957 & 0,0899 & 0,3995 & 0,0039 & 0,99 & 2,5032 & 0,0243 & 0,1325 & 0,0016 & 0,1161 & 0,0021 & 0,09 & 119 & 108 & 275,9 & 0,392 & 2,167 & 0,018 & 2,131 & 0,021 & 101 \\
\hline 6,1 & 3,3991 & 0,0457 & 0,2655 & 0,0026 & 0,92 & 3,7662 & 0,0363 & 0,0928 & 0,0012 & 0,1359 & 0,0256 & 0,44 & 40,4 & 8,5 & 160,8 & 0,053 & 1,518 & 0,013 & 1,485 & 0,026 & 102 \\
\hline 7,1 & 8,0443 & 0,1204 & 0,4289 & 0,005 & 0,97 & 2,3316 & 0,0275 & 0,136 & 0,002 & 0,126 & 0,0243 & 0,09 & 83,6 & 53,7 & 184,3 & 0,291 & 2,301 & 0,023 & 2,177 & 0,026 & 105 \\
\hline 8,1 & 7,6867 & 0,1483 & 0,4106 & 0,0061 & 0,96 & 2,4354 & 0,0364 & 0,1358 & 0,0026 & 0,2461 & 0,0312 & 0 & 38,1 & 59,8 & 81,9 & 0,729 & 2,218 & 0,028 & 2,174 & 0,033 & 102 \\
\hline 9,1 & 3,9436 & 0,0584 & 0,28 & 0,003 & 0,97 & 3,5712 & 0,0387 & 0,1021 & 0,0014 & 0,3538 & 0,037 & 0,21 & 55 & 172 & 133,8 & 1,286 & 1,591 & 0,015 & 1,663 & 0,025 & 95 \\
\hline 10,1 & 4,3209 & 0,0885 & 0,3088 & 0,0043 & 0,92 & 3,2384 & 0,0455 & 0,1015 & 0,0021 & 0,3295 & 0,0472 & 0,08 & 66,8 & 230 & 168,6 & 1,367 & 1,735 & 0,021 & 1,651 & 0,038 & 105 \\
\hline 11,1 & 1,7914 & 0,0601 & 0,1754 & 0,0031 & 0,85 & 5,6998 & 0,1002 & 0,0741 & 0,0029 & 0,353 & 0,0254 & 0,52 & 20 & 106 & 90,7 & 1,164 & 1,042 & 0,017 & 1,043 & 0,078 & 99 \\
\hline 12,1 & 1,5089 & 0,0191 & 0,1545 & 0,0014 & 0,99 & 6,4725 & 0,0587 & 0,0708 & 0,0008 & 0,0983 & 0,0262 & 0 & 190,3 & 460 & 1073 & 0,429 & 0,926 & 0,008 & 0,953 & 0,024 & 97 \\
\hline 13,1 & 4,6485 & 0,0674 & 0,3164 & 0,0029 & 0,97 & 3,1609 & 0,0287 & 0,1066 & 0,0013 & 0,263 & 0,0051 & 0,41 & 77,5 & 181 & 202,5 & 0,895 & 1,772 & 0,014 & 1,741 & 0,023 & 101 \\
\hline 14,1 & 4,0043 & 0,0836 & 0,2876 & 0,0036 & 0,99 & 3,4769 & 0,043 & 0,101 & 0,0019 & 0,3798 & 0,0337 & 0,9 & 63,3 & 213 & 155,7 & 1,369 & 1,63 & 0,018 & 1,642 & 0,035 & 99 \\
\hline 14,2 & 4,3192 & 0,0661 & 0,3039 & 0,0029 & 0,97 & 3,2903 & 0,0313 & 0,1031 & 0,0014 & 0,362 & 0,0042 & 0,24 & 68,8 & 216 & 172,5 & 1,251 & 1,711 & 0,014 & 1,68 & 0,026 & 101 \\
\hline 15,1 & 4,4418 & 0,058 & 0,305 & 0,0025 & 0,99 & 3,2785 & 0,0272 & 0,1056 & 0,0011 & 0,1629 & 0,013 & 0,18 & 154,4 & 219 & 448,4 & 0,487 & 1,716 & 0,013 & 1,725 & 0,019 & 99 \\
\hline 16,1 & 5,8916 & 0,084 & 0,3575 & 0,0033 & 1 & 2,797 & 0,0261 & 0,1195 & 0,0011 & 0,1819 & 0,0281 & 0,02 & 366,6 & 445 & 880,4 & 0,505 & 1,97 & 0,015 & 1,949 & 0,017 & 101 \\
\hline 17,1 & 4,6928 & 0,0765 & 0,3182 & 0,0032 & 0,92 & & 0,0316 & & 0,0015 & 0,2567 & 0,0064 & 0,2 & & 141 & 152,8 & 0,919 & 1,781 & 0,016 & 1,748 & 0,025 & 101 \\
\hline 18,1 & 16,4116 & 0,2539 & 0,5664 & 0,0063 & 1 & 1,7655 & 0,0198 & 0,2101 & 0,0023 & 0,1599 & 0,0133 & 1,95 & 44,4 & 33,2 & 59,2 & 0,561 & 2,893 & 0,025 & 2,907 & 0,018 & 99 \\
\hline
\end{tabular}




\begin{tabular}{|c|c|c|c|c|c|c|c|c|c|c|c|c|c|c|c|c|c|c|c|c|c|}
\hline 19,1 & 4,3638 & 0,0733 & 0,2969 & 0,0031 & 0,94 & 3,3682 & 0,0351 & 0,1066 & 0,0014 & 0,3165 & 0,0217 & 0,23 & 65,5 & 156 & 164,2 & 0,952 & 1,676 & 0,015 & 1,742 & 0,025 & 96 \\
\hline 20,1 & 2,4617 & 0,0636 & 0,2155 & 0,0029 & 0,56 & 4,641 & 0,0618 & 0,0829 & 0,0021 & 0,0638 & 0,0084 & 0 & 35,1 & 30,8 & 149,5 & 0,206 & 1,258 & 0,015 & 1,266 & 0,049 & 99 \\
\hline 20,2 & 2,4631 & 0,0432 & 0,2192 & 0,0022 & 0,92 & 4,5621 & 0,0454 & 0,0815 & 0,0013 & 0,0766 & 0,0062 & 0 & 51,1 & 61,1 & 223,7 & 0,273 & 1,278 & 0,012 & 1,234 & 0,03 & 103 \\
\hline 21,1 & 17,9186 & 0,2225 & 0,6056 & 0,0052 & 0,99 & 1,6513 & 0,0142 & 0,2146 & 0,002 & 0,2412 & 0,0185 & 0,06 & 184,6 & 188 & 251,4 & 0,748 & 3,052 & 0,021 & 2,941 & 0,015 & 103 \\
\hline
\end{tabular}

\section{AMOSTRA SNA-125: metapelito (Unidade Serra da Boa Vista - Nappe Andrelândia)}

\begin{tabular}{|c|c|c|c|c|c|c|c|c|c|c|c|c|c|c|c|c|c|c|c|c|c|}
\hline Spot & $207 / 235$ & 1sigma & 206/238 & 1sigma & Correl. & 238/206 & 1sigma & $207 / 206$ & 1sigma & 208/206 & 1sigma & $\begin{array}{c}\% \\
\text { Com.Pb }\end{array}$ & $\begin{array}{c}\mathrm{ppm} \\
\mathrm{Pb}\end{array}$ & $\begin{array}{l}\text { ppm } \\
\text { Th }\end{array}$ & $\underset{U}{\mathrm{ppm}}$ & $\mathrm{Th} / \mathrm{U}$ & $\begin{array}{c}T \\
206 / 238\end{array}$ & $\begin{array}{c}1 \\
\text { sigma }\end{array}$ & $\begin{array}{c}T \\
207 / 206\end{array}$ & $\begin{array}{c}1 \\
\text { sigma }\end{array}$ & $\begin{array}{l}\% \\
\text { Conc. }\end{array}$ \\
\hline 1,1 & 2,0647 & 0902 & 1946 & 0,0025 & 0,03 & 5,1375 & 0,0648 & 0,0769 & 0,0036 & 11187 & 0,0093 & 0,36 & 22 & 34,5 & 85,6 & 0,403 & 1,147 & 0,013 & 1,119 & 0,091 & 102 \\
\hline 2,1 & 2,4378 & 0,0925 & 0,2136 & 0,0025 & 0,15 & 4,6823 & 0,0545 & 0,0828 & 0,0033 & 0,2837 & 0,0114 & 0,32 & 39,2 & 108 & 125,5 & 0,857 & 1,248 & 0,013 & 1,264 & 0,078 & 98 \\
\hline 2,2 & 0,7655 & 0,0234 & 0,0915 & 0,0008 & 0,77 & 10,9268 & 0,0997 & 0,0607 & 0,0018 & 0,0033 & 0,0034 & 0,25 & 74,9 & 3,6 & 669,4 & 0,005 & 0,565 & 0,005 & 0,627 & 0,066 & 89 \\
\hline 3,1 & 2,7844 & 0,0828 & 0,2398 & 0,0023 & 0,91 & 4,1698 & 0,0403 & 0,0842 & 0,0026 & 0,1621 & 0,004 & 0,18 & 52,6 & 97,1 & 177,3 & 0,547 & 1,386 & 0,012 & 1,297 & 0,059 & 106 \\
\hline 4,1 & 2,2705 & 0,0906 & 0,204 & 0,0025 & 0,4 & 4,9031 & 0,0591 & 0,0807 & 0,0034 & 0,071 & 0,0107 & 0,38 & 24,1 & 21,2 & 94,2 & 0,225 & 1,197 & 0,013 & 1,215 & 0,08 & 98 \\
\hline 5,1 & 2,8389 & 0,0814 & 0,2348 & 0,0022 & 0,63 & 4,2589 & 0,0398 & 0,0877 & 0,0025 & 0,1153 & 0,005 & 0,26 & 71,5 & 87,5 & 235,9 & 0,371 & 1,36 & 0,011 & 1,376 & 0,055 & 98 \\
\hline 5,2 & 0,739 & 0,0207 & 0,089 & 0,0008 & 0,98 & 11,2312 & 0,0982 & 0,0602 & 0,0016 & 0,0011 & 0,0011 & 0,1 & 104,2 & 4,7 & 913,3 & 0,005 & 0,55 & 0,005 & 0,61 & 0,057 & 90 \\
\hline 6,1 & 3,6266 & 0,1191 & 0,2723 & 0,0029 & 0,54 & 3,6726 & 0,0395 & 0,0966 & 0,0033 & 0,2403 & 0,0171 & 0,63 & 53 & 94,8 & 137,7 & 0,689 & 1,552 & 0,015 & 1,559 & 0,064 & 99 \\
\hline 7,1 & 2,4109 & 0,1119 & 0,2024 & 0,0029 & 0,2 & 4,9407 & 0,0696 & 0,0864 & 0,0043 & 0,224 & 0,0143 & 2,71 & 20,2 & 50,1 & 68,3 & 0,733 & 1,188 & 0,015 & 1,347 & 0,099 & 88 \\
\hline 8,1 & 1,6848 & 0,0468 & 0,1565 & 0,0014 & 0,99 & 6,3884 & 0,0573 & 0,0781 & 0,0021 & 0,1522 & 0,0321 & 0 & 107,5 & 327 & 404,7 & 0,808 & 0,937 & 0,008 & 1,148 & 0,054 & 81 \\
\hline 8,2 & 0,7611 & 0,0242 & 0,0918 & 0,0009 & 0,98 & 10,8893 & 0,1029 & 0,0601 & 0,0019 & 0,0064 & 0,0038 & 0 & 71,7 & 11,7 & 584,1 & 0,02 & 0,566 & 0,005 & 0,608 & 0,067 & 93 \\
\hline 9,1 & 2,2149 & 0,0854 & 0,1989 & 0,0023 & 0,81 & 5,0275 & 0,059 & 0,0808 & 0,0032 & 0,019 & 0,0087 & 0,55 & 16,7 & 6,2 & 67,3 & 0,093 & 1,169 & 0,013 & 1,216 & 0,078 & 96 \\
\hline 9,2 & 2,1721 & 0,0582 & 0,1989 & 0,0017 & 0,96 & 5,0276 & 0,0442 & 0,0792 & 0,0022 & 0,0367 & 0,0057 & 0,16 & 78,4 & 50,6 & 346,7 & 0,146 & 1,169 & 0,009 & 1,177 & 0,055 & 99 \\
\hline 10,1 & 2,3714 & 0,1234 & 0,2051 & 0,0034 & 0,67 & 4,8755 & 0,0808 & 0,0839 & 0,0049 & 0,2265 & 0,0094 & 12,46 & 16,8 & 40,7 & 60,2 & 0,677 & 1,203 & 0,018 & 1,289 & 0,115 & 93 \\
\hline 11,1 & 2,8567 & 0,0911 & 0,2334 & 0,0024 & 0,55 & 4,2848 & 0,045 & 0,0888 & 0,0029 & 0,2381 & 0,006 & 0,14 & 51,5 & 122 & 148,6 & 0,82 & 1,352 & 0,013 & 1,399 & 0,062 & 96 \\
\hline 12,1 & 5,346 & 0,1528 & 0,339 & 0,0034 & 0,85 & 2,9495 & 0,03 & 0,1144 & 0,0033 & 0,2643 & 0,0074 & 0,08 & 78,3 & 136 & 153,9 & 0,886 & 1,882 & 0,017 & 1,87 & 0,053 & 100 \\
\hline 13,1 & 0,6974 & 0,023 & 0,0831 & 0,0008 & 0,97 & 12,0265 & 0,119 & 0,0608 & 0,002 & 0,0028 & 0,0033 & 0,16 & 68,9 & 5,3 & 604,7 & 0,009 & 0,515 & 0,005 & 0,633 & 0,069 & 81 \\
\hline 13,2 & 0,764 & 0,0231 & 0,0908 & 0,0008 & 0,83 & 11,0173 & 0,101 & 0,061 & 0,0018 & 0,0016 & 0,0016 & 1,3 & 64,3 & 4,2 & 561,6 & 0,008 & 0,56 & 0,005 & 0,641 & 0,064 & 87 \\
\hline 13,3 & 4,9954 & 0,1275 & 0,3159 & 0,0028 & 0,96 & 3,1653 & 0,0281 & 0,1147 & 0,0029 & 0,3254 & 0,0232 & 0,26 & 102,4 & 215 & 229,9 & 0,935 & 1,77 & 0,014 & 1,875 & 0,045 & 94 \\
\hline 14,1 & 2,3253 & 0,1013 & 0,1981 & 0,0028 & 0,86 & 5,0472 & 0,0721 & 0,0851 & 0,0039 & 0,2503 & 0,0096 & 1,82 & 37,4 & 109 & 130,9 & 0,829 & 1,165 & 0,015 & 1,318 & 0,089 & 88 \\
\hline 15,1 & 0,8625 & 0,0266 & 0,1024 & 0,0009 & 0,81 & 9,7634 & 0,0898 & 0,0611 & 0,0019 & 0,0029 & 0,0033 & 0,41 & 69,9 & 1,9 & 608,4 & 0,003 & 0,629 & 0,006 & 0,642 & 0,066 & 97 \\
\hline
\end{tabular}




\begin{tabular}{|c|c|c|c|c|c|c|c|c|c|c|c|c|c|c|c|c|c|c|c|c|c|}
\hline &, 5574 & 1412, & 3255 & 0,0029 & 0,79 & 3,0724 & 0,0277 & 0,1238 & 0,0031 & 0,1283 & 0,0077 & 0,47 & 79,7 & 82,8 & 177,9 & 0,466 & 1,816 & 0,014 & 2,012 & 0,045 & 0 \\
\hline & 8173 & & & 0009 & & & & & & & & & & & 663,7 & & & & & & \\
\hline 1 & 8281 & 217 & 9984 & 0008 & & , 1581 & 0852 & 061 & 0015 & 028 & 0011 & ,24 & 28,6 & 7,8 & 114 & 007 & 605 & 005 & ,64 & 055 & 4 \\
\hline 6,2 & 2,8862 & 0944 & ,2247 & ,0025 & 0,99 & ,4509 & 0,0489 & 0,0932 & 0,003 & 1116 & 0,0166 & 0,44 & 41,9 & 55,7 & 124,6 & 0,447 & 1,307 & ,013 & 1,491 & 0,06 & 87 \\
\hline 5,3 & ,7759 & 0234 & 0919 & 0008 & 0,74 & 0,8768 & 0,099 & ,0612 & 0,0019 & 003 & 0,0024 & 0,43 & 81,2 & 8,9 & 730,3 & 0,012 & ,567 & ,005 & ,647 & 0,065 & 37 \\
\hline ,1 & 4793 & 1134 & 0,3 & 0,003 & 96 & 3331 & 0,0331 & ,1083, & ,0028 & 1755 & 0,0054 & 0,31 & 98,9 & 130 & 247,6 & 0,523 & 1,691 & ,015 & I,771 & ,047 & \\
\hline 7,2 & 7774 & ,0205 & 0928 & ,0009 & , 83 &, 774 & 0,0998 & 0607 & 0,0016 & 008 & 001 & 0,9 & 108,3 & 4,8 & 960,6 & 0,005 & 572 & 005 & & 057 & 0 \\
\hline 8,1 & 2,8404 & ,0794 & 0,2365 & ,0025 & 0,62 & 4,229 & 0,0438 & ,0871 & 0,0025 & ,283 & 0,041 & 1,13 & 34,5 & 243 & 246,4 & 0,986 & I,368 & 0,013 & 1,363 & 0,055 & 10 \\
\hline 9,1 & 2,7865 & 1133, & 0,2286 & 0,0035 & 0,28 & 4,3736 & 0,0668 & 0,0884 & 0,0041 & 0,1344 & 0,0085 & 0,54 & 24,6 & 36,1 & 78,6 & 0,46 & 1,327 & 0,018 & 1,391 & 0,091 & 95 \\
\hline 9,2 & 0,7776 & 0252 & ,0938 & 0012, & 0,37 & 0,6641 & 0,131 & 0,0601 & 0,002 & ,0081 & 0,0091 & 1,95 & 62,3 & 5,2 & 545,2 & 0,01 & 0,578 & 0,007 & 0,609 & 0,072 & 94 \\
\hline 0,1 & 2279, & 1219 & 2497 & ,0035 & 0,48 & 0055 & 0,0563 & D,0938 & 0,004 &, 1213 & 0,0114 & 0,47 & 36,7 & 48,8 & 108,1 & 0,451 & 1,437 & 0,018 & I,504 & 0,076 & 5 \\
\hline 1 & 4,3303 & 1232, & 2902, & ,0033 & 0,54 & 3,4463 & 0,0391 & 0,1082 & 0,0033 & 2276, & 0,009 & 0,13 & 50,8 & 93,8 & 120,2 & 0,78 & 1,642 & ,016 & & 0,056 & 2 \\
\hline 2,1 & 2,1968 & ,0921 & 0,1981 &, 0029 & 0,94 & 5,0486 & 0,0735 & ,0804 & 0,0037 & ,098 & 0,0156 & 0,47 & 35,9 & 32,6 & 168,8 & 0,193 & 165 & 0,015 & 1,208 & 0,088 & \\
\hline 3,1 & 2,2793 & 1043 & 0,1953 & 0,0032 & 0,28 & 5,1193 & 0,0835 & 0,0846 & 0,0044 & 0,1463 & 0,0071 & 0,4 & 23 & 42,3 & 83,4 & 0,508 & 1,15 & 0,017 & 1,307 & 0,102 & 38 \\
\hline 1 & 9078 & 1759 & ,2983 & 0048 & 0,99 & 3524 & 0,0542 & 0,1193 & 0,0053 & 1204, & 0,0256 & 1,18 & 20,3 & 22,1 & 50,9 & 0,435 & 1,683 &, 024 & 1,946 & ,089 & 36 \\
\hline 4,2 & ,808 & ,0447 & 0,0953 & 0016 & 0,84 & 0,4886 & 1725, & ,0615 & ,0038 & ,0047, & 0,0066 & 1,47 & 28,2 & 3 & 250 & 0,012 & ,587 & ,009 & 0,656 & 0135 & 39 \\
\hline & ,8298 & 0298 & 1009, & . & 0,94 & ( & 1142 &, 0596 &, 0023 & & , & 0,04 & & 4,8 & 444,8 & 0,011 & & ,007 & & 3 & \\
\hline 5,1 & 5972 & 1444 & 2229, & 0044 & 0,76 & 487 & 0,0893 & 0,0845 & 0,0055 & 1444 & 0,012 & 1,33 & 19,1 & 33,5 & 63,8 & 0,525 & 1,297 & ,023 & 1,305 & ),126 & 99 \\
\hline 7,1 & 9479 & 1806 & , 1961 & 0056 & 0,04 & 0986 & , 1449 & 0,072 & 0,0078 & 0,2077 & 0,0266 & 0,11 & 13,8 & 39,9 & 48,6 & 0,821 & 1,155 & 0,03 & 0,987 & 0,201 & 1 \\
\hline 31 & 2,9027 & 171 & 0,2412 & 0054 & 0,79 & 1465 & 0935, & 0,0873 & 0,0059 & ,1287 & 0,0251 & 1,22 & 23,6 & 38 & 77,9 & 0,487 & 1,393 & 0,028 & 1,367 & 0131 & 10 \\
\hline r & 2,2113 & 0,0717 & 0,2002 & 0,0026 & & & 0,0655 & 0,0801 & 0,0027 & 0,020 & 0,0004 & 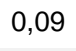 & & 18,6 & 262,3 & & & & & & 20 \\
\hline , & 014 & 1113 & 2404, & 0000 & 0,26 & 1050 & 0,063 & 0,0897 & 0,0037 & 1001 & 0,0096 & 0,58 & & $3 /, 3$ & 100,5 & 0,371 & 1,389 & 0,019 & & 8 & 97 \\
\hline 1,1 & 1,6769 & 0775 &, 1675 & 0028 & 0,78 & 5,9713 & 0,0999 & ,0726 & 0,0038 &, 1203 & 0,0119 & 0,6 & 28,4 & 48,4 & 128,3 & 0,377 & 0,998 & 0,015 & 1,003 & 0,107 & 99 \\
\hline 2,1 & 0,8209 & ,0282 & 0,1002 & 0,0013 & 0,78 & 9,9829 & 0,128 & 0,0594 & 0,0021 & 0,0014 & 0,0018 & 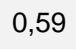 & 69,9 & 2,8 & 590 & 0,005 & 0,615 & 0,008 & 0,583 & & 10 \\
\hline , & 1,6463 & 0,0584 & 0,162 & 0,0023 & 0,00 & $0,11<0$ & 0,0858 & 0,0737 & 0,0027 & $0,1<<1$ & 0,037 & 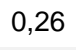 & $4<,<$ & 87 & 146,7 & 0,593 & 0,968 & 0,012 & 1,033 & , & 0 \\
\hline,+ 1 & 2,5563 & 0,090 & 0,2215 & 0,0034 & 0,54 & $4,5 \mid 44$ & 0,0685 & 0,0837 & 0,0035 & 0,1356 & 0,0098 & 0,10 & 29,5 & 48,1 & 102,3 & $0,4 I$ & , & 0,018 & 1,286 & 0,079 & 10 \\
\hline 35,1 & 1,7623 & 0,0652 & 0,1666 & ,0024 & ,97 & 004 & 0,0872 & ,, 0767 & 0,0033 & 0,0582 & 0,034 & 0 & & 29,4 & & & & 0,014 & 1,114 & & J \\
\hline 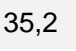 & 0,7361 & 0,0373 & 0,0893 & 0015 & & 11,2034 & 0,1883 & & 0,0034 & 0,0041 & 00050 & & 0 & 2 & 328,4 & 0,006 & & 0,009 & & & \\
\hline 0 & ו I & 0,1665 & 0,1615 &, 000 & $0, \angle 4$ & 6,191 & 0,2006 & 0,0695 & 0,0089 & 0,2265 &,, 0000 & 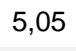 & & 34,3 & 42 & 0,818 & 0,965 & 0,029 & 0,912 & 0,238 & \\
\hline 7,1 & 1,5453 & 0,1104 & 0,1621 & ,0038 & 0,25 &, 17 & 0,1439 & 0,0691 & 0,0058 & 0,1391 & 0,0228 & 0,64 & 15,8 & 37,3 & 71,1 & 0,525 & 0,968 & 0,021 & 0,903 & 0,174 & \\
\hline
\end{tabular}




\begin{tabular}{|c|c|c|c|c|c|c|c|c|c|c|c|c|c|c|c|c|c|c|c|c|}
\hline 3,1 & ,5025 & ,2488 & 0,3321 & 0,0069 & 0,87 & 3,0113 & 0,0621 & ,1202 & 0,0064 & 0,1753 & 0,0134 & 0,58 & 27,1 & 33 & 52 & 0,634 & 1,848 & 0,033 & 1,959 & 0,093 \\
\hline 8,2 & 5,8353 & 0,2362 & 0,3407 & 0,0067 & 0,14 & 2,9348 & 0,058 & 0,1242 & 0,0058 & 0,1953 & 0,0201 & 0,35 & 21 & 32,1 & 40,9 & 0,786 & 1,89 & 0,032 & 2,017 & 0,089 \\
\hline 1 & & 1008 & & 0036 & & & ,0811 & & & & & & & & & & & & & \\
\hline 0,1 & 8 & 228 & & 4 & & 9 & 197 & 1 & & 54 & & & & 62,9 & 42,2 & & ,143 & ,04 & 988 & 284 \\
\hline 1,1 & 2,6841 & 0,2082 & 0,2202 & 0,0067 & 0,8 & 4,5417 & 0,1377 & ,0884 & 0,0095 & 0,2409 & 0,0454 & 0,78 & 13,9 & 39,1 & 46,1 & 0,848 & 1,283 & 0,036 & 1,391 & 0,201 \\
\hline 2,1 & 0,5421 & 0,0644 & 0,071 & 0,0023 & 0,86 & 14,0905 & 0,4647 & 0,0554 & 0,0078 & 0,0137 & 0,0238 & 2,11 & 20 & 0,6 & 152,3 & 0,004 & 0,442 & 0,014 & 0,428 & 0,265 \\
\hline 3,1 & 1516 & ,1125 & 2862 & 0,0029 & 0,01 & 3,4945 & 0,0358 & 0,1052 & 0,0028 & 0,1958 & 0,016 & 0,06 & 83,7 & 145 & 203,1 & 0,713 & 1,622 & 0,015 & 1,718 & 0,049 \\
\hline 4,1 & 6546 & ,0793 & 2224 & 0024 & 0,2 & 4,496 & 0,0484 & ,0866 & 0,0026 & 0,0779 & 0,0038 & 0,2 & 54,3 & 51,6 & 194 & 0,266 & 1,295 & 0,013 & 1,351 & 0,057 \\
\hline 5,1 & 4,5392 & 0,1169 & 0,305 & 0,0028 & 0,99 & $3,27 \varepsilon$ & 0,0302 & 0,1079 & 0,003 & 0,1109 & 0,0537 & 0,11 & 57,2 & 72,7 & 126,1 & 0,576 & ,716 & 0,014 & 1,765 & 0,055 \\
\hline 6,1 & 4,7171 & 0,1426 & 0,3157 & 0,0033 & 0,59 & 3,1675 & 0,0328 & 0,1084 & 0,0037 & 0,1866 & 0,0145 & 0,15 & 72,3 & 106 & 163,7 & 0,647 & 1,769 & 0,016 & 1,772 & 0,062 \\
\hline 7,1 & 0,9602 &, 1316 & 0,1141 & 0,0028 & 0,65 & 8,7612 & 0,214 & 0,061 & 0,0094 & 0,0087 & 0,0167 & 1,68 & 9,0 & 0,5 & 60,4 & 0,008 & 0,697 & 0,016 & 0,64 & 0,302 \\
\hline 8,1 & 783 & ,0929 &, 0962 &, 0021 & 0,88 & 10,399 & 0,2234 & 0,0591 & 0,0076 & 0,0062 & 0,0105 & 0,73 & 19,3 & 0,6 & 125,4 & 0,005 & 0,592 & 0,012 & 0,569 & 0,272 \\
\hline 9,1 & 0,8243 & 0,205 & 0,1058 & 0,0038 & 0,1 & 9,4535 & 0,3435 & 0565 & 0,0173 & 0,0218 & 0,0285 & 9,86 & 8 & 0,4 & 53,8 & 0,008 & 0,648 & 0,023 & 0,473 & 0,41 \\
\hline 0,1 & & ,0949 & 2676 & ,0025 & 0,96 & & ,0345 & ,0974 & 0,0027 & & & & & 47,8 & 195,4 & $0,<40$ & & 0,013 & 1,576 & 0,051 \\
\hline 1,1 & 2,1293 &, 0689 & 1941 & 0,0019 & 0,76 & 5,1515 & 0,0516 &, 0796 & 0,0027 & 0,0468 & 0,0044 & 0,23 & 5,1 & 34,8 & 234,8 & 0,148 & I,144 & 0,01 & 1,186 & 0,067 \\
\hline 2,1 & ,8967 & 0,1118 & 0,181 & 0,0027 & 0,01 & 5,5253 & 0,0818 & 0,076 & 0,0049 & 0,1997 & 0,0125 & 0,94 & 19,1 & 52,1 & 78,2 & 0,666 & 1,072 & 0,015 & 1,095 & 0,132 \\
\hline 3,1 & 1,9484 & 0,0736 & 0,1814 & 0,002 & 0,28 & 5,5118 & 0,0605 & ,0779 & 0,0032 & 0,1163 & 0,0263 & 0,47 & 46,2 & 54,4 & 208,1 & 0,261 & 1,075 & 0,011 & 1,144 & 0,082 \\
\hline 4,1 & 1,8079 & ,0454 & 0,1719 & 0015 & 0,00 & 5,8177 & 0,0497 &, 0763 & & & & & & 157 & & & & & 1,103 & nor \\
\hline 5,1 & 313 & 0,1192 & 2322 & 0029 & 0,22 & 4,3067 & 0,0538 & 0879 & 0,00 & ,2617 & 0,01 & 0,0, & 20 & 60,1 & 70,1 & 0,858 & & 0,015 & 1,38 & 0,091 \\
\hline 5,2 & 7914 & 0233 & 0962 & 0009 & 0,22 & 10,3956 & 0926 & ,0597 & 0,0018 & ,0026 & 0,0028 & 0,61 & 72,6 & 3,7 & 666,8 & 0,006 & 0,592 & 0,005 & ,592 & , ,067 \\
\hline 6,1 & 5,1836 & ,1173 & 0,3294 & 0,0028 & 0,77 & 3,0356 & 0,0259 &, 1141 & 0,0027 & 0,096 & 0,0145 & 0,1 & 104,7 & 59,6 & 249,2 & 0,239 & 1,836 & 0,014 & 1,866 & 0,042 \\
\hline 71 & 1,4385 & 0,0367 & 0,1427 & 0,0012 & (200 & 7,0088 & 0,0595 & & 0,0021 & & 0 & & & 617 & 240,1 & 0,257 & & & 1,017 & 0,000 \\
\hline 0,1 & 1256 & 0,0911 & 0,1946 & 0,0026 & $0, \pi$ & & 0,0686 & 0,0792 & 0,0038 & 0,2926 & 0,050 & 1,0 & (11, & 67,2 & 56,4 & 1,192 & & 0,014 & 1,177 & \\
\hline 9,1 & 3238 & 0,0656 & 2079 &, 002 & 0,89 & & 0,0461 & 811 & 0,0023 & & 0,0037 & & 56,1 & 106 & 02,5 & 0,523 & 217 & 11 & 1,224 & 0,058 \\
\hline 60,1 & 5,2973 & 0,1264 & 0,3315 & 0,0029 & & 3,0166 & 0,0264 & 0,1159 & 0,0029 & 0,1638 & 0,0059 & 0 & 77,6 & 93,2 & 170,6 & 0,546 & 1,846 & 0,014 & 1,894 & 0,045 \\
\hline (1) & 4,356 & 0,139 & 0,3023 & 0,0035 & 0,95 & 3,3082 & 0,0382 & 0,1045 & 0,0036 & 0,3362 & 0,0261 & 0,10 & 00,4 & 82 & 86,2 & & & 0,017 & 1,706 & 0,065 \\
\hline 62,1 & 2,8244 & 0,0649 & 0,232 & 0,0019 & 0,98 & 4,3108 & 0,0349 & 0,0883 & 0,0022 & 0,1654 & 0,0406 & 0,03 & 98,4 & 188 & 349,5 & 0,537 & 1,345 & 0,01 & 1,389 & 0,048 \\
\hline 3,1 & 2,0485 & 0,0425 & 1922, & 0,0014 & 0,99 & 203 & 0,0387 & 0773 & 0,0018 & 0,0356 & 0,0153 & 0,42 & 47,8 & 124 & 680,6 & 0,182 & & 0,008 & 1,129 & 0,046 \\
\hline 0 & & 0,0174 & 0,0874 & 0,0007 & 0,83 & & 0,0929 & & & & & & 152,1 & & 1345 & & & 0,004 & 0,58 & 0,057 \\
\hline 5,1 & ,0901 & 0,0209 & & סחט & & & 0,1081 & & & & & T, & & 19,8 & 726,2 & $0,0<1$ & $0, v 21$ & & 0,594 & 0,07 \\
\hline
\end{tabular}




\begin{tabular}{|c|c|c|c|c|c|c|c|c|c|c|c|c|c|c|c|c|c|c|c|c|c|}
\hline 66,1 & 9,8338 & 0,2184 & 0,4404 & 0,0038 & 0,99 & 2,2708 & 0,0196 & 0,162 & 0,0038 & 0,1125 & 0,0064 & 0,86 & 95,1 & 61,3 & 154 & 0,398 & 2,352 & 0,017 & 2,476 & 0,039 & 94 \\
\hline 67,1 & 1,5066 & 0,0838 & 0,1622 & 0,0023 & 0,94 & 6,1658 & 0,0892 & 0,0674 & 0,0043 & 0,0874 & 0,0513 & 4,92 & 13,9 & 29,4 & 59,7 & 0,492 & 0,969 & 0,013 & 0,849 & 0,122 & 114 \\
\hline 68,1 & 3,6811 & 0,0648 & 0,2613 & 0,0018 & 0,99 & 3,8267 & 0,0261 & 0,1022 & 0,0022 & 0,1438 & 0,0337 & 0,71 & 116,5 & 180 & 318,4 & 0,566 & 1,497 & 0,009 & 1,664 & 0,044 & 89 \\
\hline 69,1 & 5,1096 & 0,1154 & 0,3269 & 0,0027 & 0,99 & 3,059 & 0,0257 & 0,1134 & 0,0027 & 0,2764 & 0,0312 & 0 & 172,5 & 410 & 347,4 & 1,181 & 1,823 & 0,013 & 1,854 & 0,043 & 98 \\
\hline
\end{tabular}

\section{AMOSTRA SNA-168: metavulcânica (Nappe Liberdade)}

\begin{tabular}{|c|c|c|c|c|c|c|c|c|c|c|c|c|c|c|c|c|c|c|c|c|c|}
\hline Spot & 07/235 & 1sigma & $206 / 238$ & 1sigma & Correl. & $238 / 206$ & 1sigma & $207 / 206$ & 1sigma & $208 / 206$ & 1sigma & $\begin{array}{c}\% \\
\text { Com.Pb }\end{array}$ & $\begin{array}{c}\mathrm{ppm} \\
\mathrm{Pb}\end{array}$ & $\begin{array}{l}\text { ppm } \\
\text { Th }\end{array}$ & $\stackrel{p p m}{U}$ & $\mathrm{Th} / \mathrm{U}$ & $\begin{array}{c}T \\
206 / 238\end{array}$ & $\begin{array}{c}1 \\
\text { sigma }\end{array}$ & $\begin{array}{c}T \\
207 / 206\end{array}$ & $\begin{array}{c}1 \\
\text { sigma }\end{array}$ & $\begin{array}{c}\% \\
\text { Conc. }\end{array}$ \\
\hline 1,1 & 6,3347 & 0,1718 & 0,3628 & 0,0058 & 0,8900 & 2,7567 & 0,0438 & 0,1267 & 0,0037 & 0,0857 & 0,0057 & 0,24 & 27 & 15 & 58 & 0,25 & 1,995 & 0,027 & 2,052 & 0,052 & 97 \\
\hline 2,1 & 3,1012 & 0,0852 & 0,2450 & 0,0035 & 0,0100 & 4,0812 & 0,0585 & 0,0918 & 0,0025 & 0,2147 & 0,0324 & 0,93 & 35 & 54 & 101 & 0,54 & 1,413 & 0,018 & 1,463 & 0,051 & 96 \\
\hline 3,1 & 3,1809 & 0,0641 & 0,2502 & 0,0029 & 0,3100 & 3,9970 & 0,0464 & 0,0922 & 0,0018 & 0,2732 & 0,0141 & 0,05 & 97 & 176 & 266 & 0,66 & 1,439 & 0,015 & 1,472 & 0,037 & 97 \\
\hline 4,1 & 3,3360 & 0,1034 & 0,2603 & 0,0041 & 0,7500 & 3,8423 & 0,0609 & 0,0930 & 0,0030 & 0,2377 & 0,0221 & 0,13 & 44 & 81 & 119 & 0,68 & 1,491 & 0,021 & 1,487 & 0,061 & 100 \\
\hline 5,1 & 3,2182 & 0,0867 & 0,2525 & 0,0036 & 0,6200 & 3,9606 & 0,0566 & 0,0924 & 0,0026 & 0,2122 & 0,0052 & 0,48 & 37 & 58 & 108 & 0,53 & 1,451 & 0,019 & 1,477 & 0,055 & 98 \\
\hline 6,1 & 2,9982 & 0,1360 & 0,2361 & 0,0050 & 0,6200 & 4,2353 & 0,0900 & 0,0921 & 0,0048 & 0,1292 & 0,0202 & 2,40 & 10 & 9 & 34 & 0,26 & 1,366 & 0,026 & 1,469 & 0,102 & 92 \\
\hline 7,1 & 3,1743 & 0,0878 & 0,2521 & 0,0036 & 0,1000 & 3,9668 & 0,0569 & 0,0913 & 0,0026 & 0,2432 & 0,0150 & 0,13 & 54 & 101 & 148 & 0,68 & 1,449 & 0,019 & 1,453 & 0,055 & 99 \\
\hline 8,1 & 3,3060 & 0,0980 & 0,2635 & 0,0045 & 0,8800 & 3,7947 & 0,0647 & 0,0910 & 0,0025 & 0,2532 & 0,0310 & 0,34 & 48 & 74 & 135 & 0,55 & 1,508 & 0,023 & 1,446 & 0,051 & 104 \\
\hline 8,2 & 3,3765 & 0,1193 & 0,2593 & 0,0053 & 0,8900 & 3,8558 & 0,0792 & 0,0944 & 0,0032 & 0,2107 & 0,0205 & 0,54 & 49 & 92 & 138 & 0,66 & 1,487 & 0,027 & 1,517 & 0,064 & 98 \\
\hline 9,1 & 6,5446 & 0,1747 & 0,3742 & 0,0061 & 0,8600 & 2,6721 & 0,0436 & 0,1268 & 0,0030 & 0,1153 & 0,0034 & 0,20 & 49 & 32 & 103 & 0,31 & 2,049 & 0,029 & 2,055 & 0,041 & 99 \\
\hline 10,1 & 3,5606 & 0,1051 & 0,2759 & 0,0048 & 0,9300 & 3,6241 & 0,0627 & 0,0936 & 0,0026 & 0,2087 & 0,0318 & 0,10 & 37 & 59 & 106 & 0,55 & 1,571 & 0,024 & 1,500 & 0,052 & 104 \\
\hline 11,1 & 3,5047 & 0,1023 & 0,2764 & 0,0047 & 0,8800 & 3,6186 & 0,0610 & 0,0920 & 0,0024 & 0,2869 & 0,0342 & 0,17 & 68 & 148 & 177 & 0,84 & 1,573 & 0,023 & 1,467 & 0,048 & 107 \\
\hline 12,1 & 3,2819 & 0,1114 & 0,2559 & 0,0050 & 0,6900 & 3,9074 & 0,0766 & 0,0930 & 0,0031 & 0,1243 & 0,0392 & 1,26 & 26 & 25 & 81 & 0,31 & 1,469 & 0,026 & 1,488 & 0,065 & 98 \\
\hline 13,1 & 5,9551 & 0,1711 & 0,3381 & 0,0059 & 0,9200 & 2,9576 & 0,0515 & 0,1277 & 0,0032 & 0,1841 & 0,0192 & 0,32 & 56 & 56 & 111 & 0,50 & 1,878 & 0,028 & 2,067 & 0,043 & 90 \\
\hline 14,1 & 3,1467 & 0,1108 & 0,2482 & 0,0056 & 0,6000 & 4,0290 & 0,0901 & 0,0920 & 0,0025 & 0,2316 & 0,0133 & 0,98 & 24 & 38 & 70 & 0,55 & 1,429 & 0,029 & 1,466 & 0,053 & 97 \\
\hline 15,1 & 3,4662 & 0,1110 & 0,2699 & 0,0057 & 0,6800 & 3,7045 & 0,0786 & 0,0931 & 0,0022 & 0,2606 & 0,0117 & 0,41 & 46 & 82 & 122 & 0,67 & 1,541 & 0,029 & 1,490 & 0,045 & 103 \\
\hline 16,1 & 3,2732 & 0,1179 & 0,2548 & 0,0058 & 0,7500 & 3,9252 & 0,0892 & 0,0932 & 0,0027 & 0,1367 & 0,0235 & 0,74 & 14 & 16 & 46 & 0,34 & 1,463 & 0,030 & 1,492 & 0,055 & 98 \\
\hline 17,1 & 3,2486 & 0,1266 & 0,2543 & 0,0061 & 0,2900 & 3,9321 & 0,0945 & 0,0926 & 0,0030 & 0,1406 & 0,0126 & 0,96 & 12 & 12 & 36 & 0,33 & 1,461 & 0,031 & 1,481 & 0,061 & 98 \\
\hline 18,1 & 3,3491 & 0,1302 & 0,2654 & 0,0064 & 0,9700 & 3,7674 & 0,0906 & 0,0915 & 0,0030 & 0,1372 & 0,0159 & 0,27 & 27 & 22 & 93 & 0,24 & 1,518 & 0,033 & 1,457 & 0,060 & 104 \\
\hline 19,1 & 3,2968 & 0,1683 & 0,2643 & 0,0078 & 0,9100 & 3,7837 & 0,1110 & 0,0905 & 0,0042 & 0,1455 & 0,0173 & 0,44 & 13 & 16 & 41 & 0,40 & 1,512 & 0,040 & 1,435 & 0,093 & 105 \\
\hline 20,1 & 6,1721 & 0,1877 & 0,3552 & 0,0075 & 0,9200 & 2,8150 & 0,0597 & 0,1260 & 0,0026 & 0,0961 & 0,0051 & 0,12 & 69 & 38 & 143 & 0,27 & 1,960 & 0,035 & 2,043 & 0,037 & 95 \\
\hline
\end{tabular}




\begin{tabular}{|c|c|c|c|c|c|c|c|c|c|c|c|c|c|c|c|c|c|c|c|c|c|}
\hline 21,1 & 3,0945 & 0,1164 & 0,2448 & 0,0046 & 0,4800 & 4,0857 & 0,0772 & 0,0917 & 0,0031 & 0,1642 & 0,0085 & 2,87 & 22 & 27 & 68 & 0,41 & 1,411 & 0,024 & 1,461 & 0,065 & 96 \\
\hline 22,1 & 3,0932 & 0,1933 & 0,2528 & 0,0066 & 0,8400 & 3,9558 & 0,1029 & 0,0887 & 0,0054 & 0,1652 & 0,0121 & 1,29 & 24 & 29 & 67 & 0,44 & 1,453 & 0,034 & 1,399 & 0,104 & 103 \\
\hline 23,1 & 3,0266 & 0,1305 & 0,2384 & 0,0049 & 0,5400 & 4,1953 & 0,0868 & 0,0921 & 0,0038 & 0,1560 & 0,0313 & 1,51 & 15 & 17 & 49 & 0,35 & 1,378 & 0,026 & 1,469 & 0,079 & 93 \\
\hline 24,1 & 5,9282 & 0,2295 & 0,3502 & 0,0073 & 0,9500 & 2,8559 & 0,0592 & 0,1228 & 0,0045 & 0,1196 & 0,0123 & 0,61 & 32 & 22 & 72 & 0,30 & 1,935 & 0,035 & 1,997 & 0,063 & 96 \\
\hline 25,1 & 3,2621 & 0,1512 & 0,2629 & 0,0055 & 0,8900 & 3,8034 & 0,0799 & 0,0900 & 0,0042 & 0,0471 & 0,0159 & 0,39 & 26 & 7 & 84 & 0,09 & 1,505 & 0,029 & 1,425 & 0,090 & 105 \\
\hline 26,1 & 3,2232 & 0,1426 & 0,2603 & 0,0053 & 0,9800 & 3,8410 & 0,0789 & 0,0898 & 0,0032 & 0,1325 & 0,0247 & 0,28 & 44 & 48 & 133 & 0,36 & 1,492 & 0,028 & 1,421 & 0,068 & 104 \\
\hline 27,1 & 3,4115 & 0,1291 & 0,2699 & 0,0052 & 0,8200 & 3,7047 & 0,0711 & 0,0917 & 0,0031 & 0,1885 & 0,0082 & 1,61 & 29 & 38 & 89 & 0,43 & 1,540 & 0,026 & 1,460 & 0,066 & 105 \\
\hline 28,1 & 2,7014 & 0,0991 & 0,2191 & 0,0038 & 0,5600 & 4,5639 & 0,0800 & 0,0894 & 0,0033 & 0,1627 & 0,0219 & 1,49 & 19 & 24 & 68 & 0,35 & 1,277 & 0,020 & 1,413 & 0,073 & 90 \\
\hline 29,1 & 2,8035 & 0,0682 & 0,2279 & 0,0029 & 0,8000 & 4,3870 & 0,0554 & 0,0892 & 0,0020 & 0,1815 & 0,0053 & 0,78 & 63 & 87 & 199 & 0,44 & 1,324 & 0,015 & 1,408 & 0,043 & 93 \\
\hline 30,1 & 3,2622 & 0,1217 & 0,2531 & 0,0047 & 0,3800 & 3,9507 & 0,0737 & 0,0935 & 0,0036 & 0,1197 & 0,0150 & 0,59 & 21 & 20 & 63 & 0,32 & 1,455 & 0,024 & 1,498 & 0,080 & 97 \\
\hline 31,1 & 2,4627 & 0,0757 & 0,2067 & 0,0032 & 0,7000 & 4,8370 & 0,0737 & 0,0864 & 0,0024 & 0,1772 & 0,0487 & 0,50 & 33 & 69 & 116 & 0,59 & 1,211 & 0,017 & 1,347 & 0,055 & 89 \\
\hline 32,1 & 3,3289 & 0,1266 & 0,2593 & 0,0047 & 0,5400 & 3,8558 & 0,0706 & 0,0931 & 0,0037 & 0,1412 & 0,0123 & 0,52 & 18 & 20 & 56 & 0,37 & 1,487 & 0,024 & 1,490 & 0,075 & 99 \\
\hline 33,1 & 3,2566 & 0,0931 & 0,2546 & 0,0037 & 0,6000 & 3,9277 & 0,0567 & 0,0928 & 0,0025 & 0,2455 & 0,0090 & 0,82 & 32 & 55 & 91 & 0,61 & 1,462 & 0,019 & 1,483 & 0,051 & 98 \\
\hline 34,1 & 2,9582 & 0,0791 & 0,2351 & 0,0032 & 0,5900 & 4,2540 & 0,0584 & 0,0913 & 0,0023 & 0,1943 & 0,0072 & 4,69 & 32 & 46 & 100 & 0,47 & 1,361 & 0,017 & 1,452 & 0,047 & 93 \\
\hline 35,1 & 2,9292 & 0,0891 & 0,2329 & 0,0035 & 0,9700 & 4,2939 & 0,0643 & 0,0912 & 0,0029 & 0,1826 & 0,0102 & 0,26 & 25 & 34 & 78 & 0,44 & 1,350 & 0,018 & 1,451 & 0,063 & 92 \\
\hline 36,1 & 2,8486 & 0,0977 & 0,2299 & 0,0038 & 0,5800 & 4,3502 & 0,0718 & 0,0899 & 0,0031 & 0,1954 & 0,0193 & 0,76 & 15 & 21 & 49 & 0,44 & 1,334 & 0,020 & 1,423 & 0,065 & 93 \\
\hline 37,1 & 3,5581 & 0,0957 & 0,2795 & 0,0038 & 0,8800 & 3,5778 & 0,0489 & 0,0923 & 0,0024 & 0,2541 & 0,0090 & 0,33 & 54 & 103 & 146 & 0,71 & 1,589 & 0,019 & 1,474 & 0,048 & 107 \\
\hline 38,1 & 3,1839 & 0,0802 & 0,2516 & 0,0033 & 0,4700 & 3,9744 & 0,0516 & 0,0918 & 0,0021 & 0,1984 & 0,0332 & 0,31 & 61 & 101 & 176 & 0,58 & 1,447 & 0,017 & 1,463 & 0,043 & 98 \\
\hline 39,1 & 2,5554 & 0,1197 & 0,2081 & 0,0045 & 0,2800 & 4,8052 & 0,1038 & 0,0891 & 0,0046 & 0,0944 & 0,0242 & 3,17 & 7 & 6 & 31 & 0,20 & 1,219 & 0,024 & 1,405 & 0,099 & 86 \\
\hline
\end{tabular}

\section{AMOSTRA SNA-169: metapelito (Nappe Liberdade)}

\begin{tabular}{|c|c|c|c|c|c|c|c|c|c|c|c|c|c|c|c|c|c|c|c|c|c|}
\hline Spot & $207 / 235$ & 1sigma & $206 / 238$ & 1sigma & Correl. & $238 / 206$ & 1sigma & $207 / 206$ & 1sigma & $208 / 206$ & 1sigma & $\begin{array}{c}\% \\
\text { Com.Pb }\end{array}$ & $\begin{array}{c}\mathrm{ppm} \\
\mathrm{Pb}\end{array}$ & $\begin{array}{c}\text { ppm } \\
\text { Th }\end{array}$ & $\stackrel{\mathrm{ppm}}{\mathrm{U}}$ & $\mathrm{Th} / \mathrm{U}$ & $\begin{array}{c}T \\
206 / 238\end{array}$ & $\begin{array}{c}1 \\
\text { sigma }\end{array}$ & $\begin{array}{c}T \\
207 / 206\end{array}$ & $\begin{array}{c}1 \\
\text { sigma }\end{array}$ & $\begin{array}{c}\% \\
\text { Conc. }\end{array}$ \\
\hline 1,1 & 0,7831 & 0,0167 & 0,0938 & 0,0013 & 0,81 & 10,6587 & 0,1426 & 0,0605 & 0,0009 & 0,0015 & 0,0014 & 0,13 & 56,3 & 2,2 & 458 & 0,005 & 0,578 & 0,007 & 0,623 & 0,032 & 92 \\
\hline 2,1 & 0,7999 & 0,0242 & 0,0955 & 0,0013 & 0,1 & 10,467 & 0,1471 & 0,0607 & 0,0016 & 0,0075 & 0,0082 & 0,3 & 31,2 & 2,1 & 244 & 0,009 & 0,588 & 0,008 & 0,629 & 0,058 & 93 \\
\hline 3,1 & 0,7647 & 0,0217 & 0,0924 & 0,0013 & 0,55 & 10,8249 & 0,1519 & 0,06 & 0,0014 & 0,0023 & 0,0024 & 0,33 & 34 & 2,5 & 283 & 0,009 & 0,57 & 0,008 & 0,605 & 0,051 & 94 \\
\hline 4,1 & 0,7723 & 0,0172 & 0,093 & 0,0012 & 0,94 & 10,7472 & 0,1434 & 0,0602 & 0,001 & 0,0014 & 0,0015 & 0,15 & 78,5 & 4 & 654 & 0,006 & 0,574 & 0,007 & 0,611 & 0,035 & 93 \\
\hline 5,1 & 0,8414 & 0,0173 & 0,1008 & 0,0013 & 0,97 & 9,9232 & 0,1263 & 0,0606 & 0,0009 & 0,0037 & 0,0041 & 0,67 & 77,8 & 4,8 & 640 & 0,007 & 0,619 & 0,008 & 0,623 & 0,033 & 99 \\
\hline 6,1 & 9,037 & 0,1195 & 0,4201 & 0,0041 & 0,99 & 2,3806 & 0,0231 & 0,156 & 0,0019 & 0,1097 & 0,033 & 0,04 & 58,4 & 45,6 & 122 & 0,374 & 2,261 & 0,02 & 2,413 & 0,023 & 93 \\
\hline
\end{tabular}




\begin{tabular}{|c|c|c|c|c|c|c|c|c|c|c|c|c|c|c|c|c|c|c|c|c|c|}
\hline & 3677 & 025 & 1008 & 0015 & 0,99 & 9233 & 1477 & 0625 & 0012 & ,0379 & 0335 & 0,00 & 62 & 73,3 & 225 & 325 & 619 & 009 & 69 & 039 & \\
\hline & 7821 & 0188 & 0948 & 0012 & & & 1386 & 0598 & 1 & 0025 & 1 & 6 & & 3,5 & 399 & 009 & 584 & 007 & 598 & & \\
\hline 9,1 & 8284 & 0156 & 0979 & 0012 & 0,83 & 0,2114 & & 0613 & 0009 & ,0095 & ,0081 & 5,43 & 9,2 & 38,4 & 587 & 0,065 & ,602 & ,007 & ,651 & 0,03 & 2 \\
\hline 01 & 7899 & 0177 & 0953 & 0012, & 0,97 & 0,4933 & 1341 & ,0601 & ,001 & 0,002 & 0023 & 0,01 & 55,6 & 3 & 464 & 0,007 & 0,587 & 0,007 & 0,608 & 0,037 & 96 \\
\hline & 7916 & 0145 & 0953 & ,0011 & , & o,4928 & & 0602 & ,0009 &, 0018 & 0014 & 0,35 & 85,2 & 4 & 724 & 0,005 & , & 0,007 & ,612 & 0,033 & \\
\hline 2,1 & 1885 & 0307 & 1825 & 0019, & ,99 & 4809 & 0576 & ,087 & ,001 & ,014 & ,006 & ),42 & 203 & 39,8 & 883 & 0,045 & 1,08 & ,011 & 1,36 & ,022 & 9 \\
\hline 3,1 & 8274 & ,0196 & 0,0991 & 0,0013 & 0,57 & 0,0865 & 1301 & 0,0605 & 0,0011 & 0,0034 & 0,0026 & 0,92 & 62,6 & 5,1 & 530 & 0,01 & 0,609 & 0,007 & 0,623 & 0,041 & 77 \\
\hline 4,1 & ,8287 & 0,0198 & 0,1007 & 0,0012 & 0,94 & 9,9353 & 0,1161 & 0,0597 & 0,0016 & 0,0055 & 0,0065 & 1,83 & 44,4 & 14 & 353 & 0,04 & 0,618 & 0,007 & 0,593 & 0,055 & 10 \\
\hline 5,1 & 0,824 & 0,0188 & 0,0995 & 0,0012 & 0,98 & 10,052 & 0,1188 & 0,0601 & 0,0014 & 0,0021 & 0,0019 & 0,77 & 33,2 & 2,9 & 273 & 0,01 & 0,611 & 0,007 & 0,606 & 0,051 & 10 \\
\hline 6,1 & , 8183 & ,0151 & 0,0987 & 0,001 & 0,95 & 0,1318 & 0,1062 &, 0601 & 0,0012 & 0,0031 & 0,0028 & 1,51 & 65,1 & 5,6 & 529 & 0,011 & 0,607 & 0,006 & 0,608 & 0,042 & 99 \\
\hline 71 & 1,4367 & ,0238 & 1334, & 0013, & 0,93 & 4988 & ,0741 & ,0781 & ,0014 & 0,0241 & 0,0069 & 0,88 & 62,9 & 22,1 & 365 & 0,061 & 0,807 & 0,007 & 1,15 & 0,037 & $C$ \\
\hline 81 & ,0314 & ,0447 & 0,1457 &, 0019 & 0,99 & 6,8626 & 0878, & 1011, & 0,0018 & 0,2176 & 0,063 & 3,28 & 128 & 269 & 241 & 1,116 & 0,877 & 0,01 & 1,645 & & 53 \\
\hline 9,1 & 7275, & 0,0127 & 0,0861 & 0,0009 & 0,99 & 1,6172 & 0,1179 & 0,0613 & 0,0011 & 0,0049 & 0,0014 & 0,93 & 104 & 8,3 & 961 & 0,009 & 0,532 & 0,005 & 0,65 & 0,038 & 31 \\
\hline, 1 & 9035 & 0,0211 & 0,1066 & 0,0013 & 0,99 & 379 & 0,1143 & ,0615 & 0,0014 & 38 & 0,0334 & 0,54 & 64,6 & 73,9 & 228 & 0,324 & 0,653 & 0,008 & 0,655 & 0,0 & 9 \\
\hline 11 & ,8808 & 0,0208 &, 1021 & 0013, & 0,99 & 7918 & 0,1204 & ,0625 &, 0013 & 0,0435 & 0,0333 & 0 & 26,6 & 38,4 & 92,9 & 0,414 & 0,627 & 0,007 & 0,693 & 0,039 & 90 \\
\hline 1 & 7807 & 0,016 & 0 & 0,001 & 0,97 & & & ,0596 & ,0013, & 0,004 & ,0024 & & & 2,9 & 392 & 0,007 & 0,585 & 0,006 & 0,591 & & \\
\hline & 8898 & ,0183, & 10 & 0012 & 0,99 & & & ,0639 & 0013 & & Th & & 8,4 & 57,4 & 267 & 0,215 & & 0,007 & ,739 & & 3 \\
\hline 1 & 7793 & 0158 & 0936 & 001 & 0,92 & D,6864 & 0,1176 & ,0604 & 0,0013 & 0054 & 0,0037 &, 06 & 28,6 & $-0,1$ & 224 & 0 &, 577 & 0,006 & 0,618 & 45 & 3 \\
\hline 5,1 & 9582 & 0,0275 & 103 & 0014 & 0,99 & 7083 & 0,1329 & ,0675 & 0,0016 & 0,0496 & 0,0359 & 0,27 & 61,4 & 63 & 198 & 0,318 & 0,632 & 0,008 & 0,852 & 0,038 & 4 \\
\hline 61 & 6022 & 0,0911 & 0,3324 & 0,0034 & 0,99 & & 0,0305 & 0,1222 & 0,0022 & ,2006 & 0,0783 & & 5 & 118 & 162 & 0,723 & & 0,016 & 1,989 & & 93 \\
\hline & ,8798 & 0,0216 & 1031 & (0) & & 6422 & & ,0615 & 0013 & &, $00<1$ & & & & 510 & & & 0,0 & ,050 & & 10 \\
\hline 8,1 & 7519 & & 0909 & 0017 & 0,97 & ,0023 & ,20 & 06 & 0012 & 7 &, 00 & & 4,8 & 4,6 & 614 & 0,008 & 61 & & ,604 & & 2 \\
\hline 91 & 6734, & 0,0328 & 1605 & ,0025, & 0,99 & 2318 & 0,0989 & ,0756 & 0,0013 & 0,1825 & 1062 & 15,29 & 61,7 & 117 & 307 & 0,381 & 0,959 & 0,014 & 1,085 & 0,037 & 38 \\
\hline , & 0,9131 & 0,0238 & 0,1035 & 0,002 & 0,99 & & & 0,064 & & & 0,0325 & 327 & & 39,6 & 524 & 0,076 & & & & & 85 \\
\hline , & 0,8003 & 0,0164 & 0,0935 & 0,0010 & 0,95 & 10,6965 & 0,1787 & $0,00<1$ & 0,0011 & 0,0201 & 0,000 & & 121 & 29,9 & 961 & 0,031 & 0,576 & 0,009 & 0,677 & & 85 \\
\hline 2,1 & 1,1317 & 0243 & 1183 & 002 & $0,9 \varepsilon$ & & & 94 & & & 00 & & ,4 & 28,2 & 386 & 0,0 & & 0,0 & & & 9 \\
\hline (1) & 0,9133 & 0,0187 & 1073 & 0017 & 0,92 & & & 0617 & 0011 & & 0037 & & 238 & 413 & 1346 & 0,307 & & & 0,665 & 0,038 & 98 \\
\hline 34,1 & 1,2562 & & & 0,002 & 0,99 & & & & & & & & & 19,7 & 255 & & & & & & Jo \\
\hline ou, & 4,013 & 0,0585 & 0,2666 & 0,0032 & 0,99 & 3,7507 & 0,0453 & 0,1228 & 0,0018 & 0,0174 & 0,0108 & 1,00 & 73,7 & 11,9 & 213 & 0,056 & 1,524 & 0,017 & 1,997 & 0,03 & 76 \\
\hline 36,1 & 1,0723 & 0,0205 & 0,1144 & ,0018 & 0,99 & 8,7417 & 0,1407 & 0,068 & 0,0012 & 0,0191 & 0,0158 & 0,02 & 67,8 & 30,3 & 449 & 0,068 & 0,698 & 0,011 & 0,868 & 0,041 & 30 \\
\hline
\end{tabular}




\begin{tabular}{|c|c|c|c|c|c|c|c|c|c|c|c|c|c|c|c|c|c|c|c|c|c|}
\hline 37,1 & 0,8259 & 0,0205 & 0,0978 & 0,0018 & 0,93 & 10,2283 & 0,1853 & 0,0613 & 0,0012 & 0,0145 & 0,0087 & 1,96 & 62,4 & 28,5 & 443 & 0,064 & 0,601 & 0,01 & 0,649 & 0,044 & 92 \\
\hline 38,1 & 6,5487 & 0,1506 & 0,3672 & 0,0069 & 0,76 & 2,7233 & 0,0512 & 0,1293 & 0,0026 & 0,1621 & 0,009 & 0,52 & 47,9 & 52,7 & 97,5 & 0,54 & 2,016 & 0,033 & 2,089 & 0,035 & 96 \\
\hline 39,1 & 0,833 & 0,0177 & 0,0979 & 0,0017 & 0,72 & 10,2099 & 0,1725 & 0,0617 & 0,0011 & 0,0098 & 0,007 & 0,31 & 140 & 66,7 & 1046 & 0,064 & 0,602 & 0,01 & 0,663 & 0,037 & 90 \\
\hline 40,1 & 0,8985 & 0,0148 & 0,1031 & 0,001 & 0,98 & 9,7033 & 0,0921 & 0,0632 & 0,0008 & 0,0184 & 0,0073 & 0 & 85,2 & 14,7 & 679 & 0,022 & 0,632 & 0,006 & 0,716 & 0,028 & 88 \\
\hline 41,1 & 0,8247 & 0,0131 & 0,0988 & 0,0009 & 0,93 & 10,1169 & 0,0921 & 0,0605 & 0,0008 & 0,0024 & 0,0014 & 0,04 & 84,4 & 5,2 & 665 & 0,008 & 0,608 & 0,005 & 0,622 & 0,029 & 97 \\
\hline 42,1 & 0,7872 & 0,0162 & 0,0954 & 0,001 & 0,68 & 10,4794 & 0,1098 & 0,0598 & 0,0011 & 0,0019 & 0,0019 & 0,17 & 35 & 2,1 & 290 & 0,007 & 0,588 & 0,006 & 0,598 & 0,039 & 98 \\
\hline 43,1 & 6,4946 & 0,0921 & 0,3623 & 0,0034 & 0,99 & 2,76 & 0,0257 & 0,13 & 0,0015 & 0,1278 & 0,0042 & 0,16 & 89,4 & 87 & 191 & 0,456 & 1,993 & 0,016 & 2,098 & 0,02 & 95 \\
\hline 44,1 & 0,7722 & 0,0158 & 0,0902 & 0,0009 & 0,99 & 11,0864 & 0,1165 & 0,0621 & 0,001 & 0,0466 & 0,033 & 0,69 & 48,9 & 73,9 & 320 & 0,231 & 0,557 & 0,006 & 0,677 & 0,033 & 82 \\
\hline 45,1 & 0,8741 & 0,0219 & 0,1022 & 0,0012 & 0,98 & 9,7809 & 0,1141 & 0,062 & 0,0013 & 0,0288 & 0,0429 & 0,53 & 40,6 & 56,2 & 170 & 0,331 & 0,628 & 0,007 & 0,674 & 0,046 & 93 \\
\hline 46,1 & 0,8235 & 0,0145 & 0,0973 & 0,0009 & 0,84 & 10,2778 & 0,0983 & 0,0614 & 0,0009 & 0,0049 & 0,0027 & 0,07 & 88,3 & 13,5 & 691 & 0,02 & 0,599 & 0,005 & 0,653 & 0,033 & 91 \\
\hline 47,1 & 0,8136 & 0,0145 & 0,0984 & 0,0009 & 0,87 & 10,1636 & 0,0973 & 0,06 & 0,001 & 0,0123 & 0,0197 & 22,71 & 66,1 & 96,1 & 546 & 0,176 & 0,605 & 0,006 & 0,603 & 0,034 & 100 \\
\hline 48,1 & 0,9295 & 0,022 & 0,1072 & 0,0013 & 0,99 & 9,3307 & 0,115 & 0,0629 & 0,0009 & 0,0456 & 0,0364 & 1,12 & 169 & 157 & 629 & 0,249 & 0,656 & 0,007 & 0,705 & 0,023 & 93 \\
\hline 49,1 & 5,2326 & 0,0683 & 0,3067 & 0,0026 & 0,99 & 3,2604 & 0,0281 & 0,1237 & 0,0014 & 0,0679 & 0,011 & 0,7 & 90,2 & 41,4 & 224 & 0,185 & 1,725 & 0,013 & 2,011 & 0,02 & 85 \\
\hline 50,1 & 1,1559 & 0,0262 & 0,1104 & 0,0012 & 0,99 & 9,0543 & 0,0976 & 0,0759 & 0,0014 & 0,0667 & 0,0495 & 0,49 & 45,6 & 34,4 & 82,9 & 0,415 & 0,675 & 0,007 & 1,093 & 0,023 & 61 \\
\hline 51,1 & 3,6849 & 0,0522 & 0,2384 & 0,0021 & 0,99 & 4,1947 & 0,0374 & 0,1121 & 0,0016 & 0,0617 & 0,0217 & 1,47 & 51,9 & 35,8 & 149 & 0,241 & 1,378 & 0,011 & 1,834 & 0,027 & 75 \\
\hline 52,1 & 0,7572 & 0,0138 & 0,0911 & 0,0009 & 0,98 & 10,9756 & 0,1052 & 0,0603 & 0,001 & 0,0535 & 0,0438 & 1,19 & 49,7 & 174 & 384 & 0,454 & 0,562 & 0,005 & 0,613 & 0,035 & 91 \\
\hline 53,1 & 4,7814 & 0,0785 & 0,316 & 0,0033 & 0,83 & 3,1644 & 0,0327 & 0,1097 & 0,0015 & 0,1394 & 0,006 & 0,11 & 50,2 & 69,9 & 107 & 0,657 & 1,77 & 0,016 & 1,795 & 0,024 & 98 \\
\hline 54,1 & 1,3414 & 0,0528 & 0,12 & 0,0021 & 0,99 & 8,3332 & 0,148 & 0,0811 & 0,0016 & 0,0631 & 0,03 & 0,1 & 26,7 & 17,9 & 64,7 & 0,276 & 0,731 & 0,011 & 1,223 & 0,026 & 59 \\
\hline 55,1 & 1,2973 & 0,0348 & 0,1158 & 0,0015 & 0,99 & 8,6371 & 0,1146 & 0,0813 & 0,0014 & 0,0616 & 0,0477 & 0,65 & 49,7 & 47 & 113 & 0,418 & 0,706 & 0,009 & 1,228 & 0,027 & 57 \\
\hline 56,1 & 5,9405 & 0,0929 & 0,3456 & 0,0035 & 0,99 & 2,8932 & 0,0292 & 0,1247 & 0,0016 & 0,2105 & 0,0466 & 0,53 & 42,2 & 85,5 & 73,6 & 1,161 & 1,914 & 0,017 & 2,024 & 0,024 & 94 \\
\hline 57,1 & 11,6533 & 0,1226 & 0,4303 & 0,0033 & 0,99 & 2,3237 & 0,018 & 0,1964 & 0,0021 & 0,1756 & 0,0211 & 0,52 & 90,8 & 87,5 & 126 & 0,696 & 2,307 & 0,016 & 2,796 & 0,019 & 82 \\
\hline 58,1 & 5,7054 & 0,1014 & 0,3369 & 0,0037 & 0,99 & 2,968 & 0,0329 & 0,1228 & 0,0019 & 0,2812 & 0,0761 & 0,6 & 20,7 & 41,7 & 36,3 & 1,148 & 1,872 & 0,018 & 1,998 & 0,029 & 93 \\
\hline 59,1 & 1,3222 & 0,0217 & 0,1357 & 0,0012 & 0,98 & 7,3685 & 0,0662 & 0,0707 & 0,0011 & 0,0611 & 0,0254 & 1,87 & 32,7 & 39,8 & 185 & 0,215 & 0,82 & 0,007 & 0,948 & 0,032 & 86 \\
\hline 60,1 & 0,8338 & 0,0152 & 0,1009 & 0,001 & 0,92 & 9,9087 & 0,0957 & 0,0599 & 0,001 & 0,0008 & 0,0012 & 0,19 & 63,8 & 2,7 & 519 & 0,005 & 0,62 & 0,006 & 0,601 & 0,035 & 103 \\
\hline 61,1 & 1,9238 & 0,068 & 0,1876 & 0,0028 & 0,93 & 5,3306 & 0,0789 & 0,0744 & 0,0027 & 0,3315 & 0,0387 & 0,5 & 12,6 & 56,9 & 41,8 & 1,362 & 1,108 & 0,015 & 1,052 & 0,072 & 105 \\
\hline 62,1 & 0,8025 & 0,0173 & 0,0955 & 0,001 & 0,98 & 10,4709 & 0,1106 & 0,0609 & 0,0012 & 0,0213 & 0,0169 & 1,3 & 35,3 & 12,7 & 272 & 0,047 & 0,588 & 0,006 & 0,637 & 0,04 & 92 \\
\hline 63,1 & 6,7384 & 0,1448 & 0,3818 & 0,0051 & 0,71 & 2,6193 & 0,0351 & 0,128 & 0,0026 & 0,3468 & 0,0125 & 0,2 & 24,3 & 50,7 & 38 & 1,334 & 2,085 & 0,024 & 2,071 & 0,036 & 100 \\
\hline 64,1 & 6,1933 & 0,0983 & 0,3651 & 0,0037 & 0,98 & 2,7392 & 0,028 & 0,123 & 0,0017 & 0,4496 & 0,0269 & 0,09 & 49,1 & 131 & 78 & 1,682 & 2,006 & 0,018 & 2,001 & 0,024 & 100 \\
\hline 65,1 & 0,8291 & 0,0142 & 0,0997 & 0,0009 & 0,88 & 10,0307 & 0,0937 & 0,0603 & 0,0009 & 0,0025 & 0,0018 & 0 & 43,6 & 2,4 & 365 & 0,006 & 0,613 & 0,005 & 0,615 & 0,032 & 99 \\
\hline
\end{tabular}


AMOSTRA SNA-172E: metapelito (Nappe Liberdade)

\begin{tabular}{|c|c|c|c|c|c|c|c|c|c|c|c|c|c|c|c|c|c|c|c|c|c|}
\hline Spot & 7/235 & sigma & 206/238 & sigma & orrel. & $238 / 206$ & 1sigma & 207/206 & 1sigma & 208/206 & 1sigma & $\begin{array}{c}\% \\
\text { Com.Pb }\end{array}$ & $\begin{array}{c}\mathrm{ppm} \\
\mathrm{Pb}\end{array}$ & $\begin{array}{c}\text { ppm } \\
\text { Th }\end{array}$ & $\stackrel{\mathrm{ppm}}{\mathrm{U}}$ & $\mathrm{Th} / \mathrm{U}$ & $\begin{array}{c}T \\
206 / 238\end{array}$ & $\begin{array}{c}1 \\
\text { sigma }\end{array}$ & $\begin{array}{c}T \\
207 / 206\end{array}$ & $\begin{array}{c}1 \\
\text { sigma }\end{array}$ & $\begin{array}{c}\% \\
\text { Conc. }\end{array}$ \\
\hline 1,1 & & & & & & & & & & & & & & & 63,6 & & & & & & 97 \\
\hline 1,2 & 5,4454 & 0,1155 & 3271 & (201 & 0,92 & 3,0569 & 0372 & 0,1207 & 0,0025 & 0,1022 & 0,0385 & 0,03 & 163,3 & 52,4 & 352 & 0,149 & 1,824 & 0,019 & 1,967 &, 036 & 92 \\
\hline 2,1 & 1,1457 & 0,0575 & 0,1287 & 0,0022 & & 7,7678 & 0,1348 & 0,0645 & 0,0036 & & 0,0015 & & 15,6 & 13,2 & 95,4 & 0,138 & & 0,013 & & & 102 \\
\hline 3,1 & 2339 & 0919 & 1317 & 0,003 & 0,59 & 5906 & 1746 & 9 & 0,0057 & & 0,036 & 0,24 & $y$ & 42,8 & 44,2 & 0,968 & 0,798 & ,017 & 0,866 & , 186 & 92 \\
\hline 3,2 & 0,9237 & 1629 & 1079 & 0043 & 0,22 & 9,2645 & 3672 & 0,0621 & 0,0125 & 0,0412 & 0,044 & 3,36 & 2,9 & 0,2 & 21,3 & 0,012 & 0,661 & 0,025 & 0,676 & 0,374 & 97 \\
\hline 4,1 & 1,1463 & 0,0487 & 0,1278 & 0,002 & 56 & 7,8253 & 1247 & 0,0651 & 0,003 & 0,0575 & 0,0114 & 0,55 & 21 & 23,4 & 130 & 0,181 & 0775 & 0,012 & 0,776 & 0,096 & 99 \\
\hline 5,1 & 1,1033 & 0,0754 & 0,1266 & 0,0025 & 0,56 & 7,9006 & 0,150 & 0,0632 & 0,0048 & 0,0805 & 0,0355 & 1,12 & 11,1 & 20,0 & 64,8 & 0,09 & 0,100 & 0,015 & 0,716 & 0,161 & 107 \\
\hline 6,1 & 1,173 & 0,0448 & 0,1281 & 0,002 & 0,6 & 7,8049 & 0,1197 & 0,0664 & 0,0027 & 0,0506 & 0,0062 & 0,69 & 22,6 & 23,3 & 145 & 0,161 & 0,777 & 0,011 & 0,819 & 0,086 & 94 \\
\hline 7,1 & 1,1461 & 0,0626 & 0,1273 &, 0023 & 0,55 & 855 & 1426 & 0,0653 & 0,004 & 0,0705 & 0,0126 & 0,37 & 12,3 & 15,6 & 75,9 & 0,206 & 0,772 & 0,013 & 0,784 & 0,125 & 98 \\
\hline 8,1 & 1,8667 & 0,0868 & & 0021 & & 5,6986 & & & ,004 & & & & & & 48,8 & 0,874 & & & & & 92 \\
\hline 9,1 & 0,9747 & 0446 & &, 0019 & 0,96 & 8,9422 & ,1483 & 0,0632 & ,003 & 0,0763 & 0,0357 & 0,48 & 29,8 & 17,2 & 226 & 0,076 & 0,683 & 0,011 & 0,715 & 0,097 & 95 \\
\hline 9,2 & 8377 & 0347 & 1014 & 0015 & 0,61 & 9,8646 & 1477 & 0,0599 & 0,0028 & 0,0043 & 0,0058 & 0,6 & 25 & 0,8 & 206 & 0,004 & 0,622 & 0,009 & 0,601 & 0,101 & 103 \\
\hline 9,3 & 0,8423 & 0,0357 & 0,0998 & 0014 & 0,42 & 10,0192 & , 1403 & 0,0612 & 0,0029 & 0,0041 & 0,0046 & 0,66 & 19,1 & 0,8 & 162 & 0,005 & 0,613 & 0,008 & 0,647 & 0,101 & 94 \\
\hline 10,1 & 1,1771 & 0,0833 & 0,1339 & 0027 & 0,01 & 7,4707 & 0,1534 & 0,0638 & 0,0051 & 0,1257 & 0,0272 & 0,89 & 13,1 & 35 & 70,2 & 0,498 & 0,81 & 0,016 & 0,734 & 0,157 & 110 \\
\hline 11,1 & , & 0489 & & 0015 & & & 0924 & & 0,0028 & & & & 25,3 & 18 & 138 & & & & & & 102 \\
\hline 12,1 & 1,1529 & 0825 & 1295 & 0026 & & 7213 & 1551 & 0,0646 & 0,0054 & 121 & 0,0188 & 1,16 & 9,7 & 21,8 & 56,1 & 0,388 & 0,785 & 0,015 & 0,76 & 176 & 103 \\
\hline 13,1 & 1,1599 & 0,0471 & 1292 & 0018 & 0,41 & 7,7426 & 0,1086 & 0,0651 & 0,0029 & 0,0501 & 0,0084 & 0,68 & 21,6 & 20,8 & 132 & 0,158 & 0,783 & 0,01 & 0,779 & 0,095 & 100 \\
\hline 14,1 & 5,1939 & 0,1387 & ק? & 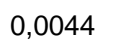 & & 3,0302 & 0,0403 & & 0,0033 & 0,2614 & 0,0126 & 0,24 & 38,8 & 70,1 & 77 & 0,911 & 1,838 & 0,021 & 1,866 & 0,053 & 98 \\
\hline 15,1 & 5,2842 & 0,1291 & $0<01$ & , 004 & & & 0,0382 & & 0,0031 & 0,0833 & 0,0058 & & & 29,3 & 106 & 0,275 & 1,808 & $0,0<$ & 1,932 & 0,046 & 93 \\
\hline 16,1 & 1,1782 & 0,0875 & 1363 & 0028 & 0 & 7,3368 & 502 & 0,0 & 005 & ,0918 & 0,016 & 2 & 71,5 & 18,7 & 67,7 & 0,276 & & 0,016 & 698 & 0,162 & 118 \\
\hline 17,1 & 1,2239 & 0,0946 & 1308 & 0,0029 & 0,38 & 7,6431 & 0,1671 & 0,0678 & 0,006 & 0,1202 & 0,0181 & 1,42 & 8,6 & 19,1 & 52,7 & 0,363 & 0,793 & 0,016 & 0,864 & 0,179 & 91 \\
\hline 17,2 & 0,8441 & 0,0255 & 0,0999 & 0,0012 & 0,92 & 10,0129 & 0,123 & & 0,0019 & 0,002 & & 2,68 & 33,8 & 1,7 & 264 & 0,006 & & 0,007 & 0,65 & 0,067 & 94 \\
\hline 18,1 & 1,0844 & 0,1096 & 0,1288 & 0,0032 & 0,01 & 7,7618 & 0,1921 & 0,061 & 0,007 & 0,1268 & 0,0371 & 2,06 & 6,4 & 14,4 & 36,9 & 0,39 & 0,781 & 0,018 & 0,641 & 0,248 & 121 \\
\hline 19,1 & 1,1098 & 0,0867 & 1267 & 0,0027 & 0,01 & 7,8923 & 168 & 0,0635 & 0,0055 & 0,1435 & 0,0186 & 1,02 & 10,4 & 32 & 60,8 & 0,526 & 0,769 & 0,015 & 0,726 & 0,188 & 105 \\
\hline 19,2 & 0,902 & 0,0415 & 1077 & 0,0016 & & 2839 & 399 & 0,0607 & & 0,0028 & 0,0048 & 0,73 & 24,5 & 0,9 & 210 & 0,004 & 0,659 & 0,009 & 0,63 & 0,104 & 104 \\
\hline 20,1 & 1,1367 & 0,0493 & 0,1266 & 0,0018 & & 7,9006 & 0,1147 & 0,0651 & 0,0032 & 0,0877 & 0,027 & 0,95 & 16,3 & 36,4 & 99,8 & 0,365 & 0,768 & 0,011 & 0,779 & 0,104 & 98 \\
\hline
\end{tabular}




\begin{tabular}{|c|c|c|c|c|c|c|c|c|c|c|c|c|c|c|c|c|c|c|c|c|c|}
\hline , 1 & 1,1426 &, 0533 & 0,1268 & 0,0018 & 0,75 & 7,8834 & 0,1132 & 0,0653 & 0,0033 & 0,1573 & 0,0095 & 0,46 & 23 & 66 & 134 & 0,491 & 0,77 & 0,01 & 0,785 & 0,102 & 98 \\
\hline 22,1 & 4,8955 & 1164 & 0,309 & 0,0029 & 0,98 & 3,2358 & 0,0307 & 1149 & 0,0028 & 0,2094 & 0,008 & 0,15 & 81,4 & 143,2 & 188 & 0,761 & 1,736 & 0,015 & 1,878 & 0,043 & 92 \\
\hline 22,2 & 1,0813 & 0,0786 & 0,1287 & 0,0025 & 0,88 & 7,7709 & 0,153 & 0,0609 & 0,0049 & 0,1087 & 0,0152 & 1,44 & 11,9 & 26,6 & 62,9 & 0,422 & 0,78 & 0,014 & 0,637 & 0,171 & 122 \\
\hline 22,3 & 0,8638 & 0,0449 & 0,1062 & 0,0016 & 0,75 & 9,4199 & 0,1445 & 0,059 & 0,003 & 0,0126 & 0,0121 & 1,37 & 31 & 16,3 & 253 & 0,064 & 0,65 & 0,009 & 0,568 & 0,112 & 114 \\
\hline 23,1 & 1,0674 & 0,0614 & 0,1221 & 0,0021 & 0,85 & 8,1889 & 0,1387 & 0,0634 & 0,0041 & 0,0962 & 0,0363 & 0,51 & 22,5 & 76,4 & 133 & 0,573 & 0,743 & 0,012 & 0,721 & 0,143 & 102 \\
\hline 24,1 & 4,7884 & 0,1083 & 0,3096 & 0,0028 & 0,87 & 3,23 & 0,0291 & 0,1122 & 0,0025 & 0,0467 & 0,0017 & 0,16 & 130,8 & 50,4 & 324 & 0,155 & 1,739 & 0,014 & 1,835 & 0,041 & 94 \\
\hline 25,1 & 13,4289 & 0,3115 & 0,5044 & 0,0051 & 0,97 & 1,9824 & 0,0199 & 0,1931 & 0,0045 & 0,1003 & 0,0205 & 0 & 82 & 29,9 & 128 & 0,233 & 2,633 & 0,022 & 2,769 & 0,038 & 95 \\
\hline 26,1 & 0,7984 & 0,0317 & 0,0953 & 0,0012 & 0,21 & 10,4956 & 0,1282 & 0,0608 & 0,0026 & 0,003 & 0,0038 & 0,88 & 17,1 & 1,1 & 155 & 0,007 & 0,587 & 0,007 & 0,631 & 0,092 & 92 \\
\hline 27,1 & 1,0309 & 0,0429 & 0,118 & 0,0015 & 0,89 & 8,4717 & 0,1107 & 0,0633 & 0,0029 & 0,1586 & 0,0246 & 0,45 & 23,9 & 86 & 125 & 0,69 & 0,719 & 0,009 & 0,72 & 0,093 & 99 \\
\hline 28,1 & 1,1574 & 0,045 & 0,1286 & 0,0015 & 0,98 & 7,7789 & 0,0923 & 0,0653 & 0,0034 & 0,1771 & 0,037 & 0,61 & 33,7 & 130,7 & 188 & 0,696 & 0,78 & 0,009 & 0,784 & 0,103 & 99 \\
\hline 29,1 & 4,6462 & 0,1329 & 0,308 & 0,0036 & 0,66 & 3,2464 & 0,0377 & 0,1094 & 0,0033 & 0,1678 & 0,0059 & 0,31 & 32,6 & 45 & 75,7 & 0,595 & 1,731 & 0,018 & 1,789 & 0,054 & 96 \\
\hline 30,1 & 1,1745 & 0,0482 & 0,1282 & 0,0017 & 0,53 & 7,7977 & 0,1018 & 0,0664 & 0,003 & 0,0633 & 0,0126 & 0,32 & 30,6 & 45,4 & 189 & 0,24 & 0,778 & 0,01 & 0,82 & 0,096 & 94 \\
\hline 31,1 & 1,2102 & 0,0516 & 0,1318 & 0,0018 & 0,87 & 7,5871 & 0,1047 & 0,0666 & 0,0029 & 0,0757 & 0,0161 & 0,82 & 23,6 & 47,4 & 140 & 0,338 & 0,798 & 0,01 & 0,825 & 0,094 & 96 \\
\hline 32,1 & 1,14 & 0,0759 & 0,1271 & 0,0026 & 0,19 & 7,8708 & 0,1632 & 0,0651 & 0,0049 & 0,1646 & 0,0213 & 1,39 & 9,1 & 24,1 & 50,7 & 0,476 & 0,771 & 0,015 & 0,777 & 0,162 & 99 \\
\hline 33,1 & 4,8499 & 0,1949 & 0,3066 & 0,0054 & 0,48 & 3,2619 & 0,0571 & 0,1147 & 0,005 & 0,3237 & 0,0247 & 0,88 & 13 & 26,9 & 27,6 & 0,977 & 1,724 & 0,026 & 1,876 & 0,079 & 91 \\
\hline 34,1 & 1,1229 & 0,0561 & 0,1264 & 0,002 & 0,83 & 7,909 & 0,1237 & 0,0644 & 0,0034 & 0,0931 & 0,0154 & 0,82 & 17,8 & 35 & 112 & 0,312 & 0,768 & 0,011 & 0,755 & 0,108 & 101 \\
\hline 35,1 & 1,555 & 0,0618 & 0,1568 & 0,0021 & 0,95 & 6,3767 & 0,0857 & 0,0719 & 0,0029 & 0,0851 & 0,0154 & 0,61 & 20,7 & 31,9 & 104 & 0,306 & 0,939 & 0,012 & 0,984 & 0,081 & 95 \\
\hline 36,1 & 1,9565 & 0,0969 & 0,1861 & 0,0033 & 0,82 & 5,3739 & 0,0943 & 0,0763 & 0,0045 & 0,242 & 0,0272 & 0,21 & 13,4 & 42,6 & 49,6 & 0,859 & 1,1 & 0,018 & 1,102 & 0,125 & 99 \\
\hline 37,1 & 1,0877 & 0,058 & 0,1251 & 0,0021 & 0,01 & 7,9917 & 0,1318 & 0,063 & 0,0038 & 0,148 & 0,0153 & 0,95 & 17,5 & 55,5 & 103 & 0,54 & 0,76 & 0,012 & 0,71 & 0,123 & 107 \\
\hline 37,2 & 1,1572 & 0,0685 & 0,1299 & 0,0024 & 0,23 & 7,7002 & 0,1421 & 0,0646 & 0,0042 & 0,1137 & 0,0177 & 1,08 & 11,7 & 23,3 & 71,1 & 0,328 & 0,787 & 0,014 & 0,762 & 0,139 & 103 \\
\hline 38,1 & 1,1935 & 0,0703 & 0,1332 & 0,0025 & 0,5 & 7,5085 & 0,1387 & 0,065 & 0,0043 & 0,1031 & 0,0168 & 1,59 & 11,2 & 18,9 & 72,5 & 0,26 & 0,806 & 0,014 & 0,774 & 0,143 & 104 \\
\hline 39,1 & 1,0908 & 0,0401 & 0,1212 & 0,0015 & 0,91 & 8,2538 & 0,0993 & 0,0653 & 0,0026 & 0,1854 & 0,0227 & 0,19 & 45,6 & 175,3 & 266 & 0,66 & 0,737 & 0,008 & 0,784 & 0,082 & 94 \\
\hline 40,1 & 1,1659 & 0,0481 & 0,1267 & 0,0017 & 0,25 & 7,8927 & 0,1059 & 0,0667 & 0,003 & 0,1684 & 0,0296 & 1,11 & 19,3 & 66,3 & 111 & 0,598 & 0,769 & 0,01 & 0,83 & 0,094 & 92 \\
\hline 41,1 & 1,1317 & 0,0497 & 0,1265 & 0,0018 & 0,95 & 7,904 & 0,1114 & 0,0649 & 0,0031 & 0,0859 & 0,0289 & 0,85 & 13,1 & 21,6 & 76,9 & 0,282 & 0,768 & 0,01 & 0,77 & 0,1 & 99 \\
\hline 42,1 & 1,1449 & 0,0484 & 0,129 & 0,0018 & 0,26 & 7,7492 & 0,1057 & 0,0643 & 0,0029 & 0,0772 & 0,0112 & 0,22 & 21,4 & 35,8 & 128 & 0,279 & 0,782 & 0,01 & 0,753 & 0,098 & 103 \\
\hline 43,1 & 1,178 & 0,0509 & 0,1304 & 0,0019 & 0,66 & 7,6658 & 0,1088 & 0,0655 & 0,0031 & 0,0863 & 0,0133 & 0, & 18 & 37,7 & 110 & 0,342 & 0,79 & 0,011 & 0,79 & 0,103 & 100 \\
\hline 43,2 & 0,8078 & 0,0343 & 0,0963 & 0,0014 & 0,57 & 10,3875 & 0,1476 & 0,0609 & 0,0028 & 0,023 & 0,0235 & 1,84 & 39,3 & 2,1 & 342 & 0,006 & 0,593 & 0,008 & 0,634 & 0,093 & 93 \\
\hline 44,1 & 1,2399 & 0,0464 & 0,1307 & 0,0018 & 0,2 & 7,6509 & 0,108 & 0,0688 & 0,0029 & 0,1119 & 0,017 & $1, \angle T$ & 16,4 & 26,9 & 100 & 0,269 & 0,792 & 0,011 & 0,893 & 0,089 & 88 \\
\hline 44,2 & 0,9113 & 0,04 & 0,1089 & 0,0016 & 0,72 & 9,1804 & 0,1384 & 0,0607 & 0,0029 & 0,009 & 0,0074 & 3,85 & 16,1 & 0,8 & 130 & 0,006 & 0,667 & 0,01 & 0,628 & 0,102 & 106 \\
\hline 45,1 & 1,9626 & 0,0528 & 0,1846 & 0,002 & 0,53 & 5,4183 & 0,0588 & 0,0771 & 0,0022 & 0,2631 & 0,0158 & 0,15 & 45,1 & 147,2 & 172 & 0,858 & 1,092 & 0,011 & 1,124 & 0,057 & 97 \\
\hline
\end{tabular}




\begin{tabular}{|c|c|c|c|c|c|c|c|c|c|c|c|c|c|c|c|c|c|c|c|c|c|}
\hline 46,1 & 1,1685 & 0,0432 & 0,1274 & 0,0017 & 0,95 & 7,8488 & 0,1078 & 0,0665 & 0,0027 & 0,0448 & 0,0064 & 0,31 & 17,4 & 16,5 & 111 & 0,149 & 0,773 & 0,01 & 0,823 & 0,087 & 93 \\
\hline 46,2 & 0,7803 & 0,0939 & 0,1006 & 0,0035 & 0,77 & 9,9434 & 0,3462 & 0,0563 & 0,0082 & 0,0215 & 0,0237 & 3 & 5,4 & 0,8 & 36 & 0,023 & 0,618 & 0,021 & 0,463 & 0,312 & 133 \\
\hline 47,1 & 3,3215 & 0,072 & 0,2551 & 0,0023 & 0,93 & 3,9205 & 0,0353 & 0,0944 & 0,0022 & 0,0783 & 0,0026 & 0,1 & 130,4 & 106,6 & 393 & 0,271 & 1,465 & 0,012 & 1,517 & 0,043 & 96 \\
\hline 48,1 & 1,1794 & 0,0517 & 0,1238 & 0,002 & 0,46 & 8,0774 & 0,1308 & 0,0691 & 0,0034 & 0,2443 & 0,0126 & 0,47 & 14,1 & 68,6 & 75,5 & 0,91 & 0,752 & 0,011 & 0,901 & 0,104 & 83 \\
\hline 49,1 & 1,1449 & 0,0487 & 0,1262 & 0,0019 & 0,49 & 7,922 & 0,1197 & 0,0658 & 0,0032 & 0,1172 & 0,0083 & 0,73 & 15 & 39,9 & 90,2 & 0,442 & 0,766 & 0,011 & 0,799 & 0,101 & 95 \\
\hline 50,1 & 1,3365 & 0,0403 & 0,1412 & 0,0016 & 0,92 & 7,0816 & 0,0806 & 0,0686 & 0,0023 & 0,0591 & 0,0211 & 0,58 & 16,7 & 16,3 & 78,5 & 0,207 & 0,852 & 0,009 & 0,888 & 0,07 & 95 \\
\hline 51,1 & 0,859 & 0,0453 & 0,0995 & 0,0018 & 0,25 & 10,0455 & 0,1801 & 0,0626 & 0,0038 & 0,0077 & 0,0081 & 0,7 & 9,5 & 1 & 80,9 & 0,013 & 0,612 & 0,01 & 0,694 & 0,131 & 88 \\
\hline 52,1 & 1,1584 & 0,0363 & 0,1277 & 0,0015 & 0,85 & 7,8295 & 0,0926 & 0,0658 & 0,0023 & 0,044 & 0,0115 & 0,22 & 26,5 & 25,7 & 173 & 0,149 & 0,775 & 0,009 & 0,799 & 0,073 & 96 \\
\hline 53,1 & 1,239 & 0,049 & 0,1344 & 0,0019 & 0,76 & 7,4425 & 0,1079 & 0,0669 & 0,003 & 0,1515 & 0,016 & 0,33 & 18,4 & 60,6 & 109 & 0,558 & 0,813 & 0,011 & 0,834 & 0,093 & 97 \\
\hline 54,1 & 1,1659 & 0,0493 & 0,1298 & 0,002 & 0,45 & 7,7035 & 0,1193 & 0,0651 & 0,0029 & 0,1265 & 0,0167 & 0,41 & 15 & 37,2 & 89,8 & 0,414 & 0,787 & 0,011 & 0,779 & 0,094 & 101 \\
\hline 55,1 & 1,1697 & 0,0412 & 0,1272 & 0,0017 & 0,09 & 7,8623 & 0,1081 & 0,0667 & 0,0025 & 0,1466 & 0,0069 & 0,27 & 26,5 & 80,5 & 155 & 0,521 & 0,772 & 0,01 & 0,828 & 0,08 & 93 \\
\hline 56,1 & 1,9858 & 0,0514 & 0,1864 & 0,0021 & 0,32 & 5,3636 & 0,0594 & 0,0772 & 0,002 & 0,1747 & 0,0124 & 2,14 & 52,5 & 104 & 209 & 0,498 & 1,102 & 0,011 & 1,128 & 0,05 & 97 \\
\hline 57,1 & 1,1112 & 0,0445 & 0,1275 & 0,0019 & 0,9 & 7,8411 & 0,1151 & 0,0632 & 0,0027 & 0,0805 & 0,0385 & 0,25 & 19,5 & 52,2 & 113 & 0,463 & 0,774 & 0,011 & 0,715 & 0,089 & 108 \\
\hline 58,1 & 1,1857 & 0,0381 & 0,1304 & 0,0016 & 0,88 & 7,6683 & 0,0961 & 0,0659 & 0,0022 & 0,1077 & 0,0534 & 0,21 & 23,6 & 107,7 & 120 & 0,897 & 0,79 & 0,009 & 0,805 & 0,071 & 98 \\
\hline 58,2 & 0,848 & 0,0223 & 0,1018 & 0,0011 & 0,91 & 9,8277 & 0,1051 & 0,0604 & 0,0016 & 0,0067 & 0,0045 & 0,16 & 46,1 & 4,7 & 377 & 0,012 & 0,625 & 0,006 & 0,619 & 0,058 & 100 \\
\hline 59,1 & 1,0392 & 0,0261 & 0,1178 & 0,0012 & 0,99 & 8,4865 & 0,089 & 0,064 & 0,0016 & 0,1182 & 0,0475 & 0,19 & 64,2 & 188,3 & 399 & 0,472 & 0,718 & 0,007 & 0,74 & 0,053 & 96 \\
\hline 60,1 & 1,1135 & 0,0278 & 0,1253 & 0,0013 & 0,99 & 7,9778 & 0,0815 & 0,0644 & 0,0018 & 0,0243 & 0,0169 & 0,37 & 32,7 & 24,9 & 219 & 0,114 & 0,761 & 0,007 & 0,756 & 0,061 & 100 \\
\hline 61,1 & 2,8929 & 0,0605 & 0,2312 & 0,0022 & 0,99 & 4,3254 & 0,0412 & 0,0908 & 0,0019 & 0,0679 & 0,0097 & 0,65 & 135,1 & 104,2 & 460 & 0,226 & 1,341 & 0,012 & 1,441 & 0,041 & 93 \\
\hline 61,2 & 0,8745 & 0,0228 & 0,1054 & 0,0011 & 0,94 & 9,4887 & 0,1015 & 0,0602 & 0,0015 & 0,0101 & 0,0042 & 3,09 & 57,9 & 1,4 & 475 & 0,003 & 0,646 & 0,007 & 0,61 & 0,055 & 105 \\
\hline 62,1 & 1,5296 & 0,0398 & 0,1524 & 0,0017 & 0,99 & 6,5599 & 0,0718 & 0,0728 & 0,002 & 0,1125 & 0,0526 & 0,28 & 38,6 & 77,6 & 189 & 0,41 & 0,915 & 0,009 & 1,008 & 0,056 & 90 \\
\hline 63,1 & 1,1367 & 0,0328 & 0,1274 & 0,0015 & 0,98 & 7,8501 & 0,0895 & 0,0647 & 0,002 & 0,0402 & 0,007 & 0,87 & 32,6 & 26,7 & 217 & 0,123 & 0,773 & 0,008 & 0,765 & 0,065 & 101 \\
\hline 64,1 & 0,9028 & 0,0399 & 0,1056 & 0,0017 & 0,99 & 9,4705 & 0,1506 & 0,062 & 0,0031 & 0,0265 & 0,0149 & 0,09 & 22,5 & 18,9 & 135 & 0,14 & 0,647 & 0,01 & 0,674 & 0,105 & 95 \\
\hline
\end{tabular}

\section{AMOSTRA SNA-180A: metapsamito (Nappe Liberdade)}

\begin{tabular}{|c|c|c|c|c|c|c|c|c|c|c|c|c|c|c|c|c|c|c|c|c|c|}
\hline Spot & $207 / 235$ & 1sigma & $206 / 238$ & 1sigma & Correl. & $238 / 206$ & 1sigma & $207 / 206$ & 1sigma & $208 / 206$ & 1sigma & $\begin{array}{c}\% \\
\text { Com.Pb }\end{array}$ & $\begin{array}{c}\mathrm{ppm} \\
\mathrm{Pb}\end{array}$ & $\begin{array}{l}\text { ppm } \\
\text { Th }\end{array}$ & $\stackrel{\mathrm{ppm}}{\mathrm{U}}$ & $\mathrm{Th} / \mathrm{U}$ & $\begin{array}{c}T \\
206 / 238\end{array}$ & $\begin{array}{c}1 \\
\text { sigma }\end{array}$ & $\begin{array}{c}T \\
207 / 206\end{array}$ & $\begin{array}{c}1 \\
\text { sigma }\end{array}$ & $\begin{array}{c}\% \\
\text { Conc. }\end{array}$ \\
\hline 1,1 & 15,3487 & 0,255 & 0,5567 & 0,0075 & 0,6 & 1,7963 & 0,0243 & 0,2 & 0,0024 & 0,2442 & 0,0701 & 0,04 & 86,3 & 111,9 & 88,2 & 1,269 & 2,853 & 0,031 & 2,826 & 0,019 & 100 \\
\hline 2,1 & 2,7048 & 0,0621 & 0,2292 & 0,0032 & 0,96 & 4,3639 & 0,0613 & 0,0856 & 0,0017 & 0,2208 & 0,0276 & 0,33 & 25,9 & 66,4 & 71,7 & 0,926 & 1,33 & 0,017 & 1,329 & 0,039 & 100 \\
\hline 3,1 & 3,2662 & 0,0889 & 0,2564 & 0,004 & 0,71 & 3,9009 & 0,0604 & 0,0924 & 0,0023 & 0,3495 & 0,0185 & 0 & 20,1 & 56,5 & 45,3 & 1,248 & 1,471 & 0,02 & 1,476 & 0,046 & 99 \\
\hline
\end{tabular}




\begin{tabular}{|c|c|c|c|c|c|c|c|c|c|c|c|c|c|c|c|c|c|c|c|c|}
\hline$t, 1$ & 8709, & ,0906 & 0,1823 & 0,0034 & 0,23 & 5,484 &, 1026 &, 0744 & 0,0037 & 0,2964 & 0,0173 & 0,25 & 8,6 & 31,1 & 29,4 & 1,058 & 1,08 & 0,019 & 1,053 & 0,098 \\
\hline 4,2 & 1,9248 & 0,0768 & 0,178 & 0,003 & 0,74 & 5,6166 & 0,0959 & 0,0784 & 0,0032 & 0,3634 & 0,0209 & 0,78 & 10,4 & 44,8 & 33,2 & 1,35 & 1,056 & 0,017 & 1,157 & 0,079 \\
\hline & 9252 & ,0646 & 182 & 0,0029 & 0,98 & 4956 & ,0872 & & & ,2687 & & & 2,2 & & 39,6 & 1,082 & ,078 & ,016 & & ,065 \\
\hline 5,1 & 2486 & ,0802 & 2022 & 0033 & ,78 & ,945 & 0817 & 0806 & 0028 & ,1522 & ,0078 & ),76 & 6,9 & 4,4 & 22,2 & 0,65 & 187 & 0,018 & 213 & ,069 \\
\hline 6,1 & 3,1528 & 0,0597 & 0,2419 & 0,0032 & 0,84 & 4,1347 & 0,054 & 0,0945 & 0,0014 & 0,0686 & 0,0316 & 0 & 48 & 48,8 & 131 & 0,372 & 1,396 & 0,016 & 1,519 & 0,029 \\
\hline 7,1 & 2,0219 & 0,0459 & 0,1907 & 0,0026 & 0,8 & 5,2441 & 0,0708 & 0,0769 & 0,0015 & 0,1331 & 0,0174 & 0,16 & 20,3 & 35,1 & 75,7 & 0,463 & 1,125 & 0,014 & 1,119 & 0,04 \\
\hline, 1 & 4,9595 & 0,0962 & 0,3314 & 0,0044 & 0,98 & 3,0172 & 0,0399 & 0,1085 & 0,0018 & 0,158 & 0,0199 & 0,26 & 34,1 & 47,6 & 71 & 0,67 & 1,845 & 0,021 & 1,775 & 0,03 \\
\hline ,1 & 6362 & 0,0573 & 0,1604 & 0,0024 &, 98 & 6,2332 & 0,0948 & 0,074 & 0,0027 & 0,159 & 0,0455 & 1,39 & 10,3 & 26,1 & 43,5 & 0,6 &, 959 & 0,014 & 1,041 &, 078 \\
\hline, 1 & 1,7455 & 0,0346 & 0,1639 & 0,002 & 0,99 & 6,0994 & 0,0751 & 0,0772 & ,0014 & 0,0313 & 0,0286 & 0,2 & 36,6 & 26,8 & 161 & 0,166 & ),979 & 0,011 & 1,127 & 0,037 \\
\hline 1,1 & 3,6351 & 0,0804 & 0,288 & 0,0038 & 0,96 & 3,4728 & 0,0458 & 0,0916 & 0,002 & 0,091 & 0,0431 & 0,2 & 21,7 & 26,2 & 57,8 & 0,452 & 1,631 & 0,019 & 1,458 & 0,041 \\
\hline 2,1 & 5,2638 & 0,0979 & 0,3517 & 0,0037 & 0,99 & 2,8436 & 0,0299 & 0,1086 & 0,0018 & 0,1762 & 0,0281 & 0,06 & 58,3 & 90,9 & 132 & 0,69 & 1,943 & 0,018 & 1,775 & 0,03 \\
\hline 3,1 & 5,7795 & 0,1266 & ,3645 & 0,0044 &, 99 & 2,7432 & 0,0329 & 0,115 & 0,002 & 0,3266 & 0,1057 & 0,05 & 83,1 & 238,3 & 139 & 1,718 & 2,004 & 0,021 & 1,88 & 0,032 \\
\hline 4,1 & 6,9707 & 0,2628 & 0,607 & 0,0061 & 0,99 & 1,6473 & 0,0165 & 0,2028 & 0,0026 & 0,1281 & 0,0275 & 0,02 & 82,3 & 79,5 & 107 & 0,745 & 3,058 & 0,025 & 2,849 & ,021 \\
\hline 0 & 9555 & 0,0635 & ,2491 & $00<1$ & 0,96 & 4,0145 & 0,0432 & 0,0861 & 0,0017 & 0,3542 & & 15,89 & 38,4 & 113,5 & 84,7 & 1,34 & 1,434 & & & 0,038 \\
\hline b, 1 & 2492, & 0,0355 & 0,1367 & 0,0016 & 0,58 & 7,3166 & 0,0854 & 0,0663 & 0,0018 & 0,1024 & 0,0952 & 0,05 & 24,7 & 67 & 121 & 0,554 &, 826 & 0,009 & 0,816 & 0,056 \\
\hline 7,1 & 2,4638 & 0,0425 & 0,2183 & 0,0021 & 0,99 & 4,5808 & 0,045 & 0,0819 & 0,0012 & 0,1305 & 0,0056 & 0,24 & 58,1 & 96,7 & 189 & 0,511 & ,273 & 0,011 & 242 & 0,03 \\
\hline 7,2 & 1,5201 & 0,0366 & 0,1494 & 0,0018 & 0,84 & 6,6936 & 0,0791 & 0,0738 & 0,0016 & 0,0527 & 0,0234 & 0,04 & 43,8 & 58,3 & 163 & 0,357 & 0,898 & 0,01 & 1,036 & 0,043 \\
\hline 0,1 & 2,3182 & 0,0552 & 0,2081 & 0,0023 & 0,74 & 4,8056 & 0,0537 & 0,0808 & 0,0018 & 0,1685 & & 0 & 15,9 & & 52,7 & 0,698 & & & & \\
\hline 9,1 & 226 &, 0484 & 0,2044 & 0,0022 & 0,94 & 4,8932 & ,0525 & $0,0 / 9$ & 0,0016 & 0,0558 & 0,00 & 0,25 & & & 105 & 0,206 & 199 & 0,012 & 172 & 0,039 \\
\hline 0,1 & 7035 & ,1303 & 3137 & 0,004 & ,99 & 3,1879 &, 0407 & 0,1088 & 0,003 & 0,1218 & 0,0642 & 0,23 & 14,7 & 16,9 & 37,8 & 0,448 & ,759 & 0,02 & 1,779 & 0,051 \\
\hline 1,1 & 13,7034 & 0,2333 & 0,5349 & 0,0057 & 0,98 & 1,8695 & 0,02 & 0,1858 & 0,0027 & 0,1763 & 0,026 & 0,19 & 36,5 & 31,1 & 46,8 & 0,665 & 2,762 & 0,024 & 2,705 & 0,024 \\
\hline 2,1 & 2,5436 & 0,0476 & 0,2257 & 0,0022 & 0,99 & 4,4308 & 0,0441 & 0,0817 & 0,0014 & 0,1415 & 0,0358 & 0,0 & 45,8 & 88,6 & 144 & 0,617 & & 0,012 & 1,239 & 0,035 \\
\hline 2,2 & 2,2844 & 0,0391 & 0,2099 & 0,0019 & 0,97 & 4,7651 & 0,0441 & 0,0789 & 0,0012 & 0,0983 & 0,0162 & 0,13 & & 10,9 & 156 & 0,474 & & & & 0,032 \\
\hline 3,1 & 1887 & 0,0587 & ,2571 & ,0025, & ,93 & 3,8895 & 0,0376 & & 0,0014 & 0,1219 & 0,004 & 0,06 & 42,6 & 56,2 & 124 & 0,454 & 475 & 13 & 424 & 0,03 \\
\hline 11 & 36715 & 0,0801 & 0,2802 & 0,0031 & 0,86 & 3,5692 & 0,0389 & 0,0951 & 0,0018 & 0,1647 & 0,0075 & 0,08 & 33,7 & 52,5 & 83,9 & 0,626 & 1,592 & 0,015 & 1,53 & 0,036 \\
\hline$\angle 4,\llcorner$ & 3,5713 & 0,0791 & 0,2731 & 0,0029 & 0,99 & 3,6623 & 0,0391 & 0,0949 & 0,002 & 0,115 & 0,0145 & 0,4 & 17,4 & 21,5 & 48 & 0,448 & & 0,015 & & 0,041 \\
\hline 0,1 & 2,059 & 0,0366 & 0,195 & 0,0017 & 0,99 & 5,1292 & 0,0455 & 0,0766 & 0,0013 & 0,1451 & 0,0665 & 0,18 & 49,2 & 81,2 & 224 & 0,363 & 1,148 & 0,009 & 1,111 & 0,034 \\
\hline 26,1 & 5,2902 & 0,0803 & 3412 & 0,0029 & 0,99 & 2,9308 & 0253 & 1124 & 0,0015 & 0,0808 & 0,0248 & 0,02 & 96,8 & 82,6 & 212 & 0,389 & ,892 & 0,014 & ,839 & 0,024 \\
\hline 2,1 & 1,8974 & 0,0847 & & 0,0028 & & 5,6865 & 0,0906 & & 0,0035 & 0,2441 & & 036 & & 30,4 & 34,4 & 0,883 & & & 1,153 & 0,094 \\
\hline 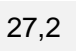 & $1,15 / 0$ & 0,0495 & 0,1731 & (ח) &, 56 & & & & 0,002 & & & & 17,6 & & 71,9 & & 1,029 & 0,011 & 1,033 & 0,055 \\
\hline
\end{tabular}




\begin{tabular}{|c|c|c|c|c|c|c|c|c|c|c|c|c|c|c|c|c|c|c|c|c|}
\hline 3,1 & 1476 & 0412 & ,1994 &, 0019 & 0,99 & 5,0139 & 0,0489 & ,0781 & 0,0013 & o,0474 & 0,019 & 0,35 & 29,6 & 36,1 & 110 & 0,329 & ,172 & 0,01 & 149 & ,033 \\
\hline 9,1 & 2,2137 & 0,0635 & 0,2041 & 0,0025 & 0,86 & 4,8996 & 0,0599 & 0,0787 & 0,0021 & 0,0951 & 0,0074 & 1,02 & 15,6 & 21,6 & 57,6 & 0,375 & 1,197 & 0,013 & 1,164 & 0,053 \\
\hline 0,1 & 5742 & 462 & & 002 & & & & & & & & & 7,6 & & 156 & ,682 & & & & 032 \\
\hline 1,1 & 5,2014 & 2277 & 5644 & 0051 & 99 & 7717 & 0159 & 1953 & 0024 & 0556 & 031 & 07 & 3,6 & 5,8 & 91 & 173 & 2,885 & 021 & ,788 & 02 \\
\hline 2,1 & 2,7903 & 0,0461 & 0,2363 & 0,0022 & 0,98 & 1,2319 & 0,0386 &, 0856 & 0,0011 & 0,015 & 0,0049 & 0,09 & 82,8 & 8,3 & 280 & 0,03 & 1,367 & 0,011 & 1,33 & 0,026 \\
\hline 3,1 & 2,3836 & 0,041 & 0,2154 & 0,0019 & 0,99 & 6415 & 0,0409 & 0,0802 & 0,0012 & 0,0856 & 0,0455 & 0,14 & 44 & 60,4 & 155 & 0,389 & 1,258 & 0,01 & 1,203 & 0,031 \\
\hline 4,1 & 6,6058 & 0,1126 & 0,3843 & 0,0038 & 0,98 & ,6018 & 0,0257 & 0,1247 & 0,0018 & 0,2209 & 0,0155 & 0,16 & 59,5 & 93,5 & 98,7 & 0,947 & 2,097 & 0,018 & 2,024 & 0,026 \\
\hline 5,1 & 2,6481 & 0,0554 & ,2337 & ,0025 & 0,98 & 2793 & 0459 & ,0822 & 0,0016 & 0,1413 & 0,0156 & 0,22 & 25,8 & 46 & 82,1 & 0,561 & 1,354 & 0,013 & 1,25 & ,039 \\
\hline 5,2 & 2,5613 & 0,0492 & 0,2282 & 0023 & 0,99 & 3829 & ,0437 & 0,0814 & 0,0015 & 0,1271 & 0,0058 & 0,18 & 27,4 & 43,8 & 91 & 0,481 & 1,325 & 0,012 & 1,232 & 0,036 \\
\hline 6,1 & 2,8094 & 0,0684 & 0,2391 & 0,0029 & 0,98 & 4,1828 & 0,0513 & 0,0852 & 0,0021 & 0,1746 & 0,0138 & 0,43 & 20,4 & 44,3 & 62 & 0,714 & 1,382 & 0,016 & 1,321 & 0,048 \\
\hline 7,1 & 3,5313 & 0,0634 & 0,2681 & 0,0026 & 0,98 & ,7299 & 0,0368 & 0,0955 & 0,0015 & 0,0736 & 0,0223 & 0,25 & 33 & 33,6 & 101 & 0,332 & 1,531 & 0,013 & 1,539 & 0,03 \\
\hline 7,2 & 3,6948 & 0,0732 & 0,2825 & 0,003 & 0,99 & ,5394 & 0,0376 & 0,0948 & 0,0018 & 0,0616 & 0,017 & 0,11 & 29 & 19,1 & 73,4 & 0,26 & 1,604 & 0,015 & 1,525 & 0,035 \\
\hline 8,1 & 5,1107 & 0,0844 & 0,3433 & 0,0032 & 0,99 & 2,9125 & 0,0272 & 0,108 & 0,0014 & 0,0751 & 0,0227 & 0,12 & 60,1 & 51,7 & 138 & 0,375 & 1,903 & 15 & 1,765 & 0,024 \\
\hline 8,2 & 4,7248 & ,0705 & 0,3201 & $00<1$ & 0,99 & & ,0262 & 0,107 & 0,0014 & & 0,0032 & 0,07 & 80,7 & 23,1 & 198 & 0,117 & & & & \\
\hline 9,1 & 3,231 & ,0737 & 0,1747 & 0,002 & 0,99 & 7248 & 0,0666 & 0,1342 & 0,0024 & 0,0755 & 0,0148 & 0,04 & 36,9 & 21,1 & 42,7 & 0,494 & 1,038 & 0,011 & 2,153 & 0,026 \\
\hline 0,1 & 3,8315 & 0,0807 & 0,2863 & 0,0032 & 0,99 & ,493 & 0,0393 & 0,0971 & 0,0019 & 0,2164 & 0,0523 & 0,27 & 28,1 & 57,6 & 63,3 & 0,91 & 1,623 & 0,016 & 1,569 & 0,037 \\
\hline 1,1 & 5,1609 & 0,0803 & 0,3427 & 0,003 & 0,92 & 2,9183 & 0,0259 & 0,1092 & 0,0018 & 0,2361 & 0,1178 & 0,05 & 81,8 & 244,7 & 162 & 1,509 & 1,899 & 0,015 & 1,787 & 0,032 \\
\hline 1,2 & 4,8481 &, 005 & 0,3215 & 0033 & 0,35 & & & 0,1094 & 0,0018 & & & 011 & 29,4 & & 61,4 & 0,848 & & & & \\
\hline 2,1 & 2,8809 & 0,0759 & 0,2152 & 0029 & 0,99 & 74 & 0,063 & 0,0971 & 0,002 & ,1707 & 0,06 & 0,35 & 40,5 & 81,3 & 80,9 & 1,005 & 1,256 & 0,015 & 569 & 7 \\
\hline 3,1 & 2,5462 & 0,04 & 0,2199 & 0022 & 0,98 & 5467 & ,0453 & 0,084 & 0,0014 & 0,1049 & 0,0118 & 0,17 & 49 & 68,1 & 158 & 0,433 & 1,282 & 0,012 & 1,292 & 0,033 \\
\hline 43,2 & 2,7064 & 0,0402 & 0,2325 & 0,0022 & 0,68 & 4,3017 & 0,0404 &, 0844 & 0,0014 & 0,0986 & 0,0277 & 0,26 & 41,2 & 36,6 & 131 & 0,279 & 1,347 & 0,011 & 1,303 & 0,031 \\
\hline 44,1 & 3,6048 & 0,0481 & 0,2788 & 0,0025 & 0,10 & & 0,0327 & 0,0938 & 0,0013 & 0,2389 &, $00<0$ & 0 & 69,7 & 169,5 & 160 & 1,058 & & & & \\
\hline 4,2 & 3,2973 & 0,0397 & 0,2575 & ,0022 & 0,99 & 3832 & ,0329 & 0,0929 & 0,0012 & $0, \angle \angle Y$ & 0,0287 & 0,1 & 122 & 285,9 & 349 & 0,82 & & 0,011 & 1,485 & \\
\hline 5,1 & 2,9306 & 1,2706 & 0,2395 & 0411 & 0,25 & 761 & 3 & ,0888 & 0,044 & 0932 & 0,1106 & 2,62 & 1,6 & & 4,1 & ,33 & 1,384 & ,22 & 399 & 0,645 \\
\hline 46,1 & 3,3749 & 0,0572 & 0,2622 & 0,0027 & 0,99 & 3,8137 & 0,0389 & 0,0933 & 0,002 & 0,1376 & 0770 & 0 & 28 & 54,8 & 65,1 & 0,842 & 1,501 & 0,014 & 1,495 & 0,045 \\
\hline 47,1 & 4,8262 & 0,0563 & 0,3251 & 0,0026 & 0,96 & & 0,0249 & 0,1077 & 0,0014 & 0,1438 & 0,0742 & 0,7 & 116 & 200,4 & 296 & 0,678 & & 0,013 & & 0,027 \\
\hline $4+, 2$ & 5,2408 & 0,0633 & 0,3314 & 0,0028 & 0,85 & 3,0177 & 0,0258 & 0,1147 & 0,0015 & 0,1524 & $0,0 / 06$ & 0,14 & 72,4 & 82,2 & 199 & 0,412 & 1,845 & 0,014 & 1,875 & 0,025 \\
\hline 48,1 & 2,0357 & 0,0384 & 0,1939 & 0,002 & 0,98 & 578 & 054 & 0,0761 & 0,0016 & 1622 & 0,027 & 0,47 & 32 & 69,9 & 114 & 0,612 & 1,142 & 0,011 & 1,099 & 0,044 \\
\hline 48,2 & 2,0438 & & 0,1953 & 0,002 & & & & & ,0016 & & & & 37,4 & & 138 & & & 0,011 & 1,092 & 0,042 \\
\hline 9,1 & 2,1950 & & U, ¿৩০ & ,0025 & & & & 0,0852 & & & & 0,10 & 24,2 & & 69,4 & & $1,0 / 0$ & 0,013 & & \\
\hline
\end{tabular}




\begin{tabular}{|c|c|c|c|c|c|c|c|c|c|c|c|c|c|c|c|c|c|c|c|c|c|}
\hline 50,1 & 1,9407 & 0,047 & 0,1896 & 0,0022 & 0,99 & 5,2745 & 0,0621 & 0,0742 & 0,0023 & 0,1762 & 0,0516 & 0,15 & 16,2 & 44,6 & 61,8 & 0,722 & 1,119 & 0,012 & 1,048 & 0,064 & 106 \\
\hline 51,1 & 2,2432 & 0,0369 & 0,2073 & 0,002 & 0,99 & 4,8248 & 0,046 & 0,0785 & 0,0015 & 0,0293 & 0,0088 & 0,26 & 29,6 & 14,9 & 115 & 0,129 & 1,214 & 0,011 & 1,159 & 0,038 & 104 \\
\hline 52,1 & 3,1906 & 0,0564 & 0,2603 & 0,0031 & 0,97 & 3,8419 & 0,0462 & 0,0889 & 0,0018 & 0,1223 & 0,0307 & 0 & 13,6 & 25,8 & 50,9 & 0,507 & 1,491 & 0,016 & 1,402 & 0,04 & 106 \\
\hline 53,1 & 2,3003 & 0,0323 & 0,2088 & 0,0021 & 0,99 & 4,7883 & 0,0474 & 0,0799 & 0,0012 & 0,1001 & 0,0741 & 0,6 & 32,7 & 74,3 & 107 & 0,697 & 1,223 & 0,011 & 1,194 & 0,029 & 102 \\
\hline 54,1 & 5,7674 & 0,0605 & 0,3472 & 0,003 & 0,99 & 2,88 & 0,0249 & 0,1205 & 0,0013 & 0,1309 & 0,1151 & 0,04 & 81,1 & 166,8 & 155 & 1,076 & 1,921 & 0,014 & 1,963 & 0,021 & 97 \\
\hline 55,1 & 4,8758 & 0,0612 & 0,3299 & 0,0031 & 0,98 & 3,0311 & 0,0289 & 0,1072 & 0,0015 & 0,166 & 0,0758 & 0,33 & 32,6 & 70,8 & 68,9 & 1,028 & 1,838 & 0,015 & 1,752 & 0,029 & 104 \\
\hline 56,1 & 2,2708 & 0,4987 & 0,2123 & 0,0235 & 0,53 & 4,7093 & 0,5216 & 0,0776 & 0,0128 & 0,1624 & 0,0867 & 0,1 & 71,6 & 183,1 & 222 & 0,825 & 1,241 & 0,113 & 1,136 & 0,081 & 109 \\
\hline 57,1 & 3,0879 & 0,045 & 0,2576 & 0,0027 & 0,96 & 3,8824 & 0,0402 & 0,0869 & 0,0013 & 0,1953 & 0,0318 & 0,08 & 43,8 & 103,4 & 116 & 0,893 & 1,477 & 0,014 & 1,359 & 0,03 & 108 \\
\hline 58,1 & 5,5107 & 0,0726 & 0,3484 & 0,0035 & 0,95 & 2,8705 & 0,0288 & 0,1147 & 0,0017 & 0,2943 & 0,1972 & 0,08 & 65 & 206,4 & 137 & 1,511 & 1,927 & 0,017 & 1,876 & 0,027 & 102 \\
\hline 59,1 & 5,8546 & 0,0704 & 0,3474 & 0,0033 & 0,99 & 2,8788 & 0,0272 & 0,1222 & 0,0016 & 0,2231 & 0,0573 & 0,05 & 48,6 & 85,9 & 81 & 1,06 & 1,922 & 0,016 & 1,989 & 0,024 & 96 \\
\hline 60,1 & 2,6117 & 0,0351 & 0,2321 & 0,0022 & 0,99 & 4,309 & 0,0403 & 0,0816 & 0,0012 & 0,0687 & 0,0358 & 0,25 & 27,7 & 51,3 & 98,9 & 0,519 & 1,345 & 0,011 & 1,236 & 0,029 & 108 \\
\hline 60,2 & 2,5258 & 0,0336 & 0,2212 & 0,0021 & 0,98 & 4,5203 & 0,0434 & 0,0828 & 0,0012 & 0,1007 & 0,0394 & 0,38 & 31,1 & 92,9 & 143 & 0,652 & 1,288 & 0,011 & 1,265 & 0,029 & 101 \\
\hline 61,1 & 2,1564 & 0,0416 & 0,2042 & 0,0025 & 0,99 & 4,8968 & 0,0601 & 0,0766 & 0,0018 & 0,3505 & 0,1178 & 0 & 26,7 & 146,5 & 66,5 & 2,205 & 1,198 & 0,013 & 1,11 & 0,045 & 107 \\
\hline 62,1 & 1,7474 & 0,0265 & 0,1746 & 0,0018 & 0,99 & 5,7284 & 0,0579 & 0,0726 & 0,0014 & 0,1536 & 0,0817 & 3,27 & 31,3 & 118,3 & 128 & 0,921 & 1,037 & 0,01 & 1,003 & 0,041 & 103 \\
\hline 63,1 & 4,8888 & 0,0615 & 0,3293 & 0,0032 & 0,99 & 3,0365 & 0,0293 & 0,1077 & 0,0014 & 0,2297 & 0,055 & 0,16 & 58,3 & 118,2 & 108 & 1,094 & 1,835 & 0,015 & 1,76 & 0,025 & 104 \\
\hline
\end{tabular}

AMOSTRA SNA-201: metawacke (Unidade Santo Antônio - Nappe Andrelândia)

\begin{tabular}{|c|c|c|c|c|c|c|c|c|c|c|c|c|c|c|c|c|c|c|c|c|c|}
\hline Spot & $207 / 235$ & 1 sigma & 206/238 & 1sigma & Correl. & $238 / 206$ & 1sigma & $207 / 206$ & 1sigma & $208 / 206$ & 1sigma & $\begin{array}{c}\% \\
\text { Com.Pb }\end{array}$ & $\begin{array}{l}\mathrm{ppm} \\
\mathrm{Pb}\end{array}$ & $\begin{array}{l}\text { ppm } \\
\text { Th }\end{array}$ & $\stackrel{\mathrm{ppm}}{\mathrm{U}}$ & $\mathrm{Th} / \mathrm{U}$ & $\begin{array}{c}T \\
206 / 238\end{array}$ & $\begin{array}{c}1 \\
\text { sigma }\end{array}$ & $\begin{array}{c}T \\
207 / 206\end{array}$ & $\begin{array}{c}1 \\
\text { sigma }\end{array}$ & $\begin{array}{l}\% \\
\text { Conc. }\end{array}$ \\
\hline 1,1 & 0,9817 & 0,0384 & 0,1146 & 0,0022 & 0,14 & 8,7286 & 0,1639 & 0,0621 & 0,0024 & 0,1283 & 0,016 & 0,3 & 33,4 & 113,1 & 224 & 0,506 & 0,699 & 0,012 & 0,679 & 0,082 & 102 \\
\hline 2,1 & 1,3959 & 0,0676 & 0,1476 & 0,0032 & 0,86 & 6,7734 & 0,1473 & 0,0686 & 0,0033 & 0,0841 & 0,0096 & 1,09 & 12 & 19,2 & 65 & 0,296 & 0,888 & 0,018 & 0,886 & 0,094 & 100 \\
\hline 3,1 & 11,685 & 0,3009 & 0,4808 & 0,0079 & 0,66 & 2,0797 & 0,0342 & 0,1762 & 0,0039 & 0,2742 & 0,0038 & 0,13 & 60,8 & 76,9 & 78 & 0,989 & 2,531 & 0,035 & 2,618 & 0,037 & 96 \\
\hline 3,2 & 0,8258 & 0,0539 & 0,0998 & 0,0026 & 0,6 & 10,0249 & 0,2576 & 0,06 & 0,0042 & 0,0074 & 0,0099 & 2,41 & 8,1 & 0,8 & 69 & 0,012 & 0,613 & 0,015 & 0,605 & 0,148 & 101 \\
\hline 4,1 & 9,172 & 0,2451 & 0,4156 & 0,0073 & 0,01 & 2,4064 & 0,0421 & 0,1601 & 0,0037 & 0,2563 & 0,0038 & 0,23 & 50,7 & 70,9 & 76 & 0,932 & 2,24 & 0,033 & 2,456 & 0,041 & 91 \\
\hline 5,1 & 1,1862 & 0,0526 & 0,129 & 0,0026 & 0,95 & 7,752 & 0,1592 & 0,0667 & 0,0029 & 0,1268 & 0,0223 & 0 & 6,7 & 4,7 & 41 & 0,117 & 0,782 & 0,015 & 0,828 & 0,092 & 94 \\
\hline
\end{tabular}




\begin{tabular}{|c|c|c|c|c|c|c|c|c|c|c|c|c|c|c|c|c|c|c|c|c|c|}
\hline 6,1 & 0,8901 & 0,0309 & 0,1033 & 0,0018 & 0,01 & 9,6773 & 0,1685 & 0,0625 & 0,002 & 0,1318 & 0,008 & 0,2 & 30,1 & 88,6 & 220 & 0,403 & 0,634 & 0,011 & 0,69 & 0,07 & 91 \\
\hline 6,2 & 1,1769 & 0,0431 & 0,1297 & 0,0023 & 0,94 & 7,7108 & 0,1389 & 0,0658 & 0,0023 & 0,0908 & 0,0123 & 0,93 & 34,3 & 64,4 & 207 & 0,312 & 0,786 & 0,013 & 0,801 & 0,078 & 98 \\
\hline 7,1 & 1,4166 & 0,1084 & 0,1547 & 0,0046 & 0,02 & 6,4641 & 0,1933 & 0,0664 & 0,0057 & 0,0932 & 0,0218 & 3,75 & 6,4 & 9,3 & 32 & 0,287 & 0,927 & 0,026 & 0,819 & 0,172 & 113 \\
\hline 8,1 & 1,1181 & 0,054 & 0,1239 & 0,0027 & 0,44 & 8,0688 & 0,1734 & 0,0654 & 0,0032 & 0,2122 & 0,0175 & 0,69 & 18 & 72,4 & 104 & 0,699 & 0,753 & 0,015 & 0,788 & 0,103 & 95 \\
\hline 9,1 & 9,2484 & 0,2253 & 0,424 & 0,0064 & 0,94 & 2,3583 & 0,0358 & 0,1582 & 0,0031 & 0,1159 & 0,0057 & 0,06 & 110,9 & 69,4 & 184 & 0,377 & 2,279 & 0,029 & 2,436 & 0,033 & 93 \\
\hline 10,1 & 0,9803 & 0,1315 & 0,1201 & 0,005 & 0,13 & 8,3256 & 0,3488 & 0,0592 & 0,0088 & 0,091 & 0,0383 & 5,1 & 4,6 & 11,2 & 29 & 0,383 & 0,731 & 0,029 & 0,574 & 0,272 & 127 \\
\hline 11,1 & 1,1854 & 0,0452 & 0,132 & 0,0024 & 0,87 & 7,5739 & 0,1397 & 0,0651 & 0,0024 & 0,1636 & 0,0068 & 0,51 & 36,2 & 113 & 209 & 0,541 & 0,799 & 0,014 & 0,778 & 0,076 & 102 \\
\hline 12,1 & 4,9408 & 0,1237 & 0,2967 & 0,0052 & 0,98 & 3,3699 & 0,0585 & 0,1208 & 0,003 & 0,0789 & 0,0165 & 0,04 & 107 & 30,3 & 229 & 0,132 & 1,675 & 0,026 & 1,967 & 0,045 & 85 \\
\hline 12,2 & 1,3213 & 0,0641 & 0,1241 & 0,0032 & 0,99 & 8,0549 & 0,2106 & 0,0772 & 0,0025 & 0,0084 & 0,0027 & 0,11 & 133,8 & 10,9 & 323 & 0,034 & 0,754 & 0,017 & 1,126 & 0,045 & 66 \\
\hline 13,1 & 1,0622 & 0,0465 & 0,1205 & 0,0023 & 0,53 & 8,3002 & 0,1575 & 0,0639 & 0,003 & 0,1735 & 0,0102 & 0,77 & 24,9 & 82,7 & 160 & 0,516 & 0,733 & 0,013 & 0,74 & 0,1 & 99 \\
\hline 14,1 & 0,9113 & 0,0501 & 0,1064 & 0,0021 & 0,01 & 9,4028 & 0,1891 & 0,0621 & 0,0037 & 0,1676 & 0,0084 & 0,31 & 17,7 & 60,8 & 123 & 0,495 & 0,652 & 0,012 & 0,679 & 0,127 & 95 \\
\hline 15,1 & 1,1388 & 0,0415 & 0,1257 & 0,0023 & 0,89 & 7,9566 & 0,1472 & 0,0657 & 0,0025 & 0,092 & 0,0319 & 0,12 & 55,7 & 154,4 & 330 & 0,468 & 0,763 & 0,013 & 0,797 & 0,08 & 95 \\
\hline 16,1 & 1,0508 & 0,0851 & 0,1228 & 0,003 & 0,57 & 8,1421 & 0,1977 & 0,0621 & 0,0055 & 0,2012 & 0,0288 & 0,88 & 10,9 & 45,3 & 60 & 0,756 & 0,747 & 0,017 & 0,676 & 0,198 & 110 \\
\hline 17,1 & 0,9956 & 0,0777 & 0,1092 & 0,0026 & 0,43 & 9,1607 & 0,2149 & 0,0661 & 0,0055 & 0,1019 & 0,0598 & 0,55 & 11,8 & 54,6 & 77 & 0,709 & 0,668 & 0,015 & 0,811 & 0,19 & 82 \\
\hline 17,2 & 0,8465 & 0,069 & 0,1021 & 0,0026 & 0,49 & 9,7972 & 0,2476 & 0,0602 & 0,005 & 0,0104 & 0,0176 & 1,23 & 10,4 & 1,6 & 92 & 0,018 & 0,627 & 0,015 & 0,609 & 0,196 & 102 \\
\hline 18,1 & 0,9823 & 0,0505 & 0,1175 & 0,0023 & 0,42 & 8,5088 & 0,1677 & 0,0606 & 0,0034 & 0,1463 & 0,0159 & 0,18 & 16,9 & 61 & 110 & 0,557 & 0,716 & 0,013 & 0,626 & 0,117 & 114 \\
\hline 19,1 & 0,849 & 0,0785 & 0,1033 & 0,0025 & 0,01 & 9,6793 & 0,2339 & 0,0596 & 0,006 & 0,3602 & 0,0302 & 0,53 & 12,9 & 104 & 80 & 1,304 & 0,634 & 0,015 & 0,589 & 0,187 & 107 \\
\hline 20,1 & 1,363 & 0,034 & 0,144 & 0,0024 & 0,89 & 6,9462 & 0,1144 & 0,0687 & 0,0018 & 0,1004 & 0,0051 & 0,03 & 105,9 & 196,9 & 539 & 0,365 & 0,867 & 0,013 & 0,889 & 0,055 & 97 \\
\hline 21,1 & 15,3328 & 0,4434 & 0,4504 & 0,0099 & 0,99 & 2,2201 & 0,0486 & 0,2469 & 0,0067 & 0,1411 & 0,0396 & 1,1 & 77,4 & 79,9 & 114 & 0,703 & 2,397 & 0,043 & 3,165 & 0,043 & 75 \\
\hline 22,1 & 1,2305 & 0,0343 & 0,1336 & 0,0023 & 0,88 & 7,4857 & 0,1272 & 0,0668 & 0,002 & 0,0703 & 0,0025 & 0,09 & 71,9 & 103,7 & 423 & 0,245 & 0,808 & 0,013 & 0,832 & 0,061 & 97 \\
\hline 23,1 & 1,1424 & 0,0406 & 0,1294 & 0,0028 & 0,81 & 7,7307 & 0,1679 & 0,0641 & 0,0024 & 0,1417 & 0,0157 & 0,27 & 26,2 & 80,2 & 150 & 0,536 & 0,784 & 0,016 & 0,743 & 0,079 & 105 \\
\hline 24,1 & 1,2419 & 0,0391 & 0,1357 & 0,0029 & 0,53 & 7,3693 & 0,1554 & 0,0664 & 0,0022 & 0,0947 & 0,0042 & 0,11 & 51,1 & 86,8 & 292 & 0,298 & 0,82 & 0,016 & 0,818 & 0,069 & 100 \\
\hline 25,1 & 1,6553 & 0,0472 & 0,1666 & 0,0034 & 0,96 & 6,0038 & 0,1221 & 0,0721 & 0,0022 & 0,2982 & 0,0095 & 0,09 & 60,7 & 250,6 & 253 & 0,992 & 0,993 & 0,019 & 0,988 & 0,061 & 100 \\
\hline 26,1 & 0,8811 & 0,0324 & 0,1027 & 0,0022 & 0,01 & 9,7391 & 0,2129 & 0,0622 & 0,0024 & 0,1562 & 0,0195 & 0,43 & 23 & 82,9 & 166 & 0,5 & 0,63 & 0,013 & 0,682 & 0,082 & 92 \\
\hline 27,1 & 0,8196 & 0,0304 & 0,0979 & 0,0021 & 0,82 & 10,2096 & 0,2216 & 0,0607 & 0,0024 & 0,0037 & 0,0035 & 0,37 & 15,9 & 0,6 & 138 & 0,004 & 0,602 & 0,012 & 0,628 & 0,084 & 95 \\
\hline 28,1 & 0,9239 & 0,051 & 0,1089 & 0,0027 & 0,58 & 9,1866 & 0,2306 & 0,0616 & 0,0037 & 0,1905 & 0,0196 & 0,46 & 12,1 & 44,5 & 78 & 0,57 & 0,666 & 0,016 & 0,659 & 0,131 & 101 \\
\hline 28,2 & 0,8837 & 0,054 & 0,1069 & 0,0029 & 0,05 & 9,3588 & 0,251 & 0,06 & 0,0036 & 0,1027 & 0,3509 & 0,15 & 39,7 & 2,4 & 336 & 0,007 & 0,654 & 0,016 & 0,603 & 0,11 & 108 \\
\hline 29,1 & 1,8732 & 0,0894 & 0,1865 & 0,0045 & 0,74 & 5,3624 & 0,1295 & 0,0729 & 0,0038 & 0,1037 & 0,0289 & 0,64 & 11,8 & 21,9 & 50 & 0,442 & 1,102 & 0,024 & 1,01 & 0,101 & 109 \\
\hline 29,2 & 0,9705 & 0,0351 & 0,1136 & 0,0024 & 0,9 & 8,804 & 0,1845 & 0,062 & 0,0026 & 0,0119 & 0,0091 & 0,74 & 26,1 & 8,1 & 190 & 0,043 & 0,694 & 0,014 & 0,673 & 0,088 & 103 \\
\hline 30,1 & 1,4845 & 0,0515 & 0,1529 & 0,0033 & 0,41 & 6,5397 & 0,1432 & 0,0704 & 0,0026 & 0,1797 & 0,0102 & 1,3 & 23,4 & 67,5 & 111 & 0,607 & 0,917 & 0,019 & 0,94 & 0,076 & 97 \\
\hline
\end{tabular}




\begin{tabular}{|c|c|c|c|c|c|c|c|c|c|c|c|c|c|c|c|c|c|c|c|c|c|}
\hline 31,1 & 1,3897 & 0,0393 & 0,1486 & 0,003 & 0,81 & 6,7285 & 0,1372 & 0,0678 & 0,002 & 0,2595 & 0,0133 & 0,11 & 70,7 & 310,6 & 325 & 0,955 & 0,893 & 0,017 & 0,863 & 0,06 & 103 \\
\hline 32,1 & 1,6581 & ,0914 & 0,1663 & 0,0043 & 0,39 & 6,014 & 0,1557 & 0,0723 & 0,0042 & 0,1934 & 0,0831 & 0,54 & 16,1 & 49,6 & 67 & 0,739 & 0,992 & 0,024 & 0,995 & 0,113 & 99 \\
\hline 33,1 & 1,5473 & 0,0716 & 0,1578 & 0,0035 & 0,94 & 6,3362 & 0,1404 & 0,0711 & 0,0038 & 0,0509 & 0,0233 & 0,83 & 10,9 & 10,4 & 57 & 0,182 & 0,945 & 0,02 & 0,96 & 0,113 & 98 \\
\hline 34,1 & 1,3989 & 0,0371 & 0,1481 & 0,0017 & 0,95 & 6,7532 & 0,0768 & 0,0685 & 0,0018 & 0,0541 & 0,0061 & 0,18 & 98,8 & 93,3 & 598 & 0,156 & 0,89 & 0,009 & 0,884 & 0,054 & 100 \\
\hline 35,1 & 1,463 & 0,0623 & 0,1524 & 0,0022 & 0,73 & 6,5603 & 0,0954 & 0,0696 & 0,0031 & 0,0626 & 0,0359 & 0,16 & 34,5 & 55,6 & 178 & 0,313 & 0,915 & 0,012 & 0,917 & 0,093 & 99 \\
\hline 36,1 & 1,4413 & 0,0417 & 0,1495 & 0,0017 & 0,99 & 6,6907 & 0,0776 & 0,0699 & 0,0021 & 0,1417 & 0,0806 & 0,67 & 37,4 & 101,5 & 179 & 0,568 & 0,898 & 0,01 & 0,927 & 0,063 & 96 \\
\hline 37,1 & 1,246 & 0,0634 & 0,1358 & 0,0022 & 0,01 & 7,3628 & 0,117 & 0,0665 & 0,0036 & 0,2322 & 0,0486 & 0,2 & 29,2 & 164,2 & 136 & 1,203 & 0,821 & 0,012 & 0,823 & 0,111 & 99 \\
\hline 38,1 & 1,0477 & 0,0389 & 0,1204 & 0,0016 & 0,97 & 8,3026 & 0,1108 & 0,0631 & 0,0024 & 0,0958 & 0,0451 & 0,19 & 39,8 & 120,1 & 237 & 0,506 & 0,733 & 0,009 & 0,711 & 0,079 & 103 \\
\hline 39,1 & 1,8794 & 0,0733 & 0,1826 & 0,0026 & 0,93 & 5,4762 & 0,0766 & 0,0746 & 0,0031 & 0,271 & 0,0126 & 0 & 21,8 & 72,1 & 80 & 0,901 & 1,081 & 0,014 & 1,059 & 0,083 & 102 \\
\hline 40,1 & 1,2067 & 0,1358 & 0,1361 & 0,0036 & 0,23 & 7,35 & 0,1953 & 0,0643 & 0,0082 & 0,1822 & 0,0354 & 1,97 & 5 & 15,4 & 28 & 0,557 & 0,822 & 0,021 & 0,752 & 0,269 & 109 \\
\hline 41,1 & 0,8095 & 0,03 & 0,0973 & 0,0013 & 0,75 & 10,2781 & 0,134 & 0,0603 & 0,0023 & 0,0091 & 0,0116 & 0,73 & 31,4 & 0,8 & 267 & 0,003 & 0,599 & 0,007 & 0,616 & 0,087 & 97 \\
\hline 42,1 & 9,558 & 0,2229 & 0,4423 & 0,0053 & 0,99 & 2,261 & 0,0271 & 0,1567 & 0,0036 & 0,249 & 0,0442 & 0,25 & 62,2 & 92,3 & 84 & 1,102 & 2,361 & 0,024 & 2,421 & 0,04 & 97 \\
\hline 43,1 & 1,0244 & 0,0443 & 0,1173 & 0,0015 & 0,94 & 8,5249 & 0,1102 & 0,0633 & 0,0037 & 0,1284 & 0,0456 & 0,85 & 82,3 & 273,1 & 528 & 0,517 & 0,715 & 0,009 & 0,72 & 0,118 & 99 \\
\hline 44,1 & 0,9201 & 0,0237 & 0,1083 & 0,0012 & 0,98 & 9,2302 & 0,1012 & 0,0616 & 0,0016 & 0,1107 & 0,0468 & 0,22 & 73,7 & 222,8 & 506 & 0,441 & 0,663 & 0,007 & 0,66 & 0,055 & 100 \\
\hline 45,1 & 5,7185 & 0,1258 & 0,3401 & 0,0038 & 0,92 & 2,9406 & 0,0327 & 0,122 & 0,0025 & 0,0964 & 0,0108 & 0,02 & 134,9 & 116,6 & 277 & 0,421 & 1,887 & 0,018 & 1,985 & 0,036 & 95 \\
\hline 46,1 & 6,7209 & 0,1831 & 0,3724 & 0,0049 & 0,87 & 2,685 & 0,0353 & 0,1309 & 0,0035 & 0,2946 & 0,009 & 0,07 & 43,2 & 73,1 & 74 & 0,994 & 2,041 & 0,023 & 2,11 & 0,048 & 96 \\
\hline 47,1 & 1,0551 & 0,0429 & 0,1189 & 0,0023 & 0,52 & 8,4134 & 0,1601 & 0,0644 & 0,0027 & 0,0986 & 0,0313 & 0,21 & 18,4 & 42,3 & 121 & 0,351 & 0,724 & 0,013 & 0,754 & 0,089 & 96 \\
\hline 48,1 & 1,1337 & 0,0442 & 0,1253 & 0,0024 & 0,44 & 7,9823 & 0,1524 & 0,0656 & 0,0026 & 0,1444 & 0,0195 & 0,1 & 29,6 & 94,5 & 174 & 0,545 & 0,761 & 0,014 & 0,795 & 0,085 & 95 \\
\hline 48,2 & 1,5901 & 0,0523 & 0,1609 & 0,0028 & 0,99 & 6,2134 & 0,1088 & 0,0717 & 0,0024 & 0,1569 & 0,0587 & 0,03 & 34,3 & 93,6 & 161 & 0,582 & 0,962 & 0,016 & 0,976 & 0,07 & 98 \\
\hline 49,1 & 1,1877 & 0,0767 & 0,1302 & 0,0033 & 0,52 & 7,6789 & 0,1953 & 0,0661 & 0,0045 & 0,0968 & 0,0143 & 0,49 & 12,1 & 26,5 & 75 & 0,354 & 0,789 & 0,019 & 0,811 & 0,141 & 97 \\
\hline 50,1 & 1,2148 & 0,0699 & 0,1274 & 0,003 & 0,91 & 7,8463 & 0,1862 & 0,0691 & 0,0046 & 0,1291 & 0,0488 & 0,2 & 13,1 & 35,7 & 74 & 0,482 & 0,773 & 0,017 & 0,903 & 0,141 & 85 \\
\hline 51,1 & 1,0871 & 0,0522 & 121 & 0,0026 & 0,89 & 8,2652 & 0,1742 & 0,0652 & 0,0033 & 0,1633 & 0,0624 & 0,29 & 21,3 & 92,4 & 125 & 0,741 & 0,736 & 0,015 & 0,78 & 0,108 & 94 \\
\hline 52,1 & 1,248 & 0,0844 & 0,1327 & 0,0035 & 0,56 & 7,5356 & 0,1974 & 0,0682 & 0,005 & 0,1795 & 0,0161 & 0,57 & 11 & 37,1 & 57 & 0,649 & 0,803 & 0,02 & 0,875 & 0,15 & 91 \\
\hline 53,1 & 1,0258 & 0,0288 & 0,1165 & 0,0019 & 0,8 & 8,5818 & 0,1408 & 0,0638 & 0,0017 & 0,0686 & 0,0091 & 1,2 & 101,2 & 177,6 & 715 & 0,249 & 0,711 & 0,011 & 0,737 & 0,058 & 96 \\
\hline 54,1 & 1,1422 & 0,032 & 0,1284 & 0,002 & 0,99 & 7,7894 & 0,124 & 0,0645 & 0,0019 & 0,0643 & 0,0135 & 0 & 73,6 & 130,8 & 478 & 0,274 & 0,779 & 0,012 & 0,759 & 0,062 & 102 \\
\hline 55,1 & 1,3146 & 0,0591 & 0,1406 & 0,0029 & 0,61 & 7,1143 & 0,146 & 0,0678 & 0,0032 & 0,409 & 0,0192 & 0,27 & 25,5 & 156,1 & 112 & 1,395 & 0,848 & 0,016 & 0,863 & 0,096 & 98 \\
\hline 56,1 & 1,0767 & 0,0331 & 0,1218 & 0,002 & 0,86 & 8,2114 & 0,1379 & 0,0641 & 0,0019 & 0,2056 & 0,0097 & 0,13 & 42,9 & 177,8 & 258 & 0,688 & 0,741 & 0,012 & 0,746 & 0,064 & 99 \\
\hline 57,1 & 0,8322 & 0,0271 & 0,1001 & 0,0017 & 0,75 & 9,9907 & 0,1683 & 0,0603 & 0,002 & 0,0034 & 0,0036 & 0 & 38,7 & 1,9 & 338 & 0,006 & 0,615 & 0,01 & 0,614 & 0,07 & 100 \\
\hline 58,1 & 0,9988 & 0,0981 & 0,1137 & 0,0037 & 0,31 & 8,7932 & 0,2839 & 0,0637 & 0,007 & 0,0761 & 0,0293 & 0,31 & 6,4 & 11,3 & 45 & 0,252 & 0,694 & 0,021 & 0,732 & 0,235 & 94 \\
\hline
\end{tabular}


AMOSTRA SNA-205B: anfibolito retroeclogítico (Nappe Liberdade)

\begin{tabular}{|c|c|c|c|c|c|c|c|c|c|c|c|c|c|c|c|c|c|c|c|c|c|}
\hline Spot & 207/235 & 1sigma & $206 / 238$ & 1sigma & Correl. & $238 / 206$ & 1 sigma & $207 / 206$ & 1 sigma & $208 / 206$ & 1sigma & $\stackrel{\%}{\text { Com.Pb }}$ & $\begin{array}{c}\mathrm{ppm} \\
\mathrm{Pb}\end{array}$ & $\begin{array}{l}\text { ppm } \\
\text { Th }\end{array}$ & $\stackrel{\mathrm{ppm}}{\mathrm{U}}$ & $\mathrm{Th} / \mathrm{U}$ & $\begin{array}{c}T \\
206 / 238\end{array}$ & $\begin{array}{c}1 \\
\text { sigma }\end{array}$ & $\begin{array}{c}T \\
207 / 206\end{array}$ & $\begin{array}{c}1 \\
\text { sigma }\end{array}$ & $\begin{array}{c}\% \\
\text { Conc. }\end{array}$ \\
\hline 1,1 & 0,8873 & ,0176 & 0,1063 & 0,0013 & 0,8600 & 9,4065 & 1147 & 0,0605 & 0,0013 & 0,0089 & 0,0020 & 0,08 & 120 & 25 & 1053 & 0,02 & 0,651 & ,008 & 0,623 & 0,046 & 104 \\
\hline 2,1 & 1,0368 & 0,0293 & 0,1077 & 0,0015 & 0,9600 & 9,2854 & 0,1335 & 0,0698 & 0,0021 & 0,0341 & 0,0142 & 6,51 & 53 & 18 & 379 & 0,05 & 0,659 & 0,009 & 0,923 & 0,063 & 71 \\
\hline 3,1 & 6,5380 & 0,1177 & 0,3793 & 0,0049 & 0,4400 & 2,6366 & 0,0343 & 0,1250 & 0,0022 & 0,1022 & 0,0119 & 3,69 & 29 & 18 & 51 & 0,36 & 2,073 & 0,023 & 2,029 & 0,031 & 102 \\
\hline 4,1 & 5,7833 & 0,2158 & 0,3418 & 0,0069 & 0,8600 & 2,9258 & 0,0593 & 0,1227 & 0,0050 & 0,2376 & 0,0125 & 0,89 & 17 & 24 & 33 & 0,71 & 1,895 & 0,033 & 1,996 & 0,074 & 94 \\
\hline 5,1 & 1,0907 & 0,0308 & 0,1252 & 0,0017 & 0,7800 & 7,9890 & 0,1089 & 0,0632 & 0,0020 & 0,0024 & 0,0026 & 0,42 & 42 & 2 & 322 & 0,01 & 0,760 & 0,010 & 0,715 & 0,065 & 106 \\
\hline 6,1 & 6,3911 & 0,1946 & 0,3645 & 0,0065 & 0,8200 & 2,7432 & 0,0489 & 0,1272 & 0,0043 & 0,1703 & 0,0089 & 0,99 & 27 & 29 & 52 & 0,55 & 2,004 & 0,031 & 2,059 & 0,060 & 97 \\
\hline 7,1 & 1,1367 & 0,0207 & 0,1261 & 0,0015 & 0,9900 & 7,9283 & 0,0954 & 0,0654 & 0,0013 & 0,0032 & 0,0018 & 0,16 & 168 & 7 & 1215 & 0,01 & 0,766 & 0,009 & 0,786 & 0,039 & 97 \\
\hline 8,1 & 1,1199 & 0,0218 & 0,1287 & 0,0015 & 0,8600 & 7,7699 & 0,0935 & 0,0631 & 0,0013 & 0,0022 & 0,0013 & 0,04 & 130 & 4 & 974 & 0,00 & 0,780 & 0,009 & 0,712 & 0,044 & 109 \\
\hline 9,1 & 1,3747 & 0,0247 & 0,1491 & 0,0018 & 0,9300 & 6,7060 & 0,0801 & 0,0669 & 0,0013 & 0,0020 & 0,0010 & 0,06 & 188 & 6 & 1177 & 0,01 & 0,896 & 0,010 & 0,833 & 0,040 & 107 \\
\hline 10,1 & 7,1502 & 0,1473 & 0,3963 & 0,0055 & 0,6100 & 2,5231 & 0,0348 & 0,1308 & 0,0029 & 0,0883 & 0,0041 & 0,16 & 63 & 30 & 127 & 0,23 & 2,152 & 0,025 & 2,109 & 0,038 & 102 \\
\hline 11,1 & 1,0985 & 0,0191 & 0,1245 & 0,0015 & 0,6600 & 8,0303 & 0,0942 & 0,0640 & 0,0012 & 0,0036 & 0,0011 & 0,12 & 182 & 12 & 1292 & 0,01 & 0,757 & 0,008 & 0,741 & 0,039 & 102 \\
\hline 12,1 & 0,8693 & 0,0181 & 0,1055 & 0,0013 & 0,7700 & 9,4781 & 0,1153 & 0,0598 & 0,0014 & 0,0065 & 0,0013 & 0,22 & 99 & 15 & 856 & 0,02 & 0,647 & 0,007 & 0,595 & 0,049 & 108 \\
\hline 13,1 & 0,8302 & 0,0185 & 0,1006 & 0,0013 & 0,2600 & 9,9426 & 0,1245 & 0,0599 & 0,0015 & 0,0113 & 0,0024 & 0,39 & 71 & 18 & 633 & 0,03 & 0,618 & 0,007 & 0,599 & 0,053 & 103 \\
\hline 14,1 & 1,4560 & 0,0274 & 0,1512 & 0,0015 & 0,9900 & 6,6143 & 0,0659 & 0,0698 & 0,0012 & 0,0036 & 0,0013 & 0,26 & 192 & 8 & 1204 & 0,01 & 0,908 & 0,008 & 0,924 & 0,035 & 98 \\
\hline 15,1 & 0,8592 & 0,0184 & 0,1029 & 0,0011 & 0,7600 & 9,7143 & 0,1018 & 0,0605 & 0,0012 & 0,0020 & 0,0013 & 0,07 & 122 & 6 & 1097 & 0,01 & 0,632 & 0,006 & 0,623 & 0,042 & 101 \\
\hline 16,1 & 0,9225 & 0,0206 & 0,1117 & 0,0012 & 0,9500 & 8,9491 & 0,0939 & 0,0599 & 0,0013 & 0,0044 & 0,0017 & 0,12 & 131 & 18 & 1098 & 0,02 & 0,683 & 0,007 & 0,599 & 0,046 & 113 \\
\hline 17,1 & 1,3465 & 0,0256 & 0,1465 & 0,0015 & 0,9600 & 6,8259 & 0,0688 & 0,0667 & 0,0011 & 0,0029 & 0,0010 & 0,26 & 170 & 8 & 1074 & 0,01 & 0,881 & 0,008 & 0,827 & 0,036 & 106 \\
\hline 18,1 & 1,0312 & 0,0218 & 0,1201 & 0,0013 & 0,9500 & 8,3251 & 0,0870 & 0,0623 & 0,0012 & 0,0028 & 0,0016 & 0,19 & 137 & 6 & 1071 & 0,01 & 0,731 & 0,007 & 0,683 & 0,041 & 107 \\
\hline 19,1 & 9,2262 & 0,1875 & 0,4399 & 0,0051 & 0,9100 & 2,2733 & 0,0261 & 0,1521 & 0,0028 & 0,1225 & 0,0028 & 0,08 & 86 & 50 & 149 & 0,33 & 2,350 & 0,023 & 2,370 & 0,032 & 99 \\
\hline 20,1 & 1,1692 & 0,0236 & 0,1338 & 0,0014 & 0,3900 & 7,4727 & 0,0769 & 0,0634 & 0,0011 & 0,0022 & 0,0011 & 0,06 & 202 & 9 & 1418 & 0,01 & 0,810 & 0,008 & 0,721 & 0,037 & 112 \\
\hline 21,1 & 1,0965 & 0,0267 & 0,1284 & 0,0014 & 0,9300 & 7,7904 & 0,0854 & 0,0620 & 0,0015 & 0,0058 & 0,0026 & 0,15 & 89 & 16 & 629 & 0,03 & 0,779 & 0,008 & 0,672 & 0,051 & 115 \\
\hline 22,1 & 0,8766 & 0,0183 & 0,1054 & 0,0011 & 0,9500 & 9,4870 & 0,0991 & 0,0603 & 0,0012 & 0,0068 & 0,0015 & 0,21 & 146 & 19 & 1209 & 0,02 & 0,646 & 0,006 & 0,615 & 0,041 & 105 \\
\hline 23,1 & 0,8611 & 0,0188 & 0,1036 & 0,0011 & 0,0100 & 9,6564 & 0,1020 & 0,0603 & 0,0012 & 0,0062 & 0,0018 & 0,13 & 112 & 14 & 1009 & 0,01 & 0,635 & 0,006 & 0,615 & 0,043 & 103 \\
\hline 24,1 & 1,1962 & 0,0221 & 0,1336 & 0,0013 & 0,8300 & 7,4874 & 0,0744 & 0,0650 & 0,0011 & 0,0033 & 0,0009 & 0,09 & 181 & 10 & 1238 & 0,01 & 0,808 & 0,008 & 0,773 & 0,035 & 104 \\
\hline 25,1 & 1,1879 & 0,0243 & 0,1317 & 0,0014 & 0,9900 & 7,5907 & 0,0796 & 0,0654 & 0,0012 & 0,0060 & 0,0054 & 0,22 & 171 & 25 & 1078 & 0,02 & 0,798 & 0,008 & 0,787 & 0,036 & 101 \\
\hline 26,1 & 1,0900 & 0,0228 & 0,1252 & 0,0013 & 0,9800 & 7,9879 & 0,0850 & 0,0631 & 0,0012 & 0,0079 & 0,0011 & 0,23 & 195 & 30 & 1363 & 0,02 & 0,760 & 0,008 & 0,713 & 0,040 & 106 \\
\hline
\end{tabular}


$\begin{array}{llllllllllllllllllllll}27,1 & 3,4231 & 0,1248 & 0,2680 & 0,0040 & 0,7500 & 3,7319 & 0,0553 & 0,0927 & 0,0036 & 0,1495 & 0,0288 & 0,84 & 51 & 114 & 147 & 0,77 & 1,530 & 0,020 & 1,481 & 0,075 & 103\end{array}$

$\begin{array}{llllllllllllllllllllllll}28,1 & 3,3495 & 0,0913 & 0,2624 & 0,0032 & 0,5900 & 3,8115 & 0,0458 & 0,0926 & 0,0026 & 0,2690 & 0,0258 & 0,06 & 51 & 93 & 137 & 0,68 & 1,502 & 0,016 & 1,480 & 0,053 & 101\end{array}$

$\begin{array}{lllllllllllllllllllllll}29,1 & 2,9518 & 0,1103 & 0,2387 & 0,0035 & 0,3600 & 4,1887 & 0,0620 & 0,0897 & 0,0035 & 0,1581 & 0,0332 & 0,17 & 12 & 10 & 40 & 0,25 & 1,380 & 0,018 & 1,419 & 0,078 & 97\end{array}$

$\begin{array}{llllllllllllllllllllllll}30,1 & 3,1030 & 0,1033 & 0,2445 & 0,0034 & 0,6300 & 4,0901 & 0,0563 & 0,0920 & 0,0032 & 0,1767 & 0,0241 & 0,51 & 42 & 62 & 128 & 0,49 & 1,410 & 0,017 & 1,468 & 0,067 & 96\end{array}$

$\begin{array}{lllllllllllllllllllllllll}31,1 & 3,2424 & 0,0942 & 0,2512 & 0,0032 & 0,6400 & 3,9807 & 0,0502 & 0,0936 & 0,0029 & 0,2096 & 0,0096 & 0,16 & 53 & 87 & 153 & 0,57 & 1,445 & 0,016 & 1,500 & 0,060 & 96\end{array}$

$\begin{array}{lllllllllllllllllllllll}32,1 & 3,1319 & 0,1148 & 0,2454 & 0,0036 & 0,0200 & 4,0752 & 0,0597 & 0,0926 & 0,0037 & 0,1774 & 0,0144 & 1,10 & 19 & 23 & 59 & 0,39 & 1,415 & 0,019 & 1,479 & 0,075 & 95\end{array}$

$\begin{array}{llllllllllllllllllllll}33,1 & 3,2501 & 0,1216 & 0,2531 & 0,0038 & 0,6900 & 3,9518 & 0,0590 & 0,0932 & 0,0038 & 0,1590 & 0,0198 & 0,77 & 15 & 14 & 46 & 0,31 & 1,454 & 0,019 & 1,491 & 0,078 & 97\end{array}$

$\begin{array}{llllllllllllllllllllll}34,1 & 7,1862 & 0,1451 & 0,4095 & 0,0042 & 0,6800 & 2,4418 & 0,0249 & 0,1273 & 0,0026 & 0,1019 & 0,0125 & 0,14 & 90 & 57 & 181 & 0,31 & 2,213 & 0,019 & 2,061 & 0,035 & 107\end{array}$

$\begin{array}{lllllllllllllllllllllllll}35,1 & 3,2703 & 0,1948 & 0,2512 & 0,0055 & 0,1300 & 3,9808 & 0,0876 & 0,0944 & 0,0062 & 0,0935 & 0,0223 & 2,23 & 9 & 7 & 31 & 0,22 & 1,445 & 0,029 & 1,516 & 0,129 & 95\end{array}$

$\begin{array}{lllllllllllllllllllllll}36,1 & 0,8147 & 0,1680 & 0,0985 & 0,0043 & 0,4300 & 10,1545 & 0,4460 & 0,0600 & 0,0136 & 0,0256 & 0,0336 & 2,29 & 3 & 3 & 27 & 0,13 & 0,605 & 0,025 & 0,604 & 0,419 & 100\end{array}$

$\begin{array}{lllllllllllllllllllllll}37,1 & 0,8228 & 0,1687 & 0,0962 & 0,0042 & 0,2900 & 10,3980 & 0,4517 & 0,0621 & 0,0146 & 0,0376 & 0,0473 & 6,26 & 4 & 2 & 27 & 0,06 & 0,592 & 0,025 & 0,676 & 0,417 & 87\end{array}$

$\begin{array}{lllllllllllllllllllllll}38,1 & 3,3714 & 0,1187 & 0,2657 & 0,0038 & 0,6100 & 3,7639 & 0,0534 & 0,0920 & 0,0035 & 0,1738 & 0,0246 & 0,43 & 20 & 18 & 59 & 0,31 & 1,519 & 0,019 & 1,468 & 0,072 & 103\end{array}$

$\begin{array}{llllllllllllllllllllllll}39,1 & 6,5214 & 0,1743 & 0,3693 & 0,0048 & 0,8500 & 2,7077 & 0,0351 & 0,1281 & 0,0036 & 0,1034 & 0,0115 & 0,25 & 37 & 23 & 80 & 0,28 & 2,026 & 0,023 & 2,072 & 0,050 & 97\end{array}$

$\begin{array}{llllllllllllllllllllll}40,1 & 1,0368 & 0,0221 & 0,1177 & 0,0011 & 0,4100 & 8,4961 & 0,0789 & 0,0639 & 0,0014 & 0,0027 & 0,0012 & 0,15 & 116 & 6 & 872 & 0,01 & 0,717 & 0,006 & 0,738 & 0,045 & 97\end{array}$

$\begin{array}{lllllllllllllllllllllll}41,1 & 1,1735 & 0,0236 & 0,1315 & 0,0012 & 0,9900 & 7,6045 & 0,0672 & 0,0647 & 0,0014 & 0,0016 & 0,0014 & 0,04 & 173 & 5 & 1139 & 0,00 & 0,796 & 0,007 & 0,765 & 0,046 & 104\end{array}$

$\begin{array}{llllllllllllllllllllllll}42,1 & 1,1519 & 0,0232 & 0,1280 & 0,0012 & 0,9100 & 7,8100 & 0,0706 & 0,0652 & 0,0013 & 0,0027 & 0,0009 & 0,06 & 164 & 10 & 1101 & 0,01 & 0,777 & 0,007 & 0,782 & 0,042 & 99\end{array}$

$\begin{array}{llllllllllllllllllllllll}43,1 & 0,9254 & 0,0213 & 0,1109 & 0,0011 & 0,9900 & 9,0212 & 0,0870 & 0,0605 & 0,0015 & 0,0067 & 0,0035 & 0,16 & 230 & 18 & 1547 & 0,01 & 0,678 & 0,006 & 0,623 & 0,053 & 108\end{array}$

$\begin{array}{llllllllllllllllllllllll}44,1 & 1,1544 & 0,0240 & 0,1284 & 0,0012 & 0,9400 & 7,7854 & 0,0722 & 0,0652 & 0,0013 & 0,0023 & 0,0009 & 0,07 & 142 & 8 & 926 & 0,01 & 0,779 & 0,007 & 0,780 & 0,043 & 99\end{array}$

$\begin{array}{lllllllllllllllllllllll}45,1 & 1,0267 & 0,0227 & 0,1198 & 0,0011 & 0,8600 & 8,3496 & 0,0791 & 0,0622 & 0,0014 & 0,0012 & 0,0010 & 0,15 & 138 & 6 & 1046 & 0,01 & 0,729 & 0,007 & 0,680 & 0,046 & 107\end{array}$

$\begin{array}{llllllllllllllllllllllll}46,1 & 0,8962 & 0,0204 & 0,1076 & 0,0010 & 0,8900 & 9,2950 & 0,0889 & 0,0604 & 0,0014 & 0,0022 & 0,0017 & 0,33 & 103 & 8 & 853 & 0,01 & 0,659 & 0,006 & 0,618 & 0,050 & 106\end{array}$

$\begin{array}{lllllllllllllllllllllllll}47,1 & 0,8538 & 0,0181 & 0,1017 & 0,0009 & 0,9000 & 9,8304 & 0,0899 & 0,0609 & 0,0013 & 0,0079 & 0,0021 & 0,06 & 111 & 18 & 986 & 0,02 & 0,625 & 0,005 & 0,635 & 0,046 & 98\end{array}$

$\begin{array}{llllllllllllllllllllllll}48,1 & 0,8493 & 0,0203 & 0,1031 & 0,0010 & 0,4500 & 9,7032 & 0,0947 & 0,0598 & 0,0015 & 0,0035 & 0,0014 & 0,07 & 94 & 10 & 808 & 0,01 & 0,632 & 0,006 & 0,595 & 0,053 & 106\end{array}$

$\begin{array}{llllllllllllllllllllllll}49,1 & 0,9224 & 0,0203 & 0,1102 & 0,0010 & 0,9700 & 9,0761 & 0,0852 & 0,0607 & 0,0013 & 0,0025 & 0,0012 & 0,08 & 122 & 7 & 940 & 0,01 & 0,674 & 0,006 & 0,629 & 0,046 & 107\end{array}$

$\begin{array}{llllllllllllllllllllllll}50,1 & 1,1423 & 0,0247 & 0,1282 & 0,0012 & 0,9300 & 7,7977 & 0,0730 & 0,0646 & 0,0014 & 0,0030 & 0,0015 & 0,32 & 101 & 11 & 694 & 0,02 & 0,778 & 0,007 & 0,761 & 0,045 & 102\end{array}$

$\begin{array}{lllllllllllllllllllllllll}51,1 & 1,1313 & 0,0232 & 0,1186 & 0,0011 & 0,9900 & 8,4284 & 0,0776 & 0,0692 & 0,0014 & 0,0077 & 0,0012 & 0,08 & 132 & 20 & 1124 & 0,02 & 0,723 & 0,006 & 0,903 & 0,044 & 80\end{array}$

$\begin{array}{lllllllllllllllllllllllll}52,1 & 0,8596 & 0,0200 & 0,1049 & 0,0010 & 0,0500 & 9,5325 & 0,0902 & 0,0594 & 0,0014 & 0,0035 & 0,0018 & 0,11 & 107 & 9 & 885 & 0,01 & 0,643 & 0,006 & 0,583 & 0,050 & 110\end{array}$

$\begin{array}{llllllllllllllllllllllll}53,1 & 1,1647 & 0,0224 & 0,1299 & 0,0013 & 0,9300 & 7,6957 & 0,0796 & 0,0650 & 0,0012 & 0,0017 & 0,0009 & 0,18 & 130 & 6 & 934 & 0,01 & 0,788 & 0,008 & 0,775 & 0,039 & 101\end{array}$

$\begin{array}{lllllllllllllllllllllllll}54,1 & 1,2595 & 0,0242 & 0,1318 & 0,0014 & 0,9900 & 7,5895 & 0,0785 & 0,0693 & 0,0013 & 0,0432 & 0,0163 & 0,12 & 153 & 42 & 1046 & 0,04 & 0,798 & 0,008 & 0,908 & 0,038 & 87\end{array}$

$\begin{array}{lllllllllllllllllllllllll}55,1 & 0,8965 & 0,0193 & 0,1081 & 0,0012 & 0,8100 & 9,2542 & 0,1011 & 0,0602 & 0,0013 & 0,0094 & 0,0018 & 0,15 & 76 & 17 & 632 & 0,03 & 0,661 & 0,007 & 0,610 & 0,047 & 108\end{array}$

$\begin{array}{llllllllllllllllllllllll}56,1 & 1,0671 & 0,0208 & 0,1222 & 0,0013 & 0,8200 & 8,1813 & 0,0845 & 0,0633 & 0,0012 & 0,0029 & 0,0011 & 0,08 & 136 & 7 & 959 & 0,01 & 0,743 & 0,007 & 0,719 & 0,042 & 103\end{array}$ 


\begin{tabular}{|c|c|c|c|c|c|c|c|c|c|c|c|c|c|c|c|c|c|c|c|c|c|}
\hline 57,1 & 1,2623 & 0,0253 & 0,1395 & 0,0015 & 0,8800 & 7,1673 & 0,0766 & 0,0656 & 0,0013 & 0,0031 & 0,0017 & 0,12 & 124 & 11 & 808 & 0,01 & 0,842 & 0,008 & 0,794 & 0,041 & 106 \\
\hline 58,1 & 1,1489 & 0,0222 & 0,1313 & 0,0014 & 0,9800 & 7,6141 & 0,0786 & 0,0634 & 0,0012 & 0,0019 & 0,0009 & 0,17 & 121 & 6 & 923 & 0,01 & 0,795 & 0,008 & 0,723 & 0,040 & 109 \\
\hline 59,1 & 6,5786 & 0,1632 & 0,3572 & 0,0053 & 0,9300 & 2,7998 & 0,0413 & 0,1336 & 0,0035 & 0,0957 & 0,0112 & 1,37 & 35 & 28 & 78 & 0,36 & 1,969 & 0,025 & 2,146 & 0,047 & 91 \\
\hline 60,1 & 1,0572 & 0,0204 & 0,1211 & 0,0012 & 0,8900 & 8,2602 & 0,0850 & 0,0633 & 0,0012 & 0,0022 & 0,0012 & 0,05 & 132 & 7 & 974 & 0,01 & 0,737 & 0,007 & 0,720 & 0,039 & 102 \\
\hline 61,1 & 1,4652 & 0,0271 & 0,1517 & 0,0016 & 0,9000 & 6,5931 & 0,0677 & 0,0701 & 0,0012 & 0,0040 & 0,0020 & 0,03 & 180 & 7 & 1144 & 0,01 & 0,910 & 0,009 & 0,930 & 0,036 & 97 \\
\hline 62,1 & 1,1192 & 0,0211 & 0,1268 & 0,0013 & 0,8300 & 7,8840 & 0,0800 & 0,0640 & 0,0011 & 0,0022 & 0,0008 & 0,17 & 200 & 8 & 1405 & 0,01 & 0,770 & 0,007 & 0,742 & 0,037 & 103 \\
\hline 63,1 & 0,8233 & 0,0159 & 0,0997 & 0,0010 & 0,7600 & 10,0287 & 0,1027 & 0,0599 & 0,0011 & 0,0056 & 0,0010 & $0,0 /$ & 163 & 27 & 1445 & 0,02 & 0,613 & 0,006 & 0,599 & 0,040 & 102 \\
\hline 64,1 & 1,2037 & 0,0221 & 0,1328 & 0,0013 & 0,3300 & 7,5278 & 0,0753 & 0,0657 & 0,0012 & 0,0019 & 0,0011 & 0,03 & 190 & 7 & 1259 & 0,01 & 0,804 & 0,008 & 0,797 & 0,037 & 100 \\
\hline 65,1 & 1,2773 & 0,0240 & 0,1373 & 0,0014 & 0,9700 & 7,2821 & 0,0747 & 0,0675 & 0,0012 & 0,0018 & 0,0009 & 0,10 & 141 & 4 & 941 & 0,01 & 0,830 & 0,008 & 0,852 & 0,038 & 97 \\
\hline
\end{tabular}

\section{AMOSTRA SNA-213: metapsamito (Unidade Serra da Boa Vista - Nappe Andrelândia)}

\begin{tabular}{|c|c|c|c|c|c|c|c|c|c|c|c|c|c|c|c|c|c|c|c|c|c|}
\hline Spot & $207 / 235$ & 1sigma & $206 / 238$ & 1sigma & Correl. & $238 / 206$ & 1sigma & $207 / 206$ & 1sigma & $208 / 206$ & 1sigma & $\stackrel{\%}{\text { Com.Pb }}$ & $\begin{array}{c}\mathrm{ppm} \\
\mathrm{Pb}\end{array}$ & $\begin{array}{l}\text { ppm } \\
\text { Th }\end{array}$ & $\stackrel{\mathrm{ppm}}{\mathrm{U}}$ & Th/U & $\begin{array}{c}T \\
206 / 238\end{array}$ & $\begin{array}{c}1 \\
\text { sigma }\end{array}$ & $\begin{array}{c}T \\
207 / 206\end{array}$ & $\begin{array}{c}1 \\
\text { sigma }\end{array}$ & $\begin{array}{c}\% \\
\text { Conc. }\end{array}$ \\
\hline 1,1 & 2,5035 & 0,0781 & 0,2128 & 0,0029 & 0,9000 & 4,6987 & 0,0636 & 0,0853 & 0,0024 & 0,0114 & 0,0022 & 0,29 & 70 & 10 & 289 & 0,04 & 1,244 & 0,015 & 1,323 & 0,053 & 94 \\
\hline 2,1 & 6,8937 & 0,2028 & 0,3790 & 0,0053 & 0,9100 & 2,6387 & 0,0370 & 0,1319 & 0,0033 & 0,1512 & 0,0423 & 0,30 & 114 & 139 & 220 & 0,63 & 2,071 & 0,025 & 2,124 & 0,044 & 97 \\
\hline 3,1 & 6,9264 & 0,1991 & 0,3714 & 0,0051 & 0,9700 & 2,6927 & 0,0370 & 0,1353 & 0,0034 & 0,1654 & 0,0112 & 0,30 & 107 & 101 & 230 & 0,44 & 2,036 & 0,024 & 2,167 & 0,043 & 93 \\
\hline 4,1 & 2,2993 & 0,0641 & 0,2009 & 0,0026 & 0,7700 & 4,9768 & 0,0632 & 0,0830 & 0,0019 & 0,0278 & 0,0041 & 1,76 & 152 & 86 & 718 & 0,12 & 1,180 & 0,014 & 1,269 & 0,045 & 93 \\
\hline 5,1 & 2,9658 & 0,0888 & 0,2412 & 0,0032 & 0,9700 & 4,1455 & 0,0557 & 0,0892 & 0,0024 & 0,1059 & 0,0043 & 0,37 & 82 & 87 & 307 & 0,28 & 1,393 & 0,017 & 1,408 & 0,052 & 98 \\
\hline 6,1 & 4,9774 & 0,1311 & 0,3221 & 0,0040 & 0,9990 & 3,1051 & 0,0388 & 0,1121 & 0,0028 & 0,1280 & 0,0188 & 0,25 & 97 & 107 & 237 & 0,45 & 1,800 & 0,020 & 1,834 & 0,046 & 98 \\
\hline 7,1 & 1,4985 & 0,0480 & 0,1512 & 0,0020 & 0,9700 & 6,6128 & 0,0884 & 0,0719 & 0,0022 & 0,0984 & 0,0057 & 0,34 & 85 & 127 & 453 & 0,28 & 0,908 & 0,011 & 0,982 & 0,062 & 92 \\
\hline 8,1 & 2,2582 & 0,0574 & 0,2024 & 0,0024 & 0,9400 & 4,9398 & 0,0581 & 0,0809 & 0,0017 & 0,1314 & 0,0040 & 0,00 & 315 & 459 & 1290 & 0,36 & 1,188 & 0,013 & 1,219 & 0,042 & 97 \\
\hline 9,1 & 2,2045 & 0,0668 & 0,2006 & 0,0026 & 0,9990 & 4,9844 & 0,0650 & 0,0797 & 0,0023 & 0,2144 & 0,0568 & 0,49 & 78 & 223 & 280 & 0,80 & 1,179 & 0,014 & 1,189 & 0,058 & 99 \\
\hline 10,1 & 4,6507 & 0,1249 & 0,3083 & 0,0039 & 0,8300 & 3,2441 & 0,0408 & 0,1094 & 0,0026 & 0,1751 & 0,0052 & 0,20 & 135 & 178 & 334 & 0,53 & 1,732 & 0,019 & 1,790 & 0,043 & 96 \\
\hline 11,1 & 2,7704 & 0,1375 & 0,2334 & 0,0044 & 0,1500 & 4,2850 & 0,0813 & 0,0861 & 0,0043 & 0,1905 & 0,0079 & 1,41 & 21 & 39 & 73 & 0,53 & 1,352 & 0,023 & 1,340 & 0,095 & 100 \\
\hline 12,1 & 2,2777 & 0,1320 & 0,2041 & 0,0042 & 0,6500 & 4,8986 & 0,1014 & 0,0809 & 0,0048 & 0,1442 & 0,0268 & 0,51 & 18 & 23 & 73 & 0,32 & 1,198 & 0,023 & 1,220 & 0,116 & 98 \\
\hline 13,1 & 2,5662 & 0,0762 & 0,2205 & 0,0029 & 0,2100 & 4,5359 & 0,0589 & 0,0844 & 0,0023 & 0,3038 & 0,0026 & 0,15 & 101 & 279 & 338 & 0,83 & 1,284 & 0,015 & 1,302 & 0,051 & 98 \\
\hline 14,1 & 2,0280 & 0,0628 & 0,1888 & 0,0023 & 0,7600 & 5,2960 & 0,0639 & 0,0779 & 0,0024 & 0,0730 & 0,0128 & 0,13 & 45 & 51 & 188 & 0,27 & 1,115 & 0,012 & 1,144 & 0,061 & 97 \\
\hline 15,1 & 2,3452 & 0,0717 & 0,2085 & 0,0025 & 0,6000 & 4,7962 & 0,0573 & 0,0816 & 0,0024 & 0,2432 & 0,0063 & 0,11 & 64 & 158 & 227 & 0,70 & 1,221 & 0,013 & 1,235 & 0,056 & 98 \\
\hline 16,1 & 3,0110 & 0,0758 & 0,2340 & 0,0025 & 0,7100 & 4,2729 & 0,0449 & 0,0933 & 0,0023 & 0,1085 & 0,0664 & 0,17 & 125 & 12 & 451 & 0,03 & 1,356 & 0,013 & 1,494 & 0,046 & 90 \\
\hline
\end{tabular}




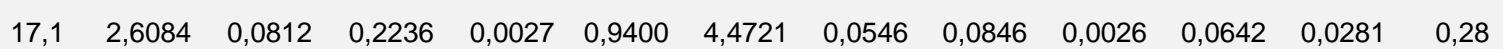

$\begin{array}{lllllllllllll}18,1 & 1,7611 & 0,0780 & 0,1691 & 0,0026 & 0,8900 & 5,9121 & 0,0903 & 0,0755 & 0,0034 & 0,2736 & 0,0197 & 0,42\end{array}$

$\begin{array}{lllllllllllll}19,1 & 1,5904 & 0,0477 & 0,1609 & 0,0018 & 0,7400 & 6,2143 & 0,0714 & 0,0717 & 0,0021 & 0,0829 & 0,0033 & 0,20\end{array}$

$\begin{array}{llllllllllllll}20,1 & 3,0038 & 0,0846 & 0,2423 & 0,0028 & 0,8800 & 4,1276 & 0,0476 & 0,0899 & 0,0025 & 0,1065 & 0,0077 & 0,94\end{array}$

$\begin{array}{llllllllllllll}21,1 & 5,3180 & 0,1378 & 0,3301 & 0,0037 & 0,4600 & 3,0293 & 0,0339 & 0,1168 & 0,0029 & 0,2802 & 0,0058 & 0,05\end{array}$

$\begin{array}{lllllllllllll}22,1 & 1,9814 & 0,0585 & 0,1882 & 0,0022 & 0,5300 & 5,3139 & 0,0610 & 0,0764 & 0,0023 & 0,1308 & 0,0141 & 0,32\end{array}$

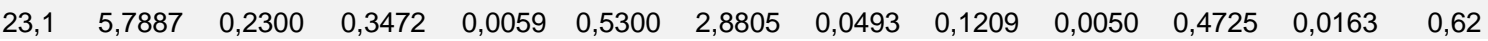

$\begin{array}{llllllllllllll}24,1 & 2,9771 & 0,1022 & 0,2405 & 0,0032 & 0,4500 & 4,1576 & 0,0556 & 0,0898 & 0,0032 & 0,0404 & 0,0085 & 0,14\end{array}$

$\begin{array}{lllllllllllll}25,1 & 3,4244 & 0,1768 & 0,2663 & 0,0051 & 0,6800 & 3,7559 & 0,0719 & 0,0933 & 0,0053 & 0,2569 & 0,0448 & 0,00\end{array}$

$\begin{array}{llllllllllllll}26,1 & 4,9102 & 0,1289 & 0,3177 & 0,0036 & 0,7200 & 3,1475 & 0,0352 & 0,1121 & 0,0029 & 0,3034 & 0,0091 & 0,31\end{array}$

$\begin{array}{lllllllllllll}27,1 & 2,4155 & 0,0594 & 0,2160 & 0,0020 & 0,9900 & 4,6301 & 0,0430 & 0,0811 & 0,0021 & 0,0987 & 0,0135 & 0,00\end{array}$

$\begin{array}{lllllllllllll}28,1 & 13,2120 & 0,3160 & 0,5158 & 0,0059 & 0,2200 & 1,9387 & 0,0221 & 0,1858 & 0,0045 & 0,1728 & 0,0080 & 0,13\end{array}$

$\begin{array}{lllllllllllll}29,1 & 5,6892 & 0,1182 & 0,3444 & 0,0029 & 0,9200 & 2,9040 & 0,0243 & 0,1198 & 0,0023 & 0,1789 & 0,0151 & 0,13\end{array}$

$\begin{array}{lllllllllllll}30,1 & 5,7065 & 0,1083 & 0,3416 & 0,0026 & 0,9900 & 2,9278 & 0,0222 & 0,1212 & 0,0022 & 0,1404 & 0,0408 & 0,04\end{array}$

$\begin{array}{lllllllllllll}31,1 & 2,8059 & 0,1177 & 0,2308 & 0,0036 & 0,9500 & 4,3326 & 0,0673 & 0,0882 & 0,0040 & 0,0711 & 0,0103 & 3,02\end{array}$

$\begin{array}{lllllllllllll}32,1 & 2,9057 & 0,0661 & 0,2365 & 0,0021 & 0,9600 & 4,2286 & 0,0370 & 0,0891 & 0,0020 & 0,0657 & 0,0030 & 0,28\end{array}$

$\begin{array}{lllllllllllll}33,1 & 2,9228 & 0,1015 & 0,2473 & 0,0032 & 0,8800 & 4,0435 & 0,0527 & 0,0857 & 0,0031 & 0,1588 & 0,0129 & 0,36\end{array}$

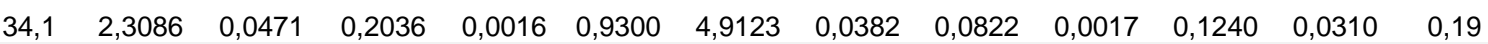

$\begin{array}{lllllllllllll}35,1 & 1,8239 & 0,0399 & 0,1691 & 0,0014 & 0,9500 & 5,9126 & 0,0487 & 0,0782 & 0,0015 & 0,2034 & 0,0398\end{array}$

$\begin{array}{llllllllllll}36,1 & 2,4577 & 0,0801 & 0,2129 & 0,0026 & 0,1200 & 4,6968 & 0,0567 & 0,0837 & 0,0029 & 0,2768 & 0,0060\end{array}$

$\begin{array}{lllllllllllll}37,1 & 1,4527 & 0,0297 & 0,1496 & 0,0011 & 0,9900 & 6,6862 & 0,0511 & 0,0704 & 0,0014 & 0,0050 & 0,0009\end{array}$

$\begin{array}{lllllllllllll}38,1 & 6,2652 & 0,1723 & 0,3002 & 0,0038 & 0,8900 & 3,3316 & 0,0422 & 0,1514 & 0,0044 & 0,2112 & 0,0234\end{array}$

$\begin{array}{llllllllllll}39,1 & 2,4075 & 0,0687 & 0,2110 & 0,0022 & 0,7900 & 4,7385 & 0,0497 & 0,0827 & 0,0025 & 0,1168 & 0,0124\end{array}$

$\begin{array}{llllllllllll}40,1 & 2,4751 & 0,0776 & 0,2155 & 0,0029 & 0,4200 & 4,6401 & 0,0622 & 0,0833 & 0,0029 & 0,0973 & 0,0074\end{array}$

$\begin{array}{llllllllllllll}41,1 & 4,8903 & 0,1016 & 0,3243 & 0,0031 & 0,8500 & 3,0835 & 0,0299 & 0,1094 & 0,0023 & 0,2642 & 0,0279\end{array}$

$\begin{array}{llllllllllll}42,1 & 5,5256 & 0,1088 & 0,3330 & 0,0030 & 0,7000 & 3,0031 & 0,0273 & 0,1203 & 0,0023 & 0,2176 & 0,0053\end{array}$

$\begin{array}{llllllllllll}43,1 & 6,4182 & 0,1202 & 0,3708 & 0,0032 & 0,9900 & 2,6968 & 0,0231 & 0,1255 & 0,0023 & 0,2562 & 0,0219\end{array}$

$\begin{array}{lllllllllllll}44,1 & 2,6347 & 0,0683 & 0,2267 & 0,0025 & 0,7900 & 4,4121 & 0,0487 & 0,0843 & 0,0022 & 0,0788 & 0,0055\end{array}$

$\begin{array}{lllllllllllll}45,1 & 1,5910 & 0,0286 & 0,1614 & 0,0012 & 0,9100 & 6,1944 & 0,0474 & 0,0715 & 0,0012 & 0,1113 & 0,0083\end{array}$

$\begin{array}{llllllllllll}46,1 & 3,4548 & 0,0613 & 0,2647 & 0,0021 & 0,8600 & 3,7773 & 0,0293 & 0,0946 & 0,0016 & 0,0982 & 0,0017\end{array}$

$\begin{array}{ccccccccc}47 & 40 & 176 & 0,23 & 1,301 & 0,014 & 1,306 & 0,060 & 99 \\ 31 & 175 & 161 & 1,08 & 1,007 & 0,014 & 1,082 & 0,088 & 93 \\ 68 & 86 & 358 & 0,24 & 0,962 & 0,010 & 0,977 & 0,058 & 98 \\ 75 & 90 & 250 & 0,36 & 1,399 & 0,015 & 1,424 & 0,052 & 98 \\ 100 & 158 & 210 & 0,75 & 1,839 & 0,018 & 1,908 & 0,045 & 96 \\ 48 & 67 & 224 & 0,30 & 1,112 & 0,012 & 1,105 & 0,059 & 100 \\ 21 & 49 & 38 & 1,30 & 1,921 & 0,028 & 1,970 & 0,075 & 97 \\ 33 & 12 & 118 & 0,10 & 1,389 & 0,017 & 1,421 & 0,068 & 97 \\ 17 & 32 & 53 & 0,62 & 1,522 & 0,026 & 1,494 & 0,108 & 101 \\ 78 & 148 & 175 & 0,84 & 1,779 & 0,017 & 1,834 & 0,046 & 97 \\ 46 & 50 & 158 & 0,32 & 1,261 & 0,011 & 1,224 & 0,052 & 102 \\ 42 & 29 & 58 & 0,50 & 2,681 & 0,025 & 2,705 & 0,040 & 99 \\ 131 & 163 & 283 & 0,58 & 1,908 & 0,014 & 1,954 & 0,035 & 97 \\ 120 & 6 & 234 & 0,03 & 1,894 & 0,012 & 1,974 & 0,033 & 95 \\ 13 & 10 & 48 & 0,21 & 1,339 & 0,019 & 1,386 & 0,088 & 96 \\ 80 & 67 & 297 & 0,23 & 1,368 & 0,011 & 1,407 & 0,043 & 97 \\ 38 & 58 & 125 & 0,47 & 1,425 & 0,017 & 1,332 & 0,071 & 106 \\ 163 & 155 & 653 & 0,24 & 1,194 & 0,009 & 1,251 & 0,040 & 95 \\ 217 & 598 & 851 & 0,70 & 1,007 & 0,008 & 1,152 & 0,038 & 87 \\ 31 & 84 & 107 & 0,79 & 1,244 & 0,014 & 1,286 & 0,070 & 96 \\ 193 & 44 & 1242 & 0,04 & 0,899 & 0,006 & 0,941 & 0,041 & 95 \\ 18 & 6 & 32 & 0,18 & 1,692 & 0,019 & 2,362 & 0,049 & 71 \\ 18 & 16 & 68 & 0,23 & 1,234 & 0,012 & 1,263 & 0,059 & 97 \\ 31 & 31 & 114 & 0,27 & 1,258 & 0,015 & 1,276 & 0,068 & 98 \\ 47 & 80 & 106 & 0,76 & 1,811 & 0,015 & 1,789 & 0,039 & 101 \\ 66 & 87 & 142 & 0,62 & 1,853 & 0,015 & 1,961 & 0,035 & 94 \\ 140 & 183 & 319 & 0,57 & 2,033 & 0,015 & 2,036 & 0,032 & 99 \\ 41 & 28 & 150 & 0,18 & 1,317 & 0,013 & 1,300 & 0,050 & 101 \\ 231 & 327 & 1154 & 0,28 & 0,965 & 0,007 & 0,971 & 0,035 & 99 \\ 231 & 193 & 703 & 0,28 & 1,514 & 0,010 & 1,521 & 0,031 & 99\end{array}$


$\begin{array}{llllllllllllll}47,1 & 2,1984 & 0,0707 & 0,1923 & 0,0026 & 0,5200 & 5,2004 & 0,0706 & 0,0829 & 0,0030 & 0,1890 & 0,0204 & 1,18 & 24\end{array}$

$\begin{array}{lllllllllllll}48,1 & 3,3804 & 0,0683 & 0,2577 & 0,0023 & 0,9800 & 3,8805 & 0,0349 & 0,0951 & 0,0019 & 0,0892 & 0,0060\end{array}$

$\begin{array}{llllllllllll}49,1 & 1,9916 & 0,0596 & 0,1790 & 0,0023 & 0,9900 & 5,5851 & 0,0718 & 0,0807 & 0,0030 & 0,1908 & 0,0366\end{array}$

$\begin{array}{llllllllllllll}50,1 & 4,9351 & 0,0937 & 0,3166 & 0,0027 & 0,2200 & 3,1585 & 0,0272 & 0,1131 & 0,0021 & 0,1551 & 0,0024 & 0,11\end{array}$

$\begin{array}{llllllllllllll}51,1 & 6,1119 & 0,1115 & 0,3440 & 0,0029 & 0,9900 & 2,9069 & 0,0242 & 0,1289 & 0,0023 & 0,1537 & 0,0134 & 0,12\end{array}$

$\begin{array}{llllllllllllll}52,1 & 2,0774 & 0,0508 & 0,1913 & 0,0020 & 0,6200 & 5,2278 & 0,0545 & 0,0788 & 0,0020 & 0,1472 & 0,0054 & 0,15\end{array}$

$\begin{array}{lllllllllllll}53,1 & 2,9510 & 0,1048 & 0,2419 & 0,0041 & 0,7000 & 4,1340 & 0,0695 & 0,0885 & 0,0035 & 0,1414 & 0,0139 & 0,42\end{array}$

$\begin{array}{llllllllllllll}54,1 & 1,9986 & 0,0356 & 0,1863 & 0,0020 & 0,8200 & 5,3680 & 0,0589 & 0,0778 & 0,0015 & 0,0544 & 0,0175 & 0,26\end{array}$

$\begin{array}{lllllllllllll}55,1 & 1,9990 & 0,0379 & 0,1856 & 0,0021 & 0,9500 & 5,3888 & 0,0608 & 0,0781 & 0,0016 & 0,0839 & 0,0115 & 0,37\end{array}$

$\begin{array}{lllllllllllll}56,1 & 4,0409 & 0,0794 & 0,2909 & 0,0035 & 0,9200 & 3,4371 & 0,0413 & 0,1007 & 0,0021 & 0,1223 & 0,0421 & 0,19\end{array}$

$\begin{array}{lllllllllllll}57,1 & 4,4122 & 0,1533 & 0,2960 & 0,0053 & 0,4400 & 3,3785 & 0,0608 & 0,1081 & 0,0042 & 0,2600 & 0,0200 & 0,99\end{array}$

$\begin{array}{lllllllllllll}58,1 & 4,4585 & 0,0744 & 0,2947 & 0,0033 & 0,7000 & 3,3935 & 0,0379 & 0,1097 & 0,0019 & 0,2514 & 0,0027 & 0,39\end{array}$

$\begin{array}{llllllllllllll}59,1 & 1,4340 & 0,0344 & 0,1450 & 0,0018 & 0,9400 & 6,8947 & 0,0851 & 0,0717 & 0,0019 & 0,0919 & 0,0102 & 0,51\end{array}$

$\begin{array}{lllllllllllll}60,1 & 2,2612 & 0,0492 & 0,1959 & 0,0025 & 0,9990 & 5,1041 & 0,0645 & 0,0837 & 0,0018 & 0,0738 & 0,0231 & 0,35\end{array}$

$\begin{array}{llllllllllllll}61,1 & 5,7585 & 0,0790 & 0,3470 & 0,0034 & 0,9900 & 2,8817 & 0,0286 & 0,1204 & 0,0018 & 0,0465 & 0,0016 & 0,08\end{array}$

$\begin{array}{lllllllllllll}62,1 & 1,6162 & 0,0370 & 0,1608 & 0,0020 & 0,9000 & 6,2189 & 0,0756 & 0,0729 & 0,0018 & 0,0164 & 0,0039 & 0,12\end{array}$

$\begin{array}{lllllllllllll}63,1 & 4,4172 & 0,0818 & 0,2964 & 0,0035 & 0,9400 & 3,3742 & 0,0400 & 0,1081 & 0,0022 & 0,4078 & 0,0242 & 0,09\end{array}$

$\begin{array}{llllllllllllll}64,1 & 3,6564 & 0,0539 & 0,2712 & 0,0028 & 0,0100 & 3,6870 & 0,0381 & 0,0978 & 0,0015 & 0,1534 & 0,0116 & 0,11\end{array}$

$\begin{array}{llllllllllllll}65,1 & 3,0227 & 0,0715 & 0,2408 & 0,0031 & 0,9200 & 4,1530 & 0,0543 & 0,0910 & 0,0024 & 0,1136 & 0,0086 & 1,03\end{array}$

\begin{tabular}{cccccccc}
63 & 92 & 0,68 & 1,134 & 0,014 & 1,267 & 0,071 & 89 \\
61 & 221 & 0,28 & 1,478 & 0,012 & 1,531 & 0,038 & 96 \\
62 & 87 & 0,71 & 1,062 & 0,013 & 1,214 & 0,077 & 87 \\
98 & 212 & 0,46 & 1,773 & 0,013 & 1,849 & 0,033 & 95 \\
82 & 212 & 0,39 & 1,906 & 0,014 & 2,082 & 0,031 & 91 \\
89 & 202 & 0,44 & 1,128 & 0,011 & 1,166 & 0,051 & 96 \\
24 & 58 & 0,42 & 1,397 & 0,021 & 1,393 & 0,079 & 100 \\
75 & 413 & 0,18 & 1,101 & 0,011 & 1,142 & 0,038 & 96 \\
31 & 208 & 0,15 & 1,097 & 0,011 & 1,150 & 0,041 & 95 \\
63 & 173 & 0,36 & 1,646 & 0,017 & 1,638 & 0,039 & 100 \\
28 & 35 & 0,82 & 1,671 & 0,027 & 1,768 & 0,072 & 94 \\
147 & 187 & 0,79 & 1,665 & 0,016 & 1,795 & 0,032 & 92 \\
98 & 238 & 0,41 & 0,873 & 0,010 & 0,978 & 0,051 & 89 \\
67 & 197 & 0,34 & 1,153 & 0,013 & 1,286 & 0,038 & 89 \\
84 & 598 & 0,14 & 1,920 & 0,017 & 1,961 & 0,026 & 97 \\
9 & 222 & 0,04 & 0,961 & 0,011 & 1,011 & 0,050 & 95 \\
129 & 129 & 1,00 & 1,673 & 0,017 & 1,768 & 0,036 & 94 \\
347 & 675 & 0,51 & 1,547 & 0,014 & 1,582 & 0,028 & 97 \\
29 & 91 & 0,32 & 1,391 & 0,016 & 1,448 & 0,050 & 96 \\
\hline
\end{tabular}

\section{AMOSTRA SNA-228: metapelito (Unidade Serra da Boa Vista - Nappe Andrelândia)}

\begin{tabular}{|c|c|c|c|c|c|c|c|c|c|c|c|c|c|c|c|c|c|c|c|c|c|}
\hline Spot & $207 / 235$ & 1sigma & $206 / 238$ & 1sigma & Correl. & 238/206 & 1sigma & $207 / 206$ & 1sigma & $208 / 206$ & 1sigma & $\begin{array}{c}\% \\
\text { Com.Pb }\end{array}$ & $\begin{array}{c}\mathrm{ppm} \\
\mathrm{Pb}\end{array}$ & $\begin{array}{c}\text { ppm } \\
\text { Th }\end{array}$ & $\stackrel{\mathrm{ppm}}{\mathrm{U}}$ & Th/U & $\begin{array}{c}T \\
206 / 238\end{array}$ & $\begin{array}{c}1 \\
\text { sigma }\end{array}$ & $\begin{array}{c}T \\
207 / 206\end{array}$ & $\begin{array}{c}1 \\
\text { sigma }\end{array}$ & $\begin{array}{c}\% \\
\text { Conc. }\end{array}$ \\
\hline 1,1 & 3,2417 & 0,0913 & 0,2526 & 0,0030 & 0,6700 & 3,9585 & 0,0476 & 0,0931 & 0,0024 & 0,1111 & 0,0047 & 0,25 & 49 & 43 & 157 & 0,28 & 1,452 & 0,016 & 1,489 & 0,049 & 97 \\
\hline 2,1 & 2,8239 & 0,1725 & 0,2231 & 0,0046 & 0,4400 & 4,4833 & 0,0921 & 0,0918 & 0,0061 & 0,1265 & 0,0177 & 3,12 & 11 & 11 & 43 & 0,27 & 1,298 & 0,024 & 1,464 & 0,126 & 88 \\
\hline 3,1 & 1,2071 & 0,0576 & 0,1280 & 0,0020 & 0,9700 & 7,8145 & 0,1203 & 0,0684 & 0,0031 & 0,2036 & 0,0323 & 3,64 & 24 & 78 & 150 & 0,52 & 0,776 & 0,011 & 0,881 & 0,090 & 88 \\
\hline 4,1 & 1,4094 & 0,0357 & 0,1432 & 0,0016 & 0,9900 & 6,9821 & 0,0756 & 0,0714 & 0,0017 & 0,1027 & 0,0470 & 0,22 & 83 & 113 & 448 & 0,25 & 0,863 & 0,009 & 0,968 & 0,049 & 89 \\
\hline 5,1 & 1,3798 & 0,0350 & 0,1452 & 0,0016 & 0,9900 & 6,8852 & 0,0750 & 0,0689 & 0,0016 & 0,1787 & 0,0385 & 0,02 & 84 & 237 & 396 & 0,60 & 0,874 & 0,009 & 0,896 & 0,049 & 97 \\
\hline 6,1 & 1,5156 & 0,0388 & 0,1545 & 0,0017 & 0,9200 & 6,4717 & 0,0707 & 0,0711 & 0,0017 & 0,1294 & 0,0174 & 0,72 & 131 & 261 & 730 & 0,36 & 0,926 & 0,009 & 0,961 & 0,050 & 96 \\
\hline
\end{tabular}


$\begin{array}{llllllllllll}7,1 & 2,4616 & 0,0563 & 0,2129 & 0,0022 & 0,8700 & 4,6974 & 0,0487 & 0,0839 & 0,0018 & 0,0751 & 0,0055\end{array}$ $\begin{array}{lllllllllllll}8,1 & 1,6834 & 0,0726 & 0,1674 & 0,0024 & 0,4400 & 5,9725 & 0,0857 & 0,0729 & 0,0033 & 0,2174 & 0,0126\end{array}$ $\begin{array}{lllllllllllll}9,1 & 1,5949 & 0,0435 & 0,1622 & 0,0018 & 0,4200 & 6,1654 & 0,0683 & 0,0713 & 0,0019 & 0,1269 & 0,0042\end{array}$ $\begin{array}{lllllllllllll}10,1 & 3,7524 & 0,0766 & 0,2595 & 0,0027 & 0,1600 & 3,8536 & 0,0398 & 0,1049 & 0,0020 & 0,0730 & 0,0063\end{array}$ $\begin{array}{lllllllllllll}11,1 & 1,5865 & 0,0389 & 0,1612 & 0,0017 & 0,7200 & 6,2023 & 0,0654 & 0,0714 & 0,0017 & 0,1410 & 0,0040\end{array}$ $\begin{array}{lllllllllllll}12,1 & 2,1521 & 0,0630 & 0,1981 & 0,0023 & 0,2800 & 5,0487 & 0,0593 & 0,0788 & 0,0023 & 0,1563 & 0,0128\end{array}$ $\begin{array}{lllllllllllll}13,1 & 2,3819 & 0,0608 & 0,2109 & 0,0023 & 0,0100 & 4,7423 & 0,0518 & 0,0819 & 0,0020 & 0,1109 & 0,0205\end{array}$ $\begin{array}{lllllllllllll}14,1 & 5,7923 & 0,1465 & 0,3489 & 0,0033 & 0,0100 & 2,8658 & 0,0270 & 0,1204 & 0,0031 & 0,3867 & 0,0065\end{array}$ $\begin{array}{lllllllllllll}15,1 & 2,3157 & 0,0625 & 0,2061 & 0,0019 & 0,5800 & 4,8525 & 0,0443 & 0,0815 & 0,0023 & 0,1544 & 0,0568\end{array}$ $\begin{array}{lllllllllllll}16,1 & 1,6010 & 0,0495 & 0,1617 & 0,0016 & 0,2600 & 6,1829 & 0,0606 & 0,0718 & 0,0023 & 0,1587 & 0,0065\end{array}$ $\begin{array}{lllllllllllll}17,1 & 2,5377 & 0,0690 & 0,2170 & 0,0020 & 0,3100 & 4,6078 & 0,0428 & 0,0848 & 0,0024 & 0,0416 & 0,0023\end{array}$ $\begin{array}{lllllllllllll}18,1 & 4,2066 & 0,1441 & 0,2861 & 0,0035 & 0,6800 & 3,4948 & 0,0432 & 0,1066 & 0,0040 & 0,3720 & 0,0120\end{array}$ $\begin{array}{lllllllllllll}19,1 & 4,1397 & 0,1295 & 0,2876 & 0,0032 & 0,5700 & 3,4776 & 0,0388 & 0,1044 & 0,0035 & 0,2184 & 0,0041\end{array}$ $\begin{array}{lllllllllllll}20,1 & 5,4590 & 0,2108 & 0,3343 & 0,0048 & 0,8900 & 2,9910 & 0,0431 & 0,1184 & 0,0055 & 0,3709 & 0,0365\end{array}$ $\begin{array}{lllllllllllll}20,2 & 1,5211 & 0,0400 & 0,1576 & 0,0013 & 0,9700 & 6,3454 & 0,0535 & 0,0700 & 0,0021 & 0,0259 & 0,0028\end{array}$ $\begin{array}{lllllllllllll}21,1 & 2,2552 & 0,0550 & 0,2020 & 0,0017 & 0,5200 & 4,9498 & 0,0419 & 0,0810 & 0,0021 & 0,1049 & 0,0668\end{array}$ $\begin{array}{llllllllllll}22,1 & 1,5722 & 0,0491 & 0,1566 & 0,0016 & 0,6200 & 6,3869 & 0,0634 & 0,0728 & 0,0024 & 0,0973 & 0,0097\end{array}$ $\begin{array}{lllllllllllll}23,1 & 1,6247 & 0,0811 & 0,1599 & 0,0023 & 0,4400 & 6,2521 & 0,0891 & 0,0737 & 0,0041 & 0,2793 & 0,0128\end{array}$ $\begin{array}{lllllllllllll}24,1 & 2,0724 & 0,0696 & 0,1907 & 0,0020 & 0,0100 & 5,2447 & 0,0559 & 0,0788 & 0,0029 & 0,1321 & 0,0132\end{array}$ $\begin{array}{lllllllllllll}25,1 & 2,7321 & 0,1356 & 0,2275 & 0,0035 & 0,5400 & 4,3953 & 0,0681 & 0,0871 & 0,0048 & 0,2080 & 0,0144\end{array}$ $\begin{array}{lllllllllllll}26,1 & 1,6539 & 0,0487 & 0,1665 & 0,0015 & 0,0100 & 6,0062 & 0,0548 & 0,0720 & 0,0021 & 0,1004 & 0,0060\end{array}$ $\begin{array}{lllllllllllll}27,1 & 1,5965 & 0,0445 & 0,1607 & 0,0014 & 0,9900 & 6,2214 & 0,0542 & 0,0720 & 0,0020 & 0,0998 & 0,0231\end{array}$ $\begin{array}{lllllllllllll}28,1 & 1,3165 & 0,0280 & 0,1410 & 0,0010 & 0,5400 & 7,0937 & 0,0518 & 0,0677 & 0,0013 & 0,0264 & 0,0033\end{array}$ $\begin{array}{lllllllllllll}29,1 & 6,0616 & 0,1349 & 0,3588 & 0,0030 & 0,7900 & 2,7869 & 0,0236 & 0,1225 & 0,0026 & 0,2969 & 0,0249\end{array}$ $\begin{array}{lllllllllllll}30,1 & 8,7541 & 0,1767 & 0,4076 & 0,0033 & 0,9900 & 2,4535 & 0,0202 & 0,1558 & 0,0031 & 0,1008 & 0,0173\end{array}$ $\begin{array}{llllllllllll}31,1 & 4,4819 & 0,1292 & 0,3060 & 0,0032 & 0,7400 & 3,2679 & 0,0338 & 0,1062 & 0,0030 & 0,2246 & 0,0239\end{array}$ $\begin{array}{lllllllllllll}32,1 & 2,6697 & 0,0574 & 0,2247 & 0,0017 & 0,9800 & 4,4508 & 0,0337 & 0,0862 & 0,0017 & 0,0748 & 0,0137\end{array}$ $\begin{array}{lllllllllllll}33,1 & 2,0111 & 0,1075 & 0,1873 & 0,0028 & 0,4300 & 5,3398 & 0,0800 & 0,0779 & 0,0046 & 0,1001 & 0,0153\end{array}$ $\begin{array}{lllllllllllll}34,1 & 1,1640 & 0,0466 & 0,1247 & 0,0014 & 0,9700 & 8,0204 & 0,0910 & 0,0677 & 0,0025 & 0,1140 & 0,0108\end{array}$ $\begin{array}{lllllllllllll}35,1 & 3,2077 & 0,1073 & 0,2524 & 0,0028 & 0,2500 & 3,9625 & 0,0441 & 0,0922 & 0,0032 & 0,1806 & 0,0085\end{array}$

$\begin{array}{cccccccccc}0,18 & 148 & 134 & 587 & 0,23 & 1,244 & 0,012 & 1,289 & 0,041 & 96 \\ 0,81 & 22 & 58 & 102 & 0,57 & 0,998 & 0,013 & 1,012 & 0,089 & 98 \\ 0,42 & 73 & 132 & 380 & 0,35 & 0,969 & 0,010 & 0,967 & 0,053 & 100 \\ 0,12 & 138 & 109 & 503 & 0,22 & 1,487 & 0,014 & 1,712 & 0,039 & 86 \\ 0,38 & 95 & 169 & 495 & 0,34 & 0,964 & 0,009 & 0,968 & 0,048 & 99 \\ 0,11 & 50 & 85 & 211 & 0,40 & 1,165 & 0,012 & 1,167 & 0,058 & 99 \\ 0,20 & 76 & 96 & 309 & 0,31 & 1,233 & 0,012 & 1,244 & 0,049 & 99 \\ 0,07 & 82 & 149 & 153 & 0,98 & 1,930 & 0,016 & 1,962 & 0,046 & 98 \\ 0,11 & 75 & 158 & 282 & 0,56 & 1,208 & 0,010 & 1,233 & 0,054 & 97 \\ 2,46 & 63 & 147 & 311 & 0,47 & 0,966 & 0,009 & 0,980 & 0,066 & 98 \\ 0,44 & 58 & 30 & 230 & 0,13 & 1,266 & 0,011 & 1,311 & 0,055 & 96 \\ 0,16 & 37 & 88 & 83 & 1,07 & 1,622 & 0,018 & 1,742 & 0,070 & 93 \\ 0,31 & 31 & 46 & 79 & 0,59 & 1,629 & 0,016 & 1,704 & 0,062 & 95 \\ 0,33 & 16 & 27 & 36 & 0,75 & 1,859 & 0,024 & 1,933 & 0,082 & 96 \\ 0,54 & 74 & 85 & 445 & 0,19 & 0,943 & 0,007 & 0,928 & 0,061 & 101 \\ 0,08 & 102 & 41 & 451 & 0,09 & 1,186 & 0,009 & 1,220 & 0,051 & 97 \\ 0,19 & 53 & 101 & 286 & 0,35 & 0,938 & 0,009 & 1,009 & 0,069 & 92 \\ 0,71 & 22 & 72 & 105 & 0,68 & 0,956 & 0,013 & 1,032 & 0,115 & 92 \\ 1,12 & 25 & 38 & 106 & 0,35 & 1,125 & 0,011 & 1,168 & 0,072 & 96 \\ 2,07 & 13 & 18 & 47 & 0,39 & 1,321 & 0,018 & 1,363 & 0,108 & 96 \\ 0,12 & 46 & 56 & 228 & 0,24 & 0,993 & 0,008 & 0,987 & 0,061 & 100 \\ 0,20 & 27 & 47 & 135 & 0,35 & 0,961 & 0,008 & 0,987 & 0,058 & 97 \\ 0,60 & 114 & 65 & 724 & 0,09 & 0,850 & 0,006 & 0,860 & 0,041 & 98 \\ 0,10 & 79 & 121 & 148 & 0,81 & 1,977 & 0,014 & 1,993 & 0,038 & 99 \\ 0,12 & 104 & 66 & 276 & 0,24 & 2,204 & 0,015 & 2,410 & 0,034 & 91 \\ 0,27 & 44 & 62 & 109 & 0,57 & 1,721 & 0,016 & 1,736 & 0,052 & 99 \\ 0,09 & 140 & 60 & 599 & 0,10 & 1,307 & 0,009 & 1,342 & 0,037 & 97 \\ 1,70 & 24 & 36 & 109 & 0,33 & 1,107 & 0,015 & 1,144 & 0,113 & 96 \\ 0,16 & 30 & 72 & 152 & 0,47 & 0,757 & 0,008 & 0,860 & 0,075 & 88 \\ 0,78 & 30 & 56 & 90 & 0,62 & 1,451 & 0,014 & 1,471 & 0,068 & 98\end{array}$




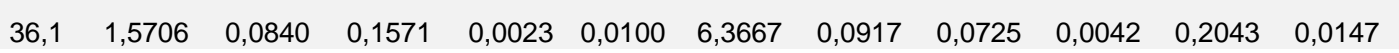
$\begin{array}{lllllllllllll}37,1 & 3,1792 & 0,0871 & 0,2110 & 0,0020 & 0,9999 & 4,7386 & 0,0455 & 0,1093 & 0,0024 & 0,1701 & 0,0369\end{array}$ $\begin{array}{lllllllllllll}38,1 & 1,6492 & 0,0378 & 0,1657 & 0,0013 & 0,9999 & 6,0350 & 0,0457 & 0,0722 & 0,0017 & 0,1393 & 0,0200\end{array}$ $\begin{array}{lllllllllllll}39,1 & 1,5288 & 0,0431 & 0,1588 & 0,0015 & 0,7100 & 6,2980 & 0,0600 & 0,0698 & 0,0020 & 0,1620 & 0,0117\end{array}$ $\begin{array}{lllllllllllll}40,1 & 2,3454 & 0,0497 & 0,2053 & 0,0017 & 0,5800 & 4,8702 & 0,0395 & 0,0828 & 0,0017 & 0,1988 & 0,0127\end{array}$ $\begin{array}{lllllllllllll}41,1 & 1,9316 & 0,0487 & 0,1849 & 0,0017 & 0,2900 & 5,4097 & 0,0497 & 0,0758 & 0,0020 & 0,2548 & 0,0079\end{array}$

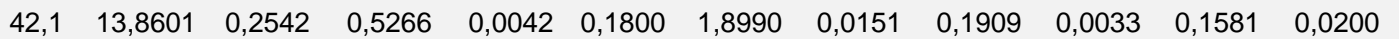
$\begin{array}{lllllllllllll}43,1 & 7,4088 & 0,1661 & 0,3977 & 0,0039 & 0,9600 & 2,5142 & 0,0246 & 0,1351 & 0,0030 & 0,0998 & 0,0078\end{array}$ $\begin{array}{llllllllllll}44,1 & 1,8387 & 0,0432 & 0,1784 & 0,0015 & 0,7600 & 5,6051 & 0,0487 & 0,0747 & 0,0017 & 0,1114 & 0,0074\end{array}$ $\begin{array}{lllllllllllll}45,1 & 5,6550 & 0,1339 & 0,3394 & 0,0033 & 0,6100 & 2,9464 & 0,0289 & 0,1208 & 0,0028 & 0,2890 & 0,0118\end{array}$ $\begin{array}{lllllllllllll}46,1 & 2,0319 & 0,0729 & 0,1863 & 0,0023 & 0,0100 & 5,3665 & 0,0657 & 0,0791 & 0,0030 & 0,2732 & 0,0214\end{array}$ $\begin{array}{lllllllllllll}47,1 & 2,2688 & 0,0443 & 0,2038 & 0,0016 & 0,8000 & 4,9058 & 0,0374 & 0,0807 & 0,0015 & 0,0651 & 0,0211\end{array}$ $\begin{array}{lllllllllllll}48,1 & 2,0754 & 0,0555 & 0,1946 & 0,0019 & 0,7800 & 5,1381 & 0,0494 & 0,0773 & 0,0021 & 0,1956 & 0,0088\end{array}$ $\begin{array}{lllllllllllll}49,1 & 4,7926 & 0,0928 & 0,3131 & 0,0025 & 0,9600 & 3,1942 & 0,0250 & 0,1110 & 0,0021 & 0,1747 & 0,0213\end{array}$ $\begin{array}{lllllllllllll}50,1 & 1,6412 & 0,0556 & 0,1664 & 0,0019 & 0,3100 & 6,0088 & 0,0672 & 0,0715 & 0,0025 & 0,1606 & 0,0092\end{array}$ $\begin{array}{lllllllllllll}51,1 & 5,8755 & 0,1221 & 0,3527 & 0,0030 & 0,9000 & 2,8352 & 0,0241 & 0,1208 & 0,0024 & 0,3607 & 0,0571\end{array}$ $\begin{array}{lllllllllllll}52,1 & 4,4941 & 0,0972 & 0,3028 & 0,0030 & 0,6800 & 3,3027 & 0,0330 & 0,1076 & 0,0024 & 0,1708 & 0,0067\end{array}$ $\begin{array}{lllllllllllll}53,1 & 1,5783 & 0,0402 & 0,1598 & 0,0017 & 0,9000 & 6,2593 & 0,0677 & 0,0716 & 0,0020 & 0,1632 & 0,0751\end{array}$ $\begin{array}{lllllllllllll}54,1 & 1,5966 & 0,0341 & 0,1608 & 0,0014 & 0,7100 & 6,2206 & 0,0557 & 0,0720 & 0,0016 & 0,2024 & 0,0197\end{array}$

\begin{tabular}{cccccccccc}
1,02 & 18 & 49 & 85 & 0,57 & 0,940 & 0,013 & 1,001 & 0,117 & 93 \\
0,11 & 55 & 71 & 113 & 0,63 & 1,234 & 0,010 & 1,787 & 0,037 & 69 \\
0,28 & 75 & 155 & 343 & 0,45 & 0,988 & 0,007 & 0,991 & 0,049 & 99 \\
0,31 & 43 & 79 & 235 & 0,34 & 0,950 & 0,008 & 0,923 & 0,056 & 102 \\
0,09 & 57 & 117 & 204 & 0,57 & 1,204 & 0,009 & 1,266 & 0,041 & 95 \\
2,72 & 43 & 111 & 163 & 0,68 & 1,093 & 0,009 & 1,089 & 0,053 & 100 \\
0,19 & 81 & 55 & 121 & 0,45 & 2,727 & 0,018 & 2,750 & 0,028 & 99 \\
0,60 & 54 & 33 & 120 & 0,28 & 2,159 & 0,018 & 2,165 & 0,038 & 99 \\
1,97 & 43 & 70 & 193 & 0,36 & 1,058 & 0,009 & 1,062 & 0,047 & 99 \\
0,26 & 28 & 37 & 56 & 0,66 & 1,884 & 0,016 & 1,969 & 0,042 & 95 \\
0,42 & 19 & 53 & 71 & 0,74 & 1,102 & 0,012 & 1,174 & 0,075 & 93 \\
0,15 & 93 & 67 & 382 & 0,18 & 1,196 & 0,008 & 1,215 & 0,036 & 98 \\
0,55 & 34 & 66 & 130 & 0,51 & 1,146 & 0,010 & 1,130 & 0,054 & 101 \\
0,16 & 66 & 71 & 153 & 0,46 & 1,756 & 0,012 & 1,816 & 0,034 & 96 \\
0,40 & 21 & 37 & 98 & 0,38 & 0,992 & 0,010 & 0,972 & 0,071 & 102 \\
0,19 & 71 & 129 & 130 & 0,99 & 1,947 & 0,014 & 1,968 & 0,035 & 98 \\
0,43 & 58 & 72 & 146 & 0,49 & 1,705 & 0,015 & 1,760 & 0,042 & 96 \\
0,40 & 42 & 82 & 243 & 0,34 & 0,955 & 0,010 & 0,976 & 0,059 & 97 \\
0,08 & 70 & 130 & 326 & 0,40 & 0,961 & 0,008 & 0,987 & 0,045 & 97 \\
0,26 & 60 & -5 & 327 & 0,02 & 1,060 & 0,009 & 1,113 & 0,049 & 95 \\
0,49 & 26 & 55 & 123 & 0,45 & 0,957 & 0,011 & 1,051 & 0,066 & 91 \\
0,35 & 83 & 171 & 242 & 0,70 & 1,431 & 0,012 & 1,495 & 0,043 & 95 \\
0,20 & 64 & 22 & 266 & 0,08 & 1,201 & 0,010 & 1,249 & 0,044 & 96 \\
0,16 & 73 & 80 & 328 & 0,25 & 1,167 & 0,009 & 1,379 & 0,045 & 84 \\
0,41 & 27 & 60 & 125 & 0,48 & 0,971 & 0,013 & 0,971 & 0,081 & 100 \\
0,99 & 23 & 32 & 67 & 0,48 & 1,510 & 0,018 & 1,581 & 0,061 & 95 \\
0,30 & 53 & 85 & 199 & 0,43 & 1,222 & 0,012 & 1,222 & 0,051 & 99 \\
0,50 & 47 & 62 & 94 & 0,66 & 1,914 & 0,019 & 1,967 & 0,046 & 97 \\
0,81 & 55 & 61 & 170 & 0,36 & 1,452 & 0,012 & 1,452 & 0,041 & 100 \\
\hline & & & & & & & & &
\end{tabular}

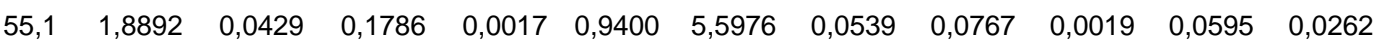
$\begin{array}{llllllllllll}56,1 & 1,6398 & 0,0466 & 0,1600 & 0,0019 & 0,0100 & 6,2511 & 0,0755 & 0,0743 & 0,0023 & 0,1549 & 0,0134\end{array}$ $\begin{array}{lllllllllllll}57,1 & 3,2007 & 0,0704 & 0,2486 & 0,0024 & 0,7000 & 4,0223 & 0,0389 & 0,0934 & 0,0021 & 0,1982 & 0,0184\end{array}$ $\begin{array}{lllllllllllll}58,1 & 2,3201 & 0,0498 & 0,2048 & 0,0019 & 0,4300 & 4,8816 & 0,0451 & 0,0821 & 0,0018 & 0,0370 & 0,0108\end{array}$ $\begin{array}{llllllllllll}59,1 & 2,4037 & 0,0459 & 0,1985 & 0,0017 & 0,9900 & 5,0389 & 0,0420 & 0,0878 & 0,0019 & 0,0968 & 0,0195\end{array}$ $\begin{array}{lllllllllllll}60,1 & 1,6025 & 0,0546 & 0,1626 & 0,0023 & 0,4300 & 6,1496 & 0,0878 & 0,0715 & 0,0027 & 0,1973 & 0,0330\end{array}$ $\begin{array}{lllllllllllll}61,1 & 3,5573 & 0,1013 & 0,2640 & 0,0036 & 0,1100 & 3,7883 & 0,0520 & 0,0977 & 0,0031 & 0,1474 & 0,0047\end{array}$ $\begin{array}{lllllllllllll}62,1 & 2,3310 & 0,0562 & 0,2087 & 0,0022 & 0,6700 & 4,7926 & 0,0502 & 0,0810 & 0,0021 & 0,0730 & 0,0356\end{array}$

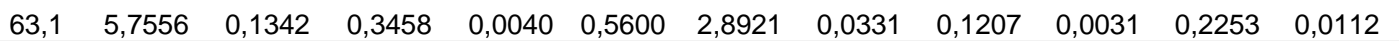


AMOSTRA NESG-1010: metawacke (Unidade Santo Antônio - Nappe Andrelândia)

\begin{tabular}{|c|c|c|c|c|c|c|c|c|c|c|c|c|c|c|c|c|c|c|c|}
\hline Spot & $207 / 235$ & 1sigma & 206/238 & 1sigma & Correl. & $238 / 206$ & 1sigma & $207 / 206$ & 1sigma & $208 / 206$ & 1sigma & $\begin{array}{c}T \\
206 / 238\end{array}$ & $\begin{array}{c}1 \\
\text { sigma }\end{array}$ & $\begin{array}{c}T \\
207 / 235\end{array}$ & $\begin{array}{c}1 \\
\text { sigma }\end{array}$ & $\begin{array}{c}T \\
207 / 206\end{array}$ & $\begin{array}{c}1 \\
\text { sigma }\end{array}$ & $\begin{array}{r}\% \text { Conc. } \\
206 / 238 \text { 207/235 }\end{array}$ & $\begin{array}{l}206 / 238 \\
207 / 206 \\
\end{array}$ \\
\hline 1,1 & 1,2532 & 0,0206 & 0,1364 & 0,0021 & 0,95 & 7,3338 & 0,1140 & 0,0663 & 0,0008 & 0,1599 & 0,0376 & 0,824 & 0,012 & 0,825 & 0,009 & 0,812 & 0,024 & 100 & 101 \\
\hline 1,2 & 0,7924 & 0,0138 & 0,0939 & 0,0015 & 0,92 & 10,6504 & 0,1712 & 0,0619 & 0,0007 & 0,0320 & 0,0077 & 0,579 & 0,009 & 0,593 & 0,008 & 0,667 & 0,025 & 98 & 87 \\
\hline 1,3 & 1,1766 & 0,0194 & 0,1296 & 0,0020 & 0,95 & 7,7139 & 0,1213 & 0,0661 & 0,0008 & 0,1511 & 0,0362 & 0,786 & 0,012 & 0,790 & 0,009 & 0,806 & 0,024 & 100 & 98 \\
\hline 2,1 & 1,4809 & 0,0269 & 0,1533 & 0,0026 & 0,94 & 6,5227 & 0,1114 & 0,0698 & 0,0010 & 0,2714 & 0,0659 & 0,919 & 0,015 & 0,923 & 0,011 & 0,921 & 0,030 & 100 & 100 \\
\hline 2,2 & 1,5111 & 0,0510 & 0,1600 & 0,0036 & 0,67 & 6,2500 & 0,1423 & 0,0709 & 0,0024 & 0,3234 & 0,0808 & 0,957 & 0,020 & 0,935 & 0,020 & 0,954 & 0,069 & 102 & 100 \\
\hline 2,3 & 1,5273 & 0,0257 & 0,1564 & 0,0025 & 0,94 & 6,3926 & 0,1011 & 0,0700 & 0,0009 & 0,2242 & 0,0555 & 0,937 & 0,014 & 0,941 & 0,010 & 0,925 & 0,026 & 100 & 101 \\
\hline 3,1 & 5,8379 & 0,0941 & 0,3448 & 0,0053 & 0,95 & 2,9004 & 0,0445 & 0,1243 & 0,0014 & 0,1605 & 0,0400 & 1,910 & 0,025 & 1,952 & 0,014 & 2,017 & 0,019 & 98 & 95 \\
\hline 3,2 & 6,8392 & 0,1100 & 0,3928 & 0,0061 & 0,96 & 2,5456 & 0,0392 & 0,1279 & 0,0014 & 0,4375 & 0,1103 & 2,136 & 0,028 & 2,091 & 0,014 & 2,066 & 0,019 & 102 & 103 \\
\hline 3,3 & 6,5455 & 0,1054 & 0,3801 & 0,0059 & 0,96 & 2,6306 & 0,0405 & 0,1250 & 0,0014 & 0,0592 & 0,0154 & 2,077 & 0,027 & 2,052 & 0,014 & 2,027 & 0,019 & 101 & 102 \\
\hline 4,1 & 3,7888 & 0,0610 & 0,2898 & 0,0045 & 0,96 & 3,4510 & 0,0532 & 0,0961 & 0,0011 & 0,1817 & 0,0469 & 1,640 & 0,022 & 1,590 & 0,013 & 1,555 & 0,021 & 103 & 105 \\
\hline 4,2 & 2,1119 & 0,0348 & 0,1797 & 0,0028 & 0,94 & 5,5663 & 0,0865 & 0,0872 & 0,0010 & 0,1591 & 0,0414 & 1,065 & 0,015 & 1,153 & 0,011 & 1,370 & 0,022 & 92 & 78 \\
\hline 5,1 & 2,2713 & 0,0361 & 0,2086 & 0,0032 & 0,96 & 4,7937 & 0,0729 & 0,0802 & 0,0009 & 0,1482 & 0,0391 & 1,221 & 0,017 & 1,203 & 0,011 & 1,207 & 0,022 & 101 & 101 \\
\hline 5,2 & 2,3080 & 0,0372 & 0,2130 & 0,0032 & 0,95 & 4,6942 & 0,0716 & 0,0794 & 0,0009 & 0,1267 & 0,0338 & 1,245 & 0,017 & 1,215 & 0,011 & 1,185 & 0,023 & 102 & 105 \\
\hline 5,3 & 2,2953 & 0,0199 & 0,2062 & 0,0017 & 0,97 & 4,8499 & 0,0406 & 0,0801 & 0,0006 & 0,1893 & 0,0832 & 1,208 & 0,009 & 1,211 & 0,006 & 1,204 & 0,016 & 100 & 100 \\
\hline 6,1 & 3,3036 & 0,0305 & 0,2707 & 0,0024 & 0,96 & 3,6946 & 0,0328 & 0,0897 & 0,0007 & 0,0718 & 0,0321 & 1,544 & 0,012 & 1,482 & 0,007 & 1,425 & 0,016 & 104 & 108 \\
\hline 7,1 & 3,5593 & 0,0317 & 0,2758 & 0,0024 & 0,97 & 3,6260 & 0,0314 & 0,0943 & 0,0008 & 0,1072 & 0,0488 & 1,570 & 0,012 & 1,540 & 0,007 & 1,521 & 0,015 & 102 & 103 \\
\hline 7,2 & 0,6855 & 0,0077 & 0,0854 & 0,0008 & 0,81 & 11,7081 & 0,1065 & 0,0586 & 0,0005 & 0,0095 & 0,0046 & 0,528 & 0,005 & 0,530 & 0,005 & 0,545 & 0,019 & 100 & 97 \\
\hline 8,1 & 2,5083 & 0,0230 & 0,2216 & 0,0020 & 0,98 & 4,5122 & 0,0405 & 0,0819 & 0,0006 & 0,5282 & 0,2490 & 1,290 & 0,011 & 1,274 & 0,007 & 1,248 & 0,015 & 101 & 103 \\
\hline 8,2 & 2,4613 & 0,0214 & 0,2186 & 0,0018 & 0,97 & 4,5746 & 0,0384 & 0,0813 & 0,0007 & 0,6080 & 0,2920 & 1,274 & 0,010 & 1,261 & 0,006 & 1,233 & 0,016 & 101 & 103 \\
\hline 9,1 & 1,2526 & 0,0121 & 0,1378 & 0,0012 & 0,90 & 7,2563 & 0,0633 & 0,0666 & 0,0006 & 0,1953 & 0,0954 & 0,832 & 0,007 & 0,825 & 0,005 & 0,820 & 0,018 & 101 & 101 \\
\hline 9,2 & 1,1629 & 0,0150 & 0,1288 & 0,0013 & 0,80 & 7,7657 & 0,0798 & 0,0654 & 0,0007 & 0,1364 & 0,0682 & 0,781 & 0,008 & 0,783 & 0,007 & 0,784 & 0,024 & 100 & 100 \\
\hline 9,3 & 4,2656 & 0,0476 & 0,2675 & 0,0027 & 0,90 & 3,7387 & 0,0375 & 0,1175 & 0,0009 & 0,2431 & 0,1237 & 1,528 & 0,014 & 1,687 & 0,009 & 1,919 & 0,013 & 91 & 80 \\
\hline 10,1 & 1,2002 & 0,0098 & 0,1322 & 0,0011 & 0,99 & 7,5646 & 0,0644 & 0,0660 & 0,0005 & 0,2383 & 0,1237 & 0,800 & 0,006 & 0,801 & 0,005 & 0,803 & 0,016 & 100 & 100 \\
\hline 10,2 & 1,2466 & 0,0107 & 0,1355 & 0,0012 & 1,00 & 7,3787 & 0,0634 & 0,0664 & 0,0005 & 0,2542 & 0,1348 & 0,819 & 0,007 & 0,822 & 0,005 & 0,817 & 0,016 & 100 & 100 \\
\hline 10,3 & 1,2320 & 0,0123 & 0,1352 & 0,0012 & 0,92 & 7,3955 & 0,0682 & 0,0668 & 0,0005 & 0,3057 & 0,1655 & 0,818 & 0,007 & 0,815 & 0,006 & 0,829 & 0,017 & 100 & 99 \\
\hline 11,1 & 4,4815 & 0,0412 & 0,2936 & 0,0028 & 0,99 & 3,4059 & 0,0324 & 0,1119 & 0,0008 & 0,3092 & 0,1710 & 1,660 & 0,014 & 1,728 & 0,008 & 1,833 & 0,013 & 96 & 91 \\
\hline
\end{tabular}




\begin{tabular}{|c|c|c|c|c|c|c|c|c|c|c|c|c|c|c|c|c|c|c|c|}
\hline 11,2 & 5,7683 & 0,1207 & 0,3631 & 0,0059 & 0,77 & 2,7541 & 0,0446 & 0,1159 & 0,0011 & 0,3051 & 0,0548 & 1,997 & 0,028 & 1,942 & 0,018 & 1,894 & 0,017 & 103 & 105 \\
\hline 12,1 & 2,1319 & 0,0491 & 0,1965 & 0,0034 & 0,75 & 5,0895 & 0,0876 & 0,0782 & 0,0008 & 0,1515 & 0,0273 & 1,156 & 0,018 & 1,159 & 0,016 & 1,156 & 0,021 & 100 & 100 \\
\hline 12,2 & 2,4070 & 0,0511 & 0,2156 & 0,0035 & 0,77 & 4,6383 & 0,0753 & 0,0816 & 0,0008 & 0,1925 & 0,0347 & 1,259 & 0,019 & 1,245 & 0,015 & 1,241 & 0,020 & 101 & 101 \\
\hline 13,1 & 1,2622 & 0,0361 & 0,1377 & 0,0027 & 0,69 & 7,2643 & 0,1425 & 0,0676 & 0,0010 & 0,3402 & 0,0614 & 0,831 & 0,015 & 0,829 & 0,016 & 0,855 & 0,031 & 100 & 97 \\
\hline 14,1 & 0,9476 & 0,0204 & 0,1121 & 0,0018 & 0,76 & 8,9170 & 0,1458 & 0,0613 & 0,0007 & 0,1629 & 0,0294 & 0,685 & 0,011 & 0,677 & 0,011 & 0,642 & 0,023 & 101 & 107 \\
\hline 14,2 & 0,8862 & 0,0211 & 0,1037 & 0,0020 & 0,82 & 9,6439 & 0,1893 & 0,0612 & 0,0006 & 0,2297 & 0,0414 & 0,636 & 0,012 & 0,644 & 0,011 & 0,639 & 0,022 & 99 & 100 \\
\hline 15,1 & 5,4143 & 0,1162 & 0,3390 & 0,0057 & 0,78 & 2,9499 & 0,0493 & 0,1154 & 0,0011 & 0,1439 & 0,0260 & 1,882 & 0,027 & 1,887 & 0,018 & 1,887 & 0,017 & 100 & 100 \\
\hline 15,2 & 5,9167 & 0,1241 & 0,3598 & 0,0058 & 0,77 & 2,7794 & 0,0451 & 0,1185 & 0,0012 & 0,2593 & 0,0469 & 1,981 & 0,028 & 1,964 & 0,018 & 1,934 & 0,017 & 101 & 102 \\
\hline 16,1 & 5,7614 & 0,1206 & 0,3530 & 0,0057 & 0,77 & 2,8328 & 0,0458 & 0,1177 & 0,0012 & 0,2853 & 0,0515 & 1,949 & 0,027 & 1,941 & 0,018 & 1,922 & 0,017 & 100 & 101 \\
\hline 17,1 & 1,1714 & 0,0248 & 0,1316 & 0,0022 & 0,77 & 7,5973 & 0,1246 & 0,0644 & 0,0006 & 0,1133 & 0,0208 & 0,797 & 0,012 & 0,787 & 0,012 & 0,749 & 0,021 & 101 & 106 \\
\hline 18,1 & 1,0269 & 0,0216 & 0,1198 & 0,0020 & 0,78 & 8,3442 & 0,1360 & 0,0627 & 0,0006 & 0,2361 & 0,0427 & 0,730 & 0,011 & 0,717 & 0,011 & 0,692 & 0,021 & 102 & 105 \\
\hline 18,2 & 0,8733 & 0,0182 & 0,1049 & 0,0017 & 0,78 & 9,5323 & 0,1541 & 0,0606 & 0,0006 & 0,0016 & 0,0005 & 0,643 & 0,010 & 0,637 & 0,010 & 0,620 & 0,021 & 101 & 104 \\
\hline 19,1 & 1,6720 & 0,0446 & 0,1690 & 0,0037 & 0,83 & 5,9158 & 0,1304 & 0,0728 & 0,0016 & 0,2405 & 0,0443 & 1,007 & 0,021 & 0,998 & 0,017 & 1,010 & 0,045 & 101 & 100 \\
\hline 20,1 & 1,2730 & 0,0260 & 0,1397 & 0,0009 & 0,32 & 7,1605 & 0,0468 & 0,0667 & 0,0010 & 0,4610 & 0,3822 & 0,843 & 0,005 & 0,834 & 0,012 & 0,823 & 0,031 & 101 & 102 \\
\hline 21,1 & 0,9957 & 0,0203 & 0,1134 & 0,0007 & 0,31 & 8,8152 & 0,0565 & 0,0632 & 0,0009 & 0,4214 & 0,3620 & 0,693 & 0,004 & 0,702 & 0,010 & 0,710 & 0,031 & 99 & 98 \\
\hline 21,2 & 0,8229 & 0,0170 & 0,0996 & 0,0007 & 0,33 & 10,0379 & 0,0682 & 0,0603 & 0,0009 & 0,0110 & 0,0100 & 0,612 & 0,004 & 0,610 & 0,009 & 0,609 & 0,032 & 100 & 100 \\
\hline 22,1 & 0,9521 & 0,0193 & 0,1114 & 0,0007 & 0,32 & 8,9746 & 0,0574 & 0,0623 & 0,0009 & 0,6176 & 0,5722 & 0,681 & 0,004 & 0,679 & 0,010 & 0,680 & 0,031 & 100 & 100 \\
\hline 22,2 & 1,0340 & 0,0213 & 0,1157 & 0,0008 & 0,35 & 8,6442 & 0,0617 & 0,0630 & 0,0009 & 0,6528 & 0,6294 & 0,706 & 0,005 & 0,721 & 0,011 & 0,704 & 0,032 & 98 & 100 \\
\hline 23,1 & 1,7602 & 0,0408 & 0,1799 & 0,0014 & 0,34 & 5,5577 & 0,0435 & 0,0739 & 0,0011 & 0,1667 & 0,1675 & 1,067 & 0,008 & 1,031 & 0,015 & 1,041 & 0,031 & 103 & 102 \\
\hline 23,2 & 1,7521 & 0,0522 & 0,1760 & 0,0024 & 0,46 & 5,6809 & 0,0773 & 0,0741 & 0,0011 & 0,1517 & 0,1582 & 1,045 & 0,013 & 1,028 & 0,019 & 1,045 & 0,031 & 102 & 100 \\
\hline 23,3 & 1,7281 & 0,0363 & 0,1706 & 0,0013 & 0,37 & 5,8610 & 0,0459 & 0,0739 & 0,0011 & 0,1808 & 0,1986 & 1,016 & 0,007 & 1,019 & 0,013 & 1,041 & 0,029 & 100 & 98 \\
\hline 24,1 & 6,5208 & 0,1319 & 0,3747 & 0,0024 & 0,31 & 2,6689 & 0,0168 & 0,1259 & 0,0018 & 0,4377 & 0,5041 & 2,051 & 0,011 & 2,049 & 0,018 & 2,039 & 0,025 & 100 & 101 \\
\hline 25,1 & 5,1904 & 0,1053 & 0,3401 & 0,0023 & 0,33 & 2,9407 & 0,0195 & 0,1106 & 0,0016 & 0,4502 & 0,5451 & 1,887 & 0,011 & 1,851 & 0,017 & 1,811 & 0,025 & 102 & 104 \\
\hline 26,1 & 0,8398 & 0,0201 & 0,1009 & 0,0013 & 0,53 & 9,9090 & 0,1258 & 0,0604 & 0,0009 & $-0,0255$ & 0,0328 & 0,620 & 0,008 & 0,619 & 0,011 & 0,611 & 0,032 & 100 & 101 \\
\hline 26,2 & 0,8563 & 0,0218 & 0,1026 & 0,0013 & 0,50 & 9,7422 & 0,1234 & 0,0619 & 0,0009 & 0,0415 & 0,0561 & 0,630 & 0,008 & 0,628 & 0,012 & 0,664 & 0,032 & 100 & 95 \\
\hline 26,3 & 1,1382 & 0,0257 & 0,1267 & 0,0014 & 0,48 & 7,8928 & 0,0852 & 0,0649 & 0,0009 & 0,7177 & 1,0266 & 0,769 & 0,008 & 0,772 & 0,012 & 0,766 & 0,031 & 100 & 100 \\
\hline 28,1 & 0,9706 & 0,0088 & 0,1128 & 0,0008 & 0,77 & 8,8648 & 0,0618 & 0,0626 & 0,0004 & 0,2824 & 0,0689 & 0,689 & 0,005 & 0,689 & 0,005 & 0,689 & 0,013 & 100 & 100 \\
\hline 29,1 & 0,8546 & 0,0094 & 0,0965 & 0,0009 & 0,81 & 10,3595 & 0,0927 & 0,0643 & 0,0005 & 0,0925 & 0,0221 & 0,594 & 0,005 & 0,627 & 0,005 & 0,746 & 0,015 & 95 & 80 \\
\hline 29,2 & 1,2411 & 0,0120 & 0,1352 & 0,0010 & 0,74 & 7,3947 & 0,0532 & 0,0662 & 0,0004 & 0,1212 & 0,0283 & 0,818 & 0,006 & 0,819 & 0,005 & 0,808 & 0,014 & 100 & 101 \\
\hline 30,1 & 2,9820 & 0,0335 & 0,2393 & 0,0023 & 0,84 & 4,1781 & 0,0394 & 0,0907 & 0,0006 & 0,1914 & 0,0437 & 1,383 & 0,012 & 1,403 & 0,009 & 1,447 & 0,012 & 99 & 96 \\
\hline
\end{tabular}




\begin{tabular}{|c|c|c|c|c|c|c|c|c|c|c|c|c|c|c|c|c|c|c|c|}
\hline 31,1 & 6,0295 & 0,0527 & 0,3602 & 0,0026 & 0,81 & 2,7762 & 0,0197 & 0,1214 & 0,0007 & 0,1211 & 0,0272 & 1,983 & 0,012 & 1,980 & 0,008 & 1,976 & 0,010 & 100 & 100 \\
\hline 31,2 & 6,2350 & 0,0968 & 0,3705 & 0,0026 & 0,46 & 2,6988 & 0,0191 & 0,1220 & 0,0019 & 0,2554 & 0,0343 & 2,032 & 0,012 & 2,009 & 0,013 & 1,984 & 0,027 & 101 & 102 \\
\hline 32,1 & 7,8552 & 0,0640 & 0,4170 & 0,0029 & 0,84 & 2,3981 & 0,0164 & 0,1379 & 0,0008 & 0,2027 & 0,0444 & 2,247 & 0,013 & 2,215 & 0,007 & 2,198 & 0,010 & 101 & 102 \\
\hline 33,1 & 5,6687 & 0,0481 & 0,3535 & 0,0025 & 0,82 & 2,8287 & 0,0197 & 0,1178 & 0,0007 & 0,2904 & 0,0623 & 1,951 & 0,012 & 1,927 & 0,007 & 1,923 & 0,010 & 101 & 101 \\
\hline 34,1 & 0,8478 & 0,0104 & 0,1011 & 0,0009 & 0,69 & 9,8941 & 0,0836 & 0,0622 & 0,0004 & 0,2556 & 0,0542 & 0,621 & 0,005 & 0,623 & 0,006 & 0,675 & 0,014 & 100 & 92 \\
\hline 34,2 & 1,1128 & 0,0091 & 0,1279 & 0,0009 & 0,85 & 7,8197 & 0,0543 & 0,0638 & 0,0004 & 0,4182 & 0,0861 & 0,776 & 0,005 & 0,760 & 0,004 & 0,729 & 0,012 & 102 & 106 \\
\hline 35,1 & 1,8255 & 0,0219 & 0,1744 & 0,0017 & 0,81 & 5,7342 & 0,0556 & 0,0767 & 0,0006 & 0,1638 & 0,0332 & 1,036 & 0,009 & 1,055 & 0,008 & 1,115 & 0,015 & 98 & 93 \\
\hline 35,2 & 3,0516 & 0,0280 & 0,2527 & 0,0019 & 0,80 & 3,9567 & 0,0291 & 0,0887 & 0,0006 & 0,2178 & 0,0432 & 1,453 & 0,010 & 1,421 & 0,007 & 1,404 & 0,012 & 102 & 103 \\
\hline 36,1 & 1,0449 & 0,0115 & 0,1193 & 0,0009 & 0,70 & 8,3807 & 0,0646 & 0,0638 & 0,0005 & 0,1589 & 0,0310 & 0,727 & 0,005 & 0,726 & 0,006 & 0,730 & 0,015 & 100 & 100 \\
\hline 36,2 & 3,7858 & 0,0731 & 0,2610 & 0,0015 & 0,29 & 3,8312 & 0,0215 & 0,1056 & 0,0014 & 0,2566 & 0,0632 & 1,495 & 0,007 & 1,590 & 0,015 & 1,728 & 0,024 & 94 & 87 \\
\hline 37,1 & 1,0815 & 0,0223 & 0,1208 & 0,0009 & 0,35 & 8,2753 & 0,0592 & 0,0651 & 0,0009 & 0,0526 & 0,0134 & 0,735 & 0,005 & 0,744 & 0,011 & 0,773 & 0,030 & 99 & 95 \\
\hline 37,2 & 2,3550 & 0,0449 & 0,2125 & 0,0012 & 0,29 & 4,7052 & 0,0260 & 0,0810 & 0,0011 & 0,3951 & 0,1001 & 1,242 & 0,006 & 1,229 & 0,013 & 1,224 & 0,026 & 101 & 101 \\
\hline 38,1 & 0,9652 & 0,0184 & 0,1126 & 0,0006 & 0,27 & 8,8847 & 0,0456 & 0,0625 & 0,0008 & 0,2106 & 0,0542 & 0,688 & 0,003 & 0,686 & 0,009 & 0,685 & 0,029 & 100 & 100 \\
\hline 39,1 & 0,8589 & 0,0165 & 0,1031 & 0,0006 & 0,28 & 9,7004 & 0,0520 & 0,0607 & 0,0008 & $-0,0008$ & 0,0014 & 0,632 & 0,003 & 0,630 & 0,009 & 0,621 & 0,029 & 100 & 102 \\
\hline 39,2 & 3,1358 & 0,0593 & 0,2515 & 0,0013 & 0,27 & 3,9754 & 0,0200 & 0,0898 & 0,0012 & 0,0962 & 0,0255 & 1,446 & 0,007 & 1,442 & 0,014 & 1,427 & 0,025 & 100 & 101 \\
\hline 40,1 & 1,7060 & 0,0345 & 0,1694 & 0,0011 & 0,33 & 5,9031 & 0,0397 & 0,0727 & 0,0011 & 0,1755 & 0,0475 & 1,009 & 0,006 & 1,011 & 0,013 & 1,005 & 0,031 & 100 & 100 \\
\hline 41,1 & 2,7746 & 0,0530 & 0,2332 & 0,0013 & 0,30 & 4,2889 & 0,0243 & 0,0849 & 0,0012 & 0,2038 & 0,0558 & 1,351 & 0,007 & 1,349 & 0,014 & 1,319 & 0,027 & 100 & 102 \\
\hline 42,1 & 4,6785 & 0,0954 & 0,3009 & 0,0023 & 0,38 & 3,3237 & 0,0256 & 0,1142 & 0,0015 & 0,3778 & 0,1049 & 1,696 & 0,011 & 1,763 & 0,017 & 1,868 & 0,024 & 96 & 91 \\
\hline 43,1 & 0,9005 & 0,0211 & 0,1057 & 0,0007 & 0,27 & 9,4603 & 0,0590 & 0,0616 & 0,0011 & 0,1236 & 0,0352 & 0,648 & 0,004 & 0,652 & 0,011 & 0,656 & 0,039 & 99 & 99 \\
\hline 43,2 & 0,9892 & 0,0205 & 0,1150 & 0,0008 & 0,32 & 8,6947 & 0,0579 & 0,0630 & 0,0009 & 0,3289 & 0,0945 & 0,702 & 0,004 & 0,698 & 0,010 & 0,702 & 0,031 & 100 & 100 \\
\hline 44,1 & 0,8636 & 0,0177 & 0,1035 & 0,0008 & 0,37 & 9,6580 & 0,0728 & 0,0611 & 0,0008 & 0,0016 & 0,0030 & 0,635 & 0,005 & 0,632 & 0,010 & 0,637 & 0,029 & 100 & 100 \\
\hline 45,1 & 1,2158 & 0,0227 & 0,1329 & 0,0006 & 0,26 & 7,5252 & 0,0363 & 0,0659 & 0,0009 & 0,2652 & 0,0786 & 0,804 & 0,004 & 0,808 & 0,010 & 0,801 & 0,028 & 100 & 100 \\
\hline 46,1 & 4,6075 & 0,0843 & 0,3158 & 0,0038 & 0,66 & 3,1664 & 0,0384 & 0,1045 & 0,0009 & 0,5250 & 0,1141 & 1,769 & 0,019 & 1,751 & 0,015 & 1,710 & 0,016 & 101 & 103 \\
\hline 47,1 & 1,7221 & 0,0302 & 0,1712 & 0,0019 & 0,64 & 5,8420 & 0,0656 & 0,0727 & 0,0006 & 0,1700 & 0,0374 & 1,019 & 0,011 & 1,017 & 0,011 & 1,007 & 0,018 & 100 & 101 \\
\hline 48,1 & 1,2105 & 0,0215 & 0,1325 & 0,0015 & 0,63 & 7,5478 & 0,0849 & 0,0654 & 0,0006 & 0,3333 & 0,0743 & 0,802 & 0,008 & 0,805 & 0,010 & 0,784 & 0,019 & 100 & 102 \\
\hline 49,1 & 5,5935 & 0,0983 & 0,3362 & 0,0038 & 0,65 & 2,9742 & 0,0338 & 0,1200 & 0,0010 & 0,3980 & 0,0899 & 1,868 & 0,018 & 1,915 & 0,015 & 1,956 & 0,015 & 98 & 96 \\
\hline 50,1 & 0,8565 & 0,0151 & 0,1022 & 0,0012 & 0,64 & 9,7860 & 0,1108 & 0,0609 & 0,0005 & 0,0026 & 0,0016 & 0,627 & 0,007 & 0,628 & 0,008 & 0,630 & 0,019 & 100 & 100 \\
\hline 51,1 & 1,1200 & 0,0195 & 0,1262 & 0,0014 & 0,64 & 7,9229 & 0,0890 & 0,0648 & 0,0006 & 0,1860 & 0,0432 & 0,766 & 0,008 & 0,763 & 0,009 & 0,764 & 0,019 & 100 & 100 \\
\hline 52,1 & 2,9383 & 0,0524 & 0,2399 & 0,0028 & 0,65 & 4,1683 & 0,0485 & 0,0901 & 0,0008 & 0,1064 & 0,0251 & 1,386 & 0,014 & 1,392 & 0,013 & 1,434 & 0,017 & 100 & 97 \\
\hline 53,1 & 6,1585 & 0,1082 & 0,3627 & 0,0042 & 0,65 & 2,7572 & 0,0316 & 0,1241 & 0,0011 & 0,4530 & 0,1087 & 1,995 & 0,020 & 1,999 & 0,015 & 2,014 & 0,015 & 100 & 99 \\
\hline
\end{tabular}




\begin{tabular}{|c|c|c|c|c|c|c|c|c|c|c|c|c|c|c|c|c|c|c|c|}
\hline 53,2 & 1,3370 & 0,0333 & 0,1302 & 0,0016 & 0,51 & 7,6795 & 0,0970 & 0,0772 & 0,0012 & 0,0113 & 0,0059 & 0,789 & 0,009 & 0,862 & 0,014 & 1,128 & 0,031 & 92 & 70 \\
\hline 54,1 & 1,0284 & 0,0187 & 0,1181 & 0,0014 & 0,65 & 8,4647 & 0,0997 & 0,0637 & 0,0006 & 0,1965 & 0,0483 & 0,720 & 0,008 & 0,718 & 0,009 & 0,728 & 0,020 & 100 & 99 \\
\hline 55,1 & 0,9836 & 0,0179 & 0,1128 & 0,0014 & 0,69 & 8,8620 & 0,1108 & 0,0625 & 0,0006 & 0,3832 & 0,0957 & 0,689 & 0,008 & 0,695 & 0,009 & 0,686 & 0,019 & 99 & 100 \\
\hline 56,1 & 1,2454 & 0,0219 & 0,1361 & 0,0015 & 0,64 & 7,3471 & 0,0826 & 0,0659 & 0,0006 & 0,2608 & 0,0660 & 0,823 & 0,009 & 0,821 & 0,010 & 0,799 & 0,019 & 100 & 103 \\
\hline 56,2 & 0,8139 & 0,0157 & 0,0976 & 0,0012 & 0,66 & 10,2478 & 0,1309 & 0,0606 & 0,0006 & 0,0074 & 0,0031 & 0,600 & 0,007 & 0,605 & 0,009 & 0,621 & 0,023 & 99 & 97 \\
\hline 57,1 & 0,9923 & 0,0161 & 0,1142 & 0,0009 & 0,50 & 8,7558 & 0,0713 & 0,0629 & 0,0010 & 0,1151 & 0,0155 & 0,697 & 0,005 & 0,700 & 0,008 & 0,700 & 0,033 & 100 & 100 \\
\hline 57,2 & 0,8063 & 0,0172 & 0,0978 & 0,0013 & 0,60 & 10,2227 & 0,1308 & 0,0612 & 0,0010 & 0,0528 & 0,0077 & 0,602 & 0,007 & 0,600 & 0,010 & 0,642 & 0,034 & 100 & 94 \\
\hline 58,1 & 7,6885 & 0,1662 & 0,3927 & 0,0039 & 0,45 & 2,5465 & 0,0250 & 0,1410 & 0,0023 & 0,1663 & 0,0219 & 2,135 & 0,018 & 2,195 & 0,019 & 2,236 & 0,028 & 97 & 96 \\
\hline 59,1 & 0,9185 & 0,0171 & 0,1076 & 0,0011 & 0,53 & 9,2977 & 0,0919 & 0,0616 & 0,0011 & 0,0385 & 0,0080 & 0,659 & 0,006 & 0,662 & 0,009 & 0,656 & 0,040 & 100 & 100 \\
\hline 59,2 & 1,1931 & 0,0189 & 0,1323 & 0,0010 & 0,47 & 7,5575 & 0,0564 & 0,0652 & 0,0010 & 0,2007 & 0,0263 & 0,801 & 0,006 & 0,797 & 0,009 & 0,776 & 0,034 & 100 & 103 \\
\hline 60,1 & 10,7582 & 0,1642 & 0,4610 & 0,0032 & 0,45 & 2,1693 & 0,0150 & 0,1698 & 0,0026 & 0,3248 & 0,0423 & 2,444 & 0,014 & 2,502 & 0,014 & 2,555 & 0,026 & 98 & 96 \\
\hline 61,1 & 10,2531 & 0,1770 & 0,4638 & 0,0044 & 0,55 & 2,1563 & 0,0206 & 0,1610 & 0,0025 & 0,2953 & 0,0383 & 2,456 & 0,020 & 2,458 & 0,016 & 2,464 & 0,026 & 100 & 100 \\
\hline 62,1 & 2,9386 & 0,0508 & 0,2374 & 0,0021 & 0,51 & 4,2132 & 0,0370 & 0,0902 & 0,0014 & 0,2237 & 0,0289 & 1,373 & 0,011 & 1,392 & 0,013 & 1,436 & 0,029 & 99 & 96 \\
\hline 63,1 & 1,6998 & 0,0267 & 0,1690 & 0,0012 & 0,46 & 5,9182 & 0,0430 & 0,0729 & 0,0011 & 0,4468 & 0,0574 & 1,006 & 0,007 & 1,008 & 0,010 & 1,011 & 0,032 & 100 & 100 \\
\hline 64,1 & 4,8013 & 0,0963 & 0,3188 & 0,0041 & 0,65 & 3,1366 & 0,0407 & 0,1090 & 0,0017 & 0,6491 & 0,0837 & 1,784 & 0,020 & 1,785 & 0,017 & 1,786 & 0,027 & 100 & 100 \\
\hline 65,1 & 0,9781 & 0,0174 & 0,1123 & 0,0010 & 0,50 & 8,9030 & 0,0787 & 0,0637 & 0,0011 & 0,2157 & 0,0277 & 0,686 & 0,006 & 0,693 & 0,009 & 0,726 & 0,038 & 99 & 95 \\
\hline 65,2 & 1,2695 & 0,0218 & 0,1356 & 0,0013 & 0,54 & 7,3750 & 0,0688 & 0,0666 & 0,0011 & 0,4072 & 0,0518 & 0,820 & 0,007 & 0,832 & 0,010 & 0,820 & 0,033 & 99 & 100 \\
\hline 66,1 & 1,6236 & 0,0175 & 0,1646 & 0,0021 & 0,99 & 6,0739 & 0,0793 & 0,0720 & 0,0009 & 0,1079 & 0,0327 & 0,983 & 0,012 & 0,979 & 0,007 & 0,986 & 0,027 & 100 & 100 \\
\hline 67,1 & 0,8342 & 0,0253 & 0,1027 & 0,0025 & 0,80 & 9,7353 & 0,2361 & 0,0611 & 0,0011 & 3,5832 & 1,8449 & 0,630 & 0,015 & 0,616 & 0,014 & 0,636 & 0,038 & 102 & 99 \\
\hline 68,1 & 1,1992 & 0,0141 & 0,1324 & 0,0018 & 0,99 & 7,5512 & 0,1022 & 0,0661 & 0,0009 & 0,2462 & 0,0739 & 0,802 & 0,010 & 0,800 & 0,006 & 0,805 & 0,029 & 100 & 100 \\
\hline 69,1 & 3,4990 & 0,0378 & 0,2661 & 0,0035 & 0,99 & 3,7582 & 0,0492 & 0,0954 & 0,0013 & 0,2273 & 0,0678 & 1,521 & 0,018 & 1,527 & 0,009 & 1,542 & 0,024 & 100 & 99 \\
\hline 70,1 & 6,7418 & 0,0790 & 0,3783 & 0,0052 & 0,99 & 2,6432 & 0,0360 & 0,1297 & 0,0017 & 0,1967 & 0,0584 & 2,068 & 0,024 & 2,078 & 0,010 & 2,091 & 0,023 & 100 & 99 \\
\hline 71,1 & 2,2383 & 0,0256 & 0,2031 & 0,0028 & 0,99 & 4,9230 & 0,0673 & 0,0798 & 0,0011 & 0,4484 & 0,1325 & 1,192 & 0,015 & 1,193 & 0,008 & 1,196 & 0,027 & 100 & 100 \\
\hline 71,2 & 2,1480 & 0,0244 & 0,1936 & 0,0026 & 0,99 & 5,1665 & 0,0698 & 0,0807 & 0,0011 & 0,1404 & 0,0414 & 1,141 & 0,014 & 1,164 & 0,008 & 1,219 & 0,026 & 98 & 94 \\
\hline 72,1 & 2,2853 & 0,0252 & 0,2027 & 0,0027 & 0,99 & 4,9341 & 0,0658 & 0,0816 & 0,0011 & 0,1305 & 0,0382 & 1,190 & 0,014 & 1,208 & 0,008 & 1,241 & 0,026 & 99 & 96 \\
\hline 73,1 & 2,3843 & 0,0262 & 0,2117 & 0,0028 & 0,99 & 4,7234 & 0,0632 & 0,0817 & 0,0011 & 1,0502 & 0,3057 & 1,238 & 0,015 & 1,238 & 0,008 & 1,242 & 0,026 & 100 & 100 \\
\hline 74,1 & 4,8125 & 0,0543 & 0,3194 & 0,0044 & 0,99 & 3,1308 & 0,0432 & 0,1094 & 0,0015 & 0,5166 & 0,1497 & 1,787 & 0,022 & 1,787 & 0,009 & 1,793 & 0,024 & 100 & 100 \\
\hline 75,1 & 12,4908 & 0,1338 & 0,4852 & 0,0064 & 0,99 & 2,0609 & 0,0273 & 0,1872 & 0,0024 & 0,3453 & 0,0995 & 2,550 & 0,028 & 2,642 & 0,010 & 2,721 & 0,022 & 97 & 94 \\
\hline 76,1 & 3,5932 & 0,0390 & 0,2653 & 0,0035 & 0,99 & 3,7692 & 0,0501 & 0,0986 & 0,0013 & 0,1935 & 0,0555 & 1,517 & 0,018 & 1,548 & 0,009 & 1,604 & 0,024 & 98 & 95 \\
\hline 76,2 & 1,1283 & 0,0165 & 0,1144 & 0,0017 & 0,99 & 8,7380 & 0,1270 & 0,0721 & 0,0010 & 0,0338 & 0,0098 & 0,699 & 0,010 & 0,767 & 0,008 & 0,990 & 0,028 & 91 & 71 \\
\hline
\end{tabular}




\begin{tabular}{|c|c|c|c|c|c|c|c|c|c|c|c|c|c|c|c|c|c|c|c|}
\hline 77,1 & 2,4028 & 0,0240 & 0,2131 & 0,0011 & 0,53 & 4,6925 & 0,0248 & 0,0820 & 0,0005 & 0,1794 & 0,0512 & 1,245 & 0,006 & 1,243 & 0,007 & 1,250 & 0,012 & 100 & 100 \\
\hline 78,1 & 1,6442 & 0,0170 & 0,1658 & 0,0009 & 0,50 & 6,0300 & 0,0312 & 0,0723 & 0,0005 & 0,5554 & 0,1545 & 0,989 & 0,005 & 0,987 & 0,007 & 0,994 & 0,015 & 100 & 100 \\
\hline 79,1 & 0,9483 & 0,0140 & 0,1110 & 0,0006 & 0,39 & 9,0104 & 0,0516 & 0,0622 & 0,0007 & 0,3658 & 0,0994 & 0,678 & 0,004 & 0,677 & 0,007 & 0,677 & 0,026 & 100 & 100 \\
\hline 80,1 & 2,2311 & 0,0278 & 0,1604 & 0,0014 & 0,71 & 6,2354 & 0,0556 & 0,1017 & 0,0007 & 0,1096 & 0,0291 & 0,959 & 0,008 & 1,191 & 0,009 & 1,660 & 0,013 & 81 & 58 \\
\hline 81,1 & 2,3520 & 0,0296 & 0,2109 & 0,0015 & 0,58 & 4,7416 & 0,0348 & 0,0815 & 0,0006 & 0,5701 & 0,1477 & 1,234 & 0,008 & 1,228 & 0,009 & 1,238 & 0,014 & 100 & 100 \\
\hline 82,1 & 5,2365 & 0,0531 & 0,3286 & 0,0017 & 0,52 & 3,0430 & 0,0161 & 0,1160 & 0,0007 & 0,4546 & 0,1151 & 1,832 & 0,008 & 1,859 & 0,009 & 1,897 & 0,011 & 99 & 97 \\
\hline 83,1 & 1,6495 & 0,0180 & 0,1668 & 0,0010 & 0,52 & 5,9963 & 0,0343 & 0,0723 & 0,0005 & 0,2197 & 0,0548 & 0,994 & 0,005 & 0,989 & 0,007 & 0,995 & 0,015 & 100 & 100 \\
\hline 84,1 & 1,1709 & 0,0138 & 0,1144 & 0,0008 & 0,57 & 8,7450 & 0,0586 & 0,0747 & 0,0005 & 0,0547 & 0,0134 & 0,698 & 0,004 & 0,787 & 0,006 & 1,063 & 0,014 & 89 & 66 \\
\hline 85,1 & 0,8943 & 0,0107 & 0,1048 & 0,0009 & 0,68 & 9,5441 & 0,0783 & 0,0621 & 0,0005 & 0,2865 & 0,0681 & 0,642 & 0,005 & 0,649 & 0,006 & 0,672 & 0,016 & 99 & 96 \\
\hline 86,1 & 5,7904 & 0,0639 & 0,3516 & 0,0023 & 0,60 & 2,8438 & 0,0188 & 0,1197 & 0,0007 & 0,5608 & 0,1303 & 1,942 & 0,011 & 1,945 & 0,010 & 1,951 & 0,011 & 100 & 100 \\
\hline 87,1 & 5,2383 & 0,0527 & 0,3309 & 0,0018 & 0,55 & 3,0217 & 0,0166 & 0,1141 & 0,0007 & 0,4042 & 0,0919 & 1,843 & 0,009 & 1,859 & 0,009 & 1,868 & 0,011 & 99 & 99 \\
\hline 88,1 & 1,2150 & 0,0129 & 0,1331 & 0,0009 & 0,61 & 7,5157 & 0,0488 & 0,0660 & 0,0004 & 0,2028 & 0,0453 & 0,805 & 0,005 & 0,807 & 0,006 & 0,802 & 0,013 & 100 & 100 \\
\hline 89,1 & 0,8507 & 0,0108 & 0,1022 & 0,0009 & 0,68 & 9,7888 & 0,0848 & 0,0616 & 0,0005 & 0,0684 & 0,0155 & 0,627 & 0,005 & 0,625 & 0,006 & 0,653 & 0,016 & 100 & 96 \\
\hline
\end{tabular}

AMOSTRA NESG-1434: metapelito (Unidade Serra da Boa Vista - Nappe Andrelândia)

\begin{tabular}{|c|c|c|c|c|c|c|c|c|c|c|c|c|c|c|c|c|c|c|}
\hline Spot & 207/235 & 1sigma & $206 / 238$ & 1sigma & Correl. & $238 / 206$ & 1 sigma & 207/206 & 1sigma & 208/206 & 1sigma & $\begin{array}{c}T \\
206 / 238\end{array}$ & 1 sigma & $\begin{array}{c}T \\
207 / 235\end{array}$ & 1 sigma & $\begin{array}{c}T \\
207 / 206\end{array}$ & 1 sigma & $\%$ Conc. \\
\hline \multicolumn{19}{|c|}{2011} \\
\hline 1,1 & 0,8502 & 0,0078 & 0,1022 & 0,0009 & 0,92 & 9,7842 & 0,0822 & 0,0603 & 0,0007 & 0,0055 & 0,0014 & 0,627 & 0,005 & 0,625 & 0,004 & 0,607 & 0,026 & 103 \\
\hline 1,2 & 5,004 & 0,0718 & 0,328 & 0,0032 & 0,69 & 3,0489 & 0,0301 & 0,1145 & 0,0019 & 0,1972 & 0,0477 & 1,829 & 0,016 & 1,82 & 0,012 & 1,873 & 0,029 & 98 \\
\hline 2,1 & 5,9991 & 0,0612 & 0,3456 & 0,0032 & 0,9 & 2,8934 & 0,0264 & 0,1276 & 0,0015 & 0,3308 & 0,0788 & 1,914 & 0,015 & 1,976 & 0,009 & 2,062 & 0,021 & 93 \\
\hline 2,2 & 0,832 & 0,0079 & 0,1003 & 0,0008 & 0,89 & 9,9744 & 0,0841 & 0,0605 & 0,0007 & 0,0019 & 0,0015 & 0,616 & 0,005 & 0,615 & 0,004 & 0,614 & 0,026 & 100 \\
\hline 3,1 & 1,4818 & 0,0143 & 0,149 & 0,0015 & 0,99 & 6,7095 & 0,0688 & 0,0686 & 0,0012 & 0,0446 & 0,0116 & 0,896 & 0,009 & 0,923 & 0,006 & 0,885 & 0,037 & 101 \\
\hline 4,1 & 14,3336 & 0,2445 & 0,5487 & 0,0086 & 0,92 & 1,8225 & 0,0286 & 0,2252 & 0,0035 & 0,6177 & 0,1441 & 2,82 & 0,036 & 2,772 & 0,016 & 3,024 & 0,024 & 93 \\
\hline 5,1 & 2,40 & 0,03 & 0,20 & 0,00 & 0,87 & 4,92 & 0,06 & 0,09 & 0,00 & 0,18 & 0,04 & 1,19 & 0,01 & 1,24 & 0,01 & 1,36 & 0,02 & 88 \\
\hline 6,1 & 0,8981 & 0,0088 & 0,1057 & 0,001 & 0,92 & 9,465 & 0,0856 & 0,0615 & 0,0007 & 0,0099 & 0,0027 & 0,647 & 0,006 & 0,651 & 0,005 & 0,65 & 0,026 & 100 \\
\hline 7,1 & 1,06 & 0,02 & 0,10 & 0,00 & 0,51 & 10,28 & 0,09 & 0,08 & 0,00 & 0,10 & 0,02 & 0,60 & 0,01 & 0,73 & 0,01 & 1,16 & 0,03 & 52 \\
\hline 8,1 & 2,66 & 0,04 & 0,18 & 0,00 & 0,79 & 5,65 & 0,07 & 0,11 & 0,00 & 0,22 & 0,05 & 1,05 & 0,01 & 1,32 & 0,01 & 1,86 & 0,03 & 57 \\
\hline 9,1 & 0,9312 & 0,0176 & 0,1087 & 0,0013 & 0,65 & 9,2034 & 0,1133 & 0,0635 & 0,0009 & 0,0285 & 0,008 & 0,665 & 0,008 & 0,668 & 0,009 & 0,719 & 0,031 & 93 \\
\hline
\end{tabular}




\begin{tabular}{|c|c|c|c|c|c|c|c|c|c|c|c|c|c|c|c|c|c|c|}
\hline 10,1 & 6,6972 & 0,1748 & 0,3786 & 0,0092 & 0,93 & 2,6411 & 0,0642 & 0,1283 & 0,0024 & 0,0205 & 0,0054 & 2,07 & 0,043 & 2,072 & 0,023 & 2,073 & 0,033 & 100 \\
\hline 11,1 & 4,49 & 0,06 & 0,28 & 0,00 & 0,96 & 3,64 & 0,04 & 0,13 & 0,00 & 0,18 & 0,04 & 1,57 & 0,02 & 1,73 & 0,01 & 2,13 & 0,02 & 74 \\
\hline 12,1 & 0,73 & 0,01 & 0,09 & 0,00 & 0,99 & 11,46 & 0,12 & 0,06 & 0,00 & 0,01 & 0,00 & 0,54 & 0,01 & 0,55 & 0,00 & 0,62 & 0,02 & 87 \\
\hline 12,2 & 13,9187 & 0,3698 & 0,5065 & 0,0058 & 0,0100 & 1,9744 & 0,0227 & 0,1993 & 0,0053 & 0,1388 & 0,0156 & 2,642 & 0,025 & & & 2,821 & 0,044 & 93 \\
\hline 13,1 & 5,981 & 0,0908 & 0,3628 & 0,0054 & 0,98 & 2,7564 & 0,041 & 0,1304 & 0,0018 & 0,9266 & 0,1631 & 1,995 & 0,025 & 1,973 & 0,013 & 2,101 & 0,023 & 95 \\
\hline 14,1 & 1,06 & 0,01 & 0,11 & 0,00 & 0,72 & 9,43 & 0,09 & 0,07 & 0,00 & 0,10 & 0,02 & 0,65 & 0,01 & 0,73 & 0,01 & 1,00 & 0,02 & 65 \\
\hline 14,2 & 7,2254 & 0,1218 & 0,3955 & 0,0061 & 0,91 & 2,5284 & 0,0389 & 0,1414 & 0,0015 & 0,3456 & 0,061 & 2,148 & 0,028 & 2,14 & 0,015 & 2,24 & 0,018 & 96 \\
\hline 15,1 & 1,4383 & 0,0192 & 0,1558 & 0,0021 & 1 & 6,4172 & 0,0854 & 0,072 & 0,0007 & $-0,0372$ & 0,0078 & 0,934 & 0,012 & 0,905 & 0,008 & 0,985 & 0,02 & 95 \\
\hline 16,1 & 0,7181 & 0,0132 & 0,087 & 0,0016 & 0,98 & 11,4989 & 0,2083 & 0,0596 & 0,0005 & 0,0048 & 0,0011 & 0,538 & 0,009 & 0,55 & 0,008 & 0,584 & 0,019 & 92 \\
\hline 17,1 & 0,8169 & 0,0056 & 0,0983 & 0,0007 & 0,99 & 10,1684 & 0,0735 & 0,0602 & 0,0005 & 0,0071 & 0,0017 & 0,605 & 0,004 & 0,606 & 0,003 & 0,606 & 0,019 & 100 \\
\hline 18,1 & 0,8523 & 0,0086 & 0,1009 & 0,0009 & 0,86 & 9,9137 & 0,0857 & 0,0615 & 0,0006 & 0,014 & 0,0043 & 0,62 & 0,005 & 0,626 & 0,005 & 0,65 & 0,022 & 95 \\
\hline 19,1 & 0,8155 & 0,0076 & 0,0976 & 0,0007 & 0,77 & 10,2436 & 0,0739 & 0,0603 & 0,0006 & 0,0071 & 0,0027 & 0,6 & 0,004 & 0,606 & 0,004 & 0,607 & 0,022 & 99 \\
\hline 20,1 & 0,7517 & 0,006 & 0,0894 & 0,0007 & 0,98 & 11,181 & 0,0877 & 0,0603 & 0,0005 & 0,0016 & 0,0008 & 0,552 & 0,004 & 0,569 & 0,003 & 0,61 & 0,018 & 91 \\
\hline 21,1 & 1,05 & 0,01 & 0,11 & 0,00 & 0,93 & 8,74 & 0,11 & 0,07 & 0,00 & 0,02 & 0,00 & 0,70 & 0,01 & 0,73 & 0,01 & 0,87 & 0,02 & 81 \\
\hline 22,1 & 0,8242 & 0,0062 & 0,0968 & 0,0007 & 0,99 & 10,3282 & 0,078 & 0,0608 & 0,0005 & 0,0036 & 0,0013 & 0,596 & 0,004 & 0,61 & 0,003 & 0,626 & 0,018 & 95 \\
\hline 22,2 & 2,79 & 0,03 & 0,19 & 0,00 & 0,89 & 5,13 & 0,05 & 0,11 & 0,00 & 0,21 & 0,04 & 1,15 & 0,01 & 1,35 & 0,01 & 1,74 & 0,02 & 66 \\
\hline 23,1 & 0,7677 & 0,0061 & 0,0925 & 0,0006 & 0,77 & 10,8101 & 0,0657 & 0,0602 & 0,0004 & 0,0073 & 0,0009 & 0,57 & 0,003 & 0,578 & 0,003 & 0,603 & 0,014 & 95 \\
\hline 24,1 & 6,4502 & 0,0419 & 0,3637 & 0,0019 & 0,81 & 2,7492 & 0,0144 & 0,1341 & 0,001 & 0,1777 & 0,0191 & 2 & 0,009 & 2,039 & 0,006 & 2,149 & 0,012 & 93 \\
\hline 24,2 & 1,43 & 0,02 & 0,11 & 0,00 & 0,91 & 8,75 & 0,13 & 0,09 & 0,00 & 0,24 & 0,03 & 0,70 & 0,01 & 0,90 & 0,01 & 1,47 & 0,02 & 48 \\
\hline 25,1 & 3,42 & 0,07 & 0,23 & 0,00 & 0,66 & 4,37 & 0,06 & 0,12 & 0,00 & 0,06 & 0,01 & 1,33 & 0,02 & 1,51 & 0,02 & 1,95 & 0,02 & 68 \\
\hline 26,1 & 1,09 & 0,01 & 0,12 & 0,00 & 0,45 & 8,50 & 0,04 & 0,07 & 0,00 & 0,06 & 0,01 & 0,72 & 0,00 & 0,75 & 0,01 & 0,82 & 0,02 & 88 \\
\hline 27,1 & 0,9469 & 0,0086 & 0,1094 & 0,0008 & 0,77 & 9,1384 & 0,0638 & 0,0618 & 0,0005 & 0,0118 & 0,0019 & 0,669 & 0,004 & 0,676 & 0,004 & 0,661 & 0,016 & 101 \\
\hline 28,1 & 3,06 & 0,09 & 0,20 & 0,00 & 0,66 & 4,97 & 0,09 & 0,11 & 0,00 & 0,13 & 0,01 & 1,18 & 0,02 & 1,42 & 0,02 & 1,74 & 0,02 & 68 \\
\hline 29,1 & 0,8154 & 0,0088 & 0,0988 & 0,0005 & 0,46 & 10,1195 & 0,0503 & 0,0605 & 0,0007 & $-0,0012$ & 0,0025 & 0,607 & 0,003 & 0,605 & 0,005 & 0,615 & 0,025 & 99 \\
\hline 30,1 & 0,8371 & 0,0102 & 0,0996 & 0,0014 & 0,99 & 10,0397 & 0,1373 & 0,0607 & 0,0009 & 0,0104 & 0,0144 & 0,612 & 0,008 & 0,618 & 0,006 & 0,623 & 0,032 & 98 \\
\hline 31,1 & 0,8357 & 0,0123 & 0,1015 & 0,0009 & 0,63 & 9,8503 & 0,0912 & 0,0608 & 0,0004 & 0,0638 & 0,0088 & 0,623 & 0,006 & 0,617 & 0,007 & 0,625 & 0,016 & 100 \\
\hline 32,1 & 0,8254 & 0,0092 & 0,0993 & 0,001 & 0,92 & 10,068 & 0,1027 & 0,0604 & 0,0004 & 0,0014 & 0,0009 & 0,61 & 0,006 & 0,611 & 0,005 & 0,611 & 0,015 & 100 \\
\hline 33,1 & 4,10 & 0,05 & 0,26 & 0,00 & 0,76 & 3,89 & 0,03 & 0,12 & 0,00 & 0,25 & 0,03 & 1,47 & 0,01 & 1,65 & 0,01 & 2,00 & 0,02 & 74 \\
\hline 34,1 & 0,8873 & 0,0059 & 0,103 & 0,0004 & 0,66 & 9,7067 & 0,0423 & 0,0626 & 0,0005 & 0,0125 & 0,0019 & 0,632 & 0,003 & 0,645 & 0,003 & 0,691 & 0,016 & 92 \\
\hline
\end{tabular}




\begin{tabular}{|c|c|c|c|c|c|c|c|c|c|c|c|c|c|c|c|c|}
\hline 1,1 & 4,7285 & 0,1132 & 0,3136 & 0,0026 & 0,9800 & 3,1884 & 0,0267 & 0,1093 & 0,0029 & 0,3643 & 0,0428 & 1,759 & 0,013 & 1,789 & 0,049 & 98 \\
\hline 2,1 & 5,0711 & 0,1529 & 0,3217 & 0,0036 & 0,5700 & 3,1086 & 0,0348 & 0,1143 & 0,0037 & 0,2728 & 0,0516 & 1,798 & 0,018 & 1,869 & 0,058 & 96 \\
\hline 3,1 & 3,5900 & 0,1342 & 0,2664 & 0,0036 & 0,1400 & 3,7533 & 0,0507 & 0,0977 & 0,0040 & 0,3789 & 0,0241 & 1,523 & 0,018 & 1,581 & 0,079 & 96 \\
\hline 4,1 & 2,4085 & 0,0834 & 0,2125 & 0,0024 & 0,3000 & 4,7051 & 0,0528 & 0,0822 & 0,0031 & 0,1081 & 0,0081 & 1,242 & 0,013 & 1,250 & 0,073 & 99 \\
\hline 4,2 & 0,8263 & 0,0272 & 0,1001 & 0,0009 & 0,8300 & 9,9867 & 0,0928 & 0,0598 & 0,0021 & 0,0022 & 0,0020 & 0,615 & 0,005 & 0,598 & 0,075 & 102 \\
\hline 5,1 & 2,3810 & 0,1176 & 0,2042 & 0,0034 & 0,0100 & 4,8977 & 0,0815 & 0,0846 & 0,0046 & 0,1667 & 0,0144 & 1,198 & 0,018 & 1,306 & 0,113 & 91 \\
\hline 6,1 & 5,4773 & 0,1573 & 0,3368 & 0,0036 & 0,4100 & 2,9689 & 0,0321 & 0,1179 & 0,0037 & 0,2474 & 0,0088 & 1,871 & 0,018 & 1,925 & 0,056 & 97 \\
\hline 7,1 & 4,6650 & 0,1218 & 0,3200 & 0,0029 & 0,3500 & 3,1253 & 0,0282 & 0,1057 & 0,0029 & 0,2606 & 0,0125 & 1,790 & 0,014 & 1,727 & 0,050 & 103 \\
\hline 8,1 & 4,4804 & 0,1041 & 0,3081 & 0,0025 & 0,8800 & 3,2452 & 0,0262 & 0,1055 & 0,0026 & 0,2013 & 0,0774 & 1,732 & 0,012 & 1,722 & 0,044 & 100 \\
\hline 9,1 & 0,9769 & 0,0440 & 0,1148 & 0,0014 & 0,9700 & 8,7117 & 0,1052 & 0,0617 & 0,0031 & 0,0124 & 0,0089 & 0,700 & 0,008 & 0,665 & 0,103 & 105 \\
\hline 9,2 & 0,8494 & 0,0198 & 0,1026 & 0,0007 & 0,6300 & 9,7441 & 0,0695 & 0,0600 & 0,0014 & 0,0036 & 0,0019 & 0,630 & 0,004 & 0,605 & 0,052 & 104 \\
\hline 10,1 & 4,5550 & 0,1054 & 0,2835 & 0,0022 & 0,9600 & 3,5273 & 0,0275 & 0,1165 & 0,0027 & 0,0976 & 0,0144 & 1,609 & 0,011 & 1,904 & 0,041 & 84 \\
\hline 11,1 & 3,3684 & 0,0718 & 0,2559 & 0,0018 & 0,3800 & 3,9073 & 0,0282 & 0,0955 & 0,0021 & 0,1596 & 0,0063 & 1,469 & 0,010 & 1,537 & 0,042 & 95 \\
\hline 12,1 & 6,1788 & 0,1608 & 0,3413 & 0,0035 & 1,0000 & 2,9298 & 0,0297 & 0,1313 & 0,0037 & 0,0989 & 0,0089 & 1,893 & 0,017 & 2,115 & 0,051 & 89 \\
\hline 13,1 & 5,9122 & 0,1419 & 0,3478 & 0,0032 & 0,3900 & 2,8755 & 0,0262 & 0,1233 & 0,0029 & 0,2316 & 0,0067 & 1,924 & 0,015 & 2,005 & 0,042 & 95 \\
\hline 14,1 & 2,9583 & 0,0741 & 0,2413 & 0,0021 & 0,9900 & 4,1438 & 0,0363 & 0,0889 & 0,0023 & 0,2161 & 0,0548 & 1,394 & 0,011 & 1,402 & 0,051 & 99 \\
\hline 15,1 & 6,0782 & 0,1658 & 0,3516 & 0,0036 & 0,9500 & 2,8438 & 0,0290 & 0,1254 & 0,0036 & 0,1151 & 0,0150 & 1,942 & 0,017 & 2,034 & 0,050 & 95 \\
\hline 15,2 & 0,8093 & 0,0403 & 0,0965 & 0,0012 & 0,9300 & 10,3580 & 0,1304 & 0,0608 & 0,0030 & 0,0076 & 0,0088 & 0,594 & 0,007 & 0,632 & 0,105 & 93 \\
\hline 16,1 & 0,7961 & 0,0259 & 0,0952 & 0,0009 & 0,9300 & 10,5072 & 0,1014 & 0,0607 & 0,0020 & 0,0026 & 0,0029 & 0,586 & 0,005 & 0,627 & 0,072 & 93 \\
\hline 16,2 & 4,5208 & 0,1495 & 0,3041 & 0,0036 & 0,9000 & 3,2883 & 0,0386 & 0,1078 & 0,0036 & 0,1724 & 0,0088 & 1,712 & 0,018 & 1,763 & 0,060 & 97 \\
\hline 17,1 & 0,8344 & 0,0309 & 0,0998 & 0,0010 & 0,5600 & 10,0206 & 0,1024 & 0,0606 & 0,0023 & 0,0082 & 0,0060 & 0,613 & 0,006 & 0,627 & 0,083 & 97 \\
\hline 17,2 & 3,1001 & 0,0942 & 0,2173 & 0,0023 & 1,0000 & 4,6020 & 0,0487 & 0,1035 & 0,0028 & 0,2106 & 0,0234 & 1,268 & 0,012 & 1,687 & 0,049 & 75 \\
\hline 18,1 & 6,8554 & 0,1557 & 0,3702 & 0,0032 & 0,6600 & 2,7009 & 0,0233 & 0,1343 & 0,0030 & 0,2183 & 0,0090 & 2,031 & 0,015 & 2,155 & 0,039 & 94 \\
\hline 18,2 & 5,5196 & 0,1127 & 0,3311 & 0,0026 & 1,0000 & 3,0206 & 0,0240 & 0,1209 & 0,0031 & 0,1309 & 0,0150 & 1,844 & 0,013 & 1,970 & 0,048 & 93 \\
\hline 18,3 & 0,8206 & 0,0311 & 0,1007 & 0,0011 & 0,7600 & 9,9307 & 0,1040 & 0,0591 & 0,0022 & 0,0043 & 0,0038 & 0,618 & 0,006 & 0,571 & 0,080 & 108 \\
\hline 19,1 & 5,7506 & 0,1425 & 0,3383 & 0,0042 & 0,8400 & 2,9562 & 0,0369 & 0,1233 & 0,0025 & 0,1213 & 0,0049 & 1,878 & 0,020 & 2,004 & 0,036 & 93 \\
\hline 20,1 & 6,4248 & 0,2033 & 0,3601 & 0,0065 & 0,2400 & 2,7768 & 0,0501 & 0,1294 & 0,0040 & 0,0708 & 0,0186 & 1,983 & 0,031 & 2,090 & 0,056 & 94 \\
\hline 20,2 & 0,8541 & 0,0199 & 0,1042 & 0,0011 & 0,9800 & 9,5939 & 0,1051 & 0,0594 & 0,0011 & 0,0053 & 0,0088 & 0,639 & 0,007 & 0,583 & 0,041 & 109 \\
\hline 21,1 & 1,9203 & 0,0491 & 0,1862 & 0,0023 & 0,9900 & 5,3715 & 0,0652 & 0,0748 & 0,0020 & 0,1005 & 0,0306 & 1,101 & 0,013 & 1,063 & 0,059 & 103 \\
\hline 22,1 & 5,9150 & 0,1517 & 0,3355 & 0,0045 & 0,8300 & 2,9805 & 0,0398 & 0,1279 & 0,0028 & 0,1366 & 0,0088 & 1,865 & 0,022 & 2,069 & 0,039 & 90 \\
\hline
\end{tabular}




\begin{tabular}{|c|c|c|c|c|c|c|c|c|c|c|c|c|c|c|c|c|}
\hline 23,1 & 4,6721 & 0,1049 & 0,2831 & 0,0031 & 0,9700 & 3,5329 & 0,0390 & 0,1197 & 0,0022 & 0,2207 & 0,0246 & 1,607 & 0,016 & 1,952 & 0,033 & 82 \\
\hline 24,1 & 0,9566 & 0,0297 & 0,1141 & 0,0015 & 0,8700 & 8,7632 & 0,1169 & 0,0608 & 0,0017 & 0,0081 & 0,0062 & 0,697 & 0,009 & 0,632 & 0,064 & 110 \\
\hline 25,1 & 6,6095 & 0,1467 & 0,3725 & 0,0042 & 0,9900 & 2,6848 & 0,0302 & 0,1287 & 0,0025 & 0,1291 & 0,0226 & 2,041 & 0,020 & 2,080 & 0,034 & 98 \\
\hline 25,2 & 0,9302 & 0,0317 & 0,1072 & 0,0015 & 0,8500 & 9,3292 & 0,1331 & 0,0629 & 0,0020 & 0,0127 & 0,0075 & 0,656 & 0,009 & 0,706 & 0,069 & 92 \\
\hline 26,1 & 4,7500 & 0,1103 & 0,3118 & 0,0036 & 0,7800 & 3,2071 & 0,0372 & 0,1105 & 0,0021 & 0,2998 & 0,0338 & 1,750 & 0,018 & 1,807 & 0,036 & 96 \\
\hline 26,2 & 0,8087 & 0,0229 & 0,0964 & 0,0012 & 0,5800 & 10,3683 & 0,1275 & 0,0608 & 0,0016 & 0,0143 & 0,0055 & 0,594 & 0,007 & 0,633 & 0,055 & 93 \\
\hline 27,1 & 2,0862 & 0,0594 & 0,1964 & 0,0026 & 0,4000 & 5,0918 & 0,0667 & 0,0770 & 0,0020 & 0,1288 & 0,0110 & 1,156 & 0,014 & 1,122 & 0,051 & 103 \\
\hline 28,1 & 1,0814 & 0,0365 & 0,1164 & 0,0016 & 0,3400 & 8,5930 & 0,1208 & 0,0674 & 0,0022 & 0,0698 & 0,0097 & 0,710 & 0,009 & 0,850 & 0,063 & 83 \\
\hline 29,1 & 0,8454 & 0,0298 & 0,1008 & 0,0011 & 0,8900 & 9,9235 & 0,1070 & 0,0608 & 0,0021 & 0,0058 & 0,0053 & 0,619 & 0,006 & 0,634 & 0,076 & 97 \\
\hline 30,1 & 5,5847 & 0,1228 & 0,3227 & 0,0027 & 0,9900 & 3,0990 & 0,0259 & 0,1255 & 0,0030 & 0,1155 & 0,0081 & 1,803 & 0,013 & 2,036 & 0,044 & 88 \\
\hline 31,1 & 0,8423 & 0,0321 & 0,1037 & 0,0012 & 0,7000 & 9,6455 & 0,1071 & 0,0589 & 0,0023 & 0,0053 & 0,0053 & 0,636 & 0,007 & 0,564 & 0,084 & 112 \\
\hline 32,1 & 2,0845 & 0,0666 & 0,1922 & 0,0021 & 0,6900 & 5,2037 & 0,0562 & 0,0787 & 0,0026 & 0,1714 & 0,0161 & 1,133 & 0,011 & 1,164 & 0,067 & 97 \\
\hline 33,1 & 5,1161 & 0,1272 & 0,3137 & 0,0030 & 0,8700 & 3,1880 & 0,0302 & 0,1183 & 0,0030 & 0,1301 & 0,0055 & 1,759 & 0,015 & 1,931 & 0,045 & 91 \\
\hline 34,1 & 5,5901 & 0,1298 & 0,3448 & 0,0030 & 0,2100 & 2,9000 & 0,0249 & 0,1176 & 0,0026 & 0,1924 & 0,0129 & 1,910 & 0,014 & 1,920 & 0,040 & 99 \\
\hline 35,1 & 4,1390 & 0,1040 & 0,2868 & 0,0027 & 1,0000 & 3,4866 & 0,0326 & 0,1047 & 0,0027 & 0,1941 & 0,0269 & 1,626 & 0,013 & 1,708 & 0,049 & 95 \\
\hline 36,1 & 0,9890 & 0,0373 & 0,1089 & 0,0013 & 0,9600 & 9,1813 & 0,1076 & 0,0659 & 0,0027 & 0,0208 & 0,0097 & 0,666 & 0,007 & 0,802 & 0,083 & 83 \\
\hline 37,1 & 4,6496 & 0,1233 & 0,2984 & 0,0030 & 0,9300 & 3,3512 & 0,0334 & 0,1130 & 0,0031 & 0,2423 & 0,0157 & 1,683 & 0,015 & 1,848 & 0,049 & 91 \\
\hline 38,1 & 9,3824 & 0,2138 & 0,4256 & 0,0037 & 0,9000 & 2,3496 & 0,0203 & 0,1599 & 0,0037 & 0,0855 & 0,0208 & 2,286 & 0,017 & 2,454 & 0,035 & 93 \\
\hline 39,1 & 0,8107 & 0,0278 & 0,0977 & 0,0010 & 0,8600 & 10,2402 & 0,1070 & 0,0602 & 0,0022 & 0,0035 & 0,0038 & 0,601 & 0,006 & 0,611 & 0,080 & 98 \\
\hline 40,1 & 0,8654 & 0,0206 & 0,1039 & 0,0008 & 0,9000 & 9,6238 & 0,0784 & 0,0604 & 0,0014 & 0,0033 & 0,0020 & 0,637 & 0,005 & 0,618 & 0,051 & 103 \\
\hline 41,1 & 0,8534 & 0,0204 & 0,1029 & 0,0008 & 0,9900 & 9,7146 & 0,0795 & 0,0601 & 0,0014 & 0,0050 & 0,0037 & 0,632 & 0,005 & 0,608 & 0,051 & 103 \\
\hline
\end{tabular}

AMOSTRA NESG-1446+1447: metapelito (Unidade Serra da Boa Vista - Nappe Andrelândia)

\begin{tabular}{|c|c|c|c|c|c|c|c|c|c|c|c|c|c|c|c|c|c|c|}
\hline Spot & $207 / 235$ & 1sigma & $206 / 238$ & 1sigma & Correl. & $238 / 206$ & 1 sigma & $207 / 206$ & 1sigma & $208 / 206$ & 1sigma & $\begin{array}{c}T \\
206 / 238\end{array}$ & 1 sigma & $\begin{array}{c}T \\
207 / 235\end{array}$ & 1 sigma & $\begin{array}{c}T \\
207 / 206\end{array}$ & 1 sigma & $\begin{array}{l}\% \\
\text { Conc. }\end{array}$ \\
\hline \multicolumn{19}{|c|}{2011} \\
\hline 1,1 & 0,8430 & 0,0167 & 0,1014 & 0,0013 & 0,63 & 9,8640 & 0,1239 & 0,0607 & 0,0006 & 0,0061 & 0,0019 & 0,622 & 0,007 & 0,621 & 0,009 & 0,623 & 0,021 & 100 \\
\hline 2,1 & 1,9558 & 0,0484 & 0,1614 & 0,0025 & 0,61 & 6,1968 & 0,0942 & 0,0909 & 0,0012 & 1,0176 & 0,2630 & 0,964 & 0,014 & 1,100 & 0,017 & 1,450 & 0,024 & 67 \\
\hline 2,2 & 0,8236 & 0,0163 & 0,0990 & 0,0012 & 0,61 & 10,1051 & 0,1211 & 0,0606 & 0,0006 & 0,0034 & 0,0013 & 0,608 & 0,007 & 0,610 & 0,009 & 0,618 & 0,021 & 98 \\
\hline
\end{tabular}




\begin{tabular}{|c|c|c|c|c|c|c|c|c|c|c|c|c|c|c|c|c|c|c|}
\hline 3,1 & 0,8963 & 0,0179 & 0,1034 & 0,0013 & 0,64 & 9,6672 & 0,1229 & 0,0611 & 0,0006 & 0,0006 & 0,0004 & 0,635 & 0,008 & 0,650 & 0,010 & 0,637 & 0,021 & 100 \\
\hline 4,1 & 3,3753 & 0,0728 & 0,2631 & 0,0044 & 0,77 & 3,8015 & 0,0632 & 0,1040 & 0,0016 & 0,2713 & 0,0683 & 1,505 & 0,022 & 1,499 & 0,017 & 1,701 & 0,028 & 89 \\
\hline 4,2 & 0,8140 & 0,0202 & 0,0986 & 0,0017 & 0,70 & 10,1445 & 0,1753 & 0,0607 & 0,0006 & 0,0045 & 0,0038 & 0,606 & 0,010 & 0,605 & 0,011 & 0,622 & 0,022 & 97 \\
\hline 5,1 & 6,6404 & 0,1543 & 0,3773 & 0,0064 & 0,72 & 2,6502 & 0,0446 & 0,1466 & 0,0016 & 0,2589 & 0,0640 & 2,064 & 0,030 & 2,065 & 0,020 & 2,303 & 0,019 & 90 \\
\hline 5,2 & 0,8019 & 0,0155 & 0,0984 & 0,0012 & 0,65 & 10,1591 & 0,1277 & 0,0602 & 0,0006 & $-0,0017$ & 0,0011 & 0,605 & 0,007 & 0,598 & 0,009 & 0,605 & 0,020 & 100 \\
\hline 6,1 & 1,1476 & 0,0227 & 0,1229 & 0,0015 & 0,63 & 8,1339 & 0,1015 & 0,0682 & 0,0007 & 0,0495 & 0,0121 & 0,747 & 0,009 & 0,776 & 0,011 & 0,873 & 0,020 & 86 \\
\hline 6,2 & 0,7977 & 0,0160 & 0,0966 & 0,0013 & 0,65 & 10,3544 & 0,1343 & 0,0600 & 0,0006 & 0,0023 & 0,0014 & 0,594 & 0,007 & 0,596 & 0,009 & 0,596 & 0,021 & 100 \\
\hline 7,1 & 0,8214 & 0,0158 & 0,0992 & 0,0012 & 0,63 & 10,0794 & 0,1213 & 0,0604 & 0,0006 & 0,0016 & 0,0006 & 0,610 & 0,007 & 0,609 & 0,009 & 0,612 & 0,020 & 100 \\
\hline 8,1 & 6,2430 & 0,1668 & 0,3667 & 0,0071 & 0,72 & 2,7267 & 0,0525 & 0,1398 & 0,0021 & 0,3994 & 0,0952 & 2,014 & 0,033 & 2,010 & 0,023 & 2,221 & 0,025 & 91 \\
\hline 9,1 & 0,8870 & 0,0169 & 0,1068 & 0,0013 & 0,63 & 9,3658 & 0,1125 & 0,0603 & 0,0006 & 0,0014 & 0,0005 & 0,654 & 0,007 & 0,645 & 0,009 & 0,609 & 0,020 & 107 \\
\hline 10,1 & 1,1674 & 0,0227 & 0,1187 & 0,0023 & 0,99 & 8,4227 & 0,1654 & 0,0710 & 0,0007 & 0,0404 & 0,0077 & 0,723 & 0,013 & 0,785 & 0,011 & 0,957 & 0,020 & 76 \\
\hline 11,1 & 0,8887 & 0,0152 & 0,1018 & 0,0019 & 0,99 & 9,8253 & 0,1825 & 0,0622 & 0,0006 & 0,0055 & 0,0015 & 0,625 & 0,011 & 0,646 & 0,008 & 0,674 & 0,020 & 93 \\
\hline 12,1 & 2,0471 & 0,0572 & 0,1814 & 0,0043 & 0,86 & 5,5137 & 0,1318 & 0,0817 & 0,0012 & 0,0874 & 0,0162 & 1,074 & 0,024 & 1,131 & 0,019 & 1,242 & 0,029 & 87 \\
\hline 12,2 & 0,8310 & 0,0151 & 0,0999 & 0,0019 & 0,99 & 10,0093 & 0,1888 & 0,0605 & 0,0006 & 0,0004 & 0,0007 & 0,614 & 0,011 & 0,614 & 0,008 & 0,614 & 0,020 & 100 \\
\hline 13,1 & 0,8261 & 0,0163 & 0,0999 & 0,0019 & 0,95 & 10,0115 & 0,1867 & 0,0610 & 0,0007 & $-0,0015$ & 0,0010 & 0,614 & 0,011 & 0,611 & 0,009 & 0,632 & 0,024 & 97 \\
\hline 14,1 & 0,8763 & 0,0139 & 0,1044 & 0,0019 & 0,99 & 9,5800 & 0,1750 & 0,0612 & 0,0005 & 0,0051 & 0,0010 & 0,640 & 0,011 & 0,639 & 0,007 & 0,639 & 0,019 & 100 \\
\hline 14,2 & 0,8377 & 0,0133 & 0,1003 & 0,0018 & 0,99 & 9,9701 & 0,1821 & 0,0607 & 0,0005 & 0,0020 & 0,0008 & 0,616 & 0,011 & 0,618 & 0,007 & 0,622 & 0,019 & 99 \\
\hline 15,1 & 0,8409 & 0,0141 & 0,1006 & 0,0019 & 0,99 & 9,9377 & 0,1871 & 0,0606 & 0,0006 & 0,0009 & 0,0006 & 0,618 & 0,011 & 0,620 & 0,008 & 0,620 & 0,020 & 100 \\
\hline 16,1 & 0,8670 & 0,0141 & 0,1028 & 0,0019 & 0,99 & 9,7291 & 0,1818 & 0,0611 & 0,0005 & 0,0013 & 0,0009 & 0,631 & 0,011 & 0,634 & 0,008 & 0,636 & 0,019 & 99 \\
\hline 17,1 & 1,8201 & 0,0340 & 0,1585 & 0,0031 & 0,99 & 6,3074 & 0,1225 & 0,0859 & 0,0009 & 0,1177 & 0,0191 & 0,949 & 0,017 & 1,053 & 0,012 & 1,341 & 0,021 & 71 \\
\hline 17,2 & 0,8402 & 0,0134 & 0,1010 & 0,0019 & 0,99 & 9,9026 & 0,1834 & 0,0606 & 0,0005 & 0,0000 & 0,0005 & 0,620 & 0,011 & 0,619 & 0,007 & 0,620 & 0,019 & 100 \\
\hline 18,1 & 1,2651 & 0,0236 & 0,1300 & 0,0026 & 0,99 & 7,6901 & 0,1530 & 0,0713 & 0,0007 & 0,0367 & 0,0059 & 0,788 & 0,015 & 0,830 & 0,011 & 0,965 & 0,020 & 82 \\
\hline 19,1 & 3,2501 & 0,0680 & 0,2098 & 0,0045 & 0,99 & 4,7658 & 0,1017 & 0,1205 & 0,0014 & 0,0373 & 0,0058 & 1,228 & 0,024 & 1,469 & 0,016 & 1,963 & 0,020 & 63 \\
\hline 20,1 & 0,7713 & 0,0197 & 0,0937 & 0,0015 & 0,62 & 10,6738 & 0,1701 & 0,0600 & 0,0006 & $-0,0026$ & 0,0012 & 0,577 & 0,009 & 0,580 & 0,011 & 0,596 & 0,023 & 97 \\
\hline 21,1 & 0,7537 & 0,0187 & 0,0915 & 0,0014 & 0,61 & 10,9280 & 0,1647 & 0,0602 & 0,0006 & 0,0012 & 0,0007 & 0,564 & 0,008 & 0,570 & 0,011 & 0,603 & 0,023 & 94 \\
\hline 22,1 & 0,6845 & 0,0181 & 0,0841 & 0,0013 & 0,59 & 11,8865 & 0,1852 & 0,0585 & 0,0008 & 0,0005 & 0,0022 & 0,521 & 0,008 & 0,529 & 0,011 & 0,544 & 0,030 & 96 \\
\hline 23,1 & 0,9146 & 0,0229 & 0,1073 & 0,0016 & 0,61 & 9,3230 & 0,1433 & 0,0614 & 0,0006 & 0,0003 & 0,0008 & 0,657 & 0,010 & 0,660 & 0,012 & 0,648 & 0,023 & 101 \\
\hline 24,1 & 1,7696 & 0,0502 & 0,1638 & 0,0030 & 0,64 & 6,1063 & 0,1106 & 0,0799 & 0,0010 & 0,0519 & 0,0112 & 0,978 & 0,016 & 1,034 & 0,018 & 1,198 & 0,025 & 82 \\
\hline 25,1 & 0,8085 & 0,0205 & 0,0978 & 0,0015 & 0,61 & 10,2264 & 0,1589 & 0,0600 & 0,0007 & 0,0027 & 0,0017 & 0,601 & 0,009 & 0,602 & 0,011 & 0,599 & 0,024 & 100 \\
\hline 26,1 & 0,8498 & 0,0209 & 0,1018 & 0,0015 & 0,61 & 9,8215 & 0,1477 & 0,0608 & 0,0006 & 0,0010 & 0,0006 & 0,625 & 0,009 & 0,625 & 0,011 & 0,626 & 0,022 & 100 \\
\hline
\end{tabular}




\begin{tabular}{|c|c|c|c|c|c|c|c|c|c|c|c|c|c|c|c|c|c|c|}
\hline 27,1 & 0,8112 & 0,0206 & 0,0975 & 0,0015 & 0,60 & 10,2531 & 0,1562 & 0,0603 & 0,0007 & 0,0008 & 0,0018 & 0,600 & 0,009 & 0,603 & 0,011 & 0,607 & 0,025 & 99 \\
\hline 28,1 & 1,0863 & 0,0277 & 0,1215 & 0,0019 & 0,62 & 8,2333 & 0,1306 & 0,0659 & 0,0007 & 0,0518 & 0,0102 & 0,739 & 0,011 & 0,747 & 0,013 & 0,798 & 0,023 & 93 \\
\hline 29,1 & 1,2638 & 0,0321 & 0,1244 & 0,0020 & 0,64 & 8,0374 & 0,1300 & 0,0739 & 0,0008 & 0,0547 & 0,0107 & 0,756 & 0,012 & 0,830 & 0,014 & 1,040 & 0,022 & 73 \\
\hline 29,2 & 0,8604 & 0,0212 & 0,1005 & 0,0015 & 0,62 & 9,9507 & 0,1506 & 0,0621 & 0,0006 & 0,0064 & 0,0016 & 0,617 & 0,009 & 0,630 & 0,011 & 0,672 & 0,022 & 92 \\
\hline 30,1 & 0,8344 & 0,0203 & 0,1003 & 0,0015 & 0,61 & 9,9703 & 0,1482 & 0,0608 & 0,0006 & 0,0017 & 0,0009 & 0,616 & 0,009 & 0,616 & 0,011 & 0,625 & 0,022 & 99 \\
\hline 31,1 & 0,7889 & 0,0192 & 0,0955 & 0,0014 & 0,61 & 10,4750 & 0,1559 & 0,0603 & 0,0006 & 0,0013 & 0,0010 & 0,588 & 0,008 & 0,591 & 0,011 & 0,607 & 0,022 & 97 \\
\hline 32,1 & 0,8392 & 0,0146 & 0,0997 & 0,0003 & 0,20 & 10,0271 & 0,0341 & 0,0612 & 0,0009 & 0,0015 & 0,0005 & 0,613 & 0,002 & 0,619 & 0,008 & 0,640 & 0,030 & 96 \\
\hline 33,1 & 1,2992 & 0,0226 & 0,1409 & 0,0007 & 0,30 & 7,0950 & 0,0372 & 0,0675 & 0,0010 & 0,0797 & 0,0173 & 0,850 & 0,004 & 0,845 & 0,010 & 0,849 & 0,030 & 100 \\
\hline 34,1 & 0,8540 & 0,0151 & 0,1021 & 0,0004 & 0,24 & 9,7981 & 0,0409 & 0,0609 & 0,0008 & 0,0031 & 0,0008 & 0,626 & 0,002 & 0,627 & 0,008 & 0,629 & 0,030 & 100 \\
\hline 35,1 & 0,8653 & 0,0158 & 0,1020 & 0,0006 & 0,30 & 9,8012 & 0,0541 & 0,0607 & 0,0008 & 0,0056 & 0,0015 & 0,626 & 0,003 & 0,633 & 0,009 & 0,624 & 0,030 & 100 \\
\hline 36,1 & 3,1340 & 0,0576 & 0,2106 & 0,0011 & 0,28 & 4,7476 & 0,0244 & 0,1082 & 0,0015 & 0,2043 & 0,0449 & 1,232 & 0,006 & 1,441 & 0,014 & 1,772 & 0,025 & 70 \\
\hline 37,1 & 0,8472 & 0,0147 & 0,1012 & 0,0004 & 0,23 & 9,8798 & 0,0401 & 0,0609 & 0,0008 & 0,0021 & 0,0007 & 0,622 & 0,002 & 0,623 & 0,008 & 0,629 & 0,030 & 99 \\
\hline 38,1 & 0,7840 & 0,0136 & 0,0950 & 0,0004 & 0,23 & 10,5238 & 0,0413 & 0,0599 & 0,0008 & 0,0003 & 0,0010 & 0,585 & 0,002 & 0,588 & 0,008 & 0,593 & 0,030 & 99 \\
\hline 39,1 & 0,8161 & 0,0146 & 0,0984 & 0,0007 & 0,37 & 10,1600 & 0,0677 & 0,0603 & 0,0008 & 0,0005 & 0,0010 & 0,605 & 0,004 & 0,606 & 0,008 & 0,608 & 0,030 & 100 \\
\hline 40,1 & 0,8447 & 0,0145 & 0,1008 & 0,0004 & 0,21 & 9,9211 & 0,0358 & 0,0606 & 0,0008 & 0,0026 & 0,0007 & 0,619 & 0,002 & 0,622 & 0,008 & 0,620 & 0,029 & 100 \\
\hline 41,1 & 2,0952 & 0,0393 & 0,1685 & 0,0011 & 0,34 & 5,9333 & 0,0375 & 0,0927 & 0,0014 & 0,1830 & 0,0416 & 1,004 & 0,006 & 1,147 & 0,013 & 1,487 & 0,027 & 68 \\
\hline 41,2 & 0,7962 & 0,0137 & 0,0959 & 0,0004 & 0,22 & 10,4269 & 0,0396 & 0,0602 & 0,0008 & 0,0012 & 0,0006 & 0,590 & 0,002 & 0,595 & 0,008 & 0,605 & 0,029 & 98 \\
\hline 42,1 & 13,6605 & 0,5091 & 0,5233 & 0,0119 & 0,61 & 1,9109 & 0,0435 & 0,2193 & 0,0067 & 0,2252 & 0,0522 & 2,713 & 0,050 & 2,726 & 0,035 & 2,982 & 0,047 & 91 \\
\hline 42,2 & 0,8628 & 0,0156 & 0,1029 & 0,0007 & 0,37 & 9,7169 & 0,0647 & 0,0609 & 0,0008 & 0,0021 & 0,0011 & 0,631 & 0,004 & 0,632 & 0,008 & 0,628 & 0,030 & 100 \\
\hline \multicolumn{19}{|c|}{2015} \\
\hline 1,1 & 0,9458 & 0,0179 & 0,1106 & 0,0010 & 0,8700 & 9,0444 & 0,0837 & 0,0620 & 0,0010 & 0,0249 & 0,0097 & 0,676 & 0,006 & & & 0,675 & 0,035 & 100 \\
\hline 2,1 & 0,8883 & 0,0171 & 0,1071 & 0,0010 & 0,9600 & 9,3365 & 0,0865 & 0,0602 & 0,0010 & 0,0009 & 0,0008 & 0,656 & 0,006 & & & 0,609 & 0,037 & 107 \\
\hline 3,1 & 0,8555 & 0,0174 & 0,1036 & 0,0010 & 0,8800 & 9,6524 & 0,0928 & 0,0599 & 0,0010 & 0,0012 & 0,0013 & 0,635 & 0,006 & & & 0,600 & 0,038 & 105 \\
\hline 4,1 & 0,7825 & 0,0155 & 0,0946 & 0,0009 & 0,9300 & 10,5674 & 0,0968 & 0,0600 & 0,0011 & 0,0017 & 0,0017 & 0,583 & 0,005 & & & 0,603 & 0,039 & 96 \\
\hline 5,1 & 0,8494 & 0,0152 & 0,1025 & 0,0009 & 0,1200 & 9,7589 & 0,0871 & 0,0601 & 0,0009 & 0,0008 & 0,0006 & 0,629 & 0,005 & & & 0,608 & 0,033 & 103 \\
\hline 6,1 & 0,8918 & 0,0186 & 0,1073 & 0,0010 & 0,5400 & 9,3162 & 0,0903 & 0,0603 & 0,0011 & 0,0018 & 0,0015 & 0,657 & 0,006 & & & 0,613 & 0,040 & 107 \\
\hline 7,1 & 0,8303 & 0,0172 & 0,1009 & 0,0010 & 0,7900 & 9,9095 & 0,0952 & 0,0597 & 0,0011 & 0,0041 & 0,0031 & 0,620 & 0,006 & & & 0,592 & 0,038 & 104 \\
\hline 9,1 & 0,8169 & 0,0172 & 0,0982 & 0,0009 & 0,9100 & 10,1819 & 0,0985 & 0,0603 & 0,0011 & 0,0012 & 0,0014 & 0,604 & 0,006 & & & 0,615 & 0,041 & 98 \\
\hline 10,1 & 0,7950 & 0,0172 & 0,0959 & 0,0009 & 0,9100 & 10,4263 & 0,1014 & 0,0601 & 0,0012 & 0,0009 & 0,0017 & 0,590 & 0,005 & & & 0,608 & 0,042 & 97 \\
\hline 11,1 & 0,9076 & 0,0172 & 0,1067 & 0,0010 & 0,6100 & 9,3696 & 0,0890 & 0,0617 & 0,0010 & 0,0134 & 0,0040 & 0,654 & 0,006 & & & 0,663 & 0,037 & 98 \\
\hline
\end{tabular}




\begin{tabular}{|c|c|c|c|c|c|c|c|c|c|c|c|c|c|c|c|c|}
\hline 12,1 & 1,1149 & 0,0203 & 0,1223 & 0,0011 & 0,9600 & 8,1775 & 0,0732 & 0,0661 & 0,0011 & 0,0157 & 0,0178 & 0,744 & 0,006 & 0,810 & 0,036 & 91 \\
\hline 13,1 & 0,8512 & 0,0170 & 0,1028 & 0,0010 & 0,8300 & 9,7320 & 0,0914 & 0,0601 & 0,0011 & 0,0006 & 0,0012 & 0,631 & 0,006 & 0,606 & 0,039 & 103 \\
\hline 14,1 & 0,8031 & 0,0190 & 0,0968 & 0,0011 & 0,9700 & 10,3331 & 0,1181 & 0,0602 & 0,0015 & 0,0007 & 0,0011 & 0,595 & 0,006 & 0,610 & 0,054 & 97 \\
\hline 15,1 & 0,8316 & 0,0174 & 0,1016 & 0,0011 & 0,9000 & 9,8425 & 0,1080 & 0,0594 & 0,0012 & 0,0008 & 0,0008 & 0,624 & 0,007 & 0,580 & 0,045 & 107 \\
\hline 16,1 & 0,8845 & 0,0192 & 0,1077 & 0,0012 & 0,9100 & 9,2819 & 0,1024 & 0,0595 & 0,0013 & 0,0007 & 0,0009 & 0,660 & 0,007 & 0,587 & 0,046 & 112 \\
\hline 17,1 & 0,8338 & 0,0228 & 0,1012 & 0,0012 & 0,8900 & 9,8855 & 0,1205 & 0,0598 & 0,0017 & 0,0011 & 0,0020 & 0,621 & 0,007 & 0,596 & 0,062 & 104 \\
\hline 18,1 & 0,8073 & 0,0214 & 0,0977 & 0,0012 & 0,9600 & 10,2403 & 0,1227 & 0,0600 & 0,0016 & 0,0008 & 0,0017 & 0,601 & 0,007 & 0,602 & 0,058 & 99 \\
\hline 19,1 & 2,3215 & 0,0453 & 0,1942 & 0,0022 & 0,8300 & 5,1501 & 0,0577 & 0,0867 & 0,0019 & 0,1069 & 0,0420 & 1,144 & 0,012 & 1,354 & 0,044 & 84 \\
\hline 20,1 & 0,8440 & 0,0176 & 0,1026 & 0,0011 & 0,5900 & 9,7470 & 0,1071 & 0,0597 & 0,0012 & 0,0006 & 0,0009 & 0,630 & 0,007 & 0,591 & 0,043 & 106 \\
\hline 21,1 & 0,8545 & 0,0215 & 0,1030 & 0,0012 & 0,6000 & 9,7051 & 0,1144 & 0,0601 & 0,0015 & 0,0020 & 0,0024 & 0,632 & 0,007 & 0,609 & 0,054 & 103 \\
\hline 22,1 & 0,7837 & 0,0169 & 0,0952 & 0,0011 & 0,7500 & 10,4998 & 0,1196 & 0,0597 & 0,0013 & 0,0008 & 0,0011 & 0,586 & 0,006 & 0,592 & 0,046 & 99 \\
\hline 23,1 & 0,9088 & 0,0215 & 0,1091 & 0,0012 & 0,8000 & 9,1628 & 0,1047 & 0,0604 & 0,0015 & 0,0051 & 0,0037 & 0,668 & 0,007 & 0,618 & 0,053 & 108 \\
\hline 24,1 & 0,8579 & 0,0187 & 0,1033 & 0,0012 & 0,9500 & 9,6824 & 0,1088 & 0,0602 & 0,0013 & 0,0017 & 0,0014 & 0,634 & 0,007 & 0,612 & 0,047 & 103 \\
\hline 25,1 & 0,9030 & 0,0184 & 0,1090 & 0,0012 & 0,3800 & 9,1773 & 0,1000 & 0,0601 & 0,0013 & 0,0020 & 0,0015 & 0,667 & 0,007 & 0,607 & 0,044 & 109 \\
\hline 26,1 & 1,8173 & 0,0376 & 0,1645 & 0,0019 & 0,7800 & 6,0792 & 0,0714 & 0,0801 & 0,0015 & 0,0306 & 0,0081 & 0,982 & 0,011 & 1,200 & 0,037 & 81 \\
\hline
\end{tabular}

AMOSTRA NESG-1552: anfibolito (Unidade Santo Antônio - Nappe Andrelândia)

\begin{tabular}{|c|c|c|c|c|c|c|c|c|c|c|c|c|c|c|c|c|c|c|c|}
\hline \multirow[b]{2}{*}{ Spot } & \multirow[b]{2}{*}{$207 / 235$} & \multirow[b]{2}{*}{ 1sigma } & \multirow[b]{2}{*}{$206 / 238$} & \multirow[b]{2}{*}{ 1sigma } & \multirow[b]{2}{*}{ Correl. } & \multirow[b]{2}{*}{ 238/206 } & \multirow[b]{2}{*}{ 1sigma } & \multirow[b]{2}{*}{$207 / 206$} & \multirow[b]{2}{*}{ 1sigma } & \multirow[b]{2}{*}{$208 / 206$} & \multirow[b]{2}{*}{ 1sigma } & \multirow{2}{*}{$\begin{array}{c}T \\
206 / 238\end{array}$} & \multirow{2}{*}{$\begin{array}{c}1 \\
\text { sigma }\end{array}$} & \multirow{2}{*}{$\begin{array}{c}T \\
207 / 235\end{array}$} & \multirow{2}{*}{$\begin{array}{c}1 \\
\text { sigma }\end{array}$} & \multirow{2}{*}{$\begin{array}{c}T \\
207 / 206\end{array}$} & \multirow{2}{*}{$\begin{array}{c}1 \\
\text { sigma }\end{array}$} & \multicolumn{2}{|c|}{ \% Conc. } \\
\hline & & & & & & & & & & & & & & & & & & $\begin{array}{l}206 / 238 \\
207 / 235\end{array}$ & $\begin{array}{l}206 / 238 \\
207 / 206\end{array}$ \\
\hline 1,1 & 1,0151 & 0,0205 & 0,1161 & 0,0016 & 0,70 & 8,6127 & 0,1215 & 0,0627 & 0,0009 & 0,4936 & 0,2277 & 0,708 & 0,009 & 0,711 & 0,010 & 0,692 & 0,030 & 100 & 102 \\
\hline 2,1 & 3,2945 & 0,0841 & 0,2623 & 0,0052 & 0,78 & 3,8132 & 0,0763 & 0,0931 & 0,0014 & 0,5478 & 0,2591 & 1,501 & 0,027 & 1,480 & 0,020 & 1,496 & 0,028 & 101 & 100 \\
\hline 2,2 & 1,2850 & 0,0284 & 0,1386 & 0,0021 & 0,70 & 7,2133 & 0,1118 & 0,0670 & 0,0011 & 0,1279 & 0,0623 & 0,837 & 0,012 & 0,839 & 0,013 & 0,833 & 0,035 & 100 & 100 \\
\hline 2,3 & 0,8974 & 0,0196 & 0,1037 & 0,0015 & 0,65 & 9,6424 & 0,1365 & 0,0614 & 0,0011 & 0,0234 & 0,0143 & 0,636 & 0,009 & 0,650 & 0,010 & 0,647 & 0,037 & 98 & 98 \\
\hline 3,1 & 1,1717 & 0,0212 & 0,1301 & 0,0016 & 0,67 & 7,6846 & 0,0933 & 0,0657 & 0,0009 & 0,3936 & 0,2017 & 0,789 & 0,009 & 0,787 & 0,010 & 0,792 & 0,029 & 100 & 100 \\
\hline 4,1 & 0,9396 & 0,0167 & 0,1099 & 0,0013 & 0,69 & 9,1006 & 0,1112 & 0,0621 & 0,0008 & 0,9280 & 0,4889 & 0,672 & 0,008 & 0,673 & 0,009 & 0,672 & 0,029 & 100 & 100 \\
\hline 5,1 & 1,5988 & 0,0299 & 0,1621 & 0,0020 & 0,65 & 6,1672 & 0,0755 & 0,0713 & 0,0010 & 0,5222 & 0,2819 & 0,969 & 0,011 & 0,970 & 0,012 & 0,964 & 0,028 & 100 & 100 \\
\hline 6,1 & 1,1821 & 0,0210 & 0,1306 & 0,0016 & 0,68 & 7,6550 & 0,0925 & 0,0658 & 0,0009 & 0,0849 & 0,0474 & 0,791 & 0,009 & 0,792 & 0,010 & 0,795 & 0,028 & 100 & 100 \\
\hline 7,1 & 1,2356 & 0,0220 & 0,1362 & 0,0017 & 0,68 & 7,3413 & 0,0893 & 0,0658 & 0,0009 & 0,1269 & 0,0731 & 0,823 & 0,009 & 0,817 & 0,010 & 0,797 & 0,028 & 101 & 103 \\
\hline
\end{tabular}




\begin{tabular}{|c|c|c|c|c|c|c|c|c|c|c|c|c|c|c|c|c|c|c|c|}
\hline 7,2 & 1,0050 & 0,0199 & 0,1159 & 0,0015 & 0,65 & 8,6312 & 0,1120 & 0,0632 & 0,0009 & 0,0585 & 0,0349 & 0,707 & 0,009 & 0,706 & 0,010 & 0,709 & 0,030 & 100 & 100 \\
\hline 8,1 & 1,2032 & 0,0215 & 0,1331 & 0,0016 & 0,67 & 7,5159 & 0,0905 & 0,0655 & 0,0009 & 0,0994 & 0,0611 & 0,805 & 0,009 & 0,802 & 0,010 & 0,787 & 0,028 & 100 & 102 \\
\hline 9,1 & 2,5424 & 0,0472 & 0,2231 & 0,0030 & 0,71 & 4,4833 & 0,0594 & 0,0827 & 0,0011 & 0,5856 & 0,3720 & 1,298 & 0,016 & 1,284 & 0,013 & 1,267 & 0,026 & 101 & 102 \\
\hline 10,1 & 1,2430 & 0,0319 & 0,1360 & 0,0018 & 0,52 & 7,3550 & 0,0972 & 0,0666 & 0,0010 & 0,0884 & 0,0582 & 0,822 & 0,010 & 0,820 & 0,014 & 0,821 & 0,031 & 100 & 100 \\
\hline 10,2 & 0,9611 & 0,0069 & 0,1096 & 0,0008 & 0,99 & 9,1271 & 0,0658 & 0,0632 & 0,0006 & 0,0559 & 0,0121 & 0,670 & 0,005 & 0,684 & 0,004 & 0,708 & 0,021 & 98 & 95 \\
\hline 10,3 & 0,9736 & 0,0146 & 0,1131 & 0,0009 & 0,53 & 8,8410 & 0,0704 & 0,0627 & 0,0012 & 0,0235 & 0,0060 & 0,691 & 0,005 & 0,690 & 0,007 & 0,694 & 0,042 & 100 & 100 \\
\hline 11,1 & 1,1233 & 0,0108 & 0,1264 & 0,0010 & 0,84 & 7,9145 & 0,0638 & 0,0649 & 0,0007 & 0,2700 & 0,0567 & 0,767 & 0,006 & 0,765 & 0,005 & 0,767 & 0,023 & 100 & 100 \\
\hline 11,2 & 0,6761 & 0,0171 & 0,0845 & 0,0019 & 0,88 & 11,8380 & 0,2643 & 0,0579 & 0,0006 & 0,0031 & 0,0034 & 0,523 & 0,011 & 0,524 & 0,010 & 0,521 & 0,022 & 100 & 100 \\
\hline 11,3 & 0,8594 & 0,0064 & 0,1022 & 0,0008 & 0,99 & 9,7800 & 0,0753 & 0,0611 & 0,0006 & 0,0025 & 0,0011 & 0,628 & 0,005 & 0,630 & 0,003 & 0,637 & 0,020 & 100 & 99 \\
\hline 11,4 & 0,8374 & 0,0067 & 0,1002 & 0,0007 & 0,93 & 9,9813 & 0,0741 & 0,0603 & 0,0006 & $-0,0008$ & 0,0010 & 0,616 & 0,004 & 0,618 & 0,004 & 0,607 & 0,021 & 100 & 101 \\
\hline 12,1 & 1,1806 & 0,0080 & 0,1301 & 0,0010 & 0,99 & 7,6866 & 0,0594 & 0,0655 & 0,0006 & 0,0909 & 0,0185 & 0,788 & 0,006 & 0,792 & 0,004 & 0,787 & 0,019 & 100 & 100 \\
\hline 12,2 & 0,8275 & 0,0339 & 0,0967 & 0,0012 & 0,31 & 10,3375 & 0,1323 & 0,0602 & 0,0023 & 0,0503 & 0,0240 & 0,595 & 0,007 & 0,612 & 0,019 & 0,606 & 0,081 & 97 & 98 \\
\hline 13,1 & 1,2183 & 0,0072 & 0,1338 & 0,0009 & 0,99 & 7,4744 & 0,0518 & 0,0656 & 0,0006 & 0,0767 & 0,0150 & 0,809 & 0,005 & 0,809 & 0,003 & 0,790 & 0,018 & 100 & 102 \\
\hline 14,1 & 1,2394 & 0,0178 & 0,1355 & 0,0020 & 0,99 & 7,3795 & 0,1084 & 0,0659 & 0,0006 & 0,0701 & 0,0136 & 0,819 & 0,011 & 0,819 & 0,008 & 0,801 & 0,019 & 100 & 102 \\
\hline 14,2 & 0,8233 & 0,0074 & 0,0990 & 0,0009 & 0,95 & 10,0970 & 0,0867 & 0,0604 & 0,0006 & $-0,0007$ & 0,0012 & 0,609 & 0,005 & 0,610 & 0,004 & 0,610 & 0,021 & 100 & 100 \\
\hline 15,1 & 1,2109 & 0,0075 & 0,1330 & 0,0010 & 0,99 & 7,5212 & 0,0551 & 0,0655 & 0,0006 & 0,1211 & 0,0231 & 0,805 & 0,006 & 0,806 & 0,003 & 0,786 & 0,018 & 100 & 102 \\
\hline 15,2 & 1,1976 & 0,0079 & 0,1299 & 0,0010 & 0,99 & 7,6960 & 0,0584 & 0,0666 & 0,0006 & 0,3941 & 0,0741 & 0,788 & 0,006 & 0,799 & 0,004 & 0,821 & 0,018 & 99 & 96 \\
\hline 16,1 & 1,1779 & 0,0175 & 0,1304 & 0,0012 & 0,60 & 7,6677 & 0,0680 & 0,0655 & 0,0011 & 0,1146 & 0,0475 & 0,790 & 0,007 & 0,790 & 0,008 & 0,788 & 0,035 & 100 & 100 \\
\hline 16,2 & 1,1469 & 0,0175 & 0,1283 & 0,0012 & 0,61 & 7,7952 & 0,0725 & 0,0666 & 0,0011 & 0,1056 & 0,0436 & 0,778 & 0,007 & 0,776 & 0,008 & 0,823 & 0,035 & 100 & 95 \\
\hline 17,1 & 2,4261 & 0,0692 & 0,2012 & 0,0040 & 0,69 & 4,9703 & 0,0978 & 0,0874 & 0,0016 & 0,2412 & 0,0999 & 1,182 & 0,021 & 1,250 & 0,020 & 1,374 & 0,035 & 95 & 86 \\
\hline 17,2 & 1,5511 & 0,0271 & 0,1583 & 0,0018 & 0,64 & 6,3174 & 0,0712 & 0,0706 & 0,0012 & 0,0179 & 0,0079 & 0,947 & 0,010 & 0,951 & 0,011 & 0,946 & 0,035 & 100 & 100 \\
\hline 18,1 & 6,9480 & 0,1842 & 0,3875 & 0,0080 & 0,77 & 2,5804 & 0,0530 & 0,1318 & 0,0023 & 0,2803 & 0,1134 & 2,111 & 0,037 & 2,105 & 0,023 & 2,118 & 0,030 & 100 & 100 \\
\hline 19,1 & 1,9727 & 0,0383 & 0,1670 & 0,0019 & 0,58 & 5,9890 & 0,0674 & 0,0862 & 0,0015 & 0,1238 & 0,0498 & 0,995 & 0,010 & 1,106 & 0,013 & 1,349 & 0,034 & 90 & 74 \\
\hline 20,1 & 1,1543 & 0,0174 & 0,1265 & 0,0011 & 0,60 & 7,9051 & 0,0713 & 0,0652 & 0,0011 & 0,7077 & 0,2834 & 0,768 & 0,007 & 0,779 & 0,008 & 0,778 & 0,034 & 99 & 99 \\
\hline 20,2 & 0,7072 & 0,0145 & 0,0858 & 0,0014 & 0,80 & 11,6492 & 0,1911 & 0,0595 & 0,0010 & 0,0079 & 0,0037 & 0,531 & 0,008 & 0,543 & 0,009 & 0,580 & 0,036 & 98 & 91 \\
\hline 21,1 & 1,1476 & 0,0173 & 0,1279 & 0,0012 & 0,61 & 7,8195 & 0,0719 & 0,0653 & 0,0011 & 0,4954 & 0,1958 & 0,776 & 0,007 & 0,776 & 0,008 & 0,779 & 0,034 & 100 & 100 \\
\hline 21,2 & 1,1874 & 0,0179 & 0,1316 & 0,0012 & 0,59 & 7,5972 & 0,0682 & 0,0659 & 0,0011 & 0,3639 & 0,1429 & 0,797 & 0,007 & 0,795 & 0,008 & 0,801 & 0,034 & 100 & 100 \\
\hline 22,1 & 1,2217 & 0,0182 & 0,1338 & 0,0012 & 0,62 & 7,4736 & 0,0686 & 0,0661 & 0,0011 & 0,0947 & 0,0370 & 0,810 & 0,007 & 0,811 & 0,008 & 0,807 & 0,034 & 100 & 100 \\
\hline 23,1 & 2,2071 & 0,0349 & 0,1945 & 0,0019 & 0,62 & 5,1406 & 0,0508 & 0,0824 & 0,0013 & 0,3671 & 0,1425 & 1,146 & 0,010 & 1,183 & 0,011 & 1,261 & 0,032 & 97 & 91 \\
\hline 24,1 & 7,6071 & 0,1115 & 0,3985 & 0,0036 & 0,61 & 2,5096 & 0,0225 & 0,1377 & 0,0022 & 0,2760 & 0,1066 & 2,162 & 0,016 & 2,186 & 0,013 & 2,195 & 0,028 & 99 & 99 \\
\hline
\end{tabular}




\begin{tabular}{|c|c|c|c|c|c|c|c|c|c|c|c|c|c|c|c|c|c|c|c|}
\hline 24,2 & 5,8191 & 0,0528 & 0,3314 & 0,0022 & 0,75 & 3,0177 & 0,0204 & 0,1272 & 0,0009 & 0,1059 & 0,0396 & 1,845 & 0,011 & 1,949 & 0,008 & 2,058 & 0,012 & 95 & 90 \\
\hline 25,1 & 1,5677 & 0,0147 & 0,1600 & 0,0011 & 0,73 & 6,2515 & 0,0426 & 0,0711 & 0,0005 & 0,4568 & 0,1724 & 0,957 & 0,006 & 0,958 & 0,006 & 0,960 & 0,015 & 100 & 100 \\
\hline 26,1 & 2,0972 & 0,0220 & 0,1825 & 0,0015 & 0,77 & 5,4797 & 0,0446 & 0,0838 & 0,0006 & 0,2383 & 0,0908 & 1,081 & 0,008 & 1,148 & 0,007 & 1,294 & 0,015 & 94 & 84 \\
\hline 26,2 & 1,0186 & 0,0129 & 0,1159 & 0,0010 & 0,68 & 8,6276 & 0,0745 & 0,0635 & 0,0007 & 0,0722 & 0,0279 & 0,707 & 0,006 & 0,713 & 0,006 & 0,720 & 0,022 & 99 & 98 \\
\hline 27,1 & 2,1566 & 0,0200 & 0,1983 & 0,0014 & 0,76 & 5,0419 & 0,0354 & 0,0788 & 0,0006 & 0,2867 & 0,1112 & 1,166 & 0,007 & 1,167 & 0,006 & 1,171 & 0,015 & 100 & 100 \\
\hline 27,2 & 1,3437 & 0,0225 & 0,1433 & 0,0013 & 0,56 & 6,9763 & 0,0657 & 0,0679 & 0,0010 & 0,1158 & 0,0460 & 0,864 & 0,008 & 0,865 & 0,010 & 0,862 & 0,032 & 100 & 100 \\
\hline 28,1 & 1,2293 & 0,0164 & 0,1348 & 0,0014 & 0,76 & 7,4195 & 0,0753 & 0,0668 & 0,0006 & 0,1297 & 0,0513 & 0,815 & 0,008 & 0,814 & 0,007 & 0,830 & 0,020 & 100 & 98 \\
\hline 29,1 & 1,1933 & 0,0119 & 0,1311 & 0,0010 & 0,73 & 7,6297 & 0,0554 & 0,0657 & 0,0005 & 0,1287 & 0,0513 & 0,794 & 0,005 & 0,798 & 0,005 & 0,793 & 0,017 & 100 & 100 \\
\hline 29,2 & 0,5298 & 0,0217 & 0,0684 & 0,0017 & 0,60 & 14,6174 & 0,3582 & 0,0562 & 0,0010 & 0,0144 & 0,0077 & 0,427 & 0,010 & 0,432 & 0,014 & 0,455 & 0,040 & 99 & 94 \\
\hline 30,1 & 1,0295 & 0,0176 & 0,1153 & 0,0014 & 0,70 & 8,6723 & 0,1030 & 0,0627 & 0,0008 & 0,0594 & 0,0248 & 0,704 & 0,008 & 0,719 & 0,009 & 0,694 & 0,028 & 98 & 101 \\
\hline 31,1 & 1,1328 & 0,0107 & 0,1263 & 0,0009 & 0,72 & 7,9184 & 0,0540 & 0,0653 & 0,0005 & 0,1682 & 0,0690 & 0,767 & 0,005 & 0,769 & 0,005 & 0,779 & 0,016 & 100 & 98 \\
\hline 32,1 & 5,9439 & 0,0614 & 0,3587 & 0,0027 & 0,74 & 2,7880 & 0,0213 & 0,1213 & 0,0010 & 0,6770 & 0,2804 & 1,976 & 0,013 & 1,968 & 0,009 & 1,975 & 0,015 & 100 & 100 \\
\hline 33,1 & 1,1891 & 0,0156 & 0,1312 & 0,0011 & 0,66 & 7,6241 & 0,0660 & 0,0657 & 0,0007 & 0,2976 & 0,1246 & 0,794 & 0,006 & 0,796 & 0,007 & 0,793 & 0,024 & 100 & 100 \\
\hline 33,2 & 0,8204 & 0,0122 & 0,0978 & 0,0010 & 0,68 & 10,2298 & 0,1037 & 0,0602 & 0,0006 & 0,0715 & 0,0167 & 0,601 & 0,006 & 0,608 & 0,007 & 0,603 & 0,021 & 99 & 100 \\
\hline 34,1 & 1,5617 & 0,0231 & 0,1598 & 0,0018 & 0,77 & 6,2587 & 0,0713 & 0,0709 & 0,0004 & 0,0505 & 0,0118 & 0,956 & 0,010 & 0,955 & 0,009 & 0,954 & 0,013 & 100 & 100 \\
\hline 34,2 & 0,7382 & 0,0112 & 0,0894 & 0,0010 & 0,71 & 11,1913 & 0,1206 & 0,0588 & 0,0008 & $-0,0192$ & 0,0074 & 0,552 & 0,006 & 0,561 & 0,006 & 0,555 & 0,029 & 98 & 99 \\
\hline 35,1 & 1,9630 & 0,0230 & 0,1648 & 0,0015 & 0,79 & 6,0698 & 0,0564 & 0,0873 & 0,0005 & 0,1715 & 0,0418 & 0,983 & 0,008 & 1,103 & 0,008 & 1,372 & 0,011 & 89 & 72 \\
\hline 35,2 & 0,8173 & 0,0102 & 0,0966 & 0,0009 & 0,76 & 10,3493 & 0,0990 & 0,0619 & 0,0004 & 0,0298 & 0,0075 & 0,595 & 0,005 & 0,607 & 0,006 & 0,664 & 0,014 & 98 & 90 \\
\hline 36,1 & 1,2211 & 0,0169 & 0,1343 & 0,0018 & 0,96 & 7,4449 & 0,0985 & 0,0659 & 0,0005 & 0,0843 & 0,0215 & 0,812 & 0,010 & 0,810 & 0,008 & 0,801 & 0,016 & 100 & 101 \\
\hline 37,1 & 2,1085 & 0,0243 & 0,1883 & 0,0017 & 0,79 & 5,3096 & 0,0486 & 0,0810 & 0,0005 & 0,2289 & 0,0590 & 1,112 & 0,009 & 1,152 & 0,008 & 1,225 & 0,011 & 97 & 91 \\
\hline 37,2 & 2,3090 & 0,0285 & 0,2025 & 0,0020 & 0,81 & 4,9390 & 0,0492 & 0,0825 & 0,0005 & 0,3418 & 0,0904 & 1,189 & 0,011 & 1,215 & 0,009 & 1,262 & 0,011 & 98 & 94 \\
\hline 38,1 & 1,0964 & 0,0151 & 0,1192 & 0,0012 & 0,71 & 8,3866 & 0,0815 & 0,0668 & 0,0005 & 0,0639 & 0,0174 & 0,726 & 0,007 & 0,752 & 0,007 & 0,829 & 0,017 & 97 & 88 \\
\hline 38,2 & 1,3557 & 0,0151 & 0,1391 & 0,0013 & 0,81 & 7,1888 & 0,0647 & 0,0706 & 0,0004 & 0,0900 & 0,0249 & 0,840 & 0,007 & 0,870 & 0,006 & 0,945 & 0,011 & 97 & 89 \\
\hline 39,1 & 1,0935 & 0,0130 & 0,1234 & 0,0011 & 0,76 & 8,1010 & 0,0734 & 0,0645 & 0,0004 & 0,2955 & 0,0836 & 0,750 & 0,006 & 0,750 & 0,006 & 0,752 & 0,015 & 100 & 100 \\
\hline 39,2 & 0,7972 & 0,0115 & 0,0944 & 0,0010 & 0,70 & 10,5886 & 0,1068 & 0,0619 & 0,0005 & 0,1141 & 0,0333 & 0,582 & 0,006 & 0,595 & 0,006 & 0,664 & 0,017 & 98 & 88 \\
\hline 40,1 & 0,7629 & 0,0132 & 0,0935 & 0,0009 & 0,59 & 10,6986 & 0,1087 & 0,0594 & 0,0008 & 0,0049 & 0,0044 & 0,576 & 0,006 & 0,576 & 0,008 & 0,575 & 0,028 & 100 & 100 \\
\hline
\end{tabular}



ANEXO V

Sistema isotópico Lu-Hf em zircão

(LA-ICP-MS) 
SNA-125: metapelito (Unidade Serra da Boa Vista - Nappe Andrelândia)

\begin{tabular}{|c|c|c|c|c|c|c|c|c|c|c|c|c|}
\hline spot & $\begin{array}{l}176 \mathrm{Hf} / \\
177 \mathrm{Hf}\end{array}$ & \pm 2 se & $\begin{array}{c}176 \mathrm{Lu} / \\
177 \mathrm{Hf}\end{array}$ & $\pm 2 \mathrm{se}$ & $\begin{array}{l}\text { U-Pb } \\
\text { Age } \\
\text { (T1) }\end{array}$ & $\varepsilon \mathrm{Hf}(0)$ & $\begin{array}{c}176 / 177 \\
\text { am }\end{array}$ & $\varepsilon \mathrm{Hf}(\mathrm{t} 1)$ & $\begin{array}{c}176 / 177 \\
\text { DM }\end{array}$ & $\begin{array}{c}\mathrm{T} \\
\mathrm{DM} \\
(2)\end{array}$ & $\begin{array}{c}176 / 177 \\
\text { DM }\end{array}$ & $\varepsilon_{\mathrm{Hf}(\mathrm{tdm})}$ \\
\hline 3,1 & 0,28172 & 3,654E-05 & 0,00079 & 1,444E-05 & 1297 & & 0,28170 & & 0,28230 & 2669 & 0,28128 & 6,60 \\
\hline 4,1 & 0,28203 & $2,746 \mathrm{E}-05$ & 0,00068 & 2,666E-05 & 1215 & $-26,37$ & 0,28201 & 0,03 & 0,28236 & 2017 & 0,28177 & 8,98 \\
\hline 11,1 & 0,28200 & ,094E-05 & 0,00041 & 1,011E-05 & 1399 & $-27,40$ & 0,28199 & 3,31 & 0,28224 & 1967 & 0,28182 & 9,20 \\
\hline 12,1 & 0,28127 & 3,226E-05 & 0,00130 & 1,53E-05 & 1870 & $-53,01$ & 0,28123 & $-13,00$ & 0,28184 & 3255 & 0,28079 & 4,22 \\
\hline 16,2 & 0,28180 & 5,83E-05 & 0,00059 & 3,161E-06 & 1474 & $-34,32$ & 0,28178 & $-2,16$ & 0,28215 & 2304 & 0,28153 & 7,82 \\
\hline 17,1 & 0,28140 & 7,202E-05 & 0,00185 & 4,908E-06 & 1771 & $-48,34$ & 0,28135 & $-10,92$ & 0,28204 & 3338 & 0,28087 & 4,56 \\
\hline 20,1 & 0,28174 & 5,412E-05 & 0,00066 & 6,822E-06 & 1504 & $-36,56$ & 0,28172 & $-3,77$ & 0,28219 & 2563 & 0,28140 & 7,17 \\
\hline 22,1 & 0,28158 & 6,927E-05 & 0,00114 & 2,528E-05 & 1208 & $-42,08$ & 0,28156 & $-16,15$ & 0,28246 & 3222 & 0,28095 & 4,99 \\
\hline 23,1 & 0,28218 & 8,978E-05 & 0,00046 & 1,219E-06 & 1146 & $-21,10$ & 0,28217 & 3,95 & 0,28239 & 1662 & 0,28201 & 10,15 \\
\hline 33,1 & 0,28218 & 5,34E-05 & 0,00080 & $7,321 \mathrm{E}-06$ & 1033 & $-21,11$ & 0,28216 & 1,13 & 0,28236 & 1493 & 0,28202 & 10,19 \\
\hline 34,1 & 0,28160 & 9,685E-05 & 0,00128 & 2,349E-05 & 1286 & $-41,46$ & 0,28157 & $-14,09$ & 0,28227 & 2869 & 0,28109 & 5,65 \\
\hline 36,1 & 0,28182 & 9,697E-05 & 0,00164 & 2,166E-05 & 912 & $-33,52$ & 0,28179 & $-14,49$ & 0,28249 & 2495 & 0,28132 & 6,78 \\
\hline 37,1 & 0,28173 & 0,0002296 & 0,00084 & $3,34 \mathrm{E}-06$ & 903 & $-36,69$ & 0,28172 & $-17,31$ & 0,28251 & 2691 & 0,28118 & 6,12 \\
\hline 43,1 & 0,28182 & 4,551E-05 & 0,00127 & $1,759 \mathrm{E}-05$ & 1718 & $-33,63$ & 0,28178 & 3,26 & 0,28203 & 2281 & 0,28161 & 8,20 \\
\hline 44,1 & 0,28182 & 5,171E-05 & 0,00143 & 2,738E-05 & 1351 & $-33,81$ & 0,28178 & $-5,06$ & 0,28229 & 2501 & 0,28143 & 7,34 \\
\hline 46,1 & 0,28171 & 4,305E-05 & 0,00118 & 2,353E-05 & 1772 & $-37,56$ & 0,28167 & 0,47 & 0,28187 & 2240 & 0,28152 & 7,78 \\
\hline 50,1 & 0,28174 & 4,045E-05 & 0,00176 & 5,024E-05 & 1576 & $-36,53$ & 0,28169 & $-3,23$ & 0,28215 & 2617 & 0,28137 & 7,04 \\
\hline 51,1 & 0,28194 & 5,832E-05 & 0,00079 & 3,491E-05 & 1186 & $-29,38$ & 0,28192 & $-3,69$ & 0,28242 & 2303 & 0,28159 & 8,10 \\
\hline 52,1 & 0,28191 & 5,093E-05 & 0,00111 & 1,343E-05 & 1095 & $-30,53$ & 0,28189 & $-7,08$ & 0,28245 & 2376 & 0,28150 & 7,67 \\
\hline 53,1 & 0,28199 & 3,492E-05 & 0,00027 & 7,346E-06 & 1144 & $-27,66$ & 0,28198 & $-2,51$ & 0,28245 & 2206 & 0,28167 & 8,47 \\
\hline 55,1 & 0,28203 & 2,526E-05 & 0,00106 & 4,238E-05 & 1980 & $-26,12$ & 0,28201 & 17,24 & 0,28227 & 2583 & 0,28183 & 9,25 \\
\hline 56,1 & 0,28130 & 3,274E-05 & 0,00197 & 3,111E-05 & 1866 & $-52,20$ & 0,28123 & $-13,02$ & 0,28190 & 3385 & 0,28076 & 4,03 \\
\hline 58,1 & 0,28204 & 4,588E-05 & 0,00124 & 1,105E-05 & 1177 & $-25,95$ & 0,28201 & $-0,82$ & 0,28239 & 2042 & 0,28175 & 8,89 \\
\hline 59,1 & 0,28199 & 3,236E-05 & 0,00075 & $1,215 \mathrm{E}-05$ & 1224 & $-27,71$ & 0,28197 & $-1,19$ & 0,28234 & 2059 & 0,28172 & 8,73 \\
\hline
\end{tabular}

SNA-168: metavulcânica (Nappe Liberdade)

\begin{tabular}{ccccccccccccc}
\hline spot & $\begin{array}{c}176 \mathrm{Hf} / \\
177 \mathrm{Hf}\end{array}$ & $\pm 2 \mathrm{se}$ & $\begin{array}{c}176 \mathrm{Lu} / \\
177 \mathrm{Hf}\end{array}$ & $\pm 2 \mathrm{se}$ & $\begin{array}{c}\mathrm{U}-\mathrm{Pb} \\
\mathrm{Age} \\
(\mathrm{T} 1)\end{array}$ & $\varepsilon \mathrm{Hf}(0)$ & $\begin{array}{c}176 / 177 \\
\mathrm{am}\end{array}$ & $\varepsilon \mathrm{Hf}(\mathrm{t} 1)$ & $\begin{array}{c}176 / 177 \\
\text { DM }\end{array}$ & $\begin{array}{c}\mathrm{T} \\
\mathrm{DM} \\
(2)\end{array}$ & $\begin{array}{c}176 / 177 \\
\text { DM }\end{array}$ & $\varepsilon_{\mathrm{Hf}(\mathrm{fdm})}$ \\
\hline 1,1 & 0,28150 & $4,341 \mathrm{E}-05$ & 0,00091 & $1,04 \mathrm{E}-05$ & 2052 & $-44,90$ & 0,28147 & $-0,31$ & 0,28172 & 2631 & 0,28129 & 6,62 \\
2,1 & 0,28195 & $5,027 \mathrm{E}-05$ & 0,00256 & $4,62 \mathrm{E}-05$ & 1463 & $-29,04$ & 0,28188 & 0,96 & 0,28216 & 2097 & 0,28169 & 8,57 \\
3,1 & 0,28210 & $4,578 \mathrm{E}-05$ & 0,00447 & $8,27 \mathrm{E}-05$ & 1472 & $-23,62$ & 0,28198 & 4,70 & 0,28215 & 1865 & 0,28186 & 9,42 \\
4,1 & 0,28206 & $4,504 \mathrm{E}-05$ & 0,00251 & $5,16 \mathrm{E}-05$ & 1487 & $-25,32$ & 0,28199 & 5,25 & 0,28214 & 1842 & 0,28188 & 9,50 \\
5,1 & 0,28200 & $3,196 \mathrm{E}-05$ & 0,00185 & $6,2 \mathrm{E}-05$ & 1477 & $-27,16$ & 0,28195 & 3,85 & 0,28215 & 1924 & 0,28182 & 9,21 \\
6,1 & 0,28207 & $4,792 \mathrm{E}-05$ & 0,00329 & $5,23 \mathrm{E}-05$ & 1469 & $-24,82$ & 0,28198 & 4,61 & 0,28215 & 1869 & 0,28186 & 9,40 \\
7,1 & 0,28213 & $4,694 \mathrm{E}-05$ & 0,00377 & $3,03 \mathrm{E}-05$ & 1453 & $-22,72$ & 0,28203 & 5,91 & 0,28217 & 1773 & 0,28193 & 9,75 \\
8,1 & 0,28202 & $6,491 \mathrm{E}-05$ & 0,00533 & $7,55 \mathrm{E}-05$ & 1446 & $-26,50$ & 0,28188 & 0,48 & 0,28217 & 2115 & 0,28167 & 8,51 \\
9,1 & 0,28163 & $2,575 \mathrm{E}-05$ & 0,00051 & $1,54 \mathrm{E}-06$ & 2055 & $-40,49$ & 0,28161 & 4,75 & 0,28172 & 2310 & 0,28153 & 7,80 \\
12,1 & 0,28208 & $4,784 \mathrm{E}-05$ & 0,00343 & $6,64 \mathrm{E}-05$ & 1488 & $-24,42$ & 0,28198 & 5,25 & 0,28214 & 1843 & 0,28188 & 9,50 \\
16,1 & 0,28201 & $4,192 \mathrm{E}-05$ & 0,00211 & 0,000117 & 1492 & $-27,06$ & 0,28195 & 4,01 & 0,28214 & 1925 & 0,28182 & 9,20 \\
17,1 & 0,28208 & $4,157 \mathrm{E}-05$ & 0,00295 & $5,35 \mathrm{E}-05$ & 1481 & $-24,41$ & 0,28200 & 5,60 & 0,28215 & 1815 & 0,28190 & 9,60 \\
21,1 & 0,28207 & $4 \mathrm{E}-05$ & 0,00329 & $8,95 \mathrm{E}-05$ & 1461 & $-24,65$ & 0,28198 & 4,61 & 0,28216 & 1862 & 0,28186 & 9,43 \\
23,1 & 0,28207 & $4,251 \mathrm{E}-05$ & 0,00318 & $8,31 \mathrm{E}-05$ & 1469 & $-24,84$ & 0,28198 & 4,69 & 0,28215 & 1864 & 0,28186 & 9,42 \\
24,1 & 0,28166 & $2,807 \mathrm{E}-05$ & 0,00047 & $1,22 \mathrm{E}-06$ & 1997 & $-39,46$ & 0,28164 & 4,53 & 0,28176 & 2279 & 0,28155 & 7,91 \\
27,1 & 0,28201 & $4,818 \mathrm{E}-05$ & 0,00308 & $5,31 \mathrm{E}-05$ & 1460 & $-27,12$ & 0,28192 & 2,32 & 0,28216 & 2008 & 0,28175 & 8,90
\end{tabular}




\begin{tabular}{lllllllllllll}
32,1 & 0,28209 & $4,665 \mathrm{E}-05$ & 0,00288 & $3,57 \mathrm{E}-05$ & 1490 & $-23,95$ & 0,28201 & 6,32 & 0,28214 & 1776 & 0,28193 & 9,74 \\
33,1 & 0,28205 & $4,024 \mathrm{E}-05$ & 0,00320 & $8,23 \mathrm{E}-05$ & 1483 & $-25,57$ & 0,28196 & 4,23 & 0,28214 & 1904 & 0,28183 & 9,28 \\
35,1 & 0,28210 & $4,454 \mathrm{E}-05$ & 0,00370 & $6,93 \mathrm{E}-05$ & 1451 & $-23,65$ & 0,28200 & 5,02 & 0,28217 & 1829 & 0,28189 & 9,55 \\
36,1 & 0,28202 & $3,929 \mathrm{E}-05$ & 0,00246 & $4,06 \mathrm{E}-05$ & 1423 & $-26,53$ & 0,28196 & 2,75 & 0,28219 & 1953 & 0,28180 & 9,10 \\
37,1 & 0,28213 & $4,966 \mathrm{E}-05$ & 0,00405 & $6,71 \mathrm{E}-05$ & 1474 & $-22,81$ & 0,28201 & 5,97 & 0,28215 & 1785 & 0,28192 & 9,71 \\
38,1 & 0,28205 & $4,58 \mathrm{E}-05$ & 0,00361 & $2,64 \mathrm{E}-05$ & 1463 & $-25,56$ & 0,28195 & 3,42 & 0,28216 & 1940 & 0,28180 & 9,15 \\
\hline
\end{tabular}

SNA-172E: metapelito (Nappe Liberdade)

\begin{tabular}{ccccccccccccc}
\hline spot & $\begin{array}{c}176 \mathrm{Hf} / \\
177 \mathrm{Hf}\end{array}$ & $\pm 2 \mathrm{se}$ & $\begin{array}{c}176 \mathrm{Lu} / \\
177 \mathrm{Hf}\end{array}$ & $\pm 2 \mathrm{se}$ & $\begin{array}{c}\mathrm{U}-\mathrm{Pb} \\
\mathrm{Age} \\
(\mathrm{T} 1)\end{array}$ & $\varepsilon \mathrm{Hf}(0)$ & $\begin{array}{c}176 / 177 \\
\mathrm{am}\end{array}$ & $\varepsilon \mathrm{Hf}(\mathrm{t} 1)$ & $\begin{array}{c}176 / 177 \\
\text { DM }\end{array}$ & $\begin{array}{c}\mathrm{T} \\
\mathrm{DM} \\
(2)\end{array}$ & $\begin{array}{c}176 / 177 \\
\text { DM }\end{array}$ & $\varepsilon \mathrm{Hf}(\mathrm{tdm})$ \\
\hline 1,1 & 0,28187 & $1,812 \mathrm{E}-05$ & 0,00065 & $1,186 \mathrm{E}-05$ & 835 & $-31,84$ & 0,28186 & $-13,77$ & 0,28264 & 2577 & 0,28134 & 6,90 \\
2,1 & 0,28203 & $3,149 \mathrm{E}-05$ & 0,00190 & $1,629 \mathrm{E}-05$ & 800 & $-26,36$ & 0,28200 & $-9,71$ & 0,28265 & 2261 & 0,28156 & 7,98 \\
3,1 & 0,28205 & $2,166 \mathrm{E}-05$ & 0,00151 & $2,027 \mathrm{E}-05$ & 866 & $-25,70$ & 0,28202 & $-7,33$ & 0,28268 & 2351 & 0,28158 & 8,07 \\
8,1 & 0,28219 & $2,784 \mathrm{E}-05$ & 0,00153 & $1,229 \mathrm{E}-05$ & 1125 & $-20,49$ & 0,28216 & 3,35 & 0,28245 & 1786 & 0,28196 & 9,92 \\
9,1 & 0,28203 & $1,728 \mathrm{E}-05$ & 0,00134 & $4,596 \mathrm{E}-05$ & 715 & $-26,34$ & 0,28201 & $-11,15$ & 0,28276 & 2404 & 0,28151 & 7,72 \\
10,1 & 0,28196 & $1,955 \mathrm{E}-05$ & 0,00142 & $3,63 \mathrm{E}-05$ & 808 & $-28,59$ & 0,28194 & $-11,53$ & 0,28264 & 2382 & 0,28147 & 7,54 \\
14,1 & 0,28146 & $2,854 \mathrm{E}-05$ & 0,00053 & $1,932 \mathrm{E}-05$ & 1866 & $-46,22$ & 0,28145 & $-5,28$ & 0,28185 & 2782 & 0,28116 & 6,02 \\
16,1 & 0,28206 & $3,547 \mathrm{E}-05$ & 0,00087 & $5,245 \mathrm{E}-05$ & 815 & $-25,14$ & 0,28205 & $-7,62$ & 0,28263 & 2141 & 0,28165 & 8,42 \\
18,1 & 0,28187 & $2,037 \mathrm{E}-05$ & 0,00123 & $2,618 \mathrm{E}-05$ & 780 & $-32,03$ & 0,28185 & $-15,47$ & 0,28266 & 2607 & 0,28130 & 6,71 \\
35,1 & 0,28213 & $3,64 \mathrm{E}-05$ & 0,00221 & $3,373 \mathrm{E}-05$ & 984 & $-22,53$ & 0,28209 & $-2,27$ & 0,28248 & 1866 & 0,28183 & 9,26 \\
43,1 & 0,28216 & $3,527 \mathrm{E}-05$ & 0,00093 & $4,571 \mathrm{E}-05$ & 790 & $-21,59$ & 0,28215 & $-4,63$ & 0,28267 & 1979 & 0,28180 & 9,11 \\
45,1 & 0,28200 & $4,575 \mathrm{E}-05$ & 0,00153 & $1,213 \mathrm{E}-05$ & 1124 & $-27,22$ & 0,28197 & $-3,45$ & 0,28242 & 2153 & 0,28166 & 8,45 \\
\hline
\end{tabular}

SNA-180A: metapsamito (Nappe Liberdade)

\begin{tabular}{ccccccccccccc}
\hline spot & $\begin{array}{c}176 \mathrm{Hf} / \\
177 \mathrm{Hf}\end{array}$ & $\pm 2 \mathrm{se}$ & $\begin{array}{c}176 \mathrm{Lu} / \\
177 \mathrm{Hf}\end{array}$ & $\pm 2 \mathrm{se}$ & $\begin{array}{c}\mathrm{U}-\mathrm{Pb} \\
\mathrm{Age} \\
(\mathrm{T} 1)\end{array}$ & $\varepsilon \mathrm{kH}(0)$ & $\begin{array}{c}176 / 177 \\
\mathrm{am}\end{array}$ & $\varepsilon \mathrm{Hf}(\mathrm{t} 1)$ & $\begin{array}{c}176 / 177 \\
\text { DM }\end{array}$ & $\begin{array}{c}\mathrm{T} \\
\mathrm{DM} \\
(2)\end{array}$ & $\begin{array}{c}176 / 177 \\
\text { DM }\end{array}$ & $\varepsilon_{\mathrm{Hf}(\mathrm{tdm})}$ \\
\hline 3,1 & 0,28158 & $2,88 \mathrm{E}-05$ & 0,00021 & $1,29 \mathrm{E}-06$ & 1476 & $-42,05$ & 0,28158 & $-9,49$ & 0,28214 & 2752 & 0,28119 & 6,14 \\
4,3 & 0,28203 & $4,115 \mathrm{E}-05$ & 0,00114 & $3,35 \mathrm{E}-05$ & 1114 & $-26,14$ & 0,28201 & $-2,29$ & 0,28244 & 2098 & 0,28172 & 8,71 \\
5,1 & 0,28193 & $4,027 \mathrm{E}-05$ & 0,00070 & $9,97 \mathrm{E}-06$ & 1213 & $-29,89$ & 0,28191 & $-3,56$ & 0,28237 & 2253 & 0,28160 & 8,14 \\
9,1 & 0,28200 & $3,607 \mathrm{E}-05$ & 0,00061 & $1,6 \mathrm{E}-05$ & 1041 & $-27,33$ & 0,28199 & $-4,71$ & 0,28248 & 2154 & 0,28165 & 8,42 \\
18,1 & 0,28187 & $3,838 \mathrm{E}-05$ & 0,00086 & $7,6 \mathrm{E}-06$ & 1217 & $-32,06$ & 0,28185 & $-5,76$ & 0,28238 & 2425 & 0,28148 & 7,58 \\
24,1 & 0,28174 & $3,57 \mathrm{E}-05$ & 0,00101 & $1,07 \mathrm{E}-05$ & 1530 & $-36,65$ & 0,28171 & $-3,68$ & 0,28211 & 2447 & 0,28143 & 7,31 \\
30,1 & 0,28204 & $4,057 \mathrm{E}-05$ & 0,00112 & $3,24 \mathrm{E}-05$ & 1274 & $-25,83$ & 0,28201 & 1,40 & 0,28222 & 1755 & 0,28187 & 9,45 \\
61,1 & 0,28213 & $3,563 \mathrm{E}-05$ & 0,00180 & $4,01 \mathrm{E}-05$ & 1110 & $-22,76$ & 0,28209 & 0,45 & 0,28240 & 1806 & 0,28188 & 9,52 \\
62,1 & 0,28218 & $3,719 \mathrm{E}-05$ & 0,00123 & $3,59 \mathrm{E}-05$ & 1003 & $-20,87$ & 0,28216 & 0,41 & 0,28241 & 1586 & 0,28198 & 10,01 \\
\hline
\end{tabular}

SNA-201: metawackes (Unidade Santo Antônio - Nappe Andrelândia)

\begin{tabular}{cccccccccccccc}
\hline spot & $\begin{array}{c}176 \mathrm{Hf} / \\
177 \mathrm{Hf}\end{array}$ & $\pm 2 \mathrm{se}$ & $\begin{array}{c}176 \mathrm{Lu} / \\
177 \mathrm{Hf}\end{array}$ & $\pm 2 \mathrm{se}$ & $\begin{array}{c}\mathrm{U}-\mathrm{Pb} \\
\mathrm{Age} \\
(\mathrm{T} 1)\end{array}$ & $\varepsilon \mathrm{Hf}(0)$ & $\begin{array}{c}176 / 177 \\
\mathrm{am}\end{array}$ & $\varepsilon \mathrm{Hf}(\mathrm{t} 1)$ & $\begin{array}{c}176 / 177 \\
\mathrm{DM}\end{array}$ & $\begin{array}{c}\mathrm{T} \\
\mathrm{DM} \\
(2)\end{array}$ & $\begin{array}{c}176 / 177 \\
\mathrm{DM}\end{array}$ & $\varepsilon_{\mathrm{Hf}(\mathrm{tdm})}$ \\
\hline 1,1 & 0,28271 & $2,288 \mathrm{E}-05$ & 0,00092 & $3,211 \mathrm{E}-05$ & 679 & $-2,29$ & 0,28270 & 12,60 & 0,28272 & 743 & 0,28268 & 13,37 \\
2,1 & 0,28215 & $3,137 \mathrm{E}-05$ & 0,00090 & $3,482 \mathrm{E}-05$ & 886 & - & 0,28214 & $-2,88$ & 0,28258 & 1897 & 0,28184 & 9,30 \\
11,1 & 0,28231 & $5,331 \mathrm{E}-05$ & 0,00076 & $5,96 \mathrm{E}-06$ & 778 & - & 16,26 & 0,28230 & 0,53 & 0,28266 & 1596 & 0,28206 & 10,39 \\
14,1 & 0,28255 & $4,89 \mathrm{E}-05$ & 0,00135 & $1,536 \mathrm{E}-05$ & 679 & $-7,91$ & 0,28253 & 6,47 & 0,28273 & 1141 & 0,28240 & 12,02 \\
16,1 & 0,28247 & $5,178 \mathrm{E}-05$ & 0,00109 & $1,503 \mathrm{E}-05$ & 676 & - & 0,28245 & 3,64 & 0,28274 & 1319 & 0,28227 & 11,38 \\
21,1 & 0,28065 & $7,707 \mathrm{E}-05$ & 0,00111 & 0,0001066 & 3165 & - & $-0,01$ & 0,28059 & $-13,09$ & 0,28112 & 4366 & 0,28020 & 1,31
\end{tabular}




\begin{tabular}{|c|c|c|c|c|c|c|c|c|c|c|c|c|}
\hline 22,1 & 0,28251 & 3,961E-05 & 0,00093 & 5,457E-06 & 832 & $-9,40$ & 0,28249 & 8,48 & 0,28262 & 1130 & 0,28240 & 12,06 \\
\hline 23,1 & 0,28261 & 5,775E-05 & 0,00124 & $7,051 \mathrm{E}-05$ & 743 & $-5,78$ & 0,28259 & 11,27 & 0,28264 & 869 & 0,28255 & 12,78 \\
\hline 24,1 & 0,28221 & 3,062E-05 & 0,00059 & $1,229 \mathrm{E}-05$ & 818 & $\begin{array}{c}- \\
19,81\end{array}$ & 0,28220 & $-2,07$ & 0,28263 & 1793 & 0,28191 & 9,68 \\
\hline 25,1 & 0,28186 & 5,477E-05 & 0,00139 & 7,507E-06 & 988 & 32,15 & 0,28184 & $-11,23$ & 0,28251 & 2502 & 0,28138 & 7,10 \\
\hline 28,1 & 0,28267 & 4,595E-05 & 0,00199 & $1,246 \mathrm{E}-05$ & 659 & $-3,55$ & 0,28265 & 10,13 & 0,28275 & 890 & 0,28258 & 12,90 \\
\hline 31,1 & 0,28199 & 7,659E-05 & 0,00138 & 7,71E-05 & 863 & 27,66 & 0,28197 & $-9,16$ & 0,28259 & 2273 & 0,28155 & 7,89 \\
\hline 32,1 & 0,28234 & 5,257E-05 & 0,00184 & 0,0001544 & 995 & $\begin{array}{c}- \\
15,37\end{array}$ & 0,28230 & 6,17 & 0,28248 & 1396 & 0,28218 & 10,98 \\
\hline 34,1 & 0,28249 & 5,199E-05 & 0,00097 & 1,312E-05 & 884 & $-9,84$ & 0,28248 & 9,15 & 0,28258 & 1127 & 0,28241 & 12,06 \\
\hline 37,1 & 0,28247 & 5,333E-05 & 0,00096 & $1,358 \mathrm{E}-05$ & 823 & 10,68 & 0,28246 & 6,99 & 0,28263 & 1219 & 0,28234 & 11,74 \\
\hline 38,1 & 0,28246 & 6,916E-05 & 0,00135 & $8,135 \mathrm{E}-05$ & 711 & 10,97 & 0,28244 & 4,09 & 0,28271 & 1318 & 0,28227 & 11,39 \\
\hline 40,1 & 0,28261 & 4,244E-05 & 0,00140 & 4,791E-05 & 752 & $-5,62$ & 0,28259 & 11,89 & 0,28263 & 832 & 0,28257 & 12,85 \\
\hline 43,1 & 0,28249 & 6,228E-05 & 0,00160 & 4,677E-05 & 720 & 10,01 & 0,28247 & 5,12 & 0,28270 & 1259 & 0,28231 & 11,60 \\
\hline 45,1 & 0,28159 & 8,98E-05 & 0,00112 & 5,431E-05 & 1985 & $\begin{array}{c}- \\
41,97\end{array}$ & 0,28154 & 1,33 & 0,28176 & 2470 & 0,28139 & 7,14 \\
\hline 49,1 & 0,28263 & 4,255E-05 & 0,00103 & 1,693E-05 & 811 & $-5,14$ & 0,28261 & 12,24 & 0,28264 & 872 & 0,28259 & 12,97 \\
\hline 54,1 & 0,28253 & 5,836E-05 & 0,00097 & 4,817E-05 & 759 & $-8,49$ & 0,28252 & 7,80 & 0,28268 & 1117 & 0,28241 & 12,10 \\
\hline 55,1 & 0,28212 & 5,293E-05 & 0,00142 & 4,666E-05 & 863 & 23,18 & 0,28209 & $-4,93$ & 0,28260 & 2009 & 0,28175 & 8,90 \\
\hline 56,1 & 0,28228 & 4,459E-05 & 0,00129 & $1,296 \mathrm{E}-05$ & 746 & $\begin{array}{c}- \\
17,38\end{array}$ & 0,28226 & $-1,56$ & 0,28268 & 1704 & 0,28198 & 10,00 \\
\hline
\end{tabular}

SNA-205B: anfibolito retroeclogítico (Nappe Liberdade)

\begin{tabular}{|c|c|c|c|c|c|c|c|c|c|c|c|c|}
\hline spot & $\begin{array}{l}176 \mathrm{Hf} / \\
177 \mathrm{Hf}\end{array}$ & $\pm 2 \mathrm{se}$ & $\begin{array}{l}176 \mathrm{Lu} / \\
177 \mathrm{Hf}\end{array}$ & \pm 2 se & $\begin{array}{l}\text { U-Pb } \\
\text { Age } \\
\text { (T1) }\end{array}$ & $\varepsilon \mathrm{Hf}(0)$ & $\begin{array}{c}176 / 177 \\
\text { am }\end{array}$ & $\varepsilon \mathrm{Hf}(\mathrm{t} 1)$ & $\begin{array}{c}176 / 177 \\
\text { DM }\end{array}$ & $\begin{array}{c}\mathrm{T} \\
\mathrm{DM} \\
(2)\end{array}$ & $\begin{array}{c}176 / 177 \\
\text { DM }\end{array}$ & $\varepsilon_{\mathrm{Hf}(\mathrm{tdm})}$ \\
\hline 3,1 & 0,28155 & 4,172E-05 & 0,00066 & 4,8E-06 & 29 & & 0,28152 & & 0,28174 & 2518 & 0,28 & 7,04 \\
\hline 6,1 & 0,28161 & 5,147E-05 & 0,00021 & 2,7E-06 & 2059 & $-41,18$ & 0,28160 & 4,55 & 0,28172 & 2325 & 0,28152 & 7,74 \\
\hline 14,1 & 0,28197 & 2,161E-05 & 0,00002 & 5,5E-07 & 924 & $-28,21$ & 0,28197 & $-7,81$ & 0,28255 & 2238 & 0,28158 & 8,06 \\
\hline 19,1 & 0,28124 & 3,012E-05 & 0,00063 & 2,6E-06 & 2370 & $-54,10$ & 0,28121 & $-2,00$ & 0,28148 & 2982 & 0,28102 & 5,32 \\
\hline 27,1 & 0,28198 & 4,075E-05 & 0,00266 & 3,9E-05 & 1481 & $-27,87$ & 0,28191 & 2,42 & 0,28215 & 2018 & 0,28175 & 8,86 \\
\hline 28,1 & 0,28195 & 5,149E-05 & 0,00508 & 0,00012 & 1480 & $-28,89$ & 0,28181 & $-1,03$ & 0,28215 & 2237 & 0,28158 & 8,07 \\
\hline 29,1 & 0,28196 & 3,943E-05 & 0,00215 & 8,9E-05 & 1419 & $-28,59$ & 0,28191 & 0,89 & 0,28219 & 2068 & 0,28171 & 8,68 \\
\hline 30,1 & 0,28201 & 3,414E-05 & 0,00244 & 5,8E-05 & 1468 & $-27,06$ & 0,28194 & 3,17 & 0,28215 & 1960 & 0,28179 & 9,07 \\
\hline 31,1 & 0,28205 & 4,758E-05 & 0,00407 & 8,3E-05 & 1500 & $-25,49$ & 0,28194 & 3,78 & 0,28213 & 1946 & 0,28180 & 9,13 \\
\hline 32,1 & 0,28205 & 3,912E-05 & 0,00239 & 8,1E-05 & 1479 & $-25,63$ & 0,28198 & 4,89 & 0,28215 & 1859 & 0,28187 & 9,44 \\
\hline 33,1 & 0,28203 & 4,491E-05 & 0,00330 & 0,00013 & 1491 & $-26,11$ & 0,28194 & 3,75 & 0,28214 & 1941 & 0,28180 & 9,14 \\
\hline 34,1 & 0,28149 & 2,915E-05 & 0,00101 & $6,5 \mathrm{E}-06$ & 2061 & $-45,20$ & 0,28145 & $-0,54$ & 0,28171 & 2652 & 0,28127 & 6,54 \\
\hline 35,1 & 0,28202 & 5,254E-05 & 0,00283 & 8,9E-05 & 1516 & $-26,49$ & 0,28194 & 4,35 & 0,28212 & 1922 & 0,28182 & 9,21 \\
\hline 38,1 & 0,28212 & 4,736E-05 & 0,00422 & 9,7E-05 & 1468 & $-23,06$ & 0,28200 & 5,43 & 0,28215 & 1815 & 0,28190 & 9,60 \\
\hline 39,1 & 0,28149 & 2,993E-05 & 0,00048 & 9,5E-07 & 2072 & $-45,22$ & 0,28147 & 0,43 & 0,28171 & 2599 & 0,28131 & 6,74 \\
\hline 42,1 & 0,28195 & 2,703E-05 & 0,00005 & $1 \mathrm{E}-06$ & 782 & $-29,07$ & 0,28195 & $-11,85$ & 0,28266 & 2382 & 0,28147 & 7,54 \\
\hline 44,1 & 0,28178 & 2,535E-05 & 0,00021 & 7,3E-06 & 790 & $-35,19$ & 0,28177 & $-17,88$ & 0,28265 & 2765 & 0,28119 & 6,13 \\
\hline 53,1 & 0,28209 & 2,259E-05 & 0,00001 & 4,4E-07 & 775 & $-24,23$ & 0,28209 & $-7,14$ & 0,28266 & 2080 & 0,28170 & 8,64 \\
\hline 60,1 & 0,28187 & 2,775E-05 & 0,00001 & $2 \mathrm{E}-07$ & 720 & $-31,82$ & 0,28187 & $-15,96$ & 0,28270 & 2591 & 0,28132 & 6,77 \\
\hline 62,1 & 0,28190 & 2,091E-05 & 0,00002 & 1,3E-06 & 742 & $-30,92$ & 0,28190 & $-14,58$ & 0,28269 & 2522 & 0,28137 & 7,02 \\
\hline 64,1 & 0,28194 & 2,034E-05 & 0,00002 & 7,3E-07 & 797 & $-29,26$ & 0,28194 & $-11,69$ & 0,28265 & 2383 & 0,28147 & 7,53 \\
\hline 65,1 & 0,28184 & 2,346E-05 & 0,00019 & $9,4 \mathrm{E}-06$ & 852 & $-33,00$ & 0,28184 & $-14,31$ & 0,28261 & 2590 & 0,28132 & 6,77 \\
\hline
\end{tabular}

SNA-213: metapsamito (Unidade Serra da Boa Vista - Nappe Andrelândia) 


\begin{tabular}{|c|c|c|c|c|c|c|c|c|c|c|c|c|}
\hline spot & $\begin{array}{l}176 \mathrm{Hf} / \\
177 \mathrm{Hf}\end{array}$ & \pm 2 se & $\begin{array}{c}176 \mathrm{Lu} / \\
177 \mathrm{Hf}\end{array}$ & \pm 2 se & $\begin{array}{l}\text { U-Pb } \\
\text { Age } \\
\text { (T1) }\end{array}$ & $\varepsilon \mathrm{Hf}(0)$ & $\begin{array}{c}176 / 177 \\
\text { am }\end{array}$ & $\varepsilon \mathrm{Hf}(\mathrm{t} 1)$ & $\begin{array}{c}176 / 177 \\
\text { DM }\end{array}$ & $\begin{array}{c}\mathrm{T} \\
\mathrm{DM} \\
(2)\end{array}$ & $\begin{array}{c}176 / 177 \\
\text { DM }\end{array}$ & $\varepsilon_{\mathrm{Hf}(\mathrm{tdm})}$ \\
\hline 1,1 & ,28214 & 4,082E-05 & 0,00049 & 5,984E-06 & & & 0,28213 & & 0,28226 & 1635 & 0,28203 & 10,25 \\
\hline 4,1 & 0,28206 & 3,121E-05 & 0,00082 & 2,097E-05 & 1269 & $-25,23$ & 0,28204 & & 0,28230 & 1867 & 0,28186 & 9,41 \\
\hline 6,1 & ),28158 & 4,984E-05 & 0,00097 & 2,429E-05 & 1834 & $-42,23$ & 0,28154 & $-2,54$ & 0,28188 & 2605 & 0,28131 & 6,72 \\
\hline 7,1 & 0,28224 & 3,496E-05 & 0,00083 & 2,701E-05 & 982 & $-18,68$ & 0,28223 & 2,50 & 0,28251 & 1628 & 0,28204 & 10,27 \\
\hline 8,1 & ,28202 & 4,344E-05 & 0,00237 & 3,275E-05 & 1219 & $-26,71$ & 0,28196 & $-1,6$ & 0,28234 & 2074 & 0,28171 & 8,66 \\
\hline 11,1 & ,28200 & 3,886E-05 & 0,00066 & 4,5E-06 & 1340 & $-27,19$ & 0,28199 & 1,97 & 0,28225 & 1938 & 0,28181 & 9,15 \\
\hline 12,1 & 0,28209 & 3,411E-05 & 0,00062 & 2,01E-05 & 1220 & $-24,12$ & 0,28208 & 2,43 & 0,28234 & 1816 & 0,28190 & 9,59 \\
\hline 13,1 & 0,28208 & 3,874E-05 & 0,00086 & 2,225E-06 & 1302 & $-24,50$ & 0,28206 & 3,65 & 0,28228 & 1802 & 0,28191 & 9,65 \\
\hline 17,1 & 0,28217 & 5,973E-05 & 0,00166 & 2,669E-05 & 1306 & $-21,27$ & 0,28213 & 6,28 & 0,28227 & 1636 & 0,28203 & 10,24 \\
\hline 18,1 & 0,28210 & 4,497E-05 & 0,00092 & 2,539E-05 & 1082 & $-23,79$ & 0,28208 & $-0,49$ & 0,28244 & 1896 & 0,28184 & 9,30 \\
\hline 19,1 & 0,28221 & 6,211E-05 & 0,00153 & 1,516E-05 & 977 & $-19,73$ & 0,28219 & 0,89 & 0,28252 & 1728 & 0,28196 & 9,91 \\
\hline 21,1 & 0,28144 & 5,221E-05 & 0,00111 & $6,212 \mathrm{E}-06$ & 1902 & $-47,09$ & 0,28140 & $-6,10$ & 0,28183 & 2883 & 0,28110 & 5,69 \\
\hline 22,1 & 0,28211 & 3,812E-05 & 0,00138 & 3,25E-05 & 1105 & $-23,37$ & 0,28208 & 0,09 & 0,28242 & 1877 & 0,28185 & 9,37 \\
\hline 24,1 & 0,28191 & 4,698E-05 & 0,00085 & 1,258E-05 & 1421 & $-30,55$ & 0,28189 & 0,21 & 0,28219 & 2113 & 0,28168 & 8,52 \\
\hline 26,1 & 0,28154 & 4,986E-05 & 0,00101 & 4,793E-06 & 1834 & $-43,44$ & 0,28151 & $-3,80$ & 0,28188 & 2686 & 0,28125 & 6,42 \\
\hline 27,1 & 0,28213 & 5,083E-05 & 0,00097 & 1,682E-05 & 1224 & $-22,65$ & 0,28211 & 3,71 & 0,28233 & 1738 & 0,28196 & 9,88 \\
\hline 30,1 & 0,28167 & $6,088 \mathrm{E}-05$ & 0,00185 & 0,0001371 & 1974 & $-39,11$ & 0,28160 & 2,52 & 0,28178 & 2390 & 0,28147 & 7,51 \\
\hline 32,1 & 0,28196 & 3,405E-05 & 0,00119 & 2,395E-05 & 1407 & $-28,56$ & 0,28193 & 1,57 & 0,28220 & 2015 & 0,28175 & 8,87 \\
\hline 33,1 & 0,28208 & 6,38E-05 & 0,00160 & $6,255 \mathrm{E}-05$ & 1232 & $-24,52$ & 0,28204 & 1,49 & 0,28233 & 1886 & 0,28185 & 9,34 \\
\hline 39,1 & 0,28211 & 8,368E-05 & 0,00101 & 5,437E-05 & 1263 & $-23,55$ & 0,28208 & 3,62 & 0,28231 & 1774 & 0,28193 & 9,75 \\
\hline 44,1 & 0,28202 & 6,515E-05 & 0,00165 & 3,722E-05 & 1300 & $-26,45$ & 0,28198 & 0,96 & 0,28228 & 1972 & 0,28178 & 9,03 \\
\hline 65,1 & 0,28197 & 5,044E-05 & 0,00085 & 4,129E-06 & 1448 & $-28,53$ & 0,28194 & 2,83 & 0,28217 & 1967 & 0,28179 & 9,05 \\
\hline
\end{tabular}

SNA-228: metapelito (Unidade Serra da Boa Vista - Nappe Andrelândia)

\begin{tabular}{|c|c|c|c|c|c|c|c|c|c|c|c|c|}
\hline pot & $\begin{array}{l}76 \mathrm{Hf} / \\
177 \mathrm{Hf}\end{array}$ & $2 \mathrm{se}$ & $\begin{array}{l}76 \mathrm{Lu} \mathrm{/} \\
177 \mathrm{Hf}\end{array}$ & $\pm 2 \mathrm{se}$ & $\begin{array}{l}\text { U-Pb } \\
\text { Age } \\
\text { (T1) }\end{array}$ & $\varepsilon \mathrm{Hf}(0)$ & $\begin{array}{c}176 / 177 \\
\text { am }\end{array}$ & $\mathrm{Hf}(\mathrm{t} 1)$ & $\begin{array}{c}176 / 177 \\
\text { DM }\end{array}$ & $\begin{array}{c}\mathrm{T} \\
\mathrm{DM} \\
(2)\end{array}$ & $\begin{array}{c}176 / 177 \\
\text { DM }\end{array}$ & $\varepsilon_{\mathrm{Hf}(\mathrm{tdm})}$ \\
\hline & & & & & & & & & & & & \\
\hline 6,1 & 0,28215 & & & & & & & & & 1862 & 0,28186 & \\
\hline 7,1 & 28214 & 05 & 00117 & 06 & 1289 & $-22,52$ & 0,28211 & & & 700 & ,28198 & \\
\hline 8,1 & 28206 & & (volue & & 1012 & $-25,02$ & & $-2,98$ & & 2001 & & \\
\hline 11,1 & 28210 & 834E-05 & 00129 & 2 & & & 8208 & & & & & \\
\hline 13,1 & 28215 & & & & 1244 & & & & & & & \\
\hline 14,1 & ,28162 & 4,888E-05 & ,00088 & 3,938E-06 & 1962 & & & & & & & \\
\hline 15,1 & 28221 & & & & 1233 & & & & & & & \\
\hline 16,1 & 28201 & 35E-05 & 15 & $1,627 \mathrm{E}$ & & & & $-5,86$ & 51 & & & \\
\hline 21,1 & 0,28223 & 3,425E-05 & 0,00188 & $5,034 \mathrm{E}-05$ & 1220 & $-19,19$ & 0,28219 & 6,34 & 0,28234 & 1566 & 0,28208 & 10,49 \\
\hline 22,1 & ,28213 & 458E-05 & 00168 & 3,187E-05 & 1009 & & 0,28210 & & 8249 & 1899 & & \\
\hline 321 & 0,28220 & $3,848 \mathrm{E}-05$ & ,00156 & $1,033 \mathrm{E}-05$ & 1342 & $-20,30$ & 0,28216 & & 0,28225 & 1546 & & 10,57 \\
\hline 40,1 & ,28209 & 3,832E-05 & 0,00194 & $2,393 \mathrm{E}-$ & 1266 & $-24,12$ & 0,28204 & 2,32 & 0,28230 & 1859 & 0,28 & \\
\hline & 28112 & & & & & & & & & & & \\
\hline & 0,28216 & 3,638E-05 & 0,00239 & $4,631 \mathrm{E}$ & 121 & & 0,28211 & & 0,282 & 1744 & & \\
\hline 4 & 0,28181 & 2,885E-05 & 0,00060 & 8,087E-06 & 1816 & $-34,10$ & 0,28179 & & & 2066 & 0,28171 & 8,69 \\
\hline 52,1 & ,28185 & $=-05$ & 22 & ,927E-05 & $17 €$ & $-32,46$ & 0,2 & & & 2046 & 0,2 & 8,76 \\
\hline 53,1 & 0,28203 & 4,085E-05 & 0,00110 & 1,687E-05 & 976 & $-26,18$ & & $-5,31$ & & 2120 & & 8,49 \\
\hline 54,1 & 0,28208 & 7,07E-05 & 0,00106 & 6,724E-06 & 987 & $-24,44$ & 0,28206 & $-3,31$ & 0,28251 & 2002 & 0,28176 & 8,92 \\
\hline
\end{tabular}




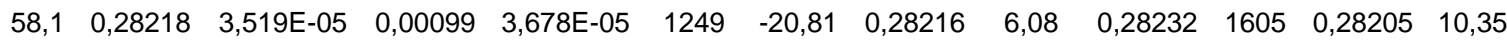
$\begin{array}{lllllllllllll}62,1 & 0,28205 & 4,623 \mathrm{E}-05 & 0,00040 & 4,466 \mathrm{E}-05 & 1222 & -25,71 & 0,28204 & 1,07 & 0,28234 & 1905 & 0,28183 & 9,27\end{array}$ $\begin{array}{lllllllllllll}64,1 & 0,28183 & 7,812 \mathrm{E}-05 & 0,00130 & 1,639 \mathrm{E}-05 & 1452 & -33,26 & 0,28180 & -2,27 & 0,28217 & 2294 & 0,28154 & 7,86\end{array}$

NESG-1010: metawacke (Unidade Santo Antônio - Nappe Andrelândia)

\begin{tabular}{|c|c|c|c|c|c|c|c|c|c|c|c|c|}
\hline spot & $\begin{array}{l}176 \mathrm{Hf} / \\
177 \mathrm{Hf}\end{array}$ & $\pm 2 \mathrm{se}$ & $\begin{array}{c}176 \mathrm{Lu} / \\
177 \mathrm{Hf}\end{array}$ & $\pm 2 \mathrm{se}$ & $\begin{array}{l}\text { U-Pb } \\
\text { Age } \\
\text { (T1) }\end{array}$ & $\varepsilon \mathrm{Hf}(0)$ & $\begin{array}{c}176 / 177 \\
\text { am }\end{array}$ & $\varepsilon \mathrm{Hf}(\mathrm{t} 1)$ & $\begin{array}{c}176 / 177 \\
\text { DM }\end{array}$ & $\begin{array}{c}\mathrm{T} \\
\mathrm{DM} \\
(2)\end{array}$ & $\begin{array}{c}176 / 177 \\
\text { DM }\end{array}$ & $\varepsilon_{\mathrm{Hf}(\mathrm{tdm})}$ \\
\hline 1,1 & 28186 & 5,02E-05 & 0,00096 & 4,783E-06 & 812 & & & $-14,79$ & 0,28264 & 2589 & 0,28132 & 6,78 \\
\hline 2,1 & 0,28176 & ,678E-05 &, 00048 & 1,455E-06 & 954 & $-35,92$ & 0,28175 & $-15,15$ & 0,28253 & 2722 & 0,28122 & 6,29 \\
\hline 3,3 & 28162 & 7,047E-05 & 0,00090 & 8,212E-06 & 2027 & & 0,28158 & & 0,28174 & 2387 & 0,28147 & 7,52 \\
\hline 4,1 & 0,28188 & 4,747E-05 & 0,00075 & 2,754E-05 & 1555 & $-31,62$ & 0,28186 & 2,20 & 0,28209 & 2089 & 0,28169 & 8,60 \\
\hline 5,3 & 0,28220 & 4,739E-05 & 0,00077 & 2,577E-05 & 1204 & $-20,09$ & 0,28219 & 6,00 & 0,28235 & 1576 & 0,28208 & 10,46 \\
\hline 10,2 & 0,28210 & 3,999E-05 & 0,00133 & 2,109E-05 & 817 & $-23,85$ & 0,28208 & $-6,53$ & 0,28263 & 2074 & 0,28170 & 8,66 \\
\hline 12,2 & 0,28212 & 4,842E-05 & 0,00029 & 7,643E-07 & 1241 & & 0,28212 & 4,39 & 0,28232 & 1707 & 0,28198 & 9,99 \\
\hline 15,2 & ,28135 & 4,634E-05 & 0,00050 & 9,705E-07 & 1934 & & 0,28 & & 81 & 26 & 0,28099 & 5,16 \\
\hline 17,1 & 0,28243 & 6,429E-05 & 0,00162 & 8,985E-05 & 749 & $-12,09$ & 0,28241 & 3,64 & 0,28268 & 1376 & 0,28222 & 11,18 \\
\hline 18,1 & 0,28262 & 6,885E-05 & 0,00096 & 1,859E-05 & 692 & $-5,41$ & 0,28261 & 9,43 & 0,28272 & 961 & 0,28253 & 12,65 \\
\hline 19,1 & 0,28223 & 5,351E-05 & 0,00111 & 3,058E-06 & 1010 & $-19,10$ & 0,28221 & 2,51 & 0,28249 & 1649 & 0,28202 & 10,20 \\
\hline 20,1 & 0,28221 & 6,473E-05 & 0,00077 & 8,813E-06 & 823 & $-19,71$ & 0,28220 & $-1,95$ & 0,28263 & 1789 & 0,28192 & 9,69 \\
\hline 22,1 & 0,28227 & 4,679E-05 & 0,00058 & 4,33E-06 & 680 & $-17,73$ & 0,28226 & $-3,00$ & 0,28273 & 1745 & 0,28195 & 9,85 \\
\hline 23,2 & 28215 & 6,346E-05 & 0,00313 & 2,759E-05 & 1045 & & 0,28209 & $-0,96$ & 0,28247 & 1897 & 0,28184 & 9,30 \\
\hline 24,1 & 0,28143 & 4,308E-05 & 0,00057 & 1,147E-05 & 2039 & $-47,36$ & 0,28141 & $-2,60$ & 0,28173 & 2767 & 0,28118 & 6,12 \\
\hline 26,3 & 0,28237 & 3,862E-05 & 0,00046 & 5,022E-06 & 766 & $-14,15$ & 0,28237 & & 0,28267 & 1460 & 0,28216 & 10,88 \\
\hline 27,1 & 0,28260 & 8,285E-05 & 0,00095 & 6,941E-06 & 798 & $-6,14$ & 0,28258 & 11, & 0,28265 & 942 & 0,28254 & 12,72 \\
\hline 28,1 & 0,28231 & 5,652E-05 & 0,00073 & 3,774E-06 & 689 & $-16,29$ & 0,28230 & $-1,42$ & 0,28273 & 1652 & 0,28202 & 10,19 \\
\hline 29,2 & ,28259 & 7,017E-05 & 0,00044 & 1,257E-05 & 808 & $-6,36$ & 0,28259 & 11,27 & 0,28264 & 932 & 0,28255 & 12,76 \\
\hline 30,1 & 0,28182 & 5,777E-05 & 0,00056 & 2,981E-06 & 1447 & $-33,71$ & 0,28180 & $-2,10$ & 0,28217 & 2280 & 0,28155 & 7,91 \\
\hline 31,1 & 0,28146 & 8,018E-05 & 0,00062 & 2,222E-06 & 1976 & $-46,30$ & 0,28144 & $-3,02$ & 0,28178 & 2745 & 0,28120 & 6,2 \\
\hline 34,2 & 0,28259 & 8,85E-05 & 0,00079 & 3,227E-06 & 729 & $-6,34$ & 0,28258 & 9,38 & 0,28270 & 993 & 0,28250 & 12,54 \\
\hline 36,1 & ,28183 & 5,574E-05 & 0,00069 & 1,419E-05 & 730 & $-33,24$ & 0,28182 & $-17,49$ & 0,28270 & 26 & 0,28124 & 6 \\
\hline 38,1 & 0,28227 & 5,966E-05 & 0,00073 & 7,665E-06 & 685 & $-17,91$ & 0,28226 & $-3,14$ & 0,28273 & 1757 & 0,28194 & 9,81 \\
\hline 45,1 & 0,28191 & 7,263E-05 & 0,00095 & 4,291E-06 & & & & & & & & \\
\hline 48,1 & 0,28210 & 8,178E-05 & 0,00076 & $9,604 \mathrm{E}-06$ & 784 & $-23,81$ & 0,28209 & $-6,91$ & 0,28266 & 2072 & 0,28171 & 8,67 \\
\hline 53,1 & 0,28129 & 24505 & 0,00063 & $1,24 \mathrm{E}-05$ & 2014 & & & & & & 0,28092 & 4,83 \\
\hline 54,1 & 0,28265 & 8,74E-05 & 0,00059 & 4,66E-06 & 728 & $-4,39$ & 0,28264 & 11,41 & 0,28270 & 861 & 0,28260 & 13,01 \\
\hline 56,1 & 0,28226 & $5,058 \mathrm{E}-05$ & 0,00056 & 1,751E-06 & 799 & $-18,08$ & & & & & & 10,04 \\
\hline 57,1 & 28245 & 5,846E-05 & ,00113 & 4,849E-06 & 700 & -11 & 0,28244 & & 0,28272 & 13 & 0,28225 & 11,3 \\
\hline 63,1 & 0,28222 & 8,43E-05 & 0,00057 & 4,27E-06 & 1011 & $-19,50$ & 0,28221 & 2,49 & 0,28249 & 1652 & 0,28202 & 10,19 \\
\hline 64,1 & 0,28168 & 4,498E-05 & 0,00031 & 2,359E-05 & 1786 & $-38,61$ & 0,28167 & 0,8 & 0,28192 & 235 & 0,28150 & 7,6 \\
\hline 65,2 & 0,28231 & 4,481E-05 & 0,00081 & 7,038E-06 & 820 & $-16,19$ & 0,28230 & 1,48 & 0,28263 & 1568 & 0,28208 & 10,49 \\
\hline 66,1 & 0,28200 & S & 0,00149 & 1,349E-05 & 986 & $-27,19$ & 0,28198 & $-6,3$ & 0,28251 & 2195 & 0,28161 & 8,22 \\
\hline 69,1 & 0,28189 & 5,164E-05 & 0,00060 & 6,57E-06 & 1542 & $-31,15$ & 0,28187 & 2,53 & 0,28210 & 2058 & 0,28172 & 8,72 \\
\hline 70,1 & 0,28120 & $4,352 \mathrm{E}-05$ & 0,00029 & 4,401E-06 & 2091 & $-55,65$ & 0,28119 & $-9,36$ & 0,28169 & 3234 & 0,28083 & 4,39 \\
\hline 73,1 & 0,28195 & 34E-05 & 0,00213 & 5,11E-05 & 1242 & $-28,99$ & 0,28190 & $-3,22$ & 0,28232 & 2193 & 0,28162 & 8,23 \\
\hline 74,1 & 0,28158 & 6,587E-05 & 0,00088 & 4,596E-06 & 1793 & $-42,30$ & טעוט, & $-3,41$ & 0,28191 & 2629 & 0,28129 & 6,63 \\
\hline 77,1 & 0,28217 & 8,742E-05 & 0,00092 & 5,998E-06 & 1250 & $-21,23$ & 0,28215 & 5,7 & 0,28232 & 1628 & 0,28204 & 10,27 \\
\hline 78,1 & 0,28210 & 6,311E-05 & 0,00058 & 1,414E-06 & 994 & $-23,60$ & 0,28209 & $-1,99$ & 0,28250 & 1924 & 0,28182 & 9,21 \\
\hline
\end{tabular}




\begin{tabular}{ccccccccccccc}
79,1 & 0,28275 & $7,962 \mathrm{E}-05$ & 0,00107 & $5,068 \mathrm{E}-06$ & 677 & $-0,63$ & 0,28274 & 13,84 & 0,28274 & 665 & 0,28274 & 13,70 \\
86,1 & 0,28181 & $5,543 \mathrm{E}-05$ & 0,00170 & $3,18 \mathrm{E}-05$ & 1951 & $-33,91$ & 0,28175 & 7,45 & 0,28180 & 2057 & 0,28172 & 8,72 \\
87,1 & 0,28157 & $5,456 \mathrm{E}-05$ & 0,00140 & $1,845 \mathrm{E}-05$ & 1868 & $-42,54$ & 0,28152 & $-2,64$ & 0,28186 & 2638 & 0,28128 & 6,60 \\
88,1 & 0,28232 & $7,281 \mathrm{E}-05$ & 0,00124 & $1,701 \mathrm{E}-05$ & 802 & $-15,84$ & 0,28231 & 1,21 & 0,28264 & 1571 & 0,28208 & 10,48 \\
\hline
\end{tabular}

NESG-1434: metapelito (Unidade Serra da Boa Vista - Nappe Andrelândia)

\begin{tabular}{|c|c|c|c|c|c|c|c|c|c|c|c|c|}
\hline spot & $\begin{array}{l}176 \mathrm{Hf} / \\
177 \mathrm{Hf}\end{array}$ & $\pm 2 \mathrm{se}$ & $\begin{array}{c}176 \mathrm{Lu} / \\
177 \mathrm{Hf}\end{array}$ & $\pm 2 \mathrm{se}$ & $\begin{array}{l}\text { U-Pb } \\
\text { Age } \\
\text { (T1) }\end{array}$ & $\varepsilon \mathrm{Hf}(0)$ & $\begin{array}{c}176 / 177 \\
\text { am }\end{array}$ & $\varepsilon \mathrm{Hf}(\mathrm{t} 1)$ & $\begin{array}{c}176 / 177 \\
\text { DM }\end{array}$ & $\begin{array}{c}\mathrm{T} \\
\mathrm{DM} \\
(2)\end{array}$ & $\begin{array}{c}176 / 177 \\
\text { DM }\end{array}$ & $\varepsilon_{\mathrm{H} f(\mathrm{tdm})}$ \\
\hline 2,1 & 0,28130 & 3,8568E-05 & 0,00058 & 1,282E-05 & 1869 & $-52,07$ & 0,28128 & $-11,15$ & 0,28186 & 3177 & 0,28087 & 4,60 \\
\hline 3,1 & 0,28178 & 5,1946E-05 & 0,00078 & 1,653E-05 & 1581 & $-35,00$ & 0,28176 & $-0,66$ & 0,28207 & 2291 & 0,28154 & 7,87 \\
\hline 4,1 & 0,28201 & 3,876E-05 & 0,00135 & 5,634E-05 & 1250 & $-26,77$ & 0,28198 & $-0,17$ & 0,28232 & 2006 & 0,28176 & 8,91 \\
\hline 8,1 & 0,28189 & 4,2965E-05 & 0,00127 & 3,417E-05 & 1722 & $-31,19$ & 0,28185 & 5,72 & 0,28197 & 1992 & 0,28177 & 8,96 \\
\hline 15.1 & 0,28167 & 3,761E-05 & 0,00105 & 4,19E-05 & 2034 & $-38,89$ & 0,28163 & 5,14 & 0,28173 & 2269 & 0,28156 & 7,95 \\
\hline 21,1 & 0,28206 & 5,4193E-05 & 0,00078 & 2,357E-05 & 1063 & $-25,23$ & 0,28204 & $-2,26$ & 0,28245 & 1994 & 0,28176 & 8,95 \\
\hline
\end{tabular}

NESG-1552: anfibolito (Unidade Santo Antônio - Nappe Andrelândia)

\begin{tabular}{|c|c|c|c|c|c|c|c|c|c|c|c|c|}
\hline spot & $\begin{array}{l}176 \mathrm{Hf} / \\
177 \mathrm{Hf}\end{array}$ & $\pm 2 \mathrm{se}$ & $\begin{array}{c}176 \mathrm{Lu} / \\
177 \mathrm{Hf}\end{array}$ & $\pm 2 \mathrm{se}$ & $\begin{array}{l}\text { U-Pb } \\
\text { Age } \\
\text { (T1) }\end{array}$ & $\begin{array}{c}\varepsilon \\
\operatorname{Hf}(0)\end{array}$ & $\begin{array}{c}176 / 177 \\
\text { am }\end{array}$ & $\varepsilon \mathrm{Hf}(\mathrm{t} 1)$ & $\begin{array}{c}176 / 177 \\
\text { DM }\end{array}$ & $\begin{array}{c}\mathrm{T} \\
\mathrm{DM} \\
(2)\end{array}$ & $\begin{array}{c}176 / 177 \\
\text { DM }\end{array}$ & $\varepsilon_{\mathrm{Hf}(\mathrm{tdm})}$ \\
\hline 1,1 & 0,28253 & 2,54E-05 & 0,00159 & $3,8 \mathrm{E}-05$ & 692 & $-8,47$ & 0,28251 & 6,08 & 0,28272 & 1176 & 0,28237 & 11,89 \\
\hline 2,2 & 0,28221 & 3,771E-05 & 0,00135 & 3,81E-05 & 833 & 20,02 & 0,28218 & $-2,37$ & 0,28262 & 1823 & 0,28189 & 9,57 \\
\hline 3,1 & 0,28208 & 4,545E-05 & 0,00177 & 3,518E-05 & 792 & 24,32 & 0,28206 & $-7,78$ & 0,28265 & 2133 & 0,28166 & 8,44 \\
\hline 4,1 & 0,28250 & 3,36E-05 & 0,00091 & 6,233E-06 & 672 & $-9,53$ & 0,28249 & 4,90 & 0,28274 & 1236 & 0,28233 & 11,68 \\
\hline 5,1 & 0,28240 & 4,332E-05 & 0,00242 & 8,483E-06 & 964 & 13,06 & 0,28236 & 6,73 & 0,28253 & 1344 & 0,28225 & 11,29 \\
\hline 6,1 & 0,28208 & 3,71E-05 & 0,00095 & 1,619E-05 & 795 & $\begin{array}{c}- \\
24,36\end{array}$ & 0,28207 & $-7,32$ & 0,28265 & 2107 & 0,28168 & 8,54 \\
\hline 9,1 & 0,28205 & 6,617E-05 & 0,00139 & 8,755E-06 & 1267 & 25,51 & 0,28202 & 1,42 & 0,28230 & 1917 & 0,28182 & 9,23 \\
\hline 10,1 & 0,28205 & 2,476E-05 & 0,00143 & 3,972E-05 & 746 & $\begin{array}{c}- \\
25,61\end{array}$ & 0,28203 & $-9,87$ & 0,28268 & 2230 & 0,28159 & 8,09 \\
\hline 11,1 & 0,28208 & 4,128E-05 & 0,00065 & $1,144 \mathrm{E}-05$ & 767 & 24,49 & 0,28207 & $-7,90$ & 0,28267 & 2122 & 0,28167 & 8,49 \\
\hline 12,1 & 0,28204 & 3,703E-05 & 0,00167 & 4,89E-05 & 821 & 25,96 & 0,28201 & $-8,75$ & 0,28263 & 2217 & 0,28160 & 8,14 \\
\hline 13,1 & 0,28209 & 4,452E-05 & 0,00177 & 1,878E-05 & 790 & $\stackrel{-}{-}$ & 0,28206 & $-7,77$ & 0,28265 & 2131 & 0,28166 & 8,45 \\
\hline 14,1 & 0,28215 & 3,419E-05 & 0,00118 & $5,215 \mathrm{E}-05$ & 801 & 21,91 & 0,28213 & $-4,86$ & 0,28264 & 1956 & 0,28179 & 9,09 \\
\hline 16,1 & 0,28188 & 3,273E-05 & 0,00048 & 6,613E-06 & 788 & 31,54 & 0,28187 & $-14,42$ & 0,28265 & 2547 & 0,28135 & 6,93 \\
\hline 18,1 & 0,28150 & $5,09 \mathrm{E}-05$ & 0,00162 & 6,33E-05 & 2118 & 45,04 & 0,28143 & 0,02 & 0,28167 & 2661 & 0,28126 & 6,51 \\
\hline 20,1 & 0,28214 & 3,336E-05 & 0,00154 & 1,95E-05 & 778 & 22,40 & 0,28212 & $-6,03$ & 0,28266 & 2012 & 0,28175 & 8,88 \\
\hline 21,2 & 0,28211 & 3,919E-05 & 0,00111 & 2,778E-05 & 801 & 23,42 & 0,28209 & $-6,33$ & 0,28264 & 2049 & 0,28172 & 8,75 \\
\hline 22,1 & 0,28207 & $3,168 \mathrm{E}-05$ & 0,00110 & $8,088 \mathrm{E}-06$ & 807 & 24,84 & 0,28205 & $-7,62$ & 0,28264 & 2135 & 0,28166 & 8,44 \\
\hline 24,1 & 0,28159 & 5,393E-05 & 0,00132 & $1,14 \mathrm{E}-05$ & 2195 & 41,74 & 0,28154 & 5,45 & 0,28161 & 2372 & 0,28148 & 7,57 \\
\hline 25,1 & 0,28236 & 3,242E-05 & 0,00110 & 4,081E-06 & 960 & 14,57 & 0,28234 & 5,97 & 0,28253 & 1390 & 0,28221 & 11,13 \\
\hline 26,2 & 0,28211 & 2,419E-05 & 0,00158 & 2,298E-05 & 720 & $\begin{array}{c}- \\
23,27\end{array}$ & 0,28209 & $-8,15$ & 0,28270 & 2101 & 0,28168 & 8,56 \\
\hline 27,1 & 0,28214 & 3,061E-05 & 0,00114 & 1,492E-05 & 1171 & 22,45 & 0,28211 & 2,62 & 0,28237 & 1767 & 0,28193 & 9,77 \\
\hline 29,1 & 0,28203 & 2,551E-05 & 0,00140 & 3,172E-05 & 793 & 26,39 & 0,28200 & $-9,63$ & 0,28265 & 2251 & 0,28157 & 8,02 \\
\hline 31,1 & 0,28216 & 4,174E-05 & 0,00217 & 1,95E-05 & 779 & 21,53 & 0,28213 & $-5,46$ & 0,28266 & 1977 & 0,28178 & 9,01 \\
\hline
\end{tabular}




\begin{tabular}{|c|c|c|c|c|c|c|c|c|c|c|c|c|}
\hline 32,1 & 0,28144 & 4,365E-05 & 0,00097 & 2,732E-05 & 1975 & 47,13 & 0,28140 & $-4,34$ & 0,28178 & 2828 & 0,28114 & 5,90 \\
\hline 33,1 & 0,28256 & 2,305E-05 & 0,00147 & 2,228E-05 & 793 & $-7,33$ & 0,28254 & 9,43 & 0,28265 & 1039 & 0,28247 & 12,38 \\
\hline 34,1 & 0,28226 & 3,257E-05 & 0,00336 & 6,923E-05 & 954 & 18,14 & 0,28220 & 0,82 & 0,28253 & 1714 & 0,28197 & 9,96 \\
\hline 37,2 & 0,28212 & 4,329E-05 & 0,00041 & 6,935E-06 & 1262 & $\begin{array}{c}- \\
22,88\end{array}$ & 0,28212 & 4,78 & 0,28231 & 1699 & 0,28198 & 10,02 \\
\hline 39,1 & 0,28263 & $2,984 \mathrm{E}-05$ & 0,00123 & $2,433 \mathrm{E}-05$ & 752 & $-5,20$ & 0,28261 & 10,81 & 0,28268 & 918 & 0,28256 & 12,80 \\
\hline
\end{tabular}


ANEXO VI

Geoquímica elemental em zircão

(Elementos traço e terras raras por LA-ICP-MS) 
SNA-125: metapelito (Unidade Serra da Boa Vista - Nappe Andrelândia)

\begin{tabular}{|c|c|c|c|c|c|c|c|c|c|c|c|c|}
\hline spot: & 59,1 & 56,1 & 53,1 & 43,1 & 37,1 & 36,1 & 34,1 & 33,1 & 23,1 & 20,1 & 11,1 & 4,1 \\
\hline $\mathrm{Li} 7$ & 4,2700 & 5,4600 & 11,8000 & 14,7300 & $<1,33$ & 1,9400 & 4,8000 & 15,0700 & 2,1700 & $<0,87$ & 1,6900 & 2,2800 \\
\hline Mg24 & 19,8300 & 77,5600 & 8,7000 & 41,5400 & 15,1500 & 13,0800 & 11,6300 & 219,9900 & 1,2600 & 5,8400 & 1,0200 & 2,8800 \\
\hline Al27 & 188,0700 & 787,4300 & 189,7200 & 255,2700 & 205,6200 & 506,1000 & 96,5000 & $1.529,7100$ & 4,8000 & 16,3400 & 5,0800 & 11,1300 \\
\hline Si29 & $191.826,2800$ & $169.086,2000$ & $181.662,9400$ & $149.095,7700$ & $172.338,7200$ & $186.243,7500$ & $171.500,6100$ & $163.525,4200$ & $168.762,3000$ & $163.331,1300$ & $163.922,5200$ & $162.014,5800$ \\
\hline P31 & 447,7600 & 359,7700 & 515,4800 & 347,5900 & 429,9500 & 861,6700 & 291,3100 & 431,0100 & 306,7300 & 214,7700 & 181,3600 & 193,2000 \\
\hline Ca44 & $<283,78$ & $<391,96$ & $<360,39$ & $<537,81$ & $<318,40$ & $<296,74$ & $<351,00$ & $<698,80$ & $<272,81$ & $<256,04$ & $<269,14$ & 324,5200 \\
\hline Sc45 & 239,8600 & 275,7400 & 286,7100 & 331,9000 & 269,3900 & 234,0600 & 249,3900 & 342,1200 & 194,7600 & 191,3400 & 221,0200 & 191,6800 \\
\hline Ti49 & 20,0200 & 37,1600 & 16,6100 & 10,8600 & 10,3700 & 27,2800 & 3,9600 & 60,5300 & 22,6000 & 12,9200 & 16,5500 & 3,4600 \\
\hline Mn55 & 1,6600 & 5,8700 & 2,2400 & $<1,96$ & 2,4500 & 8,2800 & 1,4700 & 17,6100 & $<0,99$ & $<0,95$ & $<1,01$ & $<1,09$ \\
\hline Fe56 & 270,9100 & 727,7300 & 155,3200 & 254,4700 & 184,3800 & $1.392,5400$ & 119,1800 & $1.237,4700$ & $<18,71$ & 28,4500 & $<18,95$ & 36,9100 \\
\hline $\mathrm{Rb} 85$ & 0,8300 & 1,3800 & 0,1770 & 0,5500 & 0,3400 & 0,8900 & 0,3600 & 3,6300 & $<0,114$ & 0,2300 & $<0,150$ & 0,2300 \\
\hline Sr88 & 0,7300 & 1,3900 & 0,4280 & 0,5900 & 0,4730 & 1,5800 & 0,7200 & 6,0500 & 0,3920 & 0,1680 & 0,2450 & 0,2140 \\
\hline Y89 & $1.165,0800$ & 979,4400 & 694,3100 & $1.039,8900$ & $1.242,5200$ & $2.547,4000$ & $1.209,9100$ & $1.233,2500$ & 824,7700 & 724,1100 & 742,8400 & 977,4900 \\
\hline Zr91 & $496.007,1300$ & $496.007,1600$ & $496.007,1600$ & $496.007,1900$ & $496.007,1300$ & $496.007,1300$ & $496.007,1300$ & $496.007,1600$ & $496.007,1300$ & $496.007,1600$ & $496.007,1600$ & $496.007,1300$ \\
\hline $\mathrm{Nb93}$ & 15,6000 & 8,6100 & 7,2300 & 8,1600 & 6,5600 & 11,2000 & 12,0800 & 8,2900 & 8,6500 & 7,0200 & 5,9200 & 9,3400 \\
\hline Mo95 & 8,5400 & 6,1400 & 12,2400 & 6,7000 & 7,5900 & 5,2300 & 11,6800 & 8,4600 & 7,5500 & 6,8300 & 5,5900 & 6,9400 \\
\hline Ba137 & 1,5800 & 6,6900 & 0,9200 & 2,7800 & 2,5800 & 2,2400 & 1,2600 & 23,0900 & $<0,38$ & $<0,294$ & $<0,316$ & 0,7700 \\
\hline La139 & 1,3600 & 1,4500 & 0,9900 & 0,3500 & 1,9900 & 5,1200 & 0,2700 & 10,0600 & $<0,042$ & 0,1050 & $<0,042$ & 0,0640 \\
\hline Ce140 & 18,2700 & 37,8100 & 6,8900 & 5,7700 & 18,3700 & 53,2800 & 10,3100 & 113,4000 & 7,6600 & 6,6700 & 18,3700 & 20,9800 \\
\hline Pr141 & 0,5600 & 1,8200 & 1,2700 & 0,5500 & 2,9600 & 5,7200 & 0,7200 & 21,6700 & 0,2280 & 0,3030 & 0,1410 & 0,0980 \\
\hline $\mathrm{Nd} 143$ & 3,5700 & 11,4600 & 10,3400 & 5,6500 & 17,6000 & 32,5000 & 5,7000 & 149,0200 & 2,1500 & 3,2000 & 3,2000 & 0,9900 \\
\hline Sm147 & 3,9700 & 5,8800 & 10,4700 & 6,4000 & 13,5000 & 22,7300 & 6,0700 & 62,1500 & 4,3600 & 3,9500 & 5,4200 & 2,7800 \\
\hline Eu151 & 0,3800 & 2,3300 & 1,3800 & 1,4100 & 2,2600 & 3,7300 & 1,0500 & 17,3700 & 0,3000 & 0,4300 & 0,8400 & 0,2000 \\
\hline Gd157 & 23,3600 & 14,5500 & 32,1800 & 23,4900 & 33,0700 & 83,2900 & 26,1800 & 74,4500 & 15,5700 & 14,3400 & 22,0100 & 15,5900 \\
\hline Tb159 & 8,6400 & 5,9700 & 9,3300 & 6,9300 & 10,5700 & 26,2600 & 9,5100 & 17,6500 & 6,4900 & 4,9300 & 6,9000 & 7,1100 \\
\hline Dy163 & 103,1600 & 78,2900 & 87,8900 & 95,4600 & 121,3000 & 286,9700 & 126,1100 & 137,7900 & 80,0400 & 60,1000 & 74,6200 & 80,8100 \\
\hline Ho165 & 43,5200 & 33,5600 & 25,3400 & 36,1500 & 47,4100 & 101,7000 & 45,1000 & 40,3600 & 28,2400 & 25,3800 & 27,1800 & 34,9600 \\
\hline
\end{tabular}




\begin{tabular}{|c|c|c|c|c|c|c|c|c|c|c|c|c|}
\hline Er166 & 204,5500 & 163,8100 & 86,7700 & 169,2500 & 203,9400 & 404,9300 & 196,0200 & 163,0400 & 121,4000 & 109,4600 & 113,3700 & 152,8600 \\
\hline Tm169 & 43,1200 & 36,9100 & 15,5300 & 43,6300 & 39,2600 & 75,1200 & 38,1200 & 34,5800 & 23,3000 & 22,6200 & 23,0300 & 34,5300 \\
\hline Yb173 & 431,6200 & 376,2700 & 118,5900 & 432,4700 & 359,8700 & 625,8600 & 374,5800 & 344,0800 & 207,1600 & 191,7100 & 195,6900 & 306,2900 \\
\hline Lu175 & 89,1600 & 76,5900 & 21,4000 & 91,9800 & 74,6100 & 125,1400 & 71,9100 & 76,6400 & 43,4500 & 42,8600 & 41,8500 & 70,6800 \\
\hline $\mathrm{Hf179}$ & $12.337,9200$ & $11.628,0800$ & $14.373,4400$ & $11.755,5000$ & $12.080,3100$ & $11.618,4900$ & $12.103,5200$ & $12.123,8800$ & $10.834,7200$ & $10.510,5600$ & $10.538,2200$ & $11.714,4300$ \\
\hline Ta181 & 3,5500 & 1,7500 & 0,5900 & 3,3900 & 0,5700 & 2,1500 & 1,7100 & 2,4500 & 1,0000 & 0,8600 & 0,2590 & 1,5200 \\
\hline Pb207 & 27,1600 & 40,5700 & 24,6000 & 27,6700 & 11,3900 & 11,8700 & 26,8200 & 34,5600 & 7,9500 & 12,4600 & 15,4100 & 18,6800 \\
\hline Pb208 & 10,9800 & 25,1300 & 7,5500 & 5,8500 & 6,7500 & 7,9100 & 9,2500 & 9,0200 & 4,9500 & 6,4100 & 19,7000 & 11,5800 \\
\hline Th232 & 124,3300 & 158,9300 & 69,4900 & 46,1900 & 74,6100 & 39,3400 & 78,7700 & 63,5500 & 42,9500 & 50,5800 & 190,1900 & 98,5200 \\
\hline U238 & 535,8500 & 399,4000 & 474,4200 & 953,0100 & 240,8000 & 174,5100 & 536,4100 & $1.083,7100$ & 114,9000 & 116,0600 & 197,0600 & 251,9100 \\
\hline
\end{tabular}

SNA-168: metavulcânica (Nappe Liberdade)

\begin{tabular}{|c|c|c|c|c|c|c|c|c|c|c|c|c|c|c|}
\hline spot: & 5,1 & 9,1 & 12,1 & 21,1 & $\begin{array}{c}5 \\
\text { (sem U-Pb) }\end{array}$ & 21,1 & 37,1 & 36,1 & 38,1 & 27,1 & 32,1 & 16,1 & 35,1 & 23,1 \\
\hline $\mathrm{Li} 7$ & 9,16 & $<1,74$ & 7,69 & 1,60 & 16,46 & $<1,47$ & 5,68 & 3,19 & 7,51 & 11,54 & 8,50 & 3,07 & 13,55 & 18,29 \\
\hline Mg24 & 10,26 & 1,38 & 2,02 & $<0,37$ & 8,56 & 0,92 & 3,07 & 1,04 & 2,11 & 4,62 & 4,83 & 1,82 & 29,24 & 1,79 \\
\hline $\mathrm{Al} 27$ & 100,49 & 3,65 & 78,90 & 2,76 & 468,94 & 20,32 & 42,07 & 36,95 & 30,98 & 131,06 & 76,31 & 13,83 & 104,72 & 84,73 \\
\hline Si29 & $161.251,23$ & $181.333,44$ & $161.649,63$ & $164.581,56$ & $187.194,59$ & $151.881,02$ & $169.108,81$ & $186.586,53$ & $173.695,69$ & $173.459,36$ & $180.212,42$ & $176.612,45$ & $179.538,59$ & $181.217,34$ \\
\hline P31 & 282,83 & 218,19 & 227,49 & 244,89 & 532,89 & 182,61 & 484,47 & 515,20 & 253,05 & 331,52 & 859,57 & 242,90 & 272,24 & 561,28 \\
\hline Ca42 & & & & & & & $<755,71$ & $2.339,18$ & $<731,87$ & $<754,02$ & $1.784,50$ & $<912,52$ & $<842,46$ & $<719,36$ \\
\hline Ca44 & $<335,69$ & $<356,57$ & $<363,58$ & $<247,98$ & $<352,02$ & $<375,66$ & $<94,86$ & $<109,92$ & 200,45 & $<93,68$ & 96,81 & $<115,26$ & $<104,61$ & 199,47 \\
\hline Sc45 & 206,27 & 217,21 & 192,67 & 210,15 & 271,64 & 197,52 & 186,86 & 198,70 & 134,09 & 139,53 & 280,27 & 146,02 & 129,86 & 162,90 \\
\hline Ti49 & 7,69 & 7,37 & 3,94 & 3,44 & 51,40 & 8,53 & 11,14 & 6,46 & 4,81 & 8,30 & 13,31 & 3,68 & 7,84 & 7,70 \\
\hline Mn55 & $<1,26$ & $<1,33$ & 2,84 & $<0,93$ & 6,37 & $<1,35$ & 0,75 & 0,78 & 0,85 & 2,67 & 1,39 & $<0,75$ & 2,46 & 3,40 \\
\hline Fe56 & 70,02 & $<19,74$ & 42,12 & $<13,74$ & $1.477,74$ & 49,67 & 38,31 & 27,42 & 43,52 & 51,14 & 89,50 & 13,48 & 110,33 & 62,30 \\
\hline Co59 & & & & & & & $<0,077$ & $<0,116$ & $<0,102$ & 0,14 & 0,09 & $<0,12$ & $<0,126$ & 0,13 \\
\hline Rb85 & 0,37 & $<0,212$ & 0,28 & 0,18 & 0,91 & 0,22 & 0,34 & $<0,39$ & $<0,32$ & $<0,31$ & 0,68 & 0,73 & $<0,36$ & $<0,30$ \\
\hline Sr88 & 0,99 & 0,09 & 0,83 & 0,30 & 2,94 & 0,30 & 0,59 & 0,49 & 0,53 & 0,72 & 0,68 & 0,23 & 1,47 & 0,84 \\
\hline Y89 & $1.911,99$ & 517,54 & $1.493,18$ & $1.250,93$ & $1.245,36$ & 765,86 & $4.449,67$ & $4.136,55$ & $2.017,70$ & $2.458,01$ & $6.723,96$ & 846,64 & 980,93 & $2.233,55$ \\
\hline Zr91 & $496.007,16$ & $496.007,16$ & $496.007,13$ & $496.007,19$ & $496.007,13$ & $496.007,13$ & $503.410,28$ & $503.410,31$ & $503.410,31$ & $503.410,22$ & $503.410,25$ & $503.410,22$ & $503.410,22$ & $503.410,25$ \\
\hline
\end{tabular}




\begin{tabular}{|c|c|c|c|c|c|c|c|c|c|c|c|c|c|c|}
\hline $\mathrm{Nb93}$ & 6,42 & 6,63 & 6,12 & 6,20 & 11,70 & 7,41 & 3,81 & 2,84 & 2,36 & 2,08 & 6,24 & 1,05 & 1,76 & 2,29 \\
\hline Mo95 & 4,32 & 5,98 & 7,16 & 5,40 & 5,23 & 6,48 & 1,45 & 1,05 & 1,83 & 0,86 & 0,77 & 1,25 & 1,20 & 0,82 \\
\hline Sn118 & & & & & & & $<0,79$ & 1,48 & $<0,69$ & $<0,79$ & $<0,68$ & 1,62 & $<0,84$ & $<0,80$ \\
\hline Sb121 & & & & & & & $<0,199$ & $<0,25$ & $<0,18$ & $<0,23$ & $<0,186$ & $<0,26$ & $<0,22$ & $<0,165$ \\
\hline Ba137 & $<0,43$ & $<0,38$ & 0,74 & $<0,19$ & 2,06 & 0,22 & $<0,28$ & 0,48 & $<0,35$ & 0,74 & $<0,31$ & $<0,32$ & 1,84 & 0,94 \\
\hline La139 & $<0,034$ & 0,04 & $<0,054$ & 0,05 & 1,07 & $<0,081$ & $<0,034$ & 0,04 & $<0,039$ & 0,26 & 0,14 & $<0,050$ & $<0,041$ & $<0,030$ \\
\hline Ce140 & 7,02 & 5,22 & 4,79 & 4,31 & 22,89 & 8,49 & 17,51 & 8,66 & 8,32 & 8,57 & 16,53 & 2,57 & 2,92 & 6,40 \\
\hline Pr141 & 0,15 & 0,06 & 0,17 & 0,05 & 1,41 & 0,10 & 0,60 & 0,20 & 0,28 & 0,65 & 0,44 & $<0,0257$ & $<0,038$ & 0,15 \\
\hline $\mathrm{Nd} 143$ & 2,82 & 0,78 & 4,25 & 1,53 & 8,34 & $<0,57$ & 10,78 & 4,84 & 3,67 & 7,49 & 10,10 & 0,29 & 0,82 & 2,91 \\
\hline Sm147 & 5,44 & 1,63 & 5,94 & 3,11 & 9,17 & 3,01 & 17,81 & 14,01 & 6,57 & 10,35 & 25,73 & 3,32 & 1,88 & 5,99 \\
\hline Eu151 & 2,85 & 0,15 & 2,03 & 1,52 & 3,02 & 0,14 & 6,24 & 4,89 & 2,50 & 3,32 & 8,66 & 1,24 & 0,64 & 1,84 \\
\hline Gd157 & 35,34 & 10,52 & 26,85 & 19,03 & 32,69 & 13,24 & 83,48 & 86,57 & 32,65 & 47,15 & 154,70 & 15,35 & 13,96 & 33,14 \\
\hline Tb159 & 12,77 & 4,19 & 8,67 & 7,07 & 9,66 & 5,56 & 29,34 & 32,48 & 12,21 & 17,08 & 55,97 & 5,12 & 5,29 & 13,20 \\
\hline Dy 163 & 153,03 & 48,32 & 107,70 & 91,51 & 116,22 & 62,05 & 352,74 & 381,27 & 152,45 & 196,94 & 645,69 & 63,68 & 79,88 & 171,64 \\
\hline Ho165 & 57,31 & 17,78 & 46,46 & 37,01 & 43,12 & 26,00 & 135,27 & 146,55 & 62,83 & 78,87 & 239,20 & 30,90 & 32,21 & 70,51 \\
\hline Er166 & 280,71 & 78,61 & 233,73 & 181,37 & 194,69 & 109,58 & 625,11 & 611,22 & 315,69 & 368,73 & $1.006,51$ & 137,66 & 169,55 & 340,42 \\
\hline Tm169 & 62,52 & 15,47 & 55,00 & 40,35 & 40,64 & 22,52 & 137,83 & 122,86 & 75,71 & 82,42 & 195,01 & 31,05 & 39,68 & 74,87 \\
\hline Yb173 & 629,98 & 145,64 & 594,66 & 423,75 & 364,03 & 204,19 & $1.375,44$ & $1.081,23$ & 840,22 & 826,79 & $1.749,69$ & 318,74 & 409,29 & 757,44 \\
\hline Lu175 & 146,31 & 30,11 & 148,94 & 104,32 & 85,70 & 40,74 & 272,49 & 205,19 & 175,18 & 166,35 & 317,40 & 74,29 & 86,67 & 154,25 \\
\hline $\mathrm{Hf179}$ & $9.332,26$ & $11.550,77$ & $10.478,34$ & $9.694,53$ & $15.649,48$ & $12.137,05$ & $8.792,13$ & $9.910,99$ & $9.328,06$ & $8.870,08$ & $9.580,16$ & $12.396,59$ & $9.491,72$ & $9.022,22$ \\
\hline Ta181 & 0,61 & 0,53 & 0,97 & 0,76 & 2,94 & 0,79 & 1,52 & 1,38 & 1,60 & 1,17 & 2,23 & 0,94 & 0,73 & 1,14 \\
\hline Pb206 & & & & & & & 267,27 & 118,38 & 332,92 & 153,91 & 190,47 & 124,94 & 79,79 & 141,27 \\
\hline Pb207 & 14,36 & 22,07 & 18,57 & 5,91 & 98,96 & 51,14 & 26,35 & 13,96 & 33,97 & 17,60 & 21,04 & 14,77 & 9,21 & 17,07 \\
\hline Pb208 & 11,86 & 7,72 & 11,18 & 3,67 & 24,33 & 18,23 & 27,73 & 12,18 & 28,56 & 16,60 & 22,47 & 5,18 & 4,70 & 13,01 \\
\hline Th232 & 92,56 & 41,56 & 64,91 & 30,42 & 207,99 & 89,62 & 202,41 & 80,40 & 213,96 & 103,37 & 154,96 & 31,76 & 29,21 & 71,35 \\
\hline U238 & 166,56 & 111,59 & 191,99 & 70,20 & 818,88 & 231,30 & 285,45 & 130,12 & 357,97 & 177,62 & 206,07 & 118,74 & 97,13 & 173,82 \\
\hline
\end{tabular}


SNA-172E: metapelito (Nappe Liberdade)

\begin{tabular}{|c|c|c|c|c|c|c|c|c|c|c|c|c|}
\hline spot: & 2,1 & 3,1 & 3,2 & 4,1 & 13,1 & 14,1 & 8,1 & 9,1 & 10,1 & 18,1 & 45,1 & 64,1 \\
\hline $\mathrm{Li} 7$ & 10,1500 & 2,9800 & 2,2500 & 5,9200 & 9,6200 & 0,0034 & 8,3400 & 3,0900 & 2,0100 & $<2,26$ & $<1,66$ & 7,2500 \\
\hline Mg24 & 1,4200 & 1,3400 & 7,2400 & 1,1200 & 6,6800 & 0,0026 & 0,6800 & 5,0600 & 0,5400 & 0,7800 & 2,3900 & 3,4400 \\
\hline Al27 & 34,4600 & 64,9400 & 39,6100 & 33,8500 & 70,0600 & 0,0477 & 54,0200 & 109,0700 & 30,5200 & 32,0800 & 35,5900 & 70,3400 \\
\hline Si29 & $179.118,7500$ & $186.764,5800$ & $166.417,1300$ & $182.180,7300$ & $226.437,8400$ & 152,0300 & $170.378,7800$ & $199.704,2500$ & $179.892,3000$ & $175.205,7200$ & $161.317,0300$ & $187.056,9800$ \\
\hline P31 & $1.108,8300$ & 818,9800 & 57,9100 & 715,0500 & 769,7600 & 0,2200 & $1.058,8000$ & 788,3300 & 921,9000 & 812,4700 & 370,8300 & 817,4400 \\
\hline $\mathrm{Ca} 44$ & $<364,00$ & $<359,39$ & $<350,52$ & $<305,04$ & $<387,93$ & $<0,27$ & $<262,43$ & $<332,75$ & $<313,78$ & $<317,95$ & $<243,41$ & $<285,97$ \\
\hline Sc45 & 324,6200 & 338,5000 & 237,0500 & 332,2900 & 274,0300 & 0,2020 & 305,7900 & 340,8400 & 322,8900 & 312,2700 & 207,3500 & 296,8400 \\
\hline Ti49 & 5,6600 & 6,8500 & 5,4800 & 8,0500 & 6,6700 & 0,0137 & 4,6200 & 381,0700 & 9,3600 & 12,8300 & 7,2700 & 5,5200 \\
\hline Mn55 & $<1,25$ & $<1,31$ & $<1,23$ & $<1,06$ & $<1,44$ & 0,0013 & $<0,97$ & 5,6600 & $<1,16$ & $<1,14$ & $<0,88$ & 1,2100 \\
\hline Fe56 & $<29,36$ & $<29,30$ & 37,4300 & 129,3100 & 82,0000 & $<0,023$ & $<22,27$ & 55,4700 & $<25,95$ & $<26,47$ & 22,9400 & $<23,90$ \\
\hline $\mathrm{Rb} 85$ & 0,4800 & 0,6700 & $<0,19$ & 0,2600 & 1,3900 & 0,0007 & 0,1700 & 0,2600 & 0,3230 & 0,2300 & 0,3800 & 0,6000 \\
\hline Sr88 & 0,4400 & 0,6200 & 0,2820 & 0,3320 & 0,5700 & 0,0002 & 0,2600 & 0,7400 & 0,5190 & 0,4930 & 0,3890 & 0,7700 \\
\hline Y89 & $2.234,2900$ & $1.508,5900$ & 186,1900 & $1.439,6600$ & $1.676,8600$ & 0,7030 & $2.143,2800$ & $1.799,4600$ & $2.296,2900$ & $1.857,6300$ & $1.315,0300$ & $2.197,3900$ \\
\hline Zr91 & $496.007,0900$ & $496.007,0600$ & $496.007,0900$ & $496.007,0900$ & $496.007,0900$ & 439,9000 & $496.007,0900$ & $496.007,0900$ & $496.007,0900$ & $496.007,0900$ & $496.007,1300$ & $496.007,1300$ \\
\hline $\mathrm{Nb93}$ & 6,8800 & 7,0200 & 7,1800 & 6,3200 & 11,0400 & 0,0066 & 6,3300 & 14,2900 & 6,1000 & 6,9400 & 8,6300 & 6,1700 \\
\hline Mo95 & 7,8500 & 8,2400 & 7,7200 & 6,3000 & 8,6500 & 0,0067 & 7,0300 & 5,8400 & 6,6300 & 7,0300 & 7,0100 & 6,6600 \\
\hline Ba137 & $<0,262$ & $<0,44$ & 0,4400 & 0,1390 & 1,4400 & $<0,00029$ & $<0,35$ & $<0,37$ & $<0,24$ & $<0,35$ & 0,4900 & 0,4000 \\
\hline La139 & $<0,049$ & 0,3700 & 0,3740 & $<0,050$ & 0,9100 & 0,0001 & 0,3900 & 2,4000 & 0,0410 & 0,1440 & 0,6500 & 0,5740 \\
\hline Ce140 & 0,8300 & 2,1500 & 1,7300 & 0,8800 & 3,9300 & 0,0308 & 2,6100 & 9,0700 & 1,5900 & 2,2600 & 14,0000 & 2,8100 \\
\hline Pr141 & $<0,040$ & 0,3110 & 0,1640 & 0,0380 & 0,3800 & 0,0002 & 0,0400 & 1,2600 & 0,0690 & 0,2370 & 0,5550 & 0,2940 \\
\hline $\mathrm{Nd} 143$ & 0,7800 & 0,6300 & 1,2800 & 0,7200 & 4,2700 & 0,0007 & 1,6600 & 6,0300 & 2,4500 & 2,9900 & 3,5800 & 2,3900 \\
\hline Sm147 & 2,9300 & 4,2000 & 1,0100 & 3,8800 & 3,0300 & 0,0027 & 3,9700 & 5,3800 & 4,8800 & 5,1700 & 4,5900 & 4,5500 \\
\hline Eu151 & 0,1190 & 0,3800 & $<0,119$ & 0,1610 & 0,1900 & 0,0004 & 0,2400 & 5,1800 & 0,1540 & 0,2670 & 0,5000 & 0,5700 \\
\hline Gd157 & 27,1400 & 20,2300 & 2,6900 & 29,7200 & 12,7100 & 0,0111 & 30,6300 & 27,8300 & 40,7100 & 39,3000 & 25,3700 & 28,2000 \\
\hline Tb159 & 12,2900 & 11,1400 & 1,2900 & 12,2200 & 8,6100 & 0,0049 & 14,5400 & 11,1800 & 16,2300 & 14,9100 & 9,7500 & 14,2800 \\
\hline Dy163 & 183,1900 & 127,4400 & 15,8200 & 146,1100 & 116,2200 & 0,0606 & 179,2300 & 144,4700 & 196,0100 & 178,5100 & 113,9200 & 187,7800 \\
\hline Ho165 & 75,5300 & 57,4900 & 4,9800 & 48,5600 & 54,9400 & 0,0246 & 68,6600 & 60,5000 & 78,3900 & 68,0100 & 44,2600 & 77,6000 \\
\hline
\end{tabular}




\begin{tabular}{|c|c|c|c|c|c|c|c|c|c|c|c|c|}
\hline Er166 & 380,3000 & 274,6800 & 17,2400 & 198,1800 & 300,1400 & 0,1200 & 323,4600 & 296,4700 & 358,7500 & 295,5200 & 194,4800 & 348,1200 \\
\hline Tm169 & 77,4300 & 61,1500 & 3,0000 & 37,7000 & 62,3800 & 0,0256 & 66,2400 & 67,2600 & 75,8700 & 58,7300 & 39,8600 & 73,8100 \\
\hline Yb173 & 673,0700 & 605,0500 & 26,3600 & 327,4700 & 587,8200 & 0,2520 & 585,1800 & 628,1900 & 676,8500 & 523,2200 & 348,6200 & 673,5000 \\
\hline Lu175 & 138,3600 & 120,0600 & 4,4800 & 65,0200 & 120,0600 & 0,0540 & 127,8200 & 131,5100 & 138,9500 & 104,1800 & 72,8900 & 129,6100 \\
\hline Hf179 & $13.227,9700$ & $12.771,2800$ & $13.627,5200$ & $12.546,3700$ & $13.336,0800$ & 10,4900 & $11.979,0800$ & $14.285,4100$ & $12.260,4500$ & $11.768,9800$ & $11.748,6700$ & $12.701,7000$ \\
\hline Ta181 & 0,5200 & 0,4800 & 2,1000 & 0,3060 & 3,5400 & 0,0010 & 0,3700 & 1,3500 & 0,2490 & 0,4040 & 1,7500 & 0,5210 \\
\hline Pb207 & 12,8300 & 14,4600 & 7,5100 & 10,9700 & 24,1000 & 0,0230 & 7,2600 & 14,6700 & 5,7600 & 6,5200 & 13,6100 & 7,8200 \\
\hline Pb208 & 3,0900 & 9,4400 & 1,6100 & 3,6500 & 3,5600 & 0,0180 & 2,6700 & 5,8000 & 5,6200 & 6,4700 & 11,3400 & 2,6800 \\
\hline Th232 & 49,1200 & 49,7900 & 1,5500 & 45,6700 & 49,3000 & 0,1359 & 43,2000 & 51,5500 & 76,8400 & 84,1400 & 163,0600 & 43,6600 \\
\hline U238 & 262,5300 & 280,1700 & 268,6700 & 341,0900 & $1.041,8600$ & 0,1899 & 170,0700 & 482,2400 & 176,0000 & 150,9100 & 280,3600 & 262,2700 \\
\hline
\end{tabular}

SNA-180A: metapsamito (Nappe Liberdade)

\begin{tabular}{|c|c|c|c|c|c|c|c|c|c|c|c|c|}
\hline spot: & 61,1 & 62,1 & 48,1 & 42,1 & 37,1 & 30,1 & 29,1 & 24,1 & 18,1 & 3,1 & 4,1 & 1,1 \\
\hline $\mathrm{Li} 7$ & 3,3200 & 3,0300 & $<1,09$ & 2,9100 & 3,0300 & 4,0200 & $<1,24$ & $<1,21$ & 2,3600 & $<1,04$ & 0,7700 & 3,8900 \\
\hline Mg24 & 8,8900 & $<0,55$ & 5,7700 & 2,1800 & 1,3400 & $<1,14$ & 0,4100 & $<0,51$ & 3,0000 & $<0,51$ & 1,3200 & $<0,66$ \\
\hline Al27 & 176,3600 & 10,7200 & 12,9400 & 114,8700 & 106,5700 & 30,0900 & 6,5000 & 2,7300 & 141,7500 & $<2,93$ & 58,2300 & 10,0300 \\
\hline $\mathrm{Si} 29$ & $172.595,9800$ & $186.207,4500$ & $175.380,2800$ & $159.433,0900$ & $166.179,5000$ & $141.701,2200$ & $172.254,6600$ & $174.103,6100$ & $163.481,3900$ & $185.848,7200$ & $178.502,9700$ & $190.905,3400$ \\
\hline P31 & 479,2200 & 247,6100 & 267,7300 & 290,7900 & 321,5100 & 509,9700 & 211,2500 & 235,0400 & 308,8100 & 197,1300 & 314,2300 & 76,5500 \\
\hline Ca44 & 352,6200 & $<294,54$ & $<333,70$ & $<468,11$ & $<557,46$ & $<455,27$ & $<244,57$ & $<258,52$ & $<289,18$ & $<316,84$ & $<326,35$ & $<331,55$ \\
\hline Sc45 & 223,0400 & 218,5900 & 213,4900 & 233,7900 & 217,5600 & 255,4000 & 216,3900 & 201,5300 & 215,6700 & 244,7000 & 250,3200 & 216,2500 \\
\hline Ti49 & 22,2000 & 11,3900 & 8,1600 & 13,0800 & 12,8100 & 11,8400 & 16,4300 & 19,2400 & 15,9800 & 26,9600 & 33,1300 & 3,2600 \\
\hline Mn55 & $<1,14$ & $<1,03$ & $<1,23$ & $<1,75$ & 3,9500 & $<1,69$ & $<0,88$ & $<0,97$ & $<1,19$ & $<1,28$ & $<1,36$ & $<1,32$ \\
\hline Fe56 & $<20,89$ & $<18,00$ & 24,6200 & 646,3700 & 132,3400 & 54,2400 & $<14,53$ & $<15,71$ & 172,4800 & $<21,56$ & $<21,59$ & $<21,44$ \\
\hline $\mathrm{Rb} 85$ & 0,3400 & $<0,19$ & $<0,20$ & 0,6600 & 0,2500 & 0,3100 & 0,1310 & $<0,130$ & 0,2700 & $<0,152$ & 0,4100 & $<0,20$ \\
\hline Sr88 & 0,6500 & 0,1550 & 0,3500 & 0,3600 & 0,7700 & 0,8300 & 0,1590 & 0,2630 & 0,2650 & 0,1560 & 0,4800 & 0,2600 \\
\hline Y89 & $1.462,5500$ & 609,9000 & $1.054,0900$ & $1.303,1400$ & $1.300,6100$ & $1.748,3800$ & 727,8700 & 870,1700 & 772,8700 & 843,6900 & $1.049,2200$ & 249,4100 \\
\hline Zr91 & $503.410,0000$ & $503.410,0000$ & $503.409,9700$ & $503.410,0000$ & $503.410,0300$ & $503.410,0000$ & $503.410,0900$ & $503.410,0900$ & $503.410,0900$ & $503.410,0600$ & $503.410,0900$ & $503.410,0600$ \\
\hline Nb93 & 9,6100 & 7,1900 & 8,6500 & 8,9600 & 7,9900 & 8,5100 & 8,6000 & 7,8100 & 9,4000 & 8,8300 & 7,6200 & 7,1300 \\
\hline Mo95 & 8,0000 & 8,1300 & 6,1000 & 6,4700 & 4,5200 & 14,0000 & 7,6400 & 6,5000 & 6,8900 & 6,6400 & 6,8700 & 7,9300 \\
\hline
\end{tabular}




\begin{tabular}{|c|c|c|c|c|c|c|c|c|c|c|c|c|}
\hline Ba137 & 2,2000 & $<0,00$ & $<0,49$ & $<0,36$ & 1,6400 & 0,9900 & $<0,32$ & $<0,29$ & 0,4000 & $<0,44$ & 0,5200 & $<0,39$ \\
\hline La139 & 0,7200 & 0,2080 & 0,0930 & 0,5300 & 3,5200 & 1,0900 & $<0,025$ & $<0,054$ & 0,1500 & 0,1740 & 0,6300 & 0,1140 \\
\hline Ce140 & 35,6900 & 20,3200 & 33,0200 & 35,5400 & 29,6400 & 12,0800 & 6,8500 & 7,4500 & 38,5200 & 47,2300 & 21,8200 & 17,1800 \\
\hline Pr141 & 1,2600 & 0,2720 & 0,2190 & 1,8800 & 3,2400 & 1,8300 & 0,2090 & 0,1300 & 0,3700 & 0,2560 & 1,2600 & $<0,051$ \\
\hline $\mathrm{Nd} 143$ & 11,4900 & 2,8800 & 1,5600 & 14,3300 & 24,8300 & 14,0100 & 2,3100 & 1,2400 & 3,1200 & 2,7500 & 9,6000 & $<0,44$ \\
\hline Sm147 & 12,8500 & 3,3800 & 3,9100 & 7,2700 & 19,3200 & 14,2500 & 3,0300 & 4,1600 & 3,2700 & 3,9400 & 11,1300 & 1,7700 \\
\hline Eu151 & 3,0800 & 0,8100 & 1,3900 & 2,3000 & 6,6700 & 2,8200 & 0,2250 & 0,4200 & 0,9200 & 0,6000 & 3,7000 & 0,2900 \\
\hline Gd157 & 40,9500 & 16,6900 & 21,5000 & 38,2200 & 48,7000 & 43,1900 & 16,7900 & 18,4100 & 14,5800 & 18,7700 & 33,7300 & 6,8300 \\
\hline Tb159 & 14,4100 & 6,3300 & 6,7200 & 10,7700 & 14,1800 & 13,8100 & 5,7300 & 6,8000 & 4,1200 & 7,0300 & 10,9200 & 1,6500 \\
\hline Dy163 & 142,3400 & 58,1600 & 83,4200 & 115,4300 & 147,0100 & 141,6000 & 68,3500 & 71,2200 & 58,4200 & 80,7300 & 107,6700 & 17,6700 \\
\hline Ho165 & 52,9400 & 20,8500 & 31,1000 & 43,0900 & 46,2400 & 52,5200 & 25,6300 & 29,0400 & 22,1200 & 30,4800 & 34,0200 & 7,4900 \\
\hline Er166 & 229,3300 & 91,9800 & 139,4800 & 185,4800 & 190,3800 & 246,7500 & 109,8800 & 130,8400 & 110,3500 & 140,0900 & 141,2900 & 37,1300 \\
\hline Tm169 & 43,6800 & 19,5500 & 32,4200 & 39,1400 & 40,9200 & 49,1500 & 20,2400 & 27,2500 & 25,9000 & 30,4100 & 29,5500 & 9,9400 \\
\hline Yb173 & 389,4200 & 192,5400 & 309,7100 & 398,1000 & 366,2400 & 449,0900 & 188,7400 & 254,3300 & 263,4600 & 306,6400 & 289,9900 & 100,8900 \\
\hline Lu175 & 83,4300 & 43,4600 & 63,9800 & 86,2100 & 73,6300 & 86,9200 & 38,0200 & 51,8800 & 50,1700 & 56,4200 & 62,4700 & 25,0600 \\
\hline $\mathrm{Hf} 179$ & $11.529,9900$ & $11.272,6100$ & $10.478,1100$ & $10.183,1800$ & $9.623,8100$ & $10.604,4600$ & $10.224,5000$ & $10.480,8000$ & $10.551,3500$ & $10.940,2000$ & $10.858,9100$ & $13.483,0400$ \\
\hline Ta181 & 1,0500 & 0,6300 & 1,1000 & 0,7100 & 1,1700 & 1,5600 & 0,6800 & 0,8100 & 1,6300 & 0,8900 & 0,6200 & 0,2600 \\
\hline Pb207 & 14,8500 & 9,4800 & 15,3200 & 16,2700 & 24,9900 & 19,1700 & 10,0400 & 9,9500 & 8,9200 & 9,7200 & 4,5700 & 74,1200 \\
\hline Pb208 & 22,4300 & 6,0100 & 11,6000 & 16,9000 & 5,2400 & 11,3000 & 5,0100 & 6,5000 & 9,0400 & 18,0800 & 8,6000 & 16,2700 \\
\hline Th232 & 182,3300 & 74,9200 & 102,8700 & 118,5400 & 89,8700 & 103,3800 & 50,3000 & 49,5700 & 123,9100 & 152,0800 & 87,9900 & 60,6900 \\
\hline U238 & 243,4400 & 235,6400 & 204,5900 & 287,2600 & 496,5500 & 354,8200 & 169,1100 & 111,4100 & 285,8900 & 92,0500 & 120,9400 & 149,9000 \\
\hline
\end{tabular}

SNA-201: metawackes (Unidade Santo Antônio - Nappe Andrelândia)

\begin{tabular}{ccccccccccc}
\hline spot: & 1,1 & 6,1 & 19,1 & 26,1 & 18,1 & 32,1 & 40,1 & 45,1 & 47,1 \\
\hline Li7 & 3,90 & 3,91 & $<0,98$ & 5,82 & $<0,83$ & 2,12 & $<0,00090$ & 9,47 & 6,68 & 2,55 \\
Mg24 & 1,55 & 0,72 & 48,39 & 216,59 & 2,05 & 94,16 & 0,07 & 103,95 & 123,84 & 118,97 \\
Al27 & 18,59 & 2,09 & 203,76 & 432,83 & 3,79 & 335,91 & 0,32 & 399,60 & 589,01 & 279,12 \\
Si29 & $185.859,91$ & $175.785,25$ & $180.347,31$ & $175.663,98$ & $171.551,63$ & $208.667,09$ & 153,31 & $164.946,66$ & $212.371,48$ & $184.166,84$ \\
P31 & 124,10 & 91,72 & 212,29 & 816,21 & 227,94 & 339,83 & 0,54 & 294,39 & 324,22 & 164,69
\end{tabular}




\begin{tabular}{|c|c|c|c|c|c|c|c|c|c|c|}
\hline Ca44 & $<248,61$ & $<271,73$ & $<362,59$ & $1.456,62$ & 338,94 & $<372,70$ & 0,69 & $<534,79$ & $<571,16$ & 458,05 \\
\hline Sc45 & 221,16 & 202,57 & 284,00 & 272,78 & 289,26 & 275,91 & 0,32 & 298,39 & 339,89 & 296,57 \\
\hline Ti49 & 3,85 & 3,05 & 32,06 & 35,61 & 15,59 & 31,06 & 0,02 & 29,56 & 13,68 & 23,90 \\
\hline Mn55 & 11,24 & $<0,86$ & 11,55 & 6,61 & $<0,84$ & 6,84 & 0,01 & 2,05 & 3,19 & 2,46 \\
\hline Fe56 & $<16,92$ & $<17,21$ & 36,44 & 265,70 & $<14,59$ & 155,96 & 0,18 & 85,79 & 455,03 & 262,27 \\
\hline Rb85 & $<0,105$ & $<0,147$ & 0,34 & $<0,24$ & 0,23 & 0,40 & 0,00 & 0,75 & $<0,36$ & $<0,22$ \\
\hline Sr88 & 0,40 & 0,19 & 1,12 & 2,26 & 0,51 & 1,17 & 0,00 & 1,18 & 1,54 & 0,85 \\
\hline Y89 & 387,76 & 449,76 & $1.009,71$ & $1.695,45$ & $1.549,68$ & $1.018,82$ & 0,90 & 817,44 & $1.314,37$ & 460,74 \\
\hline Zr91 & $503.410,22$ & $503.410,19$ & $503.410,16$ & $503.410,19$ & $503.410,19$ & $503.410,22$ & 439,90 & $503.410,19$ & $503.410,16$ & $503.410,25$ \\
\hline $\mathrm{Nb93}$ & 5,51 & 7,02 & 7,04 & 9,15 & 5,98 & 9,94 & 0,01 & 9,67 & 24,12 & 7,06 \\
\hline Mo95 & 6,40 & 6,23 & 5,75 & 9,14 & 6,20 & 9,58 & 0,01 & 7,82 & 40,81 & 9,58 \\
\hline Ba137 & 0,62 & $<0,180$ & 3,02 & 4,79 & $<0,173$ & 4,10 & 0,01 & 4,32 & 6,89 & 4,10 \\
\hline La139 & 0,62 & 0,03 & 10,76 & 3,74 & 0,07 & 5,44 & 0,01 & 7,09 & 6,09 & 1,08 \\
\hline Ce140 & 7,20 & 24,25 & 100,33 & 31,06 & 4,50 & 23,50 & 0,05 & 56,74 & 53,60 & 23,16 \\
\hline Pr141 & 0,88 & $<0,038$ & 15,61 & 4,62 & 0,36 & 4,33 & 0,01 & 12,93 & 12,17 & 1,26 \\
\hline $\mathrm{Nd} 143$ & 5,44 & $<0,33$ & 99,99 & 35,50 & 3,51 & 26,17 & 0,07 & 100,43 & 95,51 & 9,07 \\
\hline Sm147 & 2,50 & 0,88 & 49,85 & 13,26 & 12,72 & 12,48 & 0,04 & 44,50 & 59,09 & 4,86 \\
\hline Eu151 & 0,57 & 0,44 & 6,07 & 2,07 & 0,94 & 1,86 & 0,01 & 6,31 & 7,12 & 1,04 \\
\hline Gd157 & 7,76 & 7,03 & 67,86 & 37,88 & 44,37 & 32,46 & 0,06 & 56,49 & 72,24 & 12,12 \\
\hline Tb159 & 2,26 & 2,41 & 12,81 & 10,15 & 13,35 & 8,99 & 0,01 & 12,41 & 15,38 & 3,08 \\
\hline Dy 163 & 21,42 & 31,26 & 97,29 & 116,53 & 148,13 & 99,43 & 0,08 & 81,88 & 139,17 & 35,99 \\
\hline Ho165 & 10,72 & 13,53 & 33,78 & 48,20 & 51,37 & 39,21 & 0,02 & 23,18 & 46,97 & 14,72 \\
\hline Er166 & 61,12 & 67,15 & 151,80 & 249,86 & 208,48 & 167,57 & 0,12 & 110,95 & 170,25 & 73,64 \\
\hline Tm169 & 17,24 & 15,49 & 29,69 & 56,53 & 39,45 & 34,01 & 0,03 & 24,40 & 35,80 & 20,19 \\
\hline Yb173 & 203,03 & 172,73 & 300,91 & 570,81 & 347,30 & 331,34 & 0,32 & 295,53 & 410,31 & 253,40 \\
\hline Lu175 & 48,65 & 37,70 & 66,00 & 117,55 & 69,47 & 77,88 & 0,08 & 63,58 & 89,26 & 61,56 \\
\hline $\mathrm{Hf} 179$ & $8.947,03$ & $12.460,32$ & $10.284,83$ & $12.235,05$ & $10.250,20$ & $13.741,90$ & 9,41 & $12.477,96$ & $11.621,39$ & $12.927,29$ \\
\hline Ta181 & 0,21 & 0,57 & 0,42 & 0,74 & 0,36 & 1,20 & 0,00 & 1,18 & 0,18 & 0,35 \\
\hline Pb207 & 7,38 & 11,20 & 5,99 & 9,82 & 4,62 & 9,97 & 0,01 & 28,33 & 11,67 & 8,63 \\
\hline Pb208 & 4,83 & 8,24 & 7,65 & 7,89 & 6,42 & 4,08 & 0,00 & 5,53 & 5,33 & 8,48 \\
\hline
\end{tabular}




\begin{tabular}{lcccccccccc} 
Th232 & 72,05 & 147,27 & 106,41 & 89,87 & 91,35 & 31,76 & 0,02 & 38,99 & 77,29 & 111,42 \\
U238 & 232,56 & 404,50 & 199,62 & 347,66 & 175,79 & 180,43 & 0,26 & 346,96 & 430,31 & 275,34 \\
\hline
\end{tabular}

SNA-201: metawackes (Unidade Santo Antônio - Nappe Andrelândia) $\rightarrow$ continuação

\begin{tabular}{|c|c|c|c|c|c|c|c|c|c|}
\hline spot: & 28,1 & 16,1 & 34,1 & 43,1 & 37,1 & 44,1 & 54,1 & 11,1 & 49,1 \\
\hline Li7 & 4,29 & $<1,32$ & 7,03 & $<2,79$ & 2,09 & $<10,46$ & 8,33 & 3,03 & 6,37 \\
\hline Mg24 & 309,72 & 21,01 & 60,58 & 217,31 & 110,12 & 203,90 & 272,89 & 15,52 & 22,42 \\
\hline $\mathrm{Al} 27$ & 939,62 & 86,46 & 164,67 & 908,60 & 283 & 687,03 & $1.314,74$ & 198,61 & 359,40 \\
\hline Si29 & $188.510,02$ & $189.434,47$ & $153.126,59$ & $170.334,05$ & 145538,64 & $139.873,22$ & $171.066,44$ & $178.218,63$ & $165.182,61$ \\
\hline P31 & 325,70 & 280,16 & 56,38 & 495,71 & 199,22 & 137,41 & 251,75 & 216,33 & 146,24 \\
\hline Ca42 & & & $<669,95$ & $<670,83$ & $<399,02$ & $<2504,90$ & $<646,36$ & $<409,81$ & 791,62 \\
\hline Ca44 & $<351,47$ & $<351,35$ & $<114,90$ & 324,66 & 526,78 & 834,55 & 282,60 & $<69,57$ & 100,20 \\
\hline Sc45 & 347,26 & 280,59 & 239,86 & 278,36 & 243,88 & 275,22 & 260,09 & 218,34 & 263,04 \\
\hline Ti49 & 40,56 & 6,14 & 118,07 & 64,06 & 55,04 & 67,66 & 66,40 & 21,87 & 23,47 \\
\hline Mn55 & 6,71 & $<1,26$ & $<0,69$ & 35,60 & 1,61 & 11,98 & 14,17 & $<0,36$ & 16,03 \\
\hline Fe56 & 668,33 & $<22,19$ & 157,32 & 807,02 & 255,68 & 741,63 & $1.197,38$ & 85,14 & 131,04 \\
\hline Co59 & & & $<0,100$ & 0,67 & 0,134 & $<0,31$ & 0,25 & $<0,059$ & 0,07 \\
\hline $\mathrm{Rb} 85$ & 1,81 & 0,45 & 0,59 & 1,40 & 0,94 & 1,60 & 1,68 & 0,18 & $<0,108$ \\
\hline Sr88 & 2,17 & 0,38 & 0,96 & 4,68 & 1,27 & 2,52 & 2,92 & 0,58 & 0,62 \\
\hline Y89 & $1.395,24$ & 905,88 & 336,62 & $2.950,17$ & 791,33 & 665,46 & $1.054,89$ & 707,20 & 382,33 \\
\hline Zr91 & $503.410,22$ & $503.410,25$ & $503.410,16$ & $503.410,16$ & 503410,16 & $503.410,16$ & $503.410,16$ & $503.410,09$ & $503.410,16$ \\
\hline $\mathrm{Nb93}$ & 9,73 & 6,95 & 1,30 & 7,22 & 1,95 & 1,97 & 2,68 & 1,92 & 0,75 \\
\hline Mo95 & 11,70 & 4,82 & 1,75 & 4,88 & 1,49 & 2,94 & 1,14 & 1,40 & 2,02 \\
\hline Sn118 & & & 1,42 & $<1,16$ & $<0,70$ & $<4,49$ & $<1,17$ & 2,34 & 1,48 \\
\hline Sb121 & & & $<0,31$ & $<0,38$ & 0,38 & $<1,45$ & 0,40 & 0,37 & $<0,20$ \\
\hline Ba137 & 7,89 & 1,35 & 0,97 & 18,04 & 4,41 & 7,21 & 7,33 & 1,37 & 0,92 \\
\hline La139 & 8,82 & 0,43 & 1,07 & 68,70 & 2,52 & 5,15 & 10,91 & $<0,047$ & 2,29 \\
\hline Ce140 & 62,69 & 24,62 & 5,63 & 242,87 & 46,59 & 58,78 & 86,86 & 17,64 & 28,08 \\
\hline Pr141 & 12,49 & 0,62 & 0,73 & 68,26 & 5,17 & 9,80 & 17,87 & 0,20 & 3,86 \\
\hline
\end{tabular}




\begin{tabular}{|c|c|c|c|c|c|c|c|c|c|}
\hline $\mathrm{Nd} 143$ & 93,54 & 8,80 & 4,72 & 439,15 & 44,04 & 49,10 & 152,43 & 2,99 & 30,71 \\
\hline Sm147 & 51,50 & 4,79 & 4,24 & 222,00 & 29,7 & 48,98 & 97,37 & 2,81 & 22,89 \\
\hline Eu151 & 7,47 & 1,78 & $<0,18$ & 27,15 & 4,07 & 4,80 & 11,32 & 0,24 & 3,38 \\
\hline Gd157 & 67,46 & 23,45 & 7,47 & 276,60 & 52,99 & 72,87 & 134,56 & 11,01 & 36,79 \\
\hline Tb159 & 14,04 & 7,05 & 2,08 & 47,18 & 9,34 & 13,92 & 24,52 & 4,09 & 6,35 \\
\hline Dy163 & 121,74 & 73,59 & 20,31 & 341,64 & 70,67 & 73,00 & 136,23 & 56,30 & 42,78 \\
\hline Ho165 & 43,13 & 29,23 & 10,47 & 114,60 & 27 & 19,96 & 35,78 & 21,65 & 12,54 \\
\hline Er166 & 205,18 & 121,76 & 47,95 & 435,70 & 118,14 & 93,58 & 133,92 & 104,08 & 59,33 \\
\hline Tm169 & 46,42 & 25,38 & 15,40 & 85,35 & 26,67 & 19,68 & 31,97 & 25,47 & 14,40 \\
\hline Yb173 & 496,50 & 258,33 & 159,31 & 757,30 & 288,81 & 236,90 & 331,66 & 236,55 & 172,90 \\
\hline Lu175 & 117,33 & 58,21 & 42,15 & 135,64 & 58,58 & 57,26 & 65,86 & 45,71 & 44,87 \\
\hline Hf179 & $11.824,58$ & $12.288,79$ & $10.447,54$ & $10.866,13$ & 11139,43 & $11.629,63$ & $11.584,45$ & $10.224,44$ & $12.018,56$ \\
\hline Ta181 & 0,72 & 0,41 & 0,75 & 1,88 & 1,18 & 0,94 & 1,14 & 1,35 & 0,56 \\
\hline $\mathrm{Pb} 206$ & & & 361,72 & 228,48 & 96,42 & 132,59 & 287,56 & 220,09 & 134,17 \\
\hline Pb207 & 9,64 & 4,56 & 21,73 & 21,13 & 5,64 & 27,77 & 23,52 & 16,32 & 9,94 \\
\hline Pb208 & 4,23 & 9,24 & 12,13 & 17,21 & 7,82 & 32,85 & 12,29 & 19,25 & 4,74 \\
\hline Th232 & 52,95 & 100,73 & 86,16 & 233,17 & 122,72 & 125,98 & 103,72 & 235,28 & 41,93 \\
\hline U238 & 367,04 & 145,29 & 504,42 & 624,00 & 231,44 & 399,56 & 531,00 & 433,19 & 268,33 \\
\hline
\end{tabular}

SNA-205B: anfibolito retroeclogítico (Nappe Liberdade)

\begin{tabular}{cccccccccccc}
\hline spot: & 29,1 & 34,1 & 35,1 & 4 (sem U-Pb) & 5 (sem U-Pb) & 59,1 & 7 (sem U-Pb) & 11,1 & 26,1 \\
\hline Li7 & 5,73 & 3,77 & 4,56 & 1,81 & $<1,31$ & $<1,68$ & 9,01 & 35,68 & 40,48 & 36,79 \\
Mg24 & 1,11 & 1,66 & 6,24 & 6,61 & 10,24 & 5,78 & 6,01 & 29,30 & 3,45 & 0,54 & 1.29 \\
Al27 & 73,70 & 22,19 & 242,20 & 10,66 & $151.488,72$ & 70,81 & $1.106,36$ & $1.290,21$ & 15,28 & 151,31 \\
Si29 & $160.071,23$ & $164.559,36$ & $165.119,83$ & $158.896,61$ & $90.764,08$ & $185.929,25$ & $165.869,67$ & $166.945,05$ & $168.982,98$ & $176.448,31$ \\
P31 & 438,10 & 279,93 & 961,59 & 164,98 & $<37,54$ & 181,77 & 372,24 & 229,61 & 46,87 & 45,23 \\
Ca42 & & & & & & & & & $7.801,01$ & $<1122,99$ & $2.088,98$ \\
Ca44 & $<271,48$ & $<325,37$ & 855,69 & 843,25 & $<282,37$ & $<287,88$ & $<329,00$ & 865,97 & $<139,62$ & $<102,44$ \\
Sc45 & 224,42 & 208,87 & 245,66 & 223,89 & $<0,67$ & 276,68 & 313,38 & 119,68 & 118,58 & 103,19
\end{tabular}




\begin{tabular}{|c|c|c|c|c|c|c|c|c|c|c|}
\hline Ti49 & 6,43 & 7,46 & 9,43 & $<3,55$ & 5,19 & 7,54 & 306,08 & 10,20 & 3,16 & $<1,78$ \\
\hline Mn55 & $<1,08$ & $<1,15$ & 12,44 & 3,28 & $<1,02$ & 9,91 & 13,08 & 42,15 & $<0,83$ & $<0,64$ \\
\hline Fe56 & 118,90 & 26,47 & $1.490,31$ & 364,33 & 456,46 & 377,83 & $16.916,95$ & $6.113,63$ & 76,61 & 13,27 \\
\hline Co59 & & & & & & & & $<0,27$ & $<0,142$ & $<0,092$ \\
\hline Rb85 & 0,45 & 0,30 & 0,50 & $<0,201$ & $<0,176$ & 0,56 & $<0,190$ & 1,20 & $<0,42$ & $<0,30$ \\
\hline Sr88 & 0,53 & 0,74 & 17,07 & 0,50 & 0,12 & 0,29 & 0,46 & 0,67 & 0,28 & 0,05 \\
\hline Y89 & $2.299,41$ & 811,16 & $2.203,56$ & 389,21 & 0,06 & 665,25 & 476,82 & 191,87 & 60,43 & 50,87 \\
\hline Zr91 & $496.007,16$ & $496.007,13$ & $496.007,13$ & $496.007,13$ & 44,42 & $496.007,13$ & $496.007,09$ & $503.410,31$ & $503.410,34$ & $503.410,31$ \\
\hline Nb93 & 6,59 & 6,82 & 5,62 & 7,31 & 0,05 & 6,75 & 7,16 & 2,12 & 1,16 & 0,79 \\
\hline Mo95 & 3,52 & 5,94 & 5,02 & 8,06 & 0,34 & 6,47 & 6,93 & 1,53 & 0,76 & 1,15 \\
\hline Sn118 & & & & & & & & $<2,39$ & $<1,06$ & $<0,79$ \\
\hline Sb121 & & & & & & & & $<0,61$ & $<0,28$ & $<0,21$ \\
\hline Ba137 & 1,03 & 0,57 & 3,63 & 0,71 & $<0,00$ & 0,54 & 1,08 & $<1,03$ & 0,32 & $<0,26$ \\
\hline La139 & 0,32 & $<0,080$ & 444,51 & 0,58 & 0,20 & 0,26 & 8,35 & 4,67 & 0,18 & $<0,054$ \\
\hline Ce140 & 6,72 & 5,56 & 448,39 & 21,54 & 0,49 & 8,15 & 89,07 & 25,98 & 2,02 & 1,71 \\
\hline Pr141 & 0,28 & 0,05 & 190,29 & 0,84 & 0,06 & 0,15 & 12,77 & 5,62 & 0,17 & $<0,032$ \\
\hline $\mathrm{Nd} 143$ & 2,89 & 1,26 & 938,40 & 6,63 & $<0,38$ & 1,99 & 115,91 & 44,51 & 0,68 & 0,29 \\
\hline Sm147 & 4,66 & 2,18 & 235,01 & 6,54 & 0,10 & 2,36 & 48,79 & 36,22 & 1,23 & 0,82 \\
\hline Eu151 & 1,86 & $<0,089$ & 66,74 & 4,36 & 0,10 & 1,13 & 35,07 & 11,50 & 0,21 & 0,38 \\
\hline Gd157 & 37,71 & 15,14 & 226,50 & 8,62 & $<0,22$ & 11,68 & 71,58 & 41,25 & 1,71 & 3,24 \\
\hline Tb159 & 14,76 & 5,49 & 42,25 & 1,97 & $<0,056$ & 3,49 & 9,22 & 4,51 & 0,69 & 0,66 \\
\hline Dy163 & 186,95 & 72,55 & 325,45 & 24,38 & $<0,202$ & 47,06 & 59,44 & 25,17 & 6,49 & 5,40 \\
\hline Ho165 & 71,63 & 28,56 & 76,10 & 10,38 & $<0,037$ & 19,55 & 16,21 & 4,28 & 1,58 & 1,60 \\
\hline Er166 & 326,87 & 125,29 & 278,90 & 51,01 & 0,07 & 96,63 & 55,26 & 15,04 & 3,94 & 3,91 \\
\hline Tm169 & 70,70 & 24,60 & 56,91 & 13,34 & 0,04 & 22,50 & 8,83 & 2,28 & 0,81 & 0,58 \\
\hline Yb173 & 663,38 & 222,19 & 560,82 & 126,33 & $<0,00$ & 251,47 & 79,31 & 16,56 & 4,72 & 4,80 \\
\hline Lu175 & 145,72 & 46,17 & 122,01 & 33,25 & $<0,057$ & 59,41 & 15,60 & 3,14 & 0,68 & 0,59 \\
\hline Hf179 & $10.531,25$ & $12.624,44$ & $12.073,66$ & $10.930,36$ & 1,32 & $10.204,02$ & $14.304,92$ & $11.753,22$ & $12.638,10$ & $12.845,37$ \\
\hline Ta181 & 0,89 & 1,00 & 0,42 & 0,16 & $<0,029$ & 0,27 & 0,26 & 0,49 & 1,65 & 0,72 \\
\hline Pb206 & & & & & & & & 567,99 & 602,55 & 612,21 \\
\hline
\end{tabular}




\begin{tabular}{ccccccccccc} 
Pb207 & 8,41 & 61,52 & 14,10 & 21,23 & $<0,274$ & 19,83 & 35,36 & 47,31 & 39,94 & 41,57 \\
Pb208 & 6,67 & 14,85 & 8,04 & 7,98 & $<0,145$ & 5,76 & 8,80 & 7,68 & 1,49 & 2,05 \\
Th232 & 69,66 & 76,82 & 73,36 & 45,43 & $<0,030$ & 28,79 & 93,34 & 22,89 & 11,25 & 21,58 \\
U238 & 135,08 & 329,82 & 163,79 & 101,79 & 0,09 & 174,88 & 226,04 & $1.266,01$ & $1.288,12$ & $1.383,62$ \\
\hline
\end{tabular}

SNA-205B: anfibolito retroeclogítico (Nappe Liberdade) $\rightarrow$ continuação

\begin{tabular}{|c|c|c|c|c|c|c|c|c|c|}
\hline spot: & 60,1 & 62,1 & 61,1 & 17,1 & 38,1 & 30,1 & 28,1 & 27,1 & 33,1 \\
\hline $\mathrm{Li} 7$ & 50,03 & 53,04 & 36,25 & 41,69 & 18,63 & 2,67 & 14,19 & 3,65 & 1,98 \\
\hline Mg24 & 10,09 & $<1,06$ & 7,49 & $<0,50$ & 27,79 & 1,13 & 3,78 & 2,15 & 1,90 \\
\hline Al27 & 78,09 & 40,47 & 213,30 & 9,61 & 485,24 & 22,17 & 278,59 & 18,49 & 3,34 \\
\hline Si29 & $199.945,05$ & $197.436,19$ & $176.813,38$ & $195.900,73$ & 172480,67 & $172.243,63$ & $165.404,88$ & $178.597,45$ & $163.480,88$ \\
\hline P31 & 236,12 & 67,41 & 219,12 & 73,51 & 666,93 & 328,01 & 485,67 & 244,40 & 431,27 \\
\hline Ca42 & $1.682,50$ & $3.500,87$ & $1.323,84$ & $1.068,94$ & $<900,78$ & $<807,19$ & 824,15 & $<877,65$ & $1.028,89$ \\
\hline Ca44 & $<121,37$ & $<198,86$ & 288,98 & $<99,04$ & 286,43 & $<99,88$ & 93,24 & $<110,36$ & $<110,04$ \\
\hline Sc45 & 124,97 & 115,24 & 110,04 & 106,06 & 153,03 & 169,86 & 183,57 & 197,76 & 141,86 \\
\hline Ti49 & $<2,51$ & $<3,65$ & 7,07 & 1,85 & 13,52 & 7,24 & 17,51 & 7,22 & 2,32 \\
\hline Mn55 & 16,52 & 9,14 & 16,00 & 0,83 & 2,84 & $<0,61$ & 1,47 & $<0,71$ & $<0,69$ \\
\hline Fe56 & $2.015,31$ & 198,56 & $2.115,17$ & 60,37 & 181,62 & 14,97 & 65,37 & 25,84 & 16,65 \\
\hline Co59 & 0,21 & 0,31 & 0,37 & $<0,085$ & 0,35 & $<0,079$ & $<0,072$ & 0,41 & $<0,081$ \\
\hline $\mathrm{Rb} 85$ & 0,63 & $<0,61$ & $<0,44$ & 0,36 & 0,47 & $<0,32$ & 0,60 & 0,56 & $<0,36$ \\
\hline Sr88 & 0,29 & $<0,08$ & 0,21 & 0,25 & 1,79 & 0,26 & 1,38 & 0,17 & 0,30 \\
\hline Y89 & 89,91 & 75,47 & 166,62 & 106,84 & 3367,71 & $3.048,01$ & $4.403,54$ & $2.320,74$ & $1.815,12$ \\
\hline Zr91 & $503.410,34$ & $503.410,31$ & $503.410,34$ & $503.410,28$ & 503410,28 & $503.410,34$ & $503.410,31$ & $503.410,31$ & $503.410,28$ \\
\hline Nb93 & 1,26 & 0,71 & 1,47 & 0,76 & 3,52 & 3,12 & 5,48 & 4,55 & 2,44 \\
\hline Mo95 & 1,00 & 1,77 & 2,06 & 2,05 & 1,9 & 1,61 & 1,88 & 1,66 & 2,06 \\
\hline Sn118 & 2,21 & 2,57 & $<1,00$ & 0,85 & $<0,88$ & $<0,82$ & 0,68 & $<0,83$ & $<0,88$ \\
\hline Sb121 & 0,42 & $<0,44$ & $<0,30$ & $<0,20$ & 0,3 & $<0,194$ & $<0,19$ & $<0,22$ & $<0,24$ \\
\hline Ba137 & 0,77 & $<0,41$ & $<0,52$ & $<0,31$ & 1,07 & $<0,28$ & 0,48 & $<0,291$ & $<0,32$ \\
\hline La139 & 3,97 & 0,99 & 1,33 & 0,18 & 0,183 & $<0,038$ & 0,06 & $<0,046$ & $<0,039$ \\
\hline
\end{tabular}




\begin{tabular}{|cccccccccc} 
Ce140 & 104,94 & 4,60 & 9,35 & 2,24 & 10,51 & 11,10 & 18,37 & 10,26 & 4,42 \\
\hline Pr141 & 6,17 & 1,73 & 1,37 & 0,30 & 0,442 & 0,37 & 0,44 & 0,21 & 0,04 \\
\hline Nd143 & 38,47 & 12,13 & 16,17 & 2,06 & 6,04 & 5,32 & 8,88 & 4,47 & 1,06 \\
Sm147 & 32,98 & 6,09 & 10,93 & 1,39 & 11,89 & 10,96 & 16,33 & 9,21 & 3,68 \\
\hline Eu151 & 4,67 & 2,84 & 6,46 & 0,53 & 4,77 & 4,94 & 6,80 & 3,16 & 1,65 \\
\hline Gd157 & 19,98 & 10,29 & 19,51 & 6,18 & 66,19 & 58,47 & 90,34 & 33,37 & 29,37 \\
\hline Tb159 & 2,26 & 1,93 & 3,57 & 1,69 & 24,24 & 20,51 & 32,58 & 13,11 & 11,48 \\
\hline Dy163 & 10,74 & 9,97 & 20,26 & 10,87 & 268,76 & 250,36 & 374,02 & 155,35 & 146,63 \\
\hline Ho165 & 2,16 & 2,24 & 4,35 & 2,74 & 108,05 & 96,39 & 142,51 & 64,54 & 58,62 \\
\hline Er166 & 5,09 & 5,59 & 14,78 & 6,91 & 484,92 & 454,14 & 653,70 & 335,27 & 280,56 \\
\hline Tm169 & 1,26 & 1,31 & 2,34 & 1,17 & 102,06 & 102,22 & 145,21 & 77,03 & 65,86 \\
\hline Yb173 & 7,23 & 6,15 & 15,93 & 7,15 & 1000,42 & $1.037,02$ & $1.425,76$ & 870,52 & 643,85 \\
\hline Lu175 & 0,93 & 1,45 & 3,31 & 0,88 & 192,69 & 201,95 & 282,46 & 191,30 & 135,48 \\
\hline Hf179 & $11.931,32$ & $12.094,05$ & $12.462,16$ & $11.670,76$ & 8971,63 & $9.356,22$ & $8.937,85$ & $8.470,65$ & $8.806,47$ \\
\hline Ta181 & 1,19 & 0,41 & 0,60 & 0,66 & 1,43 & 1,55 & 1,84 & 1,33 \\
\hline Pb206 & 736,95 & 746,96 & 670,28 & 735,90 & 178,3 & 171,60 & 282,26 & 250,03 & 1,35 \\
\hline Pb207 & 45,58 & 56,24 & 43,01 & 54,66 & 17,8 & 18,07 & 28,43 & 23,89 & 15,70 \\
\hline Pb208 & 1,37 & 1,51 & 1,61 & 2,07 & 17,28 & 15,95 & 33,61 & 21,94 & 6,38 \\
\hline Th232 & 16,98 & 10,69 & 9,21 & 11,36 & 128,92 & 120,05 & 238,87 & 157,76 & 39,32 \\
\hline U238 & $1.413,39$ & $1.481,15$ & $1.388,76$ & $1.460,01$ & 225,35 & 186,78 & 317,29 & 263,44 & 128,96 \\
\hline & & & & & & & & \\
\hline
\end{tabular}

SNA-213: metapsamito (Unidade Serra da Boa Vista - Nappe Andrelândia)

\begin{tabular}{ccccccccccc}
\hline spot: & 7,1 & 6,1 & 19,1 & 20,1 & 15,1 & 14,1 & 13,1 & 22,1 \\
\hline Li7 & $<2,27$ & 12,50 & 4,42 & $<1,65$ & $<1,78$ & 2,74 & 5,20 & 2,66 & $<, 1$ \\
Mg24 & 1,96 & 18,99 & 2,21 & 1,87 & 0,85 & 1,38 & 2,44 & 5,54 & 7,44 & 187,48 \\
Al27 & 24,25 & 158,14 & 61,51 & 41,62 & 34,62 & 29,80 & 700,98 & 114,87 & 187,48 \\
Si29 & $173.022,41$ & $146.035,58$ & $160.220,92$ & $157.080,38$ & 154735,42 & $158.157,09$ & $181.323,75$ & $165.825,75$ & $174.586,48$ \\
P31 & 241,72 & 69,38 & 614,93 & 239,51 & 194,45 & 284,50 & 308,56 & 953,59 & 299,48 \\
Ca42 & 628,89 & $4.090,38$ & $<396,63$ & 408,57 & 513,21 & 628,08 & $<545,03$ & 423,60 & $<395,49$
\end{tabular}




\begin{tabular}{|c|c|c|c|c|c|c|c|c|c|}
\hline Ca44 & $<86,77$ & $<317,24$ & 99,32 & $<62,51$ & $<65,65$ & $<67,29$ & 307,53 & $<71,49$ & $<84,40$ \\
\hline Sc45 & 240,32 & 203,27 & 275,08 & 246,83 & 213,81 & 211,76 & 228,44 & 288,76 & 246,09 \\
\hline Ti49 & 5,76 & 33,12 & 26,00 & 18,96 & 10,61 & 12,77 & 36,11 & 18,12 & 32,27 \\
\hline Mn55 & 3,92 & 25,80 & 8,18 & 10,93 & 1,58 & 8,63 & 25,61 & 18,47 & 53,82 \\
\hline Fe56 & 107,20 & 314,90 & 296,57 & 324,28 & 42,76 & 203,23 & 597,72 & 460,56 & $2.789,07$ \\
\hline Co59 & $<0,077$ & $<0,34$ & $<0,070$ & 0,10 & $<0,050$ & $<0,059$ & $<0,122$ & $<0,055$ & 0,37 \\
\hline Rb85 & 0,19 & 1,16 & 0,40 & 0,38 & $<0,106$ & 0,16 & 0,46 & 0,44 & 0,86 \\
\hline Sr88 & 0,54 & 1,18 & 0,43 & 0,44 & 0,305 & 0,50 & 0,56 & 0,93 & 0,74 \\
\hline Y89 & $1.175,49$ & 567,77 & $1.541,00$ & $1.911,31$ & 547,87 & 837,58 & $1.947,69$ & $2.966,76$ & $1.103,62$ \\
\hline Zr91 & $503.410,28$ & $503.410,34$ & $503.410,31$ & $503.410,28$ & 503410,28 & $503.410,31$ & $503.410,31$ & $503.410,31$ & $503.410,31$ \\
\hline Nb93 & 3,03 & 3,56 & 1,90 & 1,14 & 1,12 & 3,11 & 0,85 & 1,67 & 2,25 \\
\hline Mo95 & 1,27 & $<1,37$ & 1,31 & 1,26 & 1,17 & 0,86 & 1,47 & 0,42 & 1,45 \\
\hline Sn118 & $<0,81$ & 5,70 & $<0,82$ & $<0,59$ & $<0,63$ & $<0,63$ & $<1,15$ & $<0,67$ & 0,80 \\
\hline Sb121 & $<0,25$ & $<0,78$ & $<0,21$ & 0,20 & $<0,164$ & 0,25 & $<0,29$ & $<0,20$ & $<0,26$ \\
\hline Ba137 & $<0,44$ & 2,00 & $<0,50$ & 1,35 & $<0,39$ & $<0,42$ & $<0,45$ & 1,20 & $<0,52$ \\
\hline La139 & 0,30 & 1,36 & 0,41 & 1,26 & 0,097 & 0,43 & 0,83 & 2,17 & 1,12 \\
\hline Ce140 & 13,57 & 7,60 & 5,31 & 7,45 & 36,4 & 15,49 & 13,33 & 18,38 & 19,29 \\
\hline Pr141 & 0,27 & 0,97 & 0,37 & 1,01 & 0,241 & 0,31 & 0,53 & 2,32 & 0,97 \\
\hline $\mathrm{Nd} 143$ & 3,29 & $<2,04$ & 3,20 & 7,84 & 2,42 & 3,08 & 5,86 & 17,99 & 7,97 \\
\hline Sm147 & 5,13 & 2,87 & 6,74 & 12,91 & 3,8 & 3,90 & 10,29 & 18,71 & 9,39 \\
\hline Eu151 & 0,96 & 0,76 & 0,55 & 2,33 & 1,09 & 0,68 & 1,25 & 3,83 & 2,29 \\
\hline Gd157 & 22,74 & 11,41 & 27,87 & 51,67 & 15,71 & 16,88 & 47,26 & 82,92 & 35,72 \\
\hline Tb159 & 8,63 & 4,42 & 10,64 & 17,40 & 4,66 & 6,30 & 16,63 & 29,71 & 11,48 \\
\hline Dy161 & 105,72 & 68,70 & 131,02 & 198,84 & 52,08 & 76,60 & 182,59 & 316,85 & 115,43 \\
\hline Ho165 & 38,27 & 17,44 & 51,14 & 66,89 & 17,36 & 28,49 & 59,20 & 103,57 & 38,14 \\
\hline Er166 & 166,89 & 88,25 & 218,77 & 273,71 & 75,77 & 129,03 & 237,23 & 423,63 & 163,54 \\
\hline Tm169 & 36,15 & 19,12 & 46,96 & 52,35 & 16,38 & 27,71 & 45,46 & 82,05 & 32,31 \\
\hline Yb173 & 324,71 & 202,57 & 447,12 & 477,24 & 171,3 & 274,09 & 349,36 & 755,40 & 296,85 \\
\hline Lu175 & 63,02 & 50,07 & 90,40 & 88,69 & 31,74 & 52,35 & 56,80 & 131,64 & 61,06 \\
\hline Hf179 & $9.962,39$ & $11.763,04$ & $10.923,46$ & $8.244,74$ & 9736,31 & $10.980,24$ & $9.191,07$ & $10.928,93$ & $10.383,96$ \\
\hline
\end{tabular}




\begin{tabular}{|c|c|c|c|c|c|c|c|c|c|}
\hline Ta181 & 1,12 & 3,48 & 1,24 & 0,80 & 0,6 & 1,05 & 0,53 & 1,15 & 2,16 \\
\hline Pb206 & 256,46 & 125,12 & 150,93 & 172,46 & 140,85 & 207,22 & 238,51 & 239,98 & 127,46 \\
\hline Pb207 & 23,21 & 12,99 & 11,22 & 17,04 & 13,75 & 16,98 & 21,18 & 21,25 & 13,34 \\
\hline Pb208 & 18,12 & 2,77 & 5,96 & 7,22 & 13,02 & 5,20 & 30,60 & 17,53 & 11,33 \\
\hline Th232 & 154,59 & 46,90 & 75,26 & 78,56 & 107,24 & 53,28 & 248,54 & 227,62 & 82,87 \\
\hline U238 & 336,14 & 425,73 & 261,94 & 239,24 & 174,01 & 260,27 & 269,07 & 391,14 & 194,17 \\
\hline
\end{tabular}

SNA-213: metapsamito (Unidade Serra da Boa Vista - Nappe Andrelândia) $\rightarrow$ continuação

\begin{tabular}{|c|c|c|c|c|c|c|c|c|c|}
\hline spot: & 25,1 & 26,1 & 39,1 & 40,1 & 34,1 & 29,1 & 54,1 & 16,1 & 62,1 \\
\hline $\mathrm{Li} 7$ & $<1,88$ & $<2,50$ & $<1,27$ & $<1,96$ & 5,47 & 6,66 & 10,50 & 2,61 & 2,70 \\
\hline Mg24 & 1,37 & 74,76 & 3,98 & 2,89 & 9,77 & 4,25 & 12,24 & 8,34 & 1,51 \\
\hline Al27 & 15,27 & $1.207,25$ & 133,21 & 291,75 & 114,36 & 98,68 & 75,46 & 259,28 & 39,35 \\
\hline Si29 & $179.767,73$ & $149.917,44$ & $153.017,83$ & $179.752,33$ & 183856,66 & $177.485,48$ & $161.228,61$ & $164.416,44$ & $181.480,75$ \\
\hline P31 & 448,82 & 322,03 & 165,57 & 306,57 & 374,66 & 840,65 & $1.609,72$ & 911,84 & 92,93 \\
\hline Ca42 & 636,09 & $<438,07$ & $<222,69$ & 581,93 & 1566,01 & $<297,84$ & 547,64 & $<331,40$ & $<242,89$ \\
\hline Ca44 & $<68,01$ & $<91,19$ & 65,58 & $<71,27$ & 200,51 & $<62,25$ & 103,34 & 149,28 & $<52,67$ \\
\hline Sc45 & 242,26 & 259,25 & 270,63 & 210,35 & 254,54 & 396,09 & 389,57 & 420,79 & 250,18 \\
\hline Ti49 & 27,84 & 39,20 & 12,56 & 15,02 & 20,44 & 15,10 & 9,72 & 20,00 & 12,33 \\
\hline Mn55 & 1,02 & 37,37 & 28,29 & 25,01 & 7,64 & 7,07 & 9,26 & 55,06 & 4,62 \\
\hline Fe56 & 60,84 & 988,51 & 233,07 & 445,38 & 224,22 & 105,07 & 283,66 & 418,59 & 37,61 \\
\hline Co59 & $<0,068$ & 0,45 & $<0,045$ & 0,10 & $<0,098$ & $<0,068$ & 0,10 & 0,09 & $<0,050$ \\
\hline $\mathrm{Rb} 85$ & 0,16 & 3,85 & 0,10 & 0,52 & 0,43 & 0,28 & 0,93 & 0,54 & $<0,089$ \\
\hline Sr88 & 0,42 & 1,74 & 0,47 & 0,66 & 1,53 & 0,77 & 0,87 & 2,82 & 0,44 \\
\hline Y89 & $1.252,86$ & $1.174,93$ & 909,46 & $1.346,94$ & 640,97 & $1.883,69$ & $4.112,92$ & $2.616,86$ & 310,67 \\
\hline $\mathrm{Zr91}$ & $503.410,31$ & $503.410,25$ & $503.410,25$ & $503.410,31$ & 503410,25 & $503.410,28$ & $503.410,31$ & $503.410,22$ & $503.410,22$ \\
\hline $\mathrm{Nb93}$ & 3,45 & 21,78 & 1,86 & 2,53 & 1,7 & 3,88 & 0,81 & 4,07 & 0,85 \\
\hline Mo95 & 0,68 & 13,00 & 0,86 & 0,70 & 1,45 & 0,70 & 1,01 & 1,42 & 0,61 \\
\hline Sn118 & 0,67 & $<0,91$ & $<0,44$ & $<0,66$ & $<1,00$ & $<0,63$ & 0,83 & 0,79 & 0,58 \\
\hline Sb121 & $<0,190$ & 0,62 & $<0,129$ & $<0,21$ & $<0,28$ & $<0,18$ & $<0,18$ & $<0,19$ & $<0,126$ \\
\hline
\end{tabular}




\begin{tabular}{|c|c|c|c|c|c|c|c|c|c|}
\hline Ba137 & $<0,45$ & 1,99 & 0,58 & 1,59 & 0,75 & $<0,41$ & 0,43 & 7,82 & 0,47 \\
\hline La139 & 0,21 & 4,49 & 2,85 & 3,40 & 1,2 & 1,24 & 2,78 & 4,12 & 0,51 \\
\hline Ce140 & 54,55 & 38,11 & 18,76 & 26,95 & 43,57 & 32,60 & 8,74 & 77,00 & 5,57 \\
\hline Pr141 & 0,55 & 3,89 & 2,90 & 2,87 & 0,98 & 1,92 & 1,12 & 4,04 & 0,40 \\
\hline Nd143 & 7,09 & 17,75 & 15,90 & 16,87 & 4,12 & 13,26 & 9,87 & 21,04 & 1,87 \\
\hline Sm147 & 10,48 & 20,56 & 12,55 & 14,89 & 8,56 & 12,67 & 10,95 & 24,12 & 3,57 \\
\hline Eu151 & 1,50 & 7,22 & 5,06 & 4,94 & 2,26 & 4,09 & 0,62 & 8,09 & 1,12 \\
\hline Gd157 & 34,03 & 51,13 & 36,23 & 48,84 & 19,95 & 43,27 & 59,81 & 77,51 & 16,35 \\
\hline Tb159 & 11,54 & 17,25 & 12,23 & 17,77 & 6,43 & 15,55 & 27,23 & 30,80 & 5,34 \\
\hline Dy161 & 123,22 & 143,42 & 115,14 & 167,89 & 59,69 & 181,34 & 338,90 & 278,76 & 39,79 \\
\hline Ho165 & 45,11 & 39,32 & 32,60 & 51,31 & 17,53 & 66,21 & 136,52 & 86,03 & 10,05 \\
\hline Er166 & 178,43 & 156,29 & 120,75 & 198,75 & 76,03 & 303,98 & 602,86 & 362,35 & 38,87 \\
\hline Tm169 & 36,88 & 31,95 & 22,49 & 38,73 & 16,77 & 64,86 & 125,86 & 75,32 & 8,41 \\
\hline Yb173 & 341,49 & 299,59 & 202,32 & 336,90 & 161,05 & 605,55 & $1.104,21$ & 734,34 & 80,65 \\
\hline Lu175 & 66,80 & 61,57 & 39,31 & 62,41 & 35,48 & 116,71 & 207,36 & 151,29 & 16,08 \\
\hline Hf179 & $8.792,54$ & $12.021,91$ & $7.034,75$ & $11.468,06$ & 10894,06 & $11.062,89$ & $11.534,68$ & $10.270,18$ & $13.098,87$ \\
\hline Ta181 & 1,01 & 1,22 & 1,13 & 1,10 & 0,79 & 2,24 & 0,66 & 1,42 & 0,56 \\
\hline Pb206 & 51,28 & 190,83 & 62,65 & 122,50 & 507,64 & 498,27 & 305,34 & 579,04 & 169,51 \\
\hline Pb207 & 6,12 & 18,80 & 4,95 & 12,52 & 49,02 & 64,50 & 26,73 & 61,16 & 17,42 \\
\hline Pb208 & 6,85 & 17,90 & 1,80 & 5,79 & 42,18 & 44,22 & 7,26 & 30,08 & 2,54 \\
\hline Th232 & 43,02 & 114,85 & 60,91 & 84,13 & 251,07 & 293,84 & 78,26 & 275,46 & 30,87 \\
\hline U238 & 46,86 & 205,95 & 173,74 & 227,58 & 517,23 & 398,40 & 442,24 & 580,46 & 298,64 \\
\hline
\end{tabular}

SNA-228: metapelito (Unidade Serra da Boa Vista - Nappe Andrelândia)

\begin{tabular}{|c|c|c|c|c|c|c|c|c|c|c|c|c|}
\hline spot: & 12,1 & 13,1 & 9,1 & 16,1 & 15,1 & 21,1 & 20,2 & 35,1 & 31,1 & 39,1 & 47,1 & 1,1 \\
\hline $\mathrm{Li} 7$ & 3,1200 & 5,5400 & 2,0000 & 2,4900 & 1,7600 & $<1,74$ & 11,0800 & 1,9500 & $<1,68$ & $<1,54$ & 6,3800 & $<1,77$ \\
\hline Mg24 & 7,0200 & 24,5100 & 2,9900 & 2,6700 & 3,3600 & 5,4900 & 10,7400 & 5,4600 & 5,2800 & 15,8100 & 35,4300 & 2,8400 \\
\hline $\mathrm{Al} 27$ & 306,4000 & 536,0500 & 46,1400 & 38,9000 & 21,0900 & 75,5200 & 38,4800 & $2.513,1000$ & 21,1700 & 84,4800 & 219,5800 & 13,1600 \\
\hline Si29 & $179.539,0500$ & $171.812,3300$ & $162.028,8600$ & $170.566,2300$ & $166.773,3600$ & $171.547,1400$ & $172.407,1600$ & $173.079,0900$ & $166.779,7500$ & $174.018,6300$ & $157.895,0500$ & $185.259,8600$ \\
\hline
\end{tabular}




\begin{tabular}{|c|c|c|c|c|c|c|c|c|c|c|c|c|}
\hline P31 & 242,2800 & 360,1900 & 273,4800 & 597,3700 & 153,7100 & 442,2800 & 727,9800 & 301,9700 & 390,6600 & 410,9700 & $1.375,2600$ & 862,3600 \\
\hline Ca42 & $1.398,6400$ & $<823,92$ & 746,5200 & $<455,81$ & 354,8400 & $2.019,6100$ & $<375,84$ & 649,9100 & 522,6300 & $<381,54$ & $<537,53$ & $<427,12$ \\
\hline Ca44 & $<78,74$ & $<134,06$ & $<76,72$ & $<74,91$ & $<55,51$ & $<76,16$ & $<59,87$ & $<61,69$ & $<68,96$ & 68,3600 & 163,2600 & 281,1100 \\
\hline Sc45 & 271,0600 & 259,3400 & 249,5800 & 335,6100 & 254,0200 & 243,2400 & 406,4200 & 234,1100 & 290,3600 & 272,4100 & 419,0500 & 215,8300 \\
\hline Ti49 & 20,6000 & 45,2600 & 6,4600 & 19,3300 & 5,4700 & 2,9100 & 16,1800 & 38,6400 & 7,1500 & 32,2000 & 83,9200 & 21,6200 \\
\hline Mn55 & $<0,74$ & $<1,20$ & 1,3400 & $<0,59$ & 0,5900 & $<0,54$ & $<0,41$ & 1,6800 & $<0,43$ & 0,5700 & 3,0600 & 0,7200 \\
\hline Fe56 & $2.016,5300$ & $<12,23$ & 57,2100 & 53,6800 & 46,8000 & 180,3200 & 71,7600 & $1.492,7900$ & 46,1400 & 41,3000 & 507,9800 & 21,7400 \\
\hline Co59 & $<0,047$ & 0,1800 & $<0,047$ & 0,0630 & $<0,046$ & 0,0770 & $<0,050$ & 0,1930 & $<0,054$ & 0,0430 & 0,1800 & $<0,057$ \\
\hline Rb85 & 0,6100 & 0,3700 & $<0,14$ & 0,2900 & 0,1840 & 0,2100 & 0,1600 & 0,2700 & 0,2690 & 0,5800 & 0,8100 & 0,2600 \\
\hline Sr88 & 0,4700 & 0,8500 & 0,5900 & 0,5250 & 0,2960 & 0,6800 & 0,4900 & 0,9490 & 0,5700 & 0,5200 & 2,7200 & 0,4900 \\
\hline Y89 & $1.108,5900$ & 851,9300 & 721,4000 & $1.608,0200$ & 850,0900 & $1.511,2700$ & $1.303,4500$ & 861,6500 & $1.946,1300$ & $1.155,0500$ & $3.816,3800$ & $2.232,8600$ \\
\hline Zr91 & $503.410,1600$ & $503.410,1600$ & $503.410,1300$ & $503.410,1600$ & $503.410,1300$ & $503.410,0900$ & $503.410,1600$ & $503.410,1300$ & $503.410,1900$ & $503.410,1900$ & $503.410,2200$ & $503.410,1900$ \\
\hline Nb93 & 1,9300 & 23,3100 & 2,1800 & 4,6900 & 1,9100 & 7,1700 & 1,5800 & 12,4100 & 2,0900 & 1,2500 & 5,7700 & 2,2500 \\
\hline Mo95 & 4,1300 & 24,8900 & 4,0800 & 5,8900 & 4,1100 & 3,1100 & 2,5700 & 4,1600 & 2,5500 & 5,0600 & 1,9700 & 2,1300 \\
\hline Sn118 & $<0,67$ & $<1,30$ & 1,3600 & $<0,71$ & $<0,55$ & $<0,74$ & $<0,61$ & $<0,61$ & $<0,72$ & $<0,63$ & $<0,90$ & $<0,74$ \\
\hline Sb121 & $<0,25$ & $<0,41$ & $<0,23$ & $<0,23$ & $<0,168$ & $<0,24$ & $<0,20$ & $<0,20$ & $<0,20$ & $<0,19$ & $<0,25$ & $<0,22$ \\
\hline Ba137 & $<0,41$ & $<0,58$ & $<0,37$ & $<0,34$ & $<0,23$ & 0,9600 & $<0,306$ & 0,9000 & $<0,40$ & 1,0600 & 6,4000 & $<0,36$ \\
\hline La139 & 0,7800 & 2,5500 & 0,6300 & 0,1990 & $<0,040$ & 0,1190 & $<0,038$ & 0,3690 & 0,0830 & 0,0880 & 3,2500 & 0,5500 \\
\hline Ce140 & 21,6000 & 19,7700 & 14,6500 & 3,7100 & 19,9200 & 36,2600 & 0,7800 & 16,3700 & 20,6400 & 3,1600 & 12,6800 & 8,0600 \\
\hline Pr141 & 0,5600 & 1,8300 & 0,5400 & 0,1030 & 0,1960 & 0,1700 & 0,0570 & 0,2980 & 0,4080 & 0,1680 & 1,1300 & 0,9500 \\
\hline $\mathrm{Nd} 143$ & 2,0600 & 8,6200 & 2,8900 & 2,4600 & 2,7300 & 2,7300 & 0,9200 & 2,2500 & 6,0100 & 1,9500 & 7,9900 & 11,5300 \\
\hline Sm147 & 4,2000 & 3,9300 & 5,1900 & 5,7000 & 6,5900 & 4,3800 & 3,7500 & 4,8800 & 10,8000 & 6,8200 & 11,4800 & 16,6600 \\
\hline Eu151 & 1,7500 & 0,4400 & 1,3200 & 0,7900 & 1,1200 & 0,6000 & 0,0760 & 0,4740 & 3,8700 & 0,3700 & 2,9400 & 2,4100 \\
\hline Gd157 & 18,2100 & 18,5500 & 16,8700 & 34,5600 & 25,9500 & 23,1400 & 21,5900 & 22,1100 & 47,6300 & 23,7700 & 75,0600 & 69,9400 \\
\hline Tb159 & 7,2900 & 7,1400 & 7,0600 & 12,5200 & 8,4800 & 9,3600 & 10,2600 & 7,3400 & 15,7400 & 8,2500 & 32,4600 & 21,7900 \\
\hline Dy 161 & 80,3400 & 79,8500 & 78,0100 & 148,8900 & 84,9100 & 113,9700 & 130,2700 & 81,8800 & 178,4800 & 106,0500 & 369,5900 & 231,4700 \\
\hline Ho165 & 35,7600 & 31,3400 & 23,5500 & 54,5500 & 29,9800 & 48,8600 & 43,4800 & 29,6600 & 68,7800 & 39,3100 & 132,8500 & 81,3100 \\
\hline Er166 & 163,2400 & 131,3800 & 101,0200 & 241,3000 & 125,1700 & 238,4000 & 180,7300 & 128,5400 & 293,7400 & 167,0300 & 564,5900 & 325,1200 \\
\hline Tm169 & 38,0100 & 27,1700 & 22,8800 & 50,1500 & 24,8000 & 57,0000 & 35,7800 & 24,7300 & 61,8500 & 36,6300 & 110,1500 & 64,3300 \\
\hline Yb173 & 384,6500 & 264,9600 & 202,1200 & 492,2700 & 227,3100 & 589,6400 & 341,4500 & 246,8400 & 566,7100 & 316,1200 & $1.020,0500$ & 562,1600 \\
\hline
\end{tabular}




\begin{tabular}{|c|c|c|c|c|c|c|c|c|c|c|c|c|}
\hline Lu175 & 80,4500 & 50,7900 & 36,5000 & 90,7000 & 41,6000 & 115,1000 & 61,4500 & 45,4100 & 111,5000 & 56,2800 & 188,6700 & 96,7500 \\
\hline Hf179 & $10.758,1900$ & $11.833,8100$ & $10.648,0800$ & $10.868,5000$ & $10.887,7100$ & $12.381,2100$ & $12.056,9000$ & $10.777,3500$ & $9.145,0300$ & $10.521,6000$ & $12.855,8600$ & $9.094,1000$ \\
\hline Ta181 & 1,3800 & 2,8700 & 1,3200 & 1,3500 & 1,1500 & 3,4500 & 1,0100 & 4,0300 & 1,0600 & 0,8100 & 2,1900 & 1,5800 \\
\hline Pb206 & 200,8800 & 309,3900 & 198,1300 & 279,6500 & 222,0600 & 294,7300 & 253,4300 & 121,2700 & 139,7200 & 104,6700 & 460,5200 & 237,1500 \\
\hline $\mathrm{Pb} 207$ & 13,6400 & 27,2200 & 17,4900 & 21,2900 & 20,2200 & 29,9700 & 22,6400 & 12,5500 & 16,1300 & 9,5000 & 40,4300 & 24,6300 \\
\hline Pb208 & 15,1600 & 10,1100 & 12,0700 & 14,1000 & 16,7200 & 9,9600 & 4,2500 & 9,6100 & 15,6700 & 8,1400 & 14,9400 & 14,2900 \\
\hline Th232 & 123,1600 & 73,1100 & 110,8400 & 140,1500 & 153,2000 & 87,0600 & 41,8900 & 62,5900 & 88,9200 & 76,1100 & 133,8900 & 99,3600 \\
\hline U238 & 282,0100 & 405,8700 & 286,4100 & 487,7000 & 288,8100 & 360,7500 & 416,8600 & 157,7200 & 127,0700 & 153,9300 & 619,9600 & 228,3900 \\
\hline
\end{tabular}

NESG-1010: metawackes (Unidade Santo Antônio - Nappe Andrelândia)

\begin{tabular}{|c|c|c|c|c|c|c|c|c|c|c|c|c|c|}
\hline spot: & 26,3 & 18,1 & 22,2 & 34,2 & 29,2 & 54,1 & 79,1 & 57,1 & 55,1 & 88,1 & 65,2 & 9,1 & 20,1 \\
\hline Li7 & $<1,69$ & 2,63 & 1,48 & 9,27 & 2,81 & 5,71 & 2,46 & 8,22 & 1,79 & 2,26 & $<2,31$ & $<1,35$ & 3,80 \\
\hline Mg24 & 14,40 & 2,91 & 2,00 & 1,80 & 1,34 & 1,10 & 2,83 & 8,13 & 2,72 & 23,44 & 379,84 & 2,30 & 12,28 \\
\hline Al27 & 48,71 & 6,10 & 35,83 & 9,31 & 2,48 & 3,08 & 16,63 & 56,66 & 27,71 & 95,87 & $2.284,52$ & 3,06 & 10,31 \\
\hline $\mathrm{Si} 29$ & $184.705,30$ & $171.201,08$ & $160.907,30$ & $163.254,27$ & $156.118,48$ & $159.196,44$ & $156.082,81$ & $168.073,61$ & $172.258,08$ & $169.796,52$ & $190.033,00$ & $171.921,81$ & $172.607,38$ \\
\hline P31 & 380,89 & 102,79 & 191,25 & 239,92 & 97,08 & 76,67 & 416,42 & 642,52 & 319,62 & 367,76 & 164,91 & 290,06 & 192,23 \\
\hline Ca42 & $<325,44$ & $<244,33$ & 441,82 & $<226,98$ & $<276,27$ & $<274,66$ & 566,08 & $<296,08$ & $<286,70$ & $<292,83$ & $1.483,55$ & $<245,71$ & $<350,16$ \\
\hline Ca44 & $<62,64$ & 68,92 & $<52,55$ & $<44,31$ & $<54,71$ & $<54,10$ & 171,24 & 123,54 & 86,49 & $<57,16$ & 695,58 & 65,09 & 94,85 \\
\hline Sc45 & 230,96 & 261,50 & 222,95 & 237,01 & 207,84 & 206,23 & 281,50 & 274,92 & 259,55 & 342,88 & 308,26 & 320,77 & 237,44 \\
\hline Ti49 & 11,25 & 15,14 & 6,23 & 17,48 & 18,09 & 93,55 & 3,77 & 12,50 & 23,51 & 12,78 & 79,59 & 20,06 & 9,94 \\
\hline Mn55 & 2,28 & $<0,25$ & 0,30 & 0,71 & $<0,28$ & $<0,29$ & 1,22 & 2,69 & 0,31 & 1,73 & 13,29 & $<0,25$ & $<0,39$ \\
\hline Fe56 & 210,16 & 42,45 & 42,19 & 41,33 & 16,52 & 15,08 & 53,11 & 28,53 & 22,97 & 169,33 & 957,89 & $<3,41$ & 18,07 \\
\hline Co59 & 0,06 & $<0,047$ & 0,20 & 0,06 & $<0,060$ & $<0,051$ & $<0,047$ & $<0,069$ & $<0,054$ & $<0,046$ & 0,32 & $<0,043$ & $<0,051$ \\
\hline Rb85 & 0,45 & $<0,091$ & 0,40 & 0,10 & $<0,095$ & $<0,086$ & 0,29 & 0,18 & 0,22 & 0,37 & 1,93 & 0,20 & 0,19 \\
\hline Sr88 & 0,52 & 0,47 & 0,44 & 0,23 & 0,17 & 0,68 & 0,57 & 0,79 & 0,40 & 0,60 & 5,68 & 0,33 & 0,58 \\
\hline Y89 & $2.825,28$ & 683,02 & 826,20 & 673,66 & 211,44 & 48,47 & $1.633,06$ & $1.653,54$ & 878,35 & $1.148,04$ & 806,29 & 704,82 & 684,31 \\
\hline Zr91 & $503.410,19$ & $503.410,22$ & $503.410,19$ & $503.410,19$ & $503.410,22$ & $503.410,16$ & $503.410,16$ & $503.410,13$ & $503.410,16$ & $503.410,13$ & $503.410,13$ & $503.410,13$ & $503.410,13$ \\
\hline Nb93 & 3,35 & 1,65 & 4,30 & 1,14 & 0,30 & 0,23 & 3,17 & 3,27 & 3,19 & 2,53 & 2,46 & $1.097,00$ & 1,47 \\
\hline Mo95 & 1,62 & 0,77 & 1,44 & 1,27 & 1,08 & 0,68 & 1,10 & 0,81 & 0,85 & 0,31 & 1,29 & 1,02 & 0,94 \\
\hline
\end{tabular}




\begin{tabular}{|c|c|c|c|c|c|c|c|c|c|c|c|c|c|}
\hline Sn118 & 1,38 & 0,71 & $<0,54$ & $<0,46$ & $<0,60$ & $<0,55$ & $<0,53$ & $<0,66$ & 0,84 & $<0,62$ & $<0,84$ & $<0,53$ & $<0,77$ \\
\hline Sb121 & $<0,18$ & $<0,13$ & $<0,14$ & $<0,113$ & $<0,151$ & $<0,15$ & $<0,18$ & $<0,18$ & $<0,14$ & $<0,16$ & $<0,24$ & $<0,137$ & $<0,19$ \\
\hline Ba137 & $<0,34$ & $<0,27$ & $<0,35$ & $<0,23$ & $<0,36$ & $<0,30$ & $<0,37$ & 0,66 & $<0,32$ & 0,54 & 12,77 & $<0,34$ & 0,46 \\
\hline La139 & 12,23 & $<0,037$ & 5,10 & 0,07 & 0,06 & $<0,062$ & 0,10 & 1,89 & 0,32 & 5,71 & 4,15 & 0,12 & $<0,058$ \\
\hline Ce140 & 45,94 & 10,57 & 41,39 & 24,94 & 4,47 & 0,84 & 21,62 & 28,78 & 47,35 & 13,53 & 31,06 & 3,00 & 12,47 \\
\hline Pr141 & 6,91 & 0,22 & 1,87 & 0,23 & $<0,033$ & $<0,029$ & 0,14 & 1,76 & 0,12 & 2,79 & 1,16 & 0,17 & 0,05 \\
\hline $\mathrm{Nd} 143$ & 31,64 & 2,05 & 13,18 & 1,98 & $<0,32$ & 0,50 & 1,79 & 22,42 & 1,82 & 14,93 & 3,86 & 0,43 & 0,97 \\
\hline Sm147 & 25,83 & 2,43 & 7,21 & 4,56 & 0,76 & $<0,24$ & 4,57 & 15,27 & 3,83 & 7,29 & 4,64 & 1,30 & 2,75 \\
\hline Eu151 & 2,99 & $<0,065$ & 1,88 & 1,38 & 0,21 & $<0,087$ & 0,83 & 2,21 & 0,89 & 1,50 & 1,20 & 0,16 & 0,40 \\
\hline Gd157 & 82,94 & 13,81 & 22,03 & 18,81 & 2,80 & $<0,23$ & 25,30 & 57,93 & 16,36 & 34,07 & 17,39 & 11,55 & 10,56 \\
\hline Tb159 & 26,48 & 4,38 & 7,22 & 5,80 & 1,05 & 0,16 & 9,69 & 17,33 & 5,86 & 10,13 & 4,55 & 4,98 & 5,01 \\
\hline Dy161 & 262,60 & 56,14 & 75,48 & 58,39 & 14,34 & 1,46 & 127,26 & 158,95 & 71,04 & 116,67 & 49,12 & 60,57 & 55,00 \\
\hline Ho165 & 90,05 & 21,12 & 25,81 & 21,09 & 6,62 & 1,29 & 53,48 & 54,50 & 28,91 & 40,49 & 20,45 & 24,26 & 22,93 \\
\hline Er166 & 365,06 & 107,52 & 117,99 & 91,88 & 31,13 & 6,40 & 260,27 & 237,00 & 133,82 & 178,20 & 105,40 & 116,53 & 105,14 \\
\hline Tm169 & 71,26 & 23,10 & 25,42 & 20,47 & 7,68 & 1,93 & 56,64 & 49,36 & 29,50 & 37,38 & 24,93 & 24,23 & 23,28 \\
\hline Yb173 & 661,23 & 257,77 & 246,41 & 202,35 & 86,23 & 27,10 & 598,52 & 473,85 & 292,16 & 344,98 & 291,27 & 244,78 & 241,45 \\
\hline Lu175 & 116,85 & 59,93 & 47,82 & 40,89 & 18,31 & 8,77 & 121,61 & 84,43 & 60,15 & 64,37 & 69,88 & 48,65 & 44,77 \\
\hline Hf179 & $9.881,30$ & $11.118,46$ & $10.336,61$ & $9.214,87$ & $9.968,86$ & $9.110,20$ & $10.542,04$ & $9.786,46$ & $10.205,98$ & $10.698,50$ & $9.242,74$ & $10.533,88$ & $11.918,04$ \\
\hline Ta181 & 1,54 & 1,00 & 1,17 & 0,78 & 0,24 & 0,20 & 0,88 & 1,39 & 1,14 & 0,89 & 0,78 & 0,50 & 0,94 \\
\hline Pb206 & 321,28 & 102,62 & 81,49 & 282,32 & 69,44 & 31,60 & 69,27 & 278,53 & 107,18 & 133,67 & 83,05 & 50,12 & 159,50 \\
\hline Pb207 & 24,99 & 8,27 & 4,74 & 20,76 & 4,92 & 2,23 & 5,22 & 20,92 & 7,41 & 11,23 & 6,50 & 4,71 & 14,49 \\
\hline Pb208 & 63,54 & 6,01 & 9,30 & 22,53 & 2,30 & 0,30 & 6,55 & 5,77 & 13,70 & 8,91 & 7,80 & 2,88 & 14,95 \\
\hline Th232 & 962,08 & 84,83 & 167,83 & 347,36 & 31,82 & 3,00 & 102,58 & 94,20 & 213,56 & 115,95 & 129,31 & 40,97 & 164,11 \\
\hline U238 & 689,66 & 529,69 & 205,09 & 624,88 & 125,19 & 71,10 & 192,62 & 635,88 & 261,93 & 243,44 & 205,05 & 109,03 & 308,54 \\
\hline
\end{tabular}

NESG-1552: anfibolito (Unidade Santo Antônio - Nappe Andrelândia)

\begin{tabular}{cccccccccccccc}
\hline spot: & 4,1 & 1,1 & 39,1 & 29,1 & 31,1 & 34,1 & 33,1 & 25,1 & 5,1 & 9,1 & 24,1 & 37,1 & 27,1 \\
\hline Li7 & $<0,00151$ & 3,36 & 2,92 & 13,43 & $<2,29$ & 13,35 & 95,05 & $<1,68$ & 1,92 & 2,20 & 3,91 & $<1,69$ & 2,91 \\
Mg24 & 0,00 & 25,38 & 73,55 & 20,98 & 19,54 & 20,91 & 141,20 & 101,13 & 11,95 & 7,32 & 4,93 & 45,94 & 19,37
\end{tabular}




\begin{tabular}{|c|c|c|c|c|c|c|c|c|c|c|c|c|c|}
\hline Al27 & 0,01 & $1.769,17$ & 316,48 & 692,12 & 997,34 & 353,32 & $1.429,02$ & $3.387,54$ & 166,66 & 135,51 & 79,51 & 90,18 & 108,82 \\
\hline Si29 & 151,61 & $169.328,34$ & $159.202,02$ & $160.500,16$ & $152.823,78$ & $175.708,39$ & $115.359,90$ & $168.514,20$ & $170.800,09$ & $197.572,73$ & $164.496,94$ & $172.269,19$ & $149.584,41$ \\
\hline P31 & 0,24 & 283,13 & 205,00 & 757,38 & 874,37 & 962,90 & 381,93 & 92,15 & 340,28 & 328,81 & 182,58 & 187,33 & 226,33 \\
\hline Ca42 & 0,81 & $<429,06$ & 561,48 & $<1050,20$ & $<435,82$ & $1.886,03$ & $<8695,13$ & 616,03 & 977,95 & $<263,66$ & $<235,23$ & $<306,75$ & 610,15 \\
\hline Ca44 & $<0,055$ & $<80,31$ & 116,14 & 343,64 & 117,46 & 207,12 & $<1660,91$ & $<59,08$ & 77,82 & 89,88 & $<46,02$ & $<58,72$ & $<52,76$ \\
\hline Sc45 & 0,28 & 268,18 & 249,16 & 378,36 & 302,99 & 402,75 & 124,20 & 348,61 & 240,13 & 344,18 & 281,63 & 240,66 & 244,78 \\
\hline Ti49 & 0,01 & 56,39 & 37,00 & 84,08 & 68,19 & 52,62 & $<24,02$ & 61,19 & 23,78 & 99,04 & 13,05 & 28,14 & 22,44 \\
\hline Mn55 & 0,00 & 6,51 & 2,89 & 7,27 & 10,31 & 13,25 & 15,19 & 4,05 & 3,02 & $<0,27$ & 0,65 & 0,42 & 0,50 \\
\hline Fe56 & 0,02 & $2.064,06$ & 537,56 & 952,62 & $1.207,43$ & 839,35 & 869,14 & 710,77 & 219,64 & 977,81 & 84,56 & 117,37 & 235,34 \\
\hline Co59 & $<0,00006$ & 0,55 & 0,18 & 0,36 & 0,46 & $<0,113$ & 3,08 & 0,42 & 0,16 & 0,17 & $<0,044$ & $<0,066$ & 0,18 \\
\hline $\mathrm{Rb} 85$ & 0,00 & 0,66 & 1,29 & 0,82 & 1,28 & 0,53 & $<3,09$ & 3,90 & 0,51 & 0,40 & 0,28 & 0,19 & 0,33 \\
\hline Sr88 & 0,00 & 0,74 & 0,19 & 0,89 & 0,43 & 1,10 & $<1,09$ & 2,07 & 0,83 & 0,44 & 0,37 & 0,33 & 0,34 \\
\hline Y89 & $1.600,00$ & $1.196,55$ & 847,43 & $1.982,46$ & $2.226,30$ & $2.617,55$ & 522,62 & 313,11 & $2.702,02$ & $1.162,06$ & 902,06 & 512,34 & 844,34 \\
\hline $\mathrm{Zr} 91$ & 439,90 & $503.410,19$ & $503.410,22$ & $503.410,19$ & $503.410,19$ & $503.410,22$ & $503.410,19$ & $503.410,19$ & $503.410,22$ & $503.410,19$ & $503.410,19$ & $503.410,22$ & $503.410,16$ \\
\hline Nb93 & 0,01 & 3,00 & 1,83 & 1,69 & 1,05 & 3,48 & 5,20 & 0,83 & 0,83 & 3,04 & 2,74 & 1,27 & 1,94 \\
\hline Mo95 & 0,00 & 1,36 & 2,00 & 1,55 & $<0,24$ & 2,03 & 8,74 & 0,29 & 1,21 & 1,44 & 1,27 & 0,74 & 1,04 \\
\hline Sn118 & 0,00 & 1,01 & $<0,66$ & $<1,97$ & $<0,81$ & 2,69 & 49,83 & 1,10 & 2,78 & $<0,54$ & $<0,49$ & 1,22 & 1,13 \\
\hline Sb121 & $<0,00016$ & $<0,24$ & $<0,18$ & $<0,53$ & $<0,236$ & 0,64 & $<4,98$ & 0,21 & $<0,19$ & $<0,14$ & $<0,137$ & 0,16 & $<0,169$ \\
\hline Ba137 & 0,00 & 3,79 & 4,47 & 2,41 & $<0,56$ & 1,67 & $<9,51$ & 21,60 & 0,81 & 1,42 & $<0,30$ & 1,44 & 0,60 \\
\hline La139 & $<0,00005$ & 1,03 & 1,02 & 1,36 & 0,58 & 8,73 & $<1,42$ & 0,20 & 0,42 & 1,47 & $<0,040$ & 0,27 & 0,06 \\
\hline Ce140 & 0,07 & 51,32 & 56,53 & 9,44 & 3,77 & 61,98 & 20,54 & 2,85 & 14,27 & 35,43 & 6,49 & 33,94 & 12,56 \\
\hline Pr141 & 0,00 & 0,51 & 1,67 & 1,47 & 0,44 & 8,79 & $<0,94$ & 0,23 & 0,77 & 1,13 & 0,04 & 0,21 & 0,09 \\
\hline $\mathrm{Nd} 143$ & 0,00 & 3,41 & 6,08 & 9,13 & 2,21 & 41,68 & $<8,25$ & 1,45 & 10,00 & 3,14 & 1,23 & 2,45 & 1,37 \\
\hline Sm147 & 0,01 & 6,72 & 11,35 & 10,11 & 2,62 & 28,24 & 16,36 & 1,25 & 14,60 & 4,38 & 1,77 & 5,30 & 3,32 \\
\hline Eu151 & 0,00 & 3,09 & 4,07 & 1,24 & $<0,13$ & 10,55 & 4,78 & 0,83 & 3,43 & 2,38 & 0,52 & 1,56 & 0,27 \\
\hline Gd157 & 0,03 & 22,84 & 23,81 & 30,76 & 32,97 & 79,43 & 59,62 & 4,89 & 65,77 & 25,99 & 12,65 & 15,14 & 13,80 \\
\hline Tb159 & 0,01 & 8,63 & 8,98 & 13,27 & 13,29 & 24,87 & 6,27 & 1,25 & 21,99 & 8,52 & 5,41 & 4,79 & 5,33 \\
\hline Dy161 & 0,13 & 100,07 & 73,35 & 170,00 & 172,05 & 254,46 & 56,92 & 16,61 & 262,20 & 103,46 & 76,05 & 48,52 & 66,89 \\
\hline Ho165 & 0,05 & 37,82 & 27,89 & 67,65 & 71,62 & 89,65 & 14,36 & 8,16 & 98,51 & 37,64 & 30,54 & 17,86 & 27,74 \\
\hline Er166 & 0,25 & 183,07 & 135,21 & 314,84 & 317,56 & 397,51 & 55,50 & 47,73 & 420,69 & 179,08 & 148,73 & 73,39 & 124,81 \\
\hline
\end{tabular}




\begin{tabular}{|c|c|c|c|c|c|c|c|c|c|c|c|c|c|}
\hline Tm169 & 0,05 & 39,87 & 32,61 & 65,70 & 66,30 & 85,22 & 30,44 & 15,68 & 84,25 & 42,51 & 33,05 & 16,19 & 27,37 \\
\hline Yb173 & 0,54 & 427,47 & 340,28 & 606,60 & 628,95 & 831,93 & 304,22 & 239,19 & 752,84 & 448,78 & 337,92 & 159,72 & 267,80 \\
\hline Lu175 & 0,10 & 85,52 & 71,91 & 121,94 & 121,97 & 159,90 & 55,30 & 70,51 & 136,89 & 93,90 & 67,95 & 31,93 & 53,80 \\
\hline Hf179 & 7,82 & $10.726,94$ & $12.484,97$ & $12.254,13$ & $11.682,85$ & $13.176,36$ & $5.562,72$ & $11.727,71$ & $11.152,89$ & $10.548,80$ & $9.453,73$ & $10.522,35$ & $9.728,48$ \\
\hline Ta181 & 0,00 & 1,03 & 1,07 & 1,37 & 1,08 & 4,48 & $<1,21$ & 0,36 & 0,63 & 1,56 & $1.023,00$ & 0,60 & 0,67 \\
\hline Pb206 & 0,08 & 116,30 & 122,19 & 141,15 & 118,79 & 499,42 & 10,38 & 52,30 & 182,28 & 240,91 & 358,98 & 133,54 & 87,77 \\
\hline Pb207 & 0,01 & 8,38 & 9,18 & 10,16 & 11,95 & 35,12 & 8,16 & 4,37 & 16,04 & 20,69 & 50,39 & 12,80 & 7,59 \\
\hline Pb208 & 0,01 & 13,90 & 7,73 & 6,02 & 5,32 & 20,28 & 3,25 & 3,42 & 19,43 & 30,56 & 10,79 & 13,59 & 5,33 \\
\hline Th232 & 0,16 & 154,63 & 77,67 & 80,73 & 68,21 & 288,03 & 35,43 & 27,43 & 189,12 & 278,11 & 54,71 & 101,94 & 49,94 \\
\hline U238 & 0,20 & 263,80 & 232,69 & 302,23 & 284,25 & 980,43 & 94,61 & 148,72 & 279,06 & 325,80 & 266,37 & 160,69 & 122,38 \\
\hline
\end{tabular}


ANEXO VII

Geoquímica elemental em granada

(Elementos traço e terras raras por LA-ICP-MS) 
Granada B1 da amostra SNA-205B (anfibolito retroeclogítico - Nappe Andrelândia)

\begin{tabular}{|c|c|c|c|c|c|c|c|c|c|c|c|c|}
\hline spot: & Grt-1 & Grt-2 & Grt-3 & Grt-4 & Grt-5 & Grt-6 & Grt-7 & Grt-8 & Grt-9 & Grt-10 & Grt-11 & Grt-12 \\
\hline & \multicolumn{12}{|c|}{ RASTER } \\
\hline $\mathrm{Li7}$ & 6,97 & 7,40 & 8,07 & 8,18 & 5,13 & 11,98 & 11,28 & 7,08 & 8,00 & 15,55 & 9,97 & 3,53 \\
\hline $\mathrm{Na} 23$ & 119,65 & 122,75 & 146,70 & 151,80 & 43,66 & 229,34 & 222,03 & 62,16 & 64,94 & 185,21 & 128,20 & 26,34 \\
\hline Mg25 & 17513,45 & 18416,29 & 15081,35 & 22909,59 & 22365,89 & 21226,49 & 18563,84 & 25683,10 & 29272,27 & 21241,60 & 27466,26 & 16255,84 \\
\hline Al27 & 115664,78 & 128111,00 & 122655,31 & 141778,08 & 114613,84 & 111681,69 & 101942,43 & 113407,70 & 111574,87 & 98551,45 & 113670,19 & 86471,48 \\
\hline Si29 & 176879,05 & 176879,05 & 177813,92 & 177954,16 & 179777,17 & 176551,83 & 175523,47 & 177533,45 & 177439,95 & 178141,13 & 178047,64 & 177860,64 \\
\hline P31 & $<22,25$ & $<26,53$ & $<25,06$ & 43,22 & $<26,25$ & $<24,03$ & $<23,37$ & $<24,78$ & $<29,16$ & $<25,44$ & $<26,77$ & $<19,93$ \\
\hline Ca42 & 74210,07 & 82389,21 & 68702,91 & 68102,41 & 67569,50 & 63971,75 & 68139,73 & 60103,36 & 68354,57 & 57627,05 & 65428,97 & 50853,14 \\
\hline Sc45 & 89,35 & 80,14 & 66,57 & 54,51 & 66,66 & 41,69 & 39,45 & 53,40 & 59,47 & 26,81 & 33,66 & 39,16 \\
\hline Ti49 & 396,96 & 454,90 & 516,41 & 458,91 & 209,83 & 1009,32 & 1140,25 & 264,50 & 265,90 & 1057,24 & 582,74 & 184,05 \\
\hline V51 & 240,28 & 315,87 & 220,11 & 197,80 & 174,86 & 194,97 & 187,91 & 182,53 & 184,44 & 259,13 & 243,85 & 121,88 \\
\hline Cr52 & 270,74 & 329,72 & 294,12 & 246,63 & 173,47 & 317,43 & 249,69 & 284,07 & 419,51 & 178,69 & 139,88 & 38,49 \\
\hline $\mathrm{Fe} 54$ & 130002,78 & 155932,14 & 179602,44 & 134322,31 & 163693,80 & 156142,88 & 118511,58 & 145815,88 & 179883,95 & 153704,67 & 161477,17 & 95809,11 \\
\hline Mn55 & 1406,01 & 2131,51 & 2813,56 & 5898,58 & 5925,12 & 10726,92 & 10187,80 & 5362,68 & 5692,28 & 14536,10 & 8829,03 & 4190,58 \\
\hline Fe57 & 166762,88 & 210854,45 & 220181,97 & 190254,97 & 210153,56 & 191883,34 & 154064,70 & 195282,69 & 233106,81 & 205055,44 & 226687,39 & 125674,90 \\
\hline Co59 & 29,80 & 33,09 & 27,36 & 28,13 & 31,34 & 36,43 & 35,61 & 38,11 & 54,20 & 52,43 & 33,30 & 26,14 \\
\hline $\mathrm{Ni62}$ & $<2,00$ & $<1,91$ & $<1,86$ & 1,43 & $<2,17$ & $<1,32$ & $<2,96$ & 2,22 & $<2,75$ & 1,85 & $<2,40$ & 1,65 \\
\hline Zn66 & 39,97 & 41,87 & 38,70 & 55,79 & 44,96 & 59,69 & 56,79 & 40,41 & 62,77 & 46,85 & 44,75 & 20,56 \\
\hline Rb85 & $<0,060$ & $<0,066$ & 0,08 & $<0,061$ & $<0,080$ & $<0,081$ & $<0,068$ & $<0,056$ & $<0,101$ & 0,06 & $<0,063$ & $<0,056$ \\
\hline Sr88 & $<0,028$ & 0,02 & 0,02 & 0,04 & 0,10 & $<0,0222$ & 0,69 & $<0,027$ & $<0,033$ & $<0,026$ & $<0,023$ & 0,03 \\
\hline Y89 & 56,89 & 57,97 & 39,84 & 22,38 & 120,17 & 14,34 & 20,49 & 65,65 & 136,97 & 29,76 & 45,86 & 39,96 \\
\hline Zr90 & 1,48 & 1,59 & 2,12 & 1,21 & 0,63 & 2,64 & 3,40 & 0,71 & 0,97 & 2,16 & 1,90 & 0,50 \\
\hline Nb93 & 0,01 & $<0,030$ & $<0,029$ & $<0,029$ & $<0,022$ & $<0,023$ & 0,05 & $<0,028$ & $<0,040$ & $<0,0226$ & $<0,0298$ & $<0,0127$ \\
\hline Cs133 & $<0,0154$ & $<0,034$ & $<0,033$ & $<0,028$ & $<0,0261$ & $<0,025$ & $<0,027$ & $<0,034$ & $<0,036$ & $<0,0264$ & $<0,022$ & $<0,025$ \\
\hline Ba137 & $<0,159$ & $<0,21$ & 0,18 & $<0,15$ & $<0,138$ & $<0,145$ & 4,44 & $<0,199$ & $<0,172$ & $<0,170$ & $<0,149$ & $<0,156$ \\
\hline La139 & $<0,0117$ & $<0,019$ & $<0,0188$ & 0,02 & $<0,025$ & $<0,0133$ & 0,16 & 0,06 & $<0,028$ & 0,04 & $<0,0138$ & $<0,0102$ \\
\hline Ce140 & $<0,0235$ & 0,03 & $<0,0188$ & 0,02 & 0,05 & $<0,0264$ & 0,19 & 0,08 & $<0,022$ & 0,08 & $<0,027$ & $<0,0143$ \\
\hline
\end{tabular}




\begin{tabular}{|c|c|c|c|c|c|c|c|c|c|c|c|c|}
\hline Pr141 & $<0,0100$ & 0,01 & $<0,0113$ & $<0,0162$ & $<0,0151$ & $<0,0112$ & 0,03 & 0,03 & $<0,019$ & $<0,0107$ & $<0,026$ & $<0,0120$ \\
\hline $\mathrm{Nd} 146$ & $<0,060$ & $<0,156$ & $<0,166$ & $<0,069$ & $<0,091$ & 0,11 & 0,33 & 0,22 & 0,27 & 0,06 & $<0,070$ & 0,08 \\
\hline Sm149 & 0,19 & 0,32 & $<0,141$ & 0,12 & 1,46 & $<0,082$ & 0,11 & 1,22 & 1,22 & $<0,114$ & $<0,123$ & $<0,129$ \\
\hline Eu151 & 0,28 & 0,16 & 0,08 & 0,09 & 1,35 & $<0,041$ & $<0,038$ & 1,08 & 2,08 & $<0,040$ & 0,07 & 0,23 \\
\hline Gd157 & 3,01 & 1,52 & 1,62 & 0,39 & 11,58 & 0,17 & 0,36 & 9,31 & 16,72 & 0,27 & 1,52 & 2,54 \\
\hline Tb159 & 1174,00 & 0,58 & 0,68 & 0,28 & 3,39 & 0,13 & 0,17 & 2,57 & 5,31 & 0,29 & 0,54 & 0,64 \\
\hline Dy161 & 9,72 & 6,51 & 7,66 & 2,79 & 23,55 & 1,67 & 2,80 & 15,94 & 31,52 & 2,07 & 4,54 & 6,14 \\
\hline Ho165 & 2,07 & 2,22 & 2,35 & 0,70 & 4,03 & 0,61 & 0,84 & 2,63 & 5,50 & 1,13 & 1,52 & 1,26 \\
\hline Er166 & 6,11 & 7,65 & 6,62 & 1,98 & 8,41 & 2,79 & 3,28 & 6,01 & 12,34 & 4,61 & 5,26 & 3,98 \\
\hline Tm169 & 0,81 & 1280,00 & 0,91 & 0,27 & 0,82 & 0,51 & 0,72 & 0,67 & 1,42 & 0,89 & 1,07 & 0,52 \\
\hline Yb172 & 4,78 & 9,84 & 7,43 & 2,26 & 5,46 & 3,88 & 4,42 & 4,16 & 10,32 & 6,85 & 9,10 & 3,77 \\
\hline Lu175 & 0,79 & 1,51 & 1,18 & 0,42 & 0,62 & 0,96 & 0,75 & 0,48 & 1,03 & 1,93 & 1,59 & 0,49 \\
\hline Hf178 & $<0,092$ & $<0,093$ & $<0,073$ & $<0,074$ & $<0,048$ & 0,14 & $<0,079$ & 0,07 & $<0,103$ & $<0,068$ & $<0,089$ & $<0,038$ \\
\hline Ta181 & $<0,0206$ & $<0,0196$ & $<0,0190$ & $<0,0136$ & $<0,013$ & $<0,0188$ & $<0,0209$ & $<0,0182$ & $<0,016$ & $<0,013$ & $<0,0236$ & 0,01 \\
\hline Pb208 & 0,12 & $<0,089$ & 0,09 & $<0,081$ & 0,54 & 0,16 & 0,15 & 0,15 & 0,51 & 0,53 & 0,35 & 0,10 \\
\hline Th232 & $<0,0129$ & $<0,00$ & 0,01 & $<0,030$ & $<0,028$ & $<0,025$ & $<0,0186$ & $<0,0243$ & 0,02 & $<0,024$ & $<0,0150$ & 0,01 \\
\hline U238 & $<0,0223$ & 0,01 & 0,01 & 0,01 & $<0,0199$ & 0,02 & $<0,0193$ & $<0,0206$ & $<0,018$ & 0,06 & $<0,0157$ & $<0,0117$ \\
\hline
\end{tabular}

Granada B2 da amostra SNA-205B (anfibolito retroeclogítico - Nappe Andrelândia)

\begin{tabular}{|c|c|c|c|c|c|c|c|c|c|c|c|c|c|}
\hline spot: & Grt-1 & Grt-2 & Grt-3 & Grt-4 & Grt-5 & Grt-6 & Grt-7 & Grt-8 & Grt-9 & Grt-10 & Grt-11 & Grt-12 & Grt-3b \\
\hline & \multicolumn{6}{|c|}{ RASTER } & \multicolumn{7}{|c|}{ SPOT } \\
\hline $\mathrm{Li} 7$ & 5,86 & 2,53 & 7,73 & 3,86 & 7,22 & 4,83 & 14,05 & 6,44 & 10,09 & 7,66 & 5,52 & 3,48 & 4,87 \\
\hline $\mathrm{Na} 23$ & 166,91 & 85,03 & 131,55 & 56,28 & 46,02 & 30,16 & 100,82 & 62,30 & 118,14 & 94,67 & 23,67 & 27,45 & 126,21 \\
\hline Mg25 & 26334,88 & 13204,95 & 13692,82 & 15746,48 & 21924,70 & 23766,36 & 23793,27 & 25136,84 & 23338,58 & 16662,53 & 25800,25 & 22662,51 & 16834,23 \\
\hline $\mathrm{Al} 27$ & 120177,45 & 95066,16 & 103569,21 & 91269,35 & 117293,35 & 113233,80 & 110506,48 & 103363,91 & 109884,23 & 104177,88 & 123072,16 & 123207,50 & 112152,11 \\
\hline Si29 & 179823,92 & 177533,47 & 179590,19 & 176785,56 & 177299,75 & 177626,95 & 178281,38 & 178889,05 & 179777,19 & 178421,59 & 178748,83 & 177206,27 & 179590,19 \\
\hline P31 & $<33,84$ & $<25,59$ & $<26,35$ & $<24,70$ & $<24,90$ & $<26,11$ & $<32,66$ & $<34,11$ & 44,54 & $<30,35$ & $<26,14$ & $<21,74$ & $<33,98$ \\
\hline Ca42 & 75791,77 & 89866,32 & 70580,88 & 66488,06 & 64595,88 & 46730,69 & 59482,78 & 68179,97 & 63341,32 & 87842,34 & 55968,86 & 59391,02 & 99127,16 \\
\hline Sc45 & 70,92 & 68,94 & 49,46 & 40,19 & 54,63 & 45,11 & 32,47 & 56,32 & 33,43 & 52,05 & 71,07 & 37,45 & 76,28 \\
\hline
\end{tabular}




\begin{tabular}{|c|c|c|c|c|c|c|c|c|c|c|c|c|c|}
\hline Ti49 & 569,42 & 337,38 & 409,75 & 307,96 & 223,20 & 206,12 & 686,65 & 292,10 & 610,68 & 354,39 & 148,05 & 187,13 & 526,67 \\
\hline V51 & 293,66 & 217,82 & 191,85 & 185,79 & 204,84 & 172,31 & 317,51 & 208,32 & 228,30 & 223,46 & 153,25 & 148,24 & 278,04 \\
\hline Cr52 & 359,70 & 107,06 & 170,11 & 269,22 & 228,55 & 319,35 & 447,73 & 329,40 & 284,22 & 86,94 & 109,34 & 16,07 & 191,98 \\
\hline $\mathrm{Fe} 54$ & 160814,42 & 108714,83 & 124242,75 & 169159,08 & 139818,83 & 122994,35 & 135561,67 & 137402,27 & 126402,02 & 147861,84 & 156370,84 & 108522,03 & 137850,31 \\
\hline Mn55 & 2733,80 & 1234,81 & 2204,98 & 7096,01 & 5949,19 & 9127,22 & 7421,46 & 6617,11 & 6606,32 & 2476,41 & 5727,75 & 5597,18 & 2146,44 \\
\hline $\mathrm{Fe} 57$ & 200444,06 & 153041,80 & 141280,16 & 221853,02 & 190091,30 & 162738,77 & 197653,81 & 195762,66 & 185970,80 & 213331,19 & 231866,63 & 160700,45 & 209122,55 \\
\hline Co59 & 48,47 & 25,63 & 29,63 & 27,90 & 32,98 & 39,28 & 40,42 & 44,22 & 36,21 & 32,61 & 33,36 & 32,54 & 31,54 \\
\hline Ni62 & 1,76 & 3,04 & 4,99 & $<2,13$ & $<1,25$ & $<1,89$ & $<2,30$ & $<2,35$ & $<2,04$ & $<3,05$ & $<2,55$ & $<2,18$ & $<4,02$ \\
\hline Zn66 & 64,83 & 42,47 & 44,85 & 32,90 & 43,95 & 36,90 & 40,81 & 47,75 & 33,77 & 34,93 & 35,03 & 31,59 & 47,32 \\
\hline $\mathrm{Rb} 85$ & $<0,056$ & $<0,052$ & 1,62 & $<0,062$ & $<0,067$ & $<0,072$ & 0,10 & 0,06 & $<0,065$ & $<0,072$ & $<0,051$ & $<0,049$ & 0,10 \\
\hline Sr88 & $<0,033$ & $<0,023$ & 1,67 & 0,14 & 0,10 & 0,03 & 0,08 & 0,03 & 0,04 & $<0,032$ & $<0,019$ & 0,05 & $<0,046$ \\
\hline Y89 & 57,31 & 33,14 & 27,50 & 43,91 & 82,26 & 62,89 & 27,61 & 101,99 & 27,44 & 34,02 & 73,34 & 65,33 & 38,87 \\
\hline $\mathrm{Zr90}$ & 2,20 & 1,12 & 1,72 & 1,11 & 0,75 & 0,64 & 1,54 & 0,85 & 1,77 & 0,93 & 0,63 & 0,69 & 1,53 \\
\hline $\mathrm{Nb93}$ & $<0,029$ & 0,03 & 0,04 & $<0,025$ & $<0,033$ & $<0,027$ & $<0,058$ & $<0,039$ & $<0,0241$ & $<0,031$ & $<0,030$ & 0,02 & $<0,030$ \\
\hline Cs133 & $<0,036$ & $<0,0271$ & 0,15 & $<0,028$ & $<0,026$ & 0,02 & $<0,034$ & $<0,040$ & $<0,024$ & $<0,032$ & $<0,024$ & $<0,022$ & $<0,030$ \\
\hline Ba137 & $<0,127$ & $<0,152$ & 0,27 & 2,25 & 0,19 & $<0,136$ & 0,18 & 0,09 & $<0,173$ & $<0,148$ & $<0,151$ & $<0,15$ & $<0,170$ \\
\hline La139 & $<0,034$ & $<0,0234$ & 0,37 & 0,05 & 0,08 & $<0,0185$ & $<0,027$ & $<0,028$ & 0,01 & $<0,0147$ & $<0,0212$ & 0,02 & $<0,024$ \\
\hline Ce140 & $<0,0166$ & $<0,0230$ & 0,14 & 0,28 & 0,10 & $<0,026$ & $<0,016$ & $<0,022$ & $<0,019$ & $<0,0204$ & $<0,0120$ & 0,12 & $<0,029$ \\
\hline Pr141 & $<0,023$ & 0,01 & 0,05 & 0,03 & 0,02 & $<0,0180$ & $<0,0179$ & $<0,0223$ & 0,00 & 0,01 & $<0,0141$ & 0,01 & $<0,0140$ \\
\hline $\mathrm{Nd} 146$ & 0,20 & $<0,077$ & 0,17 & 0,38 & $<0,114$ & $<0,106$ & 0,17 & $<0,108$ & $<0,094$ & $<0,070$ & $<0,083$ & 0,21 & 0,06 \\
\hline Sm149 & 1,28 & 0,18 & 0,12 & 0,21 & 0,82 & 1,12 & $<0,23$ & 1,67 & 0,16 & $<0,123$ & 1,24 & 0,76 & 0,22 \\
\hline Eu151 & 0,97 & 0,47 & 0,20 & 0,30 & 0,94 & 1,01 & 0,17 & 1,82 & 0,05 & 0,09 & 1,46 & 0,38 & 0,10 \\
\hline Gd157 & 7,25 & 2,48 & 0,60 & 1,02 & 7,77 & 7,03 & 1,62 & 13,82 & 1,58 & 1,11 & 12,24 & 4,37 & 0,81 \\
\hline Tb159 & 1,55 & 0,81 & 0,29 & 0,56 & 2,76 & 2,43 & 0,56 & 3,99 & 0,56 & 0,46 & 2,75 & 1,69 & 0,28 \\
\hline Dy161 & 11,15 & 9,32 & 3,51 & 5,48 & 20,09 & 14,73 & 5,25 & 28,10 & 4,28 & 5,23 & 19,33 & 13,82 & 3,98 \\
\hline Ho165 & 2,44 & 2,25 & 1,15 & 1,54 & 3,84 & 2,33 & 0,95 & 4,62 & 1,01 & 1,49 & 3,38 & 2,35 & 1,62 \\
\hline Er166 & 5,43 & 5,11 & 4,16 & 5,04 & 8,29 & 5,43 & 3,41 & 10,25 & 3,37 & 3,59 & 6,18 & 5,41 & 5,01 \\
\hline Tm169 & 0,73 & 0,78 & 0,82 & 0,66 & 0,94 & 0,65 & 0,54 & 0,98 & 0,50 & 0,46 & 0,66 & 0,80 & 0,97 \\
\hline Yb172 & 5,82 & 7,44 & 7,68 & 6,42 & 5,85 & 4,35 & 3,62 & 7,05 & 4,37 & 2,99 & 5,41 & 3,78 & 9,32 \\
\hline Lu175 & 0,94 & 0,49 & 1,25 & 1,06 & 0,63 & 0,60 & 0,53 & 0,83 & 0,66 & 0,35 & 0,42 & 0,38 & 1,25 \\
\hline
\end{tabular}




\begin{tabular}{|c|c|c|c|c|c|c|c|c|c|c|c|c|c|}
\hline $\mathrm{Hf} 178$ & 0,08 & $<0,038$ & $<0,058$ & $<0,040$ & $<0,090$ & 0,06 & 0,19 & $<0,053$ & $<0,065$ & $<0,069$ & $<0,058$ & 0,04 & 0,09 \\
\hline Ta181 & $<0,00$ & $<0,0159$ & $<0,0169$ & 0,02 & $<0,0117$ & $<0,0216$ & $<0,0213$ & $<0,027$ & $<0,0133$ & $<0,0312$ & $<0,0117$ & $<0,00$ & $<0,0163$ \\
\hline Pb208 & 0,16 & 0,07 & $<0,039$ & 0,11 & 0,09 & 0,37 & $<0,062$ & 0,08 & 0,12 & $<0,058$ & $<0,056$ & $<0,041$ & $<0,068$ \\
\hline Th232 & 0,01 & $<0,0243$ & $<0,0129$ & 0,03 & 0,02 & $<0,0269$ & 0,02 & $<0,0164$ & $<0,0142$ & $<0,0150$ & 0,03 & 0,03 & 0,03 \\
\hline U238 & $<0,031$ & $<0,0124$ & 0,02 & $<0,026$ & 0,00 & $<0,031$ & $<0,024$ & $<0,029$ & $<0,0208$ & $<0,0268$ & $<0,0129$ & $<0,0246$ & $<0,0181$ \\
\hline
\end{tabular}




\section{ANEXO VIII}

Geoquímica elemental em granada

(Elementos maiores por microssonda eletrônica) 
Granada B1 da amostra SNA-205B (anfibolito retroeclogítico - Nappe Andrelândia)

\begin{tabular}{|c|c|c|c|c|c|c|c|c|c|c|c|}
\hline \multicolumn{2}{|c|}{ elemento: } & $\mathrm{Si}$ & $\mathrm{Al}$ & $\mathrm{Fe}$ & $\mathrm{Mn}$ & $\mathrm{Ca}$ & $\mathrm{Ti}$ & $\mathrm{Cr}$ & $\mathrm{Mg}$ & $\mathrm{O}$ & total \\
\hline \multirow{7}{*}{ grt-1 } & mass $\%$ & 17.69 & 10.77 & 20.65 & 0.1809 & 8.15 & 0.0609 & 0.0078 & 1.67 & 40.10 & 99.29 \\
\hline & Ox mass $\%$ & 37.84 & 20.36 & 26.57 & 0.2336 & 11.41 & 0.1015 & 0.0115 & 2.77 & - & 99.29 \\
\hline & Norm El\% & 17.82 & 10.85 & 20.80 & 0.1822 & 8.21 & 0.0613 & 0.0079 & 1.68 & 40.39 & 100.00 \\
\hline & Norm ox\% & 38.11 & 20.51 & 26.76 & 0.2353 & 11.49 & 0.1023 & 0.0115 & 2.79 & - & 100.00 \\
\hline & At prop & 6.030 & 3.824 & 3.541 & 0.0315 & 1.948 & 0.0122 & 0.0014 & 0.657 & 24.000 & 16.045 \\
\hline & k-value & 0.13377 & 0.07651 & 0.17853 & 0.001537 & 0.07717 & 0.000535 & 0.000072 & 0.01022 & - & \\
\hline & $\mathrm{k}-(\mathrm{std})$ & 0.95689 & 0.50766 & 0.36849 & 0.101102 & 0.24192 & 0.000964 & 0.000184 & 0.13608 & - & \\
\hline \multirow{7}{*}{ grt-2 } & mass $\%$ & 17.69 & 10.85 & 20.79 & 0.2493 & 8.21 & 0.0510 & 0.0283 & 1.55 & 40.17 & 99.59 \\
\hline & Ox mass $\%$ & 37.84 & 20.50 & 26.75 & 0.3219 & 11.48 & 0.0851 & 0.0413 & 2.56 & - & 99.59 \\
\hline & Norm El\% & 17.76 & 10.90 & 20.88 & 0.2503 & 8.24 & 0.0512 & 0.0284 & 1.55 & 40.34 & 100.00 \\
\hline & Norm ox\% & 38.00 & 20.59 & 26.86 & 0.3232 & 11.53 & 0.0854 & 0.0415 & 2.57 & - & 100.00 \\
\hline & At prop & 6.019 & 3.845 & 3.559 & 0.0434 & 1.957 & 0.0102 & 0.0052 & 0.608 & 24.000 & 16.046 \\
\hline & k-value & 0.13379 & 0.07710 & 0.17981 & 0.002118 & 0.07772 & 0.000448 & 0.000258 & 0.00946 & - & \\
\hline & $\mathrm{k}-(\mathrm{std})$ & 0.95702 & 0.51157 & 0.37112 & 0.139353 & 0.24363 & 0.000808 & 0.000664 & 0.12585 & - & \\
\hline \multirow{7}{*}{ grt-3 } & mass $\%$ & 17.78 & 10.81 & 21.05 & 0.2218 & 8.07 & 0.0331 & 0.0212 & 1.55 & 40.24 & 99.77 \\
\hline & Ox mass $\%$ & 38.04 & 20.42 & 27.08 & 0.2864 & 11.29 & 0.0551 & 0.0310 & 2.57 & - & 99.77 \\
\hline & Norm El\% & 17.82 & 10.83 & 21.10 & 0.2223 & 8.08 & 0.0331 & 0.0212 & 1.55 & 40.33 & 100.00 \\
\hline & Norm ox\% & 38.13 & 20.47 & 27.14 & 0.2870 & 11.31 & 0.0553 & 0.0310 & 2.57 & - & 100.00 \\
\hline & At prop & 6.042 & 3.823 & 3.596 & 0.0385 & 1.920 & 0.0066 & 0.0039 & 0.608 & 24.000 & 16.038 \\
\hline & k-value & 0.13453 & 0.07675 & 0.18209 & 0.001885 & 0.07638 & 0.000291 & 0.000194 & 0.00946 & - & \\
\hline & $\mathrm{k}-(\mathrm{std})$ & 0.96234 & 0.50927 & 0.37582 & 0.124020 & 0.23944 & 0.000524 & 0.000498 & 0.12593 & - & \\
\hline \multirow{7}{*}{ grt-4 } & mass $\%$ & 17.80 & 10.94 & 20.91 & 0.7216 & 7.02 & 0.0978 & 0.0149 & 2.11 & 40.47 & 100.08 \\
\hline & Ox mass $\%$ & 38.07 & 20.66 & 26.91 & 0.9317 & 9.82 & 0.1632 & 0.0217 & 3.50 & - & 100.08 \\
\hline & Norm El\% & 17.78 & 10.93 & 20.90 & 0.7210 & 7.01 & 0.0978 & 0.0149 & 2.11 & 40.44 & 100.00 \\
\hline & Norm ox\% & 38.04 & 20.65 & 26.88 & 0.9310 & 9.81 & 0.1631 & 0.0217 & 3.50 & - & 100.00 \\
\hline & At prop & 6.012 & 3.846 & 3.553 & 0.1246 & 1.661 & 0.0194 & 0.0027 & 0.825 & 24.000 & 16.044 \\
\hline & $k$-value & 0.13417 & 0.07732 & 0.18103 & 0.006138 & 0.06644 & 0.000862 & 0.000136 & 0.01294 & - & \\
\hline & $\mathrm{k}-(\mathrm{std})$ & 0.95974 & 0.51306 & 0.37364 & 0.403776 & 0.20830 & 0.001555 & 0.000350 & 0.17220 & - & \\
\hline \multirow{7}{*}{ grt-5 } & mass $\%$ & 17.98 & 10.89 & 20.44 & 0.7035 & 6.60 & 0.0564 & 0.0471 & 2.38 & 40.50 & 99.60 \\
\hline & Ox mass \% & 38.46 & 20.58 & 26.30 & 0.9084 & 9.24 & 0.0941 & 0.0688 & 3.95 & - & 99.60 \\
\hline & Norm El\% & 18.05 & 10.94 & 20.52 & 0.7063 & 6.63 & 0.0566 & 0.0473 & 2.39 & 40.66 & 100.00 \\
\hline & Norm ox\% & 38.62 & 20.66 & 26.40 & 0.9120 & 9.28 & 0.0945 & 0.0691 & 3.97 & - & 100.00 \\
\hline & At prop & 6.070 & 3.828 & 3.470 & 0.1214 & 1.562 & 0.0112 & 0.0086 & 0.929 & 24.000 & 16.001 \\
\hline & $k$-value & 0.13547 & 0.07699 & 0.17677 & 0.005980 & 0.06245 & 0.000497 & 0.000431 & 0.01465 & - & \\
\hline & $\mathrm{k}-(\mathrm{std})$ & 0.96903 & 0.51085 & 0.36485 & 0.393399 & 0.19578 & 0.000896 & 0.001107 & 0.19492 & - & \\
\hline \multirow{7}{*}{ grt-6 } & mass $\%$ & 17.65 & 10.85 & 20.49 & 1.10 & 6.61 & 0.1127 & 0.0403 & 2.24 & 40.16 & 99.26 \\
\hline & Ox mass $\%$ & 37.77 & 20.50 & 26.35 & 1.43 & 9.25 & 0.1879 & 0.0590 & 3.71 & - & 99.26 \\
\hline & Norm El\% & 17.79 & 10.93 & 20.64 & 1.11 & 6.66 & 0.1135 & 0.0406 & 2.26 & 40.46 & 100.00 \\
\hline & Norm ox\% & 38.05 & 20.65 & 26.55 & 1.44 & 9.32 & 0.1894 & 0.0594 & 3.74 & - & 100.00 \\
\hline & At prop & 6.010 & 3.845 & 3.507 & 0.192 & 1.577 & 0.0225 & 0.0074 & 0.881 & 24.000 & 16.042 \\
\hline & k-value & 0.13294 & 0.07659 & 0.17732 & 0.00939 & 0.06261 & 0.000994 & 0.000370 & 0.01372 & - & \\
\hline & $\mathrm{k}-(\mathrm{std})$ & 0.95098 & 0.50823 & 0.36598 & 0.61795 & 0.19627 & 0.001793 & 0.000950 & 0.18265 & - & \\
\hline
\end{tabular}




\begin{tabular}{|c|c|c|c|c|c|c|c|c|c|c|c|}
\hline \multicolumn{2}{|c|}{ elemento: } & $\mathrm{Si}$ & Al & $\mathrm{Fe}$ & $\mathrm{Mn}$ & $\mathrm{Ca}$ & $\mathrm{Ti}$ & $\mathrm{Cr}$ & $\mathrm{Mg}$ & O & total \\
\hline \multirow{7}{*}{ grt-7 } & mass $\%$ & 17.55 & 10.87 & 20.61 & 1.13 & 6.55 & 0.0940 & 0.0227 & 2.27 & 40.09 & 99.20 \\
\hline & $\begin{array}{c}\text { Ox } \\
\text { mass } \%\end{array}$ & 37.55 & 20.55 & 26.52 & 1.46 & 9.17 & 0.1568 & 0.0332 & 3.77 & - & 99.20 \\
\hline & Norm El\% & 17.70 & 10.96 & 20.78 & 1.14 & 6.60 & 0.0948 & 0.0229 & 2.29 & 40.41 & 100.00 \\
\hline & $\begin{array}{l}\text { Norm } \\
\text { ox\% }\end{array}$ & 37.85 & 20.71 & 26.73 & 1.47 & 9.24 & 0.1581 & 0.0334 & 3.80 & - & 100.00 \\
\hline & At prop & 5.986 & 3.861 & 3.535 & 0.197 & 1.565 & 0.0188 & 0.0042 & 0.896 & 24.000 & 16.063 \\
\hline & k-value & 0.13209 & 0.07670 & 0.17845 & 0.00964 & 0.06205 & 0.000830 & 0.000208 & 0.01392 & - & \\
\hline & k-(std) & 0.94487 & 0.50897 & 0.36831 & 0.63424 & 0.19453 & 0.001497 & 0.000535 & 0.18524 & - & \\
\hline \multirow{7}{*}{ grt-8 } & mass $\%$ & 17.76 & 10.97 & 21.69 & 0.6924 & 5.99 & 0.0305 & 0.0055 & 2.44 & 40.42 & 99.99 \\
\hline & $\begin{array}{c}\text { Ox } \\
\text { mass } \%\end{array}$ & 37.98 & 20.73 & 27.90 & 0.8940 & 8.38 & 0.0508 & 0.0080 & 4.04 & - & 99.99 \\
\hline & Norm El\% & 17.76 & 10.97 & 21.69 & 0.6925 & 5.99 & 0.0305 & 0.0055 & 2.44 & 40.42 & 100.00 \\
\hline & $\begin{array}{l}\text { Norm } \\
\text { ox\% }\end{array}$ & 37.99 & 20.74 & 27.91 & 0.8941 & 8.38 & 0.0508 & 0.0080 & 4.04 & - & 100.00 \\
\hline & At prop & 6.005 & 3.864 & 3.690 & 0.1197 & 1.419 & 0.0060 & 0.0010 & 0.952 & 24.000 & 16.056 \\
\hline & k-value & 0.13339 & 0.07721 & 0.18794 & 0.005897 & 0.05672 & 0.000270 & 0.000050 & 0.01488 & - & \\
\hline & $\mathrm{k}-(\mathrm{std})$ & 0.95420 & 0.51229 & 0.38791 & 0.387913 & 0.17780 & 0.000486 & 0.000129 & 0.19799 & - & \\
\hline \multirow{7}{*}{ grt-9 } & mass $\%$ & 17.75 & 11.02 & 21.15 & 0.6713 & 6.15 & 0.0221 & 0.0332 & 2.58 & 40.46 & 99.83 \\
\hline & $\begin{array}{c}\text { Ox } \\
\text { mass } \%\end{array}$ & 37.96 & 20.82 & 27.21 & 0.8668 & 8.60 & 0.0369 & 0.0486 & 4.28 & - & 99.83 \\
\hline & Norm El\% & 17.78 & 11.04 & 21.19 & 0.6724 & 6.16 & 0.0221 & 0.0333 & 2.58 & 40.53 & 100.00 \\
\hline & $\begin{array}{l}\text { Norm } \\
\text { ox\% }\end{array}$ & 38.03 & 20.85 & 27.26 & 0.8683 & 8.62 & 0.0369 & 0.0487 & 4.28 & - & 100.00 \\
\hline & At prop & 5.997 & 3.876 & 3.595 & 0.1160 & 1.456 & 0.0044 & 0.0061 & 1.007 & 24.000 & 16.058 \\
\hline & k-value & 0.13331 & 0.07758 & 0.18313 & 0.005713 & 0.05820 & 0.000195 & 0.000306 & 0.01581 & - & \\
\hline & $\mathrm{k}-(\mathrm{std})$ & 0.95364 & 0.51477 & 0.37797 & 0.375783 & 0.18245 & 0.000352 & 0.000785 & 0.21040 & - & \\
\hline \multirow{7}{*}{ grt-10 } & mass $\%$ & 17.82 & 10.93 & 19.79 & 2.13 & 6.11 & 0.0758 & 0.0306 & 2.56 & 40.50 & 99.95 \\
\hline & $\begin{array}{c}\text { Ox } \\
\text { mass } \%\end{array}$ & 38.11 & 20.66 & 25.47 & 2.74 & 8.55 & 0.1265 & 0.0447 & 4.24 & - & 99.95 \\
\hline & Norm El\% & 17.83 & 10.94 & 19.81 & 2.13 & 6.12 & 0.0759 & 0.0306 & 2.56 & 40.52 & 100.00 \\
\hline & $\begin{array}{l}\text { Norm } \\
\text { ox\% }\end{array}$ & 38.13 & 20.67 & 25.48 & 2.75 & 8.56 & 0.1266 & 0.0447 & 4.24 & - & 100.00 \\
\hline & At prop & 6.013 & 3.842 & 3.361 & 0.367 & 1.446 & 0.0150 & 0.0056 & 0.998 & 24.000 & 16.048 \\
\hline & k-value & 0.13406 & 0.07709 & 0.17143 & 0.01810 & 0.05790 & 0.000670 & 0.000280 & 0.01571 & - & \\
\hline & k-(std) & 0.95899 & 0.51152 & 0.35384 & 119.032 & 0.18152 & 0.001209 & 0.000719 & 0.20902 & - & \\
\hline \multirow{7}{*}{ grt-11 } & mass $\%$ & 17.80 & 10.95 & 21.03 & 0.9991 & 5.60 & 0.0334 & 0.00 & 2.78 & 40.43 & 99.62 \\
\hline & $\begin{array}{c}\text { Ox } \\
\text { mass } \%\end{array}$ & 38.09 & 20.69 & 27.06 & 12.900 & 7.83 & 0.0556 & 0.00 & 4.61 & - & 99.62 \\
\hline & Norm El\% & 17.87 & 10.99 & 21.11 & 10.028 & 5.62 & 0.0335 & 0.00 & 2.79 & 40.58 & 100.00 \\
\hline & $\begin{array}{l}\text { Norm } \\
\text { ox\% }\end{array}$ & 38.23 & 20.77 & 27.16 & 12.949 & 7.86 & 0.0559 & 0.00 & 4.63 & - & 100.00 \\
\hline & At prop & 6.020 & 3.856 & 3.577 & 0.1727 & 1.327 & 0.0066 & 0.000 & 1.086 & 24.000 & 16.045 \\
\hline & k-value & 0.13360 & 0.07697 & 0.18214 & 0.008505 & 0.05298 & 0.000295 & 0.00000 & 0.01704 & - & \\
\hline & k-(std) & 0.95571 & 0.51071 & 0.37594 & 0.559485 & 0.16609 & 0.000532 & 0.00000 & 0.22675 & - & \\
\hline \multirow{7}{*}{ grt-12 } & mass $\%$ & 17.79 & 10.87 & 20.11 & 0.5535 & 7.18 & 0.0290 & 0.0130 & 2.36 & 40.30 & 99.20 \\
\hline & $\begin{array}{c}\text { Ox } \\
\text { mass } \%\end{array}$ & 38.05 & 20.54 & 25.87 & 0.7147 & 10.05 & 0.0483 & 0.0190 & 3.91 & - & 99.20 \\
\hline & Norm El\% & 17.93 & 10.96 & 20.27 & 0.5580 & 7.24 & 0.0292 & 0.0131 & 2.38 & 40.62 & 100.00 \\
\hline & $\begin{array}{l}\text { Norm } \\
\text { ox\% }\end{array}$ & 38.36 & 20.71 & 26.08 & 0.7205 & 10.13 & 0.0487 & 0.0191 & 3.94 & - & 100.00 \\
\hline & At prop & 6.034 & 3.840 & 3.431 & 0.0960 & 1.708 & 0.0058 & 0.0024 & 0.924 & 24.000 & 16.039 \\
\hline & k-value & 0.13406 & 0.07692 & 0.17375 & 0.004702 & 0.06791 & 0.000255 & 0.000119 & 0.01451 & - & \\
\hline & k-(std) & 0.95900 & 0.51043 & 0.35863 & 0.309302 & 0.21289 & 0.000459 & 0.000305 & 0.19306 & - & \\
\hline
\end{tabular}


Granada B2 da amostra SNA-205B (anfibolito retroeclogítico - Nappe Andrelândia)

\begin{tabular}{|c|c|c|c|c|c|c|c|c|c|c|c|}
\hline \multicolumn{2}{|c|}{ elemento: } & $\mathrm{Si}$ & Al & $\mathrm{Fe}$ & $\mathrm{Mn}$ & $\mathrm{Ca}$ & $\mathrm{Ti}$ & $\mathrm{Cr}$ & $\mathrm{Mg}$ & $\mathrm{O}$ & total \\
\hline \multirow{7}{*}{ grt-1 } & mass $\%$ & 17.98 & 10.99 & 20.63 & 0.2446 & 7.21 & 0.0649 & 0.0141 & 2.40 & 40.75 & 100.29 \\
\hline & Ox mass $\%$ & 38.47 & 20.76 & 26.54 & 0.3159 & 10.09 & 0.1083 & 0.0207 & 3.99 & - & 100.29 \\
\hline & Norm El\% & 17.93 & 10.95 & 20.57 & 0.2439 & 7.19 & 0.0647 & 0.0141 & 2.40 & 40.63 & 100.00 \\
\hline & Norm ox\% & 38.36 & 20.70 & 26.46 & 0.3150 & 10.06 & 0.1080 & 0.0206 & 3.97 & - & 100.00 \\
\hline & At prop & 6.033 & 3.837 & 3.480 & 0.0420 & 1.696 & 0.0128 & 0.0026 & 0.932 & 24.000 & 16.035 \\
\hline & $k$-value & 0.13558 & 0.07773 & 0.17832 & 0.002078 & 0.06818 & 0.000571 & 0.000129 & 0.01480 & - & \\
\hline & k-(std) & 0.96987 & 0.51576 & 0.36805 & 0.136689 & 0.21375 & 0.001029 & 0.000332 & 0.19691 & - & \\
\hline \multirow{7}{*}{ grt-2 } & mass $\%$ & 17.75 & 10.84 & 20.31 & 0.1995 & 8.32 & 0.0413 & 0.0209 & 1.82 & 40.31 & 99.61 \\
\hline & Ox mass $\%$ & 37.98 & 20.49 & 26.13 & 0.2576 & 11.64 & 0.0689 & 0.0305 & 3.02 & - & 99.61 \\
\hline & Norm El\% & 17.82 & 10.89 & 20.39 & 0.2003 & 8.35 & 0.0414 & 0.0210 & 1.83 & 40.46 & 100.00 \\
\hline & Norm ox\% & 38.13 & 20.57 & 26.23 & 0.2586 & 11.68 & 0.0691 & 0.0306 & 3.04 & - & 100.00 \\
\hline & At prop & 6.022 & 3.829 & 3.465 & 0.0346 & 1.977 & 0.0082 & 0.0038 & 0.715 & 24.000 & 16.054 \\
\hline & k-value & 0.13428 & 0.07703 & 0.17548 & 0.001694 & 0.07867 & 0.000362 & 0.000190 & 0.01120 & - & \\
\hline & $\mathrm{k}-(\mathrm{std})$ & 0.96054 & 0.51115 & 0.36219 & 0.111431 & 0.24662 & 0.000653 & 0.000489 & 0.14910 & - & \\
\hline \multirow{7}{*}{ grt-3 } & mass $\%$ & 17.96 & 10.93 & 20.91 & 0.2145 & 8.20 & 0.0753 & 0.0252 & 1.63 & 40.65 & 100.60 \\
\hline & Ox mass $\%$ & 38.42 & 20.66 & 26.90 & 0.2770 & 11.47 & 0.1256 & 0.0368 & 2.71 & - & 100.60 \\
\hline & Norm El\% & 17.85 & 10.87 & 20.78 & 0.2132 & 8.15 & 0.0749 & 0.0250 & 1.63 & 40.41 & 100.00 \\
\hline & Norm ox\% & 38.19 & 20.54 & 26.74 & 0.2753 & 11.40 & 0.1249 & 0.0366 & 2.69 & - & 100.00 \\
\hline & At prop & 6.040 & 3.828 & 3.536 & 0.0369 & 1.932 & 0.0149 & 0.0046 & 0.635 & 24.000 & 16.029 \\
\hline & k-value & 0.13594 & 0.07771 & 0.18084 & 0.001823 & 0.07761 & 0.000662 & 0.000230 & 0.01002 & - & \\
\hline & k-(std) & 0.97245 & 0.51565 & 0.37325 & 0.119892 & 0.24332 & 0.001193 & 0.000591 & 0.13331 & - & \\
\hline \multirow{7}{*}{ grt-4 } & mass $\%$ & 17.68 & 10.90 & 22.24 & 1.03 & 6.40 & 0.0801 & 0.0237 & 1.76 & 40.28 & 100.39 \\
\hline & Ox mass $\%$ & 37.82 & 20.59 & 28.61 & 1.32 & 8.96 & 0.1336 & 0.0347 & 2.91 & - & 100.39 \\
\hline & Norm El\% & 17.61 & 10.86 & 22.16 & 1.02 & 6.38 & 0.0798 & 0.0237 & 1.75 & 40.13 & 100.00 \\
\hline & Norm ox\% & 37.67 & 20.51 & 28.50 & 1.32 & 8.92 & 0.1331 & 0.0346 & 2.90 & - & 100.00 \\
\hline & At prop & 6.000 & 3.851 & 3.796 & 0.178 & 1.523 & 0.0159 & 0.0044 & 0.689 & 24.000 & 16.057 \\
\hline & k-value & 0.13317 & 0.07684 & 0.19305 & 0.00875 & 0.06077 & 0.000710 & 0.000219 & 0.01065 & - & \\
\hline & k-(std) & 0.95258 & 0.50988 & 0.39845 & 0.57538 & 0.19053 & 0.001280 & 0.000563 & 0.14179 & - & \\
\hline \multirow{7}{*}{ grt-5 } & mass $\%$ & 17.73 & 11.00 & 21.27 & 0.7060 & 5.96 & 0.0124 & 0.0078 & 2.68 & 40.44 & 99.81 \\
\hline & Ox mass $\%$ & 37.93 & 20.79 & 27.36 & 0.9116 & 8.34 & 0.0206 & 0.0114 & 4.45 & - & 99.81 \\
\hline & Norm El\% & 17.76 & 11.02 & 21.31 & 0.7073 & 5.97 & 0.0124 & 0.0078 & 2.69 & 40.52 & 100.00 \\
\hline & Norm ox\% & 38.00 & 20.83 & 27.42 & 0.9133 & 8.36 & 0.0207 & 0.0114 & 4.45 & - & 100.00 \\
\hline & At prop & 5.993 & 3.873 & 3.616 & 0.1220 & 1.412 & 0.0025 & 0.0014 & 1.047 & 24.000 & 16.067 \\
\hline & k-value & 0.13308 & 0.07738 & 0.18418 & 0.006009 & 0.05642 & 0.000109 & 0.000072 & 0.01643 & - & \\
\hline & k-(std) & 0.95196 & 0.51348 & 0.38016 & 0.395284 & 0.17687 & 0.000197 & 0.000184 & 0.21862 & - & \\
\hline \multirow{7}{*}{ grt- 6} & mass $\%$ & 17.76 & 10.96 & 20.81 & 0.8565 & 6.23 & 0.0274 & 0.0383 & 2.71 & 40.51 & 99.91 \\
\hline & Ox mass $\%$ & 38.00 & 20.71 & 26.78 & 11.059 & 8.72 & 0.0457 & 0.0560 & 4.50 & - & 99.91 \\
\hline & Norm El\% & 17.78 & 10.97 & 20.83 & 0.8572 & 6.24 & 0.0274 & 0.0384 & 2.72 & 40.54 & 100.00 \\
\hline & Norm ox\% & 38.03 & 20.73 & 26.80 & 11.068 & 8.73 & 0.0457 & 0.0561 & 4.50 & - & 100.00 \\
\hline & At prop & 5.995 & 3.851 & 3.533 & 0.1478 & 1.474 & 0.0054 & 0.0070 & 1.058 & 24.000 & 16.071 \\
\hline & $k$-value & 0.13347 & 0.07715 & 0.18015 & 0.007286 & 0.05898 & 0.000242 & 0.000352 & 0.01665 & - & \\
\hline & $\mathrm{k}-(\mathrm{std})$ & 0.95478 & 0.51194 & 0.37184 & 0.479309 & 0.18490 & 0.000436 & 0.000904 & 0.22163 & - & \\
\hline
\end{tabular}




\begin{tabular}{|c|c|c|c|c|c|c|c|c|c|c|c|}
\hline \multicolumn{2}{|c|}{ elemento: } & $\mathrm{Si}$ & $\mathrm{Al}$ & $\mathrm{Fe}$ & $\mathrm{Mn}$ & $\mathrm{Ca}$ & $\mathrm{Ti}$ & $\mathrm{Cr}$ & $\mathrm{Mg}$ & O & total \\
\hline \multirow{7}{*}{ grt-7 } & mass $\%$ & 17.83 & 11.02 & 20.52 & 0.7908 & 6.23 & 0.0768 & 0.0439 & 2.79 & 40.62 & 99.92 \\
\hline & $\begin{array}{c}\text { Ox } \\
\text { mass } \%\end{array}$ & 38.14 & 20.82 & 26.40 & 10.211 & 8.72 & 0.1281 & 0.0641 & 4.63 & - & 99.92 \\
\hline & Norm El\% & 17.84 & 11.03 & 20.54 & 0.7915 & 6.24 & 0.0768 & 0.0439 & 2.79 & 40.65 & 100.00 \\
\hline & Norm ox\% & 38.17 & 20.84 & 26.42 & 10.220 & 8.73 & 0.1282 & 0.0642 & 4.63 & - & 100.00 \\
\hline & At prop & 6.000 & 3.861 & 3.474 & 0.1361 & 1.470 & 0.0152 & 0.0080 & 1.086 & 24.000 & 16.050 \\
\hline & k-value & 0.13395 & 0.07763 & 0.17753 & 0.006724 & 0.05893 & 0.000677 & 0.000402 & 0.01718 & - & \\
\hline & $\mathrm{k}-(\mathrm{std})$ & 0.95822 & 0.51509 & 0.36641 & 0.442332 & 0.18476 & 0.001221 & 0.001033 & 0.22867 & - & \\
\hline \multirow{7}{*}{ grt-8 } & mass $\%$ & 17.89 & 11.04 & 20.63 & 0.7895 & 6.27 & 0.0323 & 0.0622 & 2.82 & 40.75 & 100.28 \\
\hline & $\begin{array}{c}\text { Ox } \\
\text { mass\% }\end{array}$ & 38.27 & 20.86 & 26.53 & 10.194 & 8.77 & 0.0539 & 0.0909 & 4.68 & - & 100.28 \\
\hline & Norm El\% & 17.84 & 11.01 & 20.57 & 0.7873 & 6.25 & 0.0322 & 0.0620 & 2.82 & 40.64 & 100.00 \\
\hline & Norm ox\% & 38.17 & 20.80 & 26.46 & 10.165 & 8.75 & 0.0538 & 0.0907 & 4.67 & - & 100.00 \\
\hline & At prop & 6.002 & 3.855 & 3.480 & 0.1354 & 1.474 & 0.0064 & 0.0113 & 1.095 & 24.000 & 16.058 \\
\hline & k-value & 0.13447 & 0.07774 & 0.17845 & 0.006713 & 0.05928 & 0.000285 & 0.000570 & 0.01737 & - & \\
\hline & $\mathrm{k}-(\mathrm{std})$ & 0.96187 & 0.51587 & 0.36832 & 0.441595 & 0.18585 & 0.000514 & 0.001465 & 0.23121 & - & \\
\hline \multirow{7}{*}{ grt-9 } & mass $\%$ & 17.98 & 10.96 & 21.24 & 0.8781 & 6.29 & 0.0261 & 0.0215 & 2.49 & 40.75 & 100.64 \\
\hline & $\begin{array}{c}\text { Ox } \\
\text { mass } \%\end{array}$ & 38.46 & 20.71 & 27.32 & 11.338 & 8.80 & 0.0435 & 0.0315 & 4.14 & - & 100.64 \\
\hline & Norm El\% & 17.86 & 10.89 & 21.10 & 0.8725 & 6.25 & 0.0259 & 0.0214 & 2.48 & 40.49 & 100.00 \\
\hline & Norm ox\% & 38.21 & 20.58 & 27.15 & 11.267 & 8.75 & 0.0432 & 0.0313 & 4.11 & - & 100.00 \\
\hline & At prop & 6.031 & 3.829 & 3.583 & 0.1506 & 1.479 & 0.0051 & 0.0039 & 0.967 & 24.000 & 16.048 \\
\hline & $k$-value & 0.13529 & 0.07725 & 0.18393 & 0.007474 & 0.05955 & 0.000230 & 0.000198 & 0.01528 & - & \\
\hline & $\mathrm{k}-(\mathrm{std})$ & 0.96776 & 0.51256 & 0.37963 & 0.491628 & 0.18669 & 0.000415 & 0.000508 & 0.20336 & - & \\
\hline \multirow{7}{*}{ grt-10 } & mass $\%$ & 17.84 & 11.06 & 20.87 & 0.4876 & 6.65 & 0.0249 & 0.0055 & 2.51 & 40.61 & 100.05 \\
\hline & $\begin{array}{c}\text { Ox } \\
\text { mass } \%\end{array}$ & 38.17 & 20.89 & 26.84 & 0.6296 & 9.30 & 0.0415 & 0.0080 & 4.16 & - & 100.05 \\
\hline & Norm El\% & 17.83 & 11.05 & 20.86 & 0.4874 & 6.65 & 0.0248 & 0.0055 & 2.51 & 40.59 & 100.00 \\
\hline & Norm ox\% & 38.15 & 20.88 & 26.83 & 0.6293 & 9.30 & 0.0414 & 0.0080 & 4.16 & - & 100.00 \\
\hline & At prop & 6.007 & 3.875 & 3.533 & 0.0839 & 1.569 & 0.0049 & 0.0010 & 0.977 & 24.000 & 16.050 \\
\hline & $k$-value & 0.13422 & 0.07804 & 0.18050 & 0.004146 & 0.06289 & 0.000219 & 0.000050 & 0.01543 & - & \\
\hline & $\mathrm{k}-(\mathrm{std})$ & 0.96013 & 0.51783 & 0.37256 & 0.272700 & 0.19715 & 0.000395 & 0.000129 & 0.20530 & - & \\
\hline \multirow{7}{*}{ grt-11 } & mass $\%$ & 17.88 & 11.02 & 21.86 & 0.5946 & 6.00 & 0.0354 & 0.0222 & 2.50 & 40.68 & 100.58 \\
\hline & $\begin{array}{c}\text { Ox } \\
\text { mass } \%\end{array}$ & 38.24 & 20.82 & 28.13 & 0.7678 & 8.39 & 0.0591 & 0.0325 & 4.15 & - & 100.58 \\
\hline & Norm El\% & 17.77 & 10.95 & 21.74 & 0.5912 & 5.96 & 0.0352 & 0.0221 & 2.49 & 40.44 & 100.00 \\
\hline & Norm ox\% & 38.02 & 20.70 & 27.96 & 0.7633 & 8.34 & 0.0588 & 0.0323 & 4.12 & - & 100.00 \\
\hline & At prop & 6.008 & 3.855 & 3.696 & 0.1022 & 1.413 & 0.0070 & 0.0040 & 0.971 & 24.000 & 16.055 \\
\hline & $k$-value & 0.13434 & 0.07750 & 0.18947 & 0.005064 & 0.05681 & 0.000313 & 0.000205 & 0.01528 & - & \\
\hline & $\mathrm{k}-(\mathrm{std})$ & 0.96097 & 0.51428 & 0.39106 & 0.333114 & 0.17809 & 0.000565 & 0.000526 & 0.20334 & - & \\
\hline \multirow{7}{*}{ grt-12 } & mass $\%$ & 17.72 & 10.95 & 21.64 & 0.6957 & 5.99 & 0.0356 & 0.0109 & 2.42 & 40.34 & 99.80 \\
\hline & $\begin{array}{c}\text { Ox } \\
\text { mass } \%\end{array}$ & 37.91 & 20.69 & 27.84 & 0.8983 & 8.38 & 0.0594 & 0.0160 & 4.01 & - & 99.80 \\
\hline & Norm El\% & 17.76 & 10.97 & 21.68 & 0.6971 & 6.00 & 0.0357 & 0.0110 & 2.42 & 40.42 & 100.00 \\
\hline & Norm ox\% & 37.98 & 20.73 & 27.89 & 0.9001 & 8.40 & 0.0595 & 0.0160 & 4.02 & - & 100.00 \\
\hline & At prop & 6.005 & 3.863 & 3.688 & 0.1205 & 1.423 & 0.0071 & 0.0020 & 0.947 & 24.000 & 16.056 \\
\hline & $k$-value & 0.13312 & 0.07704 & 0.18748 & 0.005925 & 0.05675 & 0.000315 & 0.000101 & 0.01478 & - & \\
\hline & $k-(s t d)$ & 0.95226 & 0.51121 & 0.38696 & 0.389758 & 0.17791 & 0.000568 & 0.000259 & 0.19667 & - & \\
\hline
\end{tabular}

